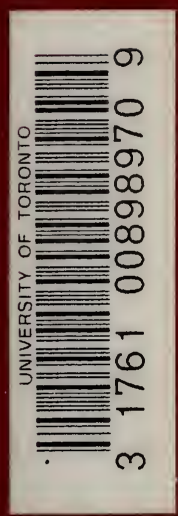





\section{THE POETRY OF JULIAN DEL CASAL:}

A CRITICAL EDITION 



\title{
THE POETRY OF JULIAN DEL CASAL: A CRITICAL EDITION
}

\author{
VOLUME TWO
}

Robert Jay Glickman

A University of Florida Book

The University Presses of Florida

Gainesville 


\title{
COPyright (C) 1978 by Robert Jay Glickman
}

\author{
All rights reserved
}

\section{PRINTED BY}

Rose Printing Company, Incorporated

Tallahassee, Florida

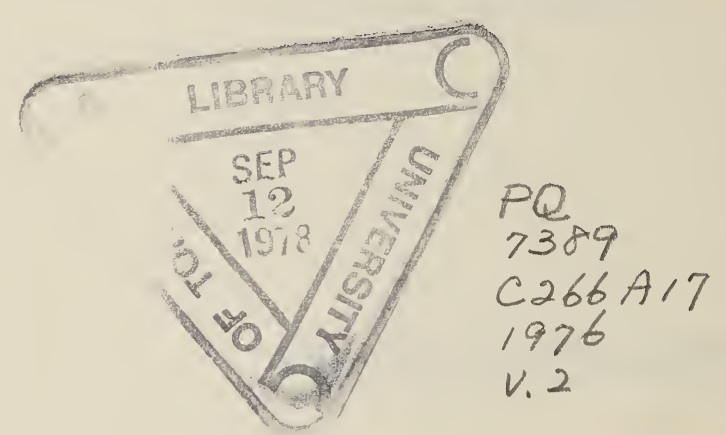

Library of Congress Cataloging in Publication Data

Casal, Julián del, 1863-1893.

The poetry of Julián del Casal.

"A University of Florida book."

Includes bibliographical references.

I. Glickman, Robert Jay, 1928- 


\section{Contents}

ILLUSTRATIVE MATERIAL

vii

LIST OF ABBREVIATIONS

$\mathrm{x}$

INTRODUCTION

xiii

ACKNOWLEDGMENTS

xix

HOJAS AL VIENTO

NIEVE

Appendixes
A. Some Bio-Bibliographical Articles on Casal
B. Some Early Criticism of Casal's Poetry

Bibliography

List of Names and Subjects

Indexes to Publication Data

I. Alphabetical Listing of Titles and Variant Titles
A. Titles
B. Variant Titles

II. Chronological Listing of Poems

III. Poems in Book Order 
Digitized by the Internet Archive in 2015 


\title{
Illustrative Material
}

\author{
TABLES
}

1 Artists Mentioned by Casal before the Publication of Hojas

2 Non-Cuban Authors Mentioned by Casal before the Publication of Hojas

3 Sonnets in Hojas, Nieve, and Rimas

4 The Publication of Casal Poems in Mexican, Guatemalan, and Costa Rican Periodicals during the Author's Lifetime:

A Tentative Bibliography

5 Rubén Darío: Works Published in La Habana Literaria

6 Table of Metrical Data

\section{PLATES}

1 Julián del Casal y Ugareda, the Poet's Father

2 Revisions in "El adiós del polaco"

3 The Staff of La Habana Elegante

4 Autograph of "El sueño en el desierto" $(F, 4$ November 1888)

5 Revisions in "A Coralia"

6 Pedro II of Brazil

7 Two Reactions to the Overthrow of Pedro II (HE, 8 December 1889)

8 A Concert by Ina Lasson and the Joran Sisters (Program as Advertised in the 4 March 1890 Issue of La Gaceta de la Habana)

9 Casal's First Letter to Gustave Moreau

10 Julián del Casal: Portrait with Dedication to Moreau

11 Letter to Luis G. Urbina (22 May 1890) 
12 "Bocetos antiguos": Sequence in Journals Compared with Sequence in Nieve $\quad 160$

13 Enrique José Varona 163

14 Aurelia Castillo de González 167

15 "La agonía de Petronio" (HE, 17 May 1891) 172

16 "Mi museo ideal" (HE, 30 August 1891) 182

17(A) "Sueño de gloria": First Two Pages of the Autograph that

Casal Sent to Moreau 188

17(B) "Vestíbulo": Autograph that Casal Sent to Moreau 190

18 Gustave Moreau: Self-Portrait 193

19 Salomé 194

20 L'Apparition 195

21 Prometheus 196

22 Lorenzo Vecchietta: An Illustration for the Divine Comedy 197

23 Galatée 198

24 Hélène sur les murs de Troie 199

25 Hercule et l'Hydre de Lerne $\quad 200$

26 La Naissance de Vénus 201

27(A) Sapho se précipitant dans la mer $\quad 202$

27(B) La Péri 203

28 L'Enlèvement d'Europe 204

29 Hercule au Lac Stymphale 205

30 "Marfiles viejos": Order of Publication 228

31 Sequence Changes in the Poems of "Marfiles viejos" 228

32 María del Carmen de la Lastra y Owens, the Poet's Mother 235

33 Esteban Borrero Echeverría 246

34 "La gruta del ensueño": Order of Publication 250

35 Sequence Changes in the Poems of "La gruta del ensueño" 250

36 Jeanne Samary by Jacques-Charles-Ferdinand Humbert 253

$37 \quad$ María Cay 257

38 A Kakemono Whose Subject Resembles the One Depicted by Casal

39 Ludwig II of Bavaria 273

40 Neuschwanstein Castle 274

41 Linderhof Castle: Replica of the Grotta Azzurra 274

42 Raimundo Cabrera 283

43 Two Surimono of the Kind that Inspired Casal 337

44 Eulalia de Borbón 351

$45 \quad$ Romeo y Julieta by Juana Borrero 364 
46 “Cuerpo y alma” (HE, 29 October 1893) 374

47 Hortensia del Monte $\quad 387$

48 Serafina Valdivia y Huidobro $\quad 388$

49 Juana Borrero 390

50 Corina Rowland y del Monte 391

51 "Comisión literaria" (HE, 10 May 1891) 395

52 "Centenario del descubrimiento de América: Certamen" (HL, 15 July 1892) 


\section{List of Abbreviations}
B Bustos
C Cartas

Cp Corona poética que a la eterna memoria del gran Cristóbal Colón ofrecen en el IV centenario del descubrimiento de América los alumnos del Real Colegio de Belén

CRI Costa Rica Ilustrada

CT El Correo de la Tarde

d dedication

D LaDiscusión

DC El Diario del Comercio

E El Ensayo

ED Ecos de las Damas

F El Fígaro

$\mathrm{H} \quad$ Hojas al viento

HCR El Heraldo de Costa Rica

$\mathrm{HE}$ La Habana Elegante

$\mathrm{Hg}$ El Hogar

HL La Habana Literaria

L La Lucha

LC Library of Congress

M ElMuseo

MR El Monitor Republicano

MS Manuscript

$\mathrm{N} \quad$ Nieve

p part

P El País

$\mathrm{Pb} \quad$ El Pueblo

PL El Partido Liberal 
R Rimas

s subtitle

t title

U El Universal

UC La Unión Constitucional

UT University of Toronto

V Varia

Ve LaVerdad 


\section{Introduction}

Volume II furnishes detailed information about the texts which comprise Volume I. Each major division of the poetry - Hojas al viento $(\mathrm{Hp} 0)$; Nieve (Np0), "Bocetos antiguos" (Np1), "Mi museo ideal" (Np2), "Cromos españoles" (Np3), "Marfiles viejos" (Np4), "La gruta del ensueño" (Np5); Rimas ( $\mathrm{Rp} 0)$; and Varia (Vp0) - is introduced by a general commentary. This is followed immediately by specific discussions of each poem within the division. In most cases, the specific discussions consist of an introductory statement, notes to the introductory statement, a record of variants, and notes to the variants. These items are printed consecutively and each has a distinctive format.

The Introductory Statement. The main purpose of the introductory statement is to outline the poem's history and to describe the principal characteristics of each of its versions. The introductory statement is not always limited to these points, however. Indeed, a special effort is made to provide additional information so that the author, his times, and the intricacies of his art may be better understood. As a result, the introductions vary considerably in subject matter and length.

Notes to Introductory Statement. Discussions of tangential importance as well as support for assertions made in the introduction to a poem will be found in notes which directly follow the introductory statement. These notes will be easily recognized by their characteristic heading and format (see H3). While all poems have an introduction, not all introductions have notes (see H4).

Variants. According to Enrique Hernández Miyares, one of the poet's closest friends, Casal would generally draft an idea in pencil and, after making needed corrections, would produce a pen and ink copy of his work for submission to the printer. ${ }^{1}$ Although none of the pencil drafts appears to have survived, a few pen and ink versions have come down to us. The earliest is a manuscript of "El sueño en el desierto," which was photographed by El Fígaro and was published in that journal's "Autógrafos" column on 4 November 1888; it is reproduced in Volume III of the Edición del Centenario and in Plate 4 of the present edition. The 
second-earliest extant manuscript is "Aves mis versos son...," which Casal inscribed in the album of Rosario Armenteros de Herrera in August 1890. A reproduction of this poem may be found in Volume III of the Edición del Centenario. Finally, research by this writer has led to the discovery of two autographs that Casal sent to Gustave Moreau in December of 1891: "Sueño de gloria" and "Vestíbulo." Since these documents have never been seen by scholars, significant parts of them are reproduced photographically in this edition. ${ }^{2}$

The disappearance of all manuscripts except the ones just mentioned prevents us from tracing the evolution of Casal's poetry from its very beginnings. Nevertheless, we are able to document the development of most compositions from the moment of their initial appearance in journals until their final publication in book form. This was a vital period in the history of Casal's poems, for at this time, the author made a conscious effort to remove flaws that had escaped his notice in previous versions. As might be expected, Casal devoted most of his attention to the verbal content of his works. However, he also took considerable pains with non-verbal factors such as the position of the poems within a series, their layout on the page, and the punctuation marks that would help bring out their intellectual and rhythmic contours. Casal's belief that all these elements had a role to play in the process of communication obliges us to provide detailed information about them in the present edition.

The record of variants shows textual changes in successive versions of Casal's poetry. Certain exceptions must be noted in this regard, however. Since there is no evidence that the author continued to revise his poems after publishing them in book form, the record of variants excludes all versions of $H, N$, and $R$ poems which came out after the Imprenta $\mathrm{El}$ Retiro edition of Hojas al viento (1890), the Imprenta La Moderna edition of Nieve (1892), and the Imprenta La Moderna edition of Rimas (1893). Also excluded from the record of variants are references to a few versions which, though published during Casal's lifetime, could not be examined by this editor. Allusion to such items is made, however, in the introductory statements and in Indexes I, II, and III.

Differences in format, title, subtitle, and/or dedication which occur between one version of a poem and another are described in the introductory statement, but differences in wording and punctuation that appear in the body of a poem are listed in the record of variants. Since orthography has been modernized in this edition, no consistent effort is made to register differences in spelling. Orthographic variants are recorded, however, when they are associated with changes in punctuation or wording (see $\mathrm{H} 3 / 30$ ).

The record of variants has the following characteristics. Each version of a poem is assigned a column. The earliest version is placed in the leftmost column, and all subsequent versions are listed to the right of it in chronological order. A blank space in any column to the right of an entry 
means that the last form shown has been retained in this version (see $\mathrm{H} 3 / 1$ ). An abbreviation in a column indicates that the form used here is identical to the one found in the version designated by the abbreviation (see $\mathrm{H} 3 / 11){ }^{3}$ At times, a portion of text is printed beside an abbreviation (see H3/68 and H3/83). This means that, except for the element(s) shown, the new version is the same as the one indicated by the abbreviation. When an entry is too long to fit into a column, it is broken at a convenient point and the overflow is printed, right-justified, on the next line (see H3/64). An asterisk * to the left of a line number indicates that a comment about the line will be found in the Notes to Variants section (see H3/76). A paragraph sign in parentheses $(\mathbb{I})$ means that the line is indented (see H3/77). Brackets [ ] around the first letter in a word signify that the letter was capitalized in the version cited, even though it was not the initial letter in the sentence (see H3/83). The word sic in brackets [sic] calls attention to a typographical error (see $\mathrm{H} 3 / 20$ ).

Notes to Variants. These notes are found immediately after the record of variants and have a distinctive format. Although they vary in content, most often they explain why this editor preferred one version of a poem to another or why, in certain instances, he felt obliged to introduce slight changes into the text. Whatever subject they deal with, however, they all have a common aim: to give the reader every opportunity to trace the history of a poem's development, and to understand the reasons behind each of the major decisions which this editor made when preparing the text.

\section{OTHER COMPONENTS OF VOLUME II}

Illustrative Material. As a complement to the material described above, Volume II contains a number of tables, plates, and illustrations. These have been introduced to help the non-specialist gain a feeling for the spiritual climate in which Casal operated, and to help the scholar check the bases upon which certain conclusions about the poet and his times have been founded. Among the most interesting items are reproductions of photographs which Casal used as inspiration for some of his bestknown poems. A key to the nature and location of the illustrative material is presented on pp. vii-ix.

Appendixes. Although many articles on Casal and his poetry have been listed by bibliographers and have been alluded to by critics, most of the articles that were composed in the 1880's and 1890's are now extremely difficult to procure. Aware of this fact, the compilers of the Edicion del Centenario wisely decided to include some nineteenth-century items in their reprint of Casal's works. Because the sample which they selected for publication still leaves some important gaps, however, this editor reproduces fourteen pieces that were written by contemporaries of Casal: six 
bio-bibliographical articles (Appendix A) and eight critical comments on the poet's work (Appendix B). Spelling and punctuation have been modernized in these selections, but no effort has been made to correct factual errors committed by their authors.

Bibliography. A list of materials that were found to be especially useful in the preparation of this edition is presented on pp. 443-451.

List of Names and Subjects. As indicated above, this editor's introductions to Casal's poems are quite varied with regard to subject matter. Although circumstances occasionally permit a given theme to be discussed under a single poem-heading, they often require that different aspects of the subject be treated in different parts of the book. In order to help the reader locate data which might be of special interest to him, a full catalogue of names and subjects is provided near the end of this volume. For illustrations of the way in which information is indexed, see the entries entitled "Darío, Rubén" (p. 453) and "Orientalism" (p. 455).

Indexes to Publication Data. Data concerning the publication of Casal's poems are presented in separate indexes at the end of the book. Index I lists the poems alphabetically by title (see p. 457). To the left of each title, one finds the reference number by which the composition is known in this study, as well as signs indicating whether any version of the work came out with a variant title, subtitle, or dedication. To the right is a record of all versions which are known to have appeared before the termini ad quem that are specified on p. xiv. In addition, a list of variant titles is given on p. 459. Index I should be used when one knows the title of a poem and wishes to find its code number or date(s) of publication.

Index II lists the poems in chronological order by section (Hojas al viento, Nieve, Rimas, and Varia). In essence, the information concerning the poems is the same as that provided in Index I. Unlike Index I, however, the key reference column is not found in the center of the page, but rather on the right (see p. 461). By consulting this column, it is possible to determine which works appeared in a given year and in which order they came out.

Index III differs from Index II in that the poems of Hojas al viento, Nieve, and Rimas are listed in book order, rather than in chronological order (see p. 464). This index, which has its key reference column on the left-hand side of the page, should be used when one knows the code number of a work and wishes to find its title and date(s) of publication.

These are the principal characteristics of Volume II of The Poetry of Julián del Casal: A Critical Edition.

\section{NOTES}

1 "Hojas al viento," in Enrique Hernández Miyares, Obras completas (Havana: Academia Nacional de Artes y Letras, 1916), vol. II, p. 10; reproduced in Appen$\operatorname{dix} B$. 
2 A handwritten copy of "Colón en la Rábida" is known to have existed in this century, but it can no longer be found. The manuscript, which had been donated to Havana's Real Colegio de Belén after Casal's death, was transcribed by a member of the Jesuit community and was published in 1932 together with a brief description of the document. Since no photographs of it seem to have been preserved, there is no way of verifying the accuracy of the transcription. For additional information about this poem, see my discussion of V13.

3 For a complete list of abbreviations used in this work, see pp. $\mathrm{x}-\mathrm{xi}$. 



\section{Acknowledgments}

This volume is the product of several years of sustained effort. During its gestation, I received assistance from numerous institutions, agencies, and individuals. My debt to each of them is great.

I wish to express my deepest thanks to G. L. Stagg, Chairman, Department of Hispanic Studies, University of Toronto, for his constant encouragement of my research endeavors; to the Canada Council and the University of Toronto's Office of Research Administration for their financial support of the investigative phase of my work; and to the Humanities Research Council of Canada for its most generous grant in aid of publication.

Because I was working at a great distance from primary sources, the gathering of data on Casal, his works, and his times often proved extremely difficult. My task was made considerably easier than it would otherwise have been, however, as a result of the cooperation of the Canadian Embassy in Havana, the Cuban Consulate in Toronto, and the Biblioteca Nacional José Martí in Havana, whose staff members located the periodical versions of Casal's poems and furnished me with photocopies of that material; of Mary McTavish and Carole Weiss of the Reference Department of the University of Toronto's John A. Robarts Library, who found the answers to countless questions which arose as my research progressed; of Jean Paladilhe, Curator of the Musée Gustave Moreau in Paris, and Pierre-Louis Mathieu, who furnished me with copies of Casal's letters to Moreau and gave me invaluable information concerning the relationship between the two men; of Ernesto Mejía Sánchez, who allowed me to use his extensive files on the publication of Casal poems in Mexican and Central American periodicals; of Ana Rosa Núnez of the Reference Department of the University of Miami's Otto G. Richter Library, who, in response to my inquiries, uncovered basic data on Ina Lasson and the Joran sisters; and of Marie-Thérèse de Forges, Curator of the Département des Peintures of the Musée du Louvre, who supplied me with data on Jacques-Charles-Ferdinand Humbert, whose portrait of Jeanne Samary inspired one of Casal's best-known poems. 
Invaluable to me as I made my way through the dark wood of Casal research were the intellectual stimulation, scholarly counsel, technical assistance, and moral support given unstintingly by Enrica Jemma Glickman, Division of Humanities, York University. Of my gratitude to her, "Oh quanto è corto il dire ...."?

I am grateful to the following institutions and individuals for providing me with photographic materials. Pictures pertaining to Casal's "Mi museo ideal" were obtained from and are reproduced with the permission of the Musée Gustave Moreau, the Réunion des Musées Nationaux, the British Library Board, the Art Institute of Chicago, J. E. Bulloz, Mrs. Eugene A. Davidson, and Robert Lebel. Advice from John Vollmer and T. M. Quirk of the Royal Ontario Museum in Toronto enabled me to locate material illustrative of Casal's orientalism. A print of Ukiyoe, by Katsukawa Shunsen, was obtained from the Zauho Press of Tokyo and is reproduced with the permission of the Tokyo National Museum; and prints of Surimono (Katsushika Hokusai, Japanese, 1760-1849, woodblock print, Spaulding Collection, 21.7871) and of Lady Arranging her Hair before a Mirror (Hokusai, ukiyoe, painting, Bigelow Collection, 11.7424) were furnished, together with permission to reproduce them herein, by the Museum of Fine Arts, Boston. Material illustrating my discussion of Ludwig II of Bavaria originated with the Associated Press in Frankfurt and the Bayerische Verwaltung der Staatlichen Schlösser, Gärten und Seen in Munich; and photos of three of Casal"s contemporaries originated with the Hispanic Society of America in New York, whose permission to reproduce them is very much appreciated. The photograph of Jeanne Samary was generously made for me by her descendant, Thérèse Alié, in whose home Humbert's painting now hangs.

I extend special thanks to David Cluff of the University of Toronto, to Ivan A. Schulman of the University of Florida, and to Alan M. Gordon of the University of Toronto, each of whom read the manuscript and made suggestions which helped me substantially to improve its quality.

I am also indebted to Patricia Moat of York University for her accurate typing of the manuscript, and to Marjorie Ratcliffe, Oscar Jan Müllerbeck, Anne Elizabeth Hofland, and Evelyn Rugg of the University of Toronto for their careful proofreading of the printed text.

For any errors or omissions in this volume, I alone take full responsibility.

Robert Jay Glickman 


\section{THE POETRY OF JULIAN DEL CASAL:}

\section{A CRITICAL EDITION}


iCubramos siempre de rosas

el camino de los soñadores!

J. del C. 


\section{Hojas al viento}

Julián del Casal was not a prodigy like Rubén Darío. Nevertheless, he had highly refined sensibilities, an absorbing interest in literature and the visual arts, and an irrepressible urge to create works of beauty. These attributes led him to produce some of the finest poetry of nineteenthcentury Spanish America. During his youth and early manhood, Casal became familiar with the works of writers and artists from different lands and different ages. The names cited in his prose and poetry suggest the range of his interests and the extent of his cultural preparation (see Tables 1 and 2). As later discussion will show, some of the figures mentioned by him had a marked influence on his view of reality and the direction of his creative efforts during the initial phase of his career.

Casal's passion for art and literature was a vital part of his being. Every day his abhorrence of the world increased, and every day his need for beauty became more profound. While other people paid scant attention to the negative aspects of urban living, Casal was repelled by many things and did all he could to avoid them. He tried to escape from the "polvo que alfombra las calles; del viento cálido que sopla en todas direcciones; de los miasmas que ascienden del antro negro de las cloacas; de los ómnibus que desfilan al vapor; de los carretones que pasan rozando las aceras; del vocerío de los vendedores, que araña los nervios; de los empleados que corren a las oficinas; de las gentes que preguntan si Oteiza vendrá; y de las innumerables calamidades que vagan esparcidas en la atmósfera de nuestra población ...."1 Above all, however, he fled from large popular gatherings, for he found contact with the masses thoroughly repugnant to his senses. The foul odors, strident sounds, and violent contacts; the crudeness, the disorder, and the loss of independent movement as he was sucked into the crowd made his stomach turn and his blood run cold.

Of all the irritating elements in his environment, noise seems to have been one of the most offensive to Casal's delicate nerves. Although some exceptions may be noted, even the sound of music could cause him extreme discomfort: "Casi tanto como las gentes que ríen alto, como los carretones que ruedan por las calles y como los vendedores que pregonan 
nuestros periódicos, me disgustan los instrumentos musicales. El piano es uno de ellos; no sólo me produce su sonido un efecto desagradable, sino enfermizo. Oída de cerca, cada nota, por baja que sea, me hace el mismo daño que un martillazo en las sienes. No atenúan la sensación las bellezas armónicas de la pieza tocada, ni las maravillas de la ejecución.”2 Casal's aversion to crowds and his fundamental dislike of musical instruments should be kept in mind when we read the music reviews that he submitted to La Discusión and El País, ${ }^{3}$ for those factors help explain why his articles usually lack detailed analyses of the performances he attended and why they contain comments on matters that professional music critics would, in all probability, consider tangential (see my discussion of $\mathrm{H} 49$ ).

With rare exceptions, when Havana did not repel him, it numbed his spirit with tedium. Above him always were the same sky, the same sun, the same stars. The air he breathed was ever impregnated with the same odors. The streets he trod seemed impervious to change. The cafés where he took refreshment and the restaurants where he dined were always frequented by the same patrons. The same actors played again and again in the same theaters. Forever moving in a fixed circle, he found the everyday routine an abomination, and, like Baudelaire, he was prompted to exclaim: "O Satan, prends pitié de ma longue misère!"4

Like the city, the world of nature also failed to please Casal. Evidence shows that in order for it to interest him for its own sake - and not as a backdrop for human activity, as in "Tras la ventana" $(\mathrm{H} 6)$ or "Idilio realista" (H43) - nature had to be intensely dramatic, like the scene described in "Crepuscular" (R2), or it had to be subjected to the rules of art, like the Jardín de las Delicias in Guanabacoa. ${ }^{5}$ Instead of artistry, however, Casal generally found an ugly sameness in nature. The unchanging blueness of the sky and verdure of the terrain bored him, on the one hand, and chafed his sense of color harmony, on the other: indeed, the eternal juxtaposition of blue and green in the Cuban landscape produced one of the most anti-aesthetic impressions Casal could imagine. ${ }^{6}$ Furthermore, unbridled nature was not dramatic in a noble sense; on the contrary, it was heartless, destructive, and seemingly intent on bringing out the worst in man. ${ }^{7}$ It is no wonder, therefore, that we find very little nature description per se in Casal's poetry and prose.

In Casal's opinion, the plastic arts had none of the drawbacks of crude reality. They imposed order and harmony on the chaotic flux of life. They gave pleasure to the sight and gratified the touch, without offending the other senses. They combatted boredom by capturing the drama of human existence at the moment of greatest intensity and locking it in a form that resisted the incursions of time. They proved that, even in an age when crass materialism and insolent democracy were shattering noble traditions of the past, there still existed superior beings who could commit themselves to the ancient ideal of Beauty. Thus, they elevated the spirit of those who, opposing the iconoclasm of the epoch, still believed in God, 
and gave to doubters some hope that the universe was not entirely devoid of higher values. In short, they permitted the beholder to withdraw from the maelstrom of life into a haven of serenity where he could forget his afflictions and experience all the joys that eluded him in his daily journey through the world (see H22).

For these reasons, Casal grasped every opportunity to leave reality behind and pass into the alluring realm of Art. At times, he would visit galleries that exhibited works of local artists such as Armando Menocal. When he was especially fortunate, he would be invited to the studio of an outstanding painter like Guillermo Collazo or to the home of an elite member of Havana society, where he could feast his eyes on the finest paintings, statuary, and furniture, as well as on a dazzling array of curios imported into Cuba from every part of the globe. ${ }^{8}$ Most often, however, he would spend his time in shops that displayed objets d'art from lands which seemed untainted by the ugliness that characterized his own milieu, ${ }^{9}$ he would search for prints of works by artists whom he particularly esteemed, he would examine verbal reproductions of paintings that were capturing the imagination of foreign literati like Huysmans (see my discussion of N8), or he would invent his own graphic creations and bring them into being with the artistry of words.

"El poeta y la sirena" (V2), which was published on 5 March 1881, indicates how early in his development as a writer Casal tried to do with words what graphic artists did with line and color. Of the two types of depiction which appear in the poem, however, it was not the description of places and objects that especially interested Casal, but, rather, the description of people. Indeed, almost everywhere we look, we find evidence showing that one of his most cherished goals was el retrato elevado hasta el arte. ${ }^{10}$

What Casal did in "El poeta y la sirena" he would do many times in the future, both in poetry and prose: that is, he would begin his verbal canvases with a description of the setting, and would then concentrate on the figure that was to occupy the foreground of attention. Sometimes, the introductory description would be fairly long, and thus would carry special weight in the composition. Representative of this technique are ll. 1-28 of "Amor en el claustro" (H3) and the first two paragraphs of "El viaje a Venecia." 11 Sometimes, the introductory description would be quite short and would allow the reader to move from the setting to the center of interest within the span of a single sentence. Lines 1-8 of "El adiós del polaco" (H17) are illustrative of this variant in the basic pattern. From time to time, however, Casal would omit background description altogether and would focus directly on his subject. On these occasions, he followed one of two procedures: after depicting salient physical characteristics of the subject, he would either add a comment on the surface reality that he had just described - see "Estatua de carne" (H33) and the opening paragraphs of "El General Sabas Marín y su familia"12 - or, as in 
TABLE 1

ARTISTS MENTIONED BY CASAL BEFORE THE PUBLICATION OF HOJAS

French

Italian
Perugino [Pietro Vannucci]

Other

(1446-1523)

Leonardo da Vinci

(1452-1519)

Albrecht Dürer
(1471-1528)

Tiziano Vecellio

(1477-1576)

Giorgione [Giorgio

Barbarelli] (1478-1511)

Correggio [Antonio Allegri] (1494-1534)
Hans Holbein (1497-1543)

Veronese [Paolo Cagliari] (1528-1588)

Petrus Paulus Rubens (1577-1640)

Nicolas Poussin

(1594-1665)

Lorenese [Claude Gellée] (1600-1682)

Giovan Battista Piranesi (1720-1778)

Jacques-Louis David

(1748-1825)

Ferdinand-Victor-Eugène

Delacroix (1799-1863)

Jean-Louis Lachaume de

Gavaux (1820-1882)

William Adolphe

Bouguereau

(1825-1905)

Léon-Joseph-Florentin

Bonnat (1834-1923)

John George Brown

(1831-1913)

Laurens Alma-Tadema (1836-1912)

Giacomo Ginotti

(1837-1897)

Rembrandt van Rijn (1606-1669)

Bartolomé Esteban Murillo (1618-1687)

Charles-Émile Auguste

Carolus-Duran

(1838-1917) 
the case of "Una maja" (N19), he would withhold comment and let the portrait speak for itself. But whatever technique he might employ in a given work of prose or poetry, his ideal remained fundamentally the same from the beginning of his career to the end: namely, to create verbal portraits - or bustos, as he sometimes called them - of exceptional beauty and accuracy. By contrast, paisajismo was only of secondary importance to Casal. ${ }^{13}$

Immersion in art was not the only way to freedom for Casal, however. To his mind, travel also provided a means of escaping from the bonds of duty and the weariness of work, which led to boredom first, and then despair. ${ }^{14}$ As he learned firsthand when he went to Spain in 1888 , a journey by sea would deliver the soul into a state of blissful calm, while exploration of a foreign land would rouse the spirit from its quietude and electrify it with countless new sensations. Of course, one could not travel all the time. Nevertheless, there was a substitute which was always available and which, in certain ways, was even better than the real thing: literature. Like travel, books gave the individual a chance to escape the here and now, and to broaden the scope of his experience. In contrast to travel, though, books were inexpensive, they allowed the voyager to move in the untainted environment of imagination, and they could be replaced immediately if, for some reason, they failed to satisfy the needs or tastes of the moment.

Throughout his life, Casal was an avid reader. Some of the works he read were classics that had been consecrated by generations of readers on both sides of the Atlantic. Others were novelties recommended by friends who had just returned from abroad, publications that he had come across personally during his short stay in Spain, or books and periodicals that had been sent to Havana by contacts in various foreign cities. So great was the number of items being published in his time, however, that he was obliged to impose severe limitations on his natural curiosity. ${ }^{15}$

Although it is unreasonable to assume that Casal's knowledge of Hispanic literature was abnormally limited, certain interesting facts emerge from an examination of the works he published between December 1885 and May 1890, when Hojas went on sale. For one thing, the only nonCuban Spanish Americans whose names he mentioned were from Mexico: Salvador Díaz Mirón, Manuel Gutiérrez Nájera, Francisco A. de Icaza, Manuel J. Othón, Juan de Dios Peza, Manuel Puga y Acal, Vicente Riva Palacio, and Luis G. Urbina. The absence of allusions to authors from other Spanish American countries cannot be taken to mean that Casal was unaware of their existence, for, in addition to the books he had been obliged to study in school and the ones he had acquired on his own initiative at a later date, he read poems, stories, and articles by a variety of American writers in the many periodicals that entered Cuba during the period in question. What Casal's silence about American writers does suggest is that his preferred sources of literary inspiration lay elsewhere.

Considering that he was educated in a Spanish colony, it might also 
seem strange that, aside from the eight Mexican authors just mentioned, Casal cited only nineteen Hispanic writers in all the works he published before May 1890: Arolas, Bartrina, Bécquer, Ercilla, Espronceda, Fernández Bremón, Eugenio Antonio Flores, Francisco Gras y Elías, Meléndez Valdés, Núñez de Arce, Pardo Bazán, Pi y Margall, Manuel Reina, Salvador Rueda, Ruiz Aguilera, F. Salazar, José Selgas y Carrasco, Esteban Manuel de Villegas, and José Zorrilla. Although this list shows which authors Casal had read, the presence of a particular name should not be taken as a sure sign of admiration. His remarks concerning Flores, Gras y Elías, and Salazar make this point quite clear. ${ }^{16}$ On the other hand, the absence of certain writers - the major figures of Spain's Golden Age, for instance - should not be interpreted to mean that he was unfamiliar with or unresponsive to their works. It may simply be that he lacked an occasion to refer to them in his writings. Yet if one believes that admiration makes its own opportunities, then Casal's omissions are eloquent indeed.

Though critics of Spanish American letters seldom emphasize the fact, it is clear that important similarities existed between economic and literary realities in the late nineteenth century. For example, just as the prodigious development of the transportation industry and the generalized application of laissez-faire policies in international commerce enabled Spanish American moneyed classes, with ever greater ease, to import manufactured goods as well as culinary, recreative, and sartorial fashions from Western culture centers, it was inevitable that commerce and technology would also exert a dramatic influence on the writers of the time. Like their wealthy compatriots, whose incessant acquisitiveness they so frequently censured, the fin de siglo writers often tried to fill their own world - either the real one in which they lived, or the literary one in which they dreamed - with the latest fashions from abroad. Basically, these authors imported two things into America: first, they brought in literary compositions by artists who had gained renown in Europe (which helps explain the numerous transcriptions and translations of foreign works that appear in Spanish American periodicals of the time) and, second, they introduced the raw materials and techniques of literary production that had been the bases of the foreigners' success. Any land, of course, might make a contribution to the enrichment of American letters, but, as far as quantity and excellence of production were concerned, none could compete with France. And, as Justo Sierra indicated in his prologue to the poems of Manuel Gutiérrez Nájera, there was no reason whatever to turn away from France. Since that nation had been setting Western cultural standards for so many decades, why should Americans look instead to Spain? After all, if they did so, they would merely be importing French influence secondhand, for, as history clearly proved, sooner or later the Spaniards too had fallen under the Gallic spell. ${ }^{17}$ Simply stated, therefore, the motto was "Let's cut out the middleman!" And this position - based in 
part on a desire to keep up to date with progress, and in part on a need to erase the shameful memory of years of Spanish domination - was taken with as much conviction by Cuban authors like Casal, who still lived under Spanish rule, as by those whose forefathers had given them the cherished legacy of political freedom.

Aside from any political implications which his remarks to Enrique Hernández Miyares may have had, there is ample evidence that, insofar as literature was concerned, Casal would have been an ardent supporter of "el partido anexionista francés," if such an organization had been founded in Cuba during his youth. ${ }^{18}$ Any doubt that might arise about this point will quickly be dispelled by a glance at the list of French authors to whom Casal alluded in his poetry and prose between the middle of December 1885 and the beginning of May 1890. As shown in Table 2, his references were frequent and varied. They may be categorized as follows (with selected examples in parentheses): the naming of an author (Barbey D'Aurevilly), a character (Daudet's Sapho), or a work (Flaubert's Salammbô); the use of an illustrative quotation, either in the original French (Mendès) or in translation (Molière); the paraphrasing of a seminal idea (Bourget); the publication of an incidental critique (Zola) or an extensive book-review (Maupassant); the adoption of a pseudonym of unmistakable literary origins (Hernani); the translation of especially admired poems (Gautier) or short stories (Baudelaire); and the imitation of literary models of limited proportions (Coppée's "Le Pharaon") or of broad scope (the works of Juliette Lambert).

Table 2 reveals another fact, however: even though Casal had a general leaning towards French literature, he also had very definite preferences within it. Various factors help explain these preferences, but three points deserve particular attention. First of all, Casal felt a sentimental, philosophical, or aesthetic kinship with certain writers. Baudelaire was one of these. Second, he knew that if an author had been well chosen to begin with, the reading of additional works by him would not likely result in "cruentas decepciones." 19 Guy de Maupassant would surely occupy a place in this category. And third, he found that, despite the uniqueness of his tastes, he could not avoid being swept along by the tide of admiration that certain masters had generated among cultured people of his time. More than any other writer, Victor Hugo had this kind of impact in the western world during the nineteenth century. The words of Manuel González Prada show why Hugo was so important: "Para estudiar el espíritu de nuestro siglo necesitamos leer las pájinas del gran poeta: conociendo a Victor Hugo, sabemos lo que fuimos, lo que somos, lo que anhelamos ser. Más que el tipo de una raza, debe llamarse el hombre representativo de una época." ${ }^{20}$ In his esteem for Hugo, therefore, Casal proved that he was no different from the majority of his contemporaries.

Between 1885 and 1890, Hugo appears quite often in Casal's works. Sometimes, Casal makes a brief allusion to Hugo in a newspaper article; 
on occasion, he imitates the great man's poetry; and during the seven months just preceding and following the publication of Hojas, he consistently uses the Hugo-inspired pseudonym "Hernani." It is possible, however, that Hugo's influence on Casal did not end here. The very titles Les Feuilles d'automne and Hojas al viento bear a conceptual similarity that may not be entirely coincidental. The following excerpt from Hugo's "Préface" may have suggested to Casal both the title of his collection and the subject matter of "Introducción" $(\mathrm{H} 1)$ :

Qu'est-ce d'ailleurs que ces pages qu'il livre ainsi, au hasard, au premier vent qui en voudra? Des feuilles tombées, des feuilles mortes, comme toutes feuilles d'automne... . C'est un regard mélancolique et résigné, jeté çà et là sur ce qui est, surtout sur ce qui a été. C'est l'écho de ces pensées, souvent inexprimables, qu'éveillent confusément dans notre esprit les mille objets de la création qui souffrent ou qui languissent autour de nous.... Ce sont enfin, sur la vanité des projets et des espérances, sur l'amour à vingt ans, sur l'amour à trente ans, sur ce qu'il y a de triste dans le bonheur, sur cette infinité de choses douloureuses dont se composent nos années, ce sont de ces élégies comme le cœur du poète en laisse sans cesse écouler par toutes les fêlures que lui font les secousses de la vie. ${ }^{21}$

If we regard Casal's "Introducción" as the poetic counterpart of Hugo's "Préface," we observe still another similarity: just as Hugo placed an impassioned autobiographical poem, "Ce siècle avait deux ans . . .," immediately after his introductory remarks, Casal placed "Autobiografía" right after his own "Introducción." This, too, may be mere coincidence; yet when we consider the extent of Casal's admiration for Hugo, we find it difficult to dismiss the possibility that Hugo may have influenced not only Casal's choice of title for his first book of poems, but also the manner in which he would present that book to his readers.

Irrespective of its source of inspiration, the title Hojas al viento clearly implies that Casal's first collection of verse is an "autumn" book. This impression is reinforced by the contents of "Introducción," a poem in which Casal states that publication of Hojas will help him shed the cares that have made the immediate past a time of bitter sorrow. Once his preoccupations are cast to the winds of oblivion, he will be able to welcome new dreams-dreams that will fill his soul with joys like those he possessed in the carefree springtime of his life.

Hojas al viento may be an "autumn" book in a more concrete way than this, however. Despite the fact that it came out in the spring of 1890 , there is reason to believe that Casal wanted it to appear in the fall of 1889. From a strictly practical standpoint, its impact would be greater if the book were published in the fall or winter-the "high season" for social life and 
cultural activities - than if it were brought out in the spring or summer. Casal's awareness of this fact is implicit in the following statement about the seasons which he made in the 7 July 1890 issue of La Discusion:

El Verano, dios terrible, representado en las antiguas mitologías de los países septentrionales bajo la forma de un monstruo colérico, volcando sobre el mundo, desde las alturas celestes, una especie de tanque de plomo derretido que, al caer en la tierra, abrasa la vegetación, seca las aguas y paraliza las fuerzas vitales; se ha presentado cruelmente este año entre nosotros, seguido de su innumerable cortejo de males, haciendo emigrar a muchas familias que, para huir de sus cóleras, se marchan al extranjero o se refugian en los pintorescos caseríos de los alrededores de nuestra población.

Fuera de los teatros, no es posible encontrar, en esta época, ningún sitio agradable en que pasar las noches, porque los salones cierran sus puertas hasta la llegada del invierno, estación propicia para todo género de diversiones. ${ }^{22}$

Additional support for the theory that Casal wished to publish Hojas in the latter half of 1889 is derived, by implication, from a review of his conduct during subsequent years. His handling of Nieve and Bustos y rimas shows that he did indeed consider fall and winter as the best time to bring his work before the public. According to Casal, Nieve was a "winter" book by its very nature: "Se titula Nieve, porque la nieve, como mi poesía, es pasajera, porque es cosa de invierno y yo me encuentro en el de mi vida y, por último, porque sobre el fondo claro, casi transparente de mis condiciones, lo que me aleja de los decadentes, se descubren los mismos tonos que tienen los témpanos a la luz." ${ }^{23}$ The logical time to publish such a book would be winter, and, as Casal informed Gustave Moreau on 11 August 1891 , that was precisely when it was supposed to come out: "Dans le'hiver prochain, je songe a publier mon second volume de vers ..." (C1/23-25). ${ }^{24}$ Unfortunately, circumstances prevented him from realizing this plan, and, like Hojas, Nieve appeared in the spring (see my discussion of $\mathrm{Np} 0$ ). In contrast to Hojas and Nieve, Bustos y rimas went to press at the height of the literary season-its schedule being only slightly delayed by the author's demise.

The obvious question to ask at this point is, "If it is true that Casal wanted to publish Hojas in the fall of 1889, what prevented him from doing so?" The major reason, it may be assumed, was financial inability.

In the fall of 1888 , about six months after losing his job as clerk in the Dirección de Hacienda, Casal sold the last piece of property that had been willed to him by his father. This sale brought in enough cash to pay for the trip to Europe which he had dreamed of for so many years. As anyone who knew him might have expected, however, Casal spent his money 
recklessly while abroad and, in a short time, was forced to return to Havana (see my discussion of H25).

The period immediately following his return was an extremely difficult one for Casal. Not only had he used up his meager patrimony, but he saw no way to recoup his losses quickly. As far as is known, he lacked regular employment from the moment of his return until 28 November 1889 , when he was hired as a columnist by the daily newspaper La Discusión. Under the circumstances, it was impossible for Casal to publish a book of poems at his own expense in 1889 , and, since no Maecenas came forth with an offer to publish it for him, the project had to wait until a more propitious time.

The job on La Discusion had several drawbacks, not the least of which was that it obliged Casal to attend functions and write about subjects that were extremely distasteful to him. Nevertheless, it had one outstanding virtue: at a time of pressing financial need, it gave him a modest, but steady income. This was supplemented by small amounts which he earned every now and then by publishing a short piece in one of Havana's other periodicals. As a result of these activities, Casal became known to an ever wider circle of readers, and, in spite of his peevish tone and elitist attitude, which irritated some people, his prestige grew in the eyes of those with superior culture and more refined tastes. One such person, Ricardo del Monte, demonstrated his faith in Casal's potential by offering him the "Crónica Semanal" of El País after José Fornaris indicated that he planned to give up writing that column. Whatever esteem del Monte may have had for Casal, however, was far outweighed by Casal's admiration for del Monte-and not without reason.

Ricardo del Monte y Rocío (b. Cimarrones, Matanzas Province, 1830; d. Havana, 20 February 1909) was a nephew of Domingo del Monte, one of the most influential figures in Cuban literature and politics during the first half of the nineteenth century. The fact that he was closely associated with his uncle in Cuba and that he travelled with him in Europe after 1843, when Don Domingo was forced to leave his homeland for political reasons, accounts in large measure for the soundness of Ricardo's cultural background, the acuteness of his critical vision, the excellence of his literary and journalistic production, and the earnestness of his participation in Cuban social and political affairs.

Ideologically, Ricardo del Monte was an advocate of autonomismo, and, in 1878, when the Partido Liberal was founded to promote this cause, he was chosen to draft the Party's "Manifiesto al país." Like its author, this document was moderate in all respects. Its basic message was that advancement towards desired goals should come about through evolutionary means and not through the violence of revolution. Despite its moderation, however, the manifesto was quite explicit about the aims of the Party and left no doubt that the men it spoke for were sincerely dedicated to the welfare of the Cuban people. 
Over the years, del Monte's commitment to autonomismo expressed itself in many ways, but the most important of all his activities in this regard were his endeavors in the field of journalism. When the Partido Liberal came into being, he joined with Antonio Govín y Torres to direct $\mathrm{El}$ Triunfo, the Party's official organ. In the course of time, this newspaper changed its name to El Trunco and then to El Pais, yet one thing always remained the same: del Monte's exemplary direction of the paper from 1878 until Cuba became free of Spanish domination. After that, there were new tasks for del Monte to undertake, but that chapter lies beyond the scope of the present study.

During his youth, Casal had heard a great deal about del Monte and had become familiar with a number of his works, among them the critical essay "El efectismo lírico." ${ }^{5}$ Then one night, while attending a wedding reception, Casal saw del Monte for the first time. As he explains in Bustos, the impression that this renowned gentleman made on him was truly inspiring: "se presentó ante mi vista ... revelando en su traje la severa elegancia de un londonense y en sus maneras la delicadeza encantadora de un diplomático, a la vez que el deseo incesante de buscar la sombra, de huir de los sitios de honor, de pasar inadvertido entre los concurrentes y de no atraer las miradas de ninguno de ellos." Then, after presenting a detailed description of del Monte's physical characteristics, Casal concludes the portrait with the following comment on his spiritual essence: "Del conjunto de su persona se desprendían, como vapores perfumados del disco de un astro, cierta indolencia criolla, cierta modestia natural y, por encima de todo, cierta bondad oculta, discreta, silenciosa, atrayente, retentiva y espiritual."26

Although Casal does not say when they became acquainted, there is good reason to believe that it was before May 1888. Obviously, as a member of the Círculo Habanero, Don Ricardo would have had contacts with Casal through La Habana Elegante, the society's official organ and, since 1885, Casal's main outlet for the publication of original literary works (see Np3). Nevertheless, when we read Casal's 13 May 1888 article on Cuban journalists, we get the impression that the two men were still not on intimate terms. ${ }^{27}$ In the months that followed, however, they drew closer together and, while Casal was still employed at La Discusión, del Monte arranged to have him join the staff of El Pais. In gratitude for this consideration, Casal publicly dedicated his first collection of poems to Don Ricardo. ${ }^{28}$ The words he used in his dedicatory statement on p. 3 of Hojas reveal the intensity of his admiration for this distinguished gentleman:

A Ricardo del Monte, al muy querido y muy venerado maestro, dedica sus primeros versos, J. del C. 
Hojas al viento was printed at Havana's Imprenta El Retiro on or about 5 May 1890. It was a modest ninety-six page paperback whose price, as indicated on the cover, was "un peso en billetes." According to a notice in the 11 May 1890 issue of El Figaro, it could be found at Havana's principal bookstores. The actual number of sales is unknown, but in all probability it was fairly limited. For one thing, the printing run was relatively short. ${ }^{29}$ In addition to this, however, was the fact that, in his enthusiasm at seeing his dream a reality, Casal gave out so many complimentary copies of the book that, to quote Enrique Hernández Miyares, "de seguir regalándoselo a todo el mundo, como sigue, ipobre editor!"30

Although Hojas al viento may not have been destined for financial success, it was read and reviewed by a number of critics almost as soon as it came off the press. Among them were "Rui Blas," Benjamín de Céspedes, Francisco Chacón, Nicolás Heredia, Enrique Hernández Miyares, Enrique José Varona, and Manuel Zeno Gandía. ${ }^{31}$ Whether, like Enrique Hernández Miyares, they were intimate friends of Casal, or, like the Puerto Rican writer Manuel Zeno Gandía, they had never met him personally, all of these critics avoided calling attention to the minor flaws in Hojas, for they knew that this was Casal's first book, and, realizing that he was a poet of talent, wished to encourage him as much as possible. What was obvious to them was that Casal lived in perpetual conflict with his environment and that, in order to alleviate his pain, he took refuge in books which reflected the ideas, emotions, and life-style of people who inhabited a world much different from his own. Varona, for example, indicated that Casal often filled his poetry with elements that were neither part of Cuba's history nor its present reality: "trovadores vagabundos y castellanas melancólicas; jaurías y monteros; góndolas azules y pajes efebos; conventos en ruinas y monjes sombríos; y llega hasta a contemplar pastorcillas rubias bajo el sol tropical o a la sombra de los plátanos rumorosos." Heredia and Zeno Gandía stressed the fact that Casal's poetry was marred by a persistent melancholy that was not of Cuban origin, but was derived from Decadent literature imported from Europe. Nevertheless, all agreed that Casal had many points in his favor. No influence from abroad, it appeared, could stifle the sincerity of his feelings, weaken the vigor of his dreams, or dull the acuteness of his poetic intuition. Perhaps not every poem was a jewel, but certain facts could not be denied: Casal had a vividnesss of imagination, facility for rhyme, and control over form that were noteworthy indeed; his expression was original, yet correct; and his imagery was abundant, colorful, and moving. As a result, he exerted an uncommon power over his readers. Without a doubt, this young writer seemed destined to enjoy a brilliant future.

\section{HpO: Notes to Introductory Statement}

1 "Album de la Ciudad: El Fénix" (D, 13 March 1890), in Ed. del Cent., vol. II, p. 75 . 
2 "Veladas teatrales: Un cornetinista" (D, 23 April 1890), in Ed. del Cent., vol. II, p. 113.

3 See Ed. del Cent., vols. II and III.

4 This verse is used as a refrain in Baudelaire's "Les Litanies de Satan," poem CXX in Les Fleurs du mal. In his article "Noches morosas" ( $D, 15$ January 1890), Casal quotes the line as follows: "O Satan! aie pitié de ma longue misère ..." (Ed. del Cent., vol. II, p. 27).

5 See "Fuera de la Ciudad: Un jardín" ( $D, 14$ January 1890), in Ed. del Cent., vol. II, p. 25.

6 See my discussions of "En el campo" (R36) and "Tras una enfermedad" (N36).

7 See Casal's "Carta abierta" to Carlos Noreña $(F, 14$ September 1890), in Ed. del Cent., vol. I, p. 168.

8 Cf. his description of Collazo's studio in Ch. XIII of La Sociedad de la Habana (HE, 24 June 1888), in Ed. del Cent., vol. I, p. 152.

9 See "Album de la Ciudad: El Fénix" (D, 13 March 1890), in Ed. del Cent., vol. II, pp. 75-77.

10 See the first two paragraphs of "Armando Menocal: Nuevos retratos" (D, 3 March 1890), in Ed. del Cent., vol. II, p. 63.

11 This composition, dating from 2 September 1886, was Casal's contribution to the communal novel Solos, that was published in installments by El Fígaro (see Ed. del Cent., vol. I, pp. 161-162).

12 Ed. del Cent., vol. I, p. 132.

13 "Paisaje de verano" (N46) is one of the few nature descriptions in which Casal makes no reference whatever to human beings.

14 See "Crónica" (F, 2 June 1889), in Ed. del Cent., vol. I, p. 165.

15 See "Picota literaria" (D, 22 March 1890), in Ed. del Cent., vol. II, p. 84.

16 Ibid., pp. 84-85.

17 Justo Sierra, "Prólogo," in Obras de Manuel Gutiérrez Nájera: Poesía (Mexico: Oficina Impresadora del Timbre, 1896), pp. vii-viii.

18 "Julián del Casal, patriota," in Hernández Miyares, Obras completas (Havana: Academia Nacional de Artes y Letras, 1916), vol. II, p. 36; reproduced in Ed. del Cent., "Poesías," p. 307.

19 "Picota literaria," in Ed. del Cent., vol. II, p. 84.

20 Manuel González Prada, "Victor Hugo," in Pájinas libres (Paris: Tipografía de Paul Dupont, 1894), p. 170. The essay is dated 1885.

21 Oeuvres poétiques complètes (Montreal: Éditions Bernard Valiquettes, 1944), p. 126.

22 "Salones habaneros: Una recepción" ( $D, 7$ July 1890), in Ed. del Cent., vol. II, p. 175.

23 Ed. del Cent., vol. III, p. 90.

24 The code reference C1/23-25 should be interpreted as Carta 1, lines 23-25. A transcription of the twelve letters that Casal wrote to Moreau between 11 August 1891 and 1 January 1893 is to be found in Robert Jay Glickman, "Julián del Casal: Letters to Gustave Moreau," Revista Hispánica Moderna, año XXXVI, nos. 1-2 (1972-1973), pp. 101-135. Each letter has been assigned a sequential 
code number $(\mathrm{C} 1, \mathrm{C} 2$, etc.) and, to further simplify reference, line numbers have been printed in the margin. Thus, the coding system used for the letters is essentially the same as the one used for the poetry.

25 Published in La Revista de Cuba, vol. III (1878), pp. 133-172. According to Casal, this was del Monte's finest critical study.

26 Bustos y rimas (Havana: Imprenta La Moderna, 1893), pp. 11 and 13; Ed. del Cent., vol. I, pp. 245-246.

27 See the paragraph in "La prensa" (HE, 13 May 1888) which Casal devotes to del Monte (Ed. del Cent., vol. I, p. 147).

28 Casal makes this admission in a letter to Esteban Borrero Echeverría on 19 March 1891 (see Ed. del Cent., vol. III, p. 85).

29 José Antonio Fernández de Castro, "Glosa a unas líneas de Casal," in Social, vol. VIII, no. 3 (March 1923), p. 14.

30 "Hojas al viento," in Obras completas, vol. II, p. 13. Casal did not limit his generosity to Cuban friends and colleagues, but sent copies of Hojas abroad as well. Among the Spanish American recipients of the book were Luis G. Urbina (see Plate 11, where Casal's letter of 22 May 1890 is reproduced), Rubén Darío (see Np0), and Manuel Gutiérrez Nájera (see N6).

31 Rui Blas, "Comentario sobre Hojas al viento y su autor" (La Tribuna, 7 May 1890); Benjamín de Céspedes, "Hojas al viento" ( $F, 25$ May 1890); Francisco Chacón, "Versos de Casal (Hernani): Crónica sobre el libro de Casal" (D, 8 May 1890); Nicolás Heredia, "Julián del Casal (Hojas al viento)," in Puntos de vista (Havana: A. Alvarez, 1892), pp. 170-175; Enrique Hernández Miyares, "Hojas al viento," in Obras completas (Havana: Academia Nacional de Artes y Letras, 1916), vol. II, pp. 9-13; Enrique José Varona, "Hojas al viento," Revista Cubana, vol. XI (May 1890), pp. 473-477; Manuel Zeno Gandía, "Hojas al viento" ( $F, 29$ June 1890).

TABLE 2

\section{NON-CUBAN AUTHORS MENTIONED BY CASAL BEFORE THE PUBLICATION OF HOJAS}

LANGUAGE GROUPS. All authors are listed according to the language in which they wrote. The groups are Classical (i.e., Greek and Latin), English, French, German, Italian, Persian, Russian, and Spanish. For the reader's convenience, the Spanish list has been divided into two categories: Peninsular and Mexican. Although there can be no doubt that, before publishing Hojas, Casal knew the works of authors from other countries of the Hispanic world, he did not refer to those authors in sources that are available to us.

AUTHOR. The names are arranged alphabetically within each language group. Whaî must be emphasized is that the list represents only a small part of Casal's total exposure to literature during the initial period of his career. For example, besides failing to include numerous classical and Hispanic writers whose works were part of the standard school curriculum of the time, it does not contain 
references to a considerable number of "non-standard" writers with whom Casal was probably familiar before he published Hojas (e.g., Rubén Darío, Ugo Farchetti, Jules Lemaître, Stéphane Mallarmé, Henry Charles Read, and Paul Verlaine). There are two reasons for these omissions: first, scholars have not found everything that Casal wrote before May 1890; and second, Casal chose to mention only certain authors in the writings that have been collected.

PLACE OF PUBLICATION. The following abbreviations are used: HE = La Habana Elegante, $\mathrm{D}=$ La Discusión, $\mathrm{F}=$ El Fígaro, $\mathrm{x}=$ not published in any periodical before appearing in Hojas.

Date of PUblication. The dates shown in this column indicate all direct and indirect references which Casal is known to have made before the beginning of May 1890 . However, the first date beside a name should not be taken to mean that Casal had just become acquainted with the works of the author; although this was true in certain instances, the fact is that, in others, he had been introduced to his works some time earlier.

SOURCE. This section indicates where Casal's references may be found. A Roman numeral followed by an Arabic number (e.g., I, 180) signifies a location, by volume and page, in the Ed. del Cent. An "H" followed by an Arabic number (e.g., H43) identifies a poem in Hojas. If this code is in turn followed by a solidus and another Arabic number (e.g., H43/45), the reference is to a specific line in the poem. "Nunn" plus an Arabic number refers to a page in Marshall E. Nunn's Selected Prose of Julián del Casal.

$\begin{array}{llll}\text { AUthor } & \begin{array}{l}\text { PLACE } \\ \text { OF PUB. }\end{array} & \begin{array}{l}\text { DATE } \\ \text { OF PUB. }\end{array} & \text { SOURCE } \\ \text { Anacreon } & \text { CLASSICAL } & & \\ & \text { HE } & 20 \mathrm{Dec} 85 & \mathrm{I}, 180 \\ \text { Caesar } & \mathrm{HE} & 12 \mathrm{Feb} 88 & \mathrm{I}, 192 \\ \text { Cicero } & \mathrm{HE} & 12 \mathrm{Feb} 88 & \mathrm{I}, 191 \\ \text { Horace } & \mathrm{HE} & 12 \mathrm{Feb} 88 & \mathrm{I}, 191 \\ & \mathrm{HE} & 20 \mathrm{Dec} 85 & \mathrm{I}, 180 \\ \text { Vergil } & \mathrm{HE} & 12 \mathrm{Feb} 88 & \mathrm{I}, 192 \\ & \mathrm{HE} & 24 \mathrm{Nov} 89 & \mathrm{H} 43 / 45 \\ & \mathrm{HE}, \mathrm{F} & 8 \mathrm{Dec} 89 & \mathrm{H} 45 / 51 \\ \text { Zoilus } & \mathrm{D} & 15 \mathrm{Jan} 90 & \mathrm{II}, 27 \\ & \mathrm{HE} & 23 \mathrm{Feb} 90 & \mathrm{III}, 160 \\ & \mathrm{HE} & 20 \mathrm{Dec} 85 & \mathrm{I}, 186\end{array}$

ENGLISH

Byron, Lord (George Gordon)

$\begin{array}{lrl}\text { HE } & \text { 20 Dec } 85 & \text { I, 180 } \\ \text { F } & \text { 2 Sep } 86 & \text { I, 162 } \\ \text { HE } & \text { 22 Jan } 88 & \text { H37/7 } \\ \text { HE } & \text { 8 Apr } 88 & \text { I, 140 } \\ \text { HE } & \text { 23 Feb } 90 & \text { III, 161 }\end{array}$


Hp0

AUTHOR

De Quincey, Thomas

Moore, Thomas

Poe, Edgar Allan

Rossetti, Dante Gabriel

Shakespeare, William

Spencer, Herbert

Amiel, Henri-Frédéric

Banville, Théodore de

Barbey d'Aurevilly,

Jules Amedée

Baudelaire, Charles

Béranger, Pierre-Jean de

Boisgobey, Fortuné Hippolyte Auguste

Bouilhet, Louis

Bourget, Paul

Chateaubriand, François-

René de

Chaulieu, Guillaume Amfrye, abbé de

Coppée, François

PLACE DATE

OF PUB.

D

D

HE

$\mathrm{HE}$

D

D

D

HE

HE

\section{FRENCH}

\section{$\mathrm{HE}$}

D

D

D

$\mathrm{HE}$

$\mathrm{HE}$

$\mathrm{HE}$

$\mathrm{HE}$

HE

D

D

D

D

D

HE

D

HE

HE

D

D

D

D

HE

HE

F

HE

$\mathrm{F}$

HE

$\mathrm{HE}$
OF PUB.

SOURCE

2 Apr $90 \quad$ II, 96

1 May 90 II, 119

20 Dec 85 I, 180

20 Dec 85 I, 182

27 Feb $90 \quad$ II, 60

4 Mar $90 \quad$ II, 66

21 Apr $90 \quad$ II, 109

16 Mar $90 \quad \mathrm{H} 49 / 8$

13 Apr 90 I, 209

13 Apr $90 \quad$ I, 209

13 Mar $90 \quad$ II, 76

20 Feb $90 \quad$ III, 158

26 Apr $90 \quad$ II, 115

27 Mar 87 III, 93-4

3 Apr $87 \quad$ III, 95

24 Apr 87 Nunn, 133-4

16 Oct 87 III, 96-100

12 Feb $88 \quad$ I, 191

15 Jan $90 \quad$ II, 27

2 Apr $90 \quad$ II, 96

21 Apr 90 II, 109

28 Apr 90 III, 117-8

29 Apr $90 \quad$ III, 119

20 Dec 85 I, 179, 185

27 Mar $90 \quad$ II, 88

13 Apr $90 \quad$ I, 209

11 Nov 88 H36

7 Mar $90 \quad$ II, 69

13 Mar $90 \quad$ II, 77

26 Apr $90 \quad$ II, 115

30 Apr $90 \quad$ II, 118

20 Dec $85 \quad$ I, 179

12 Feb $88 \quad$ I, 191

2 Jun 89 I, 163

20 Dec 85 I, 180

12 Aug $86 \quad$ H9

26 Sep $86 \quad$ H 15

1 Apr 88 I, 135 
AUTHOR

Daudet, Alphonse

Dumas, Alexandre, fils

Duvalier, Alcide

Feuillet, Octave

Flaubert, Gustave

Gautier, Théophile

Goncourt, Edmond de

Hérédia, José Maria de

Houssaye, Arsène

Hugo, Victor

Huysmans, Joris-Karl

Lamartine, Alphonse de

Lambert, Juliette

Leconte de Lisle,

Charles-Marie

Loti, Pierre (Julien Viaud)

Maupassant, Guy de
PLACE

OF PUB.

$\mathrm{HE}$

$\mathrm{HE}$

D

D

$\mathrm{HE}$

HE

D

$\mathrm{HE}$

HE

D

HE

$\mathrm{F}$

$\mathrm{HE}$

HE

$\mathrm{HE}$

D

$\mathrm{x}$

D

D

$\mathrm{X}$

$\mathrm{HE}$

$\mathrm{HE}$

$\mathrm{HE}$

$\mathrm{HE}$

HE

D

D

D

D

$\mathrm{HE}$

$\mathrm{HE}$

$\mathrm{HE}$

HE

D

F

D

D

D

D

D

$\mathrm{HE}$

D

D
DATE

OF PUB.

SOURCE

12 Feb $88 \quad$ I, 189

20 May 88 I, 149

21 Apr $90 \quad$ II, 110

24 Apr $90 \quad$ II, 114

20 Dec 85 I, 179

1 Apr 88 I, 138

23 Jan 90 II, 32

23 Feb $90 \quad$ III, 161

13 Apr $90 \quad$ I, 208-9

26 Apr $90 \quad$ II, 115

20 Dec 85 I, 179

8 Apr $86 \quad$ H 19

15 Apr $88 \quad$ I, 143

6 May $88 \quad$ I, 194

3 Feb $89 \quad$ I, 203

3 Mar $90 \quad$ II, 63

(?)

$\mathrm{H} 7$

28 Nov $89 \quad$ II, 11

26 Apr $90 \quad$ II, 115

(?)

H40

20 Dec 85 I, 179

20 Dec $85 \quad$ I, 179, 184, 185

25 Jul $86 \quad \mathrm{H} 14$

29 Aug $86 \quad$ H23

6 May $88 \quad$ I, 194

24 Feb $90 \quad$ II, 57

3 Mar $90 \quad$ II, 64

5 Apr $90 \quad$ II, 99

26 Apr 90 II, 115

20 Dec $85 \quad$ I, $179,180,185$

25 Mar $88 \quad$ I, 131

5 May $89 \quad$ I, 154

26 May 89 I, 156

4 Mar $90 \quad$ II, 66

2 Jun $89 \quad$ I, 165

15 Feb $90 \quad$ II, 55

30 Dec 89 II, 21

7 Mar $90 \quad$ II, 71

2 Apr 90 II, 96

8 Apr 90 II, 100

13 Apr $90 \quad$ I, 207, 209

16 Apr 90 III, 111-2

19 Apr 90 III, 113-4 
AUTHOR

Mendès, Catulle
PLACE

OF PUB.

$\mathrm{D}$

HE

HE

F

D

D

Méry, Joseph

Millevoye, Charles-Hubert

Molière (Jean-Baptiste Poquelin) D

Montépin, Xavier de HE

Musset, Alfred de

Nerval, Gérard de

Nodier, Charles

Ohnet, Georges

Rabelais, François

Ribot, Théodule-Armand

Richepin, Jean

Rollinat, Maurice

Saint-Évremond, Charles de

Sainte-Beuve,

Charles-Augustin de

Staël, Mme de (Anne-Louise-

Germaine Necker)

Ulbach, Louis

Vigny, Alfred de

Villiers de l'Isle-Adam,

Auguste

D

$\mathrm{D}$

D

Voltaire (François-Marie Arouet) HE Zola, Émile

HE

HE

DE

HE

HE

HE

HE

HE

HE

HE

$\mathrm{D}$

HE

HE

F

HE

HE

HE

$\mathrm{HE}$
HE

HE

D

GERMAN

Goethe, Johann Wolfgang von

Heine, Heinrich
HE

HE

D

D

HE

HE
DATE

OF PUB.

SOURCE

26 Apr $90 \quad$ II, 115

12 Feb 88 I, 192

25 Mar 88 III, 101-2

20 Oct 89 III, 106-8

2 Apr 90 II, 96

25 Apr $90 \quad$ III, 115-6

20 Dec 85 I, 179

20 Dec $85 \quad$ I, 179

16 Jan $90 \quad$ II, 29

13 Apr $90 \quad$ I, 209

20 Dec 85 I, 179, 180, 182

3 Feb $89 \quad$ I, 199

20 Dec $85 \quad$ I, 179

20 Dec 85 I, 179

13 Apr $90 \quad$ I, 209

20 Dec 85 I, 179

13 May 88 I, 146

7 Mar $90 \quad$ II, 69

20 Dec 85 I, 186

20 Dec 85 I, 180

2 Sep $86 \quad$ I, 161

25 Mar 88 I, 132

15 Sep 89 III, 103-5

20 Dec 85 I, 179

17 Jan $90 \quad$ II, 30

8 Mar $90 \quad$ II, 72

26 Apr $90 \quad$ II, 115

20 Dec 85 I, 180

20 Dec 85 I, 179

12 Feb 88 I, 189

13 Apr $90 \quad$ I, 208

26 Apr $90 \quad$ II, 115 
AUTHOR

Schopenhauer, Arthur

Uhland, Ludwig

Zedlitz, Baron von

Alighieri, Dante

Boccaccio, Giovanni

Cantù, Cesare

Ferrari, Severino

Lara, Contessa (Evelina

Cattermole-Mancini)

Leopardi, Giacomo

Petrarca, Francesco

Stecchetti, Lorenzo

(Olindo Guerrini)

Tasso, Torquato

PLACE DATE

OF PUB.

F

D

D

D

D

$\mathrm{HE}$

$\mathrm{HE}$

HE

ITALIAN

$\mathrm{HE}$

$\mathrm{HE}$

$\mathrm{HE}$

$\mathrm{HE}$

D

HE

$\mathrm{HE}$

D

D

$\mathrm{D}$

HE

$\mathrm{HE}$

$\mathrm{HE}$

F

PERSIAN

Hāfiz (Shams ad-din Muhammad) HE

RUSSIAN

Dostoyevsky, Feodor

Turgenev, Ivan
$\mathrm{D}$

$\mathrm{HE}$

D

SPANISH

Peninsular

Arolas, Juan

Bartrina, Joaquín María

Bécquer, Gustavo Adolfo

Ercilla y Zúñiga, Alonso de

Espronceda, José de
HE

D

HE

D

HE

HE
OF PUB.

SOURCE

1 Dec $87 \quad$ H34

1 Apr $90 \quad$ II, 95

2 Apr $90 \quad$ II, 96

24 Apr $90 \quad$ II, 114

15 Jan $90 \quad$ II, 26

13 Apr $90 \quad$ I, 208

20 Dec $85 \quad$ I, 180,185

20 Dec 85 I, 185

20 Dec $85 \quad$ I, 185

17 Jan $86 \quad$ H6/26-7

17 Feb $89 \quad H 25 / 36$

24 Nov $89 \quad \mathrm{H} 43 / 52$

6 Mar $90 \quad$ II, 67

6 May 88 I, 193

1 Apr 88 I, 136

17 Jan $90 \quad$ II, 30

2 Apr $90 \quad$ II, 96

10 Apr 90 III, 109-10

20 Dec 85 I, 185

20 Dec 85 I, 185

3 Mar $89 \quad \mathrm{H} 27$

2 Sep $86 \quad$ I, 162

20 Dec $85 \quad$ I, 180

$14 \operatorname{Mar} 90 \quad$ II, 78

25 Mar $88 \quad$ I, 132

2 Apr 90 II, 96
20 Dec $85 \quad$ I, 179

22 Mar $90 \quad$ II , 84-5

20 Dec 85 I, 180,181

22 Mar $90 \quad$ II, 85

3 Feb $89 \quad$ I, 199

20 Dec 85 I, 185 
Hp0

AUTHOR

Fernández Bremón, José

Flores, Eugenio Antonio

Gras y Elías, Francisco

Meléndez Valdés, Juan

Núñez de Arce, Gaspar

Pardo Bazán, Emilia

Pi y Margall, Francisco

Reina, Manuel

Rueda, Salvador

Ruiz Aguilera, Ventura

Salazar y Quintana, F.

Selgas y Carrasco, José

Villegas, Esteban Manuel de

Zorrilla, José

\section{Mexican}

Díaz Mirón, Salvador

Gutiérrez Nájera, Manuel

Icaza, Francisco A. de

Othón, Manuel J.

Peza, Juan de Dios

Puga y Acal, Manuel

Riva Palacio, Vicente

Urbina, Luis G.

\begin{tabular}{|c|c|c|}
\hline $\begin{array}{l}\text { PLACE } \\
\text { OF PUB. }\end{array}$ & $\begin{array}{l}\text { DATE } \\
\text { OF PUB. }\end{array}$ & SOURCE \\
\hline $\mathrm{D}$ & 2 Apr 90 & II, 96 \\
\hline $\mathrm{D}$ & 22 Mar 90 & II, 84 \\
\hline $\mathrm{D}$ & 22 Mar 90 & II, 84 \\
\hline $\mathrm{HE}$ & 20 Dec 85 & I, 180 \\
\hline $\mathrm{HE}$ & 12 Feb 88 & I, 192 \\
\hline $\mathrm{HE}$ & 20 Dec 85 & $\mathrm{I}, 185$ \\
\hline $\mathrm{D}$ & 28 Nov 89 & II, 11 \\
\hline D & 22 Mar 90 & II, 85 \\
\hline $\mathrm{HE}$ & 20 Dec 85 & I, 179-86 \\
\hline D & 30 Apr 90 & II, 117 \\
\hline $\mathrm{HE}$ & 20 Dec 85 & $\mathrm{I}, 179$ \\
\hline D & 22 Mar 90 & II, 85 \\
\hline $\mathrm{HE}$ & 20 Dec 85 & I, 179 \\
\hline $\mathrm{HE}$ & 20 Dec 85 & $\mathrm{I}, 180$ \\
\hline $\mathrm{HE}$ & 20 Dec 85 & I, 179,185 \\
\hline $\mathrm{HE}$ & 14 Nov 86 & III, 162 \\
\hline
\end{tabular}

HE

HE

HE

HE

HE

HE

HE

HE

$\begin{array}{ll}\text { 3 Feb } 89 & \text { I, 199 } \\ \text { 3 Feb } 89 & \text { I, 199 } \\ \text { 3 Feb 89 } & \text { I, 199-203 } \\ \text { 3 Feb } 89 & \text { I, 199 } \\ \text { 3 Feb } 89 & \text { I, 199 } \\ \text { 3 Feb } 89 & \text { I, 199 } \\ \text { 3 Feb 89 } & \text { I, 199 } \\ \text { 3 Feb } 89 & \text { I, 199 }\end{array}$




\section{H1: INTRODUCCION}

It is extremely difficult to determine when "Introducción" was written because the poem did not appear in any periodical before it was printed in Hojas. Two possibilities present themselves, however: it may have been composed in April 1890, in which case the words "otro Mayo" (1. 10), besides having a symbolical meaning, would also reflect the fact that Casal expected his book to go on sale in May of that year; or, as suggested by the imagery of 1l. 1-6, it may have been written several months earlier in the expectation that Hojas would be published in the fall or winter of 1889 . Because it is uncomplicated, the first hypothesis has a certain attractiveness; nevertheless, as shown by my discussions of $\mathrm{Hp} 0$ and $\mathrm{H} 2$, persuasive arguments can be advanced in support of the second theory.

\section{H1: VARIANTS}

l. $H$

1 Arbol

pensamiento
GLIC

(ף)Arbol

\section{H1: Note to Variants}

1: Logically, the structure of the initial clause (ll. 1-3) requires a comma after pensamiento. Since Casal often let an end-of-verse blank substitute for a comma, and since his doing so in this instance is not an impediment to the immediate comprehension of the passage, no attempt is made to emend the punctuation of 1.1 .

The expression end-of-verse blank is used in this book to denote the blank space found at the end of a line of poetry. Though most readers tend to ignore it today, the end-of-verse blank actually served as a punctuation mark of low intensity. Normally, it signalled a pause somewhat less emphatic than that occasioned by the comma. Since Casal was prone to make concept coincide with line limit, he sometimes used the end-of-verse blank in place of the comma to produce an end-stop (see H37/13, 19). It should also be noted that, even in cases of enjambment, he did not wish to divest the line completely of its integrity as a rhythmic unit. Under conditions of enjambment, therefore, the end-of-verse blank should be treated as a signal for a rising inflection or sustained tone - in lieu of a pause - before the new line is begun (see H1/11-12).

\section{H2: AUTOBIOGRAFIA}

This poem was originally published in La Habana Elegante on 30 March 1890. The following note from the editor indicates that, at the time in 
question, the selection of material for Hojas was not yet final: "Esta composición reemplazará al prólogo en un libro de versos que, con el título de Hojas al Viento, está próximo a publicarse. (N. de la R.)" Unfortunately, no one knows what this prólogo actually was. It may have been a passage in prose, no longer extant, or it may have been a poem-possibly the very same "Introducción" that we now find at the beginning of Hojas. Supporting the latter possibility is the fact that Casal did not write introductions in prose for either Nieve or Rimas: he began Nieve with a poem entitled "Introducción" and he used a four-line excerpt from Baudelaire's "Bénédiction" as preface to Rimas. Whatever the case, by the time Hojas went to press, Casal had changed his mind again, and instead of leading off with "Autobiografía," he opened the book with "Introducción" (Hl).

As shown in the record of variants, the Hojas version of "Autobiografía" differed from the $H E$ version both in wording and in punctuation. In addition, the original format was modified in two respects. 1) Indentation: in $H E$ the initial verse in each stanza was indented, while in Hojas all verses were left-justified. 2) Separation of stanzas: in $H E$ all stanzas except the first two were separated by a centered rule, while in the Hojas version the centered rule was used throughout. This sign of stanzaic division was frequently employed in early versions of Casal's works but was suppressed when the poems were published in book form. In Hojas, "Autobiografía" was the only poem in which it was retained. In the present edition, the centered rule has been omitted from all poems.

On 1 June 1890,ElPueblo reproduced the poem for its readers. Instead of using Hojas as its source, however, El Pueblo copied from the earlier $H E$ version. This is clearly stated in a footnote, but the note gives no explanation about why El Pueblo used the $H E$ version instead of the one that was published in Hojas. Accessibility of the definitive version does not seem to be a factor here because, by 1 June, Hojas had not only been published and distributed, but had also been reviewed (see $\mathrm{Hp} 0$ ). Be that as it may, since the El Pueblo version postdates Hojas, it is not listed in the record of variants.

A word about the form and content of "Autobiografía." The poem consists of 68 hendecasyllabic lines which follow the unbroken rhyme pattern á-o. These lines are organized into nine stanzas, the majority of which are composed of single sentences. Contrary to what we find in some other long poems that Casal wrote (e.g., H43, H3, and H15), the stanzas are not grouped into larger units by the insertion of Roman numerals, triple asterisks, rows of dots, or any other sign that is traditionally used for this purpose. The uniformity of the metrical pattern, the consistency of the rhyme scheme, the frequency with which stanzas are composed of only one sentence, and the absence of structural divisions larger than the stanza give the impression that the poem is all of a piece. An examination of the content, however, shows that this is not the case. "Autobiografía" easily divides into two major parts which are equal in length but different, 
though related, in subject matter. In Part I (ll. 1-34), Casal outlines the salient features of his existence. The death of loved ones brought an end to childhood joys and left him alone in the world. The world - a hostile place, made fearsome by its escollos, cuestas, lóbregos espacios, desiertos campos, and noches tormentosas - gravely wounded him during his tender years. Now, his youth, like the loved ones who expired before his eyes when he was a child, can neither be revived nor consoled. In Part II (ll. 35-68), Casal brings to light the principal spiritual factors which guide his conduct in the present. The emphasis here is on escape. By taking refuge in Art and the love of Culture, he strives to forget the sorrows that oppress his heart; by heroically enduring the torments of his earthly martyrdom, he nurtures his dream of ultimate salvation; and by proudly casting aside all material ambitions, he gains the freedom he needs to pursue his fantastic visions of a superior existence.

This is the way Casal saw himself when he was in his twenty-seventh year, and, judging from the importance he gave to the poem's position in Hojas, this is the way he wanted his readers to see him. Whether the work is an autobiografia or, more accurately, a paisaje espiritual (like N28) is debatable; however, there is no doubt that it is one of the most significant attempts at self-analysis Casal ever made. Not only does it show how he viewed the past and the present, but it also indicates how he intended to face the future.

H2: VARIANTS

l. $H E$

* 20 dejando en

21 tempestuosas,

24 [y] á luz [sic] relámpagos. [sic]

29 ver en cadavérico; [sic]

30 opaco,

* 31 desbruñido-

32 labios

42 sacra

43 mayores

44 [q]ue,

45 martio, [sic]

46 la firmeza del cristiano,

47 ciela [sic]

* 53 día

* 57 visible,

58 extásio

* 60 dios
H

dejando, en

tormentosas,

[y] á la luz

relámpagos!

ver, en

cadavérico,

opaco

desbruñido,-

labios,

blanca

mayores,

[q]ue

martirio,

su firmeza

de cristianos,

cielo

día,

visible

extásio,

Dios,
GLIC

$H E$

$H+\mathrm{a}$

desbruñido-,

$H E$

$H E$

$H E$

$H E$

extasio, 
20: In the $H$ version, Casal may have added the comma after dejando in order to achieve a rhythmic effect. Upon first reading, however, the comma can easily be mistaken for a syntactic signal, which it is not. Therefore, the $H E$ version is followed in the present edition.

31: At the time that Casal wrote, it was customary to use the comma + dash combination (, , ) either before a parenthetical statement, as in ll. 53-54 of the $H$ version, or after such a statement, as in 1.31 of $H$. However, since the parenthetical phrase logically goes with the utterance that immediately precedes it, and since the dashes around the phrase really function like parentheses, the only reasonable place to use a comma in combination with a dash would be at the conclusion of the parenthetical insertion, and the only acceptable way to use it would be dash + comma $(-$,$) . This is the rationale$ behind the punctuation changes which I have made in 11.31 and 53 .

53: See note to l. 31 .

57: Because two commas were present in 1. 58, Casal may have chosen to suppress the comma in 1.57 of the $H$ version in order to effect a smoother reading of the passage. In view of the fact that a change in subject occurs in 1. 58 , however, this modification is not regarded as an improvement (cf. 1l. 61-62, where Casal did not alter the original punctuation). Therefore, the $H E$ punctuation is restored.

60: Like most of his contemporaries, Casal did not usually place a comma before an inverted exclamation point. His addition of the comma in $H$ seems to have been motivated by a desire to stress the fact that he looked upon mi entusiasmo as an equivalent of un Dios. Thus, the comma had the function of expressions such as 0 sea or es decir.

\section{H3: AMOR EN EL CLAUSTRO}

"Amor en el claustro" was first published in the 5 August 1883 issue of El Museo. Three years later, on 1 August 1886, it appeared in La Habana Elegante with relatively few variants. When Casal revised the poem for Hojas, however, he made some highly significant changes in wording and punctuation. These are shown in the record of variants, below. The several versions of "Amor en el claustro" are also distinguished by differences in format. These, together with the changes in vocabulary and punctuation, reveal how scrupulous Casal was about every detail of his art:

1) In $M$, ll. $43-52$ were printed as a separate stanza. No such division was made in $H E$ or in $H$.

2) In $M, 11.61-96$ were set apart from the rest of the text by centered rules. This device was omitted from the $H E$ text. In $H$, the lines were once again displayed as a separate section but, in this instance, centered asterisks were used in place of the centered rules of the original version. 
3) In $M$, ll. 61-96 were set off by dashes and quotation marks (-“...”-). In $H E$, the quotes and the final dash were suppressed; only the introductory dash in 1.61 was retained. In $H$, the dash at the end of 1.96 was restored.

4) In $M$, the initial line of every quatrain of the exhortatory passage (ll. 61-96) was indented. Indentation was preserved in the two subsequent versions of the poem; however, a blank line was added between stanzas. This made the quatrains stand out as distinct thought units even more dramatically than they had in the original version. In addition to the fact that it was well marked as a quotation, this passage was distinguished from the rest of the poem by its rhyme scheme: instead of being based on the assonantal pattern $a$-o which characterized ll. 1-60 and 97-110, this section was based on the consonantal pattern $A B A B$.

5) The manner in which Casal prepared his reader for the change in content and structure that was to begin in 1.61 is also of interest. In $M$, he divided ll. 53-60 into two stanzas of four lines each (with 11.53 and 57 indented), in spite of the fact that he was still following the assonantal rhyme scheme which had characterized the poem from the outset. In $H E$ and $H$, he continued to indent 1.53 , but instead of doing the same with 1. 57, he left-justified it and inserted a row of dots before it. In the present edition, in order to highlight the transitional nature of 1l. 53-60, the row of dots is carried over from $H E$ and $H$, and 1.57 is indented as it was in $M$.

"Amor en el claustro" also went through a process of evolution with regard to its dedication. When published in $M$, the poem had no dedication at all; when it came out in $H E$, it was dedicated "A José M. de Céspedes," and when it appeared in $H$, it bore the slightly emended inscription "A José María de Céspedes."

José María de Céspedes (b. 1829) was a distinguished law professor at the University of Havana and played an important role in orienting Casal at the start of his writing career. It is likely that Céspedes and Casal became acquainted around 1880 when the poet was a first-year law student. In 1883, Céspedes began to hold weekly literary gatherings at his home and, on these occasions, established members of the cultured elite mingled with eager young writers such as Casal. The passage quoted below shows that Casal gave "Amor en el claustro" its first public reading at one of these gatherings; this fact helps explain why he dedicated the poem to Céspedes in 1886 and 1890. The passage is also significant because it proves that, even at the beginning of his career as a poet, Casal was inspired by painters and was strongly inclined to use poetry as a vehicle for the creation of verbal canvases:

Hasta hace algunos años, se celebraban semanalmente, en el salón del Dr. José Ma. de Céspedes, unas veladas íntimas de carácter literario, a las que acudían muchos amantes de las letras cubanas....

Atraído por el éxito de las veladas, me presenté una noche 
en aquella casa, con objeto de leer un pequeño poema que acababa de escribir. Habiendo sentido siempre un gran amor por la pintura, yo había tratado de hacer, en aquella composición, dos cuadros poéticos, uno en el estilo del Perugino y otro en el estilo de Rembrandt. En el primero trazaba la figura de una joven novicia que se paseaba, al claro de luna, por los jardines de un claustro italiano, formando ramilletes de lirios y violetas. Allí todo era lila, blanco, ámbar y azul. En el segundo, la misma joven, que había pronunciado ya los votos supremos, aparecía al pie de un altar, desgarrando el sayal y echada la toca hacia atrás, pidiendo a Dios, en la noche, que alejara de su memoria la imagen de un guerrero a quien había amado en sus primeros años. Todo era aquí blanco y negro. Bajo los tintes místicos del primero había tanto sensualismo oculto, que me decidí a esconderlo y sólo presenté el segundo, pues ambos podían mostrarse aislados. ${ }^{1}$

In addition to proving that Casal was deeply influenced by the visual arts from the very beginning of his career, "Amor en el claustro" brings to light one of the cardinal rules in his personal code of morality: namely, that love, once given, must be eternal. One of the clearest illustrations of this rule is found in "Quimeras," where the suitor, enslaved by love, not only lists for his lady all the ways in which he will show his devotion during her lifetime, but also affirms that, if she dies, he will continue to cherish her memory in the depths of his spirit, "como guarda la adelfa en su corola / el rayo amarillento de la luna" (H20/43-44). Casal places the same emphasis on eternal constancy at the end of "Del libro negro," where the speaker, in a last embrace, binds himself to his sweetheart's corpse and leaves his soul with her forever: "Uní mi boca con su yerta boca; / estreché convulsivo su garganta, / y en aquel triste abrazo y mudo beso / la dejé toda el alma" (H4/41-44).

Although he felt that some people actually do experience pure, unending love, Casal was convinced that he would never enjoy such good fortune. This is implicit in his treatment of certain love situations in Hojas. Some of these are described in the first person; of equal importance, however, are the third-person situations in which Casal obviously identifies with one of his protagonists and injects his own values into the picture. By surveying all of these cases and examining some of his translations as well, it is possible to determine what Casal imagined to be the consequences of loving: either death would rob him of his beloved ("Del libro negro," "Tras la ventana"), or the irresistible demands of life would interrupt their relationship ("El adiós del polaco"), or his intense passions, once given an outlet, would defile his body and corrupt his soul ("A Berta"), or his devotion would be repaid with infidelity during his lifetime or soon after his demise ("La nube," "Confidencia," "Adiós al Brasil del Emperador don Pedro II"; "Post umbra"). In order to protect himself 
against such hazards, Casal shied away from intimate personal relationships: to these, in essence, he was dead ("Engañada"). However, since he could not entirely repress his need to love ("La última noche"), he found ways of satisfying his amorous yearnings without exposing himself to the perils he so intensely feared: he addressed his passion to individuals who were not physically present ${ }^{3}$ or who, by soon departing, would be forever beyond his reach ("Ausencia," "Versos azules"); he lavished his attentions on inanimate objects of exceptional beauty ("Mis amores"4); and he directed his fondest thoughts to halcyon realms of fantasy ("El Arte," "La canción de la morfina").

In its emphasis on fidelity, "Amor en el claustro" reveals how easy it was for Casal to become ensnared in a trap of his own making where love was concerned. By entering the convent, his protagonist indicated that she planned to remain faithful to her dead lover forever. Paradoxically, though, by taking religious vows, she became unfaithful to the deceased, for the contract she made with the Church obliged her to surrender herself completely to Christ. To complicate matters even further, the lady's inability to keep her dead lover's image out of mind after she took her vows was essentially an act of infidelity towards Christ, for a bride of the Lord should never be enamored of anyone else.

\section{H3: Notes to Introductory Statement}

1 "José Fornaris," Bustos y rimas (Havana: Imprenta La Moderna, 1893), pp. 105-107; reproduced in Ed. del Cent., vol. I, p. 276.

2 "Adiós al Brasil ..." provides one of the most intriguing examples of infidelity in Hojas. The essence of the poem is that the beloved (Brazil) becomes enamored of another suitor (Republicanism) and sends away the faithful lover (Dom Pedro) who has devoted his entire life and all his energies to her welfare. The historical circumstances behind this poem are discussed in my introduction to H45.

3 The most striking relationship of this kind is the one that Casal established with Gustave Moreau (see my discussion of Np2).

4 It is possible that the radical changes which Casal made in the $H$ version of "Mis amores" were to some extent influenced by this tendency to transfer amorous feeling to inanimate love-objects.

H3: VARIANTS

l. $M$

1 de los nocturnos

4 luz, que escaso

* 11 [a]llí, colosal

12 brazos;-
$H E$

incierto de los

H

GLIC

luz que, escaso,

[a]llí M

con amor

brazos; 
1. $M$

15 altar

20 al argentino

23 blancas

26 cándidas naranjo;

27 [y] en

28 Señor

29 reloj,

30 majestuoso

34 media noche

35 Señor

37 ánima atrevida,

38 gravedad, Cláustro;

39 [e]lla, entonces, atraviesa,

* 43

45 por que [sic]

46 moribundo y lacerado,

49 [q]ue

56 [d]o se elaboran

* 57 (ף)Más...

58 carmíneos

* 60 canto.

62 primaveras,

63 [y] en

$64[u] n$ enjambre de sueños y

66 [e]n mi torno cual fúlgidas visiones,

67 [a]lzaron el altar de mi

68 [s]obre tantos amantes corazones;

70 [r]icas

74 [a] aquel que verjeles,

75 corazon un dia,

* 76 laureles.

77 (ף)Yo

81 (ף)Mas,
$H E$

GLIC

altar,

al moribundo

naranjo,

magestuoso

cláustro;

el $[s i c]$ ambarino

al ambarino blancas, fragantes

[y], en

señor

reloj

gigantesco

medianoche

señor

M

ánimo atrevido, gravedad claustro;

[e]lla entonces

atraviesa

porque

moribundo y lacerado

moribundo, ensangrentado,

[q]ue,

[d]onde se

mezclan

Mas...

canto:

divinos

primaveras

[y], en

[á]ureo enjambre de fúlgidas

[m]e prodigaban sus mejores dones,

[y] al poder de mi angélica

[v]í doblegarse

$[\mathrm{v}] \mathrm{i}+H E$ altivos

corazones. [sic]

M

[b]landas

[a]quel que,

verjeles

corazón un día

laureles;

(ף) $+H E$

M (a) 
1. $M$

83 i[a]y! alterna tambien el alma mia

84 amor y otro

87 fulgurar

* 89 iSeñor! De

94 corazon... iDios

95 viva,

96 [s] in batallar con el

97 de fuego

98 frescas

* 101 alma los recuerdos,

103 surgir esplendorosa y bella

105 desecharla...

106 orar...

108 donde luce el santo,
$H E$

i[o]h Dios! alterna

así en el alma mía

amor otro

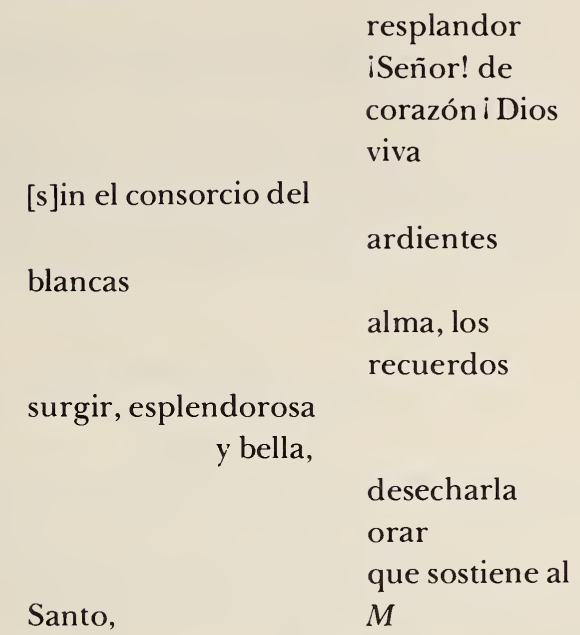

\section{H3: Notes to Variants}

$H$

$H E+$ mia

GLIC

$H E$

11: If we assume that omission of the comma in $H$ was a purposeful change introduced by Casal, rather than an error committed by the compositor, it is difficult to understand what might have motivated the change. This is especially so because 1.8 , whose structure parallels that of 1.11 , was not altered in $H$. In my edition, both verses are punctuated as they were in the periodical versions.

$43,57,60$ : See the discussion of format in my introduction to this poem.

74: Because I feel that the end-of-verse blank is an inadequate punctuation mark in this instance, I have restored the comma found in the original periodical version.

76: Since the use of a semicolon weakens two whole stanzas (1l. 73-76 and 77-80) at a most dramatic point in the poem, it seems appropriate to favor the more emphatic punctuation of the original version.

89: Even though it is impossible to determine whether the change from $D e$ to $d e$ was made on purpose or whether it was a typographical error, it is worthwhile to assume that the change was a conscious one because the lower-case form significantly enriches the text. It accomplishes this by converting "iSeñor!" from a simple exclamation that concludes the clause "Es tan bella" to a kind of verbal punctuation mark which both separates and joins the statements that precede and follow it. That is, the lower-case de causes "iSeñor!" to act like an emphatic comma between parallel statements ("Es tan bella" and "de tal encanto ... aparece") whose conclusion is indicated in 1. 91. As a result, the emotional intensity of the entire stanza is increased. 
101: The punctuation change in $H$ improved the rhythm of 11. 101-102. Rather than being considered as a unique phenomenon, it should be looked upon as part of an overall effort by Casal to make his verses lighter and more flexible.

\section{H4: DEL LIBRO NEGRO}

"Del libro negro" was first published in La Habana Elegante of 27 June 1886. Since Cuban library contacts did not have a copy of that issue, my version of the poem is based exclusively on the printing that appeared in Hojas.

\section{H4: VARIANTS}

l. $H$

GLIC

* 44 la

\section{H4: Note to Variants}

44: A common tendency in spoken Spanish is to use la as a substitute for le when the indirect object is feminine. In this instance, Casal was probably unaware that he had departed from the official norm for written Spanish.

\section{H5: ACUARELA}

According to Esperanza Figueroa ("Bibliografía de Julián del Casal," p. 34) and the compilers of the Ed. del Cent. (vol. III, p. 197), "Acuarela" appeared originally in the 3 January 1886 issue of La Habana Elegante. Unfortunately, Cuban library sources could not locate this issue in their holdings. As a result, it has been necessary to base the present version of the poem exclusively on the text that was printed in Hojas.

\section{H5: VARIANTS}

\section{l. $H$}

* 1 ( $($ )Sentada

* 6 tierra;

* 36 risueña;

64 lastimera.........
GLIC

risueña, lastimera...

\section{H5: Notes to Variants}

1: This is the only line that is indented in the $H$ version. In the present edition, however, the initial verse in every stanza is indented.

6: An examination of Casal's poetry makes it clear that the author used more 
and stronger punctuation at the beginning of his career than he did at the end. In "Acuarela," a relatively early poem, the punctuation of certain lines (e.g., 6, 26, 28, 30, and 32) may seem strong to the modern reader. However, Casal's system - which permitted a generous use of semicolons - did have points in its favor. For instance, in the verses cited above, the use of semicolons instead of commas obliges the reader to decelerate his speed. As a result, the components of each sentence tend to stand out with greater clarity.

36: On the whole, Casal's tendency to "overpunctuate" will cause no problems to the reader. There are a few instances, however, where the poet's preference for heavy punctuation led him to unnecessary extremes. Line 36 is one such case. Therefore, the punctuation has been simplified in the present edition.

\section{H6: TRAS LA VENTANA}

This composition was first published in La Habana Elegante on 17 January 1886. Its title at that time was "Luz y sombra." When preparing Hojas, Casal changed the title, altered the wording and punctuation of the text, and modified the format. The following differences in format distinguish the two versions of the poem: 1) In La Habana Elegante, a centered rule was used to separate the title from the text and to set each new stanza off from the one preceding. All of these dividers, except the one between the title and the text, were suppressed in the Hojas version. 2) In La Habana Elegante, a row of dots was printed from margin to margin just above the centered rule that separated Il. 43 and 44 . The effect of this was to split the poem into segments that reflected the dichotomy of the title, luz vs sombra. Although Casal was always inclined to structure his thought on the basis of antitheses and polarities, ${ }^{1}$ he made this feature of his thinking less noticeable in the Hojas version of the poem than it had been in the $H E$ version. He accomplished this not only by substituting "Tras la ventana" for the original title, but also by removing the row of dots from the text (see note to 1.43 ).

\section{H6: Note to Introductory Statement}

1 See Ivan A. Schulman, "Las estructuras polares en la obra de José Martí y Julián del Casal," Revista Iberoamericana, vol. XXIX, no. 56 (July-December 1963), pp. 251-282.

H6: VARIANTS

l. $H E$

1 ventana

4 gentil

5 llena verde
H

ventana, verde cubre

fresco

GLIC 
l. $H E$

10 luminosas;-

11 cruzar

20 azulada,

26 Paolo

27 Francesca

* 30 por

* 37a [p]álidas cual las rosas amarillas,

39 gallardo

* 43 amapolas......

44 (1) Yo al oir

47 soñaban,

48 lúgubre

* 49 adorada,

53 divina

mirada;

63 hermosa,
H

GIIC:

luminosas;

cruzar,

azulada

Paolo

Francesca

(This verse did not appear in $H$.)

galante

amapolas.

(ף) Yo, al oir

$H+$ oír

soñaban;

lóbrega

adorada

$H E$

brillante

mirada:

hermosa

\section{H6: Notes to Variants}

30: In images which he composed several years after writing this stanza, Casal used the word por in much the same way as he did here: see N20/5 in the $H L$ version of 15 February 1892, and R25/4 in the $P$ version of 25 August 1893 . When he revised the last of these poems, he replaced the original por with sobre. This made the image less like the one in N20 and more like the one in "Tras la ventana."

37a: Since stanza length and rhyme patterns are not constant in this poem, there is no way of telling whether this verse was omitted intentionally or by mistake.

43: The row of dots in the $H E$ version marked the sudden change in viewpoint from the objective to the subjective: that is, from the speaker's concentration on events taking place in external reality $(l u z)$ to his evocation of images which exist only in his inner world (sombra). On the one hand, Casal's suppression of the dots conforms with his tendency to simplify the punctuation of later versions of his works; on the other, however, it represents an exception to his tendency to emphasize the antithetical character of reality.

49: In order to raise the dramatic intensity of 1.50 to its proper level, the comma is restored after adorada.

\section{H7: LA NUBE}

"La nube" did not appear in Cuban periodicals before it was published in Hojas. Casal's source of inspiration was Théophile Gautier's "Le Nuage": 
Dans son jardin la sultane se baigne,

Elle a quitté son dernier vêtement;

Et délivrés des morsures du peigne

Ses grands cheveux baisent son dos charmant.

Par son vitrail le sultan la regarde, Et, caressant sa barbe avec sa main, Il dit: L'eunuque en sa tour fait la garde, Et nul hors moi ne la voit dans son bain.

- Moi je la vois, lui répond, chose étrange!

Sur l'arc du ciel un nuage accoudé;

Je vois son sein vermeil comme l'orange

Et son beau corps de perles inondé.

Ahmed devint blême comme la lune,

Prit son kandjar au manche ciselé,

Et poignarda sa favorite brune....

Quant au nuage, il s'était envolé! ${ }^{1}$

Théophile Gautier (b. Tarbes, 31 August 1811; d. Neuilly, 23 December 1872) was widely read by Spanish American men of letters in the last quarter of the nineteenth century. Like so many of his contemporaries, Casal greatly admired the French master. Not only did he mention Gautier by name in several of his prose works, ${ }^{2}$ but in his subtitles to "La nube" and "Las palomas" (H19) he made it plain that Gautier was also a source of poetic inspiration. Casal did not always acknowledge his debt to Gautier in such clear terms, however. As Max Henríquez Ureña points out, Gautier's influence "se manifiesta en Casal, proteica y sutil, deslizándose al través de las palabras y los giros que pudieran parecer más insignificantes." 3

\section{H7: Notes to Introductory Statement}

1 Poésies complètes de Théophile Gautier (Paris: Charpentier, 1862), p. 165.

2 See Ed.del Cent., vol. I, pp. 143, 176, 179, 194, 203; vol. II, pp. 63, 144.

3 Breve historia del modernismo, 2nd ed., pp. 121-122.

H7: VARIANTS

l. $H$

* 1 En

11 [d]ice:-el

* 12 baño.-

* 16 inundado.-

19 favorita......

* 20 cuando
GLIC

(I) En

dice: -El

favorita... 
1: In $H$, the initial line in each stanza is left-justified. In the present edition, all of these lines are indented.

12, 16: The dash in 1.16 is an indispensable signal: without it, there would be no immediate way of telling that the lines which follow are not a continuation of the nube's response. The dash at the end of 1.12 , however, is not indispensable because 1.13 begins with a dash. What accounts for the redundant dash in 1. 12 seems to be a desire by Casal to keep his quotation system consistent throughout the poem.

20: It is impossible to determine whether the lackluster ending of "La nube" resulted from a confusion in Casal's mind between quant à and quand, or from the difficulty of expressing Gautier's "Quant au nuage, il s'était envolé" in an eight-syllable Spanish line with assonance in á-o. Whatever the case, the dynamism of Gautier's final verse is lost in Casal's version of the poem.

\section{H8: NOCTURNO}

"Nocturno" was first published in the 19 April 1885 issue of La Habana Elegante. A centered rule was printed between the title and the text, and centered asterisks were placed after stanzas I and XI. The initial verse of each quatrain was indented. Double quotes were used to introduce each of the stanzas in the section delimited by the asterisks. In addition, quotation marks were placed at the end of stanza XI. Beneath the text were the date of composition ("Marzo, 1885") and the name of the author ("J. Casal").

According to Ernesto Mejía Sánchez, "Nocturno" also appeared on 20 January 1886 in La Verdad, a fortnightly Masonic journal that was put out by the members of the Gran Logia de Colón e Isla de Cuba. In spite of repeated efforts, the present writer was unable to procure a copy of this version of the poem. As a result, it does not figure in the record of variants, below.

Four years later, a revised version of "Nocturno" was published in $H o j a s$. The basic $H E$ format was not altered in the new version. Nevertheless, the Hojas version did differ from the original in several respects: the author's name - for obvious reasons - was not printed at the end of the poem, the date of composition was suppressed, four lexical substitutions were made in the text, and a considerable number of punctuation changes were introduced. Of all the changes in punctuation, the most puzzling is the insertion of double quotes at the end of stanzas II-X. Since this punctuation system is excessive even for Casal, the method used in the $H E$ version is restored in the present edition.

The importance of "Nocturno" lies mainly in the fact that it is Casal's first and longest poetic statement about his father. Julián del Casal y 
PLATE 1

Julián del Casal y Ugareda, the Poet's Father

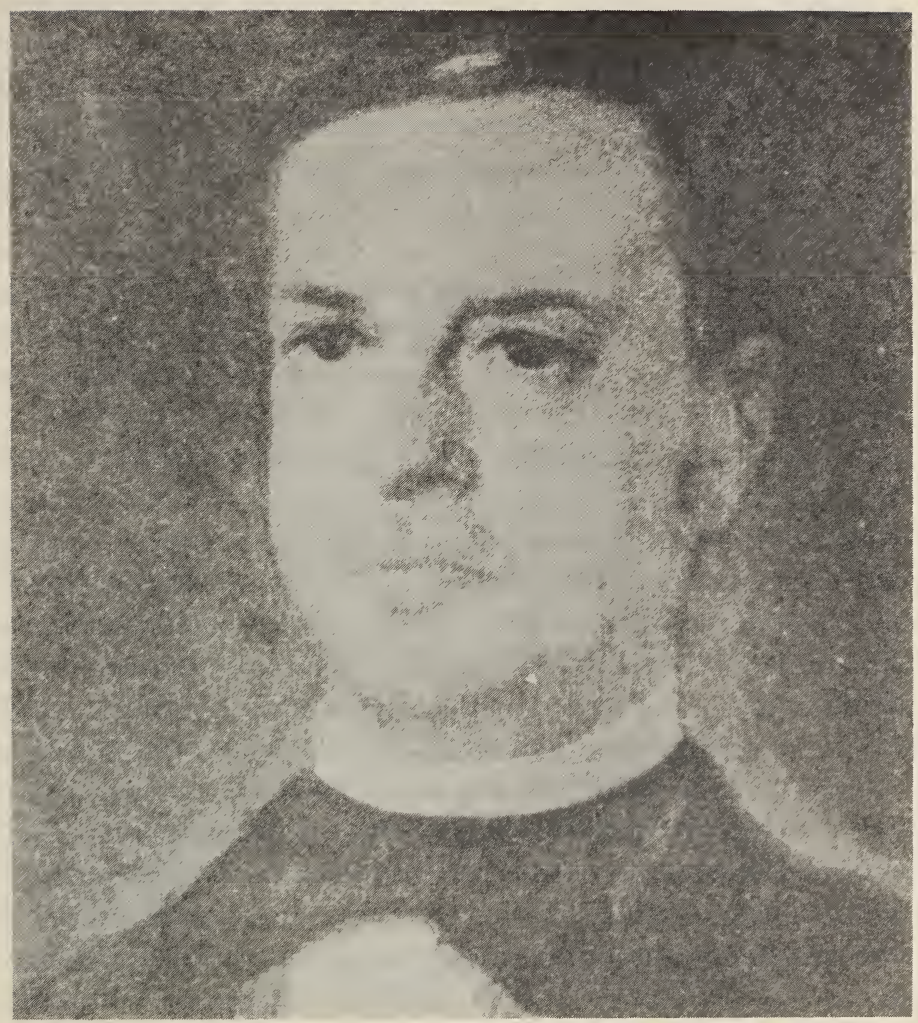

Ugareda, a native of the Basque port town of Santurce, left Spain at an early age to seek his fortune in Cuba. Like so many of his compatriots who took up residence in America, he worked diligently to improve his lot. After several years of toil and privation, he merged his capital resources with those of another small entrepreneur and formed a business known as "Gutiérrez y Casal." Thus, he became a partner in the management of "Guamuticas" and "Panchita," sugar refineries that were located in Cárdenas and Sagua la Grande, a short distance to the east of Havana. In 1860, D. Julián married María del Carmen de la Lastra y Owens in the Iglesia del Santo Angel Custodio of Havana. During the seven years which followed, the Casals had four children. Scarcely anything is known about the first two. The third, José Julián Herculano, was born on 7 November $1863 .{ }^{1}$ The last child, Carmelina, was born on 31 December 1867. Shortly afterward, Da. María del Carmen died of complications associated with the birth of her daughter.

In the words of Manuel de la Cruz, D. Julián was an "hombre de 
negocios, osado y de gran sentido práctico."22 Nevertheless, the loss of his wife and the growing needs of his children exerted enormous pressure on him and, in a search for strength and consolation, he turned with increasing ardor to prayer and the writings of the mystics. Finally, his devotion to religion became so intense that his home began to assume the character of an "oratorio." ${ }^{3}$ D. Julián's private world, however, was not the only source of preoccupation; the world of business in which he moved was also being threatened by forces beyond his control. José Antonio Portuondo describes his plight in the following way:

no era la guerra solamente, que promovían por Oriente los hacendados sin esperanzas de mejoras por la vía legal, lo que había traído la desgracia. Eran ya, de antes, las pérdidas en los ingenios pequeños, porque ni el Guamuticas ni el Panchita, con sus métodos a la penúltima o a la antepenúltima, podían competir con los grandes ingenios equipados con los últimos adelantos mecánicos que ya se estaban imponiendo. Alguna vez los dos socios de la firma Gutiérrez y Casal discutirían la conveniencia de reducirse a la condición de cultivadores, exclusivamente, y servir a algún ingenio poderoso, o la de fundir sus dos pequeños y crear uno mayor con todos los adelantos, en un esfuerzo arriesgado; pero nunca llegaron a un acuerdo, y al fin determinaron separarse. La firma Gutiérrez y Casal quedó disuelta, y el padre del poeta se dio a luchar, él solo, con la mala situación. Era el ocaso del pequeño productor y el nacimiento de los grandes centrales. Era el preludio de la gran industria, que abrumaba al desorientado descendiente de los pescadores vizcaínos. . . . D. Julián ensayó todos los medios para evitar la ruina de su casa y cuando todos los esfuerzos fueron vanos, el descendiente de los bravos pescadores de Santurce dejó el timón de su nave destrozada en las manos de Dios. ${ }^{4}$

The answer to his fervent prayers for deliverance came on 9 February 1885. On that day, death finally relieved Julián del Casal y Ugareda of all his worldly burdens.

The question of D. Julián's influence on his son has never ceased to intrigue the critics. Unfortunately, however, little concrete data on the subject has come to light. As a consequence, it has been necessary to formulate opinions on the basis of the limited information which Casal himself supplied in his works.

In the 12 February 1888 issue of La Habana Elegante, Casal published an article entitled "Galería Mignon: Ezequiel García." Imbedded in that article - a work composed exactly three years after D. Julián's death - we find a concise statement on fathers in general. The attitude expressed here, though held by many young men in the Hispanic world, seems to 
reflect Casal's own experience: "Los niños, por regla general, son muy semejantes. Casi todos tienen una madre que los mime, un padre que los asuste, una nodriza que los pervierta y un hermano que los haga rabiar." The impression that this statement is a reflection of Casal's personal feelings about $\mathrm{D}$. Julián is supported by the three poems in which his own father appears as the central figure: "Nocturno" (H8), "Mi padre" (N27), and "Recuerdo de la infancia" (R12). Let us consider these poems now.

Casal published "Nocturno" on 19 April 1885, just two and a half months after the death of his father. It is interesting to note that, in the four years prior to "Nocturno," only four compositions by Casal had found their way into print. "iUna lágrima!" (V1), his first published work, appeared in the 13 February 1881 issue of El Ensayo. Two other poems were printed soon afterward in the same journal: "El poeta y la sirena" (V2), on 5 March 1881, and "Huérfano" (V3), on 27 March 1881. More than two years passed before Casal published his next composition, "Amor en el claustro" (H3); this poem came out in El Museo on 5 August 1883. Then, for twenty long months, no work by Casal appeared in print.

Is it mere coincidence that this period of scarce productivity was the same period during which Casal, who had concluded his stay as an interno in the Real Colegio de Belén, ${ }^{6}$ was living with his father in the somber apartment on Compostela Street? To judge from what Casal says in "Nocturno" about his father's attitudes towards vanitas (ll. 17-20), fame (ll. 25-26), beauty (ll. 33-36), and the public confession of sorrow (ll. 41-44), it seems reasonable to assume that D. Julián - either by parental stricture or by his forbidding presence alone - discouraged his son from expressing his innermost sentiments in so public a medium as the press. If this was the case, then the publication of "Nocturno" and all the poems which followed it might be considered, at least in part, as a gesture of rebellion against the wishes of $\mathrm{D}$. Julián. As we shall see below, however, it was an act of rebellion that was fraught with internal conflict and a fear of reprisal.

"Mi padre," which was first published on 31 May 1891, may be considered as a busto en verso of Julián del Casal y Ugareda. In this sonnet, the poet portrays his father with less apparent emotional involvement than elsewhere. This cannot be explained solely by the fact that Casal was then writing under strong Parnassian influence, for just two months earlier, on 5 April 1891, he had published another sonnet in the "Marfiles viejos" series which was laden with emotion: "A mi madre." The difference in tone between these poems suggests how hard it must have been for Casal to give vent to his true feelings when confronted by $\mathrm{D}$. Julián-a sermonizing father, forbidding in aspect, who approached his son reprovingly in person and in dream, but who himself was unapproachable.

"Recuerdo de la infancia" makes it plain that Casal could not remain detached where his father was concerned. In this poem, which was first published on 4 September 1892, Casal evokes a dramatic nocturnal scene 
that apparently haunted him throughout his life. Here, as in "Nocturno," he paraphrases admonitions of D. Julián which must have augmented the feelings of guilt that plagued him from the day his mother died (see N26). Towards the end of his life, as his illness became more severe and as his misfortunes increased, Casal seems to have taken the words of his father more and more to heart. However, "Recuerdo de la infancia" suggests that, at times, he was less inclined to interpret the pronouncements of $\mathrm{D}$. Julián as words of guidance uttered by a loving soul than as words of doom which prophesied the punishment that his transgressions would bring upon him.

\section{H8: Notes to Introductory Statement}

1 For a transcript of Casal's baptismal certificate, see my discussion of N26.

2 Cromitos cubanos (Havana: "La Lucha," 1892), p. 301; Ed. del Cent., "Poesías," p. 317.

3 Manuel de la Cruz, loc. cit.

4 José Antonio Portuondo, “Angustia y evasión de Julián del Casal," Ed. del Cent., vol. I, pp. 45 and 51; the article was originally published in Cuadernos de Historia Habanera, vol. XIII (1937), pp. 55-87.

5 Ed. del Cent., vol. I, p. 189; italics are mine.

6 Marshall E. Nunn indicates that Casal entered the Colegio de Belén on 29 September 1873 and received his baccalaureate on 6 June 1879 ("The Life and Works of Julián del Casal,” p. 45).

H8: VARIANTS

l. $H E$

4 sombras

6 puerto,

7 observé

dolorida

* 8 desierto.

18 avecilla;

21 bien

30 lejos:

31 sol;

33 hermosa.

$34 \mathrm{El}$

* oculta

* bella,

35 flores,

36 nubes,

38 vacilantes;

39 i[v]ale
H

sombras,

puerto

observé,

dolorida,

desierto."

$H E$

avecilla,

bien,

lejos;

sol:

hermosa:

[e]l

oculta,

HE

bella

$H E$

flores

nubes

vacilantes.

iVale 
l. $H E$

40 brillantes!

44 conocerla

45 padre!

48 lecho (punctuation indistinct)

49 fatigado

51 adormece

52 canto peregrino.
H

diamantes!"

conocerlo

padre.

lecho;

fatigado,

duerme

armonioso trino.
GLIC:

diamantes!

\section{H8: Notes to Variants}

8: In the $H$ version, quotation marks were placed at the end of $11.8,12,16,20$, $24,28,32,36$, and 40 , as well as at the end of 1.44 . In the present edition, as in $H E$, close-quotes are used only at the end of 1.44.

34: When revising this poem for $H$, Casal inserted a comma after oculta. He apparently did this in order to place greater emphasis on the prepositional phrase which followed. At the same time, however, he removed the comma that had appeared after bella in the $H E$ version. In $H$, therefore, 1.34 concluded with an end-of-verse blank which, in my opinion, was too weak to give bajoforma bella the emphasis that Casal seems to have desired. Although sound reasons might be advanced for adding a comma after bella, it is felt that the words in 1.34 need no internal reinforcement. What they do demand is to be separated in a dramatic way from the illustrative statements which follow in 1l. 35-36. Such an effect can be achieved merely by restoring the punctuation found in the $H E$ version. (See H37/16 for a case where a similar prepositional phrase was justifiably set off by commas.)

\section{H9: EL ECO}

This work was first brought to public attention by El Figaro on 12 August 1886. The poem was entitled "Intima" and had as its subtitle the statement "(Imitación de François Coppée)." A centered rule was used to separate each stanza from the one that followed, and a dash was used both at the beginning and at the end of direct quotations in the text. Below the composition were the date "(1886)" and the name of the author. When Casal prepared this poem for publication in Hojas, he suppressed the centered rules between stanzas, the terminal dashes that had signalled the end of a quotation, the date, and his name; he changed the title to "El eco"; and he shortened the subtitle to "(Imitación de Coppée)."

Casal's interest in François Coppée (b. Paris, 12 January 1842; d. Paris, 17 May 1908) is evidenced by occasional references in his prose as well as by two poems, $\mathrm{H} 9$ and $\mathrm{H} 15$. This interest was far from unique during the Modernist period, however. Indeed, versions of Coppée poems were written by some of the most distinguished figures of the time and were 
published by important literary journals in every part of Spanish America. Although we do not know when or under what circumstances Casal became acquainted with the works of Coppée, there is no mystery about which aspect of Coppée's art made the strongest impact on him: “... Francisco Coppée, como todo el que ha sufrido mucho, si no rima sus tristezas, se inspira en las ajenas, reflejando en sus versos la profunda piedad que siente hacia los seres humildes, dolientes o extraviados...."1 One of the poems which made an especially great impression on Casal was "L'Écho." This poem became the source of inspiration for $\mathrm{H} 9$ :

J'ai crié, dans la solitude:

"Mon chagrin sera-t-il moins rude,

Un jour, quand je dirai son nom?"

Et l'écho m’a répondu: "Non."

"Comment vivrai-je, en la détresse

Qui m'enveloppe et qui m'oppresse,

Comme fait au mort son linceul?"

Et l'écho m’a répondu: "Seul!"

"Grâce! le sort est trop sévère!

Mon cœur se révolte! Que faire

Pour en étouffer les rumeurs?"

Et l'écho m’a répondu: "Meurs!"2

\section{H9: Notes to Introductory Statement}

1 Ed. del Cent., vol. II, p. 144.

2 Oeuvres complètes de François Coppée (Paris: L. Hébert, 1892), “Poésie," vol. II, pp. 313-314.

H9: VARIANTS

l. $F$

3 [q]ue dia?-

* 4 -iNunca!-

7 sudario?-

* 8 -iSolo!-

* 9 ( $(\mathbb{)}$ )-iGracias,

10 ¿Cómo

11 gemidos?-

* 12 -iMuere!respondió.
H

[q]ué [sic]

dia?

-iNunca!

sudario?

-iSolo!

(ף) iGracias, [sic]

-¿Cómo [sic]

gemidos?

-iMuere!

réspondió. [sic]
GLIC

F

día? $+H$ 
4, 8, 12: As I indicated above, Casal suppressed all terminal dashes when he revised this poem for $H$. This gave the composition a more pleasing appearance than it had had originally. It should be noted that omission of the dashes in ll. 4,8 , and 12 caused contemporary readers no more of a problem than did the removal of dashes elsewhere in the poem. The reason is that, in Casal's time, exclamation points were regarded as very strong punctuation marks. Indeed, they signalled such an emphatic pause that it was not necessary to supplement them with other signs. For this reason, I have not restored the terminal dashes to ll. 4, 8, and 12 (as Cabrera Saqui and Monner Sans, for example, have done), nor have I added other punctuation marks (e.g., commas) after the quoted statements in these lines.

9: The logic of the stanza indicates that the initial dash should precede 1. 9. This obliges us to interpret the punctuation variants in $11.9-10$ of $H$ not as conscious changes by Casal, but as errors committed by the typesetter.

\section{H10: INVERNAL}

This poem was first published in La Habana Elegante on 28 February 1886 under the title "Invierno." Following the title was the dedication "A Enrique Hernández Miyares" and the subtitle "Fragmento." The changes that were made when the composition was prepared for publication in Hojas attest to the poet's concern for finding the most effective means of expression possible: the title was changed to "Invernal," the subtitle was suppressed, the wording of the text was altered, the punctuation was modified, and four stanzas at the beginning of the poem were relocated. The following is a graphic representation of the changes Casal made in stanza position:

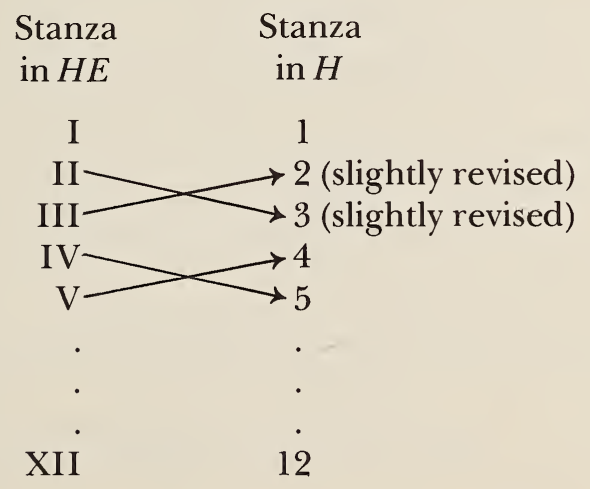

Given the descriptive nature of stanzas II-V and the conceptual similarity which they share, the value of the transpositions is open to debate. 


\section{H10: VARIANTS}

l. $H E$

3 lluviosos,

* 5 embravecida,

6 espantoso puebla;

7 [y] está llena la

8 [y] la celeste bóveda de

9 ( $($ )Las tristes y azuladas

22 colmenas:

* 25 sombrío

29 (ף) iOh primavera!

¿Por qué

34 lúgubre

35 campiña

* 37 Juventud,

39 mí...... icuando

41 huir:-¿jpor qué

* 42 i[o]h Juventud!

44 emjugó [sic]

* 45 ( $($ )Solo
H

lluviosos

enbravecida, [sic]

$H E$

espa toso [sic]

$H E$

puebla,

[1]lenando la ancha

[y] el cielo gris de impenetrable

( ()Bandadas de ruidosas

colmenas;

sombrío,

$H E$

iOh [sic]

$H E$

Primavera!

¿Porqué [sic]

$H E$

lóbrego

floresta

juventud,

$H E$

mí icuando

huir: ¿ Por que [sic]

i[o]h juventud!

$H+$ qué

$H E$

\section{H10: Notes to Variants}

5: The reader is reminded that verses 5-20 were in a different order in $H E$, and that the numbers cited in the record of variants, above, refer to lines in the $H$ version.

25: The comma which Casal inserted in the $H$ version tends to be very misleading. Since no convincing reason for its presence has been found, the comma has been omitted from this edition.

37, 42: Juventud is represented as a goddess in 1. 37, and is addressed as a living being in 1. 42. Under the circumstances, it seems more appropriate to capitalize the word than to write it with a lower-case $j$. Therefore, the $H E$ spelling has been restored.

45: In some editions (e.g., those of Cabrera Saqui, Monner Sans, and the $E d$. del Cent.), this word is spelled with an accent: sólo. It is this editor's feeling that such an interpretation completely destroys Casal's image. To see this, it is necessary merely to compare the two possible forms and their meanings:

Su...recuerdo...ha quedado $\begin{aligned} & \text { sólo (only) } \\ & \text { solo (alone) }\end{aligned} \quad$ en mi mente como

alguna rosa queda [sola (alone)] en el valle después de haber el huracán pasado. 


\section{H11: MIS AMORES}

"Mis amores" was first published in the 18 July 1886 issue of La Habana Elegante and four years later, with significant revisions, was incorporated into Hojas. The poem's simple history, however, has seldom been recorded with accuracy. In his Selección de poesias (p. lix), Geada cited 18 July 1887 as the date of its appearance in $H E$. Later, Duplessis ("Julián del Casal," p. 143) erred when reporting the date which his predecessor had himself cited incorrectly: "Para Geada, cosa que no hemos podido comprobar, data del año 1886 [sic]." Duplessis indicated, however, that he had found a copy of the poem in the 11 May 1890 issue of El Figaro. Two years before Duplessis' reference, Esperanza Figueroa had called attention to the $F$ version of the poem ("Bibliografía de Julián del Casal," p. 35). In light of this, it is odd that Cabrera Saqui failed to give any of the above information in his 1945 edition of Casal's poetry (see Poesias completas, p. 77). Strange, too, is the fact that, when re-issuing Cabrera Saqui's text, the compilers of the $E d$. del Cent. did not add the missing data in a note to the text, even though they listed both the $H E$ and the $F$ versions in their Casal bibliography (see vol. III, p. 197). In the record of variants to the present edition, no reference is made to the $F$ version because it came out after Hojas was published.

When comparing the original $H E$ version of "Mis amores" with the one that appeared in Hojas, we notice that while the title was left intact, other parts of the composition were modified to a significant extent: the subtitle was expanded from "Soneto" to "Soneto Pompadour," 1 three changes were made in stanza II, and the original tercets were replaced with entirely new ones. As can be seen below, Casal's revision of 11. 9-14 completely changed the character of the poem:

\section{$H E$}

9 Pero amo mucho más, Rosa hechicera

10 Que escuchas mis cantares amorosos,

11 Contemplar, con miradas devorantes,

12 El oro de tu larga caballera [sic],

13 El rojo de tus labios temblorosos

$14 \mathrm{Y}$ el negro de tus ojos centellantes.

\section{$H$}

9 El rico piano de marfil sonoro,

10 El sonido del cuerno en la espesura,

11 Del pebetero la fragante esencia,

12 Y el lecho de marfil, sándalo y oro,

13 En que deja la virgen hermosura

14 La ensangrentada flor de su inocencia. 
As indicated in my discussion of "Amor en el claustro" (H3), it is conceivable that the radical change which Casal made in the Hojas version of "Mis amores" was influenced to some extent by the fact that, as a substitute for strong amorous bonds with women, Casal developed an increasing attachment to inanimate objects of rare and striking beauty. Although psychological factors of this kind were probably involved, it is possible that Casal's revision of "Mis amores" was influenced by other factors as well. For example, at some time before 1892, Cornelius Edouard Price wrote "Ce que j'aime," a réplica to Casal's poem. ${ }^{2}$ It is not known whether Price based his sonnet on the 1886 version of "Mis amores" or on the one that appeared four years later in Hojas. A detailed comparison of the Spanish and French compositions, however, strongly suggests that Price used the 1886 version of the poem as his source of inspiration. If he did, then the additional possibility arises that Price's sonnet antedated Hojas and that Casal re-wrote the tercets of "Mis amores" under the influence of "Ce que j'aime":

\section{Ce que jaime}

1 J'aime la nacre, les émaux, les marbres blancs,

2 Les gemmes dans les feux de l'or qui les enchâsse,

3 L'infini du ciel pur et la mystique châsse,

4 Les regards de la lune et le vol des milans.

5 J'aime aussi la chanson des pâtres nonchalants,

6 Plus que l'appel du cor des grands seigneurs en chasse,

7 Et les oiseaux d'été que la froidure chasse,

8 Et le rythme des vers aux sublimes élans.

9 J'aime à voir les blés blonds sous le soleil torride,

10 Le miroir de l'étang qui bleuit et se ride,

11 Et les bœufs dans les prés errer paisiblement.

12 Mais j'aime plus encore la chaste adolescente

13 Qui meurt, ayant perdu ses rêves et l'amant,

14 Dans l'éclat virginal de sa chair innocente. ${ }^{3}$

\section{H11: Notes to Introductory Statement}

1 A year and a half after the original version of "Mis amores" came out, Casal published "Los funerales de una cortesana" (HE, 20 November 1887), a short story dealing with the burial of Madame de Pompadour. His treatment of King Louis XV, Madame Du Barry, and Madame de Pompadour was one of the earliest modernista interpretations of aristocratic life in XVIII century France. Two and a half years later, in Hojas al viento, he added the word "Pompadour" to 
the subtitle of "Mis amores" as a way of announcing to his reader the theme of refined elegance which he would develop in the poem.

2 "Ce que j'aime," with a dedication to Casal, was published in 1892 in Pour l'Amour des vers, Price's first collection of poems. For information on Price and his relationship with Casal, see my discussion of Np5.

3 Quoted from Max Henríquez Ureña, "Poetas cubanos de expresión francesa," Revista Iberoamericana, vol. III, nos. 5-6 (February-May 1941), p. 325. I have made three changes in the text as cited by Henríquez Ureña: 1.1 (blancs $>$ blancs,), 1. 10 (que >qui), and 1. 13 (que > qui). The changes indicated for 11.1 and 13 were already made by Monner Sans in his Julián del Casal y el modernismo hispanoamericano (Mexico: El Colegio de México, 1952), p. 243.

\section{H11: VARIANTS}

\section{l. $H E$}

7 voladores

$8[y]$ las tristes alemanas.
$H$

voladores, [l]as flébiles alemanas,

GLIC

* 9-14

\section{H11: Note to Variants}

9-14: The text of the original version is shown above in my commentary on the poem.

\section{H12: LAZOS DE AMOR}

This poem was first published in El Fígaro of 28 January 1886 under the title "Lazos de muerte." The composition was dedicated "A un amigo" and a centered rule was used in the text between stanzas. In revising the work for Hojas, Casal retained the original dedication, but suppressed the centered rules, modified the wording and punctuation of the text, and changed the title to "Lazos de amor." This change of title apparently occurred at the last moment, because no correction was made in the table of contents, where the poem continued to be listed as "Lazos de muerte."

\section{H12: VARIANTS}

l. $F$

2 yo tu sufrir:

3 i[c]ontigo

4 i[c]ontigo

8 centella $[$ sic $]$

9 ví,
$H$

tu hondo sufrir.

iContigo

iContigo

centella.

ví

$\mathrm{vi}+H$ 


\section{H13}

l. $F$

10 [d]e un

11 bella

* 19 diamante,

22 [l]os perfumes

flor;

25 ( () De mi lira la armonia

26 [n]o te dirá afliccion:

$27 i[y] o$

30 profundo,

* 33 pesar,
H

[d]el

hermosa

diamante

[e]l perfume

flor,

(ף)En mi pálida poesía

[n]o encontrarás

aflicción.

iYo

profundo

pesar

\section{H12: Notes to Variants}

19: The comma of the $F$ version is restored in the present edition because an end-of-verse blank is too weak to emphasize the structural and conceptual parallelisms that characterize ll. 19-20, or, on first reading, to prevent the inadvertent linking of ardiente in 1.20 with diamante in 1.19.

33: Use of an end-of-verse blank in this instance is not considered censurable. Indeed, suppression of the comma at the end of 1.33 reinforces the idea of unity which Casal has been stressing throughout the poem and which, in the final stanza, he brings to a climax through the use of uno-una and unio-no separar in parallel sequence.

\section{H13: AUSENCIA}

This work was first published in the 6 December 1885 issue of $L a$ Habana Elegante. Its title at that time was not "Ausencia," but "Desde lejos." The date " 1884 " appeared beside the author's name and indicated when the poem had been composed. Duplessis ("Julián del Casal," p. 144) asserts that he found "Ausencia" in the 26 September 1886 issue of $E l$ Figaro; however, no critic writing after Duplessis has mentioned the existence of an 1886 version of the poem, and none could be located by this editor.

"Ausencia" came out once again in the 5 May 1890 issue of LaDiscusión. All evidence suggests that Hojas had been printed by this time and that the poem was published in La Discusion as a means of advertising the book. For this reason, no reference is made to the $D$ version in the record of variants, below.

\section{H13: VARIANTS}

l. $H E$

* $13-16$

(ף)Sabrás que si á veces dudo pasan!

GLIC

(ף)Que si á veces he dudado $\quad H+\mathrm{a}$ pasan. 


\section{H13: Note to Variants}

13-16: In addition to changing the title from "Desde lejos" to "Ausencia," Casal made a most important textual change when he revised the poem for publication in $H$ : namely, he inserted four new verses immediately after 1.12 of the original version. Thus, what had been 1.13 in $H E$ became 1.17 in $H$. The words "Sabrás que" (which had appeared at the beginning of 1.13 in $H E$ ) were used at the beginning of the new stanza, and a minor adjustment was made in the initial line of the next stanza (see l. 17).

\section{H14: EL PUENTE}

"El puente" was first published on 25 July 1886 in La Habana Elegante; its subtitle was "(Imitación de Victor Hugo)." Five weeks later, "A Olimpia" (H23), another paraphrasing of Hugo, came out in the same journal. The fact that Casal wrote versions of two poems by Hugo (b. Besançon, 26 February 1802; d. Paris, 22 May 1885) is not at all surprising, for in the months after Hugo's death, countless American authors offered eulogies to the departed master, and periodicals of almost every type published translations of his poems either as single items or in homenaje series. An example of the latter is Bogotá's Papel Periódico Ilustrado, vol. IV, pp. 364-373, which presented translations by twenty-five writers, among them such notable figures as Andrés Bello, Miguel Antonio Caro, Gregorio Gutiérrez González, José Manuel Marroquín, Antonio Sellén, and José Asunción Silva. Hugo's popularity in Spanish America, however, was not restricted to men of letters or to the period immediately following his death. According to Emilio Carilla, "si hay un nombre que recorre prácticamente, a lo largo de su fama y honda influencia, el siglo XIX americano, ese nombre es el de Víctor Hugo. Ninguno, como él, tuvo tanta aceptación, despertó tantas admiraciones e hizo nacer tantos remedos. Hasta llegó a trascender ámbitos típicamente populares y determinó - ya en vida - la dimensión del mito. . . . Germán Arciniegas recuerda los retratos de Hugo en las casas americanas durante las guerras civiles del pasado siglo. Se imprimieron pañuelos en honor al escritor, con su efigie y la de escenas de sus obras más difundidas. Un pintor venezolano, Michelena, alcanzó algún prestigio como ilustrador de Hugo. En fin, sus bustos inconfundibles llegaron hasta nuestro siglo, y no es raro encontrar todavía alguno."1

Casal based "El puente" on the initial poem in the sixth book of Hugo's Les Contemplations:

\section{Le Pont}

J'avais devant les yeux les ténèbres. L'abîme

Qui n'a pas de rivage et qui n'a pas de cime 
Était là, morne, immense; et rien n'y remuait. Je me sentais perdu dans l'infini muet.

Au fond, à travers l'ombre, impénétrable voile, On apercevait Dieu comme une sombre étoile. Je m'écriai:-Mon âme, ô mon âme! il faudrait, Pour traverser ce gouffre où nul bord n'apparaît, Et pour qu'en cette nuit jusqu'à ton Dieu tu marches, Bâtir un pont géant sur des millions d'arches. Qui le pourra jamais? Personne! O deuil! effroi! Pleure!-Un fantôme blanc se dressa devant moi Pendant que je jetais sur l'ombre un oil d'alarme, Et ce fantôme avait la forme d'une larme; C'était un front de vierge avec des mains d'enfant; Il ressemblait au lys que sa blancheur défend; Ses mains en se joignant faisaient de la lumière. Il me montra l'abîme où va toute poussière, Si profond que jamais un écho n'y répond, Et me dit:-Si tu veux, je bâtirai le pont. Vers ce pâle inconnu je levai ma paupière. -Quel est ton nom? lui dis-je. Il me dit:-La prière. ${ }^{2}$

When preparing his material for Hojas, Casal made a few minor changes in the 1886 version of "El puente." These are listed in the record of variants which follows.

\section{H14: Notes to Introductory Statement}

1 El romanticismo en la América hispánica (Madrid: Gredos, 1958), pp. 63, 65. Casal also had a bust of Hugo. According to Marshall Nunn, who saw it in the home of the poet's sister, it was made of wood and was a gift from Aniceto Valdivia ("The Life and Works of Julián del Casal," p. 45).

2 Oeuvres poétiques complètes (Montreal: Éditions Bernard Valiquette, 1944), p. 385 .

H14: VARIANTS

l. $H E$

$3[\mathrm{y}]$

4 siniestra

* 5 veía,

* 6 ansiedad,

8 llegar

* 10 ahora descansa?

13 deseas.

14 dije-La plegaria.
H

[y], celeste veía; ansiedad subir tiene su estancia?deseas, [sic] $H E$ dije. - La

GLIC

$H E$

Plegaria. 
5: In several places in $H$ (see $\mathrm{H} 5 / 6$ and $\mathrm{H} 6 / 10$, for example), Casal used a semicolon instead of a comma to mark the end of a complex introductory statement. In this poem, the semicolon has a special virtue which the comma of the original version did not: it obliges the reader to pause long enough to avoid being surprised by the sudden change in subject which takes place between 1.5 and l. 6 (veía [yo] > exclamó mi alma). For this reason, the punctuation of the $H$ version is considered to be an improvement over that found in $H E$.

6: The comma of the $H E$ version is restored in the present edition in order to bring the subject of "exclamó" into relief.

10: The dash is necessary at the end of this verse: it alerts the reader to the fact that the two lines which follow are not part of the statement made by yo in 11. 7-10, but are narrative verses that introduce the response of La Plegaria. A comparable case is found in $\mathrm{H} 7 / 16$.

\section{H15: EL ANHELO DEL MONARCA}

This poem was first published in the 26 September 1886 issue of $L a$ Habana Elegante. The subtitle of that version was "Tradición." Two rows of dots were printed from margin to margin between 11. 44-45. When revising the poem for publication in Hojas, Casal changed the subtitle to "(Imitación de Coppée.)"; he suppressed one of the rows of dots between 11. 44-45; and, as he so frequently did before re-issuing his works in book form, he made several changes in wording and punctuation.

The intensity of Casal's admiration for Coppée in mid-1886 is shown by the fact that, within a month and a half, he published two poems inspired by the great French master: "El eco" (H9) and "El anhelo del monarca" (H15). The latter composition was based on "Le Pharaon," one of the "Récits Épiques" that was included in Les Récits et les Élégies:

Le devin Thoutmès quatre est mort, et sa momie

Est dans son hypogée à jamais endormie;

Thoutmès quatre est au rang des dieux-rois. Et son fils,

Le nouveau pharaon d'Égypte, Aménophis,

A pris possession du trône de son père.

Coiffé du bandeau d'or où se tord la vipère,

Le torse droit, les mains sur les cuisses, les yeux

Perdus dans on ne sait quel rêve soucieux,

Un morne et foid sourire à ses lèvres lippues,

Il reçoit, au milieu des colonnes trapues

De son palais couvert d'hiéroglyphes peints,

L'hommage des guerriers et des prêtres thébains.

Sur les trépieds d'airain fument les aromates; 
Et, prosterné, le chef des hiérogrammates Lui prédit les grandeurs de son règne futur: "Salut, roi de Kémit! pharaon trois fois pur, En qui sont la santé, la vigueur et la vie!

Parle. Ta volonté sainte sera servie.

C'est pour toi que les trois gardiens, Fré, Knef et Fta, Rendent le Nil fécond de la source au delta, Et pour toi que les sphinx et les cynocéphales Lancent vers le soleil leurs clameurs triomphales.

Ordonne, pharaon sublime! Que veux-tu?

La récolte est à toi jusqu'au moindre fétu:

Dicte un ordre, et ce peuple immense, tu l'affames.

A toi l'Égypte! A toi les hommes et les femmes, Et les produits du sol, et tous les animaux!

Veux-tu la gloire? Eh bien! roi puissant, dis deux mots, Et nous rassemblerons ta flotte et tes armées:

Les nations seront par ton bras décimées,

Et tu feras courir leurs plus fameux guerriers,

Captifs près de ton char, comme des lévriers;

Et tu reculeras au loin ton territoire

Et graveras partout ta stèle de victoire.

Parle! Dédaignes-tu la guerre et ses hasards?

Ton cœur est-il épris des plaisirs et des arts?

O maître, fais-nous donc savoir ta fantaisie,

Et parmi les parfums cent esclaves d'Asie,

Radieuses ainsi que l'aurore en été

Et parant de bijoux leur brune nudité,

Au son des tambourins et des doubles crotales

T'enivreront de leurs danses orientales!

Ton caprice veut-il construire un monument

Où dure ta mémoire impérissablement

Et près de qui seront trop petits et timides

Le Lac, le Labyrinthe et les trois Pyramides?

Rêve aussi colossal que tu pourras rêver,

Fils des dieux! et, pour toi, nous ferons soulever

Des milliers de blocs lourds par des millions d'hommes.

O pharaon! tout est à toi dans les vingt nomes,

Le soldat casqué d'or, le prêtre circoncis,

Le scribe, l'artisan à son travail assis,

Ceux de tous les métiers et de toutes les castes,

Et jamais tes désirs ne seront assez vastes.

Parle, ordonne, commande! et nous obéirons."

Il dit; et tous sont là, muets, courbant leur fronts.

Mais, se sentant le cœur plein d'un dégoût immense

Et s'étant demandé comme il sied que commence 
Ce règne qu'on lui peint si prospère et si beau, Le jeune roi répond:

"Bâtissez mon tombeau."1

\section{H15: Note to Introductory Statement}

1 Oeuvres complètes de François Coppée (Paris: L. Hébert, 1892), "Poésie," vol. II, pp. 188-191. In his article "La antigua nobleza," which was published in $H E$ on 1 April 1888 and which was destined to be Chapter II of La Sociedad de la Habana, Casal gave direct evidence of having also read Une Idylle pendant le siège (see Ed. del Cent., vol. I, p. 135).

\section{H15: VARIANTS}

l. $H E$

7 [q]ue espirales

* 20 olvido;

* 23 [q]ue, halagadora,

26 serena

28 melancolía?

40 placercs. [sic]

45 (ף)El

* 46 [s]u

47 respondió:
H

[q]ue, espirales, olvido: [sic]

[y], encantadora, serena, melancolía. [sic] placeres.

El

[1]a contestó, HE

GLIC

HE

$H E$

\section{H15: Notes to Variants}

20: The colon at the end of this line in $H$ was probably a typographical error, for, when Casal wished to terminate an introductory statement, he generally used either a comma or a semicolon (see, for ex., H5/6, H6/10, and H 14/5).

23: From the point of view of logic, que is better than $y$ in this position. However, que has a feature which makes it inferior to $y$ : it adds one more $k$ sound to a pair of verses (1l. 23-24) which refer to the enchanting voice of a seductive woman. With que present, these verses become unpleasant to the ear. When $y$ is substituted, the number of velar occlusives drops from four to three, and the sound of the verses is brought into closer harmony with the thought that they express.

46: It is interesting to note that Casal did not change su to $l a$ in 1.18 , despite the fact that that verse was so similar to this one.

\section{H16: CONFIDENCIA}

"Confidencia" was first published in the 17 March 1889 issue of $E l$ Figaro. In this version, the date "(Marzo, 89.)" was printed together with 
the author's name below the text. When preparing his material for Hojas, in addition to suppressing the latter elements, Casal made several changes in the body of the poem.

\section{H16: VARIANTS}

l. $F$

1 adorada,

2 te alejas adusta de mis brazos?

4 hecho pedazos.

5 ( $($ ) iDímela!-¿ंNo [sic] vida...?

6 -iNunca!-¿’Por qué no hablas con franqueza?

* 8 fiel.-¿Quién?-La Pobreza.
H

adorada

doblas la cabeza sobre el pecho? pedazos hecho.

(ף)-Dímela:-¿No vida?

-iNunca!-Si mientes, permanezco seria. fiel.-¿Quién-?La [sic] Miseria.
GLIC

F

(ף)-Dímela. -¿̇No

-iNunca! $-\mathrm{Si}+H$

fiel. -¿Quién? -La

\section{H16: Note to Variants}

8: It is interesting to observe the conceptual similarity between the cluster querida ... siempre fiel ... Pobreza/Miseria which is found in 11. 7-8 of this poem and the inverse grouping pobreza ...fiel . . companero/novia which appears in the last stanza of "Nihilismo" (R3), a poem written three years later:

Ansias de aniquilarme sólo siento

o de vivir en mi eternal pobreza, con mi fiel compañero, el descontento, y mi pálida novia, la tristeza.

\section{H17: EL ADIOS DEL POLACO}

"El adiós del polaco" was first published on 15 July 1886 by El Fígaro. The date "(Julio, 1886.)" was printed to the left of the author's name at the end of the poem. Before publishing the composition in Hojas, Casal made significant changes in the text.

1. FORMAT.

a. In both versions, the poem was divided into three sections. Roman numerals were used in El Fígaro; centered asterisks were used in Hojas.

b. In El Fígaro, a centered rule separated all stanzas except those between which Roman numerals appeared. The centered rules were omitted from Hojas.

c. In El Figaro, ll. 1-8 were presented as a single stanza. Thus, the format of Part I was distinct from that of Part III, in which the 
eight component verses were arranged as two stanzas. In Hojas, 1l. 1-8 were divided into two stanzas.

d. The manner in which the text was printed in El Figaro emphasized the fact that the poem was built upon two distinct metrical patterns: octosyllabic verses in Parts I and III, and alternating heptasyllabic and hendecasyllabic verses in Part II. The metrical structure of Part II was transparent because each heptasyllabic line was indented four spaces from the left margin. The format of Part II was changed in Hojas: only the initial verse in each stanza was indented. As a result, the difference in metrical pattern was not immediately perceptible to the eye. Rather, it subtly imposed itself on the reader's consciousness as he proceeded through the text.

On the whole, these changes in format were an improvement over the original printing, for they created an impression of overall architectural balance and insured that the movement from one segment of the poem to another would be smooth.

2. CONTENT. When revising the poem for Hojas, Casal made major changes only in Part II. These changes, however, significantly altered the character of the work.

a. Stanzas I, VII, and X were omitted.

b. Stanzas II, III, and IV were relocated.

c. Stanzas VIII and IX were revised.

d. A new stanza was written and inserted in third position.

For the reader's convenience, a graphic representation of these changes is shown in Plate 2 and the $F$ version of Part II is reproduced below. The import of Casal's revisions will be discussed subsequently.

$\begin{array}{cc}\text { Stanza } & \text { Stanza } \\ \text { in } F & \text { in } H\end{array}$

I

omitted

II

III
II.

-¿No escuchas el lamento

Lanzado por la patria dolorida,

En las alas del viento

Cruzar, clamando libertad y vida?

¿No ves á los tiranos

Desgarrar de la pátria inmaculada,

Con infamantes manos,

La veste azul de perlas adornada?

¿No escuchas el sonido

Del clarin estruendoso de batalla

Y el horrendo estampido

Con que el cañon atronador estalla? 
IV

V

VI 6

VII omitted

VIII 7

IX 8

X omitted

XI 9

XII
¿ No ves subir al cielo

Rojo vapor de sangre que aún humea, Mezclándose en su vuelo Al humo negro de incendiaria tea?

Polonia, enardecida

Por el rigor de sus constantes penas, Álzase decidida

A romper para siempre sus cadenas.

Al grito de venganza, Sus ofendidos hijos valerosos,

Empuñando la lanza,

Se arrojan al combate presurosos.

La inexorable suerte

No doblega sus ánimos viriles,

Y ni la misma muerte

Logra aterrar sus almas juveniles.

Tu amor abandonando, Tambien me arrojo á la feroz pelea,

Para vivir luchando

Por nuestra santa y redentora idea.

Nunca podrá la ausencia Extinguir el ardor con que te quiero!

iEn la humana existencia

Sólo el primer amor es duradero!

Tu amor es en el dia

Brillante sol que en el silencio adoro,

Y en la noche sombría

La blanca estrella de mis sueños de oro.

iAdios! Si de la gloria

A merecer no alcanzo los favores,

Conserva en tu memoria

El recuerdo feliz de mis amores.

Dame el último beso,

El beso de tu amante despedida,

Para guardarlo impreso

Hasta el postrer instante de la vida.

A comparison of the two versions will reveal the significance of the 
major changes that were made in this poem. At the beginning of Part II of the 1886 version, Casal established an alternating pattern of auditory and visual images:

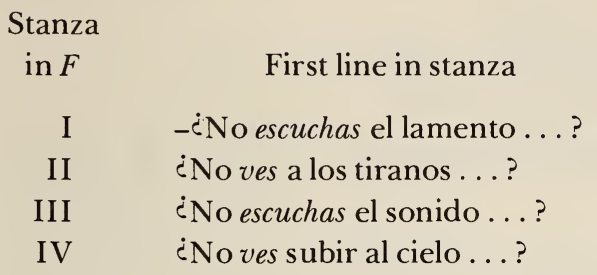

Type of image

(auditory)

(visual)

(auditory)

(visual)

One of the features of this organization was that it reproduced the chaotic nature of human perception in the midst of battle. Reproduction of disorder, however, was not one of Casal's ideals. Quite the contrary: as an artist, his fundamental aim was to bring order out of the chaos of reality. Accordingly, on revising the poem, he first gave an overall view of the invasion and then focused on its consequences. That is, he began by calling attention to the clarion's signal to attack and the artillery's thunderous response to its command (III), the destruction caused by the bombardment (IV), and the onslaught of the enemy troops (new in Hojas); then he introduced the image of Poland's ravishment (II).

Although Casal chose to omit stanza I from the Hojas version, he could have retained it without difficulty simply by placing it after the "¿No ves a los tiranos ... ?" image. This relocation would have had two points in its favor. First, it would have added to the realism of the situation, because the lament of the victim would be a natural result of her violation. Second, it would have created an aesthetically pleasing structural arrangement, because the auditory image " ¿No escuchas el lamento . . . ?" would counterbalance the image that Casal placed at the beginning of the section in Hojas. If Casal had reasoned this way, the revised version of Part II would have begun as follows:

\begin{tabular}{cll}
$\begin{array}{c}\text { Stanza } \\
\text { in } H\end{array}$ & \multicolumn{1}{c}{ First line in stanza } & Type of image \\
1 & - ¿No escuchas el sonido ...? & (auditory) \\
2 & ¿No ves alzarse al cielo ...? & (visual) \\
3 & ¿No ves las numerosas ...? & (visual) \\
4 & ¿Noves a los tiranos ...? & (visual) \\
(I) & ¿No escuchas el lamento ...? & (auditory)
\end{tabular}

Casal did not see things this way, however, and omitted stanza I from Hojas. Why he did so is open to conjecture, but he may have felt that inclusion of the stanza would retard the movement of the poem and thus reduce its power. What was desired in the first instance was to summarize dramatically, yet succinctly, the infamous attack on Poland. Once this aim 
PLATE 2

Revisions in "El adiós del polaco"

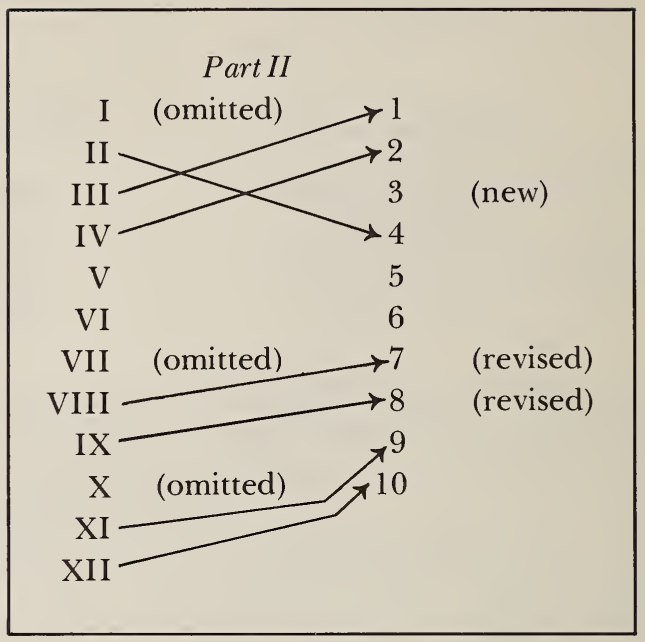

had been achieved (stanzas $1-4$ ), it was advisable not to dwell on Poland's humiliation (as would be the case if stanza I were retained), but quickly to stress the nation's will to arise and throw off her chains (stanza 5).

The desire to make his poetic statement in the most economical way possible also seems to explain why Casal deleted stanza VII. After mentioning Poland's will to regain her freedom (stanza 5) and enunciating the decision of her sons to hurl themselves into combat (stanza 6), the next logical point for the speaker to establish is his own position in the conceptual hierarchy patria < hijos valerosos <yo. To speak of hijos' fearlessness in the face of death (stanza VII) would not only be superfluous under the circumstances, but would also delay the expected conclusion, which is that "[yo] también me arrojo a la feroz pelea ..." (stanza 7).

Similar reasoning may be applied to an analysis of why Casal omitted stanza X. The speaker made his feelings towards his beloved quite clear in stanza 8 . The only thing left to do was to bid her farewell (stanza 9) and seal the parting with a kiss (stanza 10). To add anything else would be to weaken the character of the speaker and to lessen the impact of the poem.

In spite of the fact that love of country is the central theme in "El adiós del polaco," this poem was not mentioned by Enrique Hernández Miyares in his discussion of patriotism in Casal. ${ }^{1}$ It may be that Hernández Miyares omitted the poem because it does not deal with Cuba; however, it is also possible that he detected within it an underlying ambivalence which would have weakened his argument about Casal's patriotic feelings. On the one hand, Casal endowed the Polish warrior with an uncompromising love of country; but on the other, he suggested that patriotism, like the invading horde, also leaves helpless victims in its wake. Not only is the 
young girl's future sacrificed, but so too is the warrior's, for unlike passions such as art, science, and religion, patriotism seldom rewards fidelity with more than death and oblivion. ${ }^{2}$ This may be one of the major reasons behind Casal's disinclination to write patriotic poetry. ${ }^{3}$

\section{H17: Notes to Introductory Statement}

1 “Julián del Casal, patriota," Obras completas, vol. II, pp. 35-40; Ed. del Cent., "Poesías," pp. 307-311.

2 See "Adiós al Brasil del Emperador don Pedro II" (H45) as well as the initial paragraph of "Enrique José Varona" in Bustos.

3 Other aspects of the patriotism question are discussed in my comments to H44, H48, and R15. See also, Casal's letter of 19 March 1891 to Esteban Borrero Echeverría, in Ed. del Cent., vol. III, p. 87.

\section{H17: VARIANTS}

l. $F$

4 mañana,

5 guerrero,

* 9 (ף) ¿ंNo

11 horrendo

12 [c]on que el cañon atronador estalla?

13 subir

24 adornada?

29 venganza,

30 ofendidos

34 [t]ambien me arrojo pelea,

35 (ศ) [p]ara vivir luchando

36 [p]or nuestra santa y

37 (ף)Nunca podrá

38 [e]xtinguir el ardor con

40 duradero! que te quiero!

41 (I) iAdios!

* 42 favores,

44 feliz

45 beso,

46 [e]l beso de tu amante despedida,

47 guardarlo

54 [é]l
$H$

mañana;

guerrero

(ף) - ¿No

hórrido

[d]el tronante cañón y la metralla?

alzarse

recamada?

venganza

esforzados

[a]udaz me lanzo

-[p]obre paria buscando

[m]uerte á la luz de

GLIC

(ף)Ni el tiempo ni

[h]arán que olvide tu cariño tierno.

el eterno!

(ף)Adios.

favores

fellz [sic]

F

F

beso

[c]on el postrer adios de la $\quad H+$ adiós partida,

llevarlo

[é]1
( ()Adiós.

pelea

$H+\mathrm{a}$ 


\section{H17: Notes to Variants}

9: The reader is reminded that the line numbers shown in the record of variants are those of the $H$ version. Casal's reorganization of Part II made it necessary for him to use the dash as a prefix to 1.9 in 1890 (see my reproduction of the $F$ text, above).

42: It is felt that the $F$ version should be followed, since the comma would emphasize the line of demarcation between the si clause, whose subject is yo, and the following clause, whose subject is tú. Indeed, it seems even more appropriate to use a comma in this instance than in cases such as H20/30, where the subject of both clauses is the same.

\section{H18: LA MAYOR TRISTEZA}

This poem was first published in the 13 May 1888 issue of La Habana Elegante. Its subtitle was "Soneto." The text was printed in a script-style typeface, and the composition occupied the entire first page of the journal. The variants which appeared in Hojas were mainly changes in punctuation.

\section{H18: VARIANTS}

l. $H E$
2 vida,
4 ayude subir [sic]
5 que
6 ruega
7 lleva,
dolorida,
9 ( $)$ Pero más
10 Dios, ni

$H$

vida

ayude á subir

que,

pide

lleva

dolorida

(ף)Pero mas

Dios ni

\section{GLIC}

$H+\mathrm{a}$

(ף) iPero más

\section{H19: LAS PALOMAS}

"Las palomas" was first published in the 8 April 1886 issue of El Fígaro. In this version, it was subtitled "(De T. Gautier.)" and bore the date "Abril, 1886." When Casal revised the work for publication in Hojas four years later, he expanded the subtitle to "(Imitación de T. Gautier.)," introduced a number of lexical and punctuation changes into the text, and suppressed the date.

Casal's source of inspiration was "Les Colombes," the second poem in the group designated as "Poésies diverses." 1 The poem, which seems to 
have been a favorite of Spanish American admirers of Théophile Gautier, reads as follows:

Sur le coteau, là-bas où sont les tombes,

Un beau palmier, comme un panache vert

Dresse sa tête, où le soir les colombes

Viennent nicher et se mettre à couvert.

Mais le matin elles quittent les branches:

Comme un collier qui s'égrène, on les voit

S'éparpiller dans l'air bleu, toutes blanches,

Et se poser plus loin sur quelque toit.

Mon âme est l'arbre où tous les soirs, comme elles,

De blancs essaims de folles visions

Tombent des cieux, en palpitant des ailes,

Pour s'envoler dès les premiers rayons. ${ }^{2}$

\section{H19: Notes to Introductory Statement}

1 Casal also translated "Le Nuage," the first poem of this series. See my comments on $\mathrm{H} 7$.

2 Poésies complètes de Théophile Gautier (Paris: Charpentier, 1862), pp. 165-166.

\section{H19: VARIANTS}

l. $F$

2 que á un sepulcro presta

sombra,

3 noche a

4 blanco grupo

6 rósea

7 desgranado,

9 palmera;

10 sueños

11 vienen,
$H$

[q]ue sombra [sic] blanca

fosa,

noche. á [sic]

[n]ívea banda

roja

desgarnado, [sic]

palmera:

ensueños

vienen
GLIC

$H+$ sombrea

F

F

\section{H20: QUIMERAS}

This composition was originally published in La Habana Elegante of 1 January 1888 under the title "Ensueño." The subtitle of this version was "En el álbum de una dama." When Casal revised the work prior to publishing it in Hojas, he changed the title to "Quimeras" and omitted the 
subtitle. In addition, he made some very significant alterations in the text of the poem. Of particular interest are the major revisions which he made in the last two stanzas:

$H E$

37 Pero si algún rival osado entrase

38 En la mansión augusta,

39 Donde serás la reina de mi alma

$40 \mathrm{Y} \mathrm{mi}$ alma la fiel esclava tuya;

41 Verá sólo, con ojos espantados

42 Y cólera profunda,

43 Que mientras un puñal clavo en tu seno

44 Venenoso licor mi boca apura.

$H$

37 Mas si te arranca la implacable Muerte

38 De la mansión augusta,

39 Donde serás la reina de mi alma

$40 \mathrm{Y}$ mi alma la fiel esclava tuya;

41 Yo guardaré en mi espíritu sombrío,

42 Tu lánguida hermosura,

43 Como guarda la adelfa en su corola

44 El rayo amarillento de la luna.

These changes are important because they correct an unfortunate deviation which marred the original. In the 1888 version, after devoting nine stanzas to an amorous evocation of all that he would do to satisfy the whims of his loved one, the speaker suddenly brings a hypothetical rival into the picture (1. 37). As a result of this fancied intrusion, which he interprets as a threat to his relationship with the young woman, the speaker murders his beloved and takes his own life as well. This violent and completely unexpected - act casts the entire poem into a new light. It implies that the speaker's earlier generosity was egocentrically motivated and was not inspired by a concern for the happiness of his beloved. It also suggests that he lacked the inherent qualities necessary to win and hold the lady's affection, and that this deficiency induced him to entice her with extravagant promises. Under these circumstances, the appearance of another suitor was tantamount to betrayal by his loved one and served to confirm his own doubts about himself. The intended violence portrayed at the end of the poem may therefore be interpreted as punishment to the lady for her "infidelity" and to himself for his shortcomings as a lover.

By re-writing the last two stanzas, Casal returned to the course which he had originally established in stanzas I-IX. Now the speaker remains 
consistent throughout the poem, and no one can question the integrity of his character or doubt the magnanimity of his love. Despite these changes, Death still comes between the lovers in the new version. The fact that Death is now represented as an independent, abstract force, rather than an instrument of private passion, should not detract from the significance of its retention as a poetic element in the Hojas version. Indeed, one might say that, given Casal's somber outlook on life, it would have been quite unusual if he had suppressed this theme from the poem and concluded the work on a happier note.

A final point of interest is Casal's revision of the last stanza. By creating the image mi espiritu sombrio : tu lánguida hermosura = la adelfa : el rayo amarillento de la luna, the poet fell into two patterns which were to become hallmarks of much of his later work. The first, here expressed through the choice of the poisonous adelfa, is a view of himself as a contaminated and contaminating being. The second is the chiaroscuro image pattern which he was to favor with ever greater frequency as time went on.

\section{H20: VARIANTS}
l. $H E$
$H$
GLIC
1 divina
adorada
8 podré
pueda
angustia.
16 soberbios
angustia [sic]
$H E$
18 oscuras
suntuosos
de luna,
23 brillante
* 26 escultura,
30 (ף)[a]brasan
41
fulgente
(ף)[s]urgen de
sombrío,
sombrío
43
[c]cmo [sic]
como

* 37-44

\section{H20: Notes to Variants}

26: Casal, who tended to express himself in thought units of two verses, inserted a comma after escultura in order to oblige the reader to make an emphatic pause before the long subject of admirará (see ll. 27-28). This use of the comma for rhyth mic purposes has been accepted in the present edition.

37-44: The contents of these lines in the $H E$ and $H$ versions have been reproduced above in my commentary on this poem.

\section{H21: LA URNA}

"La urna" was first published in the 25 December 1887 issue of $L a$ Habana Elegante. This version was attractively printed in italics and was the 
sole item on the front page of the journal. Only minor changes in wording and punctuation were made when the poem was revised for publication in Hojas.

\section{H21: VARIANTS}
l. $H E$
2 [b]lanca
4 yo decía
7 nítidos
8 amé,
15 ivacía!

GLIC

[f]ina balbucía pulidos amé vacía.

\section{H22: EL ARTE}

This poem, subtitled "Soneto," first appeared on 27 May 1888 in $L a$ Habana Elegante. It was printed in a script-style typeface and was displayed as the sole item on the front page of the journal. Several minor changes in wording and punctuation characterize the revised version which Casal published in Hojas two years later.

\section{H22: VARIANTS}

l. $H E$

2 cansado,

3 dios

5 intenso

6 envenenado,

* 9 pura

11 [b]usca

arte

ignoradas;

12 [c]omo

al ver la

oscura,

13 pideá

* 14 baña

hondas [sic]
$H$

cansado

Dios

intenso,

envenenado

[h]alla

Arte

ignoradas,

(ף)[c]omo

en fria

$H+$ fría

osbcura, [sic]

obscura,

\section{H22: Notes to Variants}

9: If Casal had used a comma after pura in this line, the words "solitaria y pura" could easily be interpreted as a parenthetical modifier of alma grande, rather than as part of the adjective series "grande, solitaria y pura" which is the real 
modifier of alma. Similar constructions are found elsewhere in Casal's poetry. Two examples are H38/49-50 ("y mi alma noble, soñadora y franca / está por tu pasión envilecida,") and H42/9-10 ("Y una pupila azul, radiosa y bella / fulgura tras los pálidos cristales"). It is interesting to note that Casal did use a comma after the third adjective in the original version of $\mathrm{H} 42$, but that he removed the punctuation mark when he revised the poem.

14: The change from baña ... ondas to inund $\ldots \ldots$ olas increased the number of $u$ and $l$ sounds in the final verse. This created an onomatopoeic effect which reinforced the meaning of the words and thus augmented the power of the entire image.

\section{H23: A OLIMPIA}

Esperanza Figueroa ("Bibliografía de Julián del Casal," p. 34) and the Ed. del Cent. (vol. III, p. 198) indicate that this composition was first published under the title "A una mexicana" in the 29 August 1886 issue of La Habana Elegante. Since this version could not be obtained from Cuba, the text shown in the present edition had to be based exclusively on the one that appeared in Hojas.

In his subtitle to "A Olimpia," Casal acknowledged that his poem was a "Paráfrasis de V. Hugo," but did not disclose which of Hugo's works was his specific source of inspiration. Nevertheless, the subject matter, the octosyllabic metrical pattern, the function of infinitives, and the overall syntactic structure of the composition, which is only one sentence long, all suggest that Casal based "A Olimpia" on Hugo's "Contempler dans son bain ... .," composed on 12 September 1828 and later included in Les Feuilles d'automne:

Contempler dans son bain sans voiles

Une fille aux yeux innocents;

Suivre de loin de blanches voiles;

Voir au ciel briller les étoiles

Et sous l'herbe les vers luisants;

Voir autour des mornes idoles

Des sultanes danser en rond;

D'un bal compter les girandoles;

La nuit, voir sur l'eau les gondoles

Fuir avec une étoile au front;

Regarder la lune sereine;

Dormir sous l'arbre du chemin;

Etre le roi lorsque la reine,

Par son sceptre d'or souveraine,

L'est aussi par sa blanche main; 
Ouïr sur les harpes jalouses

Se plaindre la romance en pleurs;

Errer, pensif, sur les pelouses

Le soir, lorsque les andalouses

De leurs balcons jettent des fleurs;

Rêver, tandis que les rosées

Pleuvent d'un beau ciel espagnol,

Et que les notes embrasées

S'épanouissent en fusées

Dans la chanson du rossignol;

Ne plus se rappeler le nombre

De ses jours, songes oubliés;

Suivre fuyant dans la nuit sombre

Un Esprit qui traîne dans l'ombre

Deux sillons de flammes à ses pieds;

Des boutons d'or qu'avril étale

Dépouiller le riche gazon;

Voir, après l'absence fatale,

Enfin, de sa ville natale

Grandir la flèche à l'horizon;

Non, tout ce qu'a la destinée

De biens réels ou fabuleux

N'est rien pour mon âme enchaînée

Quand tu regardes inclinée

Mes yeux noirs avec tes yeux bleus! ${ }^{1}$

\section{H23: Note to Introductory Statement}

1 Oeuvres poétiques complètes (Montreal: Éditions Bernard Valiquette, 1944), p. 140 .

\section{H23: VARIANTS}

l. $H$

* 15 decirnos:-iBien mio,

* 16 diera!

\section{GLIC}

decirnos: “iBien mío, diera!";

\section{H23: Note to Variants}

15-16: The $H$ system of punctuating ll. 15-16 has been modified in this edition in order to make it immediately clear that a) the quotation ends on 1.16 , and b) 
that the word morir in 1.17 introduces the next link in an unbroken chain of clauses, each of which begins with an infinitive (ll. 1-36). The conclusion of the extremely complex sentence of which the poem is composed is stated in 11. $37-40$.

\section{H24: EL ANHELO DE UNA ROSA}

This composition first appeared in the 13 June 1886 issue of La Habana Elegante under the title "El deseo de una rosa" and with the subtitle "Soneto." Its source of inspiration was identified by Ramón Meza in his reminiscences about the life and works of Julián del Casal: "Nuestro artículo El Florero, publicado en el número 6 de junio de 1886, en $L a$ Habana Elegante, donde continuábamos siendo compañeros de redacción, mereció el honor de inspirarle la ... poesía ...."1 Although Meza took credit for having inspired the poem, Casal dedicated it "A Manuel de la Cruz y Fernández."

Manuel de la Cruz was born in Havana on 17 September 1861. During his youth, he had the opportunity to visit Spain and France, and, in the course of his travels, developed a cosmopolitan viewpoint that was destined to exert a marked influence on his behavior in later years. On returning to Cuba, he devoted much of his time to literary pursuits. He spent long hours reading, of ten in the company of Casal, Aurelio Mitjans, and Ramón Meza; ${ }^{2}$ he participated in the lively discussions that took place each afternoon at La Galería Literaria; ${ }^{3}$ at times under his own name and at times under the pseudonym Juan Sincero, he collaborated on local periodicals such as La Habana Elegante (see photo, Plate 3), El Fígaro, ${ }^{4}$ and La Revista Cubana; and, as a correspondent for La Nación of Buenos Aires, he helped keep Hispanic readers informed about developments on the Cuban literary scene. Because of his competence in the latter capacity, he was asked by Francisco Lagomaggiore of Argentina to assist in the preparation of América literaria, a comprehensive survey of Spanish American belles lettres. Flattered by this request, he wrote the "Reseña histórica del movimiento literario en la Isla de Cuba," a highly perceptive evaluation of Cuban literary activity during the period 1790-1890. Despite the excellence of this study, however, he achieved greater renown for his Cromitos cubanos (Havana: "La Lucha," 1892). This collection of twenty semblanzas includes a chapter on Casal that was written shortly after the publication of Nieve. Although many of his contemporaries were shocked by the audaciousness of his style, a select few realized that he was helping to breathe new life into Hispanic prose and, therefore, were inclined to minimize the seriousness of his excesses. This was the position of Mercedes Cabello de Carbonera, for example:

Un libro nuevo de Manuel de la Cruz, es un fausto acon- 
PLATE 3

The Staff of La Habana Elegante

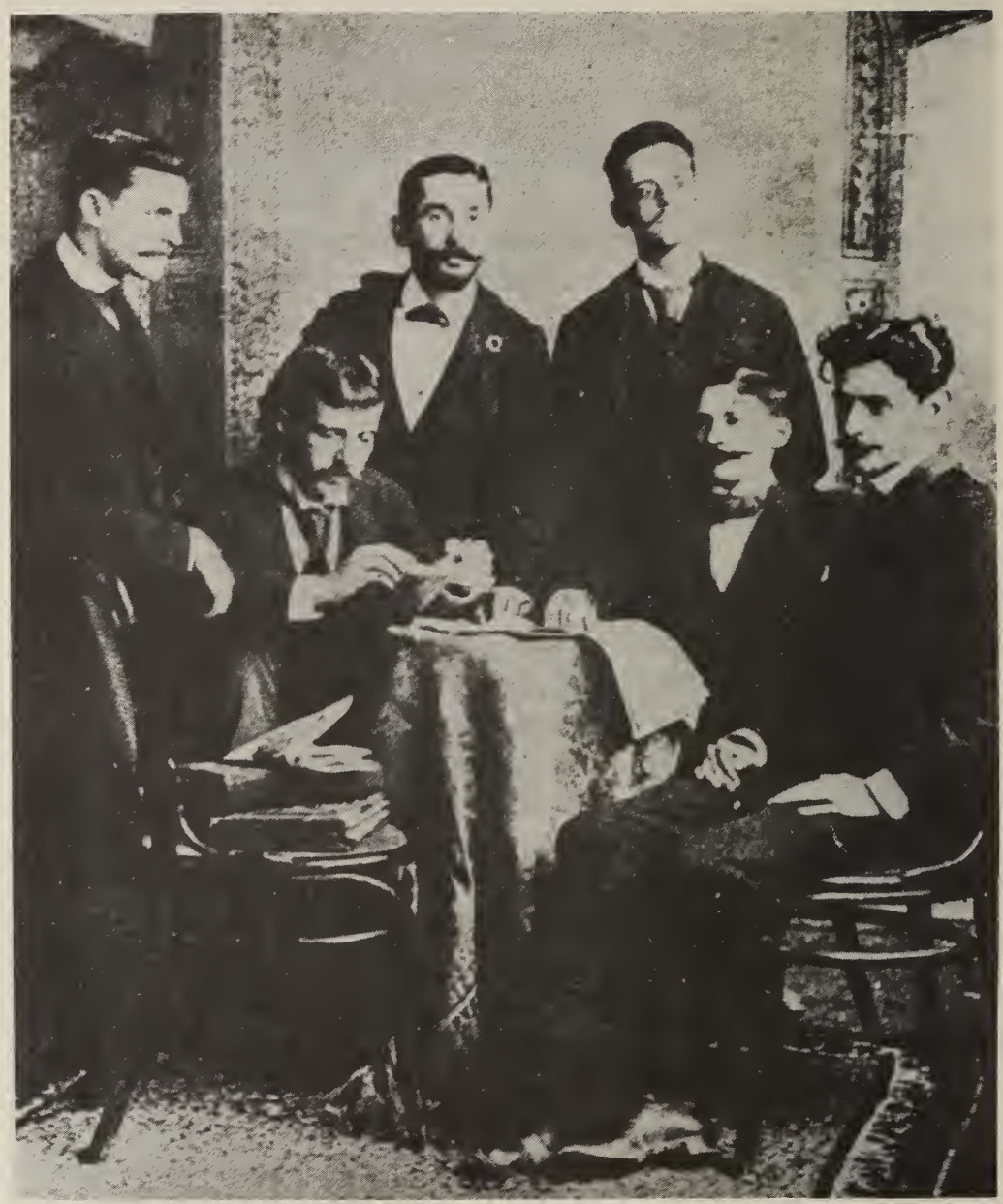

From left to right: Wenceslao Gálvez, Julián del Casal, Héctor de Saavedra, Ramón Meza, Enrique Hernández Miyares, and Manuel de la Cruz.

tecimiento literario que en América todos debemos celebrar, suponiendo, como debemos suponer, que es una nueva joya que viene a enriquecer la literatura hispano americana. . . . Quizá en algunos momentos peca por la ampulosidad en la expresión, por la exhuberancia en la hipérbole; pero en cambio, iqué poderío el de la forma, qué fantasía en los símiles, y sobre todo, iqué caudal tan inagotable de colorido! Todos los colores del prisma, todos los cambiantes del iris, resplandecen 
en esas páginas más próximas a la rima que a la prosa, un tanto alambicadas y multiformes, pero sin tocar jamás en esos remilgos del lenguaje, en esos giros pedantescos, en esas construcciones enrevesadas de los fraseólogos, que hacen fatigosa la lectura y soporífero el libro.

Algunos críticos del eminente publicista cubano, hanle censurado el caudal de imaginaciones, que tan abundantemente gasta en sus trabajos literarios, aun en aquellos de índole puramente histórica; sin dejar de reconocer el fondo de verdad que hay en tal afirmación, creemos que bien puede dispensársele ese lujo de imaginación, en gracia de sus altas dotes de colorista y paisajista de primer orden; que de otra suerte, tanto valdría el quejarnos de que la primavera abunde en flores, en brisas, en perfumes, aun en días de desolación y luto para nosotros. ${ }^{5}$

In addition to the Cromitos cubanos, de la Cruz wrote short stories; a translation of Eça de Queiroz' novel A reliquia; essays of a literary, historical, and political nature; and two important studies on Cuba's efforts to free herself from Spanish domination: Episodios de la revolución cubana (1890) and La revolución cubana y la raza de color (1895). An ardent separatist, he emigrated to the United States after the abortive revolution of 1895. First in Florida, then in New York, he continued the struggle for Cuban independence. However, like his idol José Martí, he was denied the joy of seeing the liberation of his homeland. Death came to him in New York on 19 February 1896, when he was in his thirty-fifth year. His complete works were published in seven volumes between 1924-1926 under the direction of José María Chacón y Calvo.

The 1886 version of the poem that Casal dedicated to Manuel de la Cruz read as follows:

1 Yo era la rosa que en la selva umbría

2 Mi caliz purpurino desplegaba:

3 Por mi el ave sus cantos entonaba,

4 Por mí la estrella su fulgor vertía.

5 Cuando el sol en oriente aparecía

6 El rocío de perlas me inundaba,

7 Y el lago en su cristal me retrataba

$8 \mathrm{Y}$ el aura mis aromas esparcía.

9 Teniendo que morir, porque el destino

10 Hizo que breve mi existencia fuera,

11 Arrojándome al polvo del camino; 


\section{Quiero exhalar mi esencia postrimera \\ 13 Prendida en algun seno alabastrino \\ $14 \mathrm{O}$ en los rizos de oscura cabellera.}

On 30 June 1888, the sonnet was published in slightly revised form by El Fígaro. The title was changed to "Monólogo de una rosa marchita"; the dedication and subtitle of the previous version were replaced by "En el álbum de la Srita. Cristina Granados"; minor textual alterations were made; and the date "(1888.)" was printed with the author's name at the end.

In contrast to what he had done in 1888 , Casal made extensive revisions in the work before publishing it in Hojas. He changed the title to "El anhelo de una rosa"; he dedicated the composition once again to Manuel de la Cruz; he restored the subtitle of the 1886 version; and most important of all, he re-wrote the first eight verses of the poem.

When the history of this piece is studied in detail, several interesting points emerge. First of all, in the 1888 version, one can detect a tendency towards simplification of the vocabulary (aura $>$ aire, aromas $>$ perfumes), a softening in tone (quiero > quisiera), and a movement towards a more static imagery (exhalar $>$ estar). Despite the fact that these changes were only minor alterations, one of them was really a portent of the future as far as Casal's stylistic development was concerned: the replacement of exhalar with estar pointed to what, in the Nieve period, would become a distinct inclination to create less active images. Clear signs of this tendency may be found in the 1890 revisions which Casal made in 11. 1-8 of the poem: he reduced the number of verbs from eight to five; he substituted preterit forms (abri, vertio, vi) for the imperfect forms of the earlier versions (desplegaba, entonaba, vertía, aparecía, inundaba, retrataba, esparcía); he enriched images by increasing the number of adjectives and nouns (e.g., "el lago en su cristal" > "Del lago azul en el cristal sereno" and "me retrataba" $>$ "vi mi corola retratarse ufana"); and he made more lengthy statements about fewer primary subjects (in 11. 7-8, for example, he suppressed references to ave, estrella, and sol, and added the two-line simile "como ante fina luna veneciana / ve una hermosura su marmóreo seno").

\section{H24: Notes to Introductory Statement}

1 "Julián del Casal," Ed. del Cent., "Poesías," p. 247.

2 Ibid., pp. 222-223.

3 Federico Villoch, "Las tardes de La Galería Literaria," Ed. del Cent., "Poesías," pp. 304-305.

4 One of Manuel's contributions to El Fígaro was Chapter VI of the communal novel Solos, which came out in installments in 1886. The chapter, entitled "Apoteosis," was signed with the pseudonym Juan Sincero.

5 “Cromitos cubanos," El Perú Artístico, año I, no. 18 (15 March 1894), p. 212. 
H24: VARIANTS

l. $H E$

F

GLIC

* 2 desplegaba:

desplegaba;

5 oriente

Oriente

7 [y] el

[e]l

8 aura

aire

aromas

perfumes

11 camino;

camino

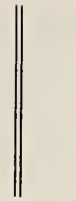

12 (I)[q]uiero exhalar mi

(ף)[q]uisiera estar en mi esencia postrimera hora postrimera

$H E$

(ף)[a]nhelo estar, en mi hora postrimera,

\section{H24: Note to Variants}

2: The reader is reminded that the first eight lines of the $H E$ and $F$ versions were re-written in 1890 .

\section{H25: NOCTURNO}

This poem, the later of the two nocturnos which Casal included in Hojas (see H8), was originally published in the 17 February 1889 issue of $L a$ Habana Elegante. It was printed in two columns on the first page of the journal. Beneath the left-hand column was a note indicating the place and year of composition: "Madrid 1889."

Information on Casal's trip to Europe is very sketchy. It appears that he left Havana on the steamship "Château Margaux" in November 1888. Enrique Hernández Miyares described the circumstances of the author's departure in the following way:

Cierta ocasión (perdónenseme las fechas) llegó a casa regocijado en extremo, luciendo un nuevo traje, hecho todo un dandy - un Barbey d'Aurevilly, como él decía - y me refiero a aquella época en que, arrastrado por mí, estrechó algunas amistades, visitó diversos salones, y con el frac al hombro y el lápiz pronto, escribió los célebres artículos "La Sociedad de la Habana"1 en los que satirizó al General Marín y habló tal vez con irreverencia del señor Obispo (lo que le valió su cesantía, porque entonces era empleado - iamanuense! - de Hacienda; y lo que fue la base o partida de la excomunión lanzada contra este periódico) aquella ocasión, decía, llegó a casa, me invitó a almorzar en "El Louvre", y en mitad del almuerzo me mostró una gran cantidad de dinero. "He vendido el solar... ya sabes, y no me regañes - me dijo - tal día me embarco en el vapor francés, y ni sé a qué voy, ni cuándo he de volver, ni si he de 
quedarme en Europa... iQuién sabe! Si mis lejanos parientes del Cardenal de la Lastra me valen iquién sabe! - repetía - si aquello es lo que me figuro y puedo vencer, tal vez me quede. Me hastía esto; desde el sol refulgente y ardoroso, hasta los mercaderes; sólo pudieran atraerme muchos de mis compatriotas infelices; pero de todos modos, me voy, aunque, como me sospecho, vuelva pronto y en tercera."

Se fue. ${ }^{2}$ Yo lo acompañé a bordo, junto con algunos pocos amigos íntimos, hasta que el vapor levó anclas y fue a refugiarse en el lecho del horizonte, envolviéndose con el manto oscuro del crepúsculo...

En el primer puerto (Santander) me escribió incluyéndome su soneto "En el mar", que luego formó parte de su primer libro "Hojas al viento". ${ }^{3}$

On reaching Santander, Casal visited relatives of his maternal grandfather, Antonio de la Lastra, whose brother Luis (b. Santander, 1 December 1804; d. Sevilla, 5 May 1876) had brought distinction to the family as Archbishop of Valladolid, Archbishop of Sevilla, and ultimately Cardinal. Casal then moved on to Madrid, where he spent the major part of his time. In the capital, besides visiting museums and seeing the usual tourist attractions, he mingled with artists from many countries. The Spanish American writer who apparently made the deepest impression on him was Francisco A. de Icaza, whose works were unknown to him before he got to Europe. In his article "Recuerdos de Madrid" ( $H E, 3$ February 1889), Casal gave the following information about the young Mexican poet and the circumstances under which he met him:

A pesar de que he seguido siempre, con verdadero interés, el movimiento literario de Méjico, como se sigue el vuelo de una bandada de águilas, que se remonta por la inmensidad azul, tachonada de astros; no había leído las poesías de Francisco de Icaza, segundo secretario de la legación de Méjico en España, cuyas composiciones admiré, por primera vez en La Ilustración Española y otros periódicos madrileños de gran circulación.

Yo conocí más tarde al autor, en la Cervecería Inglesa, establecimiento frecuentado por la mayor parte de los artistas que viven en Madrid. Era un joven elegante de tipo verdaderamente parisiense. . . . Después de tratarlo he podido apreciar como pocos, sus excelentes cualidades. Lleva en su corazón, como en un cofre de sándalo, dos joyas preciosas, inhallables en los espíritus modernos: el amor al Arte y una modestia excesiva. No he conocido ningún artista que sea tan severo para consigo mismo, ni tan indulgente para los demás. Pocos aman tanto lo bello y odian tanto lo vulgar. Puedo decir, 
sin equivocarme, que es un hombre de mundo y un noble de la literatura. ${ }^{4}$

In spite of being in a new environment and enjoying the intellectual stimulation that came from associating with artists like Icaza, Casal continued to feel lonely and depressed. He began to miss the old haunts, as well as close friends whom he had left behind in Cuba, and as his nostalgia increased, he found it more and more difficult to suppress his sadness. Reflection merely brought to the surface doubts that had plagued him in the past, and these further soured the joys that life was offering him in such abundance. Partly to make his stay in Madrid more fruitful and partly to conquer loneliness, he spent his limited funds with a recklessness that obliged him to end his European holiday much sooner than he had planned. According to Hernández Miyares, "gastó en unas cuantas semanas el dinero presupuesto para muchos meses, sin darse cuenta, 'porque lo tenía'; y cuando el hambre de Europa, que no hay quien la ampare, le avisó a su estómago, y cuando el gabán y la chistera, las ropas interiores y los libros fueron empeñados, volvió a la Habana desalentado, macilento, con un nuevo fardo de desilusiones y 'sin solar'."

The date of Casal's arrival in Cuba has not been ascertained. Indeed, the opinion of scholars varies to a considerable extent on this question. Some critics suggest that he returned from Europe in January $1889{ }^{6}{ }^{6}$ others affirm that he came back in April or May of that year; ${ }^{7}$ and still others maintain that he returned in $1890 .{ }^{8}$ Bibliographical evidence such as that found in the Ed. del Cent., vol. III, pp. 201-202, makes it possible for us to conclude only that he arrived in Havana at some time between the end of January and the end of November 1889. Exactly when will have to be determined by future investigation (see my discussion of H42).

In 1890, when preparing his material for Hojas, Casal re-read the Madrid "Nocturno" and found that the original text was still basically to his liking: as is shown in the record of variants, he limited his revision of the poem to eight changes in punctuation and only one change in wording.

\section{H25: Notes to Introductory Statement}

1 La Sociedad de la Habana was a series of articles that Casal published in $H E$ between 25 March and 24 June 1888. According to an announcement in the 15 April 1888 issue of the journal, he was planning to publish a book of twenty-six chapters dealing with diverse segments of Havana society. His initial articles caused such a controversy, however, that he was not only forced to stop issuing installments in $H E$, but, as Hernández Miyares indicates, he was also obliged to give up his job with the Government.

2 Hernández Miyares gives the impression that Casal left Havana immediately after his sad experience with La Sociedad de la Habana. The fact is that several months elapsed between the two events. 
3 “Julián del Casal," Ed. del Cent., "Poesías," pp. 312-313.

4 Ed. del Cent., vol. I, p. 200.

5 Ed.del Cent., "Poesías," p. 314.

6 Nunn, "The Life and Works of Julián del Casal," pp. 53-55.

7 Monner Sans, Julián del Casal y el modernismo hispanoamericano, p. 22.

8 Portuondo, "Angustia y evasión de Julián del Casal," Ed. del Cent., vol. I, p. 62.

\section{H25: VARIANTS}

l. $H E$

* 25 yermo,

* 29 retrato

31 largo

33 reflexión

34 mismo

* 36 del

* 37 aislamiento

43 calma

* 45 (ף)Así

46 lámpara

* 50 siempre,
H

yermo

retrato,

luengo

reflexión,

mismo,

aislamiento,

calma,

Así

$H E$

GLIC

$H E$

lámpara,

siempre

\section{H25: Notes to Variants}

25: It will be noted that, in 1.25 of $H$, Casal removed the comma that he had placed after yermo in the $H E$ version, and that, in 1.37 , he added a comma after the word aislamiento. The fact that there is a change of subject in 1. 38 , but none in 1.26 may help explain why he modified the punctuation in this way.

29: From the syntactic point of view, the comma that Casal inserted after retrato in the $H$ version creates a false impression about the function that "mirando en un retrato" has in the sentence as a whole. Strictly speaking, if the comma were to be retained, it should be balanced by another comma after mirando. This would indicate that "en un retrato" acts as an adverbial clarifier between the verb mirando and its direct object in the following verse. Addition of yet another comma, however, would fragment 1.29 excessively. In view of these considerations, it seems that the simplest solution to the problem would be to restore the $H E$ version: that is, to eliminate the comma after retrato.

36: It was (and still is) common to find Spanish American writers inserting a definite article before the name Dante. The frequency of this error, even among the most outstanding authors, is probably an indication of how superficial their knowledge of Italian really was. In Italian, the definite article is used only before a surname; thus, the proper forms are "Dante" and "l'Alighieri." The Spanish equivalents would be "Dante" and "el Alighieri."

37: See note to 1.25. 
45: In $H$, Casal did not indent the first line of a stanza that was preceded by a row of dots. In the present edition, the practice is to indent the initial verse in each stanza.

50: At first glance, the structure of 1.50 appears to be very close to that of 1. 29: each verse has a verb + prepositional phrase combination which is followed by a direct object in the next line. When analyzed more carefully, however, the two lines reveal the presence of significant differences, and these suggest that distinct systems of punctuation be used. The major differences concern 1) the nature of the direct object - in 1.30 , it is a noun phrase; in 1.51 , it is a noun clause - and 2) the fact that the verb in 1.50 is followed by an adverb of time - siempre - while no such qualifier modifies the verb in 1. 29. In 1. 50, the prepositional phrase that separates observo from the following noun clause object seems clearly to call for demarcation by commas; and, in the $H E$ version, it was indeed punctuated in this way. This method of punctuating 1. 50 insured conceptual clarity. It had two drawbacks, however. On the one hand, it caused a very noticeable interruption in the rhythmic flow of the line. On the other hand, it tied the word siempre more closely to observo than was desirable. That is, it inhibited the creation of the subtle, but provocative ambiguity that would result if siempre were left to float freely between observo and con mortal tristeza. For these reasons, the $H$ punctuation of 1.50 has been preserved in the present edition.

\section{H26: TODAVIA}

There is no evidence that this composition was published in Cuban periodicals before it appeared in Hojas.

For Casal, the earliest cause of irremediable grief was the death of his mother, for it deprived him of the tender demonstrations of love which he had enjoyed in his infancy and which, like every child, he required in order to feel secure (see my discussion of N26). As the years passed, his anguish became a constant companion and, when he turned to verse, a recurrent source of inspiration. Indeed, in one way or another, he brought the theme of family love into his poetry at every stage of his career (for example, see V1, his first published poem, and 11. 61-67 of $\mathrm{R} 41$, his last published work).

Casal's personal loss had several important consequences. For one thing, it gave him a sense of brotherhood with all children who, like himself, were forced to travel the road of life without the comfort of parental affection. It served him also as a wellspring of compassion for every person who, in his view, was denied the means of fulfilling his most cherished dreams. Social rank was of no consequence to Casal. People as different as the illegitimate child, the somber dreamer, the humble priest, the tattered beggar, the bereaved lover, the joyless prince, and the wistful King of Bavaria were all seen as equals - "pálidos seres de sonrisa mustia, / 
huérfanos para siempre de ilusiones / y desposados con la eterna angustia" (R19/26-28) - and were his inspiration for the poignant exclamation which concludes "Voe soli":

¿Cuántas almas que viven solitarias alzando a lo infinito sus plegarias, no encuentran, en sus horas de hondo duelo,

otra alma que, aunque igual a la serpiente, les perfume el espíritu doliente con el óleo fragante del consuelo!

Because he knew the anguish of being left defenceless and unconsoled in a hostile world, Casal looked with special favor on those who concerned themselves with the plight of the forsaken. Thus, he admired General Manuel Salamanca y Negrete and Doña Matilde León, because he saw the former as "el gran protector de los oprimidos" 1 and the latter, who was the wife of General Sabas Marín, as "la madre de los desheredados."2 On the other hand, he had contempt for those who lacked compassion. As time went on, he became more and more bitter about the lack of pity that existed in the world and, on occasion, even turned his wrath upon God, whose unwillingness to satisfy his deepest need led him to the brink of blasphemy (see N32).

\section{H26: Notes to Introductory Statement}

1 From "El General Salamanca" (HE, 5 May 1889), as reproduced in Ed. del Cent., vol. I, p. 155.

2 From "El General Sabas Marín y su familia" (HE, 25 March 1888), as reproduced in Ed. del Cent., vol. I, p. 134.

\section{H26: VARIANTS}

l. $H$

10 calló $[$ sic $]$

11 Siendo
GLIC

calló.

( $($ )Siendo

\section{H27: ENGAÑADA}

This poem, first published in the 3 March 1889 issue of La Habana Elegante, was originally subtitled "(Paráfrasis del italiano)." It was printed in italics on the first page of the journal, and each stanza was separated from the one that followed by a centered asterisk. When Casal revised the 
poem for publication in Hojas, he changed the subtitle to "Paráfrasis de L. Stechetti [sic]," eliminated the asterisks, and made minor alterations in wording and punctuation.

Lorenzo Stecchetti was the pseudonym of the Italian poet Olindo Guerrini (b. Fiumara, 4 October 1845; d. Bologna, 4 February 1876), who enjoyed considerable popularity in Spanish America at the end of the XIX and beginning of the XX centuries. Translations of his poetry by writers of every persuasion were commonplace in Spanish American journals throughout the Modernist period. Guerrini's pseudonym, however, was often misspelled by his admirers, who would reduce the $c c$ to $c$ but preserve the $t$, so that the name would read "Stechetti." As can be seen from the subtitle to the Hojas version of "Engañada," Casal also made this mistake.

The poem from which Casal drew his inspiration for "Engañada" reads as follows:

No, non chiamarmi giovane

Perchè i capelli miei son lunghi e biondi

E le mie guancie floride

Di molli carni e di color giocondi.

Son come il frutto fradicio

Dentro e che serba il suo color di fuora.

Donna, ti sembro giovane

E sono un morto che cammina ancora.

Chiusa per sempre ho l'anima

Alle dolci lusinghe ed ai conforti.

Donna, non mi sorridere;

Donna, non mi tentar; rispetta i morti.

\section{H27: VARIANTS}

l. $H E$

2 cana,

3 ostento sonriente

* 4 mañana; [sic]

11 todavía.........
H

cana

ostento, sonriente,

manzana;

todavía......
GLIC

todavía...

\section{H27: Note to Variants}

4: It is impossible to determine for certain whether the word manana in the $H E$ version was a typographical error or not. Because of the nature of the original image, I am inclined to believe that it was in fact a mistake which the compositor made when copying the text from Casal's manuscript. 
This poem, one of several eulogies dedicated to Mariano Ramiro, who had died just one year before, was published in El Fígaro on 8 December 1887. The title of the poem in this version was "Ofrenda a Mariano Ramiro." When Casal revised the work for publication in Hojas, he changed the title to "Ofrenda" and added the subtitle "En la tumba de un poeta."

Mariano Ramiro was a Cuban writer who was celebrated locally for such novels as Cándido and Amor a la vida, and for collections of poetry entitled Versos and Punto final. In addition, he was an active collaborator on numerous periodicals that were published on the island-among them, $E l$ Fígaro of Havana, La Aurora of Matanzas, and El Horizonte of Cárdenas. At the time of his death, he was editor of El Radical.

As Casal informs us, Ramiro's name was closely linked with that of Manuel Serafín Pichardo: "Durante los primeros días de permanencia entre nosotros, [Pichardo] conoció al célebre Mariano Ramiro, bajo cuya protección se dio a conocer en el mundo literario. Pichardo encontró, en el llorado poeta, ${ }^{1}$ no sólo un discreto consejero, que aplaudía sus ensayos, al par que los censuraba, sino un padre amantísimo que le abrió espontáneamente las puertas de su hogar. El nombre de Pichardo vivirá unido al de Ramiro, como el de Gautier va unido al de Víctor Hugo. . . . Alentado por su querido maestro, fundó, en 1885, con varios amigos, tan conocidos, como inteligentes, un semanario, titulado El Fígaro, que honra a sus redactores. . . . Al llegar el aniversario de la muerte de Ramiro, El Fígaro ostenta, en sus columnas, trabajos dedicados a la memoria del maestro, rodeados de grandes orlas negras." ${ }^{2}$ These data show why Casal, who was a friend of Pichardo, ${ }^{3}$ chose to publish the first version of his tribute to Ramiro in El Fígaro.

\section{H28: Notes to Introductory Statement}

1 Although Ramiro's prose exceeded his poetry in volume, his reputation was largely built on the quality of his verse. This explains why Casal refers to him here as el llorado poeta and why he used the word poeta in the subtitle of the Hojas version of "Ofrenda."

2 "La joven Cuba. Galería Mignon: Manuel Serafín Pichardo," Ed. del Cent., vol. I, p. 194. The article was originally published on 6 May 1888 in $H E$.

3 For further information on their relationship, see my discussion of $\mathrm{H} 45$.

H28: VARIANTS

l. $F$

$H$

GLIC

6 pía

grata 


\section{H29: DESOLACION}

This sonnet was first published in the 23 October 1887 issue of $L a$ Habana Elegante. It was printed in italics on the front page of the journal. Only 1.1 was indented. The Hojas version differed from the original in the following respects: ll. 1, 5, and 9 were indented; minor alterations in punctuation and wording were made in several verses; and a major revision was made in the second stanza (1l. 7-8). Because the significance of some of these variants will be discussed in detail, the original version is reproduced hereinafter:

\section{Desolación.}

\section{SONETO.}

1 ¿No habeis visto la lóbrega capilla

2 Del antiguo convento de la aldea?

3 iYa el incensario en el altar no humea

4 Ni santo cirio ante la imágen brilla!

5 En la torre, agrietada y amarilla,

6 El pájaro fatídico aletea,

7 El viento por las naves se pasea

8 Y mueve la colgante lamparilla.

9 Ningun monje, sombrío, solitario,

10 Amortajado en su sotana oscura,

11 Póstrase á orar, con místico deseo;

12 Y há tiempo no resuena en el santuario

13 Ni la plegaria de la vírgen pura,

14 Ni la blasfemia horrible del ateo.

When this version of "Desolación" is viewed as a whole, one perceives that, after the two introductory verses, there is a neat balance of parts: six lines are devoted to a description of the locale (1l. 3-8), and six lines are devoted to the human element (1l. 9-14). By introducing the pecador image into the Hojas version (ll. 7-8), Casal disrupted this balance and gave the poem a new structure. This may be seen through a comparison of the following diagrams: 

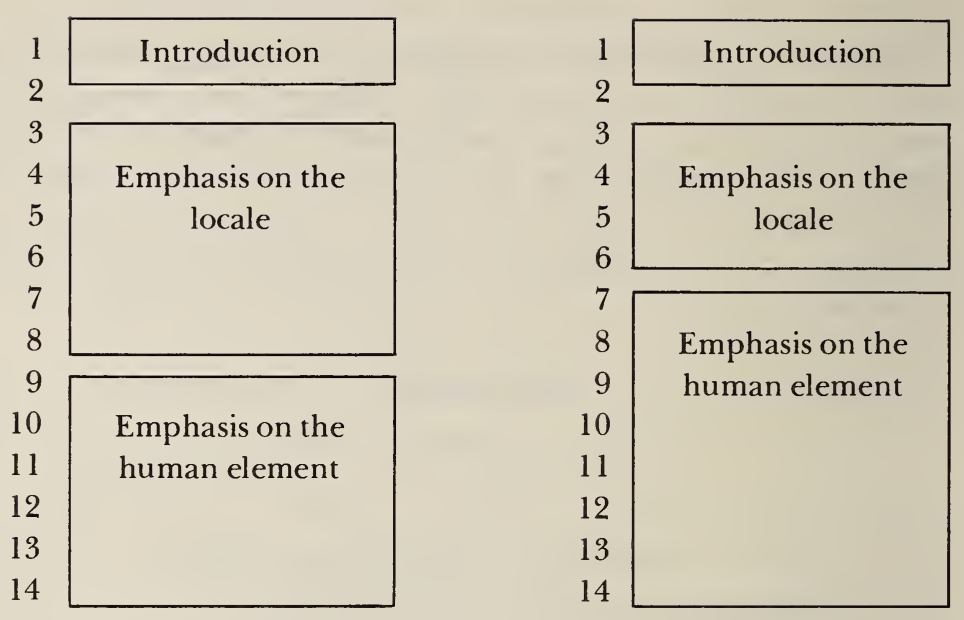

Despite the fact that introduction of the pecador image did away with the sequence of torre, pájaro fatidico, viento, and naves, it did not reduce the emotional power of the sonnet. On the contrary, because it increased the total number of negative elements in the poem, it created an even more intense feeling of emptiness and gloom.

The other lexical variants in Hojas are also interesting. The movement from santo $>$ ardiente (1.4) and from amortajado > arrebujado (1. 10) suggests that, as the years passed, Casal was adopting a more impersonal attitude towards his religion, or at least towards its symbolic objects. ${ }^{1}$ For their part, sotana > capucha (1. 10) and virgen > joven (1.13) testify to the author's constant concern for accuracy in the construction of images and in the use of words.

\section{H29: Note to Introductory Statement}

1 See the last stanza of "La urna" (H21), a poem that was published two months after "Desolación."

H29: VARIANTS

l. $H E$

3 iYa

4 santo

brilla!

6 aletea,
H

Ya

ardiente

brilla.

aletea; 
l. $H E$

7 [e]l viento por las naves se pasea

8 [y] mueve la colgante lamparilla.

9 Ningun monje,

10 [a]mortajado sotana

$12 \mathrm{Y}$

13 vírgen

14 blasfemia
$H$

[y] á Dios no eleva el pecador la idea

[d]oblegada en el suelo

la rodilla.

(ף)Ningún monje

[a]rrebujado

capucha

$\mathrm{Y}[s i c]$

joven

blafemia [sic]
GLIC

$H+$ idea,

$H E$

\section{H30: EL SUEÑO EN EL DESIERTO}

According to Esperanza Figueroa ("Bibliografía de Julián del Casal," p. 34), this poem was first published in the 17 October 1886 issue of $L a$ Habana Elegante. Because the Cuban libraries which assisted me in gathering periodical versions of Casal's poetry did not possess a copy of that issue of the journal, it was impossible for me to examine that version of the poem. Hence, no reference to it is made in the record of variants.

On 4 November 1888, El Fígaro published "El sueño en el desierto." The compilers of the $E d$. del Cent. included a photograph of this version in the illustrations which they presented at the end of vol. III, but made no reference to the existence of this version when they printed the poem in their "Poesías" volume. Furthermore, upon preparing the text for publication, they also overlooked a serious error of interpretation which Cabrera Saqui had committed and which - as shown in my note to 1. 4, below - could easily have been corrected if the Cabrera Saqui version had been compared with that of El Figaro. Because the $F$ version is one of the few extant autograph copies of Casal's poetry, it is reproduced in the present edition (see Plate 4).

In Hojas, the format differed from that of the $F$ version: 1. 1, which had been left-justified in El Figaro, was now indented, and a row of dots was inserted between 1l. 18-19. Also, the punctuation was altered in several places and the wording of two lines was modified. Most important, however, is the fact that Casal lengthened the poem by inserting two new verses after 1.9 of the earlier version.

\section{H30: VARIANTS}

l. $F$

1 Cuando

3 palma

* 4 fatiga,
$H$

(ף)Cuando

palmta, [sic]

faiga, [sic]
GLIC

$F+$,

F 
H30

PLATE 4

Autograph of "El sueño en el desierto"

$(F, 4$ November 1888)

AUUROGIRAIOE.

CL Sueño en el desierto.

Cuando el nijo intojaje del clessierts Ata un blambar jegna wry lagnecida al fuerte lionso de giganxe palma 3) trequa dando á mu martile yatiga, Gue en el lects de tastada arena Donde la lus reverberar te miray Sueña en los verdes campros anehunatos En gue se clevon la gallarda eypiga Sonda far el sal resplandecuinto En ca Kibu gre farma su familia; En el bjano casis mitteniato Aya Aombra al dectanso leconvida, Sen el havem pablado de mujeres Bellas, como lá hur del mediodia, Iue entre nubes de aromas enervantes Orachigan al sultín dulces caricias. Orso al salis del sueñoventurass Solo ve, chlatadas las pupilas, Devierto el arenal ilimitado Ala celecte báveda rajira. Inlián del Casal

82 
l. $F$

6 mira,

* 10

* 11

14 sombra al descanso

le convida,

15 harem

17 [q]ue enervantes

* 19 Pero

21 [d] esierto ilimitado

* $22[\mathrm{y}]$ celeste rojiza.

mira;

[e]n la plácida fuente cristalina

[q]ue le apaga la sed abrasadora;

frescura á descansar convida;

harem,

[q]ue,

enervantes,

(ף)Pero

[d] esierto, ilimitado;

(ף) $[\mathrm{r}] \mathrm{oja},[s i c] \quad$ roja, inmensa vacía.

\section{H30: Notes to Variants}

4: If one examines the $H$ version, it is apparent that the $t$ of fatiga was mistakenly inserted into palma on the line above. It is extremely difficult to see what led Cabrera Saqui astray at this point. Although he correctly changed faiga back to fatiga, he decided that palmta should not be palma, but planta. The Ed. del Cent. has perpetuated this error.

10-11: These verses were not present in $F$, but were added in $H$.

19: A row of dots was inserted after 1.18 of the $H$ version. As a result, I consider 1. 19 to be the beginning of a new stanza. For this reason, it is indented in my edition.

22: The compositor mistakenly indented the last line of the poem in $H$.

\section{H31: MENSAJE}

"Mensaje" was originally published in La Habana Elegante on 9 February 1890. It was printed in italic type on the front page of the journal. This version of the poem was subtitled "(En el álbum de la Srta. Ernestina Oliva.)." ${ }^{1}$ Each stanza was separated by a centered rule from the one that followed.

On 15 February 1890, the editors of El Pueblo reproduced the poem without substantive changes. Italics were not used in this version.

When Casal prepared "Mensaje" for publication in Hojas, he changed the subtitle to "En un álbum," altered the punctuation of two lines, and revised the wording in four places. As far as format is concerned, the only difference between this version and the ones that preceded it lies in the fact that the centered rule between stanzas was omitted from the Hojas printing. 


\section{H31: Note to Introductory Statement}

1 For references by Casal to Ernestina Oliva, see the Ed. del Cent., vol. III, pp. $42,48,52$, and 59 .

\section{H31: VARIANTS}

\begin{tabular}{|c|c|c|c|}
\hline l. $H E$ & $\mathrm{~Pb}$ & $H$ & GLIC \\
\hline 1 brotan & & arranco & \\
\hline 6 [h] echas ya & & [h]echas & \\
\hline 9 oido & & oido, & oído, \\
\hline 13 boca & & boca, & \\
\hline $21[\mathrm{y}][\mathrm{sic}]$ & (I) $[y]$ & & \\
\hline 22 recónditos & recínditos [sic] & $H E$ & \\
\hline 23 [1]a fragancia & & [r]áfagas & \\
\hline exquisita & & perfumadas & \\
\hline 24 [l]a lumbre & & [d]estellos & \\
\hline abrasadora & & abrasantes & \\
\hline
\end{tabular}

\section{H31: Note to Variants}

6: The word hechas modifies mano in 1. 5. This is not an especially felicitous poetic license, because the singular noun and plural adjective are in such close proximity. In order to avoid the problem, Casal would have had to re-write 11. 5-6. There was no other alternative open to him, for 1) if he had changed mano to manos, he would have run into a rhyme problem in 1.7 ; and 2) if he had changed hechas to hecha, he would have created an awkward image with entretejer, a verb that requires a plural subject.

\section{H32: EN EL MAR}

In his Obras completas, Enrique Hernández Miyares states that Casal, who had left for Spain in November of 1888 , mailed him a letter containing a copy of "En el mar" when he reached the port of Santander. ${ }^{1}$ On 6 October 1889, the sonnet was published in El Fígaro under the title "El viajero." This version was subtitled "Soneto" and was dated "(Otbre. 89)."

When Casal prepared the sonnet for publication in Hojas, he changed the title from "El viajero" to "En el mar" and made two small modifications in the text.

\section{H32: Note to Introductory Statement}

1 Obras completas (Havana: Academia Nacional de Artes y Letras, 1916), vol. II, pp. 122-123; Ed. del Cent., "Poesías," p. 313. 
H32: VARIANTS

l. $F$

4 fosforescente

11 Polo.

12 tierra

13 nacido,
H

fosforecente [sic]

polo.

tiera [sic]

nacido
GLIC

F

F

\section{H33: ESTATUA DE CARNE}

This poem was first published in the 18 December 1887 issue of $L a$ Habana Elegante. Duplessis ("Julián del Casal," p. 148) affirms that "es un poemita dedicado a la encantadora María Cay." The fact is, however, that no such dedication appears either in this version or in the Hojas version of 1890. Further along in his study, Duplessis refers to Casal's "apasionado homenaje a la blonda [sic] hermosura de María Cay en Estatua de carne" (p. 151). This allusion to the lady's coloring represents a compounding of the original error: obviously, the "blonda hermosura" of which Duplessis speaks is derived from ll. 15-16 of the poem, where Casal says that "el aura ... deshacía / los blondos rizos de su fino pelo." It is doubtful that the lady described in "Estatua de carne" was María Cay, however, for in "Camafeo," whose original title was "Srita. María Cay," Casal makes it plain that Miss Cay was a brunette: "Desciende en negros rizos tu cabello" (N39/17; italics are mine). ${ }^{1}$

The task of identifying Casal's source of inspiration is made even more difficult by the fact that Manuel de la Cruz uses the term estatua de carne in a reference to an experience that Casal had in June 1879, when he was only fifteen and half years old and was still attending the Real Colegio de Belén: "Huérfano y pobre, salió del claustro tenebroso y frío, para ser la víctima propiciatoria de una estatua de carne; su primera pasión, en vez de ser la ofrenda inmaculada a una virgen ideal y pudorosa, fue el desenfreno de un cenobita que saliese de su maceración y su abstinencia para caer en los aturdimientos de una orgía." 2 Arturo Mora y Varona gives a detailed account of the occurrence in his 21 December 1890 article "Internato." Because it is so explicit about the circumstances of the poet's sexual initiation, this article is reprinted in Appendix A of the present edition.

Before publishing "Estatua de carne" in Hojas, Casal made minor changes in wording and punctuation. These are listed in the record of variants which follows.

\section{H33: Notes to Introductory Statement}

1 For information on Miss Cay, see my discussion of N43. 
2 “Julián del Casal," Cromitos cubanos, p. 302; Ed. del Cent., "Poesías," p. 317. Italics are mine.

\section{H33: VARIANTS}

\section{l. $H E$}

9 nítidas

* 18 modelaron

19 brotar tenebrosa

20 abrasantes llamas del deseo.

21 ( $($ ) Pero

22 pesar: iLa compadezco,

24 besos!
H

lánguidas

modelaran

brotar,

tenebrosa,

llamas abrasantes

(Omitted in H.) [sic]

deseo;

(I) [p]ero

pesar:-La

compadezco

besos.
$H E$

GLIC

pesar: -La

\section{H33: Notes to Variants}

18: It is impossible to determine whether Casal was responsible for this change or whether the compositor made a mistake when setting the type for $H$.

20: The erroneous omission of $\mathrm{del}$ in the $H$ version was probably caused by the fact that the compositor had to make two changes in this line. His efforts to incorporate those changes undoubtedly made him oblivious to the presence of $d e l$ in the modified manuscript from which he was working.

\section{H34: LA PENA}

This poem first appeared on 1 December 1887 in El Figaro. It was subtitled "(Paráfrasis de H. Heine)." The date "(1887)" was printed to the left of Casal's name at the foot of the poem. Although basically satisfied with the El Figaro version, Casal felt that he should make some changes in his text before publishing it in Hojas. These changes are listed in the record of variants, below.

According to Max Henríquez Ureña, “A Pérez Bonalde se debe . . la la difusión de la poesía de Heine, merced a la inspirada traducción que, en 1877, publicó del Intermezzo lírico (Lyrisches Intermezzo), a la que, en 1885, subsiguió la versión íntegra del Cancionero (Das Buch der Lieder), labor en la que, al menos en parte, lo habían precedido, desde 1857, Eulogio Florentino Sanz en España y, hacia 1875, Francisco Sellén . . . ."1 At present, there is no information to show whether Casal based his version of the poem on a Spanish translation by one of these men, on a French translation which he might have encountered, or on the Heine original. ${ }^{2}$ The Heine poem reads as follows: 
Wenn ich an deinem Hause

Des Morgens vorüber geh',

So freut's mich, du liebe Kleine,

Wenn ich dich am Fenster seh'.

Mit deinem schwarzbraunen Augen

Siehst du mich forschend an:

"Wer bist du, und was fehlt dir,

Du fremder, kranker Mann?"

Ich bin ein deutscher Dichter,

Bekannt im deutschen Land;

Nennt man die besten Namen,

So wird auch der meine genannt.

Und was mir fehlt, du Kleine,

Fehlt manchem im deutschen Land;

Nennt man die schlimmsten Schmerzen,

So wird auch der meine genannt. ${ }^{3}$

\section{H34: Notes to Introductory Statement}

1 Breve historia del modernismo, 2nd ed., p. 31.

2 In his article "Album de la ciudad: Retratos femeninos" (D, 1 April 1890), Casal addresses himself to Oscar Held in the following terms: "ve a medianoche, como de costumbre, a nuestro café nocturno, donde beberemos la amarilla cerveza de Strasburgo y te recitaré para aplacar tu modestia enojada, alguna balada de Heine, que la última de ellas, vale más, sí, muchísimo más-a lo menos para nosotros-, que la obra completa de ese viejo ambicioso que se llama Bismarck" (Ed. del Cent., vol. II, p. 95; italics are mine). Casal did not indicate in which language he would recite the Heine poem. Incidental references to Heine by Casal may be found in the Ed del Cent., vol. I, pp. 180, 185, 263, 278; vol. II, pp. 96, 114; and vol. III, p. 114.

3 This poem was one of 90 lieder that were written in 1823-1824. The collection, which was known as "Die Heimkehr," was first published in book form in 1826. Together with other early works by Heine, it was incorporated into Das Buch der Lieder in 1827.

H34: VARIANTS

l. $F$

7 - ¿Quién

8 vive en

11 bellezas,

12 [f]amosa desgracias, [sic]
H

¿Quién

oprime

bellezas

[y] también

desgracias.
GLIC

F 
13 [v]engo

lejanos climas

14 nostalgia;
Vengo

lejanas tierras

nostalgía; [sic]

\section{H35: MADRIGAL}

There is no evidence to show that "Madrigal" came out in Cuban periodicals before it was published in Hojas.

The Ed. del Cent. (vol. III, p. 203) asserts that the subtitle in Hojas was "En el álbum de la Srta. Myrta Martínez Ibor." An examination of the 1890 printing reveals, however, that the subtitle was "En un álbum." The error that appears in the $E d$. del Cent. is apparently related to an entry in Esperanza Figueroa's "Bibliografía de Julián del Casal" (p. 37), which indicates that the poem was reproduced in the 11 January 1891 issue of $E l$ Fígaro under the rubric "Madrigal. En el álbum de la Srta. Myrta Martínez Ibor." Further along in its bibliography, the Ed. del Cent. adds that the poem was reprinted in El Hogar on 29 October 1891 with the title "A Mirta." Since these post-Hojas versions are not in my possession, I cannot verify the data supplied by Figueroa or the compilers of the $E d$. del Cent.; and since no reference to Myrta Martínez Ibor appears in studies on Casal or in his collected prose, I am unable to shed light on why he may have written the poem in her album. To complicate matters even further, it turns out that "Madrigal" was published in the 30 September 1894 issue of La Revista Azul of Mexico with the following prefatory note and textual variants:

** $*$ Versos inéditos de Julián del Casal. Los

ha traido Virginia Fábregas en su album:

Ahí van mis versos. Negras mariposas

nacidas en el campo de mis sueños, no guardan ni el perfume de las rosas que libaron en dias más risueños.

Si del album salvando la distancia alguno de ellos á tus labios toca, haz que muera aspirando la fragancia de la flor purpurina de tu boca.

(Boldface mine; original text otherwise unaltered.)

The obvious questions are: 1) who was Virginia Fábregas; 2) when was she in Cuba; 3) what was her relationship with Casal; 4) did her version of the poem - described as versos inéditos and showing three textual variants - antedate the version which Casal published in Hojas; and 5) why did Casal write the same poem in another lady's album? 


\section{H36: LA ULTIMA NOCHE}

This poem, subtitled "(De L. Bouilhet)," was first published in the 11 November 1888 issue of La Habana Elegante, where it was printed in italics on the front page. A centered rule separated each stanza from the one that followed. In the Hojas version, the centered rule was removed and, as the record of variants shows, a considerable number of changes were made in wording and punctuation.

Louis Bouilhet (b. Cany, 27 May 1822; d. Rouen, 18 July $1869^{1}$ ) was one of an elite group of French authors who helped bring oriental motifs into vogue in the western world during the latter half of the nineteenth century. He was particularly interested in the culture of China and even learned the language of that fascinating land. Poems based on Chinese themes and translations of works by Chinese poets may be found in his Festons et Astragales (1859) as well as in his posthumous collection Dernières Chansons (1872). It should be noted, however, that "La última noche" was not inspired by Bouilhet's oriental poetry, but by a work of less exotic cast that appeared in his Dernières Chansons:

\section{Dernière Nuit}

Toute ma lampe a brûlé goutte à goutte, Mon feu s'éteint avec un dernier bruit. Sans un ami, sans un chien qui m'écoute. Je pleure seul dans la profonde nuit.

Derrière moi - si je tournais la tête Je le verrais - un fantôme est placé: Témoin fatal apparu dans ma fête, Spectre en lambeaux de mon bonheur passé.

Mon rêve est mort, sans espoir qu'il renaisse.

Le temps m'échappe, et l'orgueil imposteur

Pousse au néant les jours de ma jeunesse,

Comme un troupeau dont il fut le pasteur.

Pareil au flux d'une mer inféconde, Sur mon cadavre au sépulcre endormi Je sens déjà monter l'oubli du monde, Qui, tout vivant, m'a couvert à demi.

Oh! la nuit froide! oh! la nuit douloureuse! Ma main bondit sur mon sein palpitant. Qui frappe ainsi dans ma poitrine creuse? Quels sont ces coups sinistres qu'on entend? 
Qu'es-tu? qu'es-tu? parle, ô monstre indomptable Qui te débats, en mes flancs enfermé?...

Une voix dit, une voix lamentable:

"Je suis ton cœur, et je n'ai pas aimé!"2

\section{H36: Notes to Introductory Statement}

1 There is some doubt about the exact date of Bouilhet's death. In his preface to the Dernières Chansons, Gustave Flaubert says: "Son mal (une albuminerie connue trop tard) était irrémédiable, et, le 18 juillet 1869, il expira sans douleur, ayant près de lui une vieille amie de sa jeunesse, avec un enfant qui n'était pas le sien, et qu'il chérissait comme son fils" (Oeuvres de Louis Bouilhet: Festons et Astragales; Melanis; Dernières Chansons [Paris: Alphonse Lemerre, n. d.] p. 289). Recently, evidence has come to light that would indicate that Bouilhet actually died on 19 June 1869. Since the question has still not been resolved, I have chosen to record the date specified by Flaubert.

2 Oeuvres de Louis Bouilhet, pp. 383-384.

\section{H36: VARIANTS}

l. $H E$

1 gota,

2 ruido:

3 i[n]adie

$4 \mathrm{i}[\mathrm{n}]$ adie

5 Detrás [sic]

8 pasado!

10 [a]rrastra

* 13 iOh [sic]

fría!

Dame

algun

reposo [sic]

14 palpitante?

15 pecho

16 resonante?

17 ( $($ )¿Quién

20 " $\mathrm{Yo}$

amado!"
H

gota

ruido.

iNadie

iNadie

(ף)Detrás

pasade! [sic]

[s]e lleva

(ף) $\mathrm{iOh}$,

helada!

iDáme

tu

reposo!

adolorido?

seno

repetido?

¿Quién [sic]

$H E$

-Yo

amado.
$H E$

(ף) $+H E$

GLIC

$H+$ Dame

\section{H36: Note to Variants}

13: Since I feel that it is incorrect to place a comma after the vocative oh, the punctuation mark is suppressed in my edition. 


\section{H37: FATUIDAD POSTUMA}

This poem was first published in the 22 January 1888 issue of $L a$ Habana Elegante. Its title in this version was "Vanidad póstuma" and it was dedicated "(A mis amigos.)." The poem was printed as the sole item on the first page of the journal. However, unlike the majority of Casal's works that were given this position of honor, it was not set in italic type. The initial line of each stanza, rather than being indented, was left-justified.

When Casal prepared this work for publication in Hojas, he preserved the original dedication but altered the title to "Fatuidad póstuma." $\mathrm{He}$ also introduced a few lexical and punctuation changes into the body of the poem. In contrast with the format of the 1888 version, the first line in each stanza was indented in Hojas.

In the March-April 1947 issue of Realidad, Julio Caillet-Bois indicates that Casal's inspiration for "Fatuidad póstuma" may have come from "Coquetterie posthume," one of the poems found in Gautier's Émaux et camées: ${ }^{1}$

Quand je mourrai, que l'on me mette,

Avant de clouer mon cercueil,

Un peu de rouge à la pommette,

Un peu de noir au bord de l'œil;

Car je veux, dans ma bière close,

Comme le soir de son aveu,

Rester éternellement rose

Avec du khol sous mon œil bleu.

Pas de suaire en toile fine;

Mais drapez-moi dans les plis blancs

De ma robe de mousseline,

De ma robe à treize volants.

C'est ma parure préférée:

Je la portais quand je lui plus;

Son premier regard l'a sacrée,

Et depuis je ne la mis plus.

Posez-moi, sans jaune immortelle,

Sans coussin de larmes brodé,

Sur mon oreiller de dentelle

De ma chevelure inondé.

Cet oreiller, dans les nuits folles,

A vu dormir nos fronts unis, 
Et sous le drap noir des gondoles

Compté nos baisers infinis.

Entre mes mains de cire pâle,

Que la prière réunit,

Tournez ce chapelet d'opale,

Par le pape à Rome bénit:

Je l'égrènerai dans la couche

D'où nul encor ne s'est levé;

Sa bouche en a dit sur ma bouche

Chaque Pater et chaque Ave. ${ }^{2}$

\section{H37: Notes to Introductory Statement}

1 Cited by Monner Sans, Julián del Casal y el modernismo hispanoamericano, p. 47, n. 7.

2 Oeuvres de Théophile Gautier (Paris: Alphonse Lemerre, Éditeur, 1890), vol. III, pp. 25-26.

\section{H37: VARIANTS}

l. $H E$

10 patria,

12 lustroso

* 13 hoguera,

18 tengo ya puesta

* 19 restos,

22 la Verdad su jóven
$H$

patria

luctuoso

hoguera

fijé en un tiempo

restos

ahora la Verdad su

GLIC

\section{H37: Note to Variants}

13, 19: It will be observed that in these instances, as elsewhere in $H$ (see $\mathrm{H} 1 / 1$, for example), Casal tended to rely more heavily on the end-of-verse blank as time went on. The consequence of using this punctuation mark instead of a comma was that the rhythm became more buoyant.

\section{H38: A BERTA}

This composition was first published under the title "A Coralia" in the 28 October 1888 issue of El Fígaro. The subtitle "Fragmentos," as well as the rows of dots after the fourth and seventh stanzas (see below), made it plain that Casal had not yet developed his poetic idea to the full. Indeed, at this stage in its evolution, the poem consisted of four stanzas less than it was destined to have in the future: 


\section{Á CORALIA.}

\section{FRAGMENTOS.}

Stanza

in $F$

[I] Yo no temo el rigor de los tiranos, Ni el azote brutal de injusta suerte:

iTémole á tus hechizos sobrehumanos!

iLo mismo dan la vida que la muerte!

[II] Aunque apartarme de tu lado quiera, Siempre al poder de tus encantos cedo.

iVivir lejos de tí me desespera!

¡Estar lejos de tí me infunde miedo!

[III] Guiado por la luz de tus miradas Que produce fatales espejismos, He ganado las cumbres escarpadas Para caer sangrando en los abismos.

[IV] Si en tus robustos brazos me encadenas Y á tu semblante la pasión asoma, Parece que circula por tus venas La sangre de las hijas de Sodoma.

[V] Aguila soy de poderoso vuelo Caida en el abismo de la vida; Teniendo fuerzas para alzarme al cielo Siento mi planta en lodazal hundida.

[VI] La hora de ser grande ya me tarda, Porque anulas mis fuerzas infinitas. Cuando quiero subir, dices: aguarda Mas si quiero bajar, me precipitas.

[VII] Ayúdame á salvar mi oscuro nombre De las oscuras ondas del olvido, Que sólo la mujer hace del hombre Héroe adorado ó criminal temido. 
[VIII] Hoy sólo anhelo desatar los lazos En que me tienen tus encantos preso, Pues dejaré mi vida entre tus brazos Como dejo en tu boca ardiente beso;

\section{[IX] Y mi alma noble, soñadora y franca}

Está por tu pasión envilecida, Como ligera mariposa blanca En pantano de sangre sumergida.

\section{(Octubre.)}

JULIAN DEL CASAL.

On 12 May 1889, an extensively revised version of the poem was printed in standard type on the front page of La Habana Elegante. The work now bore the title "AbismoS" ${ }^{1}$ and consisted of thirteen stanzas. The subtitle, rows of dots, centered rules, and date which had been part of the El Figaro version were all omitted from this printing. The diagram shown in Plate 5 will allow the reader to see, in broad outline, how the two versions differed in structure.

An analysis of the major changes which Casal made in the new version of the poem will show that, with one exception, they were all commendable: a) Revision of stanza III, plus its insertion after stanza 9, allowed Casal to develop more effectively and at a more opportune moment the theme of woman's absolute control over man's destiny. b) Stanza IV did not fit well into the logic of the 1888 version, and it was not essential at any point in the revised version either. Furthermore, the hijas de Sodoma image was not in very good taste. Under these circumstances, Casal was wise to suppress the stanza. c) The fundamental idea that inspired stanza V was essentially the same as the one that inspired stanza IX. Indeed, the similarity between the two stanzas was not limited to concept alone: even the -ida rhyme was repeated in the same position in both stanzas. Because stanza V preceded the crucially located stanza IX, it lessened the impact of the latter strophe. Hence, Casal did well to omit stanza V from the new version of the poem. d) With stanza III re-worked and re-located, and with stanzas IV and V suppressed, Casal could develop more fully the yo, hombre-tú, mujer antithesis that was at the heart of the poem. Since stanzas I and II already placed emphasis on the yo, it was logical for Casal to elaborate the tú part of the idea now. This was the function of stanzas 3-4 in the revised version. e) Probably feeling that it was advisable to swing the pendulum back to $y o$ at this point, Casal composed stanzas 5 and 7 . The error here, however, was to insert stanza VI between the new stanzas, for this broke the conceptual unity of those stanzas and therefore weakened their effect. It would have been more logical if Casal had kept stanzas 5 and 7 together and used stanza VI as a prelude to stanza 8. This, I believe, 
PLATE 5

Revisions in "A Coralia"

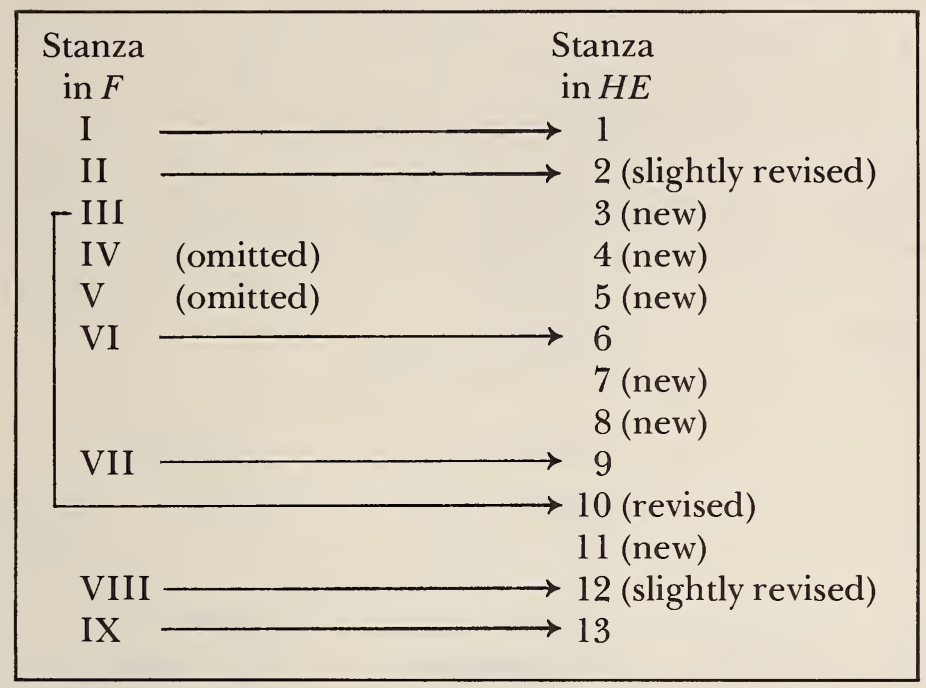

was the only serious mistake that Casal made when revising the poem. f) With stanza 8, Casal paved the way for a return to the major theme: woman's power over man (stanza 9) and, in particular, the subservience of yo, hombre to the rule of tú, mujer (stanzas 10-11). g) After this point was made, it was quite proper to retain the concluding stanzas of the original version as the final statements in the new poem (stanzas 12-13).

When Casal prepared the poem for publication in Hojas, he changed the title from"Abismos" to "A Berta," but made relatively few alterations in the text. Apparently, the major overhaul which he had performed in 1889 left him basically satisfied.

\section{H38: Note to Introductory Statement}

1 The title was not "Abismo," as Figueroa ("Bibliografía de Julián del Casal," p. 35) and the Ed. del Cent. (vol. III, p. 200) indicate. Since the final $s$ was capitalized, these bibliographers apparently took it to be part of the design that surrounded the word in the $H E$ version.

H38: VARIANTS

l. $F$

* 1 tiranos,

2 suerte:

* 3 i[t]émole

4 i[l]o
$H E$

tiranos

suerte.

¡Témole

iLo 
l. $F$

5 quiera,

* 8 lejos

* 9

13

19

21 tarda,

22 infinitas.

23 Cuando

subir, aguarda

24 quiero

* 25

26

30

32

* 37

39

* 45 (ף)Hoy sólo anhelo

47 [p]ues dejaré mi vida entre

48 [c]

ardiente

beso;

* 49 franca
$H E$

quiera

cerca

mal,

alma......

tarda

infinitas;

[c]uando

ascender,

aguarda;

intento

profundo,

pasión,

la

la gloria

(ף)Déjame sólo

[p]orque mi vida

dejaré en

[c]ual

mi ardoroso

beso, mal

H

GLIC

alma...

F

F

F

F

profundo;

pasión

$\mathrm{tu}$

las gloria [sic]

$H E$

$H E+$ solo

[c]omo

$F$

\section{H38: Notes to Variants}

1: The numbers shown in the record of variants refer to lines in all versions except the $F$ version. As indicated above, this version was considerably shorter than those which followed.

3: In all versions, Casal used the singular object pronoun-le despite the fact that his referent, hechizos, was plural and was located in the same verse as the pronoun.

8: The change from lejos to cerca is in accord with the stress on antithesis throughout the poem.

9: Lines 9-20 did not exist in the $F$ version.

25: Lines 25-32 did not exist in the $F$ version.

37: Although 11. 37-40 appeared in the $F$ version, it is best to consider them as new lines in the $H E$ version, since the revision was so extensive.

45: In the 1880's and 1890's, the accentuation system in Spanish was not as rigorously observed as it is today. In the $H$ version of this poem, it is especially difficult to determine whether Casal intended solo to mean "only" or "by myself." I am inclined to favor the latter interpretation. That is why I list the $H$ form as a variant of the $H E$ reading.

49: See $\mathrm{H} 22 / 9$ and $\mathrm{H} 42 / 9$. 


\section{H39: VESPERTINO}

This poem was first published in the 6 November 1887 issue of $L a$ Habana Elegante. It was printed in italics on the front page of the journal. In this version, the work was entitled "Al llegar la noche" and bore the subtitle "Soneto." All text-lines were left-justified. Before publishing the composition in Hojas, Casal changed the title to "Vespertino" and modified the wording of two verses. In Hojas, the initial line in each stanza was indented. Unfortunately, the text of the 1890 version was marred by three typographical errors.

\section{H39: VARIANTS}

\section{l. $H E$}

2 señoriales,

4 [e]rizados

* espinas;

5 [v]eo llegar las tristes

6 [a] las ardientes costas

* 11

13 Noche
H

senoriales, [sic]

[e]rizadas [sic]

espinas. [sic]

(q) Veo

las azuladas

[1]legar á las regiones
GLIC

$H E$

$H E$

$H E$

(ף) $+H E$

$H+\mathrm{a}$

noche

\section{H39: Notes to Variants}

4: In the $H E$ version of 1887 , the introductory stanza ended with a semicolon. This punctuation mark showed that the scene-setting had been concluded and that the main idea was to begin in the next stanza. In $H$, a period stands in place of the original semicolon. Given the syntactical and ideological relationships which exist between stanzas I and II, the period is interpreted as a typographical error. For this reason, the semicolon is restored in 1.4 and veo is written in lower-case in 1. 5 .

11: Although the function of an azada is to chop up the soil (i.e., to leave its own huellas in the earth), Casal emphasizes the destructive effect of the earth upon the hoe. The psychological implications of this inversion are truly fascinating.

\section{H40: LA CANCION DEL TORERO}

"La canción del torero" came out for the first time in Hojas al viento. In his subtitle, Casal indicates that it is an imitation of a poem by José M[aría] de Heredia, the Cuban author (b. Santiago, 22 November 1842; d. Château de Bourdonné, France, 2 October 1905) who was destined to gain worldwide renown for his Parnassian masterwork Les Trophées (1893). Although the subtitle to "La canción del torero" credits Heredia or Hérédia, as he is more commonly known - as the source of inspiration, it 
does not specify which of Hérédia's poems served as the model. Investigation has revealed that the source was a piece that first came out in the 20 December 1879 issue of La Vie Moderne as a facsimile autograph entitled "La Fête de Paris-Murcie." On 10 June 1884, the poem appeared in Monde Poétique; this time, however, it was entitled "Redondillas" and the second stanza of the original was omitted. Casal's translation was not based on these early versions of the poem, but on one that was published on 21 September 1889 in the literary supplement of Le Figaro under the title "Chanson de Torero." It was with this title that Casal referred to Hérédia's poem when writing to Gustave Moreau on 17 February 1892: "Dans mon premier recueil de vers, publiè au commencement du dernier annèe, j'ai traduit sa Chanson de Torero . .." (C6/119-123). ${ }^{1}$ The text from which Casal worked reads as follows:

\section{CHANSON DE TORERO}

Debout au milieu de l'arène Sous l'œil des taureux andalous, Je n'ai jamais tremblé, ma Reine, Qu'à l'éclair de tes yeux jaloux.

J'ai vu crier vingt mille bouches, J'ai vu sur moi, doux ou hagards, Parmi les beuglements farouches, Se poser vingt mille regards;

J'ai vu, - comme moi tu t'en railles! Avec des bonds désespérés

Traînant de lourds paquets d'entrailles,

Courir les chevaux éventrés;

J'ai vu sortir la corne rouge

Du dos troué d'un picador;

Mais, pour si peu, mon cœur ne bouge

Sous le satin pailleté d'or.

Ni le bravo d'une main blanche,

Ni l'œillade d'un long œil noir...

Je reste le poing sur la hanche,

Sans rien entendre et sans rien voir.

C'est mon taureau que je regarde Et, souriant, j'attends le choc Pour lui pousser jusqu'à la garde Un éblouissant coup d'estoc. 
Mais sous tes yeux ardents je tremble Et me signe à leurs feux maudits, Car j'y vois flamber tout ensemble Et l'Enfer et le Paradis!²

In the next few years, Casal became acquainted with other works by Hérédia and even tried to imitate his sonnet style in "Mi museo ideal" (C6/107-113). What Casal admired most about Hérédia was that he was "un pintor ... que sólo ve formas y colores" 3 and that his art was "sonoro como el bronce, puro como el diamante y deslumbrador como un tapiz asiático . . . "4 Casal's reverence for Hérédia became so intense that he considered him to be one of his literary gods (C6/114). Modest and hypercritical by nature, however, Casal was reluctant to show his own work to the great master. Thus, when Moreau suggested that he let Hérédia translate one of his compositions into French, Casal stated that he was not worthy of such an honor. He even refused to send Hérédia a copy of "La canción del torero" because, as he explained to Moreau, "en relisant mes vers, je les ai trouvè très mauvais. Je m'en souviens aujourd'hui, comme un père solitaire de ses petits enfants morts" (C6/125-129). In spite of this, when Nieve was published, Casal managed to overcome his timidity and sent Hérédia a copy of the book (see p. 143).

\section{H40: Notes to Introductory Statement}

1 It will be observed that Casal erred in this statement: Hojas had not been published the year before, but almost two years earlier.

2 For more complete bibliographical information on the poem, see Miodrag Ibrovac, José-Maria de Heredia: sa vie -son œuvre (Paris: Les Presses Françaises, 1923), pp. 587-588.

3 Bustos y rimas, p. 113; Ed. del Cent., vol. I, p. 278.

4 Ed. del Cent., vol. II, p. 144.

H40: VARIANTS

l. $H$

9 (ף)Ví,

* 20 [a]lentejuelada

27 empujó [sic]
GLIC

( $(\mathrm{V}) \mathrm{Vi}$

empujo

\section{H40: Note to Variants}

20: Without indicating that he was changing this word, Cabrera Saqui substituted an adjective of his own preference: lentejueleada. The $E d$. del Cent. followed Cabrera Saqui without question, despite the fact that alentejuelado appears elsewhere in Casal's works: e.g., we find the expression "alentejuelados de 
oro" in the essay "Armando Menocal" (D, 13 February 1890), which is reproduced in vol. II, p. 51, of the Ed. del Cent.

\section{H41: IN MEMORIAM}

This moving composition was first published in the 1 December 1889 issue of El Figaro. Beneath the title was the following two-line dedication: "A Miguel Figueroa. / En la muerte de su esposa." The date "(Nvbre. 89.)" was printed opposite the author's name at the end of the poem. When preparing "In memoriam" for publication in Hojas, Casal did a minimum of revising: he made one lexical change, altered the punctuation of three verses, and modified the format of the dedication.

Miguel Figueroa y García (b. Cárdenas, 29 September 1851), whose grief Casal tried to assuage with this poem, was one of the most dynamic public figures of his time. During the course of his brief career, he gained renown as a brilliant defense attorney, a fervent abolitionist, an ardent supporter of Cuban autonomy from Spain, an effective parliamentarian, and a brilliant orator of the fire and brimstone variety, who vigorously expounded the ideals of the Partido Liberal. On 6 July 1893, Casal, already near death himself, learned that Figueroa had succumbed to the disease that would soon claim his own life: tuberculosis.

\section{H41: VARIANTS}

\section{l. $F$}

1 qué

7 i[l]a

18 griego,

29 gentes

39 populares

47 Abelardo

48 escuchó

52 aroma
H

quá [sic]

[1]a [sic]

griego

geutes [sic]

populares,

Abelardo,

secuchó [sic]

perfume
GLIC

F

F

F

F

\section{H42: CROQUIS PERDIDO}

The original version of "Croquis perdido" was published by La Habana Elegante on 23 June 1889. It was printed in standard type on the front page of the journal, was subtitled "Soneto," and bore the following dedication: "A. Valdivia / (Sine Irae)." The person referred to here was Aniceto Valdivia y Sisay (b. Sancti Spiritus, 20 April 1859; d. Havana, 28 January 1927), one of Casal's most intimate associates. In his early twenties, Valdivia lived in Spain. There, with eager abandon, he exposed 
himself to every type of literature available. There, too, he began his career as a professional writer: he composed articles on diverse literary subjects, wrote two plays in the style of Echegaray (La ley suprema and Senda de abrojos), and translated a considerable amount of French poetry. In Casal's article on Manuel Reina, which was published in the 20 December 1885 issue of La Habana Elegante, we also learn that Valdivia collaborated with the Spanish poet on the composition of a play entitled La Picaruela and on the translation of Maurice Rollinat's Les Nevroses. ${ }^{1}$ When Valdivia left Spain in 1885, his trunks were packed with works by European authors, most of them French. Even the pseudonym that he would use so extensively in years to come was taken from the title of a French novel: Victor Cherbuliez' Le Comte Kostia (1863).

From the moment of his arrival in Havana, Valdivia played a significant role in Cuban literary and cultural activities. At the Círculo Habanero which had been founded in April 1885 and which enjoyed the support of such important figures as José María de Céspedes, Ricardo del Monte, José Fornaris, Rafael Montoro, and Enrique José Varona - he read poetry and produced Echegaray's play El gran galeoto. In 1886, he was commissioned by El Figaro to write the first installment of the novel Solos. Manuel Serafín Pichardo and Rafael Bárzaga described the nature of this work in the following terms:

Solos será ni más ni menos el título de una pequeña novela que publicará El FíGaro, por capítulos, a imitación de Las Vírgenes Locas del Madrid Cómico, que a su vez lo ha imitado de otros periódicos franceses.

En cada número saldrá un capítulo, y el autor que haya de escribir el siguiente, no lo sabrá hasta el mismo día en que se inserte el anterior. ${ }^{2}$

Considering that Solos appeared shortly after Valdivia's return from Europe, that he was familiar with contemporary journalistic practices in Spain and France, and that he wrote the opening chapter of the novel, it seems likely that he was the one who convinced El Figaro to undertake the Solos experiment-a project in which Casal also participated (see H45). In addition, Valdivia collaborated on La Lucha, a newspaper that had been founded in 1885 by Antonio San Miguel. ${ }^{3}$ Valdivia's activities on these and other Cuban periodicals absorbed most of his time and energy. Indeed, this may have been a key reason why he did not publish his own poetry in book form-a fact which Casal publicly lamented in his "Carta abierta" to Carlos Noreña. ${ }^{4}$

Valdivia's main importance to us, however, does not lie in his journalistic activities, his translations, his original production, or his critical evaluation of the works of contemporaries such as Domingo Malpica Labarca and Juana Borrero, ${ }^{5}$ but in his influence on the life and art of Julián del 
Casal. Speaking of Valdivia's return from Europe, Ramón Meza says: "Valdivia, poseedor de vastísima erudición, un tanto desordenada por el mismo afán de leerlo todo, y de leerlo todo a un tiempo, no fue avaro con el tesoro acumulado en su memoria, ni con su biblioteca selecta de autores de la época[:] compartiólos fraternalmente con el joven poeta a quien amó desde su primer saludo."6 Valdivia was impressed by Casal's literary background. In particular, however, he admired Casal's proficiency at translation-and this may have been one of the principal reasons for his initial interest in the young poet. In his article "Julián del Casal," which appeared in La Lucha on 23 October 1893 and in La Habana Elegante on 29 October of the same year, he said: "La literatura antigua y la moderna no tenían secretos para él. Había entrado con pie seguro en la vereda enmaranada de los decadentes y simbolistas, y sin necesidad de Glosario, descifraba, a la primera lectura, lo mismo el Tratado del Gesto de René Ghil que los Rombos Rimados de Mario Varvara. iCuántas veces he ido a llevarle artículos de los Ecrits pour l'Art para que me tradujera a francés inteligible fragmentos de Jean Philibert, de Albert de Saint Paul o de Robert de Souza! Y nunca su comprensión engañó a mi anhelo; jamás una juntura de coraza permitía a la decepción meter en hendiduras de su deficiencia la hoja de la espada. Era un espejo de cristal bruñido en que se reflejaban todos los misterios del arte."7

Although Valdivia introduced Casal to the works of a considerable number of foreign authors, within a short time Casal surpassed Valdivia as an artist. On the one hand, Casal had greater innate talent and was better able to concentrate his creative energies than Valdivia. On the other, Casal went farther than his friend because, in the words of Manuel de la Cruz, Casal "ha abrazado la doctrina con el intolerante fervor de un neófito, y no la doctrina estética a secas, sino todo el dogma del decadentismo, en tanto que Valdivia no ha ido más allá de la renovación y ampliación del estilo y del lenguaje."8

Perhaps because he realized Casal's potential greatness, Valdivia did everything in his power to encourage the young poet and to make his existence easier. In fairness to Casal, however, it must be emphasized that he showed his appreciation to Valdivia many times and in many ways during the eight years of their association. Nevertheless, no information has come to light explaining why he chose to dedicate "Croquis perdido" to him. Even Ramón Meza, who discusses the genesis of the composition, does not enlighten us on that point:

Croquis perdido fue debido a la impresión que causó en el poeta la vista de la última pena aplicada a un reo en garrote vil en el campo de la Punta, donde por aquellos días eran frecuentes estos repugnantes espectáculos. Los jóvenes redactores de $L a$ Habana Elegante, fuimos todos en grupo a presenciar, algunos, los más, por primera vez, este acto de bárbara ejemplaridad 
pública. Y sacamos la más dolorosa impresión; bastó un movimiento de un piquete de soldados de caballería, guardadores del reo, hacia la gran muchedumbre que llenaba aquel campo, para que ésta, sugestionada y por el terror, huyese presa del más cobarde pánico, atropellándose en imponente confusión. La mole humana, que huía sin saber a ciencia cierta por qué, nos arrolló y pisoteó, partiendo piernas y brazos a algunos curiosos pacíficos e indefensos.

Al regresar, con el ánimo apenado, vimos a través de una celosía la silueta elegante de una desconocida dama; para ella fue el [soneto]. ${ }^{9}$

Not only does Meza fail to indicate why Casal dedicated the poem to Aniceto Valdivia, but he also neglects to specify the date on which the execution of the prisoner took place. Had he provided this information, he might have been a great help in solving the riddle of Casal's whereabouts in 1889. Unfortunately, Meza, like so many of his compatriots who wrote about the poet, tended to be lax about dates. Of course, one may stress the fact that Casal, who was prone to publish his poems almost immediately after he wrote them, did publish "Croquis perdido" on 23 June 1889. In view of the circumstances surrounding the poem's genesis, the implication would be that Casal was back in Cuba before that date. However, there is a possibility that the event to which Meza refers actually took place before Casal went to Spain in 1888 and that Casal delayed publishing the sonnet for reasons which at present are unknown. In that case, the date 23 June 1889 would not be a dependable clue to Casal's whereabouts.

Aside from the following exceptions, the Hojas version of the poem was the same as the original one: the first line of the dedication was changed from "A. Valdivia" to "A Baldivia," 10 the second line of the dedication was suppressed, one punctuation mark was removed from 1. 9, and one typographical error remained undetected in 1.12.

\section{H42: Notes to Introductory Statement}

1 Ed. del Cent., vol. I, p. 186. The "bohémien" Rollinat (b. Châteauroux, 29 December 1846; d. Ivry, 26 October 1903) became a celebrity in Parisian avantgarde circles with his Les Neuroses: Les âmes, les luxures, les refuges, les spectres, les ténèbres ... (Paris: Charpentier, 1883) and, as Reina and Valdivia attest, even found admirers in conservative Spain.

2 Ibid., vol. III, p. 126.

3 For a description and assessment of La Lucha, see Casal's article "La prensa," which appeared in the 13 May 1888 issue of La Habana Elegante (Ed. del Cent., vol. I, pp. 145-148). 
4 El Fígaro, 14 September 1890; reproduced in the Ed. del Cent., vol. I, pp. 166-169.

5 See his prologues to Malpica's novel En el cafetal (1890) and Juana Borrero's Rimas (1895).

6 "Julián del Casal," Ed. del Cent., "Poesías," p. 224.

7 Ed.del Cent., "Poesías," p. 298.

8 Cromitos cubanos, p. 315; Ed. del Cent., "Poesías," pp. 323-324.

9 "Julián del Casal," Ed. del Cent., "Poesías," p. 245.

10 Whether the $B$ in this name represents a typographical error or the printer's spelling preference is not as intriguing as the question about the " $A$ " which precedes the name. In the $H E$ version, did this letter represent the name Aniceto, or was it a preposition to which a full stop was added by mistake? If this could be determined, it would be easier to draw conclusions about the " $\mathrm{A}$ " of the Hojas version: i.e., was it the initial of Valdivia's first name, which, through error, had been stripped of its punctuation, or was it really a preposition? (Contrast this situation with $\mathrm{N} 42$, where there can be no doubt that a typographical error was committed: "A Raúl Cay" appeared in the original version, but "A. [sic] Raúl Cay" was printed in a later version.)

H42: VARIANTS

l. $H E$

$H$

GLIC

* 9 bella,

$12(\mathbb{(})[\mathrm{c}] \mathrm{omo}$

bella

[c]omo [sic]

$H E$

H42: Note to Variants

9: See $\mathrm{H} 22 / 9$ and $\mathrm{H} 38 / 49$.

\section{H43: IDILIO REALISTA}

"Idilio realista" was first published in the 24 November 1889 issue of $L a$ Habana Elegante. The eighteen stanzas of this two-part composition were dedicated "A Raúl Cay" and were printed in italic type on the front page of the journal.

Casal made a fair number of changes in the poem before he published it in Hojas. These changes are listed in the record of variants, below. However, one of Casal's revisions deserves to be discussed here: namely, the transposition of what had been stanza $\mathrm{V}$ ("El negro pavo de rojiza cresta ...") and stanza VI ("Donde la planta sus colores pierde ...") in the original version. It is obvious that, in Part I, Casal was more interested in evoking scene and mood than in developing a given idea logically. Therefore, he enjoyed a considerable amount of freedom in positioning the stanzaic components that were to form the opening section of the poem. If Casal 
had such freedom to begin with, why did he decide to change the order of stanzas V-VI when he prepared the poem for Hojas? Although the hypothesis cannot be proved, it seems reasonable to assume that something other than the subject of those stanzas motivated the change. One possibility is that Casal was attempting to avoid a repetition that had escaped his notice when he put the 1889 version together-specifically, the repetition of negros + noun and negro + noun at the beginning of stanzas IV and V of that version:

IV Negros bueyes, jaspeados de amarillo,

Caida la cabeza entre las patas, Aspiran la fragancia del tomillo Evaporada de las finas matas.

V El negro pavo de rojiza cresta Abre la cola en forma de abanico $O$ vaga luego, en actitud modesta, Escarbando la tierra con el pico.

VI Donde la planta sus colores pierde Bajo el rayo de sol que la extermina, Saca el lagarto su cabeza verde Y la abrasada lengua purpurina.

(Italics mine.)

Because the sequence of stanzas in Part I was less rigidly governed by logic than it was in some of his other poems, Casal could invert the order of stanzas V-VI and thus make the repetition more difficult to perceive. Indeed, even Ciriaco Sos Gautreau, who used the Hojas version of "Idilio realista" as one of the bases for his vitriolic criticism of Casal, failed to notice the repetition. ${ }^{1}$

Among the things which Casal did not change in Hojas was his dedication of the poem to Raoul Cay, ${ }^{2}$ who figured so prominently in Havana social circles of the time. Cay, an attaché to the Chinese consulate in Havana, was a noted society columnist who wrote the weekly "Crónica" for El Figaro. Often acting as escort to his sister María, he frequented the elegant salons and participated in the lavish celebrations of Havana's upper classes. In July of 1892, he was elected Secretary of one of the city's most important social clubs, La Caridad del Cerro. As a man about town, minor diplomat, and newspaper columnist, Cay had many opportunities to meet and correspond with the outstanding writers of his day. Federico Villoch (Ed. del Cent., "Poesías," p. 304) informs us that Cay was an active participant in the tertulias that were held daily at La Galería Literaria. Casal, who met him on these and similar occasions, developed a great 
admiration for Cay and dedicated two poems to him, H43 and N42. Rubén Darío sent him a copy of Azul . . in the spring of 1891 (see N36), dedicated "Los centauros" to him in the May 1892 issue of La Habana Literaria, and years later, recalling his first visit to Havana, paid tribute to "aquel charmant Raoul en cuya casa bebimos un té digno de Confucio." 3 When Casal died, Cay published a brief but moving eulogy to his departed friend in the 29 October 1893 issue of La Habana Elegante. ${ }^{4}$

\section{H43: Notes to Introductory Statement}

1 See Julián del Casal o un falsario de la rima (Havana: Imprenta y Papelería "La Prensa," 1893), pp. 13-15; reproduced in Ed. del Cent., "Poesías," pp. 381-382.

2 Although Casal spelled the name Raúl, Cay seems to have preferred the French form, Raoul.

3 Letras (Madrid: Editorial Mundo Latino, 1921), p. 180.

4 See Ed. del Cent., "Poesías," p. 293.

H43: VARIANTS

\begin{tabular}{|c|c|c|}
\hline l. $H E$ & $H$ & GLIC \\
\hline 2 chimenea, & chimenea & \\
\hline 7 aíre $[s i c]$ & aire & \\
\hline 12 palomas, $[s i c]$ & palomas. & \\
\hline 17 sus colores & su frescura & \\
\hline $20[y]$ la abrasada & [a]gitando la & \\
\hline \multicolumn{3}{|l|}{21} \\
\hline 26 [f]ínjenme & [s]emejan & \\
\hline 34 donde quiera & & dondequiera \\
\hline 39 pastorcilla & partorcilla $[$ sic $]$ & $H E$ \\
\hline 44 holandeses; & holandeses. & \\
\hline $45(\Phi)[\mathrm{n}] \mathrm{i}$ & $(\mathbb{\top}) \mathrm{Ni}$ & \\
\hline 46 [c]olocar & [c]olocar, & \\
\hline 53 lucir hermosa & oscilar fragante & \\
\hline 54 arranca, & arranca & \\
\hline 55 escondida & torneada & 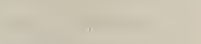 \\
\hline pantorrilla & prntorrilla $[s i c]$ & $H E$ \\
\hline 57 blondas, & blondas & \\
\hline 58 cabellos & cabellos, & \\
\hline 59 hondas, $[$ sic $]$ & ondas, & \\
\hline 63 aguarda & espera, & \\
\hline 64 [c]on el abrazo abierto a la & [p]ara hacerle al instante una & \\
\hline 65 ( $($ ) Siente de dicha el & ( $($ ) Tímida avanza hacia el & \\
\hline $\begin{array}{l}\text { corazón opreso, } \\
69 \text { que, }\end{array}$ & $\begin{array}{l}\text { follaje espeso, } \\
\text { que }\end{array}$ & \\
\hline
\end{tabular}


17: In the $H E$ version, 11. 17-20 formed stanza VI (see my discussion, above).

21: In the $H E$ version, 1l. 21-24 formed stanza $\mathrm{V}$ (see my discussion, above).

26: Casal had used finjenme in 1.26 of the $H E$ version. To his way of thinking (and this was an error he committed more than once in his career as a poet), the unemphatic form -me and the logic of the poem would be sufficient to tell the reader that the subject of escuchando (1. 31) and dirija (1. 34) was yo. By changing finjenme to semejan in the 1890 version, Casal removed one of the syntactic signals that the reader depended upon for comprehension. As a result, the subject of escuchando and dirija seems to be pez in the revised version. Ciriaco Sos, who apparently knew only the $H$ version, was one reader whom Casal managed to confuse (op. cit., p. 14).

44: Stanzas XI and XII were the only stanzas in the $H E$ version that were linked by punctuation. By changing the $H E$ semicolon to a period in $H$, Casal made every stanza in the poem a separate entity.

\section{H44: A LOS ESTUDIANTES}

"A los estudiantes," which did not appear in print before it was published in Hojas, is Casal's commentary on a black event in Cuban history. The colonial government accused eight medical students - Anacleto Bermúdez, Alonso Alvarez de la Campa, Carlos Augusto de la Torre, Carlos Verdugo, José de Marcos Medina, Angel Laborde, Eladio González, and Pascual Rodríguez y Pérez - of having desecrated the tomb of Gonzalo Castañón, director of the pro-Spanish newspaper La Voz de Cuba. Although they protested their innocence, the students were found guilty and were executed on 27 November 1871 . Two years later, proof that they had indeed been guiltless was supplied by Fermín Valdés Domínguez (1852-1910) in his report entitled Los voluntarios de la Habana en el acontecimiento de los estudiantes de medicina. As a result, the students became a symbol of Spanish injustice and a vivid illustration of why Cubans should support the struggle for independence.

Two of Casal's contemporaries left accounts of the genesis of "A los estudiantes." Unfortunately, these accounts provide no information about the year in which the sonnet was composed, nor do they agree on the question of where it was written. In his article entitled "Julián del Casal," Ramón Meza says the following: "Una mañana del 27 de noviembre, neblinosa y fría, de un cielo gris y de lloviznas muy tenues, fuimos al viejo Cementerio de Espada a rendir homenaje a la memoria de aquellos niños inocentes, vidas tronchadas cobarde y alevosamente, con cruel ensañamiento colectivo, por la más ciega y feroz intransigencia. Para aquellas siempre lloradas e inolvidables víctimas fue el soneto bosquejado ante su tumba ...." Enrique Hernández Miyares gives a different version 
of the genesis of the poem, however. In "Julián del Casal, patriota," he writes:

Yo siempre me acuerdo de una vez que hablábamos alrededor de una mesa, del 27 de noviembre de 1871: el fusilamiento de los Estudiantes. Casal hojeaba un libro francés, indiferente a la conversación, hasta que vino a interesarlo la relación de uno de los que hablaba del horrible suceso, refiriéndolo con minuciosos detalles, recordando la impresión que le causara en su imaginación infantil el bárbaro martirio de aquellos ocho niños; comentando con frases afiladas el tremendo horror de aquel día pavoroso ...

El libro de Paul Verlaine quedó cerrado sobre la mesa, y al respaldo de una cuartilla ya escrita, rimó el soneto vibrante y enérgico ...2

The question of Casal's patriotism has interested critics for years. Most commentators look upon the author as a fundamentally apolitical person -one who turned his back on the problems of his country and built a private dreamworld where he could cultivate his illusions and nurture his sadness. Hernández Miyares is one of the few who try to build a case to the contrary. His argument - which rests mainly on "A los estudiantes," "La perla," "A un héroe," and Casal's article about General Sabas Marín ${ }^{3}$ - is not a particularly convincing one because of the type of evidence used and the way in which it is interpreted. The argument is further weakened, however, by the following comment that Casal made in a letter to Esteban Borrero Echeverría on 19 March 1891: "Pienso hacer unas poesías patrióticas, sólo por complacer a usted, aunque siempre he temido mucho hacer algo en ese sentido, pues creo que deben hacerse a la perfección o no hacerse. Así se explica, me parece, que escaseen tanto en todos los Parnasos." 4 This statement of intent, made almost one year after Hojas came out, strongly suggests that Casal did not consider any poem he had written in the past as being of the patriotic variety. As far as "A los estudiantes" is concerned, such an evaluation seems quite justified. In the poem, Casal sees the students as innocent victims of treachery. Death for them, however, is shown to be a positive experience, for it brings them peace-a peace in which no one can disturb their dreams any longer. Casal ends the poem by turning against the mass of Cubans who did not defend the students in their hour of adversity. Unlike Martí, for example, Casal does not evoke the students as symbols of Cuba's need to throw off the Spanish yoke and build a new, dynamic, free society. Rather, he uses them to call attention to a negative feature of the collective Cuban personality. As Casal saw it, the Cuban inclination to avoid direct involvement in the plight of the innocent affected people in every sphere of life. In other words, "A los estudiantes" was not basically an expression of patriotic sentiment. Like "A un héroe," it was a criticism of Cuban values; and, like 
"La perla," it was a personal identification with the pure in heart who were destined to be life's victims.

\section{H44: Notes to Introductory Statement}

1 Ed. del Cent., "Poesías," p. 246; italics are mine.

2 Obras completas (Havana, 1916), vol. II, pp. 38-39; Ed. del Cent., "Poesías," p. 309. Italics are mine.

3 General Sabas Marín y González (1828-1901) arrived in Cuba in 1885. He occupied the position of Captain General of the island from 15 July 1887 to 13 March 1889.

4 Ed. del Cent., vol. III, p. 87.

\section{H45: ADIOS AL BRASIL DEL EMPERADOR DON PEDRO II}

Shortly after Cuba received news that Manoel Deodoro da Fonseca had proclaimed Brazil a republic and that the imperial family had been sent into exile, Julián del Casal and Manuel Serafín Pichardo wrote their personal reactions to these events in poetic form. Casal entitled his composition "Adiós al Brasil del Emperador don Pedro II" and Pichardo called his "Despedida del Brasil a don Pedro II." The authors read their poems at a velada, where they gave friends and colleagues a chance to offer helpful criticism. Then, on 8 December 1889, they published the poems side by side in the periodicals with which they were most closely associated at the time, La Habana Elegante and El Fígaro. Before republishing "Adiós al Brasil ..." in Hojas a few months later, Casal made a number of changes in the text of his composition. These are listed in the record of variants, below. Unfortunately, there is no way of determining which of the periodical versions was the more faithful to Casal's original manuscript.

Manuel Serafín Pichardo y Peralta (b. Santa Clara, Cuba, 12 October 1863; d. Madrid, 1937), who joined Casal in writing the poetic tribute to Dom Pedro, is best remembered for his activities in the field of journalism. According to Casal, these started early in Pichardo's life: "Desde que estaba en el colegio, donde se le penitenciaba, en algunas ocasiones, por sus felices ocurrencias, escribía un periodiquito, con el título de La Luz de la Infancia, que leían ávidamente sus compañeros. Allí se publicaron los primeros versos de Pichardo, inspirados en la injusticia de sus profesores. Más tarde fundó, en unión de otros compañeros, Las Brisas del Capiro y El Destello; hasta llegó a escribir en los primeros diarios de su ciudad natal." Having moved to Havana from Santa Clara at the age of eighteen, Pichardo found a patron in the celebrated journalist and poet Mariano Ramiro (see H28), who, with paternal affection, gave him advice and inspiration. After working for a short time as a civil servant, Pichardo 


\section{PLATE 6}

\section{Pedro II of Brazil}

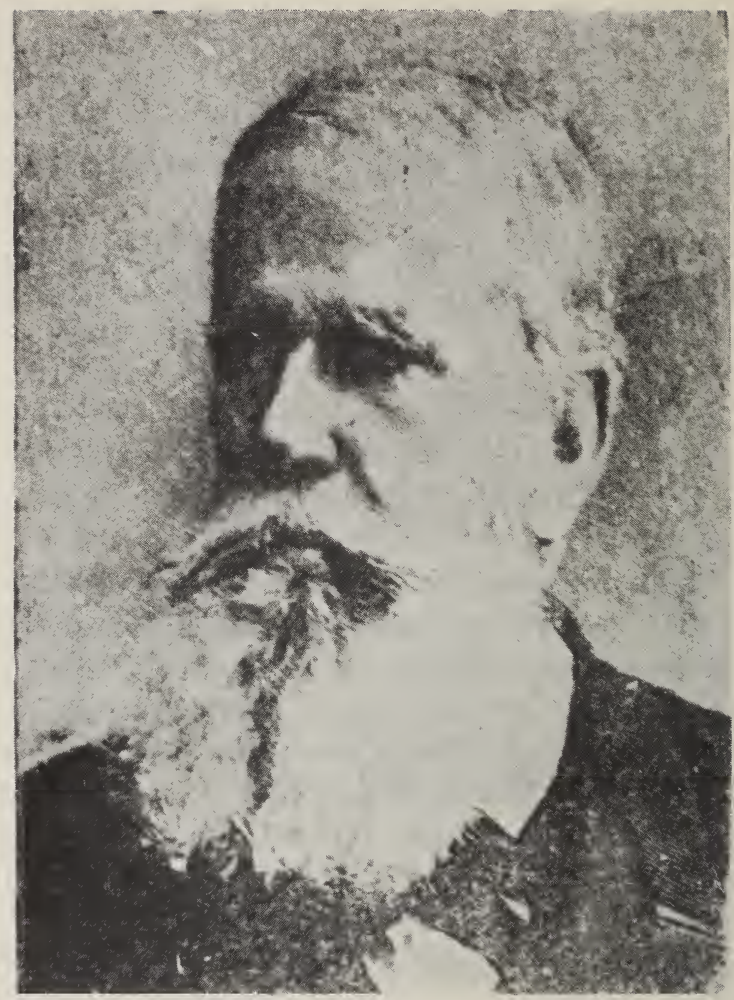

decided to devote himself entirely to his literary pursuits, and in 1885 , encouraged by Ramiro, he united with several friends to found the weekly journal El Figaro. Casal was one of those whose work Pichardo sought for publication. In 1886, for example, he brought out the original periodical versions of four of Casal's poems: "Lazos de muerte" (H12), "Las palomas" (H19), "El adiós del polaco" (H17), and "El eco" (H9). In addition, he invited Casal to write Chapter X of the communal novel Solos; this chapter, entitled "El viaje a Venecia," appeared in El Fígaro on 2 September 1886. Several weeks later, Pichardo himself wrote the fifteenth chapter, "El supremo recurso."

Among the favorite meeting places of Pichardo and Casal was the bookstore known as La Galería Literaria. According to Federico Villoch, "El Fígaro, el popular semanario de Pichardo, ponía en su portada, que la redacción y administración de dicho periódico se hallaban allí en la citada librería; pero era un decir: la administración la llevaba siempre consigo, en una cartera, de la que nunca se separaba, un señor tan menudito como 
activo, siempre sonriente, que se llamaba Fernando Díaz; y la redacción, compuesta de Pichardo, Catalá y sus amigos, se reunía allí todos los días, de 2 a 5 de la tarde, para hablar de literatura; leerse mutuamente sus versos y sus prosas, algunos de los que aparecerían en el citado periódico la próxima semana; y enterarse de las grandes obras que acababan de llegar de Madrid, París, etc."2

Casal, who was impressed from the outset by Pichardo's grace, elegance, and finesse, soon found himself magnetized more than anything else by the excellence of the young man's character: "La simpatía-esa red de hilos de oro, engarzados en perlas, que nos tienden invisiblemente las grandes almas-, hace que solicitemos su trato, ya para demostrarle nuestro afecto, ya para captarnos su estimación. Después de conocerlo, buscamos incesantemente su compañía, seguros de encontrar a su lado el más correcto buen humor y la más encantadora discreción. Pasado algún tiempo, llega a convertirse, por sus prendas morales, en amigo inseparable, no sólo de nuestros breves instantes de alegría, sino de nuestras largas horas de sombrío pesimismo. Ninguno pudiera ostentar, con más razón que Pichardo, la siguiente divisa: Mi mal es agradar."3 In addition, Casal admired Pichardo for his talents as a writer. To his mind, Pichardo, a tireless worker whose rate of production went unaffected by serious internal conflict, was the most outstanding Cuban poet of his generation. ${ }^{4}$ Judging from "Despedida del Brasil a don Pedro II," however, it seems fair to say that Casal's admiration for Pichardo's human qualities led him to be overly generous in his estimate of Pichardo's worth as a poet (see Plate 7).

As far as "Adiós al Brasil ..." is concerned, Manuel Márquez Sterling indicates that Casal made a copy of the poem available to the deposed Emperor and that Dom Pedro in turn sent Casal a letter of thanks:

- Temo enseñar a vd. estas cosas-murmuró [Casal] escondiendo entre las manos un papel.-Vd. es muy hablador, y en su primer artículo hablará de mis reliquias. Sepa vd. que estos papeles no los ha visto nadie.......

Le prometí guardar aquel secreto, y entonces me dio el papel que ocultaba entre las manos. Era una carta de D. Pedro del Brasil, en la que le daba las gracias al poeta, por haber interpretado con tanta exactitud los sentimientos del emperador desterrado, en su bella composición Adiós .......

Despite persistent searching in Brazilian and Portuguese archives, I have not been able to find the letter that Casal sent to the Emperor; likewise, scholars in Cuba have not discovered the reply which Casal received from Dom Pedro, one of the most admired rulers of the nineteenth century.

Pedro de Alcântara, the son of Emperor Pedro I and Empress Maria Leopoldina of Brazil, was born on 2 December 1825. One year later, his 
mother died, and four and half years after that tragic event, his father abdicated and left Brazil forever. Thereupon, a regency was established to direct the empire until Pedro de Alcântara would turn eighteen, the age of maturity set by Brazilian law. On 23 July 1840, however, as a result of widespread discontent with the regency, Dom Pedro, who was merely fourteen and half years of age, was declared old enough to ascend the throne. His coronation took place on 18 July 1841.

Emperor Pedro II was a constitutional monarch in an underdeveloped tropical land. This imposed serious limitations on his ability to direct affairs of state as he saw fit. Nevertheless, throughout his reign, he strived to create conditions that would insure the material, intellectual, and spiritual well-being of his subjects. Despite his tireless efforts on behalf of his people, however, in the latter years of his enlightened rule circumstances conspired against him and ultimately led to his deposition. The immediate cause of Pedro's downfall was a military revolt. Discontent had been brewing in the armed forces for a considerable time, and vigorous republican factions in the country fanned the flames of disaffection wherever possible. Finally, General Manoel Deodoro da Fonseca, who at first did not seem to desire the overthrow of the empire, cast his lot in with the anti-imperial factions and, on 15 November 1889, declared Brazil a republic. On the following day, Pedro yielded to the force of circumstance and abdicated. In the early hours of 17 November, the imperial family was taken from the palace to a cruiser in Guanabara Bay. Later, all were transferred to the packet "Alagôas."

On 22 November, the "Alagôas" left Brazilian waters and headed for Portugal. The ship reached Lisbon on 7 December 1889, in other words, one day before the poems of Casal and Pichardo were published in Havana. Empress Thereza Christina died before the month was over, and Dom Pedro succumbed in Paris on 5 December 1891. Shortly thereafter, his remains were transferred to the Church of São Vicente da Fora, where his beloved wife was buried. In September 1920, the Brazilian government voted to have the bodies of the deposed monarchs returned to Brazil. This was done in December of the same year.

Mary Wilhelmine Williams offers the following appraisal of the life and works of Dom Pedro: "Although, mentally, Dom Pedro was well above the average, he had no marks of intellectual genius. Yet he was one of the most notable people of his century. While not original or creative in his work as Emperor, he did his utmost to bring to his people the best results of human thinking throughout the world; and, in view of the national and constitutional handicaps against which he struggled, he should rank among the wisest and best rulers of the period. As a personality he was, however, more original than as a sovereign.... He was greater for what he was than for what he did. His modesty, simplicity, and democracy; tenacity of high purposes; devotion to duty as he saw it; unwearied enthusiasm 
for learning; subordination of material values to intellectual and spiritual ones; his integrity, magnanimity, understanding pity, and Christlike kindness made him one of the finest personalities of modern times. Because of this rare combination of individual qualities he was, in truth, a credit and an honor to humanity." 6

\section{H45: Notes to Introductory Statement}

1 "La joven Cuba. Galería Mignon: Manuel Serafín Pichardo" (HE, 6 May 1888), Ed. del Cent., vol. I, pp. 193-194.

2 Ed. del Cent., "Poesías," pp. 302-303.

3 "La joven Cuba ...," Ed. del Cent., vol. I, p. 193.

4 "Crónica semanal" ( $P$, 23 November 1890), Ed. del Cent., vol. III, p. 36.

5 Manuel Márquez Sterling, "Julián del Casal," Revista Azul, vol. II, no. 21 (24 March 1895), p. 329.

6 Dom Pedro the Magnanimous, Second Emperor of Brazil (New York: Octagon Books, 1966), p. 382.

H45: VARIANTS

l. $H E$

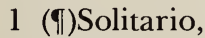

5 (ף)-País

* 6 consigna

* 7 desterrado,

9 mís [sic]

18 gloria

29 recuerde

34 marcharme

38 abierto

43 mundo,

45 amado,

48 . i[n]o

manchó

alguna!

49 (ף)Costas amadas de la vieja Europa

* 51 [m]ientras apuro del dolor la copa

* 58 proscrito:

59 i[e]ngrandecerte

60 i[a]marte

fatal

delito!
F

(ף)Solitario

(ף)-“País

mis

recuerdo [sic]

abierto,

delito!"
H

GLIC

$H E$

(ף)País

consigna,

desterrado

$H E$

$H E$

nombre

$H E$

alejarme

$H E$

mundo

amado

[n]o

empañó

alguna.

(ף)Hospitalarias costas europeas,

[c]ual las del Asia al

fugitivo Eneas, proscrito. [sic]

$H E$

iEngrandecerte

$H E$

iAmarte

$H E$ único

HE 


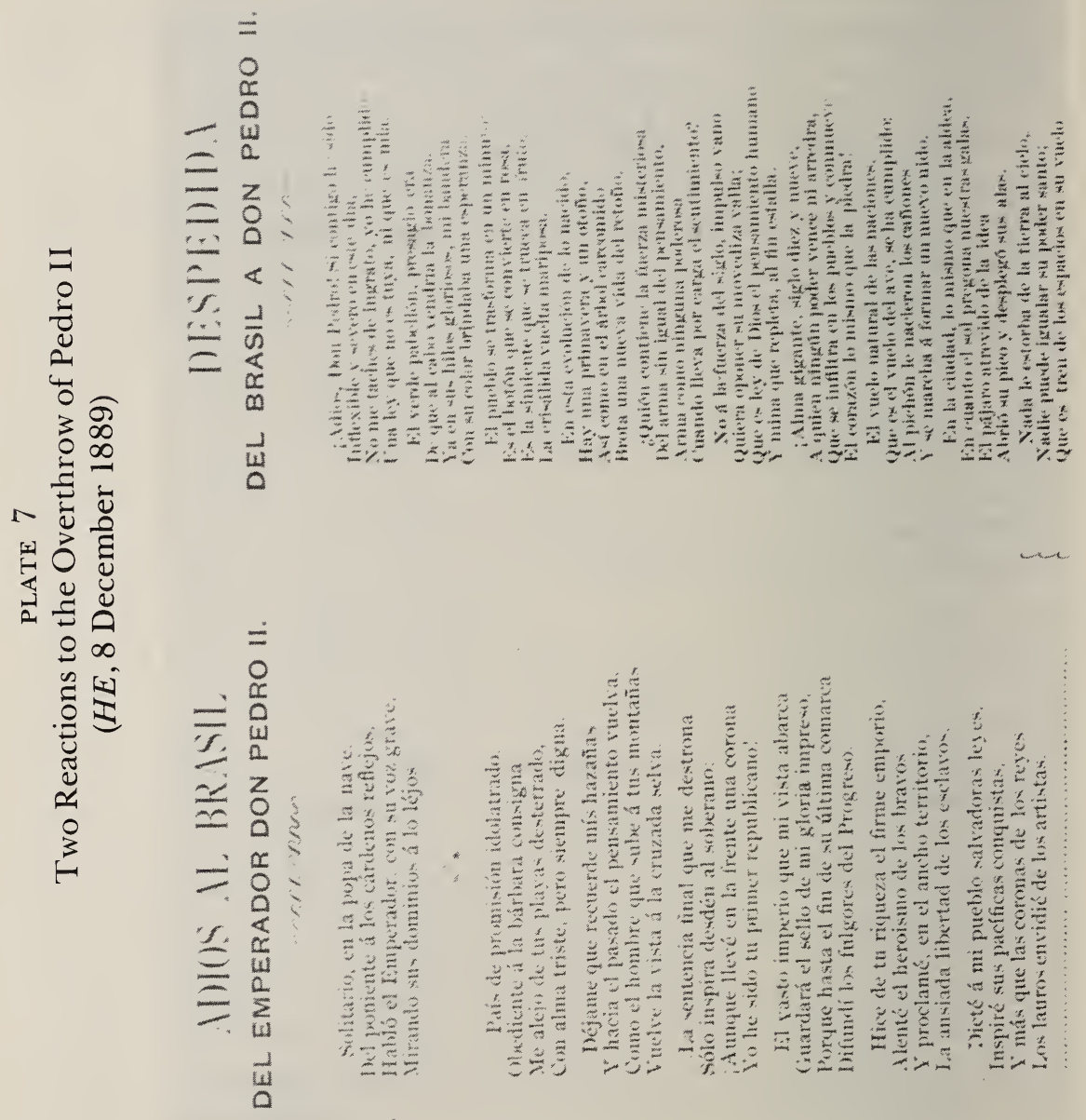




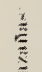

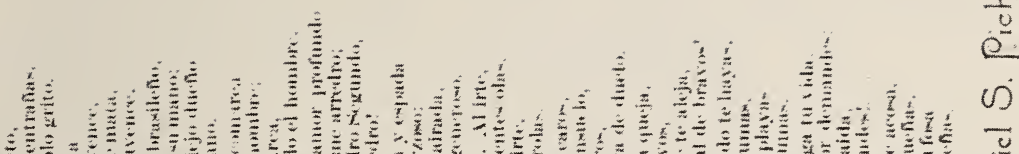

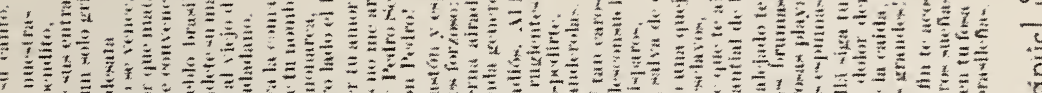

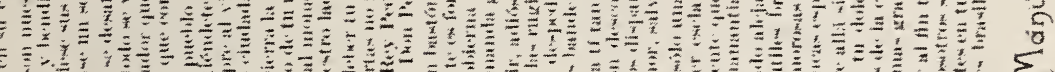
(1)

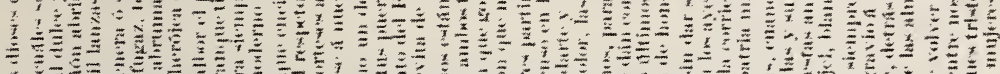

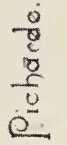

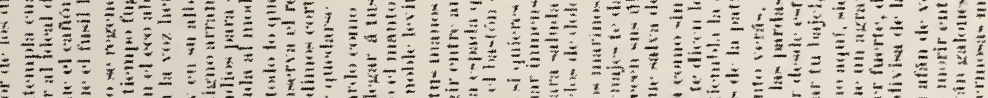

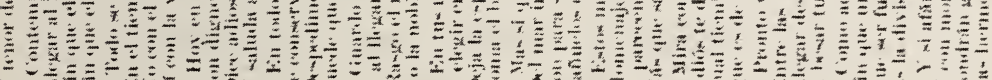

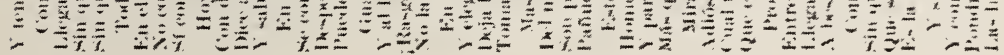

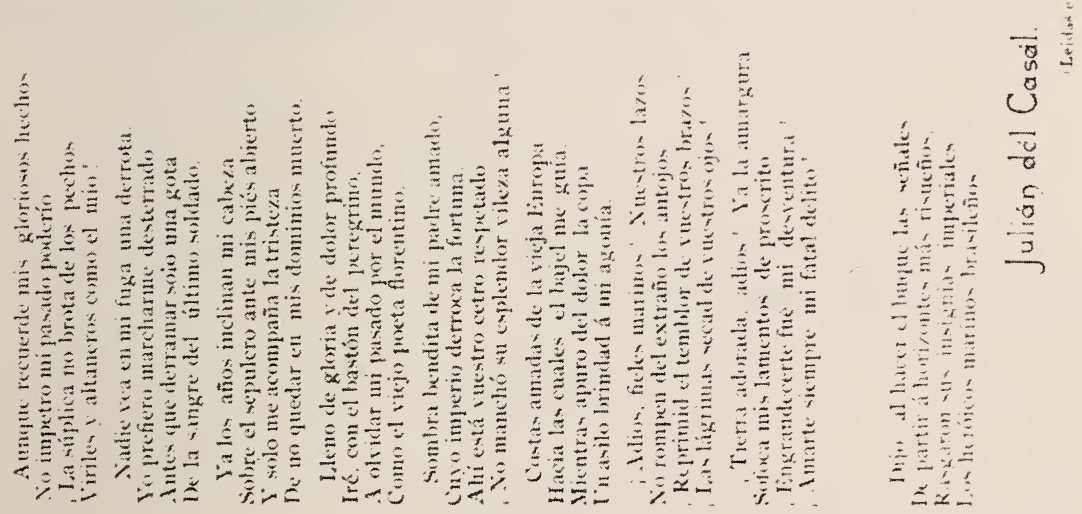


6: My feeling is that Casal's insertion of a comma in the $H$ version was ill-advised. Without the comma, the adjective phrase "obediente a la bárbara consigna" is clearly related to yo, the subject of "me alejo" (l. 7), and cannot be mistakenly associated with the noun pais which introduces the vocative phrase at the beginning of the stanza. For this reason, the $H E$ and $F$ versions are followed in the present edition.

7: The $H$ version of this line also seems inferior to the orginal versions, for, by removing the comma after desterrado, Casal substantially weakened the dramatic effect of 1. 8. The punctuation of $H E$ and $F$ is therefore restored.

51: Casal committed a factual error when he revised this line, for Vergil's epic gives no evidence that Aeneas found hospitality anywhere in Asia after his flight from Troy. It would have been more accurate if Casal had said: "Hospitalarias costas europeas, / . . / cual las de Italia al fugitivo Eneas, / un asilo brindad a mi agonía."

58: It is felt that the punctuation of this verse should be studied in conjunction with that of 1.54 . The colon of 1.54 has the value of por lo tanto: that is, it serves as a link between the statement which Dom Pedro makes in 11.53-54 and those which he enunciates in 11. 55-56. When one compares 11. 53-56 with 11. 57-60, the period in 1.58 of $H$ appears to be a typographical error, for the thought content of both stanzas is organized in basically the same way. In each case, the two concluding lines of the stanza are a direct outgrowth of the idea expressed in the two initial verses. The colon which appeared in 1. 58 of $\mathrm{HE}$ and $F$ is therefore restored in this edition.

\section{H46: POST UMBRA}

As far as is known, this composition was not published in Cuban periodicals before it came out in Hojas.

\section{H46: VARIANTS}

l. $H$

* 21 alguno, pecadora!

39 estó[sic]
GLIC

alguno

pecadora!, esté

\section{H46: Note to Variants}

21: In contrast to modern practice (but in accord with the custom of most of his contemporaries), Casal tended not to support exclamation points with additional punctuation. Thus, in $\mathrm{R} 21 / 60$, instead of writing 
he wrote

¿Por qué has hecho, ioh Dios mío!, mi alma tan triste?

¿Por qué has hecho ioh Dios mío! mi alma tan triste?

As far as H46/21 is concerned, the comma after alguno should not be interpreted as an introduction to ioh bella pecadora!, but rather as an introduction to the parenthetical mirando tus encantos, which occurs in 1. 22. If this is the case, however, the comma should not be inserted after alguno, but should be placed after pecadora! In other words, the exclamation points should be likened to dashes or parentheses, and the comma, instead of preceding the statement which those marks enclose, should follow it.

\section{H47: LA CANCION DE LA MORFINA}

This poem was first published in the 20 April 1890 issue of La Habana Elegante. It was printed in standard type on the front page of the journal. The initial line in each stanza was left-justified. The Hojas version of "La canción de la morfina" differed from the original in the following respects: the first line of each stanza was indented; the typographical errors in 11. 25, 30, and 54 were corrected; lexical changes were made in 11.48 and 69; and the punctuation was altered in twelve of the seventy-two lines. As a result of the punctuation changes, the rhythm of the Hojas version was noticeably different from that of its predecessor.

According to Margaret Robinson Berger, "La canción de la morfina" is an example of Casal's debt to Baudelaire: "As in the poem 'Ame du vin' the wine itself speaks the whole poem, so La Morfina tells us her virtues and invites us to partake. And if the form was suggested by the 'Ame du vin' the ideas, the very words, are the result of Casal's reading the essay on 'Le Haschisch' from Baudelaire's Paradis Artificiels."' Although some comparatists may feel - and not without justification - that Berger's statement of the case is a bit too strong, there is no doubt that Casal was familiar with Baudelaire's works or that he read them in the original French. Between 27 March 1887 and 16 June 1890, Casal published fifteen compositions based on Baudelaire's Petits Poèmes en prose. ${ }^{2}$ In the "Crónica semanal" which he wrote for the 14 December 1890 issue of El Pais, he described a party given by Sra. Concepción Castrillo de Polavieja shortly before her departure for Europe and quoted six lines from Baudelaire's sonnet "A Une Dame créole":

Si vous alliez, Madame, au vrai pays de gloire, Sur les bords de la Seine ou de la verte Loire, Belle digne d'orner les antiques manoirs, 
Vous feriez, à l'abri des ombreuses retraites,

Germer mille sonnets dans le cœur des poètes,

Que vos grands yeux rendraient plus soumis que vos noirs. ${ }^{3}$

In a letter written to Gustave Moreau on 15 August 1891, Casal called Baudelaire "mi maestro en poesía" and quoted four verses from the sonnet "La Beauté":

Je trône dans l'azur comme un sphinx incompris;

J'unis un cœur de neige à la blancheur des cygnes;

Je hais le mouvement qui déplace les lignes;

Et jamais je ne pleure et jamais je ne ris. ${ }^{4}$

In "Horridum somnium," the last poem in Nieve, he spoke of "las frías / hermosuras de estériles senos / que, cualflores del mal, han caído / de la vida al obscuro sendero" (N54/27-30; the italics are Casal's). In Bustos, he referred to Baudelaire as "el más grande poeta de nuestros tiempos," and quoted the last two stanzas from "Le Voyage," the closing poem of Les Fleurs du mal:

O Mort, vieux capitaine, il est temps! levons l'ancre!

Ce pays nous ennuie, ô Mort! Appareillons!

Si le ciel et la mer sont noirs comme de l'encre,

Nos cœurs que tu connais sont remplis de rayons!

Verse-nous ton poison pour qu'il nous réconforte!

Nous voulons, tant ce feu nous brûle le cerveau,

Plonger au fond du gouffre, Enfer ou Ciel, qu'importe?

$\mathrm{Au}$ fond de l'Inconnu pour trouver du nouveau ${ }^{5}$

And finally, Casal used a stanza from the poem "Bénédiction" as his epigraph to Rimas (see Rp0). All the items just mentioned are outstanding examples that attest to Casal's familiarity with the works of Baudelaire. However, one also finds a considerable number of brief references to Baudelaire and short quotations from his works scattered throughout Casal's prose. If collected and analyzed, these items would help us to determine the exact nature of Casal's interest in the French writer and to assess the true extent of his knowledge of his works.

\section{H47: Notes to Introductory Statement}

1 Margaret Robinson Berger, "The Influence of Baudelaire on the Poetry of Julián del Casal," The Romanic Review, vol. XXXVII, no. 2 (April 1946), p. 181.

2 These works are listed below in chronological order. The following symbols are used to provide additional information about the cited compositions: 
+ (A revised version was published on the second date indicated.)

$\mathrm{N}$ (Cited in the Ed. del Cent., vol. III, p. 199, but not reproduced in that collection. It will be found in Marshall E. Nunn, ed., Selected Prose of Julián del Casal, pp. 133-134.)

? (A discrepancy exists in the date of publication cited in the Ed. del Cent.: compare vol. III, pp. 100 and 199.)

* (Casal's subtitle clearly indicated that the work was an imitation of Baudelaire.)

+ "El extranjero"

+ "Los beneficios de la luna"

+ "El puerto"

+ "A una hora de la madrugada"

$\mathrm{N}$ "La torta"

? "La moral del juguete"

"La desesperación de la vieja"

"El confiteor del artista"

"El perro y el frasco"

"Un hemisferio en una cabellera"

"El loco y la Venus"

* "Las quimeras"

* “¿Cuál es la verdadera?"

* "La invitación al viaje"

* "La cámara doble"
HE: 27 Mar 87
D: 2 May 90
HE: 27 Mar 87
D: 29 Apr 90
HE: 27 Mar 87
D: 8 May 90
HE: 3 Apr 87
D: 2 May 90
HE: 24 Apr 87
$H E:\left\{\begin{array}{l}16 \text { Oct } 87 \\ 20 \text { Nov } 87\end{array}\right.$

3 Corrections to the text which is cited in the Ed. del Cent. (vol. III, pp. 53-54) have been based on the Antoine Adam edition of Les Fleurs du mal (Paris: Éditions Garnier Frères, 1961), pp. 68-69.

4 C2/73-79. It should be noted that Casal used a semicolon in place of the comma that is found after lignes in most editions of the poem.

5 "El doctor Francisco Zayas," Bustos y rimas (Havana: Imprenta La Moderna, 1893), p. 41. Corrections to Casal's version of these lines have been based on the Adam edition of Les Fleurs du mal.

\section{H47: VARIANTS}

l. $H E$

* 1 quimera,

* 18 perdido

* 20 luego;

21 [g]uardo,

25 ảureas [sic]

27 cuerpo,

28 espíritu,
H

quimera

perdido,

luego.

(ף)Guardo,

aureas

cuerpo

espíritu
GLIC

HE

$H E$

(ף) $+H E$

áureas 
l. $H E$

29 dormido,

30 mảgico [sic]

35 oceáno;

* 39 oro

48 guirnaldas

54 abandonarả: [sic]

55 ¿̇ [q]ué

57 abarca

58 olvidado

62 arcano,

69 brindo

70 suerte
H

GLIC

dormido

mágico

oceáno,

oro, oceano $+H$ HE

coronas

abandonará.

¿Qué

abarca,

olvidado,

$H E$

arcano

ofrezco

suerte,

\section{H47: Notes to Variants}

1: Although the logic of the sentence suggests that a comma be used after quimera, Casal sometimes preferred an end-of-verse blank as a substitute for the comma in constructions such as this (see $\mathrm{H} 1 / 1$, for example).

18: It is felt that the comma at the end of this line in $H$ causes an unnecessary break in the unity of the utterance. For this reason, the $H E$ version is restored.

20: The semicolon found at the end of this line in the $H E$ version seems more appropriate than the period found in $H$, since it does not sever the preceding descriptive stanzas (II-V) from the main clause that appears in stanza VI.

39: Here, as in l. 18, the end-of-verse blank is considered to be sufficient punctuation. Insertion of a comma, on the other hand, tends to break the structural and rhythmic unity of the statement. Therefore, the $H E$ version is followed in the present edition.

\section{H48: LA PERLA}

This short composition was first published in the 27 April 1890 issue of La Habana Elegante. It was printed in italics on the front page of the journal. All lines in the poem were left-justified. In the Hojas version, which was probably typeset very shortly after the periodical version came out, the initial verse in each quatrain was indented.

In his article "Julián del Casal, patriota," Enrique Hernández Miyares gives the following background information about the poem:

Un día se hablaba mucho en la prensa de anexión norteamericana, y salió a la plaza al mismo tiempo, no recuerdo con qué motivo, la sombría cuestión de razas. Más que la política, que ya se ha hecho soportable como se soporta un reuma crónico, agitaba la opinión la cuestión magna en la colonia, la económica, la que hace que el azúcar amargue, que 
no se venda por el bajo precio. Entonces es cuando sube la ola patriótica, arde la palabra en la tribuna, muerde en el periódico y palpita en el telégrafo. Y entonces se desborda el apacible riachuelo de la comunidad y salen a la superficie los problemas complicados y asoman las banderías.

Casal escribió a la sazón una balada que tituló La Perla. ${ }^{1}$

Hernández Miyares cites "La perla" as an example of Casal's patriotism. Although Casal may have written the poem at a time when the question of Cuba's position vis-à-vis Spain and the United States was being vigorously debated, patriotic sentiment was only an incidental source of inspiration for "La perla." Of much greater importance were the poet's concern about his own place in the world and his tendency to feel kinship with everyone and everything that, in his opinion, occupied a like position. Casal represents Cuba as "una perla / que el mundo ostenta en su seno..." (ll. 1-2). Depiction of the island as a bright, precious object (perla) on a negative background (mundo) is a variation on a basic pattern that is quite common in Casal's prose and poetry. Essentially, this is the way he saw himself. His portrayal of Cuba as a target of attack by two birds of prey is also intimately bound with his self-image. The picture of himself as a potential victim of merciless predators - a common Hispanic image of the individual and society - seems to have been transmitted to him mainly by his father. In "Nocturno" (H8), for example, he quotes Don Julián as follows:

"Huye del mundo y de su pompa vana cual huye del milano la avecilla, y alcanzarás, al perecer mañana, muerte feliz tras vida sin mancilla."

When these points are taken into consideration, it seems obvious that Casal was doing much more in "La perla" than expressing patriotism. Through the concrete example of Cuba, he was presenting the essence of his world-view. Specifically, he was saying that every minute incarnation of innocence and value exists in an environment of evil and is subject to attacks against its integrity. His implication was that such precious beings should be protected from the hostile forces that threaten them with destruction. This would apply to Cuba, to the martyred medical students (H44), to the brotherhood of Modernist writers that was forming throughout Spanish America, ${ }^{2}$ and, not least of all, to himself.

\section{H48: Notes to Introductory Statement}

1 Hernández Miyares, Obras completas, vol. II, p. 36; Ed. del Cent., "Poesías," p. 308 . 
2 See, in particular, his article "Rubén Darío” (HL, 15 November 1891), Ed. del Cent., vol. I, pp. 169-173.

\section{H48: VARIANTS}

l. $H E$

$1 \mathrm{Al}$ rededor

* 6 destellos:
$H$

(ף)Alrededor

destellos; [sic]

GLIC

$H E$

\section{H48: Note to Variants}

6: In 11.6 and 14, the $H E$ version uses a colon to introduce the statements which follow. The semicolon in 1.6 of the $H$ version is considered to be a typographical error, and the $H E$ punctuation is restored. In this way, the parallelism in thought and structure is maintained in stanzas II and IV.

\section{H49: VERSOS AZULES}

"Versos azules" was originally published on 16 March 1890 by La Habana Elegante. The poem was printed in italics on the first page of the journal. Its subtitle was "(En el álbum de Miss Ina Lasson)." A centered rule was used to separate each stanza from the one that followed. The $E d$. del Cent. (vol. III, p. 205) indicates that "Versos azules" also appeared in $L a$ Lucha on 21 March 1890. Since it was impossible to procure a copy of that version, however, no reference is made to it in the record of variants, below. In Hojas, Casal made a few minor changes: he shortened the subtitle to "(A Ina Lasson)," suppressed the centered rules, and made a lexical transposition in 1. 19.

Casal composed the poem shortly after attending two concerts that were given in the Gran Teatro de Tacón at the beginning of March, 1890. Writing under the pseudonym Hernani, he expressed his impressions of the events in articles entitled "La señorita Ina Lasson y las hermanas Joran" (D, 4 March 1890) and "En Tacón" (D, 6 March 1890). As indicated in Plate 8, Ina Lasson was a singer. ${ }^{1}$ Anyone who might have liked to read a commentary on Miss Lasson's talents as a vocalist, however, would have been sadly disillusioned by Casal's first report, for, enchanted by her angelic beauty, he neglected to include a detailed critique of her performance:

Ostenta la hermosura inmaculada de las vírgenes del Norte y la gracia encantadora de una parisiense de nuestros días. Viéndola surgir, con su cuerpo elegantísimo, hecho de gracia, donosura y esbeltez; con sus ojos verdes, enigmáticos y puros, como los lagos en que sólo viven los cisnes; con sus cabellos 
PLATE 8

A Concert by Ina Lasson and the Joran Sisters

(Program as Advertised in the 4 March 1890

Issue of La Gaceta de la Habana)

\section{ESTECTACUTOS.}

\section{FUNCIONES PARA IIOY.}

\section{$=\div=$}

\section{GRAN TEATRO DE TACON,}

\section{Empresa J. Palou y Compañia.}

Segunda furción de las oflebres Sritay. Toran.

Primora purte....10 Duo is dos pianos....Ronde O. P. 73....Sritas. Eliea y Clarita.

Lason.

2\%...Aria L'vissau Charmant... David...Señorita. Iua Paulina.

:R....Solo de viclín..Fantasía Fausto...Sarasate...Srta.

Segunda parte...1\& Solo de piano,...(a) Impromtu... Chopín... [b] Rapsodio No 10... Lizzt... Srita.'Lula.

$2 \%$ solo de violín...Dauzas espanolas...Sarasate... Srita. Paulina.

3o... Canto dún... La danza guachinanga: El currucu. cú... Siritas. Paulina o Ina.

Tercara parte...10 Dúo á doy pinuos La druza Macabra...Sain t Siacus...Sritís. Cula y Paulina.

2Q...Vals de concierto i P:arlá .... Arditi...Srita. Ina.

3o...All the Sprina...(a) Josolfy .. [b] Ld Campanclia ...Lis:...Srita Elisu.

4Q...Violf́n (a) cavatina, Roff...(b) Variacionca sobre Mniecs de Paganin... Brillante cjecución on el violín con solo una cucrda, por la Srita. Paulina.

Iimnción corrida, cmpezando a las ocho.

blondos, alborotados en la nuca fragante y sonrosada; y con su corpiño abierto, en forma de corazón, dejando ver el principio del seno, firme, redondo y alabastrino; se cree uno hallar en presencia de una heroína de Poe, el poeta que ha creado los tipos más ideales de mujer. Dotada de encantadora modestia, se hace admirar de todos. Tiene la pureza de un verso de Goethe, su poeta favorito. Hay algo en ella de puritano y angélico que impone respeto y admiración. Dentro de algunos 
años, porque es muy joven todavía, si continúa cultivando sus prodigiosas facultades, está llamada a brillar, no en la escena de un teatro público, sino en los salones de un monarca artista, donde recibirá los homenajes de una corte grandiosa, como la de Weimar, compuesta de hombres eminentes y mujeres nada vulgares. $^{2}$

In his second article, Casal again showed that he was interested in Miss Lasson more as a woman than as an artist:

De pie, en primer término, detrás de las ardientes candilejas se presenta vestida de blanco como Beatriz, sintiendo el temor del cervatillo ante los ojos de cien mil cazadores. Nadie se atreve entonces a respirar. Inclinada la rubia cabeza ante el público, esparce en la sala una nube de armonías, donde flotan un enjambre de sueños azules y de visiones más bellas que las de hastchit [sic]. Es una mujer como Juana de Arco, que parece tallada para las grandes empresas. No hay blancura comparable a la de su rostro, pudiendo decir de ella, como un poeta español de la Marquesa de Dos Hermanas, que

\section{"Es tan blanca y tan bella que parece que a través de su ser pasa la luna"3}

With these comments in mind and in view of his natural inclination towards form and color, rather than towards sound - an inclination that is evidenced most dramatically by the many bustos in prose and in verse which he composed during his lifetime - it is not surprising to find that, in "Versos azules," Casal concentrated on the subject of Miss Lasson's feminine charms and made only slight reference to her virtues as a singer.

\section{H49: Notes to Introductory Statement}

1 These performers were brought to Havana as part of an effort by J. Palou and his partners to improve the quality of the Tacón's offerings and thus elicit greater public support for the Theater. Casal discusses the formation of the Empresa J. Palou y Compañía and its plans for the future in "Teatros: La nueva empresa" (D, 12 February 1890); see Ed. del Cent., vol. II, p. 49.

2 Ed. del Cent., vol. II, p. 66.

3 Ibid., pp. 67-68; italics are Casal's.

H49: VARIANTS
l. $H E$
8 [s]í
19 verde mar bajo las

H

[s]i [sic]

mar bajo las verdes 


\section{Nieve}

Whatever satisfaction Casal may have derived as a result of publishing Hojas al viento was not sufficient to counterbalance the despair which gradually took possession of him in the months that followed the book's appearance. In addition to persistent spiritual conflicts, unremitting economic pressures, and increasingly evident problems with his health, one of the major sources of his despondency was his position as a current events reporter on La Discusión, for the duties he was obliged to fulfill exposed him to many aspects of life that clashed with his temperament, philosophy, and behavioral preferences. Termination of his job during the last week of July 1890 , therefore, brought some much needed relief to his tormented soul.

By summer's end, Casal's financial position took a critical turn and demanded immediate attention. Fortunately, Ricardo del Monte, the gentleman to whom he had dedicated Hojas, found it possible to keep the promise he had made earlier that year and, in September, hired Casal to write for El País. Besides improving Casal's economic situation, the job on ElPaís had the salutary effect of bringing him closer to the much-admired del Monte. Though their basic responsibilities differed, the two men shared many of the same journalistic stimuli and concerns. By the very nature of their profession, they also came into contact with many of the same political, social, and literary figures. ${ }^{1}$ And, as neighbors who occupied apartments in the same building, they had numerous opportunities to exchange views on subjects of mutual interest. ${ }^{2}$ Despite the frequency of their meetings, however, Casal always treated Don Ricardo with a respect bordering on reverence. And, as Don Ricardo shows in his commemorative article "Mi deuda" (see Appendix A), the fact that Casal "me llamaba maestro cuando diariamente estrechaba mis manos con ternura filial" seems to have left a deeper impression on him than did the public tributes he received from Casal in Hojas and in Bustos.

Although Casal's association with Don Ricardo was an enriching experience in many ways, his job on El País proved, in the long run, to be as counterproductive as the one he had held on LaDiscusion. The manner in which Casal approached his assignment to the "Crónica Semanal" is 
symbolized by the pen name he selected: Alceste. This pseudonym, which was taken from Molière's Le Misanthrope, accurately reflected Casal's outlook at the time he assumed his duties on the newspaper. As the weeks passed, however, the readers of his column began to see that they had underestimated the seriousness with which Casal had chosen his pseudonym and, what is worse, that the real objects of his contempt were their interests, their values, and their way of life. Soon, complaints about Casal began to reach El País from some of its more sensitive subscribers. This criticism apparently did not undermine del Monte's support for his embittered columnist, but it did have its effects on Casal. He knew that most people-with no lack of reason-considered him to be an eccentric, but he also felt that many truly despised him. By February 1891, a period of great physical and emotional distress, he decided that it would be best for everyone if he withdrew from the limelight and moved into the shadows he preferred. The following month, he gave up his job on El Pais and turned with ever greater fervor to his artistic endeavors.

As far as his literary pursuits are concerned, we find that in the fall of 1890-in other words, shortly before he joined the staff of El Pais-Casal began publishing the poems that would ultimately form Nieve. By 26 October, it was evident that, unlike Hojas, his new book would be divided into distinct sections and that one of these would be called "Marfiles viejos" (see my discussion of $\mathrm{Np} 4$ ). Partly because of his journalistic obligations, partly because of personal problems, and partly because of the time he needed to realize other projects that had captured his imagination, work on his poems moved along slowly during the fall and winter. Nevertheless, by March 1891, Casal had written about one half of his book of verse and one half of a book of short stories. Though he had not published all of these compositions, he had them in his portfolio and planned to bring them out as soon as he had refined them to his satisfaction. Furthermore, he intended to write a series of "impresiones literarias" and two novels. ${ }^{3}$ That is, he would do all this if he were able to muster enough courage to go on facing the world, for with each passing day, he found it increasingly difficult to cope with life and the burdens that it placed upon him. In fact, he became so depressed after leaving his job with the newspaper, that he began seriously to entertain the idea of suicide; and, had he not been as much of a Hamlet as the protagonist of the novel he described to Esteban Borrero on 19 March 1891, before long he probably would have chosen to end his suffering by this means. ${ }^{4}$

After a while, Casal's situation improved a bit and he began to think of suicide less frequently. His modest financial needs were satisfied by wages derived from a job he had found before he quit El Pais. By his own admission, this job was so inconsequential that "nadie me lo pretende quitar ni nadie se ocupa de mí." 5 Naturally, this helped reduce the emotional pressure that had made his life a nightmare in the winter of 1890 and the spring of 1891 . His tensions were also alleviated by the fact 
that he now had more time available for the things that really mattered to him: he read works by his favorite authors and by newcomers who were arousing the interest of foreign critics; he carried on a rather extensive correspondence with people at home and abroad; he enthusiastically studied reproductions of art works and, on occasion, even tried his hand at design; he spent hours dreaming about an ideal reality whose beauties might in some way make existence bearable; and, when his creative urge became too strong to contain, he settled himself in his rocking chair and, with a handful of candy to sweeten his bitterness, wrote the poems of Nieve. ${ }^{6}$

As of 11 August 1891, Casal's intention was to send Nieve to press the following winter (C1/23-25). ${ }^{7}$ This seemed feasible because he had already published thirty-two poems in local periodicals and was doing his utmost to complete each of the four sections into which he had planned to divide the book. On the dates shown in parentheses, Casal named those sections for the first time: "Marfiles viejos" (26 October 1890), "Poesías diversas" (7 December 1890), "Bocetos antiguos" (17 May 1891), and "Mi museo ideal" (11 August 1891). By mid-February 1892, he had brought out nineteen more compositions and had added a new section, "Tipos españoles." This was clearly the time to bring Nieve to a close. The book, which now consisted of fifty-one poems, was long enough to be representative yet short enough to be published economically. Furthermore, plans for a third volume of poetry were already taking shape in Casal's mind (C6/70-79) and he wished to begin executing those plans at the earliest possible moment. But Casal had still other reasons for wanting to publish Nieve during the winter. For one thing, this was his favorite season. The cold of winter banished all the acrid odors that, for months, had issued from the burning ground; the sun could no longer wound the poet's eyes with its piercing rays; and Nature, shedding the gaudy frock it had worn all summer, donned a mantle of more subtle hues. At sundown, as people turned indoors in search of warmth, a welcome silence took possession of Havana's streets. At this time of year, everything became more attractive to Casal. Why, even the habaneras grew lovelier, for, as he saw it, the heavy fabrics and elegant shades of their winter clothing did much to enhance their native beauty. ${ }^{8}$

Aside from reflecting Casal's preference for winter as a season, the title Nieve had specific symbolic implications. First of all, Casal felt that, despite his youth, he was in the winter of life. In his opinion, chronological age should not be considered the only determinant of a person's spiritual temperature. In order to verify this, one had only to look at the facts: "Hay organizaciones que, a los ochenta años, conservan un calor primaveral, mientras hay otras que, a los veinte, se sienten heladas por los rigores del invierno más crudo, del invierno que no termina jamás." ${ }^{\text {The frigidness }}$ that gripped Casal's soul had numerous causes. Among them was his belief that devotion to literature in Cuba obliged one to wander in solitude 
through a wilderness that was wholly inimical to art. Under the circumstances, he would live in the future as he had in the past: like a bear in a torrid Siberia (C6/44-45). Because his latest collection of poetry reflected these feelings, Nieve was an appropriate name for the book. But Casal had still other reasons for calling his book Nieve. "Se titula Nieve," he told a friend, "porque la nieve, como mi poesía, es pasajera, porque es cosa de invierno y yo me encuentro en el de mi vida y, por último, porque sobre el fondo claro, casi transparente de mis condiciones, lo que me aleja de los decadentes, se descubren los mismos tonos que tienen los témpanos a la luz." 10

As indicated above, Casal had valid reasons for wanting to have Nieve printed in the winter, but, as had happened on so many other occasions, circumstances beyond his control frustrated his wishes. The principal factor that caused him to delay publishing the book was the rapid deterioration of his health. Letters written in February and March 1892 show that, as time passed, the discomfort he had experienced in the spring of 1891 (see my discussion of N36) became more and more severe. Now, the symptoms of the unknown malady from which he was suffering began to cause him real alarm: fevers of unknown origin would suddenly come upon him, intense pain would seize him and prevent him from writing, the left side of his body would become paralyzed, his sight would fail, and, at times, his mind would slip into unconsciousness. As a result, Casal was forced to work ever more slowly on his book and, in light of what remained to be done, he had to move its publication date to April, As usual, he wanted to examine every poem with care and make any changes that might be necessary to improve the quality of the text. He had to evaluate the appropriateness of all the titles, subtitles, and dedications. Furthermore, since he was organizing his material into separate sections, he had to decide on how best to sequence those sections and the poems that each one would contain. Little by little, he accomplished all these tasks and, in spite of everything, managed to meet his April deadline.

We do not know exactly when Nieve came off the press, but certain facts lead us to believe that it was on or about 20 April 1892. In a letter bearing that date, Casal informed Gustave Moreau that he was sending out four copies of his book: the first, for Moreau himself; the second, for Huysmans; the third, for Hérédia; and the fourth, for Verlaine (C9/10-25). The next day, El Pais advised its subscribers that the two sonnets they were about to read had been taken from Nieve, a new book just published by Casal (see my discussion of N23). And on 30 April, the fortnightly journal La Habana Literaria inserted the following item on p. 192:

\section{NIEVE.}

Nuestros lectores se habrán enterado, por la prensa diaria, de la publicación 
que de sus últimas poesías ha hecho el aplaudido é inspirado Julián de Casal, en un bonito volumen titulado "Nieve," que en las principales librerías, y á módico precio, se expende.

En nuestro próximo número esperamos dar una noticia circunstanciada y crítica de esta obra, pues nos la promete uno de nuestros colaboradores, escritor y crítico de nota. Entre tanto nos limitamos á recomendar la adquisición de «Nieve» á los amantes de la buena poesía; y á felicitar al querido amigo Casal por el buen éxito de su libro.

The final product of Casal's endeavors was not a simple compilation of the fifty-one poems that he had published in Havana periodicals between 14 September 1890, the date on which he brought out his first post-Hojas composition, and mid-February 1892, when he felt that it was time to get Nieve ready for press. To begin with, postponement of the book's publication date until April made it possible for him to include "Medallón" (N53) and "En un hospital" (N37), which La Habana Literaria had printed in its issues of 29 February and 30 March 1892, as well as the hitherto unpublished prefatory composition entitled "Introducción" (N1). As a result, instead of consisting of 51 poems - or 52, if we assume that Casal would have added a poetic introduction to the book in any case $^{11}-$ Nieve contained a total of 54 poems.

In addition to lengthening Nieve slightly, Casal changed the relative position of the book's five sections and modified the title of two of those sections:

Order in which sections were mentioned by Casal during the composition Letter to Moreau of Nieve.

(C1: 11 Aug 91).

Final sequence in Nieve.

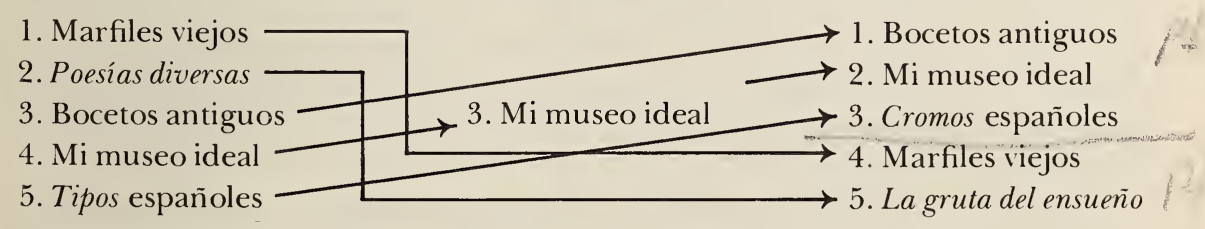

By relocating the sections, Casal in effect divided Nieve into two major parts: the first (consisting of "Bocetos antiguos," "Mi museo ideal," and "Cromos españoles") contained most of his Parnassian-type poems, while 
the second (composed of "Marfiles viejos" and "La gruta del ensueño") comprised works that were more Romantic or Symbolist in nature. ${ }^{12}$

As far as the re-working of his material was concerned, however, Casal did not stop here: he also made sequence changes within sections. As we shall see, four of Nieve's five parts were ultimately subjected to this type of revision.

Np1: “восETos Antiguos." For reasons suggested in my introductory statement to this group of poems (see pp. 158-161), Casal switched the position of "La muerte de Moisés" and "La agonía de Petronio." As a consequence, the overall structure of the series became better balanced and, therefore, aesthetically more satisfying.

Np2: "MI MUSEO IDEAL." Although Casal did not change the order he had established for N8-N17 when he published these poems on 30 August 1891, he did expand the series by adding two later compositions, "Sueño de gloria" (N18) and "Vestíbulo" (N7). It appears that he planned to use these new poems to introduce the ten sonnets of which the Moreau section had originally consisted. Nevertheless, upon reconsidering the matter, he realized that the logic of the series would be better if "Sueño de gloria" were moved from first to last position in the group. Internal evidence suggests that Casal made this decision at the eleventh hour: that is, after the poems of "Mi museo ideal" had all been typeset. As indicated in my discussion of $\mathrm{N} 18$, there can be no question about the wisdom of this transposition.

Np4: "MARFILES viEJos." When preparing Nieve, Casal brought together all the poems that had been published under the rubric "Marfiles viejos" between 26 October 1890 and 30 January 1892 (i.e., N25-N35). As shown on p. 228, however, he made four sequence changes within the group before sending the book to press. Furthermore, he lengthened the series by adding two poems which had never before appeared under the "Marfiles viejos" heading: "Tristissima nox" (N22) and "En un hospital" (N37). Hypotheses suggesting why he modified the section in this way are advanced in my discussion of $\mathrm{Np} 4$.

Np5: "LA GRUTA DEL ENSUEÑo." Casal fashioned this series from poems which had been published between 19 October 1890 and 29 February 1892 , but which, for reasons of subject matter or form, could not fit into the other sections of Nieve. In this sense, "La gruta del ensueño" was a catchall for the leftovers. But even though he was dealing with a collection of poesias diversas, Casal did not reproduce the poems in the order in which they had originally been published; rather, he created a new sequence by relocating six of them.

The only section whose order Casal did not modify before publishing Nieve was "Cromos españoles" (Np3), but it is not difficult to explain this fact: since the series was composed of only three sonnets and these had appeared in an aesthetically pleasing order when they were first published on 15 February 1892, nothing could be gained by re-sequencing them. 
Although the information given above patently confirms Cintio Vitier's observation that Nieve was "un libro lúcidamente organizado," 13 it tells only a small part of the story of how much effort Casal expended in his search for literary perfection. As the data in my introductions to the poems will show, Casal was so deeply committed to the ideals of his art that he considered nothing too insignificant to receive his attention. He was willing to add or suppress textual material; to re-work his imagery; to make lexical substitutions; to alter titles, subtitles, and dedications; and even to modify the punctuation and layout of his poetry. However, what is especially commendable in the eyes of the critic - though it must have tried the patience of his publisher on more than one occasion - is the fact that Casal was ready to make these revisions even during the final stages of printing.

From this standpoint, there can be no doubt that Nieve was Casal's book all the way. Yet it was his in other respects as well. For example, unlike Hojas, Nieve did not contain translations, paraphrasings, or imitations of specific poems by favorite authors, but was made up entirely of original compositions. In fact, the last verse translation Casal is known to have published was "La canción del torero" (H40), a poem based on the 21 September 1889 version of Hérédia's "Chanson de Torero" and ultimately incorporated into Hojas. The reason why Casal stopped publishing this type of material is not hard to see. With several years of literary apprenticeship behind him, he had already formed clear preferences in art and had achieved a considerable degree of technical competence. This tended to increase his self-assurance and induced him to exercise his art with a greater spirit of independence than before. As a result, during his Nieve period, Casal was much less inclined to imitate whole works than to extract interesting elements from his readings and, by incorporating them freely into his own poetry, create something unique in Hispanic literature.

A careful study of Nieve reveals many examples of this growing inclination to experiment with elements drawn from foreign literary sources. Themes, personalities, situations, locales, metrical forms, imagery, acoustical patterns, vocabulary ${ }^{14}$ - just about anything was fair game for Casal. In spite of this, the items that he imported with such enthusiasm did not stand out as exotic accretions of questionable relevance, but blended naturally into his works. This was because Casal made his selections in accord with existing predispositions of his personality and then adapted the new elements to harmonize with those that were already present in his poetic storehouse. As a consequence, the novelties which he introduced permitted him to make gains in two areas of fundamental importance to every poet: first, he increased his ability to express himself with accuracy and power; and, second, he added new dimensions to the aesthetic experience both for himself and for his reader.

As we shall see, not all of Casal's public agreed that this was true. As a 
matter of fact, some readers had just the opposite impression and vigorously attacked the poet because his latest work was - in the literal sense - so extravagant, so exorbitant. Of course, in light of what was fashionable in Cuban literary circles when Nieve came out, this kind of reaction was to be expected. However, in terms of what was in vogue abroad, particularly in Paris, the cultural capital of the western world, it would be extremely difficult to use Nieve as proof that Casal was "wandering off the track." Even more important, though, was the fact that he was not "straying out of orbit" as far as his own nature was concerned. Indeed, to a considerable extent, what he did in Nieve was simply a continuation of what he had done at earlier stages in his development as a writer. Take his love of the visual arts, for example. In my introduction to Hojas, I traced this facet of Casal's personality to the known beginnings of his career and offered illustrations of how it affected his production during the period 1881-1890. After the publication of Hojas, the visual arts continued to influence Casal. Now, however, the role they played became more important than before. This can be verified in several ways. To begin with, we might compare the titles and subtitles that Casal assigned to the components of his books and list the ones that have a bearing on the matter:

HOJAS AL VIENTO

H 5: "Acuarela"

H 6: "Luz y sombra" (a chiaroscuro)

H22: "El Arte"

H33: "Estatua de carne"

H42: "Croquis perdido"
NIEVE

Np 1: "Boceios antiguos"

N 3: "Bajo-relieve"

Np2: "Mi museo ideal"

"Diez cuadros de Gustavo Moreau"

N 7: "Retrato de Gustavo Moreau"

Np3: "Cromos españoles"

Np4: "Marfiles viejos"

N28: "Paisaje espiritual"

N38: "Ante el retrato de Juana Samary"

N39: "Camafeo"

N40: "Blanco y negro" (a chiaroscuro)

N43: "Kakemono"

"Pastel japonés"

N46: "Paisaje de verano"

N50: "Al carbón"

N53: "Medallón"

This list provides the first clear sign that the visual arts had a greater impact on Nieve than on Hojas. More substantial evidence is supplied, however, by an examination of Casal's penchant for word-portraits. His subjects tended to be of three basic kinds: imaginary characters, including abstractions derived from the observation of social types; historical personages; and contemporaries who, for one reason or another, had made a particularly strong impression on him. A survey of his poetry shows that all three varieties are more abundantly represented in Nieve than in Hojas. 
Besides doing a greater number of verbal portraits than before, Casal also turned directly to the graphic arts for inspiration. As demonstrated in my introduction to "Amor en el claustro" (H3), at a very early stage in his career the poet had sought to do with words what artists like Perugino and Rembrandt had done with oils. Now, ecstatic at having discovered the works of Gustave Moreau, he made every effort to learn about the French master's art and to acquire photographic reproductions of his paintings. Thanks to the cooperation of a supplier in Paris, Casal procured a number of photos that had been made from Moreau originals, and, using the most interesting ones as models, re-created poetically what he saw in the photographs. The results were impressive, indeed: except for "Salomé," which he had written a year earlier with a literary description as his probable source of inspiration, ${ }^{15}$ and "Vestíbulo," which he composed late in 1891 with imagination as his only guide, Casal based all of the sonnets of "Mi museo ideal" on pictures that he had obtained from the Photographie des Beaux-Arts during the summer of 1891. In almost every instance, his skill at translating graphics into poetry was truly remarkable. Since replicas of the photographs which inspired the sonnets are available in the present edition, the reader may judge for himself how great Casal's talent really was in this regard.

An examination of the twelve letters which Casal wrote to Gustave Moreau will allow the reader to assess the intensity of yet another of Casal's long-standing traits: namely, his need to be the disciple of some great master who would instruct him, inspire him, and love him-a master whom he could revere as his personal deity and to whom he could demonstrate his adoration without shame. The letters make it plain that this need, which had manifested itself on numerous occasions during his youth, grew considerably with the passage of time and reached a peak during his Nieve period. In fact, between the summer of 1890 and the spring of 1892, Gustave Moreau became for Casal the incarnation of a lifelong ideal: that genial creator of beauty, who lived and worked in the most exotic place in the universe, Paris, became his "Divin maittre," his "Muy venerado maestro," his "Ydolâtré, trés-idolâtré, de plus en plus idolâtré maître."

The Moreau-inspired section of Nieve calls our attention to another characteristic of Casal: his fondness for the sonnet (see Table 3, where basic data about the sonnet in Casal's collected works are presented). Although Casal wrote many more sonnets for Nieve than for Hojas (see Chart II), he did not display great inventiveness where form was concerned. Chart III makes it plain, for example, that he continued to demonstrate in Nieve the same overwhelming preference for hendecasyllables as before; while Chart IV shows that, in the sestets of Nieve, he tended to follow the same rhyme pattern that he had used in Hojas: $\mathrm{CDE}, \mathrm{CDE}$.

Casal was also conservative with respect to the essential message that he was transmitting in Nieve. He continued to love innocence and to despise 
$\mathrm{Np} 0$

TABLE 3

SONNETS IN HOJAS, NIEVE, AND RIMAS

CHART I

\begin{tabular}{lccccccc}
\hline B: $\mathrm{P}$ & \multicolumn{3}{c}{ No. of Syllables } & \multicolumn{4}{c}{ Rhyme Schemes in Sestet } \\
& 11 & 12 & 14 & CDE & CCD & CDC & CDC \\
& & & CDE & EED & DCD & DEE \\
\hline
\end{tabular}

$\begin{array}{lll}\text { H11 } & \text { x } & \text { x } \\ \text { H18 } & \text { x } & \text { x } \\ \text { H22 } & \text { x } & \\ \text { H24 } & \text { x } & \text { x } \\ \text { H29 } & \text { x } & \text { x } \\ \text { H32 } & \text { x } & \text { x } \\ \text { H39 } & \text { x } & \text { x } \\ \text { H42 } & \text { x } & \text { x } \\ \text { H44 } & \text { x }\end{array}$

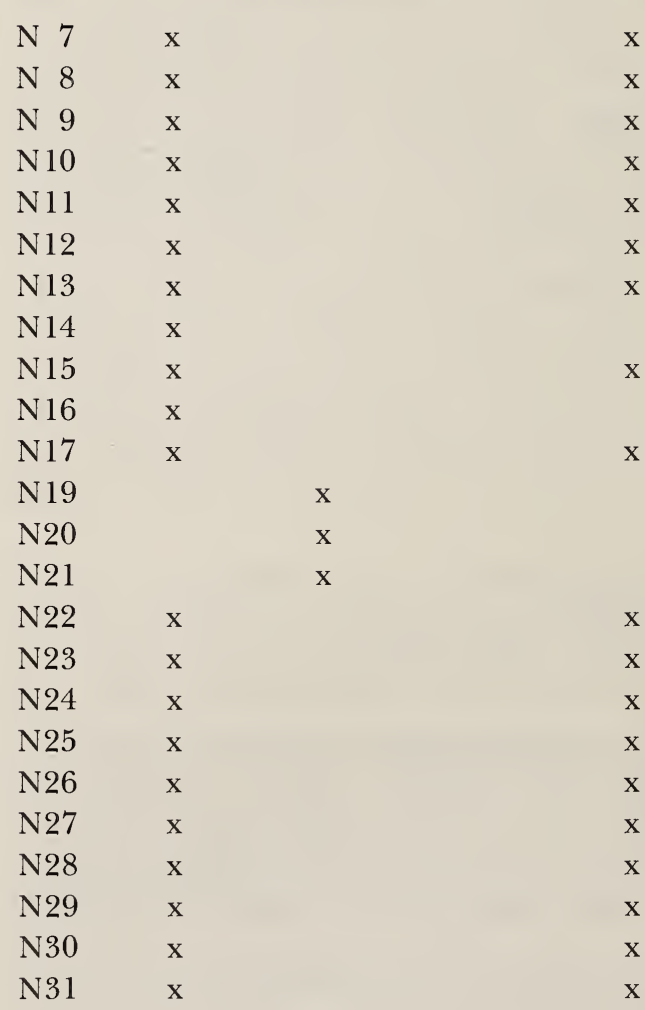




\begin{tabular}{|c|c|c|c|c|c|c|c|}
\hline \multirow[t]{2}{*}{$\mathrm{B}: \mathrm{P}$} & \multicolumn{3}{|c|}{ No. of Syllables } & \multicolumn{4}{|c|}{ Rhyme Schemes in Sestet } \\
\hline & 11 & 12 & 14 & $\begin{array}{l}\mathrm{CDE} \\
\mathrm{CDE}\end{array}$ & $\begin{array}{l}\text { CCD } \\
\text { EED }\end{array}$ & $\begin{array}{l}\mathrm{CDC} \\
\mathrm{DCD}\end{array}$ & $\begin{array}{l}\text { CDC } \\
\text { DEE }\end{array}$ \\
\hline N32 & $\mathrm{x}$ & & & $\mathrm{x}$ & & & \\
\hline N33 & $\mathrm{x}$ & & & & & & $\mathrm{x}$ \\
\hline N34 & $\mathrm{x}$ & & & $\mathrm{x}$ & & & \\
\hline N35 & $\mathrm{x}$ & & & $\mathrm{x}$ & & & \\
\hline N36 & $\mathrm{x}$ & & & $\mathrm{x}$ & & & \\
\hline N37 & $\mathrm{x}$ & & & $\mathrm{x}$ & & & \\
\hline N46 & $\mathrm{x}$ & & & $\mathrm{x}$ & & & \\
\hline N48 & $\mathrm{x}$ & & & $\mathrm{x}$ & & & \\
\hline N50 & $\mathrm{x}$ & & & $\mathrm{x}$ & & & \\
\hline R 4 & $\mathrm{x}$ & & & $\mathrm{x}$ & & & \\
\hline R 5 & $\mathrm{x}$ & & & $\mathrm{x}$ & & & \\
\hline R 8 & $\mathrm{x}$ & & & $\mathrm{x}$ & & & \\
\hline $\mathrm{R} 13$ & $\mathrm{x}$ & & & $\mathrm{x}$ & & & \\
\hline $\mathrm{R} 15$ & $\mathrm{x}$ & & & & $\mathrm{x}$ & & \\
\hline $\mathrm{R} 17$ & & & $\mathrm{x}$ & & $\mathrm{x}$ & & \\
\hline $\mathrm{R} 18$ & $\mathrm{x}$ & & & & $\mathrm{x}$ & & \\
\hline $\mathrm{R} 20$ & $\mathrm{x}$ & & & $\mathrm{x}$ & & & \\
\hline $\mathrm{R} 22$ & $\mathrm{x}$ & & & & $\mathrm{x}$ & & \\
\hline $\mathrm{R} 23$ & $\mathrm{x}$ & & & & $\mathrm{x}$ & & \\
\hline $\mathrm{R} 25$ & $\mathrm{x}$ & & & & & $\mathrm{x}$ & \\
\hline $\mathrm{R} 27$ & $\mathrm{x}$ & & & & $\mathrm{x}$ & & \\
\hline $\mathrm{R} 29$ & $\mathrm{x}$ & & & & $\mathrm{x}$ & & \\
\hline R31 & $\mathrm{x}$ & & & $\mathrm{x}$ & & & \\
\hline $\mathrm{R} 33$ & $\mathrm{x}$ & & & & $\mathrm{x}$ & & \\
\hline R35 & $\mathrm{x}$ & & & & $\mathrm{x}$ & & \\
\hline R37 & $\mathrm{x}$ & & & & $\mathrm{x}$ & & \\
\hline R39 & $\mathrm{x}$ & & & & $\mathrm{x}$ & & \\
\hline $\mathrm{R} 40$ & $\mathrm{x}$ & & & & $\mathrm{x}$ & & \\
\hline
\end{tabular}

corruption. He still disagreed with the values of his compatriots and, though in desperate need of religious faith, moved farther and farther from the Church. He suffered a constant frustration of his dreams, and, realizing that nothing could permanently bridge the gap between desire and reality, sought to discover viable means of protecting himself from the pain that life inflicted on him. Just as before, he expressed feelings of guilt, doubts about his own worth, and fears that he would be cruelly victimized by fate. Understandably, therefore, he exalted those who, unlike himself, could remain indifferent to the vicissitudes of life. He 
CHART II

\begin{tabular}{|cccc|}
\hline Book & $\begin{array}{l}\text { No. of } \\
\text { poems }\end{array}$ & $\begin{array}{l}\text { No. of } \\
\text { sonnets }\end{array}$ & $\begin{array}{l}\text { \% of } \\
\text { sonnets }\end{array}$ \\
\hline H & 49 & 9 & .18 \\
$\mathrm{~N}$ & 54 & 33 & .61 \\
$\mathrm{R}$ & $\underline{41}$ & $\underline{19}$ &.$\underline{46}$ \\
& 144 & 61 & .42 \\
\hline
\end{tabular}

CHART III

\begin{tabular}{|cccc|}
\hline Book & Hendec. & Dodec. & Alex. \\
\hline H & 9 & 0 & 0 \\
N & 30 & 3 & 0 \\
R & $\underline{18}$ & $\underline{0}$ & $\frac{1}{57}$ \\
& 57 & 3 & 1 \\
\hline
\end{tabular}

CHART IV

\begin{tabular}{|ccccc|}
\hline & CDE & CCD & CDC & CDC \\
Book & CDE & EED & DCD & DEE \\
\hline H & 8 & 0 & 1 & 0 \\
N & 27 & 4 & 1 & 1 \\
R & $\underline{6}$ & $\underline{12}$ & $\frac{1}{3}$ & $\frac{0}{1}$ \\
& 41 & 16 & 3 & 1 \\
\hline
\end{tabular}

sought escape from worldly miseries through dream and through art. $\mathrm{He}$ replaced nature with an artificial world of his own making; he cultivated the exotic; he investigated the macabre. And possessed of a boundless need to love and be loved, but still incapable of forming close emotional ties with women, he used his artistic interests as a vehicle for establishing platonic relationships that would help him conquer loneliness.

As he had done in previous years, Casal continued to write poems for albums belonging to ladies of his acquaintance. Between August 1890 and February 1892, he is known to have written five compositions of this type. 
Of these, one never found its way into print during his lifetime, four were published in periodicals on which he collaborated, and three were ultimately incorporated into Nieve. The poems are:

$\begin{array}{llr}\text { V8 } & & \text { Aug90 } \\ \text { N39 } & \text { F } & 8 \text { Mar91 } \\ \text { N51 } & \text { HE } & \text { 15 Mar91 } \\ \text { V9 } & \text { F } & \text { 31 Jan 92 } \\ \text { N53 } & \text { HL } & \text { 29 Feb 92 }\end{array}$

In addition to writing album pieces such as these, Casal dedicated a number of works to individuals for whom he had special regard or to whom he wished to express his gratitude for a particular courtesy. On page 138 is a list of persons whom Casal favored this way in Nieve. To the left of the names are codes representing poems or parts of Nieve that bore a dedication at some stage in their development. To the right of the names is a series of entries standing for each published version of the listed compositions. If publication data are given, it signifies that the version in question was dedicated to the person cited. However, if a black line appears, it means that a version was printed but was not dedicated to that person. Thus, N12 was dedicated to Edouard Cornelius Price the first three times it was published, but was not dedicated to him on the two occasions which followed, the last one being Nieve.

Examination of this list reveals a number of interesting points. For example, although Casal had dedicated Hojas to Ricardo del Monte, he did not dedicate Nieve as a whole to any special person. Rather, he chose certain parts of the book, or poems within the parts, as offerings to specific individuals. He dedicated "Mi museo ideal" (Np2) to Eduardo Rosell, "Cromos españoles" (Np3) to Enrique Hernández Miyares, and "La gruta del ensueño" (Np5) to Edouard Cornelius Price. While it is true that there was no general dedication for "Bocetos antiguos" (Np1), each one of the poems in that section did have its own dedication when Nieve came out. Thus, the only part of Nieve that was not dedicated to anyone in one way or another was "Marfiles viejos" (Np4). Insofar as "Mi museo ideal" was concerned, the dedication of N8-N17 to Eduardo Rosell on 30 August 1891 made it inappropriate to retain the original dedications of N8, N11, and N12; but, since Casal did not wish to deprive Nájera and Price of the sign of esteem which he had previously given them, he dedicated N6 to the former and Np5 to the latter when he published Nieve. Reasons for his doing so are suggested on pp. 176 and 251, respectively. The motivation behind other changes is not so clear, however. For instance, it is not known why N3 was given to Vivino Govantes y Govantes instead of to Enrique Fontanills who had been offered N8 in September 1890, but who got no mention at all in Nieve; nor is there an adequate explanation of the erratic dedicatory practices employed in "La gruta del ensueño," where 


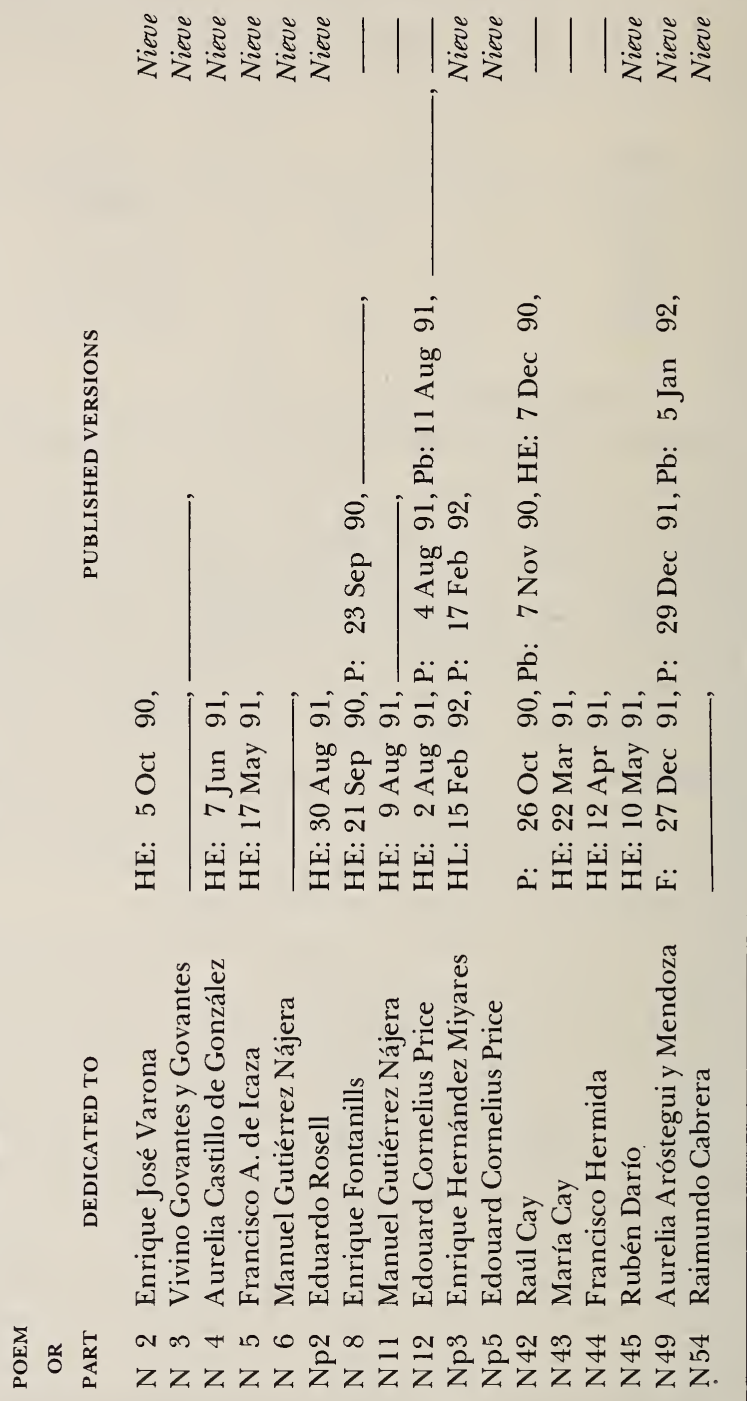

some of the dedications that had appeared in early versions of the poems were retained (see $\mathrm{N} 45, \mathrm{~N} 49$ ), while others were removed (see N42, N43, N44), and one was added (see N54).

Some of the people on the above list formed part of a more extensive, yet equally select circle that came to play an immensely important role in the poet's life: it was the group with whom he had private correspondence. From all appearances, Casal's epistolary activities took up a fair amount of time and provided him with a much needed emotional and intellectual outlet. ${ }^{17}$ He corresponded with compatriots such as Esteban Borrero Echeverría, Juana Borrero, Aurelia Castillo de González, 
América Du-Bouchet, Edouard Cornelius Price, and Cirilo Villaverde, as well as with distinguished non-Cubans such as José María Bustillos, Rubén Darío, Judith Gautier, Enrique Gómez Carrillo, Manuel Gutiérrez Nájera, Joris-Karl Huysmans, Francisco A. de Icaza, Count Robert de Montesquiou-Fézansac, Gustave Moreau, Emilia Pardo Bazán, Pedro II of Brazil, Luis G. Urbina, and Paul Verlaine. Whenever a friend or colleague visited his modest quarters, Casal would joyfully display the letters he had received. These papers, he would say, are "los compañeros de mi vida." ${ }^{8}$ So great an impression did this ritual make on Rubén Darío that he continued to recall it vividly many years after Casal's demise. ${ }^{19}$

Realizing how valuable Casal's epistolary treasures were, Aniceto Valdivia expected that Carmen del Casal would collect them and preserve them after her brother's death. ${ }^{20}$ If Carmen did collect these documents, she guarded them so jealously that they eventually disappeared. Another serious loss resulted when Dulce María Borrero died before she could publish the letters that Casal and her sister Juana had exchanged. ${ }^{21}$

In spite of the factors that have militated against their survival, a few letters have come down to us. A facsimile of the poet's first letter to Luis G. Urbina was published in the April 1909 issue of the Revista Moderna de México (see below, Plate 11). Five brief notes were collected by José Antonio Fernández de Castro and were printed in the March 1923 issue of Social. Three letters were found by Gustavo Duplessis and were incorporated into his doctoral dissertation, which was published in 1944 by the Revista Bimestre Cubana. In the following decade, four new letters by Casal came to the attention of José María Chacón y Calvo; these were printed together with some already-known material in the Fall 1958 issue of the Boletín de la Academia Cubana de la Lengua. Two additional notes came out in 1963, when Cuba's Consejo Nacional de Cultura published its Centenary Edition of Casal's works. ${ }^{22}$ And so it goes: every once in a while, some part of Casal's correspondence turns up and is placed at the disposition of scholars.

Now, twelve letters that Casal sent to Gustave Moreau have become available for study. ${ }^{23}$ These letters span the period 11 August 18911 January 1893. Eleven of them were written in the poet's imperfect but expressive French, and one was written in Spanish. The first letter is photo-reproduced in Plate 9, and a transcription of the complete collection, which has been designated as $C$ (i.e., Cartas), is to be found in "Julían del Casal: Letters to Gustave Moreau," Revista Hispánica Moderna, año XXXVII, nos.1-2 (1972-1973), pp. 111-135. Each letter has been assigned a sequential code number $(\mathrm{Cl}, \mathrm{C} 2$, etc.) and, to further simplify reference, line numbers have been printed in the margin. Thus, the coding system used for the letters is essentially the same as the one used for the poetry. As the reader will see, these letters are of enormous significance, because they throw light upon aspects of Casal's life and art which have been shrouded in mystery for some eighty years.

In addition to this hitherto unpublished correspondence, there exists in 
Np0

PLATE 9

Casal's First Letter to Gustave Moreau

La Havanne, le 11 Aont 1891

016.

Sustive Aboriean

Frés_adoné maitre:

2uaigue je

n'ai pas le bonherer de rans conmaitse gne frar des, copies devinos di. vins tableaux, $j$ 'ose vous écrise fom vous envoger lés acljoints somnets qui j'ai comprose', aprés des graver res de ces chefs d'coure: IGélene, Salonac es Galatée

Ye sais, bien, trís-vénésé-maíher, gui je n'ai pas rensti a' rendre la sutlime, hanblant el inexprima ble beante' de natres adorees fingures; mais je rêve anssi gni nons vous daig. neres accueillir ces trais somnets, iavec lav bonte' genererute des grandes ámes, cornme un temaignage paure, mais le senc frossible, de ma dbusé ámo. lis geme sans égal, parce gu' il ess le rho phlosophique, etant ou la, fais celni der le phis pur artisle gu' a va. yonne sur l'humasite'.

Pans l'ethiver proctain, jesange a fublier mon tecond nolume de vers, dons la hoisiéme, partic fortera ec thise : iffon ofbusee Yolecl ( $\mathrm{Ha}$

140 
Np0

Plate 9

Casal's First Letter to Gustave Moreau

- Sleause de Instave oboseav) tout élle se ra dedié a la glonfucakon, de nos in comprarables ouvragres. I' attends, paur me metre a l'anve, l'arrive de des co. pies de L'Opparition, Uhe Peri, Phactor, Herenles devant l'ybydre et tomt le res. he gin deja j'ai demandie á Paris. Ans sîtos que man hire serai imprimé, be pe. mier excemplaise on vons sera reserve'et envogei sant de sinite.

Ye vares supplie trés - humblement gin vous nous daigneres me pardonner les fow ses de cette lestre, puis gne je ne sais pas gue tradine le grancais a' l'espagnol el je n'ai fras nailu. me faire écrise, poer per somre, celtés lignées.

Y'attends aussi gini vons me feries $l^{\prime}$ homener de craise gin wans aves en mai, Inaigne je sais tre's loin de Pains, le plus obs cur et le phus pelit, mais le phins fer. vens, be phus sincese, le phus fide'e et be péns logal de nas admiartenss es de nos eevilteuss

twhán del Casaly

Ysla de Cuba

Redarcción de "El Pis"

Feniente-Pey 39

Yabana

141 
PLATE 10

Julián del Casal: Portrait with Dedication to Moreau
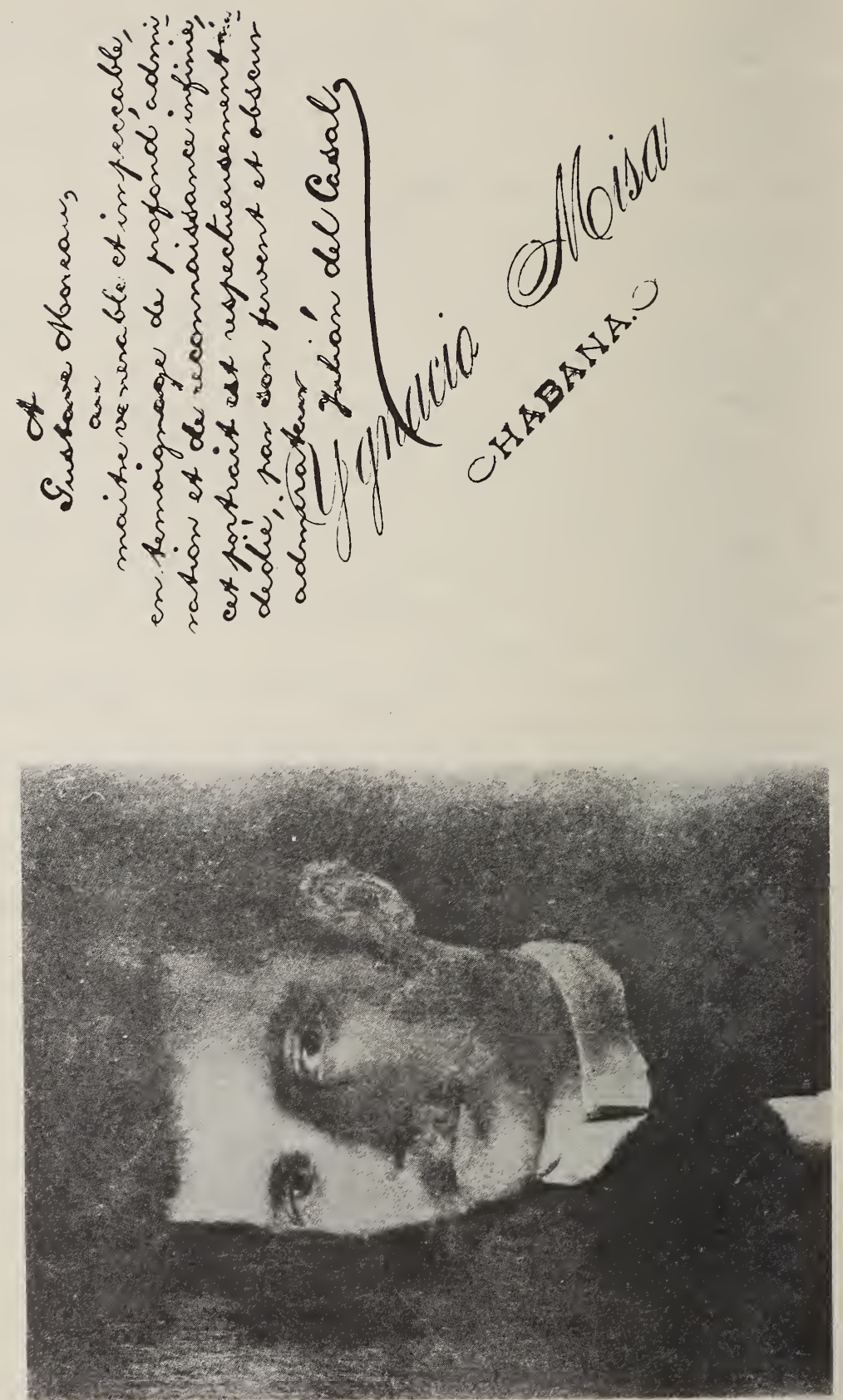
the Musée Gustave Moreau a photograph which Casal mailed with his letter of 16 September 1891. The photo-a portrait of Casal himself -was based on an oil painting by Armando Menocal and was made by Ignacio Misa of Havana; on the reverse side, it had a dedication in French from Casal to Moreau (see Plate 10). As Casal indicated in his letter of 17 February 1892, he had sent this portrait in the hope that Moreau would respond in kind (C6/143-157). Considering the time in which Casal lived, there was nothing unreasonable about such an expectation, for technological advances had simplified photography and reduced its costs to such an extent that, by 1890 , it was common practice for friends and admirers to exchange photos. Casal gave out snapshots of himself on numerous occasions (see N24, for example). With equal or greater frequency, he asked people whom he admired to give him their picture, and, in most instances, they granted his wish. As a result, the walls of his room were soon covered with what Márquez Sterling described as a "nube de retratos." 24 Unfortunately, the item that Casal wanted most of all - a picture of Gustave Moreau - could never be made part of his collection (see my introductions to Np2 and N7).

The Musée Gustave Moreau also contains one of the four copies of Nieve that Casal sent to Moreau on 20 April 1892. As Casal states in C9/10-25, one copy was for Moreau himself, and the others for Huysmans, Hérédia, and Verlaine. Curiously, however, the volume housed in the Museum library is not the one that had been destined for Moreau, but is, instead, the one that had been set aside for Hérédia. Inscribed in the book is the following dedication:

A José Maria de Heredia, en testimonio de ardiente simpatía y de profunda admiración,

20 Abril 1892

Julián del Casal

Nieve's presence in the Musée Gustave Moreau is interesting for two reasons. First of all, the fact that Casal sent the book to Moreau, rather than directly to Hérédia, supports an impression one forms when reading the Cartas: namely, that even though Casal and Hérédia were compatriots and had some knowledge of each other's work, as of 20 April 1892 they had not corresponded. Secondly, it appears that Casal was doing the same thing with Nieve that he had done with Hojas: that is, as soon as his book came off the press, he began distributing it to persons for whom he had special regard. Although it is impossible to determine how many courtesy copies he gave out, it seems to have been a fairly large number.

As we have seen, one of the recipients of Nieve was Paul Verlaine. This outstanding Symbolist, who, in 1892, was still a highly controversial figure 
in the Hispanic world, offered his judgment of Casal in a letter which he wrote to Enrique Hernández Miyares and which was subsequently published in La Habana Elegante. The passage quoted below is an excerpt from that letter and contains the essence of Verlaine's thought. What is most evident from it is the conviction that Casal was a poet to be reckoned with:

El talento de Julián del Casal . . es un talento sólido y fresco, pero mal educado. Sí, le diré a usted: yo no sé quiénes fueron sus maestros ni cuáles sus aficiones pero estoy seguro que los poetas que más han influido en él son mis viejos amigos los parnasianos. Eso se ve fácilmente en todas las páginas de Nieve, y especialmente en los Cuadros de Moreau y en Cromos españoles. Su factura, como la de ellos, es preciosa, pero demasiado igual. ... Creo, sin embargo, que el misticismo contemporáneo llegará hasta él, y que cuando la Fe terrible haya bañado su alma joven, los poemas brotarán de sus labios como flores sagradas. Es uno de esos jóvenes laxos de ciencia que necesitan reposar sus cabezas sobre el regazo de la Virgen. Lo que le hace falta es creer; cuando crea será nuestro hermano. . . . Es un hermoso cantor que Dios nos reserva ... . para los postres. Esperémosle y hagamos para recibirle una corona de laurel verde atada con una cinta color de carne morena. .. . ${ }^{25}$

The same joyous enthusiasm that led Casal to rush four copies of Nieve to Moreau as soon as it came off the press also impelled him to hand out complimentary copies of the book to friends and colleagues in Havana as quickly as he could. Although reactions given orally to Casal were never recorded and those given by letter have been lost with the rest of his correspondence, public evaluations of Nieve made by local critics are available for examination. Though scholars have not salvaged all the reviews and poetic responses that appeared in Cuban newspapers and literary journals, the list presented below suggests that the book received fairly extensive coverage in the weeks following its publication:

Conde Kostia [pseud. of Aniceto Valdivia], "Crónica sobre el libro Nieve," La Lucha, 22 April 1892.

Francisco Chacón, "Casal," El Fígaro, 24 April 1892.

Enrique Hernández Miyares, "A un poeta," La Habana Literaria, 30 May 1892 (see Np3).

Wen[ceslao] Gálvez, “Nieve," El Fígaro, 12 June 1892 (see Appendix B).

Enrique Trujillo, "Nieve," La Habana Literaria, 30 June 1892 (see Appendix B). 
Juan José Cadenas, "Crítica sobre el libro Nieve," El País, 17 August 1892.

M. Fernández Juncos, "Nieve (Por Don Julián del Casal)," El Fígaro, 21 August 1892.

Enrique José Varona, "Nieve," Revista Cubana, August 1892 (see Appendix B).

When these items are surveyed, it becomes apparent that Nieve was less often and less vigorously defended than attacked. The minority position was expressed by Enrique Hernández Miyares and a few other friends of Casal. Weighing the pros and cons of his poetry, they admitted that it contained defects but insisted that these were counterbalanced by a virtue of indisputable importance to every sensitive reader. On the negative side, they granted that the poet filled his works with melancholy, worldweariness, pessimism, and signs of neurosis; they conceded that his book rang with the cries of a tormented soul; and they confessed that he had failed to produce the kind of traditional love lyric that the public demanded. Under the circumstances, it was unreasonable to expect that Nieve would be favored by the average Cuban reader of the time. On the positive side, however, they saw that Casal's poetry could relieve the anguish that came to men of refined sensibilities from the complex fin de siglo world in which they lived. In the opinion of Casal's defenders, this strange power justified the poet's efforts and made it imperative for him to remain faithful to his Muse. But, as indicated above, this was clearly the minority position.

The attack against Nieve seems to have begun in earnest with Wen Gálvez' review in the 12 June issue of El Fígaro. Insisting that it would be improper for him to undermine his allegiance to Poetry because of his friendship for Casal, Gálvez censured the author of Nieve for having committed three flagrant sins. The first was that he had left the path of true poetry and had entered the camp of the French Decadents, who, though fashionable for the moment in certain circles, would never occupy a lasting position in the pantheon of universal letters. Second, Gálvez found that Casal's unbroken pessimism not only distorted the facts as far as the poet himself was concerned, but also had a pernicious effect on the reader: instead of elevating him, Casal's poetry plunged him into an unhealthy and unnecessary depression. And finally, he chastized Casal for wasting his poetic talents on the creation of "harmoniosas combinaciones de vocablos que nada dicen."

Enrique Trujillo was also profoundly disturbed by Casal's second book of verse. Like Wen Gálvez, he gave his readers the impression that the only influence on Nieve was that of the French Decadents. As we know, this view is in direct opposition to the judgment of Paul Verlaine, who, on examining the book, indicated that Casal had fallen mainly under the tutelage of the Parnassians and suggested that the young poet still had 
some way to go before he would be in step with the times. If Verlaine considered Nieve as basically Parnassian, then what made Trujillo see it as Decadent? The answer, I think, lies in Trujillo's fear that Decadentism might undermine traditional values. Concentrating his attentions on a few poems in Nieve which expressed the pessimism and lack of faith that typified Decadentism, he lamented the fact that Casal had chosen to align himself with the apostles of the new doctrine. It is apparent, however, that Trujillo was more interested in combatting what he considered a dangerous trend than in undertaking an objective search for truth. As far as he was concerned, he already knew the truth, and therefore could determine what was real and what was merely a deceptive image of reality created by the false prophets of France. For this reason, the questions he posed were not bona fide questions, but were instruments designed to nullify the legitimacy of views different from his own. How, he asked, could decadence be a reality in Paris if the citizens of that metropolis cultivated science, paid tribute to art, exhibited an unrivaled intellectual vigor, and were rich and happy to boot? How could there be any fundamental decadence in Cuba if that island, despite the problems of its colonial status, could produce talents such as Enrique José Varona, Rafael Montoro, Manuel Sanguily, Rafael Díaz Albertini, Nieves Xenes, and Julián del Casal? And how could disbelief and despondency be a reality in Casal if Cuban poets had never been "ni descreídos como Heine, ni desesperados materialistas como Leopardi," and if noble thoughts and generous sentiments could be found in the poetry of Nieve? Without a doubt, Trujillo's review was milder than the one written by Gálvez. Nevertheless, the fact that it substituted a long discussion of Decadentism for a complete description of Nieve and that it failed to give an objective appraisal of the book's aesthetic value was certainly not to Casal's advantage. Indeed, even the words of praise which Trujillo bestowed upon Casal subtly confirmed an unflattering point that had been made by Gálvez: namely, that Casal, in his present state, was an "extraviado."

In the August issue of the Revista Cubana, Enrique José Varona gave his assessment of Nieve. Although he admitted that Casal had many points in his favor, the dean of Cuban critics was moved by an irresistible force to play the role of Devil's advocate where Nieve was concerned. He felt that Casal was paying more attention to the siren call of the Symbolists and Decadents than to the voice of his own heart. As a result, his poetry was coming dangerously close to mannerism. He was using a vocabulary that, while strange and new, did not add vigor, clarity, and elegance to his expression; he was substituting bare enumeration for true description; he was repeating a number of visual motifs with undesirable frequency; he was cultivating certain varieties of poetry that would be better left untouched; he was writing poems that carried no significant message and therefore had no power to move the reader; at times, he was passing the limits of decency; and, all too often, he was writing just for the sake of writing. 
It is clear that, as a literary critic, Varona had a perfect right - in fact, a duty - to call attention to the weak spots in Casal's work. But what accounts for the harshness of Varona's criticism and its almost unrelenting negativism on this occasion? One explanation is that Varona was truly disappointed with Casal's performance in Nieve. In his critique of Hojas, he had acted like a loving father whose purpose was to steer Casal away from temptations that would corrupt his art. Now, two years later, Casal published a book which revealed that he had not been disposed to follow Varona's advice as closely as the great man had hoped. The measure of Varona's disappointment with Casal's behavior can be seen in the statement: "Casal se muestra muy desdeñoso de la crítica . . .." However, a study of the variants in his poetry and an examination of remarks made by those who knew how persistently Casal strived to perfect his work suggest that Varona's assertion about Casal's response to criticism was not true at all. On the contrary, Casal appears to have been quite ready to hear criticism and act upon it. The only serious restriction that he placed on the critics was that they not ask him to betray his Muse. Casal's publication of Nieve is the most eloquent confirmation of his unwillingness to compromise on this point.

In 1893, encouraged by the remarks of critics like Varona, Ciriaco Sos Gautreau wrote a vitriolic pamphlet entitled Julián del Casal o un falsario de la rima. ${ }^{26}$ This thirty-three page denunciation followed criticism that Sos had published earlier and was designed to give Casal the "golpe de gracia" (p. 11). In the opinion of Sos - or César de Guanabacoa, as he preferred to call himself on this occasion - it was necessary to take such a drastic step for several reasons. As shown first by Hojas and now by Nieve, Casal had committed the unpardonable sin of trying to be different from everyone else. Instead of using his creative powers in the traditional manner, he was making an effort to say new things in a new way. This led to results that were simply intolerable: his vocabulary was limited in scope, his diction was incorrect, his syntax was defective, his verses were filled with Gallicisms, his rhymes were forced, his imagery was unrealistic, and his message was nonsensical. In addition, Casal was attempting to deceive the public: not only did he dedicate many of his poems to well-known persons in order to create the illusion that he had excellent connections, but he wore a mask of modesty that hid a truly satanic pride. Since a person of this type could only have deleterious effects on Cuban poetry, and since he wanted to go to live in Paris with the rest of the Decadents anyway, the solution was obvious: his friends - and his enemies - should be asked to donate enough money to send him where he wanted to go.

This pamphlet by Ciriaco Sos is exceptional for two reasons. First of all, it contains the most venomous attack ever launched against Casal, a person so gentle, so timid, and so good-natured that José de Armas said he was "uno de esos pocos, muy pocos hombres de los que puede afirmarse, cuando nos abandonan para siempre, que no han hecho mal a nadie en la vida.... Para él no había rencores. La envidia no la conocía. No 
odió a nadie." ${ }^{27}$ The second unique feature of the pamphlet is that, despite its extreme bias and maliciousness, it is the most detailed and the most informative analysis of Casal's poetic style in existence.

Compared with the reviews of Hojas, these critiques of Nieve show that, as time passed, Casal's art was inspiring harsher and harsher reactions within Cuba. Ironically, however, it was eliciting ever more favorable responses abroad. Mexico, in particular, was a focal point of admiration for Casal's work - and this was only fair, because, if there was any Latin American country for which Casal had a warm spot in his heart, that country was Mexico. As far as we can tell, Casal's enthusiasm for the land that had been a traditional haven for Cuban libertarians ${ }^{28}$ began around 1886/87, when his friend Carlos Noreña brought him firsthand reports about it. According to Noreña, the capital was "una especie de París americano." ${ }^{29}$ Naturally, this designation connoted all kinds of wonderful things about the people, the way of life, and the artistic climate that one could find there. Some two years later, when Casal met Francisco A. de Icaza in Madrid, his original impression was reinforced to the point where Mexico seemed to be the incarnation of an artist's dream: “iAh! Cuando se encuentra, en el presente siglo, una república grandiosa, como la de Méjico, donde la literatura se desarrolla, a la sombra del olivo de la paz, el alma del artista se consuela, porque presiente que han de pasar pronto estos tiempos de inquietud continua y de apetitos desenfrenados, tiempos verdaderamente malditos para los espíritus superiores, $y$ han de volver los días serenos, los días inolvidables de la antigüedad, en que la Belleza era un culto, el Amor un sacerdocio y el Arte la más sublime de las religiones." 30

Casal's esteem for the neighboring republic was not only based on glowing reports given him by Mexicans and by individuals who had visited Mexico, but was also derived from a long-term exposure to the work of Mexican authors. From the time that Carlos Noreña had returned to Havana with "muchos libros, muchos periódicos,"31 Casal had done his best to keep up with progress on the Mexican literary scene. Whenever he could, he tried to procure books by writers of talent. It was easier, however, to acquire information on the latest trends by reading the periodicals that arrived in a constant stream from Mexico. Of course, at this point in history, it is impossible to determine how many different periodicals were sent to Cuba or who received them. Nevertheless, a rough impression can be formed by examining the following list, which represents only those items that had reached the director of La Habana Literaria during May and June of 1892: El Nacional, La Patria, El Partido Liberal, La Revista de Méjico, El Mundo Literario Ilustrado, México Intelectual, El Correo del Golfo, La Bandera Veracruzana, La Gaceta del Gobierno, and La Gaceta Oficial. ${ }^{32}$

Everything that Casal had learned about Mexico over the years made him wish that he might some day have an opportunity to see the splendors of that country for himself and meet its most outstanding writers in 
person. Thus, when Manuel Márquez Sterling told him that he was planning to leave for Mexico shortly, Casal, who was then writing his third book, responded in the following manner: "Yo siempre he tenido vivos deseos de conocer a México. Me encantan sus poetas, y tengo la idea de que es el París de América. Allí, según cuentan, se hace una vida enteramente europea...... iGozaría yo tanto conociendo a Gutiérrez Nájera y a Díaz Mirón!"33 Like so many of his other wishes, this one too was left unfulfilled. Yet if Casal never had the good fortune to visit Mexico in person, he did become known there during his lifetime through the medium of his work.

Thanks to Ernesto Mejía Sánchez, who, in a true spirit of humanistic cooperation, made his files on Casal available to this writer, it has been possible to formulate some idea of the degree of exposure that Casal's poetry had on the mainland between 1889 and 1893. As shown in Table 4, El Partido Liberal of Mexico gave space to the Cuban poet even before Hojas appeared, and, in the years that followed, El Partido Liberal was joined by other Mexican papers, as well as by Central American periodicals, in publishing samples of Casal's work. Some compositions were sent to the mainland by Casal himself. One such poem was "La canción del torero" (H40). The majority of Casal's works, however, were disseminated by other means. Some were extracted from Cuban journals that had been shipped abroad by their directors. Illustrative of this group are "A un amigo" (N23), "Blanco y negro" (N40), "Flores" (N41), "Vespertino" (N42), and "Mi ensueño" (N48)-i.e., the poems that were printed in $\mathrm{El}$ Correo de la Tarde on 10 and 17 January 1891, and in Costa Rica Ilustrada on 20 February 1891. As suggested by Index II, all of these poems seem to have been copied from the same source: the 7 December 1890 issue of $L a$ Habana Elegante. "La canción de la morfina" (H47) represents still another means by which Casal's works came to be known outside of Cuba. This composition appeared in the 20 December 1890 issue of El Correo de la Tarde because the newspaper's director, Rubén Darío, had received a copy of Hojas from Casal and felt that this particular poem should be brought to the attention of Guatemalan readers. We know that a complimentary copy of Hojas had reached Darío because, in the 9 December 1890 issue of his paper, he inserted the following notice: "ECOS. - Hojas al viento. - Así se titula un tomito de poesías publicado en La Habana por Julián del Casal, remitido al Director de este diario con galante dedicatoria, de la cual está agradecido. Cuando lo leamos tendremos el gusto de hablar de él extensamente."

Casal also sent complimentary copies of Hojas to Mexico City, and one of the recipients was Luis G. Urbina. When Urbina read the book, he was profoundly impressed by the art of this stranger who, in his letter of 22 May 1890, had approached him in such a warm, fraternal manner. The following comment, written two years later, shows how enthusiastically Urbina reacted to Casal's first collection of verse: 
Np0

PLATE 11

Letter to Luis G. Urbina (22 May 1890)

Yatana 22 de othayo de.1890

S. 9 .

Lins S. Thbina

ctenque no nos

Lemos excontrado.nunca, ni nos encontronemas tal ves, como be nemos los musinos guistos, las sinsmas nostaleyas, los mis mos años y, sabre tido, comola vis ha échaido tanta somber en mestras inteligencias y-s.s mestros corasones; me parece gue somos. hermanos desco. nacribs peso que., decide lijos, nos podemas amas.

ctsi, pues, ini querio hermano, reciba unsted, con el abjinto ejemplar de mes pumepar mersor, lai dr

mera jumeba del profun do casiño gue le Radea su hermano eapisitial j. sw werclaiens idninion tuluán del Casal.

Sc tencenté-Rey 102

150 
Por muchas noches me deleité con la repetida lectura del libro que cuidadosamente guardo entre mis poetas favoritos y mis poetas amigos. Admiré desde entonces al bardo cubano, y en más de una ocasión, en corrillo de jóvenes literatos, en cualquier cuarto estudiantil de bohemio, envuelto en humo de tabaco, sentado a horcajadas en la silla y alguna vez saboreando tazas de café a grandes sorbos, he recitado las poesías de Casal, entre las cuales la que más gusto de decir, la que me produce fascinaciones de rara embriaguez, la que excita más mi temperamento, es $[L]$ a Canción de la Morfina. Y no sólo admiré a Casal, sino que lo quise. iTienen tanta franqueza, tanta verdad sus melancólicos escepticismos; creo notar tantas semejanzas entre su modo de sentir y el mío; lanza a veces quejas de dolor tan humano, que no puedo menos de admirar al poeta y de querer al hombre! ${ }^{34}$

Unfortunately, Urbina's enthusiasm was no match for his tendency to procrastinate; therefore, he never found time to acknowledge receipt of Hojas or to make Casal a gift of his own book, Versos (1890). ${ }^{35}$ Apparently offended by this lack of courtesy, Casal did not send Urbina a copy of Nieve. He did post one, however, to another young Mexican poet, José María Bustillos, and, as fate would have it, Bustillos immediately showed the book to Urbina. Partly because he still found Casal's work exceptionally interesting, and partly because he knew that it was only proper to settle the long-standing debt he owed his Cuban colleague, Urbina decided to write a review of Nieve. This review was published in installments in El Siglo XIX on 10 June, 26 July, and 30 July 1892. In it, Urbina - or Daniel Eyssette, as he called himself at the time ${ }^{36}$ - quoted from "La agonía de Petronio" (N5), "Galatea" (N11), "Una maja" (N19), and "Flores" (N41). This, then, was another means by which information about Casal and samples of his poetry came to circulate on the mainland.

Casal's gift-giving, as well as purchases made by Cuban readers, quickly depleted the stocks of Nieve. As a matter of fact, a notice in $\mathrm{El} \mathrm{Pais}$ indicates that, by 11 November 1892, no more than ten copies of the book could be found at La Galería Literaria, Casal's main distribution point in Havana. Under the circumstances, it is reasonable to assume that Nieve was completely unavailable by the spring of 1893 . Moreover, if Ciriaco Sos was right in affirming that Casal himself had paid for the publication of Nieve ${ }^{37}$ then there was little hope that additional copies would be printed, because the author's financial situation was quite precarious at the time. Thus, just when Casal's poetry was eliciting serious interest abroad, it became virtually impossible to obtain his latest book.

In order to fill the gap, a Mexican edition of Nieve was produced in 1893. Although the exact date of its appearance is not known, it seems that the edition was prepared while Casal was still alive. ${ }^{38}$ The book was 
printed by "El Intransigente" from the Cuban original. However, in addition to duplicating the fifty-four poems that Casal had written, "El Intransigente" also reproduced the review of Nieve that Luis G. Urbina had published in El Siglo XIX during the summer of $1892 .{ }^{39}$

Although hardly any reliable information about the Mexican edition of Nieve has been brought to light since 1893, one fact cannot be denied: because that edition came into being, there was a significant increase in the number of mainland readers who had an opportunity to see Casal's poems as components of a carefully organized whole, rather than as isolated compositions appearing on an occasional basis in foreign or domestic periodicals. By today's standards, the group that gained this advantage was small. Nevertheless, the members of this elite circle exerted considerable influence on contemporary culture. Indeed, through their involvement with the press - as directors of newspapers and journals, writers, financial backers, or simply subscribers - they helped set the literary fashions of the time and, in the process, did much to consecrate Casal's position as a leader of the Modernist Movement in Spanish America.

\section{Np0: Notes to Introductory Statement}

1 Although Casal was no longer a permanent staff member at the time, it appears that he first met Darío at the offices of El País (see par. 4 of Darío's "Films habaneros: El poeta Julián del Casal," as reproduced by Monner Sans in Julián del Casal y el modernismo hispanoamericano, p. 254).

2 Casal resigned his job in February 1891, but continued to live in his quarters above El País until the end of December 1892.

3 See his letter of 19 March 1891 to Esteban Borrero Echeverría, in the $E d$. del Cent., vol. III, pp. 84-87. The "impresiones literarias" to which Casal refers on p. 86 began to appear on 25 January 1891 and were finally collected and published under the title Bustos in 1893.

4 For additional evidence, see 11. 9-14 of the 5 April 1891 version of "Paisaje espiritual" (N28). The implications of these lines are discussed in Np4.

5 Ed. del Cent., vol. III, p. 85.

6 Manuel Márquez Sterling, "Julián del Casal," in Revista Azul, vol. II, no. 21 (24 March 1895), pp. 328, 329.

7 This information comes from the first of the twelve letters that Casal wrote to Gustave Moreau. The code reference C $1 / 23-25$ should be interpreted as Carta 1, lines 23-25. A transcription of all the letters appears in Robert Jay Glickman, "Julián del Casal: Letters to Gustave Moreau," Revista Hispánica Moderna, año XXXVII, nos. 1-2 (1972-1973), pp. 101-135. These letters bear the following dates: C1 (11 August 1891), C2 (15 August 1891), C3 (16 September 1891), C4 (1 November 1891), C5 (15 December 1891), C6 (17 February 1892), C7 (5 March 1892), C8 (16 March 1892), C9 (20 April 1892), C10 (5 June 1892), C1 1 (19 August 1892), C12 (1 January 1893). 
8 See the first part of his "Crónica semanal" ( $P, 2$ November 1890), in $E d$. del Cent., vol. III, pp. 21-22.

9 "La última ilusión" (HE, 29 January 1893), in Ed. del Cent., vol. I, p. 227.

10 See $E d$. del Cent., vol. III, p. 90; also N1.

11 As a matter of fact, in par. 3 of the letter quoted in Ed. del Cent., vol. III, p. 90, Casal makes specific reference to an "Introducción" in verse which would explain the meaning of the book's title.

12 Two notable exceptions in the latter category are "Paisaje de verano" (N46) and "Al carbón" (N50), which, though Parnassian in character, had to be excluded from $\mathrm{Np} 1, \mathrm{~Np} 2$, and Np3 for thematic reasons.

13 "Julián del Casal en su centenario," Estudios críticos (Havana: Biblioteca Nacional José Martí, 1964), p. 19.

14 Specific information on the lexical characteristics of Hojas, Nieve, and Rimas may be found in the Comparative Frequency lists contained in vol. III of the present edition.

15 See my discussion of $\mathrm{N} 8$.

16 A photograph of the handwritten original may be found in vol. III of the $E d$. del Cent. A comment by Casal on Rosario Armenteros, the lady for whom he wrote the poem, appears in "La antigua nobleza" (HE, 1 April 1888), Ed. del Cent., vol. I, p. 138.

17 I should like to express my gratitude to Professor Karl-Ludwig Selig for generously giving me permission to reproduce here and in my discussion of Np2 material which originally appeared in my article "Julián del Casal: Letters to Gustave Moreau," Revista Hispánica Moderna, año XXXVII, nos. 1-2 (1972-1973), pp. 101-135.

18 Manuel Márquez Sterling, “Julián del Casal," p. 329.

19 "Films habaneros: El poeta Julián del Casal," La Nación (Buenos Aires), 1 January 1911. A shorter version of this article, which dates from October 1910 , is presented in the Ed. del Cent., vol. III, pp. 129-132.

20 "Julián del Casal" ( $L, 23$ October 1893; HE, 29 October 1893), reproduced in Ed. del Cent., "Poesías," p. 295.

21 Monner Sans, p. 266.

22 See José Antonio Fernández de Castro, "Fragmentos de una correspondencia de Julián del Casal," Social, vol. VIII, no. 3 (March 1923), p. 13; Gustavo Duplessis, "Julián del Casal," Revista Bimestre Cubana, vol. LIV, no. 1 (July-August 1944), pp. 65-67; José María Chacón y Calvo, "En torno a un epistolario de Julián del Casal," Boletín de la Academia Cubana de la Lengua, vol. VII, nos. 3-4 (July-December 1958), pp. 346-373; and Casal, Ed. del Cent., "Prosas," vol. III, pp. 81-90.

23 I take this opportunity to express my thanks to M. Jean Paladilhe, Curator of the Musée Gustave Moreau, and to M. Pierre-Louis Mathieu, whose splendid cooperation was an invaluable asset to me in my research on the relationship between Casal and Moreau.

24 "Julián del Casal," p. 329.

25 This portion of Verlaine's commentary was quoted by Darío in his article 
entitled "Julián del Casal" (HE, 17 June 1894). Exactly when the letter was written and when it was published, however, is not known. Although it is assumed that the text as reproduced above is basically correct, the compiler of the present edition cannot vouch for the accuracy of every detail, since he has not seen the original, and each time the passage has been quoted by Casal scholars, minor changes in wording and punctuation have been introduced into it.

26 Havana: Imprenta y Papelería "La Prensa," 1893. It is also reproduced in the Ed. del Cent., "Poesías," pp. 367-402.

27 "Julián del Casal," in Estudios y retratos (Madrid: Librería General de Victoriano Suárez, 1911), p. 307. The article was originally published in Havana on 23 October 1893.

28 See Alfonso Herrera Frangutti, Martí en México: Recuerdos de una época (Mexico: Imprenta A. Mijares y Hno., 1969), pp. 13-15.

29 "Carta abierta" (F, 14 September 1890); Ed. del Cent., vol. I, p. 167.

30 "Recuerdos de Madrid. Un poeta mejicano: Francisco de Icaza" (HE, 3 February 1889); Ed. del Cent., vol. I, p. 200.

31 Ed. del Cent., vol. I, p. 166.

32 La Habana Literaria, vol. II, pp. 240 and 288.

33 "Julián del Casal," p. 328. For an over-view of Casal's interest in Mexico and his relations with Mexican authors, see Allen W. Phillips' excellent study entitled "Una nota sobre el primer modernismo: Julián del Casal y algunos poetas mexicanos," in his Cinco estudios sobre literatura mexicana moderna (Mexico: SepSetentas, 1974), pp. 21-37.

34 Nieve (Mexico: Edición de "El Intransigente," 1893), pp. ii-iii.

35 In his "Carta abierta" to Carlos Noreña, Casal made it clear that the book he was reviewing had not come to him as a gift from the author: "Rodando de mano en mano, un ejemplar que hay en la Habana y que pertenece a Pichardo, ha llegado hasta las mías" (Ed. del Cent., vol. I, p. 167). For his part, Urbina admitted that every time he wanted to thank Casal for Hojas, a voice would rise within him and insist: "No te apresures, ámale pero no le escribas" (Nieve, 1893, p. iii).

36 Urbina took this pseudonym from Alphonse Daudet's novel Le Petite Chose (1868). For additional information on Urbina's pseudonyms, see Gerardo Sáenz, Luis G. Urbina, vida y obra (Mexico: Ediciones de Andrea, 1961), p. 43, n.2.

37 Julián del Casal o un falsario de la rima, p. 32; Ed. del Cent., "Poesías," p. 401.

38 José María Bustillos sent a complimentary copy of the Mexican edition to Francisco M. Olaguíbel on 10 November 1893. No matter how good communications might have been at the time, it is difficult to believe that an edition of Nieve could have been prepared between the moment that news of Casal's death reached Mexico and 10 November.

39 The present writer was able to examine two copies of the Mexican edition. Because of their current location, these may be designated, respectively, as the Library of Congress (LC) version and the University of Toronto (UT) version. Curiously, the review of Nieve that appears in the LC version is signed "Daniel Eyssette," while the one in the UT version is signed "Luis G. Urbina." Furthermore, even though the article is listed in the table of contents as the initial 
item in the book and, like so many other prologues, is marked with Roman numerals, it actually appears at the end of both volumes in the form of an epilogue. A detailed comparison of Casal's text and Urbina's commentary in the two versions leads to the following hypotheses: either the LC and UT versions represent different stages in a single printing of the book, with corrections inserted whenever errors were noted during the course of production; or they represent two printings from one set of plates, with corrections made before the initiation of the second printing. Three considerations lend support to these hypotheses. 1) The type and format of both versions are the same from the first page to the last. 2) While both volumes have certain errata in common, some of the errors found in the LC version are rectified in the UT version. 3) The contrary is not true: that is, errors which appear in the UT version are not corrected in the LC version. If either of the above-mentioned hypotheses is accepted, then there is no logical reason to consider the change in signature from "Daniel Eyssette" to "Luis G. Urbina" as fundamentally different from the correction of any other error in the text as originally typeset. When added to the fact that both versions of the book were printed by "El Intransigente," these considerations oblige us to reject Andrés Henestrosa's suggestion that the so-called 1893 edition of Nieve may really have been two different editions published simultaneously in Mexico ("La nota cultural," El Nacional [13 May 1964], p. 3). 
$\mathrm{Np} 0$

TABLE 4

THE PUBLICATION OF CASAL POEMS IN MEXICAN, GUATEMALAN, AND COSTA RICAN PERIODICALS DURING THE AUTHOR'S LIFETIME: A TENTATIVE BIBLIOGRAPHY*

Abbreviations: CRI = Costa Rica Ilustrada

$\mathrm{CT}=$ El Correo de la Tarde

DC $=$ El Diario del Comercio

HCR $=$ El Heraldo de Costa Rica

$\mathrm{MR}=$ El Monitor Republicano

$\mathrm{PL}=$ El Partido Liberal

$\mathrm{U} \quad=$ El Universal

Work

Mexico

Guatemala

Costa Rica

\begin{tabular}{|c|c|c|c|c|}
\hline H36 & PL & $7 \mathrm{Jul} \quad 89$ & & \\
\hline $\mathrm{H} 40$ & PL & 17 Nov 89 & & \\
\hline $\left.\begin{array}{l}\mathrm{H} 26 \\
\mathrm{H} 37\end{array}\right\}$ & PL & 27 Jun 90 & & \\
\hline H 4 & PL & 10 Aug 90 & & \\
\hline $\mathrm{H} 47$ & PL & 14 Sep 90 & & \\
\hline H36 & PL & 21 Sep 90 & & \\
\hline $\mathrm{H} 40$ & PL & 12 Oct 90 & & \\
\hline $\mathrm{H}$ & & & CT & 9 Dec $90 \dagger$ \\
\hline $\mathrm{H} 47$ & & & CT & 20 Dec 90 \\
\hline $\mathrm{H} 40$ & & & CT & 3 Jan 91 \\
\hline $\left.\begin{array}{l}\mathrm{N} 40 \\
\mathrm{~N} 42\end{array}\right\}$ & & & CT & 10 Jan 91 \\
\hline $\mathrm{N} 23$ & & & & \\
\hline N41 & & & CT & $17 \mathrm{Jan} 91+\dagger$ \\
\hline $\mathrm{N} 48$ & & & & \\
\hline N23 & & & & \\
\hline N40 & & & & \\
\hline N41 & & & & \\
\hline N42 & & & & \\
\hline N48 & & & & \\
\hline $\mathrm{N} 43$ & & & CT & 18 Apr 91 \\
\hline N 3 & $\mathrm{U}$ & 10 May 91 & & \\
\hline N22 & $\mathrm{U}$ & $26 \mathrm{Jul} 91$ & & \\
\hline $\mathrm{H} 48$ & $\mathrm{U}$ & 2 Aug 91 & & \\
\hline N11 & PL & 6 Sep 91 & & \\
\hline N42 & DC & 7 Feb 92 & & \\
\hline
\end{tabular}

CRI 20 Feb 91 


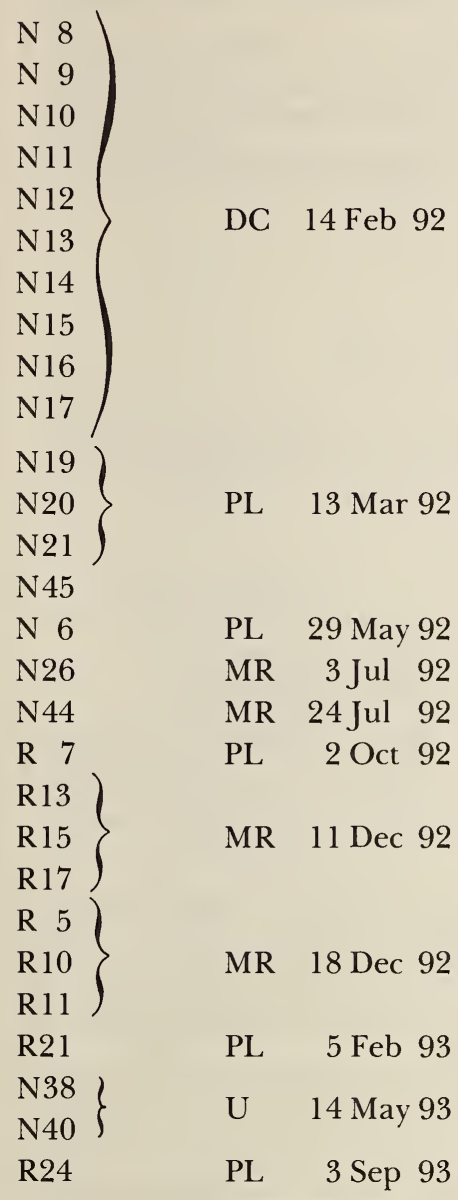

*Information supplied by Ernesto Mejía Sánchez.

$\nmid$ Rubén Darío announces receipt of a complimentary copy of Hojas. In " $E l$ Correo de la Tarde (1890-1891) de Rubén Darío," Revista Iberoamericana, vol. XXXIII, no. 64 (July-December 1967), p. 264, Otto Olivera indicates that "Quimeras" (H20) was published in CT on 13 December 1890.

$\dagger \dagger$ Olivera gives the date of publication as 14 January 1891 (loc. cit.). 


\section{N1: INTRODUCCION}

According to Esperanza Figueroa ("Bibliografía de Julián del Casal," p. 38), "Introducción" was published for the first time on 8 April 1892 in El Hogar. However, when the compiler of the present edition requested a photostatic copy of that version from Cuba, he was informed that the poem had not come out on 8 April, but on 8 May 1892. Since Nieve had been published before 8 May (see Np0), the El Hogar version does not fall within the scope of this study.

\section{Np1: BOCETOS ANTIGUOS}

A study of the "Bocetos antiguos" reveals that their sequence of appearance in Nieve did not correspond exactly to the order in which they were originally published in Havana journals:

\section{Order of Publication in Journals}

N2 "Las oceánidas"

N3 "Bajo-relieve"

N5 "La agonía de Petronio"

N4 "La muerte de Moisés"

(I) ${ }^{1}$ HE: 5 Oct

(II) HE: 19 Apr 91

N6 "El camino de Damasco" (V) HL: 30 Sep 91
Sequence in NIEVE

N2 "Las oceánidas"

N3 "Bajo-relieve"

N4 "La muerte de Moisés"

N5 "La agonía de Petronio"

N6 "El camino de Damasco"

This list suggests that Casal did not decide to collect poems under the heading "Bocetos antiguos" until after he published "Bajo-relieve." What is ironical, however, is that, when preparing Nieve for publication, he changed the order of precisely those poems which he had identified as part of the series and to which he had assigned a sequence number in the journals (i.e., "La agonía de Petronio" and "La muerte de Moisés"). Although it is impossible to offer conclusive proof showing why Casal rearranged the poems in 1892 , some theories about the matter can be formulated.

All five poems deal with personages drawn from antiquity: Prometheus, the gladiator, and Petronius belong to the Pagan tradition, while Moses and Saul of Tarsus belong to the Judeo-Christian tradition. The following chart shows that, by sequencing the poems as he did in the periodical version of "Bocetos antiguos," Casal was keeping the two traditions separate:

$P$

Prometeo

gladiador

Petronio
$J-C$

Moisés

Saulo 
By changing the order of "La agonía de Petronio" and "La muerte de Moisés" in 1892, however, Casal tacitly indicated that, although he may have originally intended to write a series of major poems on Pagan themes and to follow it with a series on Judeo-Christian ones, some other criterion for sequencing the poems had taken precedence by the time he began to prepare Nieve for publication.

The chart just presented suggests that chronology may have been the initial determinant of poem order, for it is plain that a chronological progression did exist within each group in the original series. ${ }^{2}$ Casal's 1892 change in poem sequence, however, made two things clear: first, that if an internal chronological order had existed before, it would not be emphasized now; and second, that pan-cultural chronology was not the main sequencing criterion in Nieve, for the gladiator of pagan Rome obviously did not precede Moses in the history of western civilization.

An examination of the contents of the poems suggests that the alteration in sequence may, in fact, have had a logical motive. One obvious common denominator is that each of the principal characters becomes a victim of external forces which change the course of his life. As we see from Prometheus, Moses, and Saul on the one hand, and the gladiator and Petronius on the other, those forces are either divine or human in origin. ${ }^{3}$ If the nature of the antagonist was to be the key factor in determining poem order, there is no doubt that the Nieve sequence was an improvement over the original one, for, as Plate 12 shows, the alternation of divine and human antagonists gave the series a better overall balance.

Although considerations of this sort may have had an influence on Casal, it seems likely that less abstract reasons induced him to alter the poem sequence in 1892. A glance at Plate 12 will show that a question of metrics may well have been at the heart of the matter. Of the five poems in the series, four were written entirely in hendecasyllables and one, "La agonía de Petronio," was a hybrid consisting of hendecasyllables and octosyllables (see my discussion of N5). Since all other poems in the group were hendecasyllabic, the eight-syllable verses of this composition stuck out like a sore thumb. Moreover, the content of the long octosyllabic section weakened the impact of the poem. These were two sound reasons for omitting Petronio's 50-line soliloquy from the Nieve version.

There is no doubt that suppression of the middle section made "La agonía de Petronio" a better poem. Nevertheless, this change had a surprising side effect which Casal could not have anticipated: it highlighted the similarity in imagery and tone that existed between "La agonía de Petronio" and "Bajo-relieve," the poem that came just before it in the original series. Awareness of this similarity would certainly have induced Casal to separate the two compositions in Nieve. Obviously, he had numerous possibilities as far as re-sequencing was concerned. His choice, however, was to switch the position of "La agonía de Petronio" and "La muerte de Moisés." At least three points can be listed in support of this 
PLATE 12

"Bocetos antiguos": Sequence in Journals Compared with Sequence in Nieve

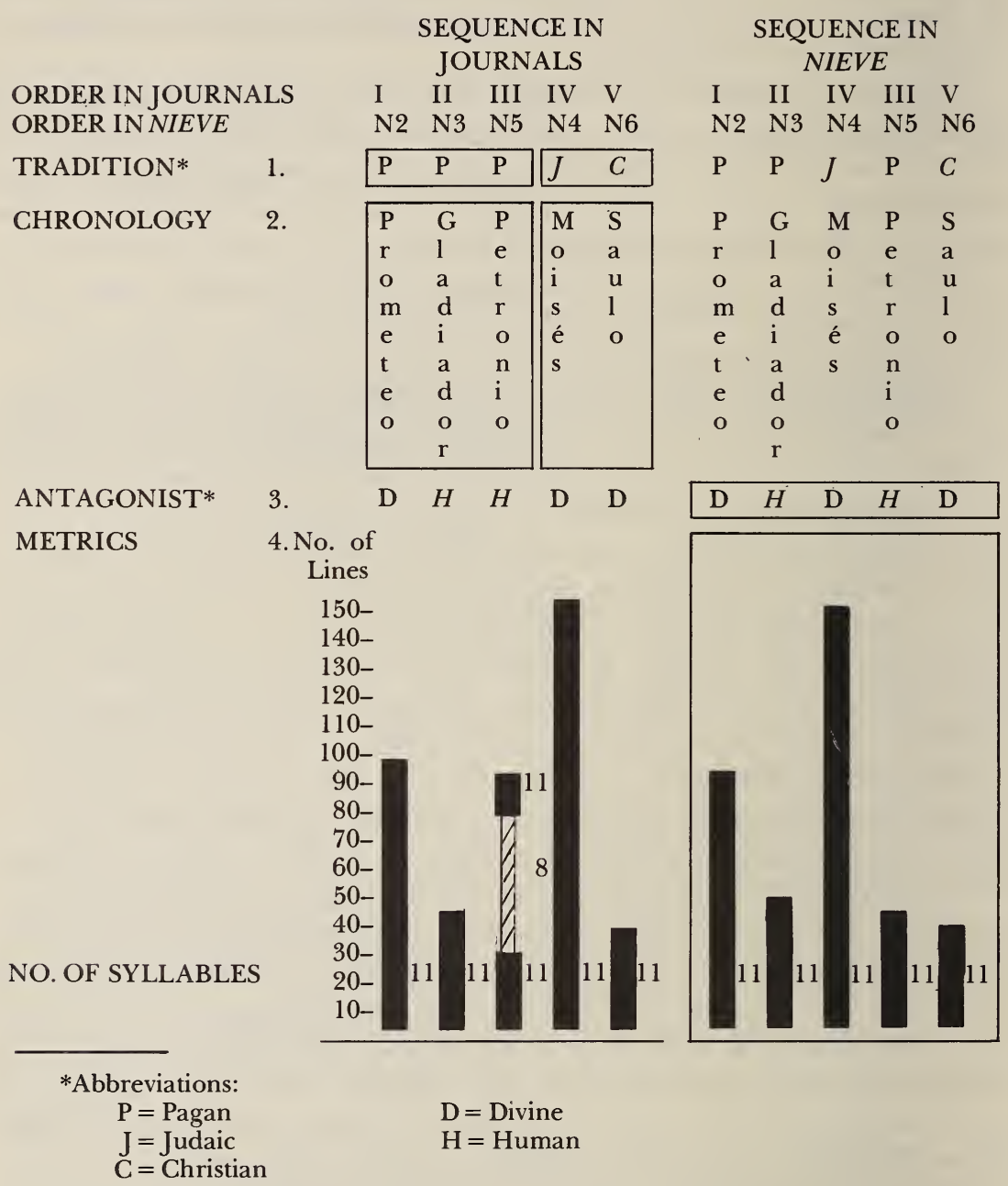

move: 1) "La muerte de Moisés," the longest and most important poem in the series, would occupy the central position. 2) The length, complexity, and dramatic force of "La muerte de Moisés" would make it virtually impossible for the reader of the new sequence to detect any similarity between "Bajo-relieve" and "La agonía de Petronio."4 3) By not juxtaposing the longest, most vivid poem - "La muerte de Moisés" - and the shortest, least dramatic - "El camino de Damasco" - at the end of the series, the finale of "Bocetos antiguos" would be much less anticlimactic 
than it would have been if the poems were kept in their original order. In other words, the change in poem position would improve the overall architecture of the series. This point is clearly demonstrated by Plate 12 .

\section{Np1: Notes to Introductory Statement}

1 Roman numerals in parentheses show poems that were not originally published under the rubric "Bocetos antiguos."

2 There is no anachronism in the "Pagan" group because, historically, the gladiator could have lived before, after, or at the same time as Petronius.

3 Cintio Vitier observes that all the poems of "Bocetos antiguos" have something in common: "se trata siempre de seres vencidos por una fuerza superior, omnipotente, muda ..." (“Julián del Casal en su centenario," p. 19). What Vitier fails to point out, however, is that the force which determines the destiny of each figure does not spring from the same source. When one considers that Casal lived his whole life in a tension that had been created within him by the great antithetical forces of the universe (cielo and tierra, alma and cuerpo), this is a most important distinction to make.

4 Casal did the same thing on a smaller scale elsewhere (see my discussion of the re-sequencing of stanzas in $\mathrm{H} 43$ ).

\section{N2: LAS OCEANIDAS}

This poem first appeared in La Habana Elegante of 5 October 1890. Like the Nieve version, it was dedicated "A Enrique José Varona."

In the $H E$ printing, the first line of each stanza was indented. In the Nieve version, there was no indentation of verses occurring in initial position within stanzas; stanzaic divisions were shown, instead, by the insertion of a blank line between strophes. In the $H E$ version, a new stanza began at 1. 13. Whether or not this verse was intended to have a similar function in Nieve is obscured by the fact that it was the first printed line on p. 8 and therefore could not be introduced by a blank line. In the present edition, l. 13 is indented in order to show that it is the beginning of a new stanza. The following considerations influenced this editorial decision: 1) the line was indented in the $H E$ version; 2) the Nieve format capitalization of the initial letter in every verse and no indentation of stanzas - in combination with the chance positioning of 1.13 at the top of a page would necessarily obscure the author's intentions concerning stanzaic division; 3) line 13 begins a new sentence and, with the exception of the short statements that introduce parts I, III, and IV (see ll. 1, 57, 89), each stanza is one sentence long.

As indicated above, Casal dedicated "Las oceánidas" to Enrique José Varona y Pera (b. Puerto Príncipe, 13 April 1849; d. Havana, 19 November 1933), one of the truly outstanding products of nineteenth 
century Cuba. Casal had numerous opportunities to meet Varona at the home of mutual friends like Esteban Borrero Echeverría; at informal gatherings such as those held at La Galería Literaria; at prestigious clubs such as El Círculo Habanero and La Caridad del Cerro; and at the editorial offices of periodicals like El Fígaro, La Habana Elegante, and La Habana Literaria. Whenever Casal wrote about Varona, he described him as a man of phenomenal intellect, spiritual refinement, and exquisite taste -a man who, just the opposite of himself, stood at the apex of human worth. The following list shows the occasions on which Varona's name comes up in the works of Casal, and indicates how Casal treated the great man in each instance:

6 May 88 Allí [in El Fígaro] escriben todos los literatos de nuestra patria, desde el eminente Varona, hasta el que tiene el honor de hablaros. ${ }^{1}$

13 May 88 Muerto su fundador, pasó la Revista de Cuba a ser dirigida por el Sr. Varona, quien la publica mensualmente, bajo el nombre de Revista Cubana, a satisfacción de sus lectores. Enrique José Varona es el primero de nuestros grandes hombres. Dotado de asombrosa inteligencia, se dedica a todos los ramos del saber humano. Filósofo eminente, goza de reputación universal, hasta el extremo de que su libro de Lógica sirve de texto, por exhortaciones de Ribot, en algunos institutos franceses; poeta exquisito, cincela sus joyas poéticas, con escrupulosidad de antiguo orfebrero florentino, para deleite de los espíritus refinados; orador notabilísimo, hace pensar, a su inteligente auditorio, en que así debían expresarse los grandes oradores de las academias de Atenas; crítico profundo, ejerce magistralmente su misión, siendo considerado su juicio como el fallo definitivo de cualquier punto científico y literario. Varona es, en resumen, una figura enciclopédica que podría brillar esplendorosamente en el cuadro del más grandioso de los siglos. ${ }^{2}$

14 Sep 90 Un crítico debe ser un hombre como Varona o Lemaitre, tan inteligente como sensible, porque hay obras creadas con la inteligencia, a la par que con el corazón, capaz de comprenderlo todo, de ponerse al diapasón de todos los artistas, hasta de los que sean opuestos a su temperamento, a sus ideas y a sus gustos. No ha de ver la obra como debiera ser, sino como es. Pasa con los libros lo mismo que con los cuadros: si no se coloca uno en el punto de vista necesario, nada podrá ver. iY hay tan pocos críticos que se coloquen bien! ${ }^{3}$ 
PLATE 13

Enrique José Varona

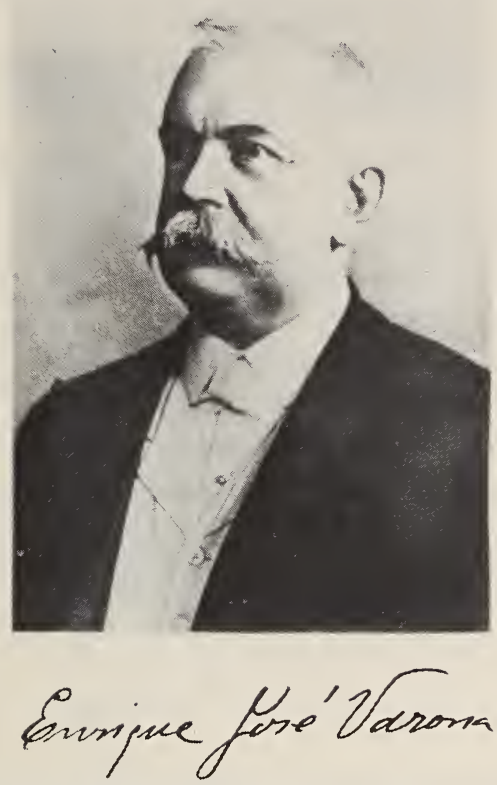

From William Belmont Parker, Cubans of To-day. Courtesy of The Hispanic Society of America, New York.

5 Oct 90 [Casal dedicates "Las oceánidas" to Varona.]

30 Nov 90 . . La Habana Elegante, semanario en que han colaborado todos los escritores de nuestros días, desde el eximio Enrique José Varona hasta el que firma Julián del Casal. ${ }^{4}$

26 Apr 91 Hombre de pensamiento, más bien que de acción, el señor Varona se consagró a servir a su patria, no con el arma en la mano y el odio al enemigo en el corazón, sino tratando de adquirir, en la soledad del gabinete de estudio, el mayor número posible de conocimientos, los cuales debían de proporcionar más tarde, al solidificarse en su inteligencia, poderosos elementos a la cultura de su país. . . . Así ha contraído méritos el señor Varona para con su patria, ofreciendo el caso singular de haber llegado a ser un gran escritor en un medio propicio para realizar toda clase de empresas, menos para las intelectuales, lo cual demuestra que poseía una vocación más sólida que ningún otro escritor cubano y que es un hombre que ama verdaderamente su Ideal, amor que no ha visto justipreciado por su pueblo, 
porque no teniendo éste más que el de la vida material, difícil le sería comprender que un individuo pueda perseguir otro más noble, más elevado, más inmaterial. ${ }^{5}$

25 May 91 [Casal indicates that he wanted Esteban Borrero Echeverría to lend him some of Juana Borrero's poems so that he could write an article about them.] No sé si le dejé entrever mi propósito, pero en vista de que usted no me daba las composiciones, me resigné a dejar de escribir el artículo que ya tenía totalmente concebido. Después me conformé también con que fuera Varona el que diese a conocer esos versos encantadores, porque su juicio sería más valioso para su niña que mi artículo impresionista ....

No creo que haya habido aquí, en ninguna época, un solo poeta que haya escrito un soneto tan perfecto a esa edad, ni creo que entre los que hoy escriben versos, no siendo Varona, exista quien la pueda igualar. ${ }^{6}$

Oct 93 [Casal uses his 26 April 1891 review of Varona's Artículos y discursos as the second essay in Bustos.]

In contrast to the constancy of Casal's position towards Varona, there seems to have been a deterioration in Varona's esteem for Casal. As soon as Hojas came out in May 1890, Varona wrote an extremely benevolent review and hastened to include it in the May issue of his Revista Cubana. When Nieve came off the press, however, Varona remained silent for some three months. Finally, he published a review of the book in the August issue of the Revista Cubana. On this occasion, his treatment of Casal was not as kind as it had been in 1890. Varona made it plain that Casal was a talented poet-that was something which, in good conscience, he was obliged to admit. Nevertheless, he purposely chose to be the Devil's advocate and, instead of emphasizing the virtues of Casal's art, he took pains to highlight its shortcomings. Indeed, Varona found so many things to say against Nieve that enemies of Casal - men like Ciriaco Sos, for example - were emboldened to attack Casal first with the weapons that Varona had put into their hands, and then with weapons that they forged themselves in their private arsenals of animosity.

\section{N2: Notes to Introductory Statement}

1 "La joven Cuba. Galería Mignon: Manuel Serafín Pichardo" ( $H E$, 6 May 1888), Ed. del Cent., vol. I, p. 194.

2 "La prensa" (HE, 13 May 1888), Ed. del Cent., vol. I, p. 146.

3 "Carta abierta" (F, 14 September 1890), Ed. del Cent., vol. I, p. 167. Varona's critique of Nieve and his short obituary on Casal (see Appendix A) 
suggest that Casal may have overestimated Varona's ability to respond sympathetically to artists whose temperament, ideas, and tastes differed from his own.

4 "Crónica semanal" ( $P, 30$ November 1890), Ed. del Cent., vol. III, p. 41.

5 This statement originally appeared in $H E$ as part of Casal's review of Artículos $y$ discursos, a book that Varona published in 1891. Casal later included the article in Bustos under the title "Enrique José Varona." The passage cited above may be found in Bustos y rimas, on pp. 29 and 32, or in the Ed. del Cent., vol. I, pp. 251-252.

6 Ed. del Cent., vol. III, pp. 87-88.

\section{N2: VARIANTS}

l. $H E$

9 estepas.

$10 \mathrm{Y}$

* 13 ( $(\mathbb{I})$ Hosco

17 leyes

Potencias

19 (absent)

20 Prometeo,

21 [s]obre el cual,

22 carnicero,

23 Typhon

32 peñón sereno,

35 noche,

47 hermosas,

51 pías

62 supremas

67 vista,

72 es leon

98 [d] evorando la entraña a
$N$

estepas,

[y]

Hosco

manos

potencias

donde solo la espuma llegar puede,

Prometeo

[y] sobre él,

carnicero

Tifón

peñasco negro,

noche

hermosas

todas

supremas,

vista

es el león

[t]orturando al vencido
GLIC

$H E$

$N+$ sólo

\section{N2: Note to Variants}

13: For the rationale behind the indentation of 1.13 in the present edition, see my introductory comments on the poem.

\section{N3: BAJO-RELIEVE}

"Bajo-relieve" was first published in the 19 April 1891 issue of $L a$ Habana Elegante. On 2 May 1891, it appeared in El Pueblo. Neither of these early versions carried a dedication. In Nieve, however, the poem was dedicated "A Vivino Govantes y Govantes." Although no information has 
come to light on the nature of Casal's relationship with Govantes, it is known that Govantes was active on the Cuban cultural scene during the period of Casal's formation as a writer. In 1884, he published a book of Ensayos poéticos (Havana: Imprenta El Adelanto), with a "Carta-prólogo" by José Fornaris. In 1885, the Imprenta de Alvarez, Pérez y Cía. of Havana brought out Rosalía (Tradición cubana) and Contra el danzón (Sátira). Govantes' bibliography also includes one-act plays such as Certamen de bellezas and Los amoríos de Luisa.

\section{N3: VARIANTS}

\section{l. $H E$}

4 brazo robusto.

13 [m]oviendo

14 patricias,

15 cortesanos,

* 17 ( ()Turbando la fatiga

20 - i Necesita

24 extraordinario

26 todavía

29 hetaíra.-Y

32 la devorante

36 brazos.

38 freste, [sic]

40 indiferente,

43 manos,

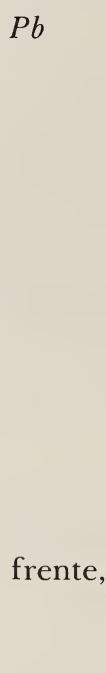

\section{$\mathrm{Pb}$}

$N$

robusto brazo.

[a]bierto

patricias

cortesanos

Sacudiendo el

(ף) $+N$

cansancio

-Necesita

$H E$

extraordinario,

todavía,

hetaíra-Y [sic]

hetaíra. - iY

\section{N3: Note to Variants}

17: In the $H E$ and $P b$ versions, this verse was the initial line of the second stanza. In $N, 1.17$ was printed at the top of p. 14; and, since indentation was not used to show stanzaic divisions, it appears that the text was meant to flow from the preceding page without a stanza break. It is felt that this was not Casal's intention, however, but resulted by chance when the poem was typeset (see $\mathrm{N} 2 / 13$, which is a similar case). Therefore, in the present edition, the verse is indented as it was in the periodical versions.

\section{N4: LA MUERTE DE MOISES}

This poem was first published in La Habana Elegante of 7 June 1891. Like the later Nieve version, it was subtitled "Leyenda talmúdica" and was dedicated "A la Sra. Aurelia Castillo de González." In both versions, it was subsumed under the heading "Bocetos antiguos." However, in $H E$ the 
PLATE 14

Aurelia Castillo de González

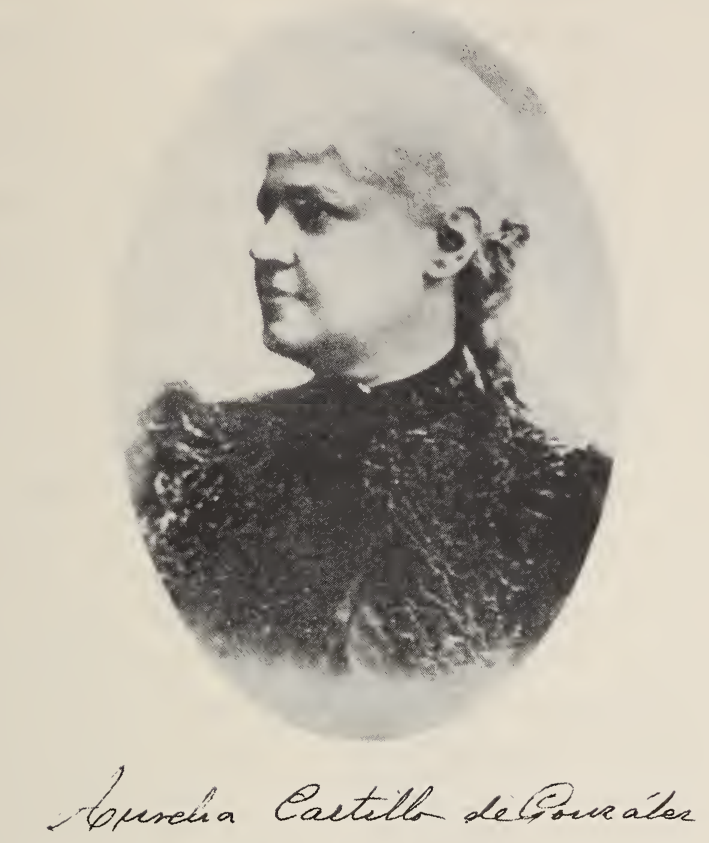

From William Belmont Parker, Cubans of To-day. Courtesy of The Hispanic Society of America, New York.

poem was numbered as fourth in the series, while in Nieve it appeared in third position. The reasons that may have prompted Casal to make this change are discussed in my general introduction to "Bocetos antiguos" (see Np1).

As indicated above, "La muerte de Moisés" was dedicated to Aurelia Castillo de González (b. Camagüey, 27 January 1842; d. Camagüey, 6 August 1920). Doña Aurelia made her formal debut as a writer in 1869 and soon became a figure of note in the world of Cuban letters. In 1874, Doña Aurelia married Francisco González del Hoyo, a major in the Spanish army. The following year, Don Francisco was ordered to return to Spain for political reasons: apparently, he had openly criticized the authorities for executing Antonio L. Luaces and Miguel Acosta. Despite her anti-Spanish feelings, Doña Aurelia dutifully accompanied her husband to the madre patria.

In 1889, Don Francisco retired from military service with the rank of lieutenant colonel. After this, the Gonzálezes spent several months touring France, Switzerland, and Italy. ${ }^{1}$ When their tour of Europe was over, they returned to Cuba. There, Doña Aurelia had an opportunity to read 
Hojas al viento and some of the new poems that Casal was preparing for his next book, Nieve. ${ }^{2}$ She was most favorably impressed by the young poet and, on at least one occasion, invited him to spend a day at her home in Guanabacoa. ${ }^{3}$ Casal, in turn, developed an intense admiration for Doña Aurelia and paid public tribute to her on 7 June 1891 with "La muerte de Moisés" and on 12 July 1891 with the article entitled "Aurelia Castillo de González." Not only was she an incarnation of one of his ideals of womanhood, ${ }^{5}$ but she actively encouraged him in his literary endeavors. Of special importance to him was the fact that she tried to bring his work to the attention of French literary figures who otherwise might never have known of its existence. ${ }^{6}$

Aurelia Castillo's bibliography consists of five major works: Fábulas (1879), Biografía de Gertrudis Gómez de Avellaneda y juicio crítico de sus obras (1887), Un paseo por Europa (1891), Un paseo por América (1895), and Ignacio Agramonte en la vida privada (1912). In 1913, upon deciding to publish her collected works, Escritos, she instructed her publisher to print only 60 copies of the book-and this, despite the fact that it was six volumes long. Her explanation of this severe limitation is a reflection of her basic humility: "con ese número basta para que guarden mis escritos algunos amigos íntimos. Una tirada mayor haría pensar que yo creo que mis trabajos son dignos de perpetuarse." " Afterward, she was surprised to learn that her publisher had disregarded her request and had printed 100 copies of the book. In addition to her major works, Dona Aurelia produced many short pieces. Among them are historical studies of Jicoténcal and Doña Marina; literary articles concerning Julián del Casal, Manuel Márquez Sterling, Mercedes Matamoros, Ramón Meza, and Nieves Xenes; translations of poems by Carducci, D'Annunzio, Vittoria Aganoor, Ada Negri, Byron, Coppée, and Lamartine; and original poems such as "Adiós de Víctor Hugo a la Francia de 1852," "Pompeya,"8 "A 'La maja' de Casal" (see N 19), and "Al autor de la bellísima poesía 'Nihilismo" " (see R3). ${ }^{9}$ On 2 January 1911 , almost eighteen years after Casal's death, the memory of the poet was still so vivid in Dona Aurelia's mind that she wrote the moving eulogy entitled "Amor supremo: A la memoria de Julián del Casal." This poem is to be found in the Ed. del Cent., "Poesías," pp. 357-360.

\section{N4: Notes to Introductory Statement}

1 As of 7 June 1890, they were still abroad (see Ed. del Cent., vol. II, p. 145).

2 It is not known whether Casal visited Dona Aurelia when he made his trip to Spain in the winter of 1888-1889.

3 See Ramón Meza, “Julián del Casal,” Ed. del Cent., "Poesías,” p. 247.

4 This article was originally published in $H E$ and was inserted into Bustos two years later. According to A. Miranda, it was the last section of Bustos that Casal was able to proofread before he died (see "Anécdota," Ed. del Cent., "Poesías," pp. 294-295). 
5 See Bustos y rimas, pp. 51-55.

6 On p. 329 of his article entitled "Julián del Casal," Manuel Márquez Sterling quotes the poet as follows: "Da. Aurelia Castillo de González le [sic] dio mis versos a algunos poetas franceses, y la hija de Gautier me escribió una bonita carta que voy a leerle a vd." Unfortunately, this letter was never published and is now probably lost.

7 Ed. del Cent., vol. III, p. 145.

8 "Pompeya" was first published in La Revista Cubana in 1890. Casal commented on the poem in a two-part article that came out in La Discusión on 6-7 June 1890. This commentary is reproduced in the $E d$. del Cent., vol. II, pp. 143-147. In 1891, Doña Aurelia republished "Pompeya" in Un paseo por Europa.

9 Doña Aurelia also assisted Gonzalo de Quesada y Aróstegui in preparing his edition of Martís Versos libres. Her contribution in this undertaking is evaluated by Ivan A. Schulman in the introduction to José Martí, Versos libres (Barcelona: Editorial Labor, 1970), pp. 37, 41.

\section{N4: VARIANTS}

l. $H E$

* 6 las [sic]

12 desierto,

17 campiñas,

23 los tropeles

28 pesadumbre,

30 negro a la

47 el tiempo,

67 la mirada

73 señor,

* 79 montaña,

87 ( 1 )Al sentir

91 acentos [sic]

93 pesares,

95 palmares;

96 grata,

* 105 consagrado

135 fiereza,

136 [a]sí yo

148 plegaria,
N

los

desierto

campiñas

las legiones

pesadumbre

negro la

el tedio,

las miradas

montaña

Señor,

$H E$

(ף)Sintiendo

acentos:

pesares

palmares:

$H E$

grata

consagrado,

$H E$

fiereza;

[a]sí yo,

plegaria

\section{N4: Notes to Variants}

6: It is presumed that the "las aromas" of the $H E$ version was a typographical error because, in this context, the meaning of the feminine form (i.e., flor del aromo) is clearly inconsistent with the sense of the sentence.

79: The comma of the $H E$ version is restored after montana in order to avoid 
ambiguity with respect to the proper antecedent of the adjective inerte (i.e., Moisés).

105: The $N$ version seems inferior to the $H E$ version because the comma inserted at the end of 1.105 emphatically separates two parallel statements which are both introduced by tras and which, together, form a conceptual unit. For this reason, the $H E$ version is restored in the present edition. Whether a comma is used or not, the fact remains that Casal committed a syntactical error here: while both past participles (consagrado and proclamado) are dependent on the auxiliary verb haber, the enclitic -te properly applies only to consagrado (i.e., tras de haberte consagrado mi vida); in contrast, no enclitic should be used with proclamado (i.e., tras de haber proclamado tu gloria en las opuestas zonas de la tierra).

\section{N5: LA AGONIA DE PETRONIO}

"La agonía de Petronio," bearing the dedication "A Francisco A. de Icaza," first appeared in La Habana Elegante of 17 May 1891. A photograph of this version is shown on p. 172 of the present edition. When certain features of this version are examined in the light of information drawn from other sources, they enable us to understand more clearly not only the development of the poem itself, but also its role in the evolution of "Bocetos antiguos." Four points are of special interest:

1. The series title "Bocetos antiguos" appeared for the first time not with "Las oceánidas" on 5 October 1890 or with "Bajo-relieve" on 19 April / 2 May 1891, but with "La agonía de Petronio" on 17 May 1891.

2. Casal introduced the original version of the poem with an epigraph taken from Le Jardin de Bérénice (Paris: Librairie Académique Didier, 1891), a novel by Maurice Barrès (b. Charmes, 19 August 1862; d. Neuilly-sur-Seine, 4 December 1923). Since this book was published shortly before the $H E$ version of "La agonía de Petronio" came out, it is obvious that Casal had very rapid access to the works of Barrès. Casal, of course, was not the only modernista to read and appreciate this author Silva, for example, had the Trois Stations de psycothérapie at his bedside on the tragic morning of 24 May 1896, and Darío mentioned Barrès six times in Los raros alone - but he was one of the earliest admirers of Barrès in Spanish America. Although he was sufficiently impressed by Le Jardin de Bérénice to use a portion of it as an epigraph to the original version of "La agonía de Petronio," Casal decided to omit the passage from the Nieve version of the poem. The following consideration may have prompted him to do this: since none of the other poems of "Bocetos antiguos" had an epigraph, it would look rather strange if "La agonía de Petronio" had one -and such a long one, at that. He could have removed this inconsistency, of course, by transferring the quotation to the page on which the series title appeared. However, this would have been inconsistent with his nor- 
mal practice of not using epigraphs to introduce a series of poems. ${ }^{2}$ The simplest solution, therefore, was to suppress the quotation altogether.

3. In the $H E$ version of "La agonía de Petronio," the Roman numeral beneath the epigraph shows that, in Casal's original plan, this poem was to be the third composition in the "Bocetos antiguos" series. When Nieve came out, however, the poem was in fourth position. Some factors which may have led Casal to make this change are presented in my discussion of $\mathrm{Np} 1$ and in par. 4, below.

4. As far as content is concerned, the original version consisted of three parts, each of which was introduced by Roman numerals. Part I was divided into 5 stanzas of 6 hendecasyllabic lines each; part II, into 5 stanzas of 10 octosyllabic lines; and part III, into 2 stanzas of 6 hendecasyllabic lines. Before publishing Nieve, Casal made a radical change: he completely eliminated the fifty verses of part II. In order to cover traces of the excision, he simply modified the last line of part I and the first line of part III. There is no doubt that this deletion made "La agonía de Petronio" much more dramatic than it had been before. Nevertheless, the change within the poem gave rise to a problem that Casal could not have foreseen: with striking clarity, it brought out the fact that "La agonía de Petronio" shared basic similarities in imagery and tone with "Bajorelieve," the poem that immediately preceded it in the original "Bocetos antiguos" series. When Nieve appeared, the poems were separated by the longest composition in the group, "La muerte de Moisés." Obviously, Casal had realized that it would have been a mistake to keep N3 and N5 in juxtaposition.

It will be noted that Casal dedicated both versions of "La agonía de Petronio" to Francisco A. de Icaza. This writer (b. Cuidad de México, 2 February 1863; d. Madrid, 28 May 1925) left his homeland in 1886 as an aide to General Vicente Riva Palacio, Mexico's Minister Plenipotentiary to Spain. About two years later, Casal met Icaza, who was then acting as Second Secretary of the Mexican Legation in Madrid. According to Enrique Hernández Miyares, "En Madrid [Casal] no tuvo otro compañero que Icaza, diplomático mexicano que honra las letras castellanas, y Salvador Rueda que se le asemejaba mucho en las aficiones." ${ }^{3}$ Casal's most extensive commentary on Icaza is "Recuerdos de Madrid. Un poeta mejicano: Francisco de Icaza." This article was published in the 3 February 1889 issue of La Habana Elegante. A passage from it is quoted in my introduction to $\mathrm{H} 25$, and the whole article is reproduced in the $E d$. del Cent., vol. I, pp. 199-203. At the end of the article, Casal lamented the fact that: "Aunque el Sr. Icaza ha escrito un número crecido de composiciones, cuyas bellezas, sonoridades y esplendores quisiera yo detallar, no ha publicado ningún volumen todavía, como la mayor parte de los poetas mejicanos, la cual no se digna coleccionar sus versos, a semejanza de los árboles que nunca se inclinan a recoger los frutos de oro que han dejado caer en el suelo" (p. 203). Casal next mentioned Icaza on 14 September 


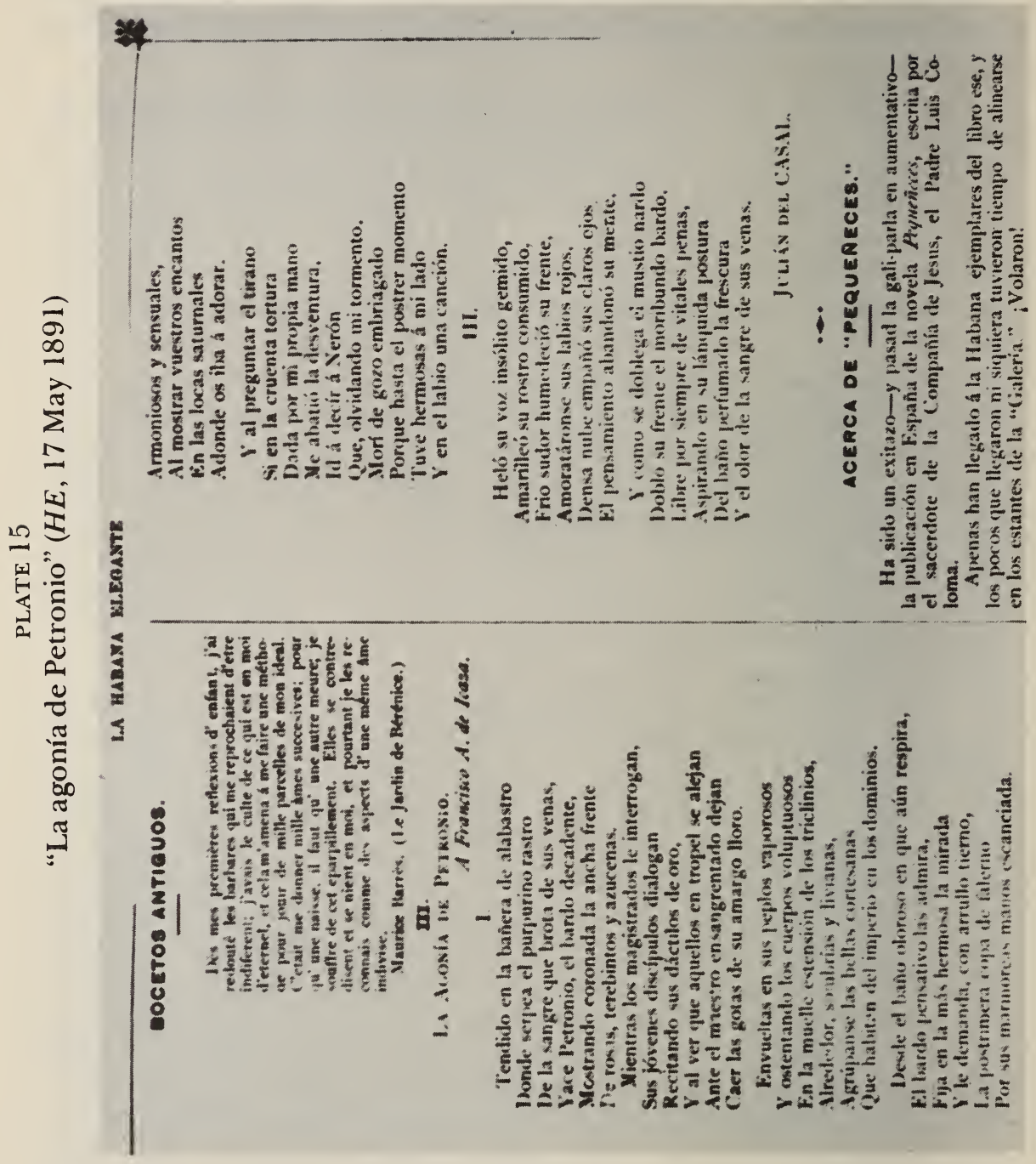




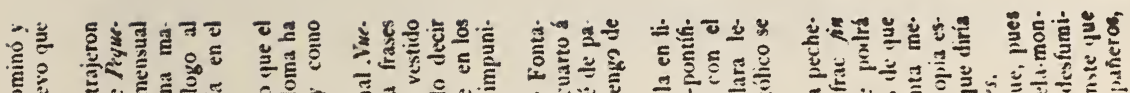
है

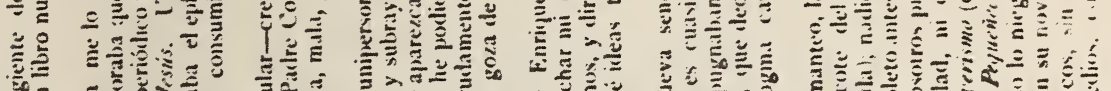

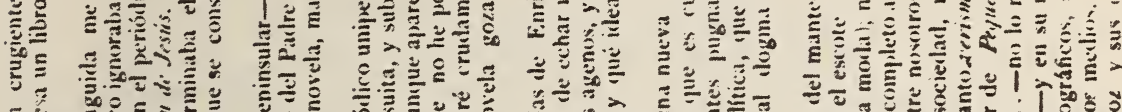

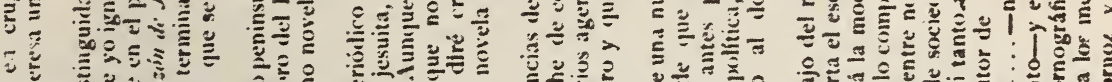

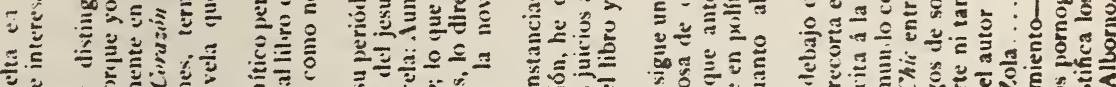

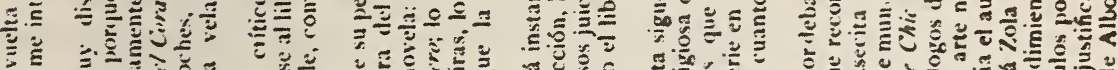

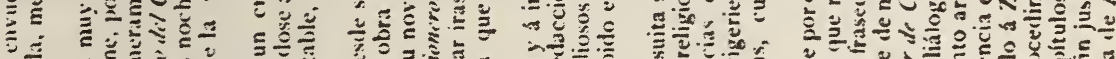

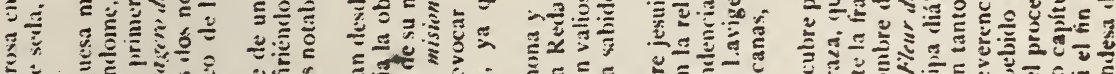

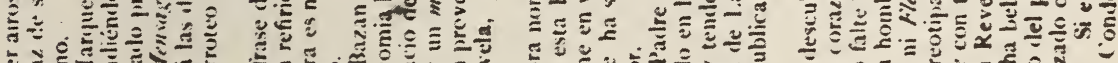

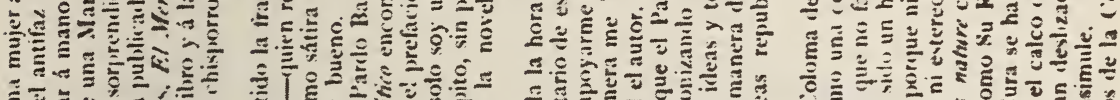

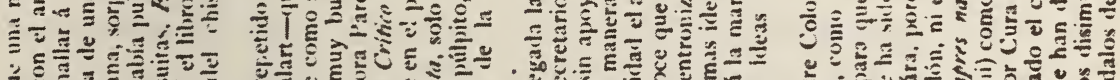

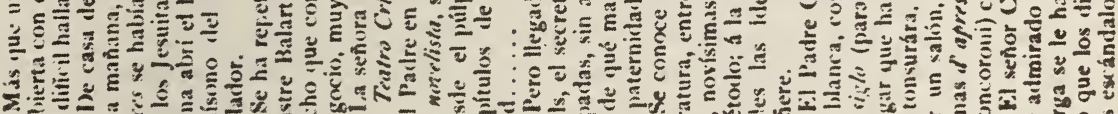

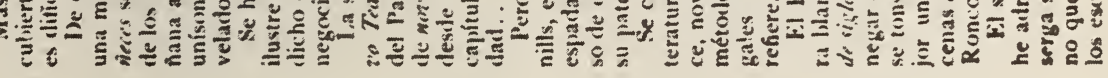

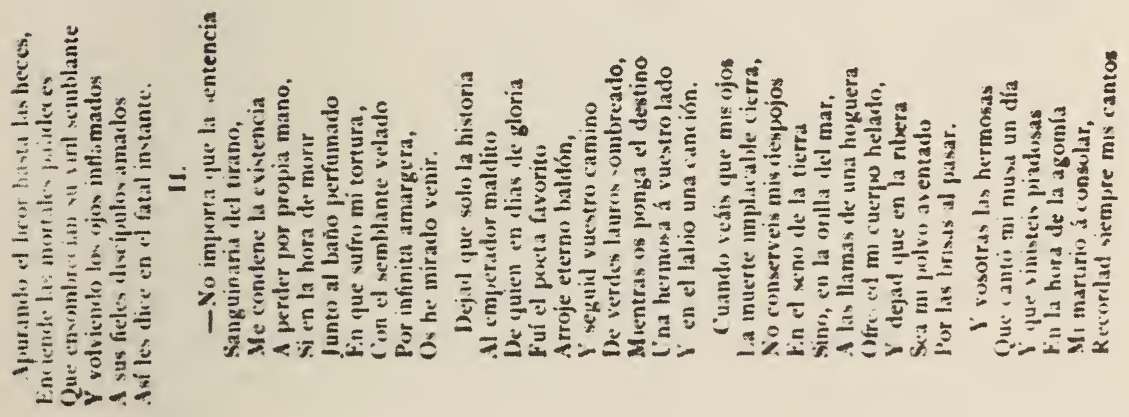


1890 in the "Carta abierta" to Carlos Noreña, which he published in El Figaro. In this piece, he expressed the same regret about Icaza's failure to publish. If Casal had lived into the twentieth century, he would have seen an end to this disappointment, for Icaza brought out four collections of poetry-Efimeras (1892), Lejanias (1899), La canción del camino (1906), Cancionero de la vida honda y de la emoción fugitiva (1922); translations of works by authors such as Turgenev, Nietzsche, Hebbel, Liliencron, and Dehmel; and numerous studies in prose.

\section{N5: Notes to Introductory Statement}

1 This passage, without the errata of the $H E$ version, can be found on p. 94 of the 1891 edition of Le Jardin de Bérénice. It is interesting to note that Barrès later changed the last line of the passage. In the definitive edition of his novel (Paris: Librairie Plon, 1921), the line reads as follows: "Dans cette succession d'imperfections, j'aspire à me reposer de moi-même dans une abondante unité. Ne pourrais-je réunir tous ces sons discords pour en faire une large harmonie?" (p. 66).

2 The most notable exception to this rule is the quotation from Baudelaire's "Bénédiction," which is found at the beginning of Rimas (see Rp0).

3 "Julián del Casal, patriota," Obras completas, vol. II, p. 36; Ed. del Cent., "Poesías," p. 307.

\section{N5: VARIANTS}

l. $H E$

3 brota

9 [r]ecitando

14 [y] ostentando

19 oloroso

$*$

27 ensombrecían semblante

* 30 [a]sí les dice en el fatal

instante.

31 (ף)Heló su voz insólito

35 ojos,

36 mente,

37 nardo

38 frente

39 vitales

40 lánquida [sic]

41 baño perfumado
$N$

corre

[o] recitan

[y] tendidos

fragante

respira

oscurecían

semblante,

[h]áblales triste en el postrer instante,

(đ)[h]asta que heló su voz mortal ojos

$H E$
GLIC

$H E$

obscurecían

mente.

nardo,

cuello

mortales

lánguida

agua perfumada 
19: The $H E$ version is restored because the end-of-verse blank in 1.19 is considered to be insufficient punctuation: the absence of a comma at the end of the adverbial clause that introduces the sentence may lead to a reading in which bardo of 1.20 is erroneously associated with respira, instead of with admira, the verb that it directly governs.

30: Fifty lines of the $H E$ version were suppressed in $N$. For the original, see Plate 15.

\section{N6: EL CAMINO DE DAMASCO}

The first printed version of "El camino de Damasco" appeared in the 30 September 1891 issue of La Habana Literaria. When Casal prepared the poem for publication in Nieve, he made several modifications in wording and punctuation, and added the dedication "A Manuel Gutiérrez Nájera."

It is evident that Casal learned about current literary developments in Mexico City from Carlos Noreña, who returned to Cuba from that "París americano" in 1886 or $1887 .^{1}$ In spite of this, Casal did not make a significant public statement about Nájera until 3 February 1889, when, in a prelude to his comments on the literary art of Francisco A. de Icaza, he described Nájera as such a notable stylist and such an exquisite poet, "que parece un escritor francés de la escuela parnasiana, vertido correctamente al castellano ...."2 Casal's next reference to Mexico appeared in his open letter to Carlos Noreña, which came out in El Fígaro on 14 September 1890. On this occasion, he lamented the fact that Nájera, like so many of his talented contemporaries in Spanish America, had not published a collection of his poetry. ${ }^{3}$ It must be emphasized, however, that Nájera's failure in this regard did not mean that his works were not known outside of Mexico. As a matter of fact, a considerable number of his poems, stories, and articles reached even the most distant parts of the Hispanic world. The principal transmission media, of course, were the Mexican periodicals for which he wrote. Because several of these were sent to Cuba on a regular basis (see my discussion of $\mathrm{Np} 0$ ), some readers on the island had direct access to his work; and, because a few of those readers were themselves editors of journals, they had the power to disseminate Nájera's work even further by inserting selected items into their own publications. Thus, for example, Enrique Hernández Miyares and Alfredo Zayas reproduced one of Nájera's "Cartas del jueves" in the 15 February 1892 issue of La Habana Literaria. In this piece, which is of particular interest to students of Casal, Nájera stated that writers from all parts of Latin America had been sending him copies of their books, but that his obliga- 
tions as a journalist prevented him from examining them with the care they deserved:

Aquí están, por ejemplo, las obras poéticas completas del excelso poeta Numa Pompilio Llona, el más opulento de los poetas latino-americanos, el magnífico Benvenuto del soneto; las tersas, límpidas, poesías de Rafael Obligado, olorosas y cuajadas de brillantes como las rosas recién abiertas al amanecer; el hechicero "Azul" de Rubén Darío, aladino maravilloso, el rey del color, príncipe veneciano de cuya elegantísima escarcela siempre van cayendo perlas; el sorprendente, extraño y ad mirable Tabaré de Juan Zorrilla de San Martín; las "Páginas al viento" [sic] de Julián del Casal, mi muy querido hermano en Banville y en Gautier; la preciosa [anto]logía de Centro América que ha tenido la exquisita bondad de enviarme mi viejo amigo Don Ramón Uriarte; las interesantísimas "Crónicas potosinas" del insigne literato Don Vicente G. Quesada, ministro en Washington y en México de la República Argentina; el "Revoltillo" y las "Páginas sueltas" que ha publicado en Curazao un crítico de mucho talento, Don Gonzalo Picón Febres; las "Páginas del Ecuador," escritas en viril y gallardo estilo por la hermosa María de Veintimilla; algunos versos bellísimos de Ismael Enrique Arciniegas; el "Paseo por Europa," impreso en la Habana y que recibo en este instante, escrito por la Sra. Aurelia Castillo de González y varios otros libros y publicaciones cuyos títulos no recuerdo: todos recibidos en menos de tres meses, todos requiriendo lectura atenta, detenido estudio, y yo, en el remolino de la prensa, sin poder fijarme un solo instante en esas almenas de feudal castillo, en esas volutas airosas, en esas cornisas de encaje, en esos árboles hospedadores de canciones, en esos lirios que se columpian blandamente. ${ }^{4}$

This "Carta del jueves" was published in Havana only a few weeks before Nieve went to press. If Thursday letters such as this were Nájera's way of "saldando cuentas poco a poco, siquiera sea en menudos abonos,", then it is not unreasonable to interpret Casal's act of dedicating the Nieve version of "El camino de Damasco" to Nájera as a gesture of gratitude also. After all, even though Nájera had erred about the title of Casal's first book, he did refer to him as "mi muy querido hermano en Banville y en Gautier"which was no small compliment from so distinguished a writer as Nájera.

As far as Nieve is concerned, it is not known whether Nájera received the original Havana edition of 1892 or whether he read Nieve in the Mexican edition of 1893 . Whatever the case, Nájera ultimately procured a copy of the book, and, as a result of having read Hojas al viento and Nieve, 
seems to have developed a great affection for Casal. The depth of his feelings for the young Cuban poet whom fate had kept from visiting Mexico may be seen in the following emotional statement which he made shortly after Casal's death:

\section{JULIAN DEL CASAL}

iOh, mi Julián del Casal! iOh, mi pobre poeta, hermano mío! No llegamos a conocernos, y tal vez por eso nos conocíamos hondamente. A veces caían tus cartas y tus versos en la mesa...... Sí, caían como suelen caer los rayos de la luna sobre la página en que escribo! Yo repetía tu nombre y repetías el mío. Fuimos, somos, como dos ecos distantes, enamorados de la misma vaga melodía. iOh, mi poeta, el de los ojos claros e indecisos que no saben ver; oh, mi poeta, el de los ojos tristes que sonríen por bondad y por cariño; oh, mi poeta, el de los ojos que no han muerto y que siempre estuvieron despidiéndose; contigo acaricié las alas rizadas del gallardo cisne; juntos creímos en Lohengrín, oh, mi poeta! Mañana.......cuando haya luz......cuando no sienta, tan fría tu NIEVE entre mis manos......cuando vuelvan a casa mis pensamientos asustados y dispersos, iré a aquel sitio melancólico en donde por primera vez nos encontramos. Mañana......hablaré de ti con mi alma.

1893

El Duque Job. ${ }^{6}$

N6: Notes to Introductory Statement

1 See Ed. del Cent., vol. I, p. 167.

2 Ed. del Cent., vol. I, p. 199.

3 Ed. del Cent., vol. I, p. 167.

$4 H L$, vol. II, no. 3 (15 February 1892), p. 62.

5 Loc. cit.

6 Revista Azul, vol. II, no. 16 (17 February 1895), p. 246. It is regrettable that the letters to which Nájera alludes are not available for study.

N6: VARIANTS

l. $H L$

8 olivo.

11 [c]ruzan, alzando

16 desiertos

23 ancas

* 24 Damasco,
N

olivo [sic]

[v]an levantando

ardientes

ancas,
GLIC

$H L$ 
25 erigida la dorada

elevada su bruñida

* 27 avanza

34 desgarra

avanza,

desgarró

\section{N6: Notes to Variants}

24: Although the comma after Damasco is not needed for syntactic purposes, there was a reluctance on the part of Casal and his contemporaries to end stanzas without punctuation.

27: A comma is inserted after avanza in the present edition because it is felt that the end-of-verse blank is too weak a signal to indicate that 1.28 does not complete the thought of 1.27 , but rather functions as the conclusion of the idea expressed in 11.25-26. Without the comma, the reader might be guided initially to read: mientras el bruto relinchando avanza entre nubes de polvo. With the comma, such a misreading would be impossible.

\section{Np2: MI MUSEO IDEAL}

"Mi museo ideal," the second major section in Nieve, was written to glorify the art of Gustave Moreau, the controversial French painter whom Casal described as "el Rey-Poeta del color, cuya paleta, como la bóveda celeste, parece tachonada de piedras preciosas . ..."1

Gustave Moreau was born in Paris on 6 April 1826. His father, a distinguished architect, recognized his talent and encouraged him to become a professional artist. Moreau's formal education as a painter began in 1846 in the atelier of François Picot. The teacher's strict adherence to traditional themes and techniques, however, soon became irksome to Moreau and, in 1848, with his father's permission, he went off to study on his own. During this period, he established a close friendship with Théodore Chassériau, a former student of Ingres and Delacroix. The fruits of Moreau's youthful labors were exhibited at the Salon in 1852 and 1853, and at the Exposition Universelle in 1855. Although the critics received these paintings favorably, they pointed out that Moreau's work still showed the influence of Delacroix and Chassériau both in choice of subject and in execution.

After the untimely death of Chassériau in 1856, Moreau went to Italy and studied the great masters of the Quattrocento. Of particular interest to him were Carpaccio, Gozzoli, and Mantegna. Upon his return to Paris, ${ }^{2}$ he began a series of major works based on mythological and biblical subjects. These paintings proved that he had turned away from his earlier Romantic models and, under the influence of the Italian masters, was developing a distinctive artistic personality. The first striking example of the new Moreau is to be found in Edipe et le Sphinx, a large oil painting 
which was presented at the Salon in 1864. In concept and style, this work differed radically from any previous treatment of the subject by fellow artists. Moreau exhibited additional works at the Salon in 1865, 1866, and 1869. Three of his best creations, however, were shown at the exhibition of 1876: they were Salomé, Hercule et l'Hydre de Lerne, and L'Apparition. In 1878 , these same works, together with four more oil paintings and four watercolors, were sent to the Exposition Universelle. The following year, in compliance with a request from his friend Antony Roux, he undertook to illustrate the Fables of La Fontaine. Although many of his other works had received praise from critics and colleagues, Georges Rouault, one of his favorite disciples, held these watercolors to be Moreau's greatest masterpiece.

The death of his mother, in 1884, was a severe shock to Moreau, and in the years that followed this personal tragedy, he withdrew more and more into seclusion. Occasionally, he would entertain friends from the world of art and letters, but he spent most of his time painting. Although he would often devote his attention to new subjects, he would also do numerous variations on themes which he had treated before. This feature of his constant striving for perfection has two consequences that are of special concern to us: on the one hand, it makes it virtually impossible to establish the exact date of many of his canvases, and, on the other, it makes it extremely hard to determine, without risk of equivocation, which version of a given subject Casal happened to use as his source of inspiration.

Recognition of Moreau's worth came in many forms: he elicited the interest of the most distinguished art critics of France, he won awards for paintings which he exhibited at the Salon, he was named to the Légion d'honneur (1875), he was elected to membership in the Académie des Beaux-Arts (1888), and he was chosen to succeed Élie Delaunay as professor of painting at the Académie (1892). With the latter appointment, Moreau entered a new period of enthusiastic and productive activity. His excellence as a teacher was amply recognized by his students, who particularly appreciated the fact that he always encouraged them to give free expression to their individual talent. Moreau's ambition, however, was not to enjoy notoriety in his own time, but to win the lasting admiration of posterity. Since he knew that it is always very difficult to get a comprehensive view of an artist's production when his works are scattered in museums and in private collections throughout the world, he willed to the State his residence and all that it contained: furniture, utensils, decorative objects, and personal files, as well as hundreds of oil paintings, watercolors, drawings, and other art works which he had not cared to send to the Salon or to other exhibitions. Thus, after his death from cancer on 18 April 1898, his home at 14 rue de la Rochefoucauld became a public museum.

The dominant theme in Moreau's art is the perpetual conflict between the forces of Good and the forces of Evil. These opponents are symboli- 
cally represented through the eternal war between the sexes. In Moreau's opinion, all the major virtues are inherent in Man, while all the major vices are inherent in Woman. In his paintings, therefore, qualities such as altruism, courage, and justice are generally embodied in handsome young men like Prometheus or Hercules, while'covetousness, corruption, and cruelty appear in the form of women like Helen of Troy and Salomé. Indifferent to the suffering she causes, Woman is particularly dangerous because of the irresistible attraction which her sensuous beauty exerts on the targets of her destructive instincts. As far as style is concerned, critics have repeatedly used two terms to describe the essential characteristics of Moreau's art: "la belle inertie" and "la richesse nécessaire." The former alludes to the almost enchanted stillness of the figures in his compositions; the latter refers to the immense number of decorative elements which the artist felt he must use to convey his idea to the observer.

In spite of the fact that Moreau received numerous honors, awards, and commendations during his lifetime, it should be emphasized that he was not especially well known to the general public and that his creations elicited sharp criticism as well as extravagant praise. For example, while an admirer such as Ary Renan felt that the work of Moreau was a monument of pure art, Degas severely criticized Moreau for indulging in excessive ornamentation: the artist, Degas sarcastically quipped, would like us to believe that the gods wore watch chains. Be this as it may, the fact is that Moreau was in great favor with some of the most outstanding writers of his century, among them, Théophile Gautier and Joris-Karl Huysmans. What these men admired most in his works were his expression of an ultra-refined aestheticism, his expert handling of detail, and his mastery of symbolism-all of which enabled him to make an idea visually perceptible and intellectually attractive.

Although it is impossible to date Casal's initial exposure to the art of Gustave Moreau, we know that it could not have been later than 21 September 1890, for, on that date, he published "Salomé," the first of the ten cuadros that would ultimately be included in "Mi museo ideal." In addition, from a letter which Casal wrote to Moreau on 15 August 1891, we learn that the poet was introduced to the works of Moreau by JorisKarl Huysmans. ${ }^{3}$ Casal's enthusiasm led him to write to a contact in Paris possibly Huysmans himself - at some time between the summer of 1890 and the summer of 1891, in order to find out how he could obtain copies of Moreau's paintings. Before the beginning of August 1891, he received "gravures" of Hélène sur les murs de Troie, Galatée, and, perhaps at the same time, Salomé. The first of these acquisitions inspired him to compose "Elena" (N12); the second, "Galatea" (N11). Casal published these sonnets in La Habana Elegante on 2 August and 9 August 1891, respectively. Then, on the 11 th of the month, he wrote his first letter to Moreau; with it he enclosed copies of "Salomé," "Galatea," and "Elena." Since he did not know the address of his "Très-adorè [sic] maître," however, he sent the 
letter by registered mail to Huysmans, with a request that it be forwarded to the painter. ${ }^{4}$ This was the beginning of a correspondence which lasted until 1 January 1893 (see Robert Jay Glickman, "Julián del Casal: Letters to Gustave Moreau," Revista Hispánica Moderna, año XXXVII, nos. 1-2 [1972-1973], pp. 101-135).

The file of Casal-Moreau letters is a precious source of information. It shows, for example, that on or about 13 August 1891, Casal received a shipment of pictures from the Photographie des Beaux-Arts, 8 rue Bonaparte, Paris. A catalogue number was written on the back of each item, but none of the photos had a title. The only works that Casal identified positively were L'Apparition, Hercule et l'Hydre de Lerne, and Prometheus. Of the eleven remaining pictures, he thought he could recognize the subject of eight, but had no idea of what the others represented. Casal's failure to identify three of the pictures was a disappointment of only minor importance, for the works that he had succeeded in recognizing more than lived up to his expectations about the quality of Moreau's art:

Al mismo tiempo, deseo participaros, no por vanidad, sino por satisfacción, que estoy asombrado de vuestras justas, originales y artísticas concepciones de vuestros Hércules, de vuestras Venus y de vuestro Prometeo. Al reves de lo que imagina la fantasía burguesa, vuestros Hércules son fuertes, pero bellos; vuestro Prometeo es un Cristo pagano, tal como debió ser el primer Redentor de los hombres; y vuestras Venus son divinamente hermosas, pero frias, indiferentes, nostálgicas y soñadoras. Ellas me traen á la memoria aquellos versos de mi maestro en poesia, del gran Baudelaire,
"Je trône dans l'azur comme un sphinx incompris;
J'unis un cœur de neige à la blancheur des cygnes;
Je hais le mouvement qui déplace les lignes;
Et jamais je ne pleure et jamais je ne ris." ${ }^{5}$

In the days that followed, while waiting for Moreau to identify the doubtful items and to tell him where he could purchase additional photographs, ${ }^{6}$ Casal wrote seven new sonnets: "Prometeo," "La aparición," "Hércules ante la Hidra," "Venus Anadyomena," "Una peri," "Júpiter y Europa," and "Hércules y las Estinfálides." Then, on 30 August 1891, he published all ten Moreau-inspired sonnets in La Habana Elegante. ${ }^{7}$ As shown in Plate 16 , the poems were grouped under the generic title "Mi museo ideal." Their subtitle was "(Cuadros de Gustavo Moreau.)." Beneath the subtitle and between two centered rules was a four-line quotation from Joséphin Soulary (b. Lyon, 23 February 1815; d. Lyon, 28 March 1891). In his review of "Pompeya," a poem written by 
PLATE 16

“Mi museo ideal” (HE, 30 August 1891)

\section{LA BABATA EUDOATT: \\ Mi Museo Idea1. \\ (Cladros de gustayo moreat.)}

Aowr nows, fils de 1 Art, rien ne raut Le mythe at sin legende ress: Nows mowrons de la atic en frise On le merveilleuse fait défaut.

\section{A FDUARDO ROSEII.}

\section{ALOME}

Fn el palacio heluren, donde el suave llumo fragante, por el onl ile whecho, Sube 1 perderse en el calatio ticho

$O$ se dilata en la anchurosa nave,

Fsta el Tetrarca de nirada grave,

harba canosa y extenuado pecho.

Solre el trono, hierátice y derecho.

Como atlormido por canciones de ave.

lielante de ell, con veste de hrocado

Fistrellada de ardiente pedreria,

Al dulce son del handolín sonoro,

Salomé baila $y$, en la diestra alzado, Muestra siempre, radiante de alegria,

In loto blanco de pistilos de oro.

\section{LA APARICION}

Nube fragante y callida tamira El fulgor del palacio de aranito, Onix. Mórfido y nácar. Infinito

Deleite invade a llerodes, I a rojiza

Espada fulgurante inmoviliza

Ilierático el verdugn, yondn grito

Arroja Salomé. frente al maldito

Especiro que sus miemhros paraliza.

Despojace del traje de buncado

$Y$ quedando vestida en un momento

lie oro $y$ perlas, afiros $y$ rulfies.

Il uye del Precursor derapitato

Que esparce en el marmóres pavimento

Lluvia de sangre en gotas carmesfes.

\section{heRCULES ANTE LA MIORA.}

En el umiral de lohrega caverna

$\checkmark$ A las purpúreas lucen del cocaso.

vurge, acechando del viajero el jaso,

Invencible y mortal, ia llidra de lerna.

Mientras se extásia su mallad interna En mirar, equarcitos al acaso.

Cuerpos de piel trillante cumo el raso,

Torso viril ó ensangrentala pierna;

llércules, coronarlo de laureles,

Repleto el cárcaj en el aureo cinto,

Firne en la diestra la petente maza,

Ante las sierpes de viscosan pieles, Detiénese en mitad del laleruntu,

fulninando en sus ojus la amenaza.

VENUS ANAOYOMENA.

Sentada al pié de verdinegras moles Solure la espalda de un delfin cetrim, Que de ta aurora el rayo purpurino jaspea de brillantes tornasules:

Fusuelta en luminosne arrelioles. Venus emerge el cuerjo slahastrino, Frente al humedo borle del camino Alfomlrato de róseos caracoles.

Moviento al nire las plateadas colas, Hancas nerćilas surcen de las olas í la deidad le formas virginalen

lievan, entre las manos elevadas, Niveas conchas de jerlas naciradax, Igneas ramas de fúlgidos corales.

Aurelia Castillo de González (see N4), Casal affirmed that Soulary was among the best poets in Europe. In Casal's opinion, poets of his type had the following characteristics: "sin haber cantado el advenimiento de las ideas democráticas, ni las maravillas de la electricidad, ni las conquistas de la ciencia, ni la altura de la torre Eiffel, etc.-cosas muy buenas, muy útiles y muy meritorias, pero que nada dicen al alma poética-, son esencialmente modernos porque en sus obras se reflejan, como en bruñido espejo, el malestar permanente, el escepticismo profundo, la amargura intensa, las aspiraciones indefinidas y el pesimismo sombrío, frutos amargos y ponzoñosos extraídos del fondo de sus almas, a fuerza de sufrimientos, de estudio, de análisis y de investigaciones que envenenan la atmósfera y les inoculan el asco de la vida, haciendo volver el pensamiento a esos seres morfinizados de ideal hacia los espacios siderales del ensueño o hacia los 
PLATE 16

"Mi museo ideal" (HE, 30 August 1891)

\section{PROMETEO.}

Pajo el dosel de gizanterea roca Vace el titśn. cual Cristo en el Calvario.

Marmóreo, indiferente y solitarin,

Sin que lrote el gemido de su binca.

Su pié desnudo en el peñasco toca

Donde agoniza un buitre sanguinario

Que ni strae su njo visionario.

Ni compasión en su animo provoca.

Excuchando el hervor de las espumas

Que se deshacen en musgosas werias,

Ve de su redención luces extrañas.

Junto $\mathrm{a}$ otro buitre de nevadas plurrias, Negras pupilas $y$ uñas marfileñaร.

Que ha extinguido la sed en sus entrafas.

\section{oalatea.}

En el seno radioso de su gruta Alfombrada de anémonas marisas, Verdes algas y ramas coralinas.

Galatea, del sueĥo el hien tlisfruta.

Desde la crilla de dorada ruta

Monde haten las ondas cristalinas.

Salpicando de espumas diamantinas

El pico negro de la roca liruta.

Polifemo, extasiato ante el desnudo

Cutroo ideal de la dommida dinca,

Olvida su fiereta, el vignt pierte.

Y mientras nermanece, ahurortn y mudo,

Mirando aquella piel color de rosa

Incendia la lujuria su ojo ierde.

\section{ELENa.}

1.az forfírica entreabe claras brechas En la axulada mecuridad, y alumbra

lhel foso en la fattdica yenumbra

Cuerpor hendidos por doralas fechas.

Cual humo frio de homicidas mechas

Fn la atmósfera opaca se vinlambra

Vapor dispelto que la brisa encumbra

A las torres de llioin, escombrus hechas.

Envaelta en veste de o, zalina gasa,

Kecamada de oro. desde el monte

IV ruinas hacinadas en el llano,

Indiferente $\mathbf{A}$ lo que en torno pass

Mira Elen hacia el livido horitonte,

Irgeiendo an lirio en la rosedin mano.
UNA PERI.

W Gre alto promontorio en que clarilea I. a aurora sus fulgores de topacio. Pálido el rostro y el calvello lació. IAnguida Peri el cuerpo laalances.

Al rojo brillo de la lue felvea Aléase del célicor palacio.

Abrazada á su lira en el espacio, Reflejada en la fúlgida marea.

Y al descender en silencioso giro, Como visión lumínica de plata

Ansiosa de encrmtrar $a$ la Desticha,

Vaga en sus lahios gélido suspiro, I en sus violícerss ojos se retrats

El cansancio infinito de la I ticha.

\section{IUPITER Y EUROPA.}

En la plays fenicia, s las boreales Radiaciones del astro matutino, Surge turopa del pielago marino, Eurvelia de la espuma en los cendales.

Júpiter, tras los ásperos lirehales, Acéchala ś la orilla del camino, Y elevando su cuerpo alahastrino Intérnanse entre oscuros chajarrales.

Mientras al borde de la ruta larga Alza la plehe su clamor sonoro. Mirandola surgir de la lionda amarga,

Desnuda va eolore su blanco toro Pue, enardecilo por la amante carge.

Frige hacia el azul los cuerners de oro.

\section{HERCULES YLAS ESTINFALIOES.}

Rased claridad de luz felor

liaha el cielo de Irodia ioure giganter Rocas negras de pico fulpurantes

F) dormido Fistinfalo sentellez.

Dhade abrupto peasacos gue aruka llércules, con miradas fulninantes. Hi casen verde de flamos fragantes $\checkmark$ la piel del keón de la Nemea,

Apoya el areo en el rolusto prch. $Y$ las candentev fechas deoprendidas Ripidas vuelan if las rerde frondis,

Hasta que aira su viril despecto Caer las Estinflides heridas,

Cotesedo sangre ea has plateadas endas.

jeuAs det CASAL.

campos remotos de las edades grandiosas, lejanas y desaparecidas." ${ }^{8}$ The epigraph which Casal chose for "Mi museo ideal" was taken from the 18 December 1880 "Prologue" that introduced Soulary's Les Jeux divins:

La science au rêve s'impose;

Le ciel antique est pris d'assaut;

Mais, ô dieux chassés de là-haut,

Beaucoup vous pleurent, non sans cause.

Pour nous, fils de l'Art, rien ne vaut

Le mythe et sa légende rose;

Nous mourons de la vie en prose

Où le merveilleux fait défaut. 
Et moi-même, poète indigne,

J'en suis encore à l'œuf de cygne

Au bord de l'Eurotas trouvé.

Ne dites pas: "La fable est vieille!"

Depuis que Léda l'a couvé,

Cet œuf est toujours de la veille.

Casal's excerpt from "Prologue" was followed by a dedication to his friend Eduardo Rosell. ${ }^{9}$ The Moreau-inspired sonnets were printed in two columns below the dedication, and the name of the author was placed at the end of the series. Two weeks later, Casal, who had just received his first letter from Moreau, sent the painter a copy of this version of "Mi museo ideal" plus a photograph of himself. The photograph, which is reproduced in Plate 10, was made from a portrait that had been done a short time before by Armando Menocal.

On 15 December 1891, in gratitude for the artist's attentions, Casal sent Moreau two still unpublished compositions, "Sueño de gloria" and "Vestíbulo." The former, he insisted, was not a masterpiece by any stretch of the imagination, but it did represent a sincere expression of his feelings. The latter was a verbal portrait of Moreau. If it contained some inexactitudes, Casal explained, these did not come about by design, but were due to the fact that he had never seen a picture of the great master. After giving Moreau this exclusive preview of the poems (see N7 for sample pages of the autograph versions), Casal published them in Cuba: "Sueño de gloria" came out in La Habana Literaria on 30 December 1891 and "Vestíbulo," presented under the title "Gustavo Moreau," appeared in El Fígaro on 15 January 1892 and in El País on 21 January 1892.

In his correspondence with Moreau, Casal indicated that he expected to publish Nieve in the winter of 1891-1892 and that "Mi museo ideal" would appear as the third section in the book (C1/23-27). For reasons that are still not clear, Nieve was published in the spring of 1892 and "Mi museo ideal" was moved up to second place in the volume. The series now included N7 and N18, rather than just N8-N17 as the $H E$ version had done. The subtitle was changed from "(Cuadros de Gustavo Moreau.)" to "(Diez cuadros de Gustavo Moreau)" and the epigraph was suppressed; the original dedication was retained, however.

Moreau was apparently flattered by all this and even suggested that José María de Heredia might translate one of the poems into French. With sincere modesty, Casal protested that he was unworthy of such an honor. Hérédia was one of the gods in his literary pantheon: not only had Casal translated "Chanson de Torero" into Spanish (see H40), but he had also tried to imitate the style of Hérédia's sonnets in "Mi museo ideal" (C6/99-129). For a relatively unknown writer like himself, to do this was right and proper; but to think that a person of Hérédia's stature might want to translate his poetry seemed rather presumptuous to Casal. 
This tone of extreme humility is evident throughout Casal's correspondence with Moreau. The young Cuban honestly felt that he was "un rêveur malade sans valeur" (C5/21-22), and when he wrote to persons of eminence such as Moreau, he sounded like an adolescent addressing a stage idol or a popular hero. But this was something which he could not avoid, for he was unable to love halfway (C3/66-69), and love for him was a sine qua non of existence: as he put it, "Je vis d'adorations, comme d'autres de meprises" (C6/114-116). His love was most intense, however, when it was directed to someone far away. In order to nurture his dreams, which were his most important possession, he needed to have a master in some distant land. That person had to be guided by the highest of values and had also to be a victim of life's incomprehension and cruelty. In Casal's view, such a person would be characterized by an uncompromising devotion to the ideal of artfor art's sake and by a steadfast resistance to the enticements of Fame. In Casal's estimation, Moreau exemplified these traits better than anyone else on the continent of Europe (C6/38-69).

After glorifying his beloved master in "Mi museo ideal," Casal composed five ballades (C8/17-26) and several odelettes inspired by Moreau's work (C10/37-39). Unfortunately, none of the ballads or odes has ever been found. But an even greater loss to scholars is the fact that Casal never completed a monograph that he proposed to write on the life and works of Gustave Moreau. As background for his study, Casal planned to read everything that had been written about the painter (C6/79-91). Then, he would travel to Paris in order to meet Moreau and work on the book. According to his estimate, he would be able to stay in Paris for about two months. After completing the book, he would ask the artist for his frank opinion of it-and if Moreau did not understand Spanish well enough, Casal would get a bilingual friend like Cornélius Edouard Price to translate it into French (C12/38-62).

As had happened so often in the past, however, the poet did not have the good fortune to realize his dream. Although direct evidence on the subject has never come to light, it appears that the deteriorating state of his health was a major cause of this new disappointment. By the spring of 1892, Casal was already plagued by fevers, fainting spells, loss of vision, and paralysis (see my discussion of R 16); and, at times, he suffered pain so intense that he could not even hold a pen (C8/49-53). These were unmistakable signs of the seriousness of his illness-a disease, incidentally, which for a while he thought was heart trouble (C3/50-54). As the pernicious malady spread through Casal's body, it lessened his ability to endure the physical hardships involved in a trip from Havana to Paris. But it raised other barriers to the fulfilment of his dream, as well. First, it considerably reduced his economic potential. Because his income was mainly derived from journalism, Casal was always in precarious financial straits. Of course, there were times when he managed to stabilize his situation to a certain degree. The year 1890, during which he was employed on a regular basis first by La Discusión and then by ElPais, seems to 
have been such a period. By mid-1891, however, the worsening condition of his health made it increasingly difficult for him to carry a normal work load. ${ }^{10}$ As a result, he began to publish fewer and fewer articles and concentrated his waning energies on writing poetry. ${ }^{11}$ Poetry may not have paid too well, but it did have one important advantage under the circumstances: it did not oblige him to follow work schedules which others, perforce, imposed.

As time passed, Casal's life-sapping illness also affected his emotional equilibrium. On the one hand, it increased the frequency with which he turned towards his private world of glowing fantasy and away from the somber reality of common men. On the other, it decreased his ability to maintain his composure when reality intruded on the dreams that he had so laboriously fashioned. This imbalance is evident in his correspondence with Moreau. Initially, Casal expressed a degree of emotional involvement that went beyond the range of normalcy. Then, as he perceived Moreau's reluctance to respond with similar fervor, he adopted the plaintive tone of a suitor whose beloved fails to satisfy his longings for a sign of true affection. What hurt him most deeply, it appears, was Moreau's refusal to grant his request for a photograph.

The matter of the photograph may seem trivial to us, but it was not to Casal. There is ample evidence to show that the poet was in the habit of sending his picture to persons whom he admired, and that he was accustomed to ask them to reciprocate. His success in the latter regard is verified by Manuel Márquez Sterling, who affirms that the walls of Casal's room were covered by a "nube de retratos." 12 Casal's attempts to obtain a photograph from Moreau began in September 1891. The months passed, but Moreau sent no photograph. This led the poet to exclaim: “ ¿N'avez pas vous recu une lettre a moi, en vous demandant votre portrait? Son envoi vous couterais si peu et me rendrerai heureux, si heureux" (C10/57-61). Moreau's answer was that he had received the letter, but that he preferred not to send Casal a picture of himself.

Moreau's refusal was not designed to slight Casal: it was dictated by his sincere belief that while an artist's work should be given public scrutiny, the artist himself should disappear from view. So strong, in fact, was his feeling about this matter, that he instructed future executors of his estate not to sanction the inclusion of his portrait in any book that might be written about him after his death. ${ }^{13}$

Although Casal understood Moreau's reasons for denying his request, he let over four months go by without answering his beloved master. One obvious cause of his silence was disappointment at Moreau's unwillingness to make an exception in his case-an exception which, in view of the importance that Moreau gave to the rule, would have been an unmistakable sign of his affection for Casal. Another cause of the long silence was Casal's fear that he might weary Moreau if he persisted in lavishing attentions upon him. The 1st of January 1893, however, provided Casal with an excuse for writing once again. Reaffirming his constancy, he sent 
Moreau greetings for the New Year and expressed the hope that he would soon be able to visit him in Paris. From all appearances, Moreau did not answer this letter and Casal did not write to him again. In spite of this, there is nothing to suggest that Casal ever gave up being Moreau's "très fidèle, très loyal et très passionnè admirateur ..." (C12/66-67).

\section{Np2: Notes to Introductory Statement}

1 “Joris Karl Huysmans," $H L$, vol. II (15 March 1892), p. 11 1; Ed. del Cent., vol. I, p. 177.

2 Moreau biographers disagree about when he returned: some say in 1859 , others insist that it was in 1860 .

3 C2/1-7. We assume that Casal meant he had discovered Moreau by reading Huysmans' novel À rebours, which was published in 1884 .

4 In a letter addressed to Huysmans on 4 October 1891, Moreau wrote the following postscript: "Je ne dois pas oublier, Monsieur, que je suis chargé par Mr. Julian del Casal de la Havane, un de vos fervents admirateurs, de vous bien remercier de l'obligeance si gracieuse que vous avez mise à être un trait d'union entre lui et moi."

5 C2/59-79. The quotation is from Baudelaire's sonnet "La Beauté" (1l. 5-8), which is found in the "Spleen et Idéal" section of Les Fleurs du mal.

6 In particular, Casal wanted copies of Phaeton, David, and Le Jeune Homme et la Mort. As far as we know, none of these works became the source of inspiration for a poem, but the last one mentioned did serve as the basis for a very interesting prose image. In his busto of José Arburu y Morell, Casal says: "Estaba predestinado a morir joven. Aquella deidad lánguida, coronada de violetas y adormideras, que Gustavo Moreau ha pintado acechando al bello adolescente que, con un haz de margaritas, anémonas y narcisos en las manos, corre a ceñirse el lauro de los vencedores, se le interpuso también en su camino y lo hirió con su lanza de oro, esmaltada de pedrería, en su carrera triunfal" (Bustos y rimas, p. 120; Ed. del Cent., vol. I, p. 280).

7 "Venus Anadyomena," "Una peri," "Júpiter y Europa," and "Hércules y las Estinfálides" appeared at the end of the Moreau series both in $H E$ and in Nieve. This suggests that Casal's plan of composition was to begin by writing a sonnet for each of the pictures that he could identify positively (i.e., Prometheus, L'Apparition, and Hercule et l'Hydre de Lerne) and then turn to the remaining works which he had received from the Photographie des Beaux-Arts.

8 "Libros nuevos" (D, 6 June 1890); Ed. del Cent., vol. II, p. 145.

9 For further information about Rosell, see the Diario del teniente coronel Eduardo Rosell y Malpica (Havana: Imprenta "El Siglo XX," 1949). It will be recalled that, on 22 October 1893, Casal was buried in the mausoleum of the Rosell family in Colón Cemetery.

10 See my discussion of N36.

11 Compare the ratio of prose to poetry during 1890 with that of the years 1891-1893 (see Ed. del Cent., vol. III, pp. 202-222).

12 “Julián del Casal," p. 328. 


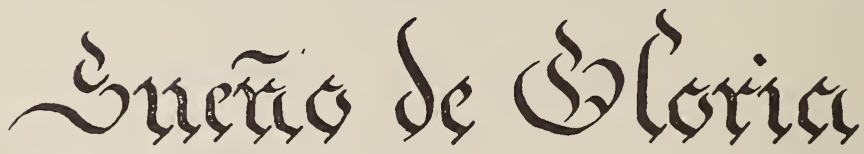 Apoteósis de Gustavo Omoneau}

Sombra glacial de bordes argentados Enluta la cestensión del firmamestó, Donde vagan los discess apagados. Der los astros nocturnos. Duerme el vients. Entir las ondas del Cedrón, plomisas. Iue hasta el sombrís yosafat duscienden Coms a', un foso inusndado de cenisas, Y en rápida canera luego ascienden Salpicands las rocas erisadas. En que, lansando pavorosas quejas, Slegarr, for las linieblas ahujentadas, Entreabiertas sus alas, las corriejas.

Der martécina lus á las reflejos 2 er clarean el lóbrego harisonte, Ferisalín destácase á lo lejos, Darmida al fié del solitario Abonte De las Olivos. Ramas erigidas En la asperesa dersus firmes flancos

13 See Henri Rupp's introduction to the Catalogue sommaire des peintures, dessins, cartons et aquarelles exposés dans les galeries du Musée Gustave Moreau (Paris, 1926). Rupp was the executor of Moreau's estate. 
N7

PLATE 17 (A)

"Sueño de gloria": First Two Pages of the Autograph that Casal Sent to Moreau

2

Parceen lasnsas de metall hundidas En cuerpas que á sus ásperas bairascos Fintas en sasigre fueros. Albontal frio Del valle solitario se evaporar; El basque ostinta fúnebre alấs, Sinte el mundo nostálgia de la aurona, Silencio alérador el aire puebla, I semeja la bóveda del cielo Encresponada de hónida lisiebla Un pálio de sombrio térciopelo.

Chispas brillantes, como, pertas de ors, Encrésdense en la gélida neguna De la celeute inmensidad. Sonoro Rumar de clas de nútida blascura Oyese resomas en el espacio Que se vela de nubes coloreadas De mácar, de granate, de tipacio Y amatista. De estrellas coronadas Las sienes is la subia cabellera Esparcida en las vestés asmladas, Coms flores de esctraña frimavera Legriones de rasadas serafines, con el clanin de platá entí las manos,

N7: VESTIBULO

On 15 December 1891, Casal sent Gustave Moreau two poems which he had composed in the painter's honor, but which he had still not published.

189 
N7

PLATE 17 (B)

"Vestíbulo": Autograph that Canal Sent to Moreau

Y el ambience lumésico embalsaman Las rasps de jardines celestiáles

Julian del Canal

Habana, 8 2iciember 1891

Mi Manse Ideal

restibulo

Retral de Gustavo Alborean

Pasto que desafía los crueler Rigors del destine; fence auster Ameolada de large cabellera, Dander al mints se enlazan los laireles.

Creator himinaso como Apeles, Si en la Inecia immortal nacido huber Cal dis is entries las disses estiviera Dor el sacks fader de sis finceles.

Del Y deal divine á los gulgores rive de lo pass ado entire las mimas,

The poems, "Sueño de gloria" (N18) and "Vestíbulo" (N7), were copied by Canal, in the order indicated, on eight sheets of ruled paper. The first and last pages of his manuscript reveal the extent of the poet's skill at calligraphy (see Plates 17A and 17B). The dates that appear on those pages - 8 December 1891 and 12 December 1891 - show that "Sueño de gloria" was written earlier than "Vestíbulo." It also seems that N 18 was conceived earlier than N7. Supporting this impression is the fact that Canal gave a detailed outline of "Sueño de gloria" in his letter of 1 November 1891 (C4/68-107), but made no mention of "Vestíbulo" until 15 December. When writing to Moreau on the latter date, Canal affirmed that "Sueño de gloria" was the more significant of the poems. Nevertheless, he indicated that "Vestíbulo" was going to have a very important place in his forthcom-

190 
PLATE 17 (B)

"Vestíbulo": Autograph that Casal Sent to Moreau

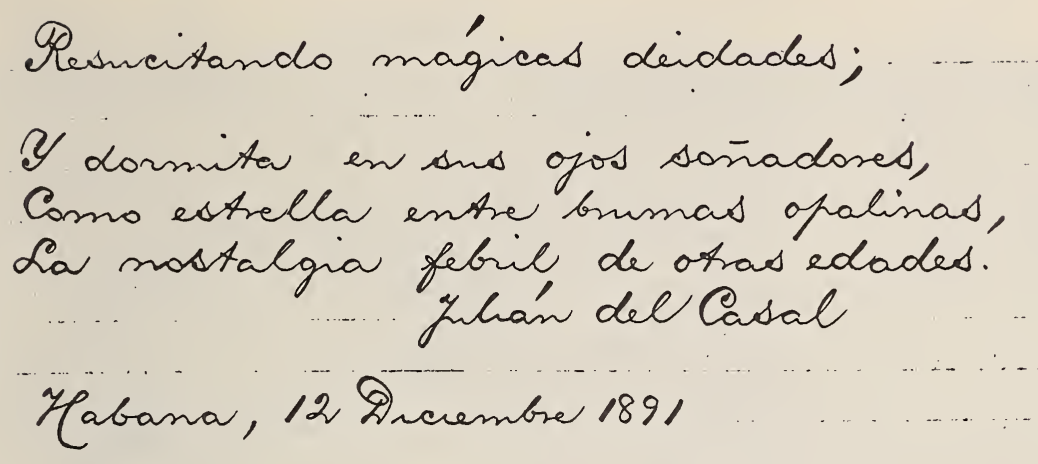

ing book: it would function as the gateway to the series he was planning to designate as "Mi museo ideal."

Although N7 had been entitled "Vestíbulo" in the manuscript version, it was called "Gustavo Moreau" when it came out in El Figaro on 15 January 1892. Another feature of the $F$ version is that it did not show the date of composition to be December 1891, but rather "(Enero, 92)."

On 21 January 1892, El País, acknowledging that its source was El Figaro, reprinted the poem with the same title and date as the ones that had appeared in $F$.

When it was published in Nieve, the poem bore no date of composition. ${ }^{1}$ However, it did have the title ("Vestíbulo") and subtitle ("Retrato de Gustavo Moreau") which Casal had given it originally.

If compared with one of Moreau's rare self-portraits (see Plate 18), "Vestíbulo" shows how well Casal was able to capture the great man's spiritual essence. It should be emphasized, however, that he was merely imagining what the artist looked like, for he had not seen a picture of Moreau prior to composing "Vestíbulo." This point is very clearly made in the letter of 15 December 1891: "Après le poeme, vous liserez un sonnet qui j'ai fait pour le Vestibule de mon Musee Ydeal, rêvant à vous. Autant le poéme que le sonnet, sont encore inedits. Yl est tres probable qui vous voyez dans le second des inexactitudes; mais, comme je n'ai pas le bonheur, trop grand pour moi, de voir votre portrait, j'ai des fantaisies sur vous et je' vous ai rêvè comme ca" (C5/28-40). Regrettably, despite repeated efforts, Casal never had the pleasure of seeing what the artist looked like (see my discussion of $\mathrm{Np} 2$ ).

\section{N7: Note to Introductory Statement}

1 It was Casal's practice to omit this information from the book version of all his poems and prose compositions. 
N7: VARIANTS

\begin{tabular}{|c|c|c|c|c|}
\hline$l$. & $M S$ & $F$ & $P$ & $N$ \\
\hline * 1 & desafía & & desafia $[s i c]$ & $M S$ \\
\hline & crueles & crüeles & & $M S$ \\
\hline 6 & hubiera & hubiera, & & $M S$ \\
\hline 9 & Del Ydeal & (ף) De su Ideal & & \\
\hline & fulgores & fulgores, & & $M S$ \\
\hline $\begin{array}{l}10 \\
11\end{array}$ & $\begin{array}{l}\text { ruinas, } \\
\text { deidades: }\end{array}$ & ruinas & deidades. [sic] & $M S$ \\
\hline
\end{tabular}

N7: Note to Variants

1: In the $M S$ and in $N$, all lines are left-justified. In all other versions, the first line in each stanza is indented.

\section{N8: SALOME}

"Salomé" was first published on 21 September 1890 in La Habana Elegante. It was printed in italics on the first page of the journal, had two subtitles - "(Cuadro de Gustavo Moreau.)" and "Soneto" - and was dedicated "A Enrique Fontanills." 1

The poem was reproduced on 23 September 1890 by El Pais, which, acknowleding its source as La Habana Elegante, stated: "He aquí el soneto que aparece en la plana de honor." In this printing, the subtitle "Soneto" was omitted.

On 30 August 1891, "Salomé" was published in modified form by $L a$ Habana Elegante (see Plate 16). This version, with minor changes in punctuation and with the dedication suppressed, was the one that Casal used for Nieve.

Writing to Moreau on 11 August 1891, Casal said that "Elena," "Salomé," and "Galatea" were based on gravures (C1/6-9). ${ }^{2}$ Four days later, in another letter to Moreau, he reiterated that those sonnets were "escritos por mí ante copias de vuestras divinas y sugestivas figuras de Elena, Salomé y Galatea" (C2/8-11). Unfortunately, he did not indicate when he obtained the prints or when he composed the sonnets. The only thing that is clear is the date on which he first published each of the poems:

\begin{tabular}{|c|c|}
\hline N 8 "Salomé" & $H E: 21$ Sep 90 \\
\hline N12 "Elena” & $H E: \quad 2$ Aug 9 \\
\hline N11 "Galatea" & $H E: 9$ Aug \\
\hline
\end{tabular}

The fact that "Salomé" came out almost a full year before the other 
PLATE 18

Gustave Moreau: Self-Portrait

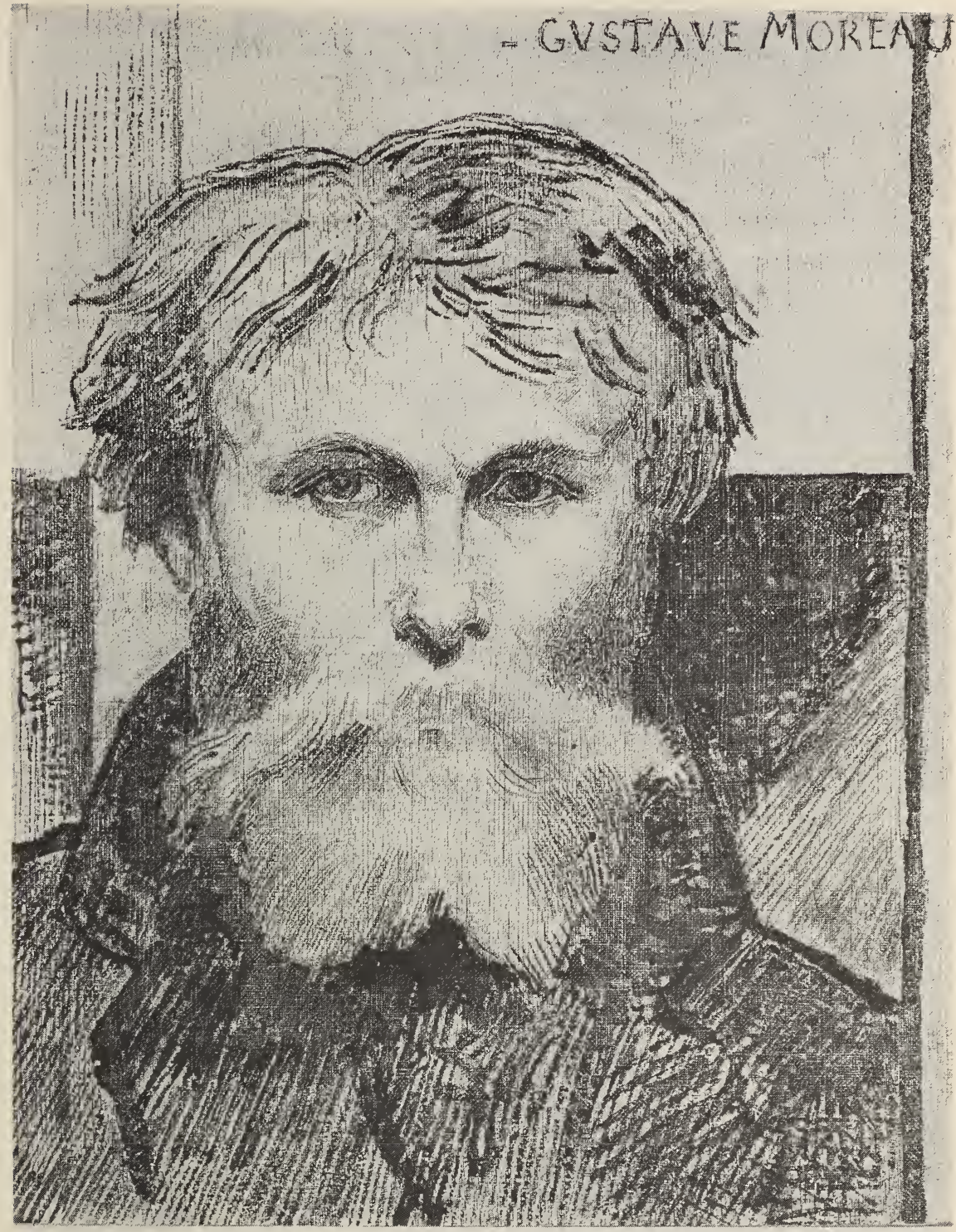

Cliché Musées Nationaux, Paris. 
Plate 19

Salomé

$$
\text { 8. }
$$
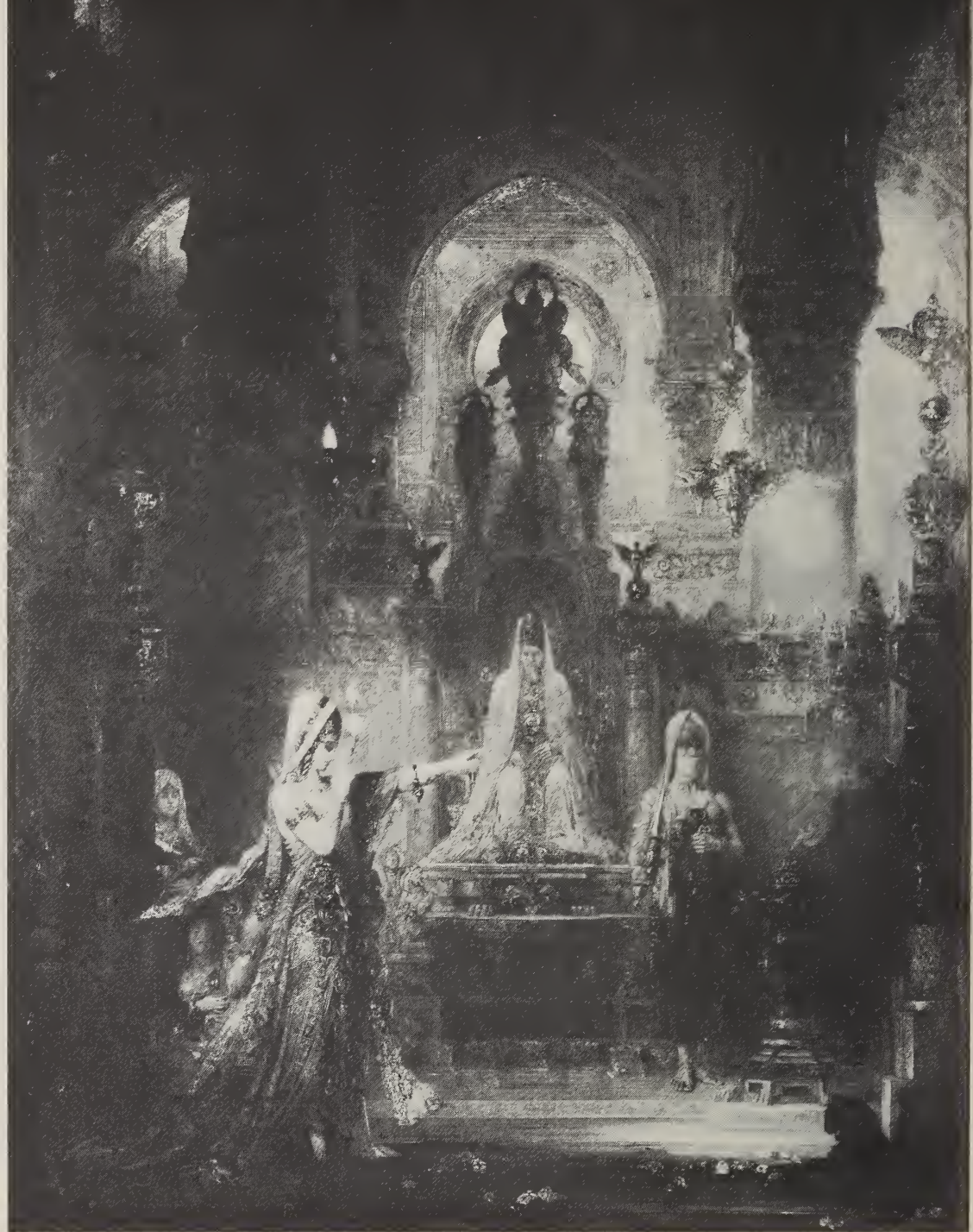

Cliché Musées Nationaux, Paris. 


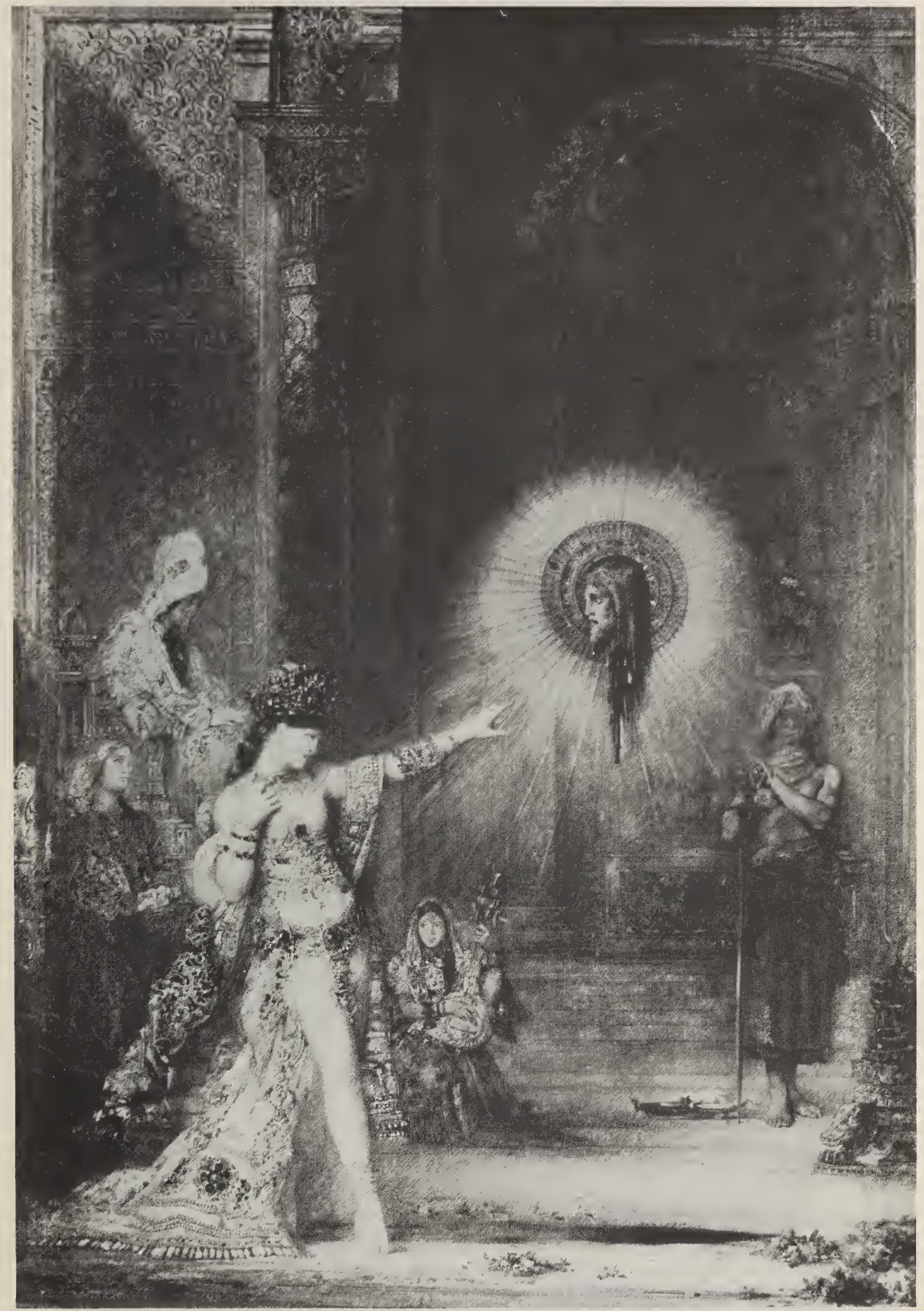


PLATE 21

Prometheus

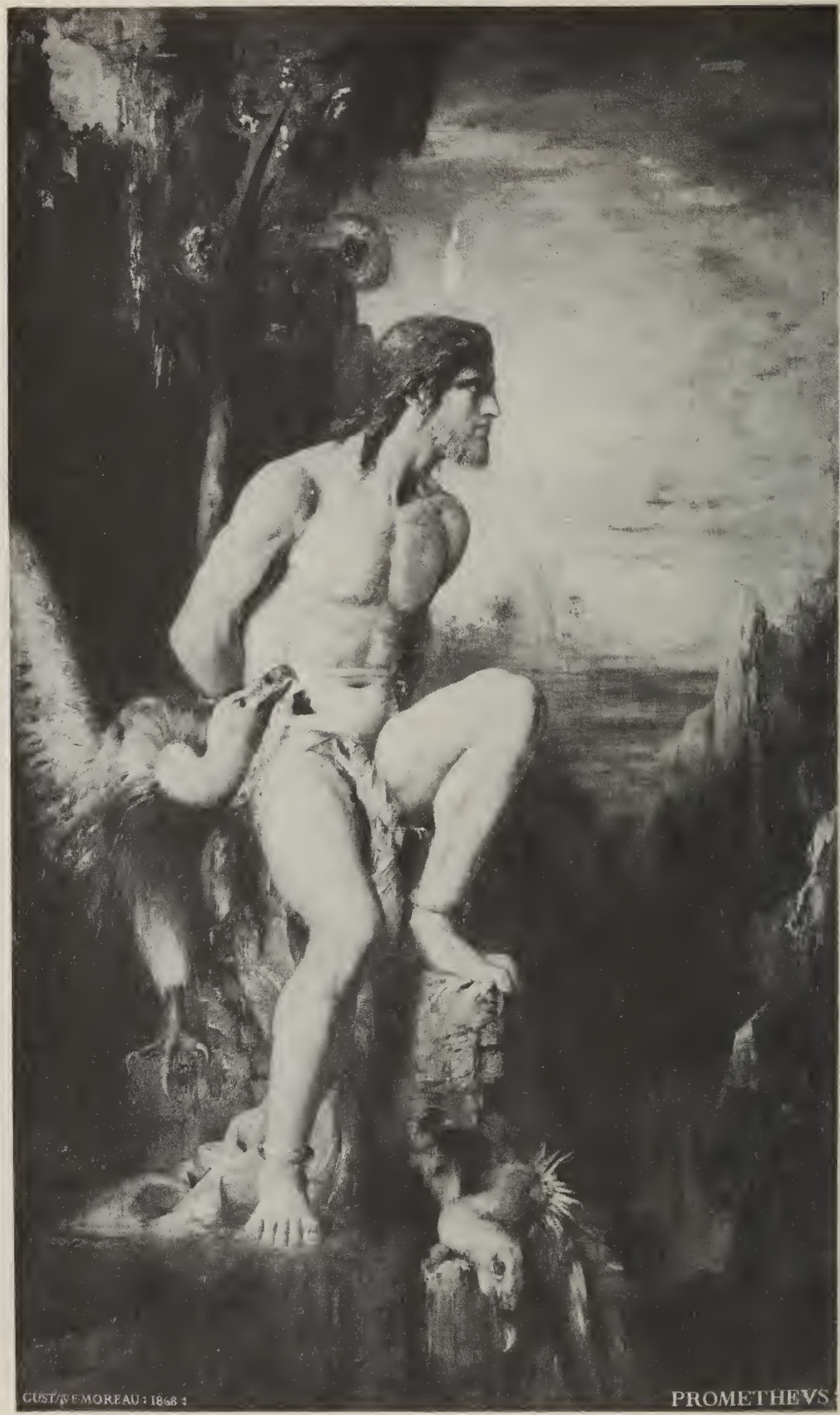

Photographie Bulloz. 
PLATE 22

Lorenzo Vecchietta: An Illustration for the Divine Comedy

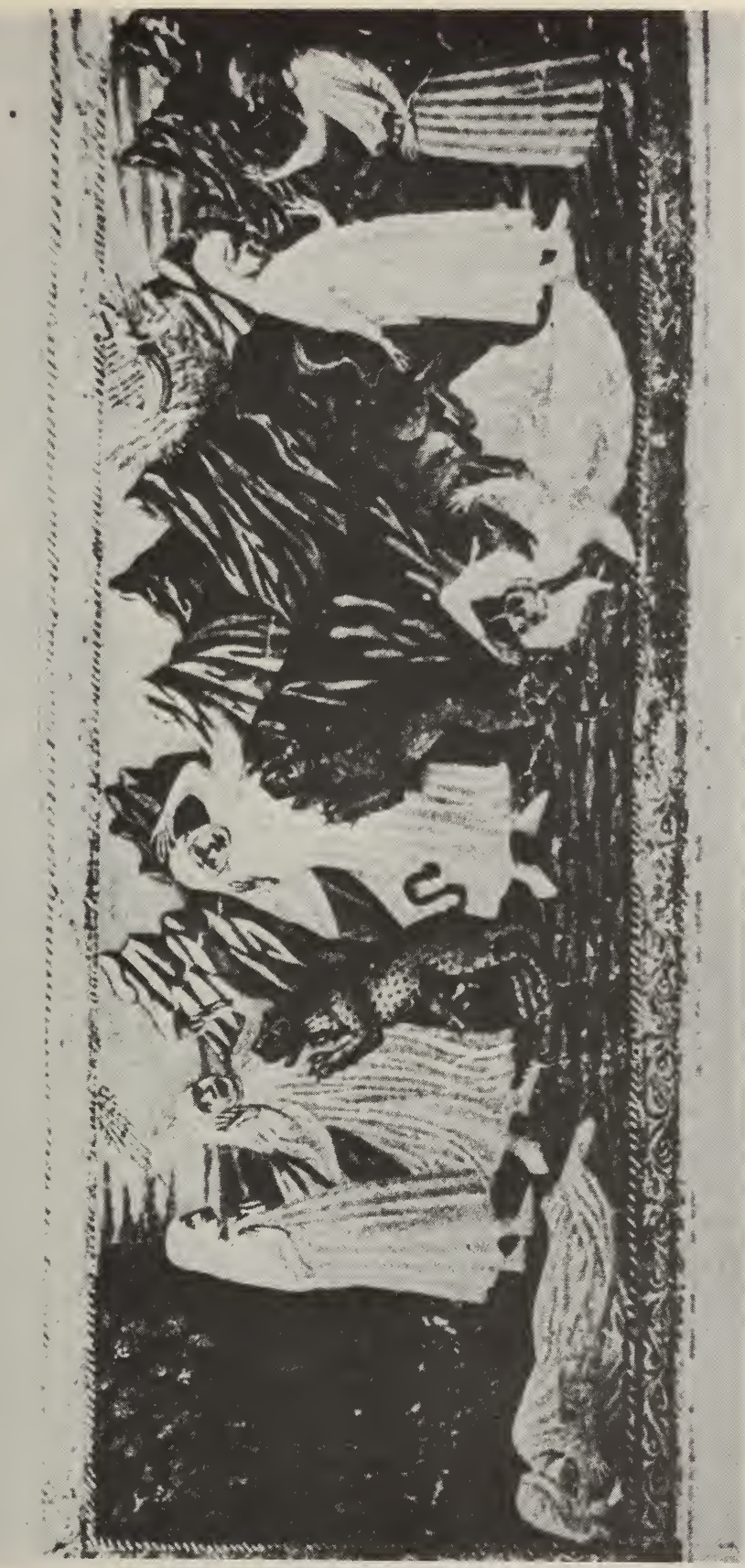

गี 
PLATE 23

Galatée

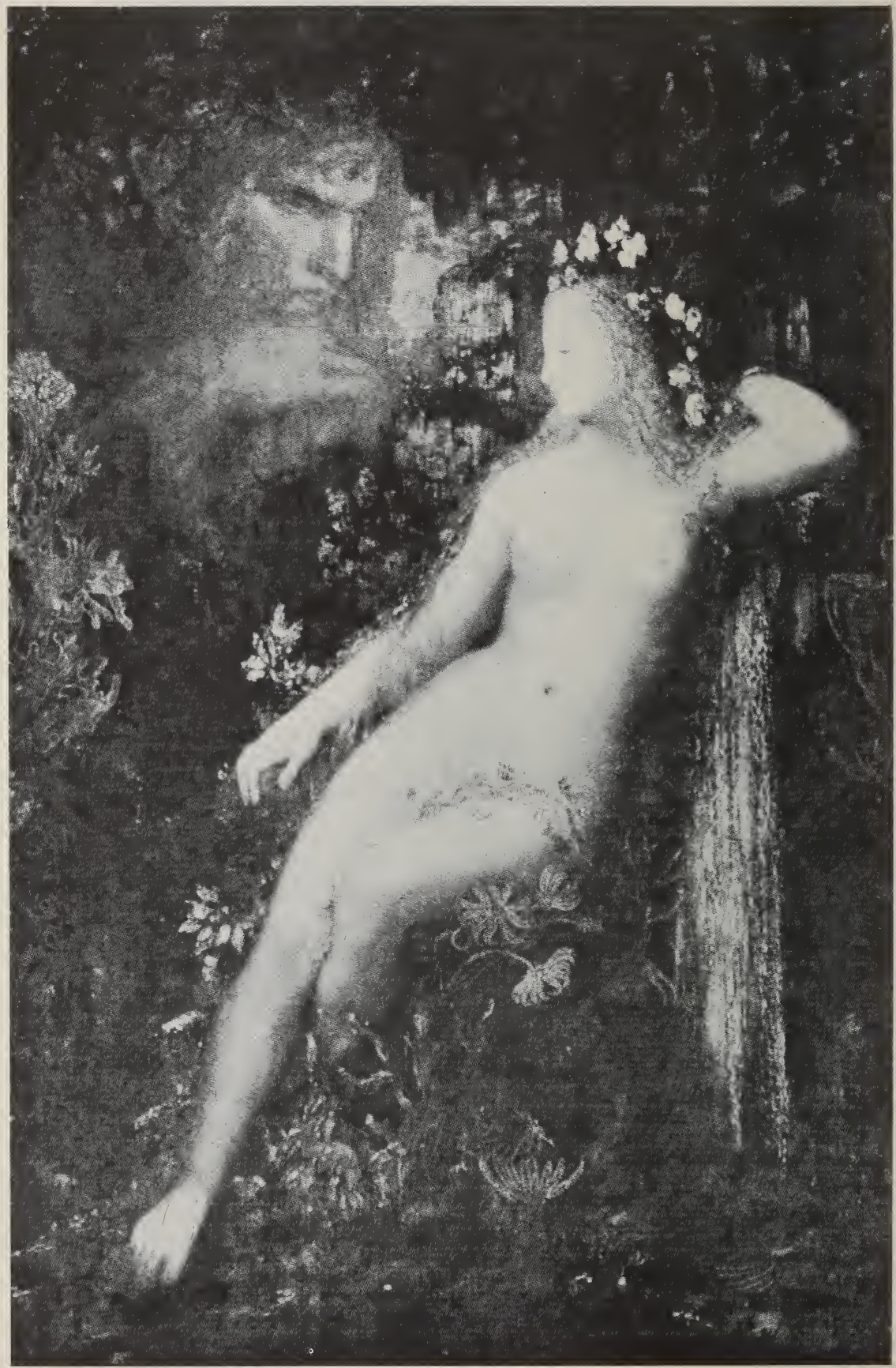

Courtesy of Robert Lebel. 
PLATE 24

Hélène sur les murs de Troie

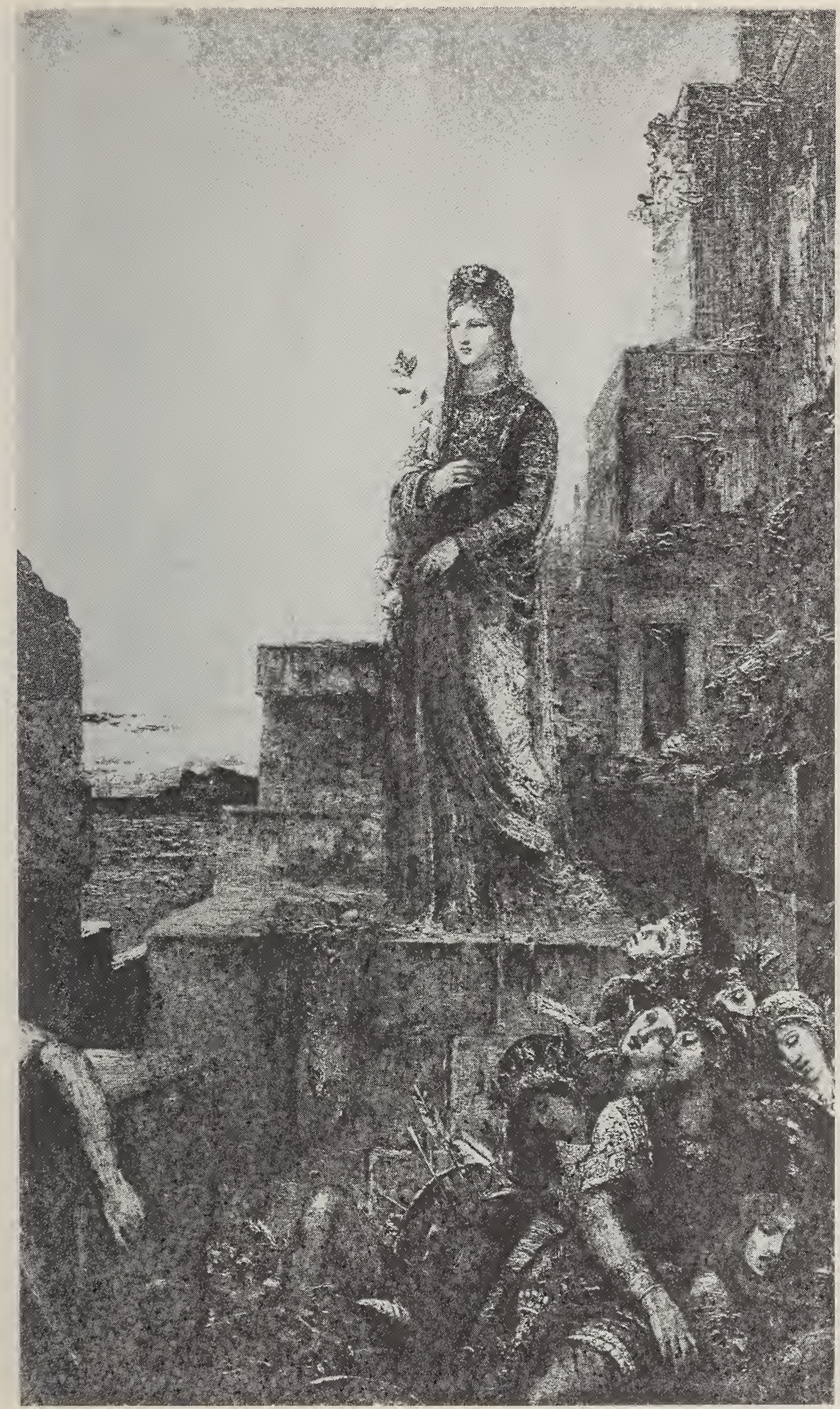

Photographie Bulloz. 
PLATE 25

Hercule et l'Hydre de Lerne

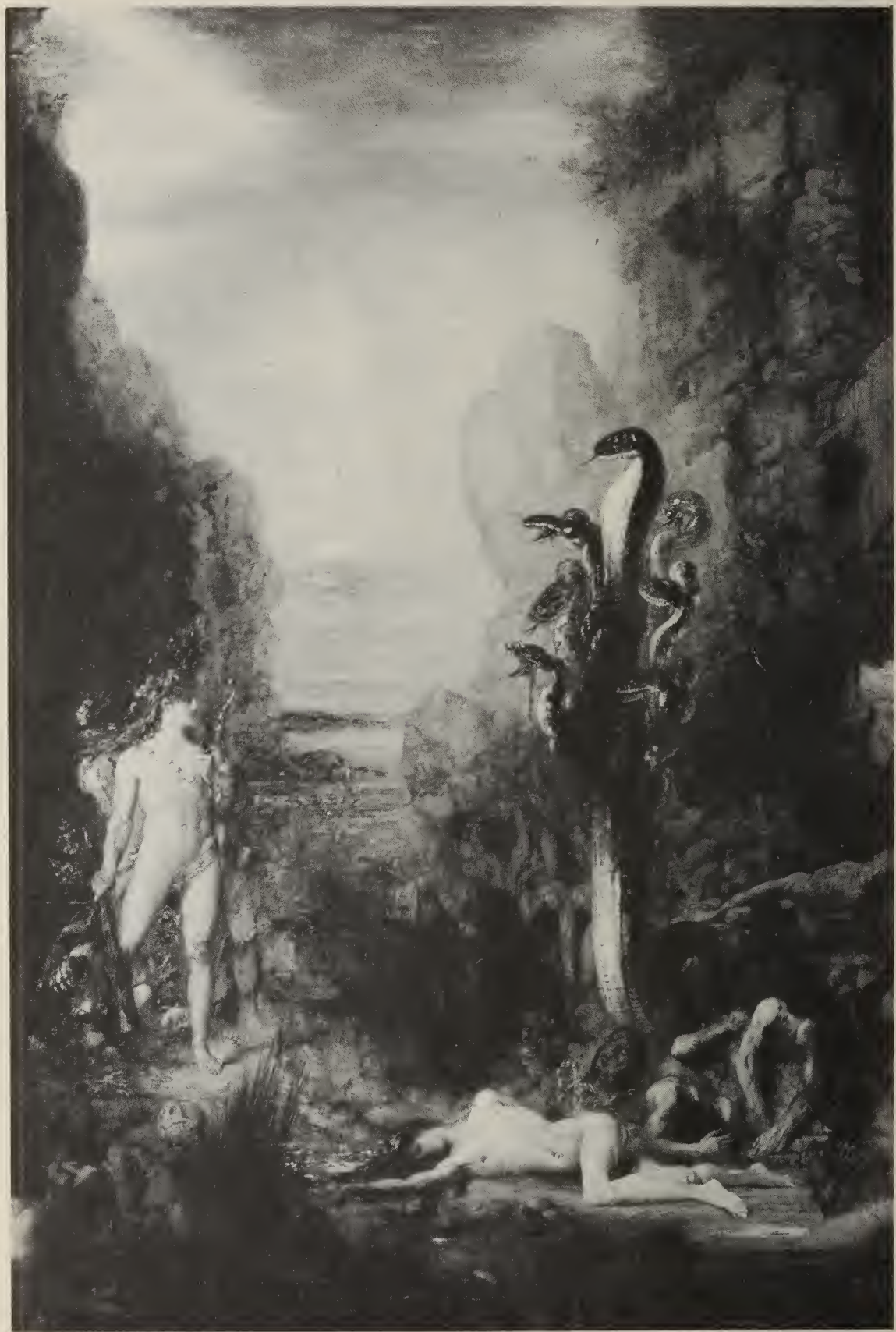

Courtesy of Mrs. Eugene A. Davidson. 
PLATE 26

La Naissance de Vénus

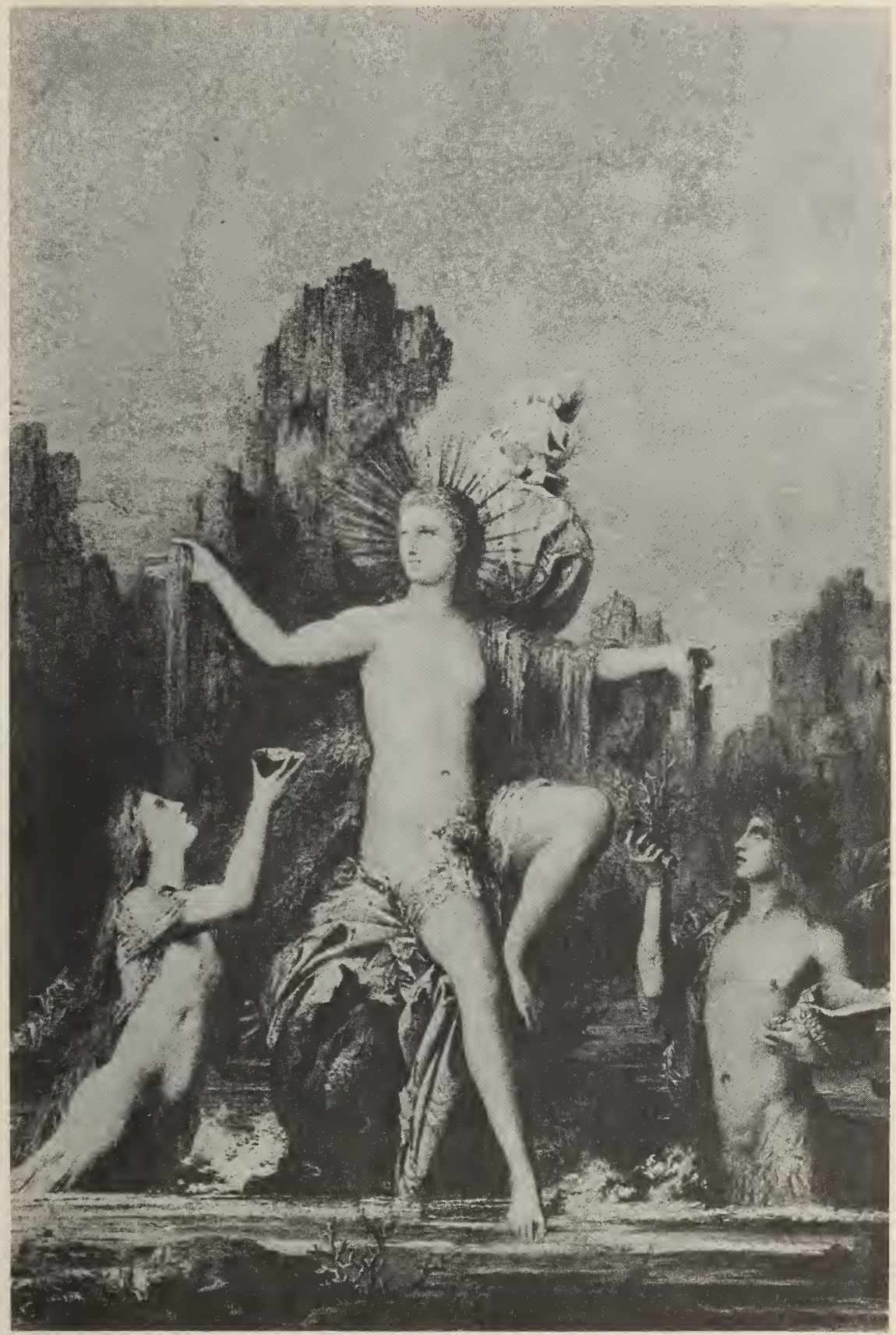

Cliché Musées Nationaux, Paris. 
PLATE 27 (A)

Sapho se précipitant dans la mer

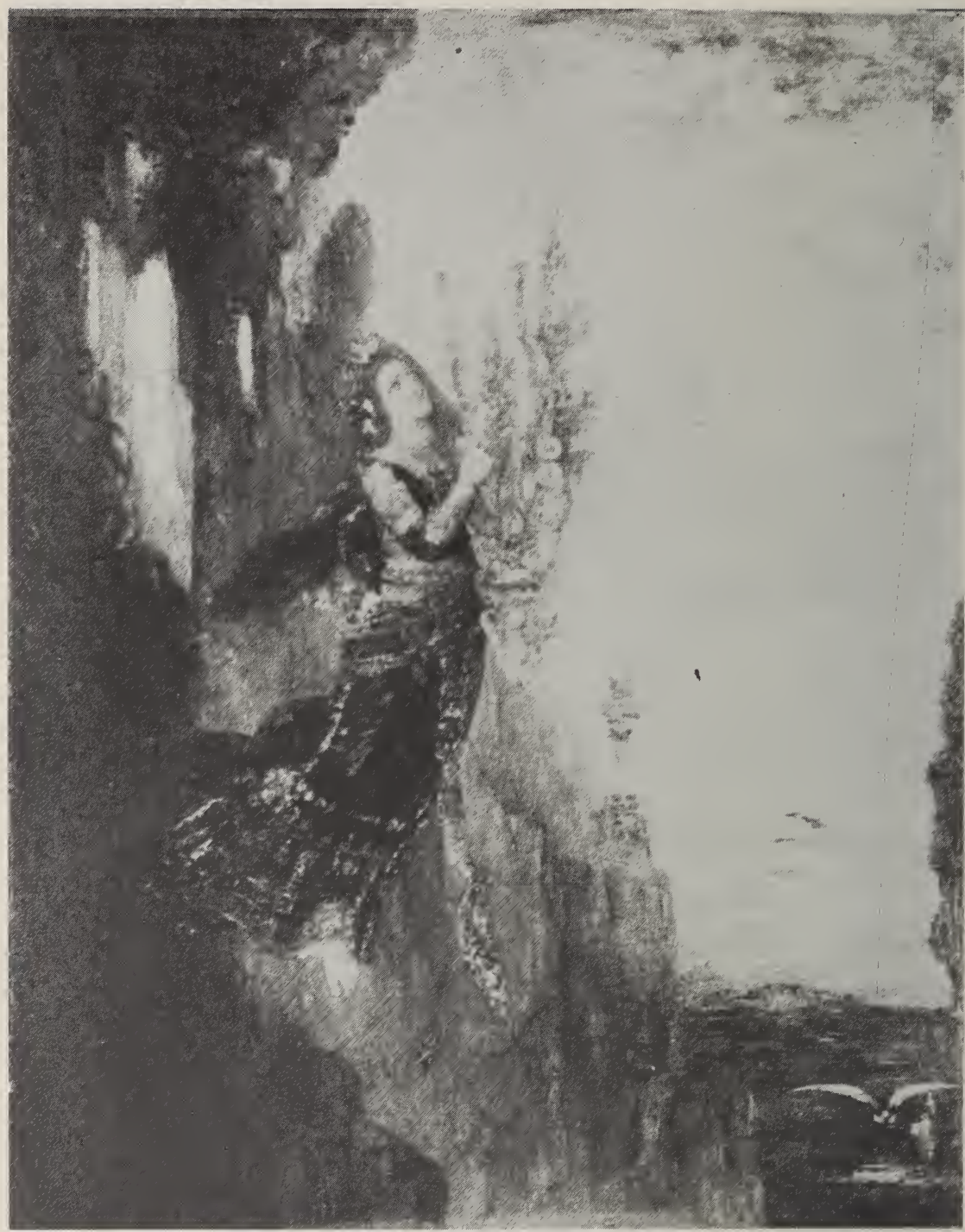

Cliché Musées Nationaux, Paris. 
PLATE 27 (B)

LaPéri

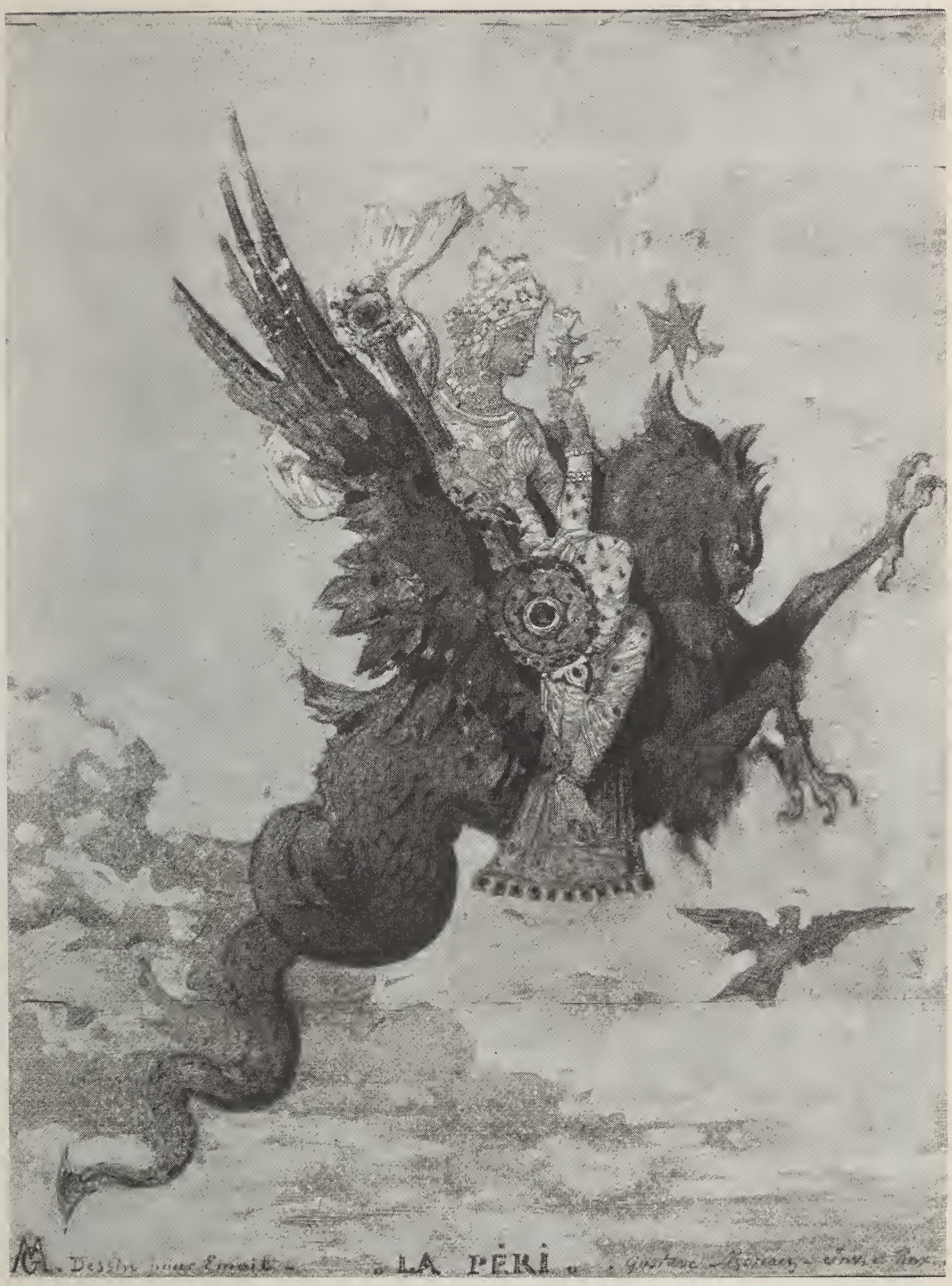

Cliché Musées Nationaux, Paris. 
PLATE 28

\section{L'Enlèvement d'Europe}

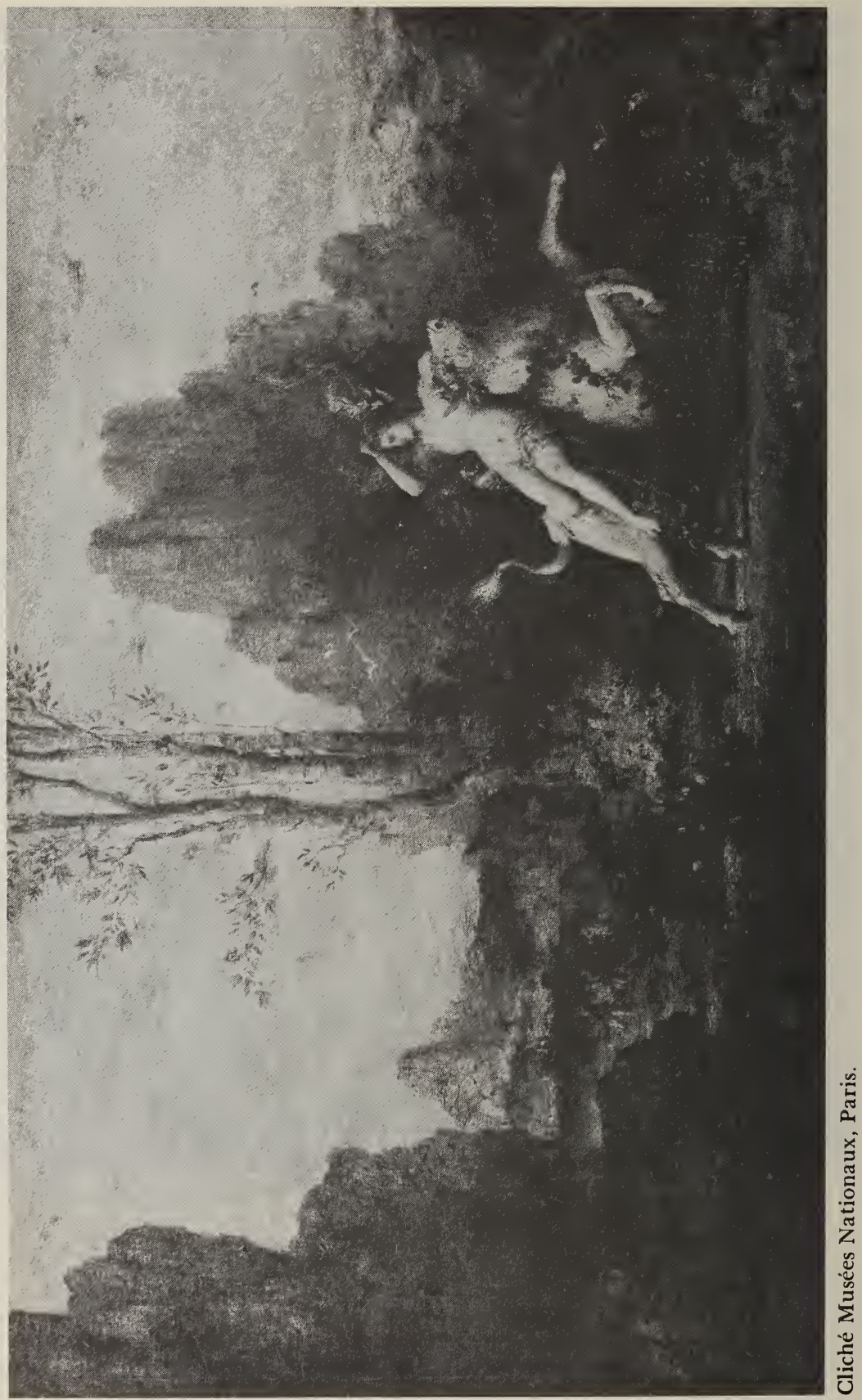




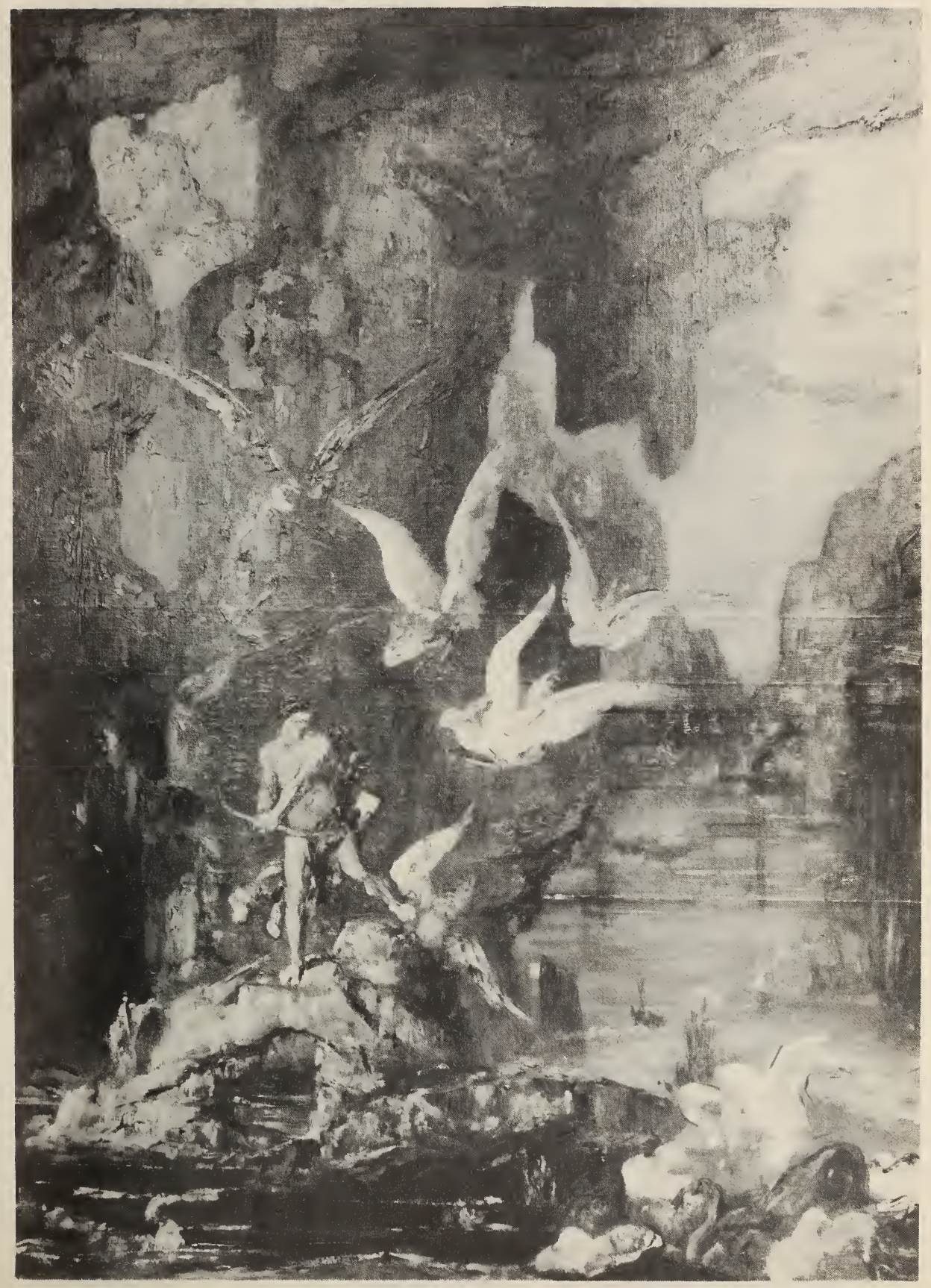


sonnets raises a question for which there is still no positive answer: namely, despite what he said in C1 and C2, did Casal really wait until he obtained a photograph of Salomé before composing the sonnet, or did he use Huysmans' detailed description in À rebours as his immediate source of inspiration? The legitimacy of this question is supported by two additional considerations. First, Casal's earliest references to Huysmans antedate all references to Moreau. Second, an examination of $\grave{A}$ rebours shows that if Casal had read Chapter V, he would obtain at least as much information about Moreau's Salomé as he would by studying a simple black and white photograph of the painting, for, as Casal himself indicated, "La pluma de Huysmans rivaliza con el pincel de cualquier pintor."

\section{N8: Notes to Introductory Statement}

1 Enrique Fontanills Nattes (b. Guanabacoa, 1871; d. Havana, 20 May 1932) was a journalist who collaborated on La Habana Elegante, El Fígaro, La Lucha, El Diario de la Marina, and other periodicals; wrote the society column (entitled "La Habana Elegante") for La Habana Literaria from 15 September 1891 to 29 March 1892; directed the journal Smart; and prepared a Guia Social de la Habana. On 29 October 1893, he published "Episodio," an anecdote about Casal, in La Habana Elegante; this may be found in the Ed. del Cent., "Poesías," pp. 293-294.

2 Marshall E. Nunn found a copy of Moreau's Salomé among Casal's personal effects ("The Life and Works of Julián del Casal," p. 45); he did not see copies of any other works by Moreau among Casal's papers, however.

3 As this list shows, the order in which Casal mentioned the poems in his letters to Moreau differed both from the order in which he published them in $\mathrm{HE}$ and from the sequence in which he placed them in Nievé.

4 "Joris Karl Huysmans," HL, vol. II (15 March 1892), p. 110; Ed. del Cent., vol. I, p. 177. For an analysis of this poem, see Francisco E. Porrata, "Salomé," in Antología comentada del modernismo, ed. Francisco E. Porrata and Jorge A. Santana (Sacramento: California State University, 1974), pp. 134-137.

\section{N8: VARIANTS}

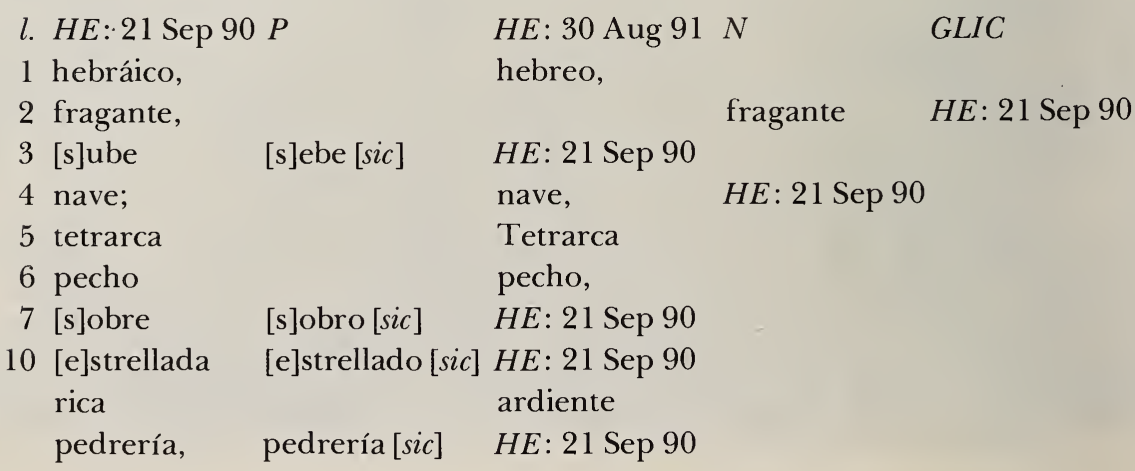


l. HE: 21 Sep 90

$12 \mathrm{y}$

alzado
$P$

HE: 30 Aug 91

$N$

$\mathrm{y}$,

alzado,

\section{N9: LA APARICION}

Although Huysmans' À rebours contains a description of L'Apparition, information found in Casal's letters to Gustave Moreau suggests that this poem was not inspired by Huysmans' verbal reproduction of the painting, but by a photocopy of the Moreau original which reached Havana on or about 13 August 1891 (C1/29-33, C2/14-21). The rapidity with which Casal worked is indicated by the date on which the sonnet was first published: 30 August 1891. This version of the poem appeared in $L a$ Habana Elegante with the rest of Casal's "Cuadros de Gustavo Moreau." Only two punctuation changes distinguish it from the Nieve version of 1892.

\section{N9: VARIANTS}

l. $H E$

7 Salomé,

10 momento
$N$

Salomé

momento,

GLIC

\section{N10: PROMETEO}

This poem was first printed on 16 August 1891 by La Habana Elegante. In this version, it bore the subtitle "(Cuadro de Gustavo Moreau.)." Two weeks later, on 30 August 1891, it was reprinted in revised form by the same journal as part of the series entitled "Mi museo ideal." By their very nature, the changes made between 16 August and 30 August 1891 and those made between 30 August 1891 and the spring of 1892, when the sonnet was prepared for inclusion in Nieve, give a clear indication of the degree to which Casal was concerned with details when giving form to his poetic ideas.

Moreau's Prometheus, which is reproduced in Plate 21, was exhibited at the Salon in 1869. One of the curiosities of the painting is the fact that it shows two birds of prey instead of one. In L'Art fantastique de Gustave Moreau, ${ }^{1}$ Ragnar von Holten suggests that the indifference of Prometheus is due to the fact that the Titan, who has been endowed with the gift of foresight, knows that his torment will not be everlasting. It is assumed, therefore, that the vulture which lies dead at Prometheus' feet symbolizes the destiny that awaits the instrument of divine punishment which now stabs the Titan's flesh.

Through his treatment of the vulture, Moreau was attempting to por- 
tray two distinct moments in the life of Prometheus. This detail is important because it calls attention to the fact that the artist not only chose subjects whose origins lay in the depths of pre-history, but also adapted age-old representational techniques to his special needs. In one form or another, the narrative device that Moreau used in Prometheus can be found in the art of many primitive societies; it was also quite common in the works of European artists of the Middle Ages and early Renaissance. A particularly interesting example is Lorenzo Vecchietta's illustration for the Divine Comedy, which is reproduced in Plate 22. ${ }^{2}$ The picture shows six successive moments in Canto I of the "Inferno": Dante asleep in the dark wood, Dante before the Mountain of Righteousness, Dante meeting the leopard, Dante confronted by the lion, Dante set upon by the she-wolf, and Dante conversing with Vergil. As far as Casal is concerned, however, the text of "Prometeo" shows that, despite his love of painting and his familiarity with the great works of western art (see $\mathrm{Hp} 0$ ), he failed to realize that the presence of two vultures in Prometheus was simply a device that Moreau had used to represent the passage of time in an art form which is by nature non-chronometric.

\section{N10: Notes to Introductory Statement}

1 Paris: Jean-Jacques Pauvert, 1960, p. 14.

2 The Vecchietta illustration is found in the Codex Sienese (1438-1444), which is currently housed in the British Museum.

N10: VARIANTS

l. $H E: 16$ Aug 91

1 verdinegra

2 Titán,

4 el gemido brote

6 sanguinario,

7 visionario

9 fragor

10 las altas peñas,

11 [m]ira en el cielo arder extrañas,

12 [m]ientras el

13 marfileñas,

14 [s]angre bebe en sus cálidas
HE: 30 Aug 91

gigantesca

titán,

brote el gemido

sanguinario

visionario,

hervor

musgosas

[v]e de su reden-

extrañas. [sic]

ción

[j]unto a otro

[q]ue ha extinguido

la sed en sus
$N$

GLIC

HE: 16 Aug 91

$H E$ : 16 Aug 91

$H E$ : 16 Aug 91

peñas

HE: 16 Aug 91

HE: 16 Aug 91

marfileñas 
This composition, subtitled "(Cuadro de Gustavo Moreau.)" and dedicated "A Manuel Gutiérrez Nájera," was originally published in $L a$ Habana Elegante on 9 August 1891. Two days later, Casal sent his first letter to Gustave Moreau. Together with that letter were clippings of "Salomé" (HE, 21 September 1890), "Elena" (HE, 2 August 1891), and his latest poem, "Galatea." On 30 August 1891, La Habana Elegante again printed "Galatea." This time, however, it did not appear alone, but was part of the sonnet series entitled "Mi museo ideal." In this version, the original subtitle and dedication were suppressed, and two minor changes were introduced into the text. It is interesting to note that, when revising the sonnet for publication in Nieve, Casal rejected the changes that he had made for the 30 August 1891 version and restored the 9 August text.

N11: VARIANTS

\author{
l. HE: 9 Aug 91 \\ 10 gentil \\ 11 pierde
}

$H E$ : 30 Aug 91
ideal
pierde,

$N$

HE: 9 Aug 91

HE: 9 Aug 91

GLIC

\section{- N12: ELENA}

This sonnet was first published on Sunday, 2 August 1891 by La Habana Elegante. The poem was printed in italics on the first page of the journal. It bore the subtitle "(Cuadro de Gustavo Moreau.)" and the dedication "A Edouard Cornelius Price." 1 The initial letter of each verse was capitalized and the first line of each stanza was indented.

On 4 August 1891, El País, acknowledging its source as La Habana Elegante ("De ese bello número copiamos el siguiente soneto que figura en la plana de honor:"2), reproduced the composition with some minor changes. As will be shown presently, the variants found in the El Pais version help shed light on newspaper practices of the time. Of special interest are the following modifications of the original text: 1) the name "Edouard" was changed to "Eduard"; 2) only ll. 1, 5, and 9 began with a capital letter; 3) l. 12 was not indented; 4) the name "Ylión" in 1.8 was spelled "Ilion"; and 5) the commas at the end of 11.12 and 13 were omitted.

On 11 August 1891, El Pueblo printed the poem. This version was introduced by the following statement: 
La Habana Elegante. - El número del domingo último, viene interesante y nutrido de buenos materiales. De ese bello número copiamos el siguiente soneto que figura en la plana de honor:

This preamble bears more than a casual resemblance to the note that appeared in El Pais, and leads one to wonder whether El Pueblo really used La Habana Elegante as its source or whether it copied from the ElPais version of the poem. The following evidence points to El Pais as the true source: 1) "Edouard" > "Eduard" became "Eduardo" in El Pueblo; 2) the first letter of $11.1,5$, and 9 was capitalized, while the first letter of all other lines was printed in lower-case; 3) 1.12 was not indented; 4) "Ylión" > "Ilion" became "Ilión"; and 5) the commas at the end of 11.12 and 13 in the original version were suppressed not only by El Pais but also by El Pueblo. A further point suggests that El Pueblo copied from El País rather than from La Habana Elegante. While ElPais, which was published on Tuesday, 4 August, could accurately speak of "El número del domingo último" when referring to the $H E$ version of the sonnet, El Pueblo could not legitimately do so: since El Pueblo came out on Tuesday, 11 August, $e l$ último domingo would have been 9 August and not 2 August, the date when the poem was published in La Habana Elegante.

On 30 August 1891, "Elena" was again printed by La Habana Elegante. Appearing this time with the nine other sonnets that formed "Mi museo ideal," it carried no subtitle or dedication, and had one variant in the text.

In the months that followed, Casal introduced changes into ll. 2, 6, and 13 of the poem. These changes, which ultimately found their way into Nieve, illustrate how insistent he was about refining his work until the very last moment before publication. ${ }^{3}$

\section{N12: Notes to Introductory Statement}

1 For further information on Price and his relationship with Casal, see Np5.

2 Unfortunately, the photocopy that was sent to me from Cuba was cut off just above this line. I suspect, however, that the words preceding this statement were not unlike those which appeared in El Pueblo on 11 August 1891 (see my discussion below).

3 For an analysis of this poem, see Julio Durán-Cerda, "Elena," in Antología comentada del modernismo, ed. Francisco E. Porrata and Jorge A. Santana (Sacramento: California State University, 1974), pp. 138-145.

\section{N12: VARIANTS}

$\begin{array}{lllll}\text { l. } H E: 2 \text { Aug } 91 & P & P b & \begin{array}{l}H E: 30 \text { Aug } 91 \\ \text { entreabe [sic] }\end{array} & \text { HE: 2 Aug 91 }\end{array} \quad$ GLIC




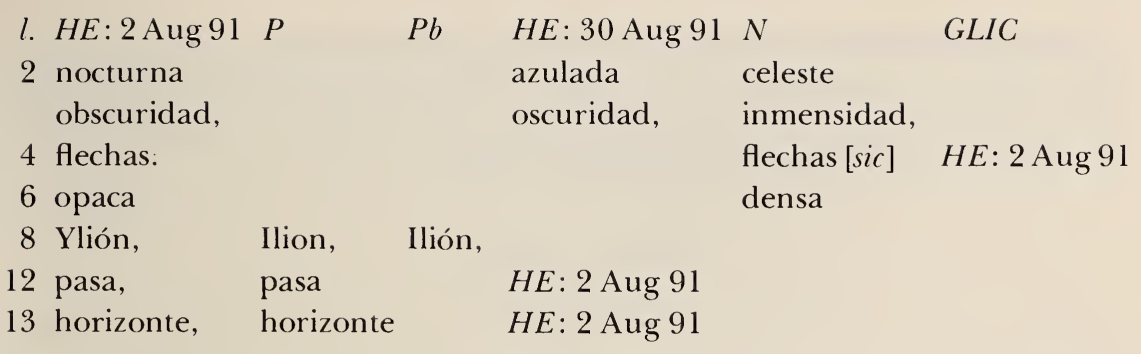

\section{N13: HERCULES ANTE LA HIDRA}

The first known printing of this sonnet is the one that appeared in the series entitled "Mi museo ideal" on 30 August 1891 in La Habana Elegante (see Plate 16). When revising the poem for publication in Nieve, Casal made only four minor changes.

\section{N13: VARIANTS}

$\begin{array}{ll}l . H E & N \\ 2[\mathrm{y}] & {[\mathrm{y}]} \\ 6 \text { mirar, } & \text { mirar } \\ \text { acaso, } & \text { acaso } \\ 12 \text { pieles, } & \text { pieles }\end{array}$

\section{N14: VENUS ANADYOMENA}

This sonnet was first published in the 30 August 1891 issue of $L a$ Habana Elegante, where it appeared as part of the series entitled " $\mathrm{Mi}$ museo ideal." Five variants distinguish the Nieve version from the original, but, for reasons explained in the notes below, only two of those variants have been included in the present edition.

Although Casal provides a certain amount of background on "Venus Anadyomena" in his correspondence with Gustave Moreau, it is extremely difficult to identify the poem's source of inspiration. What is known is that the Photographie des Beaux-Arts sent Casal two pictures of Venus in August 1891. These were listed in the firm's catalogue under the code numbers 17,984 and 19,692, and were described by Casal as "Una Venus" and "El Nacimiento de Venus," respectively (C2/29-30, 32). In all probability, the latter work was La Naissance de Vénus, which is reproduced in Plate 26. As the reader will observe, that painting has notable points of contact with 11. 9-14 of the sonnet, but does not coincide very closely with 11. 1-8. If the discrepancies between La Naissance de Vénus and the information provided in 11. 1-8 of "Venus Anadyomena" were not caused by 
the poet's attempt to compensate with his imagination for lack of clarity in the photograph, then it may be assumed that the initial lines of the poem were inspired by the picture designated as "Una Venus." What this work might have been, however, is still not certain.

\section{N14: VARIANTS}

\section{l. $H E$}

4 tornasoles;

5 arreboles,

6 Venus

emerge

alabastrino,

11 a la deidad de formas

virginales
$N$

GLIC

tornasoles,

arreboles

$H E$

Venus,

$H E$

alabastrino

HE

hasta la diosa de ojos

maternales

\section{N14: Note to Variants}

5-6: The key to Casal's punctuation of the $H E$ version is the word emerge in 1. 6. It is obvious that Casal used this intransitive verb in a transitive construction (i.e., Venus emerge el cuerpo alabastrino). As a result, it was logical to place a comma after arreboles in 1. 5, and it was equally logical to insert another comma after alabastrino in 1. 6. The punctuation changes in 11. 5-6 of Nieve suggest that Casal, having become aware of the incorrectness of the emerge construction, attempted to cover the traces of his error merely by shifting the position of the first comma and by eliminating the second one. In other words, he wanted his public to read the text in the following way: envuelta en luminosos arreboles Venus, emerge el cuerpo alabastrino frente al húmedo borde del camino. While it is true that these changes in punctuation represent an improvement in one sense, it is evident that they create another situation for which Casal can be criticized: they separate Venus - who is "Sentada al pie de verdinegras moles" (1. 1) and who is "envuelta en luminosos arreboles" (1.5)from her own "cuerpo alabastrino," which rises out of the waters in 1. 6. In order clearly to show the origin of both sets of problems, the punctuation of the $H E$ version has been restored in the present edition.

\section{N15: UNA PERI}

"Una peri" was first published in the 30 August 1891 issue of La Habana Elegante, where it was grouped with the other sonnets of "Mi museo ideal." Casal made six lexical changes in the poem before republishing it in Nieve.

In his letter of 15 August 1891, Casal indicated that he thought item 17,987 in the Photographie des Beaux-Arts catalogue was "Una Peri" (C2/39-40). Pierre-Louis Mathieu suggests, however, that what Casal had 
really received was a copy of Sapho se précipitant dans la mer. In Plate 27, a photograph of this work is shown beside the best known and most easily obtainable version of La Péri. By comparing Casal's sonnet with each of these pictures, the reader will quickly recognize the merits of Mathieu's hypothesis.

\section{N15: VARIANTS}

\section{l. $H E$}

2 fulgores

4 [l]ánguida el

5 rojo

8 [r]eflejada

* $9 \mathrm{Y}[$ sic $]$

12 gélido suspiro,
$N$

reflejos

[b]lanca

su

claro

[r]etratada

Y

lánguido suspiro
GLIC

( () $\mathrm{Y}$

\section{N15: Note to Variants}

9: The first verse in each stanza of every poem printed under the heading "Mi museo ideal" in this issue of $H E$ is indented; the only exception is 1.9 of "Una peri." Left justification of this line was obviously an oversight on the part of the compositor, and is therefore listed as a typographical error in the record of variants. Since indentation was not used to signal the beginning of stanzas in the $N$ version, left justification of " $Y$ " is not an error there.

\section{N16: JUPITER Y EUROPA}

"Júpiter y Europa" was first published in the 30 August 1891 issue of $L a$ Habana Elegante, where it was grouped with the other sonnets of "Mi museo ideal." When preparing the poem for publication in Nieve, Casal made five minor changes in the text.

It is the impression of this writer that "Júpiter y Europa" is one of the least perfect compositions in Nieve. The most serious problems derive from inconsistencies in temporal and syntactical sequences. For example, when reading the $H E$ version, one follows the actions of the protagonists in a continuing present: first, surge Europa del piélago marino (1. 3); then, Júpiter . . . acéchala a la orilla del camino (1l. 5-6). In Nieve, however, the change in tense from surge to surgio prevents the reader from viewing the action as it unfolds in time, and obliges him to assume the role of one who listens to a historical account. Just as the reader takes this position, he discovers that all subsequent verbs are in the present tense. Although such a change may heighten the dramatic impact of an oral narrative, it does not have that effect in "Júpiter y Europa." Here, indeed, its result is quite 
negative: it robs the poem of unity of perspective. The second problem arises from Casal's use of interrnanse (1. 8), whose subject is Júpiter and Europa, as a verb complement of elevando (1. 7), whose subject is Júpiter alone. The third problem stems from Casal's reference in 1.11 to an action which took place in the past (mirándola surgir de la onda) in such a way that it appears to be contemporaneous with an action that takes place in the present (desnuda va [Euopa] sobre su blanco toro). Unless the reader makes a quick mental jump, he gets the impression that Europa rides off on the bull at the same time that the crowd watches her emerge from the sea.

N16: VARIANTS

$\begin{array}{ll}\text { l. } H E & N \\ 3 \text { [s]urge } & \text { [s]urgió } \\ 6 \text { camino, } & \text { camino } \\ 7 \text { [y] } & \text { [y], } \\ \quad \text { alabastrino } & \text { alabastrino, } \\ 11 \text { honda }[s i c] & \text { onda }\end{array}$

\section{N17: HERCULES Y LAS ESTINFALIDES}

This poem was first published in La Habana Elegante on 30 August 1891. As shown in Plate 16, it was the concluding sonnet of the "Mi museo ideal" series. When preparing the poem for Nieve, Casal made a few changes in wording and punctuation.

\section{N17: VARIANTS}
l. $H E$
3 pico [sic] fulgurantes
7 casco verde fragantes
12 mira su [sic] 
press earlier than the sonnet did. "Sueño de gloria," subtitled "Apoteosis de Gustavo Moreau," was published in La Habana Literaria on 30 December 1891; "Vestíbulo," entitled "Gustavo Moreau" in its first printed version, came out in El Fígaro on 15 January 1892. These data suggest that Casal originally intended to place "Sueño de gloria" before the "Diez cuadros de Gustavo Moreau." This impression is strengthened by a nonverbal feature of the Nieve version, which might easily be overlooked: namely, the centered rule that was printed beneath the title of the poem. The only other poems in the 1892 edition of Nieve that have this mark beneath the title are N1-N7. If we keep this fact in mind when considering the question of sequencing, we are forced to conclude that "Sueño de gloria" was not originally intended to be the eighteenth poem in the book. Since it was obviously not meant to form part of the introduction to Nieve or of the "Bocetos antiguos" series, the only possible place for it would have been either immediately before or immediately after "Vestíbulo." In other words, according to the original plan, "Sueño de gloria" would have been the seventh or eighth poem in the book. But if "Sueño de gloria" was supposed to occupy such a position, when could it have been moved to its present location? The answer is almost self-evident: because decisions concerning the insertion of centered rules beneath titles are usually made by the printer and those concerning poem sequence are generally made by the author, it would seem that "Sueño de gloria" was moved to eighteenth position after the typesetting of Nieve had begun. Considering the nature of "Mi museo ideal" and the contents of "Sueño de gloria," this was a very wise decision.

N18: VARIANTS

l. $M S$

* 1

5 Cedrón, plomizas,

8 ascienden

12 [e]ntreabiertas

15 lejos,

18 flancos

20 ásperos

22 solitario

25 puebla,

27 tiniebla

34 vela

37 sienes

38 [e]sparcida

39 primavera

42 los

* 44
$H L$

N

Cedrón plomizas

ascienden,

lejos

[e]ntreabriendo

flancos,

MS

áridos

tenebroso

puebla

tiniebla,

cubre

sienes,

les [sic]
MS

MS

[e]aparcida [sic]

primavera,

MS

GLIC 
l. $M S$

45 crepúsculo

47 esplendoroso

48 candente,

50 [c] entellea

51 carmesíes

53 diestra,

59 cristiana

62 condena

63 omnipotente

66 sepulcrales,

78 besos,

* 82 tornasola,

85 las flores de

89 [f]órmanle por la espalda sus

91 los

93 nacarados

95 [1]os

98 Lleva

99 laurel

$105 \mathrm{su}$

110 [y]

112 tumultuoso

113 mejillas

116 cielo

118 perdonó,

*121 Oscurece.

128 siderales,

130 rosas

celestiales [sic]
$H L$

esplendoroso,

fulgente,

carmesíes,

diestra

humana

condena,

atornasola,

la flor de la

[f]órmanle, des-

trenzados, los

sus

[s]us

Muestra

lauro

la

[y],

mejillas,

olvidó,

nacarados,

munificente

sepulcrales

besos

MS

atornasola

$H L$

GLIC

$M S$

[l]uz proyecta

MS

$M S$

$M S$

tnmultuoso [sic] MS

cielo,

MS

(ף)Obscurece.

siderales

MS

celestiales.

flores

\section{N18: Notes to Variants}

1: The reader is reminded that variants in spelling (such as estensión in 1.1 of the $M S$ ) and variants in accentuation (such as pié in 1.16 of the MS) are not recorded in the present edition unless they appear in combination with variants in wording, punctuation, or format (see, for example, 1. 121).

44: The $M S$ and $H L$ versions clearly indicate that 1.44 begins a new stanza. This is not shown in $N$ because there is no indentation of stanzas in that book and 1. 44 appears at the top of the page. The same problem could have arisen in the case of 1.121 , which also appears at the top of the page in $N$. It was avoided, however, because the compositor of $N$ placed three centered asterisks after 1.120 at the bottom of the preceding page.

82: There are two points of interest here: the first deals with Casal's vocabulary; 
the second concerns his method of punctuation. In $\mathrm{H} 49 / 9$, Casal used tornasola. In N 18/82, he wrote tornasola in the $M S$, but atornasola appeared in the $H L$ and $N$ versions. Since Casal, who was so scrupulous in revising his works before each new publication, did not restore tornasola in $N$, it is assumed that he wished to have atornasola retained. For this reason, it is used in the present edition.

Without the comma after atornasola, it would appear on first reading that "bella y sombría" (1. 83) is part of the introductory statement (ll. 81-82) and therefore modifies "la luz se atornasola . . . ." Restoration of the comma makes it immediately apparent that "bella y sombría" refers to a noun which is to be specified later in the sentence. That noun is "Elena" and is found in 1. 86 .

121: See note to 1.44 .

\section{Np3: CROMOS ESPAÑOLES}

The three sonnets in this series - "Una maja" (N19), "Un torero" (N20), and "Un fraile" (N21) - were first published in the 15 February 1892 issue of La Habana Literaria under the heading "Tipos españoles." The entire series was dedicated "A Enrique Hernández Miyares."

On 17 February 1892, acknowledging its source as La Habana Literaria and using the same generic title that had appeared in the original version, El Pais reprinted the poems for its own readers.

Before publishing the sonnets in Nieve, Casal changed the title of the series from "Tipos españoles" to "Cromos españoles" and made significant textual alterations as well. He did not change the original dedication, however. Indeed, it would have been more than surprising if he had done so, for, if anyone deserved a tribute from Casal, that person was Enrique Hernández Miyares. ${ }^{1}$ The friendship between the two men went back to the time when they were both just beginning to face the complex responsibilities of adulthood. Hernández Miyares described their meeting in the following terms:

Casal y yo nos conocimos un día, hace muchos años, cuando el bozo nos sombreaba incipientemente los labios. Nos conocimos de ser presentados, de darnos la mano; porque hacía mucho tiempo antes que nos conocíamos de vista. Cuando yendo por una acera, me pasaba por el lado, yo lo miraba como diciéndole iquiero ser tu amigo! y él me miraba a mí - generoso y más apasionado - como queriéndome contestar iya lo soy tuyo! Pero seguíamos caminando, cada cual por opuesto rumbo, y, siempre, como yo volviese la cara para verlo por la espalda, me encontraba con sus ojos claros que habían tomado la misma determinación. 
Y aquel día que nos dimos la mano, con verdadera efusión, nos contamos uno al otro, tratándonos de usted, todas estas circunstancias, y cuando me hubo recitado de memoria una rimilla mía y yo le declamé con entusiasmo una de sus primeras estrofas, habíamos llegado al final de la escalera de mármol, donde ya nos tuteábamos, cogidos del brazo, contentísimos de haber anudado simpatías mutuas, of reciéndonos todo lo que poseíamos, aparte de la amistad: libros, periódicos, grabados, fotografías... iqué sé yo! el tesoro de los años juveniles, aumentado con el entusiasmo y el fervor de ricos gustos y ensueños literarios.

Al otro día me fue a buscar a casa; al otro día yo lo fui a buscar a él; y entonces se inició una amistad estrecha, íntima; una confraternidad, una comunión de ideas, de propósitos, y aun de finalidades, tanto más rara cuanto eran diferentes nuestros caracteres .... ${ }^{2}$

As was his habit, Hernández Miyares did not specify the date of the meeting; however, it is unlikely that it took place any later than the spring of 1885. In April of that year, a group of distinguished citizens organized El Círculo Habanero and invited La Habana Elegante, which had been in existence since 1883, to become its official organ. On 19 April 1885, Casal made his first contribution to the journal; and, from that moment on, $L a$ Habana Elegante was his preferred vehicle for the publication of original literary works. ${ }^{3}$

Between 19 April 1885 and 25 March 1888, La Habana Elegante brought out twenty poems and fourteen prose works by Casal. On the latter date, in addition to publishing "Viejos labios y joven beso" (Casal's Spanish version of a story by Catulle Mendès), it printed Chapter I of his proposed book La Sociedad de la Habana. The title of that chapter was "El general Sabas Marín y su familia." 4 This was followed a few days later by the first installment of "La antigua nobleza." On 6 April 1888, the Board of Directors of El Círculo Habanero resolved publicly to disclaim all responsibility for these articles. Before long, Hernández Miyares, who had spoken in defense of Casal, found himself in the middle of a serious controversy. On 21 April, after weighing the pros and cons of the matter, he addressed the following note to the President of El Círculo Habanero: "No conviene a los intereses de este semanario, La Habana Elegante, continuar representando a la Sociedad Círculo Habanero en la Prensa, como órgano oficial del Instituto, la Redacción ha determinado renunciar dicho cargo, desde esta fecha. - Lo que le comunico para los fines consiguientes. - Habana, 21 de abril de 1888. Por la Redacción: E. Hernández Miyares." 5

As a result of this incident, Casal was relieved of his position as a Government clerk. During the weeks that followed, conditions grew 
increasingly uncomfortable for him in Havana; therefore, he decided to consolidate the limited funds at his disposal and invest them in a trip abroad. When Casal set off for Spain, Hernández Miyares was one of a small group of friends who accompanied him to the ship in order to wish him bon voyage. As soon as Casal landed in Spain, he is reported to have sent Hernández Miyares a letter and the poem we know as "En el mar" (see my discussion of H32).

When Hojas appeared in the spring of 1890, Hernández Miyares reviewed it in La Habana Elegante. Of the several critics who evaluated the book, he was the most candidly partial of all. He had followed the development of Casal's poems from the moment of their conception to their final printing in Hojas; as a result, he could not help feeling a personal affection for them (see Appendix B). But Hernández Miyares was more than a friend of Casal: as director of La Habana Elegante, he was also a colleague-a colleague who esteemed him, in particular, for his devoted service to that journal. Therefore, he felt it proper to underplay any defects that he might find in Hojas: "Julián del Casal es mi amigo del alma y ha sido el alma de este semanario mucho tiempo. iImposible que yo le señale, como algunos críticos al uso, asonancias y alguna que otra ligera incorrección! Julián del Casal es mi hermano en ideas, aunque yo figuro en la izquierda del partido exótico, de que él es 'leader'. Así es que disimulo sus exageraciones y admiro sus quimeras." 6

There is ample evidence to prove that the friendship was by no means one-sided. However, a single example should suffice to confirm this point. On 22 November 1890, Hernández Miyares married Francisca Marty, a young socialite of great beauty and elegance. Casal described the event in an article which he published in El País on 30 November 1890. Because of what it says about Hernández Miyares, the second paragraph is doubtless the most interesting part of the report. Referring to the wedding, Casal indicates that

es el de un compañero de mi juventud, de uno de esos compañeros que se encuentran en la vida pocas veces y que, al verlo cambiar de estado, me ha parecido que cambiaba también algo de mí mismo. Se llama Enrique Hernández Miyares. Escribir simplemente su nombre, en esta ocasión, sería hacer su mayor elogio, porque sus méritos son conocidos y apreciados de todos los que pueden leer estas crónicas. Pero por si los desconoce alguno de mis lectores, no le diré sólo que el recién casado es mi amigo, lo que es bastante decirle, porque tengo muy pocos y muy alto concepto de la amistad, sino también que escribe versos inspirados, melancólicos como un collar de ópalos o alegres como una sarta de cascabeles, y [es] director del más antiguo semanario artístico de esta capital, de La Habana Elegante, semanario en que han colaborado todos 
los escritores de nuestros días, desde el eximio Enrique José Varona hasta el que firma Julián del Casal. ${ }^{7}$

Although La Habana Elegante comes to mind first when one thinks of Hernández Miyares' journalistic activities, it should not be forgotten that he played an important role on other Cuban periodicals as well. Among these was La Habana Literaria, a review which he and Alfredo Zayas founded on 15 September 1891. During the initial period of the journal's existence, Hernández Miyares' name was printed above that of Zayas, and this apparently reflected the true place of each man in the administrative hierarchy. Nevertheless, indications are that Zayas had no intention of remaining in a subordinate position. This precipitated a crisis approximately six months after La Habana Literaria began publication. The first overt sign of trouble was the departure of the society columnist, Enrique Fontanills. Fontanills' last report concerning Havana's upper crust - "La Habana Elegante" was the name of his column - appeared on 29 March 1892. Exactly one month later, Zayas got top billing on the masthead of the journal; and, in the next issue (15 May 1892), he was listed as the sole director. After that, the tone of the journal changed significantly and the number of local collaborators began to decrease noticeably. ${ }^{8}$

Despite the fact that Hernández Miyares officially terminated his collaboration with La Habana Literaria just prior to 30 April 1892, he allowed himself to make one exception as far as contributions to the journal were concerned-and this exception was motivated by his friendship for Casal. As we know, Nieve came off the press on or about 20 April 1892. In its 30 April issue, La Habana Literaria announced that it would review the book on 15 May. Possibly because of Hernández Miyares' resignation, the journal did not run a formal review until 30 June. $^{9}$ In the interim, however, it did publish a laudatory poem which Hernández Miyares had written on the occasion of Nieve's publication and which, as a friend of Casal and as a former director of La Habana Literaria, he felt should be brought to the attention of the subscribers:

\section{A UN POETA}

Si la melancolía te acompaña, Y hay nieve en el estío de tus años, Y la neurósis de este fin de siglo Te hace aborrecer lo que has amado;

Si alguna fibra al sentimiento late En tu escondido corazón, ioh bardo! E indiferente, el pesimismo tuyo, Solo ama lo bello inmaculado; 
Si del eterno femenino hermoso, No la ternura que nos hace esclavos, Sino la línea y el color, - la forma Tan solo engendra el ritmo de tus cantos;

Y es un gemido tuyo cada verso, Y es enjambre de ensueños de noctámbulo, Cada estrofa que cae cincelada

De tu Aylo de último romano

No en la mitad del áspero sendero Huyas cobarde al a moroso halago, Con que te brinda la adorada Musa Del Arte excelso, arrobador y fausto.

iLa Musa de tus sueños vaporosos, Diosa que divinizas en tus yambos, Amor ferviente de intangible Dea, Causa de tus cantares desolados!

Y si á su amor respondes, y si acude La asoladora nota del desmayo A anublar de tu rima de oro y piedras El dulce acento cadencioso y blando......

Poeta, díle en notas de tu lira, Idioma de los ángeles, que abajo, En este valle hondo, oscuro y triste El roce de sus alas es un bálsamo! ${ }^{10}$

A year and a half later, Hernández Miyares agreed to publish Bustos y rimas as the first volume of a series that was to be called the "Biblioteca de la Habana Elegante." Unfortunately, Casal died before the proofs could be corrected. Shortly after the poet's funeral, however, Hernández Miyares took full charge of Bustos y rimas and saw it through the final stages of publication. According to Wen Gálvez, he also wrote "Al público," the brief, but moving statement which introduces the book (see Rp0 and Appendix A).

Two illustrations are sufficient to show the intensity of Hernández Miyares' grief at his friend's passing. On 18 February 1894, just four months after Casal's death, he published the poignant "Rondeles: In memoriam." This was his personal tribute to the departed poet. ${ }^{11}$ Then, on the first anniversary of Casal's demise, he voiced the communal sorrow of those who, having loved him, would be forever separated from their 
"más querido amigo y compañero, el poeta originalísimo, genial, maestro de la forma ...."12

Most critics agree that the "Cromos españoles" are illustrative of Casal's mastery of form. As Monner Sans points out, the dodecasílabo de seguidilla is well chosen for the portrayal of types such as the maja, torero, and fraile $^{\mathbf{1 3}}$; and there is no question that Casal handles the combination of $7+$ 5 syllables with a fair degree of ease. Indeed, even Cintio Vitier's lefthanded compliment about the "aburridora perfección" of the poems ${ }^{14}$ is a confirmation of the general opinion. It should be noted, however, that the dodecasyllable represents a departure from Casal's norm with regard to line length: not only had he always used hendecasyllables for sonnets before writing the "Cromos españoles," but he would continue to do so afterward in all cases except "Profanación" (R17), where he chose to use alexandrines. The "Cromos españoles" also represent a departure from the norm as far as rhyme scheme is concerned. Before composing them, Casal had favored a CDE, CDE pattern in the sestets. ${ }^{15}$ In "Cromos españoles," however, he used a CCD, EED sequence; this, in fact, was to be his preferred rhyme scheme in Rimas. From this point of view, therefore, the "Cromos españoles" were closer to the sonnets of Rimas than to those of Hojas and Nieve.

Most critics also tend to cite the "Cromos españoles" when speaking of Casal's skill at description. The following remarks by Juan J. Geada seem to represent the consensus: "Su poder descriptivo es tan fiel a la imagen que contempla, ya con los ojos materiales o con los de la mente, que deja en el lector una fuerte impresión de realidad. Sus pinceladas son viriles, enérgicas y parecen darnos el relieve de las figuras hechas a buril por la mano delicada de un artista del Renacimiento. Nuestro aserto quedará confirmado con la lectura de su tríptico Cromos españoles." ${ }^{16}$ In order not to be unduly influenced by the admirers of Casal, however, we must also present the opinion of detractors such as Ciriaco Sos Gautreau. There is no doubt that this critic frequently went to extremes in his efforts to discover flaws in the poet's art. Nevertheless, some of his observations are quite valuable. His comment on the conclusion of "Una maja," for example, helps us preserve our objectivity when we assess Casal's powers of description:

Asoman sus chapines bajo su traje

Hecho de blondas negras y verde raso;

$\mathrm{Y}$ al choque de las copas de manzanilla

Riman con los tacones la seguidilla

Perfumes enervantes dejando al paso.

Aquí del olfato. iLlamar perfume al olor que despedirían aquellos chapines! iPuf! Sería cosa de taparse las narices. ${ }^{17}$ 
Casal would probably have classified Ciriaco Sos as one of the "críticos miopes, castrados de ideal, que sólo saben ver los defectos gramaticales en los libros, que señalan los vicios ajenos porque no tienen virtudes propias que enseñar y que si alguna vez se meten a creadores incurren en todo lo que han censurado a los demás." ${ }^{18}$ Two things must be recognized, however. First, if it is proper for the artist to demand perfection in art, then there is no reason why the critic should settle for less. Second, the barbs of critics like Ciriaco Sos are effective only where the artist has left himself exposed. Unfortunately, Casal left enough chinks in his poetic armor to make himself a vulnerable target.

\section{Np3: Notes to Introductory Statement}

1 Hernández Miyares (see Plate 3) was born in Santiago de Cuba on 20 October 1859 and died in Havana on 2 August 1914.

2 “Julián del Casal," Ed. del Cent., "Poesías," pp. 311-312.

3 See Ed.del Cent., vol. III, pp. 196-222.

4 Although the book was to have a total of 26 chapters, Casal published only a few segments of it (see Ed. del Cent., vol. I, p. 115). Whatever he did publish, however, he signed with the pseudonym El Conde de Camors.

5 Ed. del Cent., vol. I, p. 118.

6 "Hojas al viento," in Obras completas (Havana: Academia Nacional de Artes y Letras, 1916), vol. II, p. 13; reproduced in Appendix B.

7 Quoted from the "Crónica semanal" of 30 November 1890, as reproduced in Ed. del Cent., vol. III, p. 41.

8 Despite what had happened, Casal continued to publish in La Habana Literaria until 15 December 1892: that is, until two weeks before the journal's demise. His final contribution was "Medioeval" (R 18).

9 This was written by Enrique Trujillo and is reproduced in Appendix B.

$10 \mathrm{HL}$, vol. II (30 May 1892), p. 238.

11 See $E d$. del Cent., "Poesías," pp. 360-361.

12 “Aniversario de Casal," Ed. del Cent., "Poesías," p. 316.

13 Julián del Casal y el modernismo hispanoamericano, p. 54.

14 “Julián del Casal en su centenario," p. 22.

15 His only departures had been H24, N 14, N 16, and N33. Complete data on metrical and rhyme patterns in Casal's sonnets may be found in Table 3.

16 Selección de poesías de Julián del Casal, p. xcviii.

17 Julián del Casal o un falsario de la rima, p. 23; Ed. del Cent., "Poesías," pp. 391-392.

18 "Carta abierta" (F, 14 September 1890), Ed. del Cent., vol. I, p. 167.

N19: UNA MAJA

This sonnet was first published in the 15 February 1892 issue of $L a$ 
Habana Literaria. On that occasion, as on 17 February 1892 when it was reproduced by El País, it appeared as poem I in the series which Casal had named "Tipos españoles."

In the 29 February 1892 issue of La Habana Literaria, there is a sonnet by Aurelia Castillo de González, the lady to whom Casal had dedicated "La muerte de Moisés" some months earlier (see N4). Her poem reads as follows:

\section{A "LA MAJA" DE CASAL.}

Si fuera rey te diera por sólo un rizo, De perlas y diamantes, rica peineta; Y arrullara mis sueños tu castañeta, Que trocar sabe en fuego, nieve y granizo.

Un título creara para quien hizo Tu donaire que á todos rinde y sujeta. Eres por la fragancia dulce violeta $\mathrm{Y}$ alejandrina rosa por el hechizo.

Orlara tu figura de aureo follaje, Con perlas recamara todo tu traje, $\mathrm{Y}$ al tocar tu moreno cutis de raso,

Cual si beodo estuviera de manzanilla, Entonara contigo la seguidilla Y mi cetro y corona te echara al paso.

AURELIA CASTILLO DE GONZALEZ.

Guanabacoa, 22 de Febrero de 1892.

In a footnote, the editors of La Habana Literaria gave the following information about Doña Aurelia's sonnet: "La señora Castillo de González, después de leer, en el número anterior de La Habana Literaria, el soneto Una Maja, de Julián del Casal, improvisó el presente que tiene los mismos consonantes de aquél." When comparing the rhyming words of this poem with those of "Una maja," however, the reader of the present edition should consult 1. 5 in the record of variants, for hizo was one of several words of the original version which Casal changed when he revised the poem for Nieve. 
N19: VARIANTS

l. $H L$

2 peineta,

5 (I) Un manto de Manila que bordar hizo

6 [y]

7 violeta,

9 tímida paloma

10 [s]urge su pie ligero, traje,

12 (I) [y], manzanilla,

13 [p]ersiguiendo en su vuelo seguidilla

14 exhala
$P \quad N$

peineta

Pañolón de Manila,

fondo pajizo,

[q]ue

violeta

tímidas palomas

[a]soman sus chapines

traje

[y]

(ף) $+N$

GLIC

(ף) $+N$

manzanilla

[r]iman con los tacones

seguidilla,

dejando

\section{N20: UN TORERO}

This poem was the second of the three sonnets originally published under the heading "Tipos espanoles" in the 15 February 1892 issue of $L a$ Habana Literaria. Two days later, El Pais reproduced the poem without changes.

Although "Un torero" was first published only a few weeks before Nieve went to press, Casal was not satisfied with the composition and modified it considerably. It is particularly interesting to see how the poet managed to rework the first three stanzas within the rhyme scheme of the original version. As the record of variants shows, only the rhyme words of ll. 6-7 were affected by Casal's extensive revision of the poem.

N20: VARIANTS

l. $H L$

3 [e]l ígneo terciopelo de su

4 [r]ecamada oro,

5 reptil sombrío por ella

6 [1] a espiral perfumada de su coleta,

7 [q]ue trenzaran, con mano glacial e inquieta,

8 [1] os dedos nacarados

9 firme

11 en la arena, le embista

13 cálido
P N

[v]erde faja de seda, bajo

[f]ulgurante

oro

víbora negra que un muro

[y] a mitad del camino se

enrosca quieta,

[a]parece en su nuca fina

coleta

[t]renzada por los dedos

un

a la arena se lanze

$N+$ lance

purpúreo

GLIC

$N+$ lance




\section{N21: UN FRAILE}

Together with "Una maja" and "Un torero," this sonnet was first published under the heading "Tipos españoles" in the 15 February 1892 issue of La Habana Literaria. On 17 February, El Pais reproduced all three sonnets in the original order and under the original series title. Before publishing Nieve, Casal made significant changes in each one of the poems. The poem that underwent the least extensive revision, however, was "Un fraile."

\section{N21: VARIANTS}

l. $H L$

1 bajo

5 eco

6 [q]ue, llevado en las alas del ronco viento,

7 [p]iérdese entre las brumas

11 forja,

13 pollino
$P$

$N$

con

toque

[q]ue a la misa convoca con dulce acento

[y] se pierde en las nubes forja

$H L$

pollino,

GLIC

\section{Np4: MARFILES VIEJOS}

In conjunction with data derived from a study of "Bocetos antiguos" and "Mi museo ideal," a survey of "Marfiles viejos" suggests that, soon after publishing Hojas, Casal began to write with a fairly clear view of what his second book of poems would be like. The idea of writing a series entitled "Marfiles viejos" took shape in Casal's mind at some time between 14 September 1890, when he published "Tristissima nox," and 26 October 1890, when he used the rubric to introduce "Pax animae." $\mathrm{He}$ utilized "Marfiles viejos" as a heading on two more occasions in 1890: on 23 November, when he published "A un amigo," and on 30 November, when he published the poem we know today as "Al mismo." In the spring of 1891, Casal continued to develop the idea of "Marfiles viejos." Not only did he publish three sonnets under that heading in the 5 April issue of $L a$ Habana Elegante, but he also assigned a Roman numeral to each poem. This number indicated the position of the poem in the series at that stage of its development. As is shown in Plate 30, Casal kept on assigning numbers to the "Marfiles viejos" sonnets, although these numbers were not always printed in the journals. What did appear in the journals in all cases but one between 26 October 1890 and 30 March 1892 was the caption "Marfiles viejos." 1

An examination of Plate 31 reveals that Casal did not make extensive sequencing changes when he prepared the "Marfiles viejos" sonnets for publication in Nieve. He merely took four poems out of their original 
publication order and assigned them a new position in the series. Although few in number, these changes did increase the artistic merit of the series as a whole. This will become clear as we consider the reasons that may have prompted Casal to relocate "Pax animae," "Mi padre," "Paisaje espiritual," and "Tras una enfermedad." In order to facilitate discussion, the poems of "Marifiles viejos" will be divided into four sub-groups.

GROUP A: N22, N23, N24, N25. As shown in Plate 31, N22 came out first and was followed directly by $\mathrm{N} 25$. The poems are linked, however, by more than chronological proximity. To begin with, both sonnets have Latin titles. They are, in fact, the only members of the "Marfiles viejos" series that do have this feature. What is more, from an ideological point of view N22 leads directly into N25: in "Tristissima nox," Casal establishes the basic idea - "el vacío profundo de mi alma" (1. 14) - and in "Pax animae," he discloses what it means to be a living being that is dead inside. If this is true, then why did he move N25? The answer, it would appear, depends on a knowledge of the history of N23, N24, and N28.

On the surface, N23 is the least apropos as a variant on the basic theme of Group A. Casal seems to have realized this, because when he published N23 for the second time (HE: 7 December 1890), he placed it together with the four "Poesías diversas" that he would later include in "La gruta del ensueño." 2 Two things appear to have attracted N23 back into "Marfiles viejos," however. On the one hand, although N23 itself was not a particularly clear statement of the theme of Group A, the poetry of Leopardi, which inspired the sonnet, was a most appropriate illustration of that theme. The second factor was the poem's similarity to N24. Not only were both compositions originally entitled "A un amigo," but both were occasioned by the same type of event in the life of Casal: namely, his presentation of a gift to a friend. Since N24 was a most acceptable illustration of the profound emptiness of his soul, Casal probably felt that it would not be amiss to weld N23 and N24 together ${ }^{3}$ and keep them near the beginning of "Marfiles viejos."

The key poems in Group A, however, were still N22 and N25. The former introduced the principal theme, while the latter - in which Casal indicated that "es la vida para mí un desierto / poblado de figuras espectrales" (ll. 7-8) and that "tan sólo llega a percibir mi oído / algo extraño y confuso y misterioso / que me arrastra muy lejos de este mundo" (ll. 12-14) - brought that theme to the threshold of the original version of N28, a work whose final stanzas saw the poet contemplating suicide:

9 Huérfana el alma mía de esperanza,

10 hacia el país glacial de la locura

11 va mi razón, perdida su aureola,

13 brindándole consuelo a mi amargura,

14 la boca del cañón de una pistola. 


\section{PLATE 30 \\ "MARFILES VIEJOS" \\ ORDER OF PUBLICATION*}

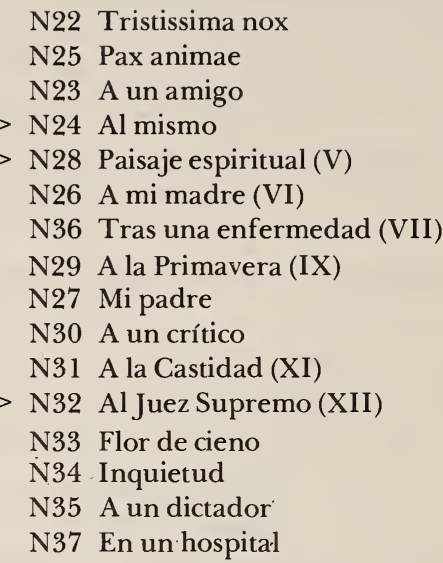

$H E: 14$ Sep 90
$H E: 26$ Oct 90
$P: \quad 23$ Nov 90
$H E: 30$ Nov 90
$H E: 5$ Apr 91
$H E: 5$ Apr 91
$H E: 5$ Apr 91
$H E: 3$ May 91
$H E: 31$ May 91
$H E: 28$ Jun 91
$H E: 19$ Jul 91
$H E: 19$ Jul 91
$H L: 15$ Oct 91
$H L: 30$ Jan 92
$H L: 30$ Jan 92
$H L: 30$ Mar 92

*The titles listed here are those of Nieve. The sign $>$ indicates that another title was used in the original version of the poem. Variant titles may be found in Index I and in my discussion of the marked poems.

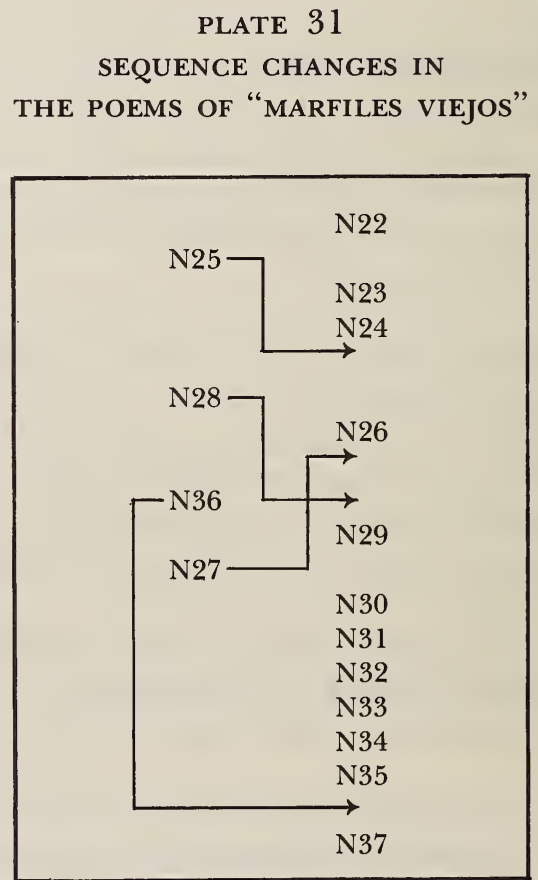


Obviously, by moving N25 from second to fourth position in the series, it was possible to affect a bridge into N28 and thus into Group B.

GROUP B: N26, N27, N28, N29. It is evident that N26 ("A mi madre") and N27 ("Mi padre") form a conceptual unit. But what place should these poems occupy in Group B? The answer depends on the content of N28. As long as this composition remained as originally published, it could be used to sound the baleful keynote of Group B. Lines 9-14 (see above) would provide an excellent introduction to N26 and N27, for Casal's mother and father, though alive in his memory, now inhabited the world beyond the grave, and their sonrisas negras ${ }^{4}$ seemed on occasion to invite the poet to give up this life and join them in the next. It must be emphasized, however, that while Casal was often impulsive in his feelings, he was seldom decisive in his actions. As quickly as he was drawn to one extreme, he would find himself emotionally attracted towards the other. Soon, the antitheses which he perceived in reality would mesmerize him and make it almost impossible for him to act (e.g., N28/5-8). In view of this, it is not strange to find him modifying N28 so that instead of exposing only one area of his psyche, it would reflect the antithetical character of his "Paisaje espiritual":

9 Y aunque no endulcen mi infernal tormento

10 ni la Pasión, ni el Arte, ni la Ciencia,

11 soporto los ultrajes de la suerte,

12 porque en mi alma desolada siento

13 el hastío glacial de la existencia

14 y el horror infinito de la muerte.

Of course, this reluctance to join the dead obliged Casal to change the location of the sonnet. The logical place for it now was after the sequence devoted to his parents and before "A la Primavera" (N29), a poem in whose final stanza Casal sought an end to the vida-muerte stalemate, preferably through the triumph of life:

12 Muere al fin, creadora ya agotada, 13 o brinda algo de nuevo a los sentidos ...

14 iya un color, ya un sonido, ya un perfume!

GROUP C: N30, N31, N32, N33, N34, N35. These sonnets deal with different subjects that interested Casal both as a man and as an artist. It seems that the thematic diversity of these poems was an important factor militating against their rearrangement. Whatever the case, it is clear that Casal saw no special advantage in taking Group C poems out of chronological order, for he made no sequence change in the Nieve version.

GROUP D: N36, N37. Although they were published - and, in all probabil- 
ity, written - almost a year apart, N36 and N37 had a common source of inspiration: the physical illness that made life a torment for Casal as he neared the age of thirty. This fact provides sufficient justification for grouping the poems together. But which poem should come first? From their titles, it would seem that N37 ("En un hospital") should have preceded N36 ("Tras una enfermedad"). As far as sequencing was concerned, however, the message contained in the body of the poems was more significant than their titles. N37 took up the idea that had been introduced the year before in N36 and carried it to its logical conclusion: from the hope that his fever, like a veil, would shut out the horrors of reality (N36), Casal moved to the point of seeing the hospital as a refuge from all the agonies of life (N37).

\section{Np4: Notes to Introductory Statement}

1 The exception was "En un hospital" (N37).

2 These poems were "Blanco y negro" (N40), "Flores" (N41), "Vespertino" (N42), and "Mi ensueño" (N48).

3 This was accomplished by the simple expedient of changing the title of N24 to "Al mismo."

4 The reader is reminded that the original version of N28 was entitled "Sonrisas negras." In view of the fact that only one object smiles at Casal in this version of the poem (see above, 11. 12-14), we wonder whether he had his parents in mind when he chose the title "Sonrisas negras."

\section{N22: TRISTISSIMA NOX}

This sonnet was first published in the 14 September 1890 issue of $L a$ Habana Elegante with the subtitle "Soneto." The poem was printed in italics on the first page of the journal. Two days later, it was reproduced by the editors of El Pais. In this version, the subtitle was omitted but no textual changes were introduced. When preparing the poem for Nieve, Casal suppressed the subtitle, made minor alterations in the text, and subsumed the poem under the section heading "Marfiles viejos" (see Np4, above).

N22: VARIANTS
l. $H E$
$P$
$N$
GLIC
1 (I) iNoche de soledad!
Noche de soledad.
(ף) $+N$
5 en
6 cabrilleando queda, hasta sollozando rueda
11 calma; calma, 


\section{N23: A UN AMIGO}

This poem was originally published in El País on 23 November 1890. The composition, which was subsumed under the heading "Marfiles viejos," had two subtitles: "(Enviándole los versos de Leopardi.)" and, below this, "Soneto." As the reader may have noticed, Casal's poems usually appeared first in La Habana Elegante and were later reproduced by El País. Cuban sources could not explain why "A un amigo" came out in El País before it was printed in La Habana Elegante.

On 7 December 1890, however, La Habana Elegante did publish the poem. On this occasion, it was printed together with "Blanco y negro" (N40), "Vespertino" (N42), "Mi ensueño" (N48), and "Flores" (N41). All of the poems were grouped under the general heading "Poesías diversas," and no indication was given that "A un amigo" belonged to the "Marfiles viejos" series. However, both of the original subtitles were retained.

When the poem was printed in Nieve, it was separated from its $H E$ companions and again subsumed under the heading "Marfiles viejos." In addition, the subtitle "Soneto" was dropped and minor textual changes were made.

A third newspaper printing appeared on 21 April 1892. On this occasion, the editors of El País, reproducing "A un amigo" and "Al mismo" (N24), made the following statement, whose importance lies in the fact that it helps us determine the approximate publication date of Nieve:

DE CASAL. - Del libro titulado Nieve, que acaba de publicar á $[$ sic] nuestro distinguido poeta y amigo querido Julian del Casal, tomamos los dos sonetos que insertamos á continuacion:

The El País 1892 version of "A un amigo" is not listed in the record of variants which follows, because it was printed after the publication of Nieve.

Although it is impossible at this distance to identify the friend to whom this sonnet was dedicated, we can discern which features of Leopardi interested Casal most. Giacomo Leopardi (b. Recanati, 29 June 1798; d. Naples, 14 June 1837) was the eldest son of Count Monaldo Leopardi and Adelaide degli Antici. Like his sister Paolina and his brother Carlo, Giacomo had a most unhappy childhood. His father was austere and overly demanding, as befitted a member of the nobility in nineteenthcentury Italy; and his mother, with her selfishness and bigotry, seemed to delight in casting seeds of bitterness among her progeny. As was customary in his social class, Giacomo was educated at home. His formal education ended when he reached the age of fourteen: at that time, his tutor quite honestly admitted that he had nothing more to teach him. In the 
years that followed, Giacomo broadened his knowledge of classical and modern literatures, philology, and philosophy, and taught himself Greek. However, his excessive devotion to study undermined his health, which was already frail. To the torments of physical illness were added the agonies of spiritual isolation, and this dual affliction kept his soul shrouded in mournfulness and gloom. Leopardi's fame as a writer is due mainly to his Canti (Florence, 1831; Naples, 1835) and to the series of prose essays entitled Operette morali (Milan, 1827). In both of these works, the central thought is intensely pessimistic: all that man seeks and longs for - love, knowledge, immortality - is nothing but illusion. From this philosophy sprang Leopardi's principal themes: the desperate longing for youth and love and joy, the inability to cope with reality, the emptiness and utter futility of life. Summarizing his boundless despair in a single unforgettable line, he said, "Io sono ... un sepolcro ambulante che porto dentro di me un uomo morto" (Zibaldone, 3 November 1825).

Given his pessimistic outlook on life, Casal could easily identify with Leopardi. Like the Italian poet, he saw himself as "un nihilista . . que no ve más que la esterilidad de los esfuerzos humanos, ni aspira más que a disolverse en el seno de la nada,"1 and held such convictions as the following:

la idea que el artista tiene de su arte o el sabio de su ciencia, está en proporción indirecta de la idea que tiene de su propio valer en aquel arte o en aquella ciencia. ${ }^{2}$

and

quien vive enterrado en un país como éste no es posible que guarde la esperanza de ser, no diré célebre, sino conocido en parte alguna de la tierra. ${ }^{3}$

Because of his agreement with Leopardi on basic questions of life and art, Casal was never able completely to outgrow the influence which the Italian poet had exerted on him during his youth. Indeed, one suspects that the impact of Leopardi's Weltanschauung became stronger and stronger with the passage of time.

\section{N23: Notes to Introductory Statement}

1 “José Fornaris," Bustos y rimas, p. 112; Ed. del Cent., vol. I, p. 278.

2 “José Arburu," Bustos y rimas, p. 126; Ed. del Cent., vol. I, p. 282.

3 “Academia de Pintura: Dos cuadros" (D, 11 July 1890), Ed. del Cent., vol. II, p. 178. 
N23: VARIANTS

\begin{tabular}{|c|c|c|c|}
\hline l. $P$ & $H E$ & $N$ & GLIC \\
\hline 2 todavía & todavía, & $P$ & \\
\hline 3 [r] eserva & & & ireserva \\
\hline envía... & & envía! & \\
\hline 9 hojas, & hojas & & \\
\hline 10 tierra, & tierra & & \\
\hline 11 siempre entre & & presa en & \\
\hline lodo,- & & lodo- & \\
\hline $14[o]$ & & [y] & \\
\hline
\end{tabular}

\section{N23: Note to Variants}

14: In the $P$ version, 1.14 was printed in italics. Standard type was used in the $H E$ and $N$ versions.

\section{N24: AL MISMO}

This poem made its first appearance in the 30 November 1890 issue of La Habana Elegante under the title "A un amigo." It was subsumed under the heading "Marfiles viejos" and had two subtitles: "(Enviándole mi retrato.)" and "Soneto." The text was printed in italics on the first page of the journal. Although Casal had had several photographs of himself made before November 1890 , it is possible that the picture to which he referred in the subtitle was based on an oil painting that had been done by Armando Menocal. As indicated in N7, the poet sent a copy of the Menocal portrait to Gustave Moreau on 16 September 1891 (see Plate 10).

Before publishing Nieve, Casal changed the poem's title from "A un amigo" to "Al mismo," dropped the subtitle "Soneto," and made slight modifications in the text. However, he retained the first subtitle of the original version and kept the poem within the "Marfiles viejos" series.

As noted in my discussion of N23, El País reproduced "Al mismo" on 21 April 1892; but since this printing postdates Nieve, it is not represented in the record of variants which follows.

\section{N24: VARIANTS}
l. $H E$
2 llama,
3 grandioso
6 del que
10 fría,

$N$

GLIC

llama marmóreo de quien fría 


\section{N25: PAX ANIMAE}

"Pax animae," subsumed under the heading "Marfiles viejos" and bearing the subtitle "Soneto," first appeared in the 26 October 1890 issue of $L a$ Habana Elegante. The poem was printed in italics on the first page of the journal and was dated "Octubre.-1890." When revising the work for Nieve, Casal dropped the subtitle, suppressed the date, and made several changes in the text. Although he kept the poem within the "Marfiles viejos" series, he gave it a position which it had not occupied when the series was being developed in the fall of 1890 . The implications of this change are discussed in my introduction to $\mathrm{Np} 4$.

\section{N25: VARIANTS}

\section{l. $H E$}

2 quiero probar.

3 corazón,

8 [d]onde vagan

10 lluvioso

* 12 (I) [p]ercibo en lo interior de mis oidos

14 obliga a partir

del
N

ansío gustar.

corazón

[p]oblado de

lluvioso,

[t]an solo llega a per-

cibir mi oido

arrastra muy

de este
GLIC

$$
\begin{aligned}
\text { (ब) }+N & + \text { sólo } \\
& + \text { oído }
\end{aligned}
$$

\section{N25: Note to Variants}

12: It will be observed that a rhyming error was committed in the $H E$ version: "mis oidos" does not rhyme with "obscurecido" (1. 9). This error was corrected by a complete revision of 1.12 in the $N$ version.

\section{N26: A MI MADRE}

This oft-quoted sonnet was first published in the 5 April 1891 issue of La Habana Elegante. Appearing after "Sonrisas negras" (see N28) and before "Tras una enfermedad" (N36), it was designated as the sixth poem in the series entitled "Marfiles viejos. / Sonetos." When preparing it for inclusion in Nieve, Casal suppressed the subtitle "Sonetos," which had preceded "A mi madre" and its companions in the $H E$ version, and made two punctuation changes in the body of the poem. Because he repositioned "Sonrisas negras"-or "Paisaje espiritual" as he called it in Nieve-"A mi madre" now occupied fifth place in the "Marfiles viejos" series. Theories about why Casal made sequence changes in this part of Nieve are advanced in my introduction to Np4.

Over the years, scholars have uncovered little concrete information 
PLATE 32

María del Carmen de la Lastra y Owens, the Poet's Mother

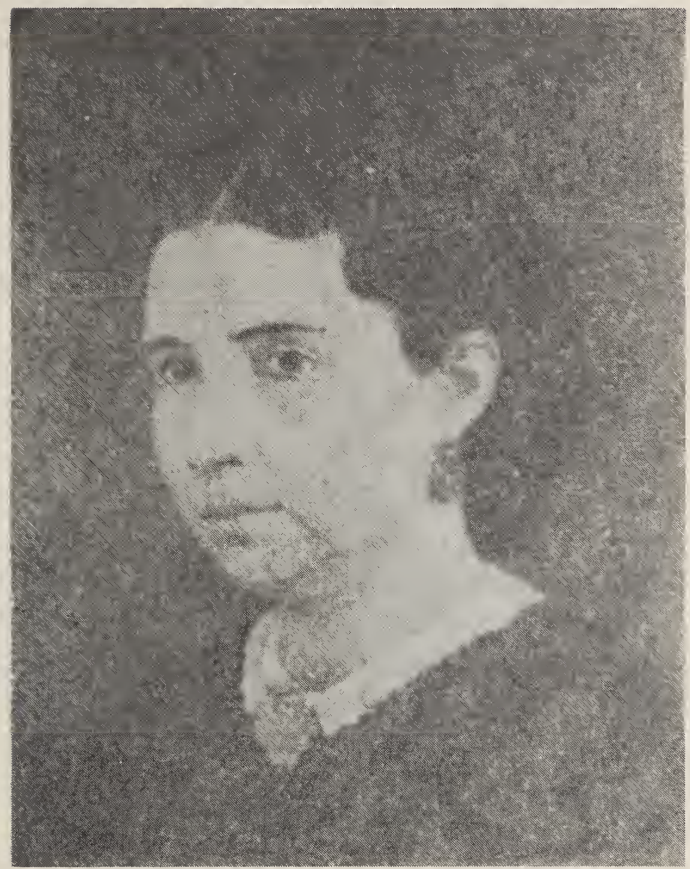

about Casal's mother. However, from the data that are available, it is possible to formulate an opinion about the role she played in shaping Casal's personality and the character of his art.

María del Carmen de la Lastra y Owens, daughter of a Spanish father, Antonio de la Lastra, and an Irish-American mother, Elena Owens, was born in San Marcos de Artemisa in the Province of Pinar del Río. In 1860, she married Don Julián del Casal y Ugareda in the Iglesia del Santo Angel Custodio in Havana. During the first two years of her married life, Doña Carmen had two children. Unfortunately, no substantial information about them has ever come to light. On 7 November 1863 , she gave birth to her third child, Julián. His baptismal certificate reads as follows: "Miércoles 23 de Dbre. de 1863. Yo Pbro. D. Carlos R. del Castillo, Cura Párroco de esta Iglesia del Santo Angel Custodio de esta ciudad de la Habana, bauticé solemnemente a un niño a quien puse por nombre José Julián Herculano, que nació el día 7 de Nbre. último, hijo legítimo de Dn. Julián del Casal, natural de Santurce en Vizcaya, y de Doña Carmen de la Lastra, natural de San Marcos de Artemisa en esta Isla y vecinos de esta feligresía: abuelos paternos Dn. Andrés del Casal y Doña Casimira Ugareda: maternos Dn. Antonio de la Lastra y Da. Elena Owens, fueron padrinos Dn. José de la Lastra y Da. Matilde de la Lastra y Owens a 
quienes advertí el parentesco espiritual que contrajeron y lo firmé.Carlos R. del Castillo."1

Although some readers of "A mi madre" have concluded that Dona Carmen died as a direct result of having brought Casal into the world, this is not true, for on 31 December 1867 she gave birth to a fourth child, María del Carmen Matilde Silvestra Josefa de la Concepción de Todos los Santos, who was known in the family as Carmelina. ${ }^{2}$ What does seem to be the case is that complications associated with the delivery of Carmelina were the immediate cause of Doña Carmen's death.

The memory of his mother's death haunted Casal throughout his lifetime. His earliest recorded statement on the subject is "Huérfano" (V3), a poem which he dedicated "A la Sra. Doña Clara Krick, / A la buena amiga de mi desgraciada madre," and published in ElEnsayo on $27 \mathrm{March}$ 1881. Seven years later, in an article on Ezequiel García, he made an emotional remark which left no doubt that the passage of time had in no way dulled his grief: "Y ¿quién mejor que una madre puede ser nuestra amiga? ¿En qué oído repercuten más hondamente nuestras quejas? ¿en qué seno reposa mejor nuestra cabeza fatigada? ¿en qué labio recogemos el beso más puro? ¿en qué brazo se apoyan más confiadamente nuestros extenuados brazos? ¿qué mano enjuga más tiernamente nuestras lágrimas? ¿quién aclama más alto nuestros triunfos? iAh! isi yo hubiera tenido la dicha de conservar la mía!"3 The following year, in "Nocturno" (H25), he made it plain that, in times of anguish, he would still gaze upon his mother's portrait in the hope that her "dulce rostro" (1.30) would bring a measure of consolation to his tormented spirit. Yet Casal had no real need for pictures: as we see from "A mi madre," which he published in April 1891, his mother's "dulce imagen" (1.5) was indelibly engraved on his mind.

The sad experience of his childhood led Casal to sympathize with others like himself whose joys had been shattered by the death of someone dear. In "iUna lágrima!" (V1), his first known poem, he described a young girl's visit to her mother's grave, while in "Todavía" (H26), which he published nine years later, he revealed that the tragedy of his youth had made him feel a kinship with every orphan in the world. His compassion did not stop at that point, however, but embraced all of those who had lost a loved one. Three poems may be cited to exemplify this point: "Lazos de muerte" (H12), "Dos fechas" (V5), and "In memoriam" (H41). These compositions date from January 1886, October 1887, and December 1889 , respectively. Of all his statements of condolence, however, undoubtedly the most poignant is the one he addressed to Gustave Moreau in 1891 upon learning that someone dear to Moreau had passed away. Here, Casal emphasized that he could share his master's grief because, "des mes premieres anneés, je vu disparaitre tous les etres qui j’ai aimée, qui j’aime encore et qui j'aimerai toujours, toujours" (C3/35-38). Like almost every other reaction he had to death, Casal's sympathy for those in mourning 
appears to have stemmed from an overwhelming fear of being left alone. To be solitario meant to go through life undefended and unconsoled; and this was more than he could bear, for, as Darío noted, "Era [Casal] de esos espíritus trémulos que viven en una a modo de niñez eterna, y que necesitan de otro espíritu que les conforte, les guíe, les ayude y les ame."

\section{N26: Notes to Introductory Statement}

1 Quoted from Juan J. Geada, Selección de poesías de Julián del Casal, p. xxvi.

2 Her baptismal certificate is reproduced by Geada (op.cit., pp. xxvi-xxvii).

3 "La joven Cuba. Galería Mignon: Ezequiel García" (HE, 12 February 1888), Ed. del Cent., vol. I, p. 190.

4 From "Julián del Casal," a letter addressed to Enrique Hernández Miyares and published on p. 4 of the 17 June 1894 issue of $H E$.

\section{N26: VARIANTS}

l. $H E$

8 garganta;

9 (I) [y],

11 [c]omo quiera
$N$

garganta,

[y]
GLIC

$(\Re)+N$

comoquiera

\section{N27: MI PADRE}

This sonnet was first published on 31 May 1891 by La Habana Elegante. It was printed in italics on the first page of the journal, under the heading "Marfiles viejos."

On 2 June 1891, the editors of El País advised their readers that $L a$ Habana Elegante had come out; below this notice, they reproduced " $\mathrm{Mi}$ padre." The text of this version differs only superficially from the $H E$ original.

When Casal arranged his compositions for publication in Nieve, he kept "Mi padre" within the series entitled "Marfiles viejos," but moved it out of its original position (see my discussion of Np4). In addition, he made two lexical modifications in the body of the poem.

In order to understand with greater clarity the sources of Casal's gloomy outlook on life, it is necessary to examine the statements which he made about his mother, who died when Casal was not yet five years old (see N26), and those which he made about his father, under whose influence he lived until he was twenty-one. The re-wording of N27/5 (see variants, below) is one of several signs which seem to indicate that Casal intensified his negative feelings towards his father as time passed. A more detailed commentary on the relationship between Casal and his father will be found in my discussion of "Nocturno" (H8). 
N27: VARIANTS

l. $H E$

1 advierte

3 el [sic]

5 (ף)El alma tuvo triste hasta

13 calmar,
$P \quad N$

advierte,

al

$H E$

Tuvo el alma más

(ף) $+N$

triste que

apagar,

\section{N28: PAISAJE ESPIRITUAL}

This sonnet was first published in the 5 April 1891 issue of La Habana Elegante. Bearing the title "Sonrisas negras,"1 it was printed under the rubric "Marfiles viejos. / Sonetos," and was introduced by the Roman numeral V, which reflected its position at that stage in the development of the series. The poem was followed on the same page by "A mi madre" (N26) and "Tras una enfermedad" (N36). Although Casal kept the poem within the "Marfiles viejos" group when preparing Nieve, he altered its position in the series (see Np4), changed its title to "Paisaje espiritual," suppressed the collective subtitle that had introduced this and the other sonnets in La Habana Elegante, and made extensive revisions in the text. As shown in the record of variants, 11. 9-14 were completely rewritten.

\section{N28: Note to Introductory Statement}

1 It is interesting to note that the adjective negras, which Casal used here in conjunction with the noun sonrisas, reflects a general atmosphere of negativism that surrounds sonrisas in his poems. For the location of all the contexts in which this noun occurs, see vol. III of the present edition.

N28: VARIANTS

\section{I. $H E$}

4 calor

9 (ף)Huérfana el alma mía de esperanza,

10 [h]acia el país glacial de la locura

11 [v]a mi razón, perdida su aureola,

12 ( $($ )[y] sólo me sonríe en lontananza,

13 [b]rindándole consuelo á mi amargura,
$N$

ardor

$\mathrm{Y}$ aunque no endulcen mi infernal tormento

[n]i la Pasión, ni el Arte, ni la Ciencia,

[s]oporto los ultrajes de la suerte,

[p]orque en mi alma desolada siento,

[e]l hastío glacial de la existencia
GLIC

( $+N$

(ब) $+N$

+ siento 


\section{N29: A LA PRIMAVERA}

"A la Primavera" first appeared in print in the 3 May 1891 issue of $L a$ Habana Elegante. It was subsumed under the heading "Marfiles viejos" and was introduced by the Roman numeral IX, which indicated its place in the series at that stage of its development. When revising his material prior to publishing Nieve, Casal decided to keep the poem within "Marfiles viejos," but moved it from ninth to eighth position in the group. Except for the minor alterations noted below, the text of the sonnet was left intact.

\section{N29: VARIANTS}

l. $H E$

11 consume! ....

$13 \mathrm{mis}$

sentidos .....

$14 \mathrm{i}[\mathrm{u}] \mathrm{n}$ color, un sonido ó un
$N$

consume!

los

sentidos ...

i[y]a un color, ya un sonido, ya un

GLIC

\section{N30: A UN CRITICO}

First appearing in the 28 June 1891 issue of La Habana Elegante, "A un crítico" was the tenth poem that Casal had written for the "Marfiles viejos" series. What made it unique was that it was presented in a sonnet format not usually associated with Casal: 1l. 9-14 were printed as an uninterrupted sestet instead of as distinct tercets, and a centered rule was used between stanzas. When preparing Nieve, Casal placed the poem ninth in the "Marfiles viejos" series, modified its wording and punctuation slightly, and changed its format by having the text printed as four separate stanzas and by suppressing the centered rules that had been used in the original version.

N30: vARIANTS

l. $H E$

1 ( $\left(\right.$ ) $\mathrm{Yo}_{\mathrm{O}}$

3 perenne primavera

4 rima.

5 ( $($ ) $)$ Yo

6 pasajera,
$N$

Yo

hermosura duradera

rima;

[y]o

pasajera
GLIC

$H E$

(ף) $+N$ 
I. $H E$

9 (ף)Mas antojos,

$12[\mathrm{~s}] \mathrm{i}$

13 amargo
$N^{\prime}$

Mas

GLIC:

HE

antojos

mismo
(ף) $+H E$

\section{N31: A LA CASTIDAD}

This sonnet was first published in La Habana Elegante on 19 July 1891. It appeared under the rubric "Marfiles viejos" and was shown to be poem XI in the series. Immediately below it was "Revelación" (see N32), which was then number XII in the group.

On 8 August 1891, "A la Castidad" alone was reproduced by El Pueblo. The editors, however, gave no indication that the sonnet had been published three weeks earlier by La Habana Elegante.

When preparing Nieve, Casal made three minor textual changes in the poem and assigned it to tenth position in "Marfiles viejos."

N31: VARIANTS

\section{l. $H E$}

3 luto,

4 ser

11 pasiones,

12 ( $)[y]$
$\mathrm{Pb}$

(1)

[y] [sic]

$$
\begin{aligned}
& N \\
& \text { luto } \\
& \text { cuerpo } \\
& \text { pasiones }
\end{aligned}
$$

GLIC (

$H E$

\section{N32: AL JUEZ SUPREMO}

This sonnet, originally entitled "Revelación" and bearing the words "Al Juez supremo" as a kind of dedication, was first published on 19 July 1891 in La Habana Elegante. Like "A la Castidad" (N31), which was printed above it, the poem was subsumed under the heading "Marfiles viejos." The Roman numeral XII preceded the title and showed that the composition was the twelfth sonnet that had been written for this series. When revising the work for Nieve, Casal suppressed the original title, put the $H E$ dedication in its place, and made three minor changes in the text. He also moved the poem from twelfth to eleventh position in the "Marfiles viejos" sequence.

\section{N32: VARIANTS}

\section{l. $H E$}

1 hondas,

5 dicha

* 6 temas,
$N$

hondas

Dicha

temas
GLIC

$H E$ 
6: The $H E$ punctuation is restored because it is felt that the structure of 11. 6-8 (imperative + explanatory statement) calls for a more emphatic pause than the one signalled by the end-of-verse blank.

\section{N33: FLOR DE CIENO}

"Flor de cieno" was first published in the 15 October 1891 issue of $L a$ Habana Literaria. It was printed under the rubric "Marfiles viejos" and was the thirteenth composition that Casal had written for this series. In Nieve, however, it appeared in twelfth place and contained a few variants in punctuation.

\section{N33: VARIANTS}

l. $H L$

2 desmorona,

5 fuera, cineraria,

10 pierde,
$N$

desmorona

fuera

cineraria

pierde

\section{N34: INQUIETUD}

"Inquietud" was first published in the 30 January 1892 issue of $L a$ Habana Literaria. On this occasion, it was printed together with "A un dictador" (N35) under the heading "Marfiles viejos." As shown in Np4, this poem was the fourteenth sonnet that Casal had written for the series.

On 3 February 1892, the editors of El País, acknowledging their source as La Habana Literaria, reproduced "Inquietud" (but not "A un dictador") for their readers. As will be seen from the record of variants, this was not a careful reprinting of the sonnet.

Some three weeks later, on 21 February 1892, El Hogar also reproduced the poem. Comparative evidence suggests that its source was the $H L$ version, and not the one printed by El Pais. Neither El País nor El Hogar indicated that the poem belonged to "Marfiles viejos."

When preparing "Inquietud" for publication in Nieve, Casal made a few minor changes in the text and moved the poem into thirteenth position in the "Marfiles viejos" section.

N34: VARIANTS

$\begin{array}{lllll}l . H L & P & H g & N & \text { GLIC } \\ 2 \text { joven } & \text { jóyen }[s i c] & H L & & \end{array}$




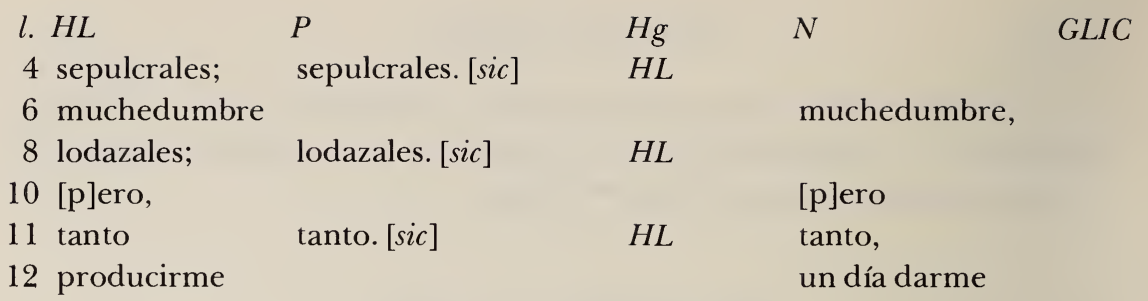

\section{N35: A UN DICTADOR}

This sonnet was first published in the 30 January 1892 issue of $L a$ Habana Literaria. It was printed together with "Inquietud" (N34) under the rubric "Marfiles viejos" and, as shown in my discussion of Np4, was the fifteenth poem that Casal had written for the series. Unlike its companion in La Habana Literaria, it did not appear in other periodicals before Nieve came out. In Nieve, it figured as the fourteenth poem of "Marfiles viejos" and contained some minor changes in wording and punctuation.

\section{N35: VARIANTS}

\section{l. $H L$}

1 bueno,

2 la asolada

3 la

6 [y]

guerra

9 ( $\mathbb{( ) M a s ,}$

11 escarnecidos,

13 derrota
$N$

bueno

tu nativa

alta

[y],

guerra,

Mas

escarnecidos;

derrota,
GLIC

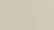

(ף) $+N$

\section{N36: TRAS UNA ENFERMEDAD}

The first known version of this poem is the one that was published by $L a$ Habana Elegante on 5 April 1891. In this printing, it appeared with "Sonrisas negras" (see N28) and "A mi madre" (N26) under the heading "Marfiles viejos. / Sonetos." A Roman numeral was placed before each title in order to show the relative position of the poems in the series. According to Casal's plan at that time, "Tras una enfermedad" was supposed to be seventh in the "Marfiles viejos" group.

Just beneath "Tras una enfermedad," the editors of La Habana Elegante made an announcement which is of particular interest to students of Modernism: 


\section{RUBEN DARIO.}

La semana última recibimos en la Redacción de LA HABANA ELEGANTE un valiosísimo paquete por el correo: tres tomos del bello libro Azul. . . . , que Rubén Darío, poeta que nació en Nicaragua y que parece un depurado modernista parisiense, enviaba como obsequio amistoso, a nuestro compañero Julián del Casal, a nuestro caro colaborador y amigo Raúl Cay y al Director de este semanario.

En dicho primoroso libro Azul... . ha coleccionado Darío sus cuentos en que las imágenes fulguran como joyas, muchos de los cuales cantos en prosa hemos publicado con fruición, secuestrándolos de periódicos centro-americanos. Además de los cuentos, los versos de Rubén Darío entre cuyos "sonetos áureos" hay también uno dedicado a Enrique Hernández Miyares, muestran, como facetas de distintos diamantes, irisadas irradiaciones.

El libro Azul... de Rubén Darío ya corre de mano en mano entre nuestros compañeros en letras, que se extrañan - como D. Juan Valera - de que haya otro Catulle Mendès, con tanta fantasía y tal arte para encerrarla en forma brillantísima, acá, en el seno de un paisillo delicioso de América, en la hermosa Nicaragua, de la que nunca ha salido.... (el cuerpo, no el alma del poeta).

Con fruición, como hasta ahora, seguiremos dando en estas columnas lo que hallemos de nuevo en el libro Azul...., regalo primoroso de su autor, que nos rinde agradecidos.

Casal's reactions to Azul ... (Guatemala, 1890) and to A. de Gilbert (San Salvador, 1889) are presented in "Rubén Darío," an article published in La Habana Literaria on 15 November 1891. This article is especially significant because it reveals the extent to which Casal saw Darío and himself as innocent victims of a hostile environment. Despite this gloomy picture, it is obvious that both Casal and Darío had enthusiastic defenders in Cuba at the time.

As far as Darío's contacts with Cuba are concerned, Esperanza Figueroa indicates that the young poet was familiar with La Habana Elegante before 1887 and that the editors of that journal made their intitial reference to his work in their 31 July 1887 issue. ${ }^{1}$ After La Habana Elegante suspended publication, compositions of Darío were accepted by La Habana Literaria. This fortnightly review, whose first issue came out on 15 September 1891, was founded by Enrique Hernández Miyares and Alfredo Zayas (see my discussion of Np3). During the turbulent year it existed, it published a total of twelve works by Darío (see Table 5). 
It is interesting to note that in the 30 July 1892 issue of the journal, just below "Un sermón," there appeared an announcement which proves that Darío visited Cuba on his way to the quadricentennial celebrations in Spain. That announcement, entitled "Comisionados de la América latina," read as follows:

El brillante escritor y reputado poeta centro-americano, D. Rubén Darío, que ha engalanado tantas veces las columnas de nuestra publicación, ora con sus espléndidos versos, ora con su magnífica prosa, se encuentra de paso entre nosotros y permanecerá algunos días en esta capital.

Rubén Darío se embarcará muy pronto para la capital de la nación española, a donde va a representar a Nicaragua en las fiestas del Centenario de Colón.

Returning to Casal's sonnet "Tras una enfermedad," we find that the Nieve version is basically the same as the original. What is different, however, is the poem's position within "Marfiles viejos": instead of being in seventh place, it is located in fifteenth position in the series. The significance of this change is examined in my introduction to Np4.

When discussing "Tras una enfermedad," one should not overlook the biographical realities that influenced its composition. By mid-February 1891, the illness alluded to in the poem was already beginning to impair Casal's working efficiency and depress his spirits. In a letter written to Esteban Borrero on the 14th of that month, Casal said: "A consecuencias de unas fiebres que tuve a principios de semana ${ }^{3}$ me he quedado tan débil, tan enervado y, sobre todo, tan triste, que pienso salir mañana para el campo, con objeto de que la tristeza me abandone o me extermine de

TABLE 5

Rubén Darío: Works. Published in La Habana Literaria

\begin{tabular}{|c|c|c|}
\hline Date & Poetry & Prose \\
\hline 30 Sep 91 & "Lieder" & \\
\hline 30 Oct 91 & "Rima" & \\
\hline 15 Dec 91 & $\begin{array}{l}\text { "Medallones": } \\
\text { "Leconte de Lisle," "Walt Whitman" }\end{array}$ & \\
\hline 30 Dec 91 & & "La risa" \\
\hline $15 \mathrm{Feb} 92$ & & $\begin{array}{l}\text { "Don Pedro [Alcántara } \\
\text { de Braganza]" }\end{array}$ \\
\hline $29 \mathrm{Feb} 92$ & "Versos de año nuevo" & \\
\hline 15 Mar 92 & "El clavicordio de la abuela"2 & \\
\hline 15 May 92 & "Los centauros"2 & \\
\hline 30 May 92 & & "Historia de un sobretodo" \\
\hline $30 \mathrm{Jul} 92$ & & "Un sermón" \\
\hline 30 Sep 92 & & "Fugitiva" \\
\hline
\end{tabular}


una vez. . . . Pienso pasarme fuera todo el resto del mes, pero como yo nunca he realizado un solo proyecto, quizás vuelva antes de que se cumpla ese plazo."4 Apparently, Casal was right to doubt that he could remain away from the city a full two weeks. In a letter dated $15 \mathrm{March}$, he told Borrero that it was already some twenty days since his return from the country. Thus, he had been away for only one week.

The malady from which Casal suffered was apparently as bad after his short holiday as it had been before. These are the symptoms as the poet described them to Borrero: "No le he escrito hasta hoy porque todos los días se me presenta alguna pesadez de cabeza, algún cosquilleo en la médula, algún escozor en la cintura, alguna punzada incesante en el corazón o alguna dolencia insignificante que me entenebrece el espíritu y me asesina la voluntad. Cuando se me presentan esas insignificancias mi único deseo es estar solo, escondido, sin hablar." Writing to Borrero again on $19 \mathrm{March}$, Casal gave ample evidence that his poor health was exerting an ever-greater influence on his behavior. On the one hand, his somber state of mind made his contributions to El Pais so infestive weekly injections of "fastidio," he called them - that he resolved to yield before the complaints of the subscribers and give up his job on the paper. In addition, environmental factors aggravated his illness. Therefore, he decided that it would be necessary to look for better quarters in more pleasant surroundings. He expressed his position quite frankly in his letter to Borrero: "Ahora quiero buscar una habitación alta, aislada en una azotea, abierta a los cuatro vientos, porque preciso aprender a pintar y porque creo que mi neurosis, o como se llame mi enfermedad, depende en gran parte de vivir en la ciudad, es decir, rodeado de paredes altas, de calles adoquinadas, oyendo incesantemente estrépito de coches, ómnibus y carretones. Procuraré irme a vivir en un barrio lejano, cerca del mar, para aguardar allí la muerte, que no tardará mucho en venir. Mientras llegue, viviré entre libros y cuadros, trabajando todo lo que pueda literariamente, sin pretender alcanzar nada con mis trabajos, como no sea matar el tiempo." 6 These, then, were the circumstances under which Casal wrote "Tras una enfermedad."

The fact that Casal revealed his feelings so frankly to Borrero shows how highly he respected him and how much he loved him. And with good reason, for Don Esteban was a truly estimable person-a man of whom the great Varona once said: "Fue el amigo a quien más quise y el hombre de más talento que he conocido."7

Esteban Borrero Echeverría was born in Camagüey on 26 June 1849. He was only two years old when his father, Esteban de Jesús Borrero, a writer and patriot, had to leave Cuba and emigrate to the United States because of his activities in the Cuban liberation movement. During this period of tribulation, Esteban's mother, an intelligent woman of strong character, supported her family by teaching school; in addition, she personally supervised Esteban's primary education. At the age of four- 
PLATE 33

\section{Esteban Borrero Echeverría}

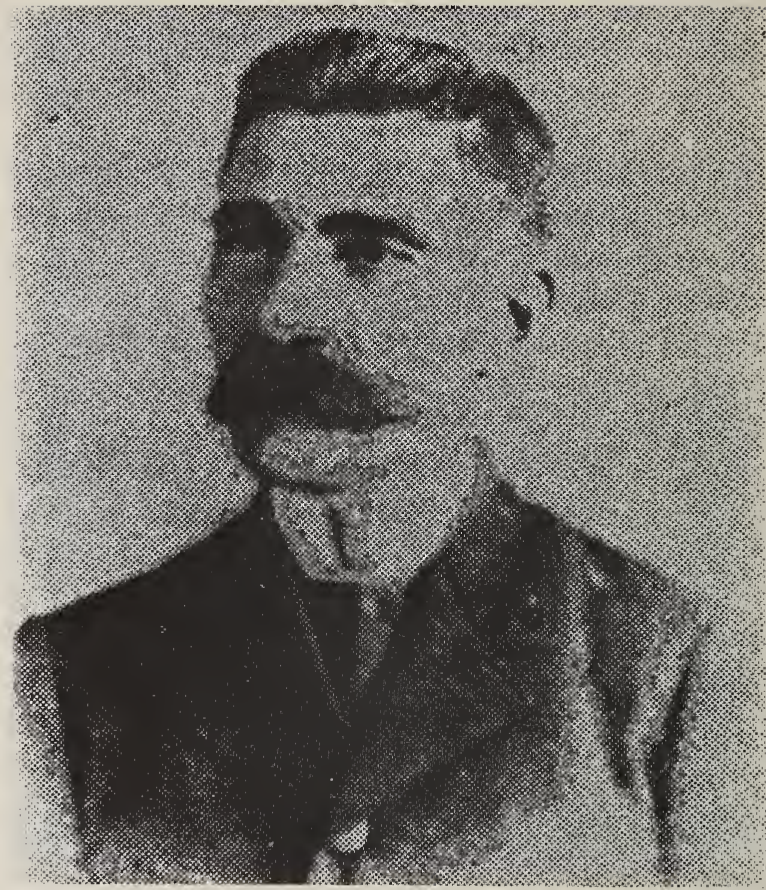

teen, after finishing his studies at the Municipal School of Camagüey, Esteban was hired as a teacher by the school authorities and, in this way, was able to lessen his mother's financial burdens.

When he was barely twenty, Borrero took part in the War of 1868 . Despite the fact that he was taken prisoner and sent back to Camagüey where he was kept under constant surveillance, he lost none of his patriotic zeal or faith in the ultimate liberation of his homeland. At the cost of great personal sacrifice, he moved to the capital and began to study medicine at the University. During this period, he married Consuelo Pierra y Agüero and fathered two daughters: Dolores and Juana (see R34). In 1879, he graduated from medical school. Soon after this, Borrero moved with his family from Havana to the outlying suburb of Puentes Grandes. ${ }^{8}$ There, he had seven more children: Elena, Mercedes, Dulce María, Consuelo, Ana María, Esteban, ${ }^{9}$ and Manuel. To all of them were transmitted their father's love of beauty and his talent for creating it. Some of the children - Juana and Dulce María, for example - allowed the public to see at least part of their production. Others - among them, Manuel - created works of art for their personal enjoyment alone. ${ }^{10}$

Besides fulfilling his responsibilities as pater familias and his obligations as a physician, Borrero engaged in medical research and in literary pursuits. In view of all the demands that were made on his time and 
energy both by his family and by the communities he served, his accomplishments as an author were commendable indeed: not only did he publish scientific articles in domestic and foreign journals, but he also made significant contributions to Cuban belles lettres. As a writer of fiction, Borrero is remembered for "Calófilo" (Revista de Cuba, 1879), *"Cuestión de monedas" (Revista Cubana, 1888), "Aventura de las hormigas" (Revista Cubana, 1888-1891), *"Machito, pichón" (HL, 1892), *“Una novelita" (Revista de Cayo Hueso, 1898), and "El ciervo encantado" (1905). ${ }^{11}$ As far as poetry is concerned, Borrero published Poesias (1878), a collection of original verse; he contributed five compositions to Arpas amigas (1879), an anthology of contemporary Cuban poets; and he brought out Grupo de familia (1895), which contained poems by four members of the Borrero family: Esteban, his father, his brother Manuel, and his daughter Juana. In addition, Borrero published El amigo del niño (1901), a reader for primary school students, and essays on diverse subjects; among the latter are "El café" (1880), "Notas biográficas y críticas sobre el Dr. Joaquín G. Lebredo" (1887), "Muerte y vida" (1895), "El fusilamiento de los estudiantes y la agonía del poder colonial de España en Cuba" (1897), "Una carta íntima" (1899), and Alrẹdedor del Quijote (1905).

The friendship between Esteban Borrero Echeverría and Julián del Casal apparently began when Borrero sent Casal some poems that he had composed. In January 1890, Casal wrote a thank-you note in which he made the following commentary: "Siento hacia usted grandes simpatías, porque en todo lo que escribe encuentro siempre cierta ironía y cierta amargura que me encanta. Los seres felices, o mejor dicho los satisfechos, me repugnan. En cambio, los tristes, o sea los descontentos, me inspiran amor." 12 Borrero, a man of great compassion, was undoubtedly moved by these lines and by the confession of loneliness that was implicit in the statement which followed: "Si usted quiere conocerme me encontrará todos los días, en mi casa, Aguiar 55, de una a cuatro de la tarde. No tengo familia y podemos hablar a gusto. Pero si no puede venir pronto mándeme a decir en qué sitio, a qué hora y en qué día puedo encontrarle." Shortly after receiving this letter, Borrero arranged his first meeting with Casal.

Casal, respected by Don Esteban and warmly welcomed by his family, paid tribute to his friend in Bustos y rimas. Indicative of Casal's feelings are the first and last sentences of his article: "Es uno de los hombres que más valen y del que menos se oye hablar.... [S]i alguno dijera que, al hablar de Borrero, he querido rendir público homenaje al amigo, yo le diría que sólo he querido al triunfo del esfuerzo individual, secundado por una inteligencia superior. ¿Quién lo ha obtenido con más heroísmo que él?’"13

As the years passed, destiny brought many hardships, disillusionments, and personal tragedies into Borrero's life. He faced all of these with a degree of courage and stoic resignation that proved him worthy of the highest admiration; but when his wife Consuelo died, he reached the limit 
of his endurance and, on 29 March 1906, in San Diego de los Baños, he took his own life.

\section{N36: Notes to Introductory Statement}

1 "Julián del Casal y Rubén Darío," Revista Bimestre Cubana, vol. L (September-October 1942), pp. 198-199.

2 Darío dedicated "El clavicordio de la abuela" to Casal and "Los centauros" to Raoul Cay. None of the other works had dedications.

3 Since 14 February 1891 fell on a Saturday, Casal's illness must have broken out some time between Sunday, 8 February, and Wednesday, 11 February.

4 Quoted by Duplessis in "Julián del Casal," p. 65.

5 From the letter of 15 March 1891 (loc. cit.).

6 Duplessis, pp. 66-67. It was a year and ten months before Casal moved into quarters such as he had described to Borrero. On 24 December 1892, he suffered an attack while at the home of Domingo Malpica Labarca. The following day, he left his oppressive room at El Pais and transferred to a rooftop apartment at the Malpica residence, which was located at 2 Virtudes Street in Havana. Malpica's "Nota biográfica" on Casal is reproduced in Appendix A.

7 Quoted by Angel I. Augier in "Juana Borrero, la adolescente atormentada," Cuadernos de Historia Habanera, no. 15 (1938), p. 34.

8 Casal gives his impressions of Puentes Grandes in “Juana Borrero," Bustos $y$ rimas, pp. 75-80. This portion of his article may be found in $E d$. del Cent., vol. I, pp. 264-266.

9 Esteban is the child about whom Borrero speaks in "El lirio de Salomé" (F, 22 October 1899), Ed. del Cent., vol. I, pp. 37-39.

10 In Juana Borrero, Poesías (Havana: Academia de Ciencias de Cuba, 1966), p. 11, Fina García Marruz indicates that Manuel wrote flawless sonnets which he never published. The source of this information was Mercedes Borrero.

11 The stories marked with an asterisk were later published in a volume entitled Lectura de Pascuas (1899).

12 Ed.del Cent., vol. III, p. 81.

13 Bustos y rimas, pp. 61 and 73; Ed. del Cent., vol. I, pp. 260 and 264. Italics are Casal's.

N36: VARIANTS

\section{I. $H E$}

6 penas

9 ( $($ ) $)[\mathrm{h}]$ as $[$ sic $]$

10 implacable Verdad
$N$

penas,

[h]az

horrible Realidad
GLIC

(ף) $+N$

\section{N37: EN UN HOSPITAL}

"En un hospital" was first published on 30 March 1892 in the fort- 
nightly journal La Habana Literaria. In this printing, Casal gave no indication that the poem had been conceived as part of "Marfiles viejos." He did incorporate it into the series, though, in Nieve (see my discussion of Np4).

On 24 April 1892, El Hogar reproduced the poem for its readers. This version is not represented in the record of variants, however, because it postdates Nieve.

\section{N37: VARIANTS}

l. $H L$

$6[\mathrm{y}] \mathrm{el}$

14 final
$N$

con su

fatal

GLIC

\section{Np5: LA GRUTA DEL ENSUEÑO}

"La gruta del ensueño" consists of seventeen poems and is therefore the longest section in Nieve. While the titles of $\mathrm{Np} 1, \mathrm{~Np} 2$, and $\mathrm{Np} 3$ give the reader some clue to the contents of those sections, and while the title of $\mathrm{Np} 4$ is, at least in part, an allusion to the form of that section's components (all the poems it contains are sonnets), the title of Np5 has no such correlative value. Furthermore, whereas the titles "Bocetos antiguos," "Mi museo ideal," "Cromos españoles," and "Marfiles viejos" trace their origins to the time when Casal was publishing early versions of the poems in Cuban periodicals, the title "La gruta del ensueño" was not associated with the poems of Np5 until shortly before Nieve went to press. As a matter of fact, the only title that had appeared in connection with poems of this section was "Poesías diversas." This designation suggests that, in contrast to the other parts of Nieve, Np5 was a catchall for compositions which, because of their subject matter, did not fit logically into "Bocetos antiguos," "Mi museo ideal," or "Cromos españoles," and which, because of their subject matter or form, could not be included in "Marfiles viejos." Since the heading "Poesías diversas" was undoubtedly too prosaic to be used in an artistic tour de force like Nieve, Casal had good reason to look for a title that was more in harmony with the others in the book. How he came to choose "La gruta del ensueño" is not known. However, one obvious possibility is that, through a simple association of color with concept, he derived the title from a place name: La Gruta Azul. ${ }^{2}$

The poems of "La gruta del ensueño" were published between 19 October 1890 and 29 February 1892. Plate 34 contains a record of their first appearance in Havana periodicals. Plate 35 shows which compositions Casal re-located in the series when he was preparing Nieve for publication. Although the motivation behind some of these changes in position seems rather transparent (see my discussion of N39, for example), no overall pattern can be discerned in Casal's re-sequencing of the section. 
$>$ N38 Ante el retrato de Juana Samary

N42 Vespertino

N40 Blanco y negro

N41 Flores

N48 Mi ensueño

PLATE 34

"LA GRUTA DEL ENSUEÑO" ORDER OF PUBLICATION*

$>$ N39 Camafeo

$>$ N51 En un álbum

$>$ N43 Kakemono

$P: \quad 19$ Oct 90

$P: \quad 26$ Oct 90

$P: \quad 2$ Nov 90

$P: \quad 16$ Nov 90

$P: \quad 16$ Nov 90

$F$ : $\quad 8$ Mar 91

$H E$ : 15 Mar 91

$H E$ : 22 Mar 91

N44 Nostalgias

N45 La reina de la sombra

HE : 12 Apr 91

N46 Paisaje de verano

N47 Flores de éter

N50 Al carbón

N54 Horridum somnium

$H E$ : 10 May 91

$H E$ : 21 Jun 91

$H E: \quad 5 \mathrm{Jul} 91$

$H E$ : 26 Jul 91

$H L: 15$ Sep 91

N52 Canas

$H L: 15$ Dec 91

N49 Canción

F: $27 \mathrm{Dec} 91$

$>$ N53 Medallón

$H L: 29 \mathrm{Feb} 92$

*The titles listed here are those of Nieve. The sign $>$ indicates that another title was used at some time in the poem's history. Variant titles may be found in Index I and in my discussion of the marked poems.

PLATE 35

SEQUENCE CHANGES IN THE POEMS OF

"LA GRUTA DEL ENSUEÑO"

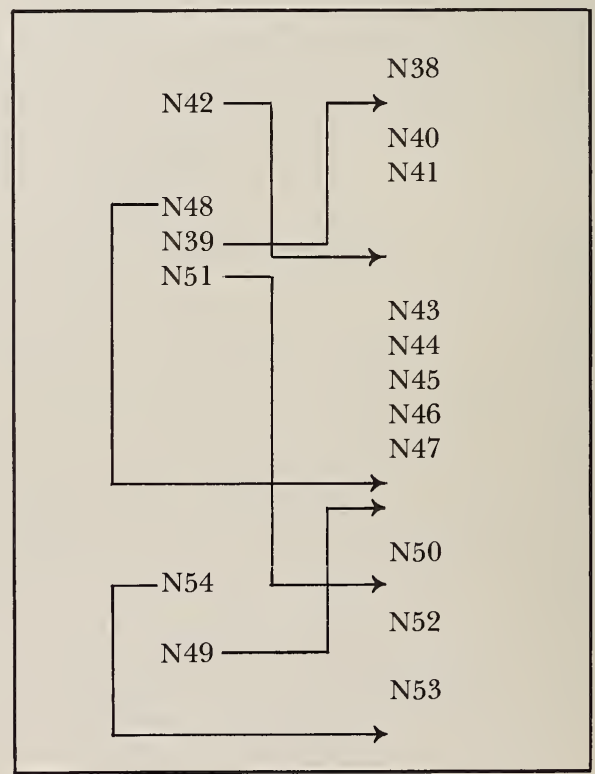


What can be established without too much difficulty, however, is Casal's reason for dedicating the poems of "La gruta del ensueño" to Edouard Cornelius Price. This writer, known more commonly as Cornélius Edouard Price, was born in Havana on 30 November 1870. Although Price's father was English and his mother was Cuban, Casal considered the young author as one of his "compatriotes francisés" (C8/6-7). As far as literary pursuits were concerned, this was an accurate description, for, when he was only twenty-one years of age, Price was already preparing a book of poems in French. Among his compositions was the sonnet "Ce que jaime," which, as indicated in my discussion of $\mathrm{H} 11$, had been influenced by Casal's "Mis amores." In 1892, the book was published in Paris by Lemerre under the title Pour l'amour des vers. It was dedicated to François Coppée, Price's benefactor in the venture (C7/10-15) and main source of inspiration. ${ }^{3}$

Before the publication of Pour l'amour des vers, however, Casal sent Price a letter which he was to take personally to Gustave Moreau. That letter, dated 5 March 1892, was apparently designed to accomplish two things. As a letter of presentation to Moreau, who had many friends in the world of art and literature, it might increase Price's chance of success at the moment when he was going to publish his first collection of poetry. In addition, by giving Price direct access to Moreau, it might enable Casal to obtain an accurate report on the artist's health (a subject about which he was deeply concerned at the time ${ }^{4}$ ) and, in all probability, a detailed description of the great man and the world in which he lived. ${ }^{5}$ In essence, then, it might be said that Casal had written the letter in the hope that it would become a key to joys - albeit vicarious ones - that he himself had yearned to experience for many months. Apparently out of gratitude to Price for visiting Moreau and giving a full account of the interview, Casal dedicated "La gruta del ensueño" to him.

\section{Np5: Notes to Introductory Statement}

1 Despite the fact that N46 and N50 are sonnets, they do not fit into "Marfiles viejos" because they are impersonal, descriptive compositions, while the poems of "Marfiles viejos" are all highly personal expressions of Casal's attitudes towards reality. The only poem in Np5 which could logically have been made part of "Marfiles viejos" is "Mi ensueño" (N48). It seems, however, that the very title of the poem would inhibit Casal from moving it out of "La gruta del ensueño."

2 In this regard, it is interesting to note that one month after Casal published "Horridum somnium" (N54) in La Habana Literaria, Raimundo Cabrera, the person to whom he would later dedicate that poem, published "La isla de Capri" in the same journal (see $H L, 15$ October 1891, pp. 54-57). This was Cabrera's translation of Mary E. Vandine's article about the enchanting island whose fabulous Grotta Azzurra had captured the imagination of thousands of nineteenth-century travellers and had inspired Ludwig II of Bavaria to duplicate its beauty on the grounds of Linderhof Castle (see my discussion of N47). 
3 See Max Henríquez Ureña, "Poetas cubanos de expresión francesa," Revista Iberoamericana, vol. III, nos. 5-6 (February-May 1941), p. 323.

4 C6/9-21, C7/31-35, C8/10-16.

5 It is likely that Casal also hoped that, as a consequence of Price's visit, Moreau would send him the portrait which he had requested in his letter of 17 February 1892 (C6/143-157).

\section{N38: ANTE EL RETRATO DE JUANA SAMARY}

Léontine-Pauline-Jeanne Samary was born in Neuilly-sur-Seine on 4 March 1857. In 1875, after receiving a first prize in acting from the Conservatoire National d'Art Dramatique, she made her professional debut at the Théâtre Français as Dorine in Molière's Tartufe. During the fifteen years that followed, she enjoyed repeated successes and ultimately became one of the most celebrated actresses in France. She died in Paris of typhoid fever on 18 September 1890 and was buried in Passy. When the news of her death reached Havana, Casal, who had seen illustrated writeups on her in Parisian journals, was inspired to compose "Ante el retrato de Juana Samary." The poem was published on 19 October 1890 as part of the first "Crónica semanal" that he wrote for El País. It was prefaced by the following comment:

Todo hombre, por muy poco desarrollada que tenga la facultad de soñar, tiene sus amadas ideales, por las que suspira, en horas de abatimiento, con todo su corazón. Esas mujeres, ya estén en el mundo, ya reposen en brazos de la muerte, llegan a adquirir mayor importancia que las amadas existentes, porque nunca se han conocido y la fantasía se complace en revestirlas de atributos inmortales. Ellas son las únicas que pueden reanimar, en ciertas almas, el anhelo de la felicidad, porque uno se forja la ilusión de que a su lado hubiera olvidado muchas cosas que nunca ha podido olvidar.

Entre las mujeres que yo he amado, como otro cualquiera, sin haberlas conocido jamás, figura en primera línea Juana Samary, la célebre actriz de la Comedia Francesa, muerta recientemente en pleno desarrollo de su genio, sin haber conocido los ultrajes de la edad. Yo la amé por un retrato de Humbert, premiado en uno de los últimos salones. Todos los periódicos franceses han publicado su retrato en estos días, pero no me agrada ninguno de ellos, porque allí no aparece la mujer, sino la incomparable soubrette que, con su cofia de batista, guarnecida de encajes, y su delantal blanco, ornado de cintas, sale a divertir en una comedia de Banville o Pailleron, a una masa desconocida de espectadores. 
PLATE 36

Jeanne Samary by Jacques-Charles-Ferdinand Humbert

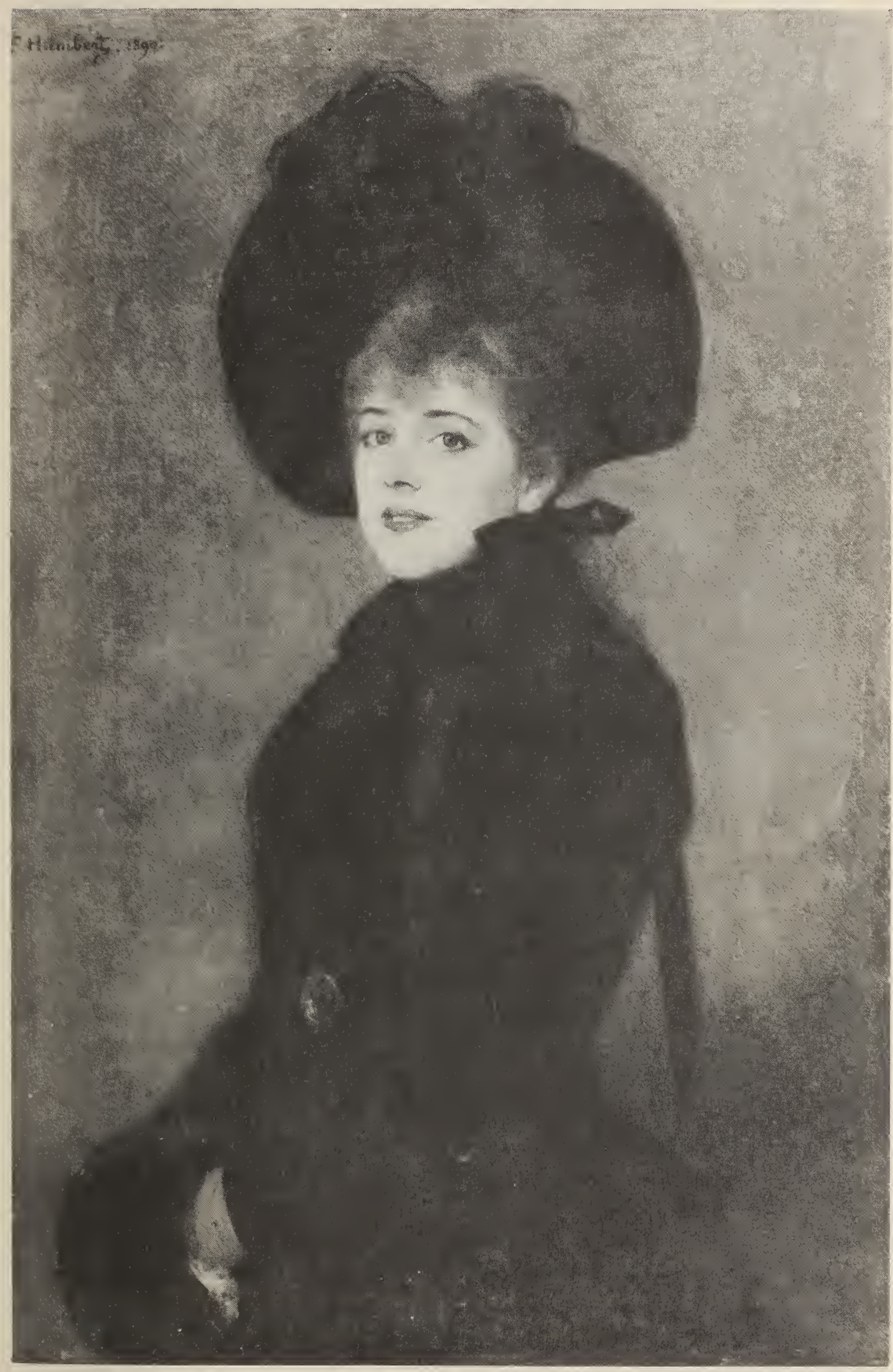

Courtesy of Thérèse Alié. 
Donde fascina verdaderamente, es [en] el retrato de Humbert. Allí aparece de perfil, sonriendo lánguidamente al espectador. La sonrisa de Samary me agrada más que la de la Gioconda, porque la de ésta revela perfidia y la de aquélla tristeza. El pintor ha dibujado el cuerpo adorable de su modelo sobre un fondo de color gris. Ella luce en la cabeza un sombrero negro, de alas levantadas, ornado de plumas obscuras. Bajo las alas del sombrero, los rizos rubios del cerquillo se ensanchan en la frente, como fino musgo de oro en la blancura de un mármol, descendiendo luego sobre las conchas rosadas de las orejas. El busto aparece envuelto en un abrigo de paño negro, cuyo cuello de terciopelo abriga la nuca olorosa de esa figura que parece creada por la fantasía de Burne Jones o por la de algún precursor del Renacimiento. Sus manos desaparecen en ancho manguito de pieles negras. Si su sonrisa vierte la gracia, su mirada esparce un relente de melancolía en el ánimo del contemplador. El cuerpo parece estremecido de frío, como un lirio azotado por el cierzo. Todo en ella es melancólico, sugestivo, voluptuoso y espiritual.

Tanto me ha gustado esta figura que el otro día, al leer la noticia de la muerte de la pobre actriz, he improvisado ante ella los siguientes versos, donde, a falta de arte, he puesto un poco del sentimiento que llenaba en aquel instante mi corazón .... ${ }^{1}$

Among the illustrations placed at the end of vol. II of the Ed. del Cent. is a full-face, waist-length picture of Samary. This photograph bears the following caption: "Jeanne Samary, célebre actriz cuyo retrato - del pintor Renoir [sic] - inspiró a Casal un artículo y un bello poema." Contrary to what the compilers of the Centenary Edition say, my lengthy quotation from Casal's article makes it plain that the source of inspiration was not the portrait by Renoir, but rather a portrait by Humbert. Jacques-Charles-Ferdinand Humbert (b. Paris, 8 October 1842; d. Paris, 7 October 1934) was well known for paintings based on historical and religious themes, and for portraits of talented women of his time. He began exhibiting his work at the Salon in 1865 and continued exhibiting there on a regular basis until 1932. During this period, he won five medals for his paintings $(1866,1867,1869,1878$, and 1900), was named to the Legion of Honor (1878), and was elected to the Institut de France (1902). His picture of Jeanne Samary was painted in 1890 and is currently in the private collection of Thérèse Alié, a descendant of the famous comedienne. Thanks to the generous cooperation of Mlle. Alié, it has been possible to include a photocopy of the Humbert portrait in the present edition (see Plate 36).

On 24 October 1890, "Ante el retrato de Juana Samary" was reproduced without change by El Pueblo. The editors were so faithful to their 
source that, instead of indicating that the author was Julián del Casal, they used the pseudonym Alceste, which had appeared at the end of the ElPais article.

A second $P b$ version of the poem came out on 19 June 1891. It differed from its predecessor in several respects. First of all, the title was changed from "Ante el retrato de Juana Samary" to "Ante el retrato de una desconocida" and was printed in parentheses. Depersonalization of the title was not a surprising modification, since Casal tended to do this before incorporating poemas de ocasión and album pieces into his collections, ${ }^{2}$ but to enclose it in parentheses was rather unexpected. Second, an entire stanza was omitted (1l. 21-24). Unfortunately, it is impossible to tell whether the omission was deliberate or whether it was a typesetter's error. Several lexical changes were also made; among them, the most interesting are those of 11.10 and 16 , for they resulted in the kind of repetition which Casal usually avoided when composing a poem, but which he sometimes failed to avoid during the process of revision. Finally, a number of punctuation changes were introduced, and these caused new rhythms to be established in the second $P b$ version.

Before publishing the poem in Nieve, Casal made a few more modifications. As far as motivation is concerned, the most mysterious of these are his return to the original title and his restoration of 1l. 21-24.

\section{N38: Notes to Introductory Statement}

1 Ed. del Cent., vol. III, pp. 12-13. It should be noted that Casal used the pseudonym Alceste in the columns of El Pais.

2 See, for example, H28, N39, N51, and N53. The following exceptions to this practice may be cited, however: H45 and R37.

N38: VARIANTS

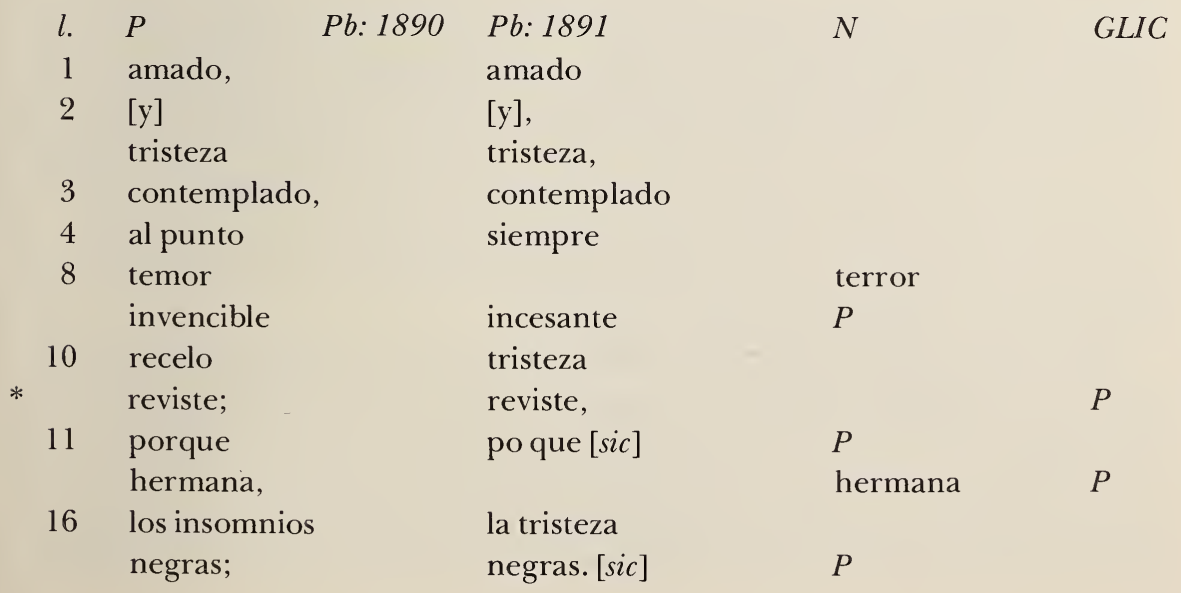




\begin{tabular}{|c|c|c|c|c|}
\hline$l$. & $P b: 1890$ & $P b: 1891$ & $N$ & GLIC \\
\hline \multirow[t]{2}{*}{ * 17} & (ף) [p]orque & (ף)Porque [sic] & $P$ & \\
\hline & saber que & saber q. & $P$ & \\
\hline * 18 & los & & tus $[s i c]$ & $P$ \\
\hline 19 & [s]iento que & [s]iento q. & $P$ & \\
\hline * 21- & & & & \\
\hline 22 & desconocido, & & desconocido & \\
\hline 25 & $\begin{array}{l}\text { la vida hemos } \\
\text { logrado, }\end{array}$ & $\begin{array}{r}\text { el mundo hemos } \\
\text { probado }\end{array}$ & & $P b: 1891+$, \\
\hline 27 & amado, & amado & & \\
\hline 28 & [q]uizás & [t]al vez & & \\
\hline
\end{tabular}

\section{N38: Notes to Variants}

10: The semicolon of the $P$ version creates a better rhythm than does the comma which was used in $P b$ (1891) and $N$; for this reason, the semicolon is restored in the present edition.

17: The first line of stanzas was not indented in $N$.

18: It appears that, in $N$, the substitution of tus for los was not a deliberate change originating with Casal: since the complement of despojos is de tu cuerpo yerto, the word tus is completely out of place.

21-24: These lines were omitted from the $P b$ version of 1891, but were restored in $N$.

\section{N39: CAMAFEO}

This composition was first published on 8 March 1891 in the "Album femenino" column of El Fígaro. As shown in Plate 37, the title in El Fígaro was "SRITA. MARIA CAY." This was printed above a three-quarter length picture of the lady, and the picture was followed by the text of the poem. In this version, no lines were indented, a centered rule was used to separate the stanzas, and a row of dots was printed after 1.24 , which was then "La sonrisa inmortal de la Joconda. . .." At the end of the poem, to the left of the author's name, was the date "(Marzo, 1891.)." Chronologically, this was the sixth poem in the series that would ultimately be called "La gruta del ensueño." After reading the work, Miss Cay, whose relationship with Casal is discussed in N43, allegedly told the poet: 'No esperaba que usted me regalara tan linda calabaza."

When preparing Nieve, Casal made some interesting alterations in the poem: he changed the title to "Camafeo," which was much more arty than the original had been; he streamlined the format by removing the centered rules and the row of dots; he simplified wording, spelling, and punctuation in several verses; ostensibly to improve the logic of the work, he inserted stanza VI of the $F$ version between stanzas III and IV; and he 
PLATE 37

María Cay

\section{ALBUM FEMENINO.}

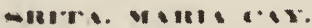

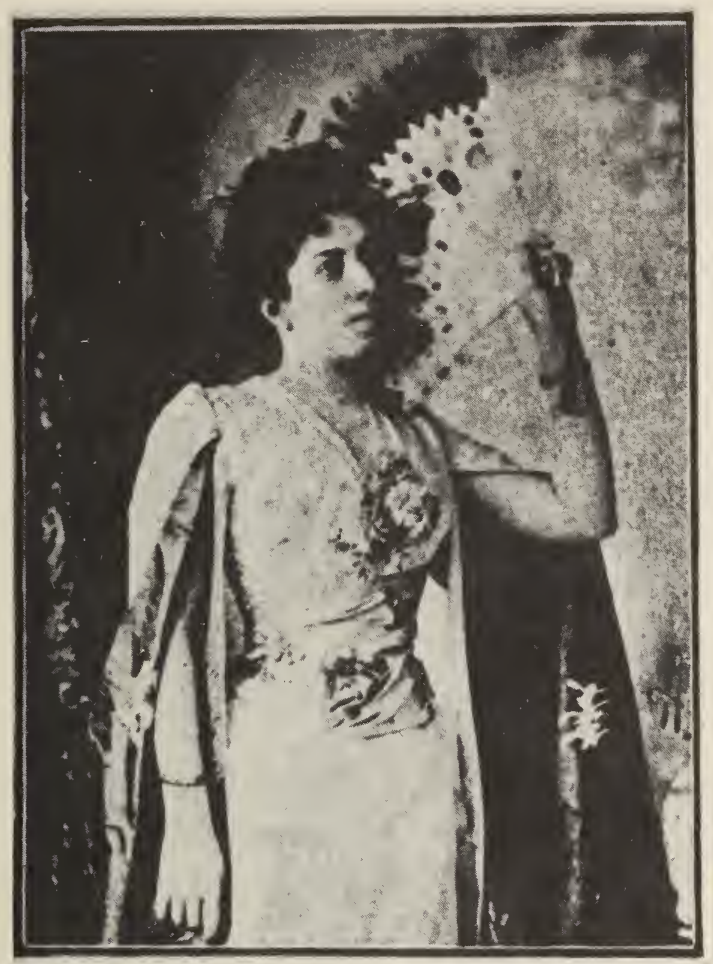

moved the poem from sixth to second position in "La gruta del ensueño." As a result of this change in sequence, "La gruta del ensueño" began with two poems inspired by women of the type that Casal had once described as "amadas ideales" (see N38).

N39: VARIANTS

l. $F$

3 cuerpo

10 savia

* 13 mirada,

16 Joconda...

17 finas hebras

21 idolatra,
N

busto

sangre

mirada

Yoconda.

negros rizos

idolatra 


\section{N39: Note to Variants}

13: Lines $13-16$ of the $N$ version had originally been $11.21-24$ in the $F$ version.

\section{N40: BLANCO Y NEGRO}

This poem was first published in the 2 November 1890 issue of ElPais. Library sources in Cuba indicated that, although they had this issue of the paper in their holdings, they could not photograph it because it was in very poor condition. Consequently, this version of "Blanco y negro" is not represented in the record of variants.

The second version of the poem appeared on 7 December 1890 in $L a$ Habana Elegante. On that occasion, it was printed with "Vespertino" (N42), "Mi ensueño" (N48), "A un amigo" (see N24), and "Flores" (N41) under the collective heading "Poesías diversas." Aside from N24, which was given a new title and was moved to another section of the book, all of the poems in this group became part of "La gruta del ensueño" in Nieve. It must be pointed out, however, that their position in Nieve was not determined by their date of initial publication (see Np5) or by the order in which they were displayed in La Habana Elegante.

\section{N40: VARIANTS}

\section{l. $H E$}

18 [e]ntre

20 huérfanas;

* 23 tierra,

$39 \operatorname{los}[s i c]$

52 amado $[$ sic $]$
$N$

[h]acia vírgenes; tierra las amado?
GLIC $H E$

\section{N40: Note to Variants}

23: The comma of the $H E$ version is restored for the same reason as given in N32/6.

\section{N41: FLORES}

This short composition made its debut in El País on 16 November 1890. Three weeks later, on 7 December 1890, La Habana Elegante reprinted it in a series entitled "Poesías diversas." This group consisted of "Blanco y negro" (N40), "Vespertino" (N42), "Mi ensueño" (N48), "A un amigo" (see N24), and "Flores." In the HE printing, however, "Flores" was mistakenly given the same subtitle, "Soneto," as N48 and N24, its immediate 
neighbors on the page. This error was rectified when the work was reproduced in the 23 December 1890 issue of El Pueblo.

It is interesting to speculate on why Casal arranged his material the way he did in Nieve. Where "Flores" is concerned, it is possible that he grouped the poem with "Blanco y negro" because both works, though different in length, were similarly organized and similarly inspired: that is, each had a bipartite structure which exploited the device of antithesis to bring out the author's lack of faith. ${ }^{1}$

\section{N41: Note to Introductory Statement}

1 The subject of antithesis is studied at length by Ivan A. Schulman in "Las estructuras polares en la obra de José Martí y Julián del Casal," Revista Iberoamericana, vol. XXIX, no. 56 (July-December 1963), pp. 251-282.

\section{N41: VARIANTS}

$\begin{array}{lllll}\text { l. } P & H E & P b & N & \text { GLIC } \\ 3 \text { astro, } & \text { astro } & & & \\ 6 \text { consumada }[s i c] & \text { consumida } & & \\ 8[\mathrm{u}] \text { na } & & & {[\mathrm{u}] \mathrm{a}[\mathrm{sic}]} & P\end{array}$

\section{N42: VESPERTINO}

Unlike Duplessis (“Julián del Casal," p. 162), we should not confuse this composition with the initial version of "Crepuscular" (R2), which was also entitled "Vespertino." The "Vespertino" of Nieve was first published in the 26 October 1890 issue of El Pais. In this version, the words "(Por Julián del Casal.)" were printed in italics beneath the title, and the poem was dedicated "A Raúl Cay."

On 7 November 1890, the work was reproduced by El Pueblo. In this version, the author's name was placed at the end of the poem, rather than at the beginning as in $\mathrm{El}$ Pais; and some changes, for which Casal was apparently not responsible, were made in the text. The original dedication was retained.

The last version to come out before Nieve was that of La Habana Elegante. In the 7 December 1890 issue of that journal, the poem was printed under the heading "Poesías diversas" together with "Blanco y negro" (N40), "Mi ensueño" (N48), "A un amigo" (see N24), and "Flores" (N41). Although the dedication was retained, it now read: "A. [sic] Raúl Cay." "Casal removed the dedication from the Nieve version.

The record of variants indicates that a year and a half after publishing "Vespertino" in El País, Casal was basically content with his original version of the poem. Not all the readers of Nieve were as satisfied with 
the work as he was, however. For example, Enrique José Varona cited 11. 16-18 in order to show that painting with words cannot be done effectively merely by agglomerating items that belong to a common conceptual category. According to Varona, when one reads a statement such as

$$
\begin{aligned}
& \text {...el sol espolvoreaba de rubíes, } \\
& \text { esmeraldas, topacios, amatistas } \\
& \text { y zafiros. }
\end{aligned}
$$

there is not enough time for the mind to grasp and appreciate each component of the image. The result is that "Se oyen palabras; no se ve nada." 2 This perceptive comment should be kept in mind when we read the poetry of Casal and other modernistas, for their tendency to list objects or attributes of objects has often been mistakenly equated with competence at description.

\section{N42: Notes to Introductory Statement}

1 See H42, n. 10. For information on Cay, see H43.

2 "Nieve," in Revista Cubana, vol. XVI (August 1892), p. 144. The entire article is reproduced in Appendix B of the present edition. For an analysis of the poem, see Robert Jay Glickman, "Vespertino," in Antología comentada del modernismo, ed. Francisco E. Porrata and Jorge A. Santana (Sacramento: Califor-

\begin{tabular}{|c|c|c|c|}
\hline l. $P$ & $\mathrm{~Pb}$ & $H E$ & $N$ \\
\hline 2 erguidos & & alzados & \\
\hline 6 tintes, & & tintes & \\
\hline $8 \operatorname{los}$ & & las $[s i c]$ & $P$ \\
\hline 10 onda & honda $[$ sic $]$ & $P$ & \\
\hline 12 tristes $[$ sic $]$ & tristes. & $P[s i c]$ & $\mathrm{Pb}$ \\
\hline $13 \mathrm{el}$ & & un & \\
\hline anreas $[$ sic $]$ & áureas & & \\
\hline 14 [e]mbriagadas, $[$ sic $]$ & & [e]mbriagadas & \\
\hline 20 nudosas & undosas [sic] & $P$ & \\
\hline 22 irguen, & & irguen & \\
\hline 23 rojas, & & rojas & \\
\hline 25 reales. & & reales $[s i c]$ & $P$ \\
\hline 29 que & q. & $P$ & \\
\hline aura & áurea [sic] & $P$ & \\
\hline
\end{tabular}
nia State University, 1974), pp. 147-149.

\section{N42: VARIANTS}


This poem was first published in the 22 March 1891 issue of La Habana Elegante. It bore the title "Pastel japonés" and was dedicated "A María Cay." A centered rule was printed after 1.8 ; this, plus the section-heading "Envío" which came after 1. 64, gave the impression that the work was conceptually divided into three segments: 11. 1-8, 9-64, and 65-76.

When preparing the poem for inclusion in Nieve, Casal made several types of modifications. He changed the title from "Pastel japonés" to "Kakemono," a term which was much more exotic sounding than the original. ${ }^{1}$ He suppressed the dedication-a move which, by detaching the poem from the specific reality of María Cay, gave it an aura of timelessness and heightened its exoticism. He made minor alterations in the wording and punctuation of the text. And he removed the centered rule which followed 1.8 in the original version. This simplification in format served to emphasize the fact that the poem was not a three-part composition, as the $H E$ version appeared to be, but was actually a two-part work in which the first section (ll. 1-64) was devoted to the poetic object tú, and the second (11.65-76) was devoted to the reactions of the yo, poeta.

María Cay was a prominent figure in elite circles of Havana society, the activities of which were reported by Casal in La Discusión between 28 November 1889 and 21 July 1890, and in El Pais between 19 October and 21 December 1890. Three factors help explain her presence at the elegant functions of the time: first, the status attained by her father when he was Chancellor of the Chinese Consulate in Havana; second, the position of her brother Raoul as consular attaché and as society columnist for $\mathrm{El}$ Figaro (see H43); third, her exceptional beauty and natural grace, attributes which captivated all who saw her, including Rubén Darío, who, after meeting her in 1892, described her as "una hermosísima cubana, gallarda, espléndida, con lánguidos y milagrosos ojos de criolla y fabulosa cabellera."

Throughout the years, the relationship between Julián del Casal and María Cay has been the subject of much speculation. According to Esperanza Figueroa, Casal was deeply in love with María, who was the great passion of his life. ${ }^{3}$ Figueroa goes so far as to say that, on visiting the Cay residence in 1892, "Darío comprende pronto que aquélla es la amada de Casal, su sueño inalcanzable . ..."4 Actually, Darío's own words on the matter were much more circumspect: "Y recordaba yo cómo Julián del Casal había cantado en admirables versos a María Cay-versos que pueden leerse en su volumen Nieve-, ¿enamorado de ella? . . . tal vez. El parece que nunca lo manifestara." 5 As a matter of fact, while Darío, Casal, and Raoul Cay were admiring objects of art from the Orient in one room, María was entertaining her fiancé, General Lachambre, in an adjoining room. This point is brought out very clearly by Darío in "El general Lachambre: Recuerdo de la Habana" and in "Manuel S. Pichardo."6 
Indeed, when all the evidence is examined, the contention that Casal was romantically involved with María Cay seems extremely difficult to support. What can be stated without risk of equivocation, however, is that Casal was very receptive to any form of beauty and, for this reason, could not remain insensitive to all the gifts that nature had bestowed upon the creole belle. In other words, rather than loving her as a man loves a woman, Casal appears to have been attracted to María Cay in the way an aesthete is attracted to a masterpiece of creation. Nevertheless, as he pointed out in "Camafeo," even this feeling was destined to be subverted by the world-weariness that cast a shroud over his heart (see N39/25-28).

As far as "Kakemono" is concerned, we know for certain that María Cay was Casal's source of inspiration. The history of the poem goes back to the night of 14 February 1890 when a costume ball was held at the elegant home of Don Demetrio Pérez de la Riva, a distinguished Cuban jurist and member of the landed elite. Casal attended the ball in his capacity of reporter for La Discusión. Among the ladies, he saw María Cay, who was dressed in a Japanese costume and, according to his report, rivalled the beauty of Mme. Chrysanthème. ${ }^{7}$ Since this ball was one of the highlights of the social season, the ladies decided to have a photographic souvenir of the occasion. In the days following the dance, they went to the studio of Oscar Held and had their pictures taken in the same costumes as they wore on the night of the ball. When the photographs were ready, they were displayed in the Suárez gallery at the corner of O'Reilly and Compostela Streets. On 1 April 1890, in his article "Album de la Ciudad: Retratos femeninos," Casal described four of the most impressive pictures in the collection. One of them was the portrait of María Cay, "vestida de Japonesa, que vaga por un jardín asiático, con el abanico de nácar abierto ante los ojos, para atenuar el brillo del sol, como si buscara la flor sagrada del loto ...."8 It was probably a copy of this portrait that Darío saw in 1892 when he visited Casal's modest quarters in the building that housed $\mathrm{El}$ País. The innate beauty of María Cay, enhanced by the Japanese costume she wore, inspired Darío to write the following sonnet:

Miró enfrente de la mesa, bañado en la luz del día el retrato de María, la adorable japonesa.

El aire acaricia y besa como un amante lo haría la orgullosa bizarría de la cabellera espesa.

Diera un tesoro de Mikado por contemplar a su lado a princesa tan gentil. 
PLATE 38

A Kakemono Whose Subject Resembles the One Depicted by Casal

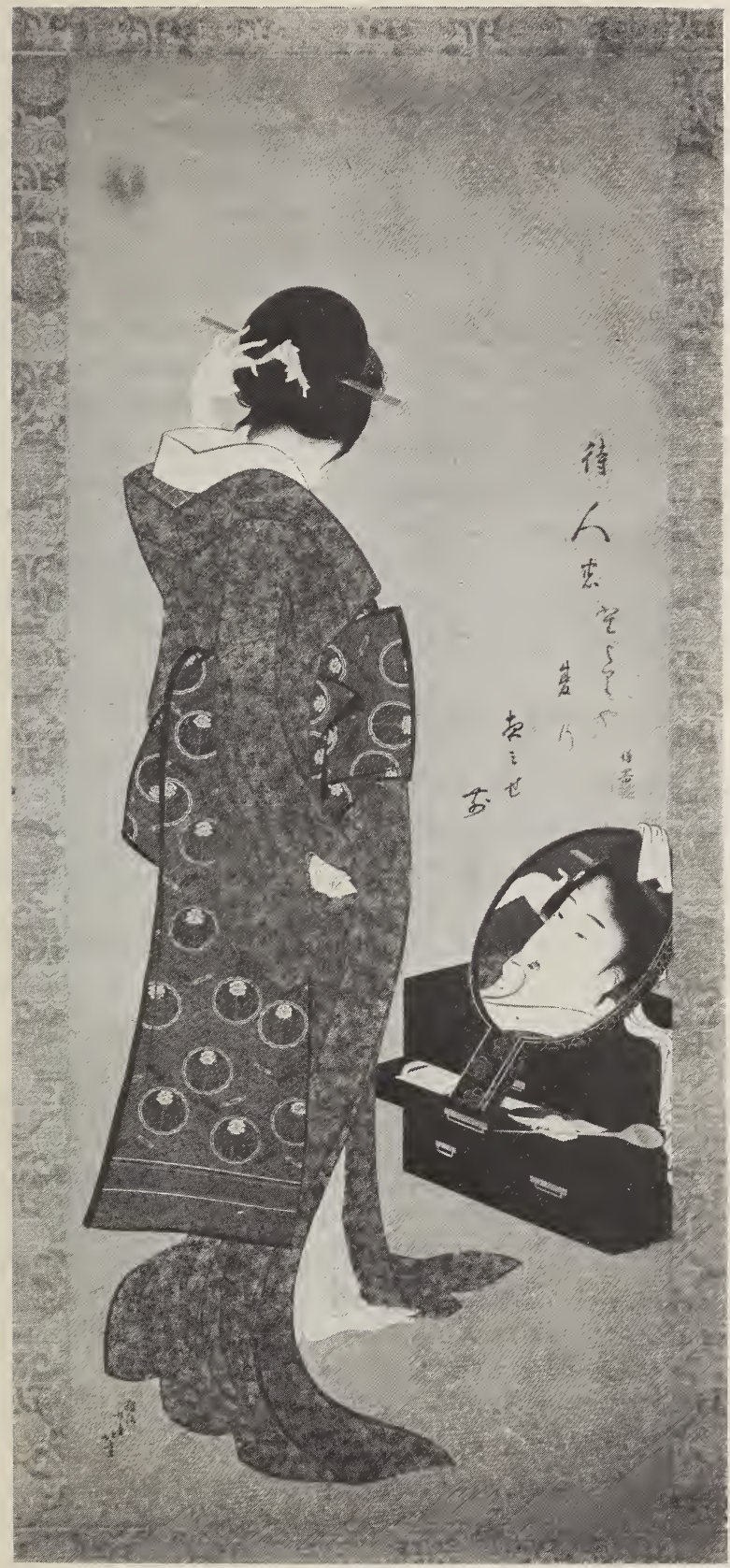

Hokusai, Lady Arranging her Hair before a Mirror.

Courtesy of The Museum of Fine Arts, Boston. 


\section{Y ordenara a su pintor pintarla junto a una flor en un vaso de marfil. ${ }^{9}$}

In contrast to the enthusiasm that was generated in Darío both by María Cay in Japanese garb and by Casal's description of her in the "admirables versos" of $\mathrm{N} 43,{ }^{10}$ we find the highly critical reaction of Enrique José Varona to his compatriot's artistic flirtation with orientalism: "No sabemos si los kakemonos japoneses llegarán a aclimatarse en el arte occidental. Pero nos agradaría ver empleadas las facultades exquisitas de Casal en asuntos más altos, que en pintar en jarrones, biombos, platos, estuches o abanicos, una gentil criolla con los atavíos postizos de una emperatriz de los nipones en un bal masqué. El poeta, hastiado de nuestra vida prosaica de factoría americana, se escapa a las regiones soñadas de ese oriente remoto forjado en la fantasía de invernadero de Judith Gautier. Busca el arte a los lejos, para vivir por el arte. ¿Por qué habrá dicho Proudhon: l'art pour l'art aboutit à des chinoiseries?" 11 As will be shown in my discussion of "Sourimono" (R7), even this criticism by Varona did not deter Casal from looking to the Orient for poetic inspiration in the months that followed the publication of Nieve.

\section{N43: Notes to Introductory Statement}

1 The Japanese word Kakemono means literally "a hanging thing." Technically, it is a format designation which describes the manner in which a painting or example of calligraphy is mounted. The mounting consists of a heavy paper backing, brocade borders, a pierced rod at the top by means of which the picture can be hung, and a cylindrical rod at the bottom around which the work is rolled for storage. A hanging scroll whose subject resembles the one depicted by Casal in this poem is shown in Plate 38 .

2 From "El general Lachambre: Recuerdo de la Habana" (La Nación of Buenos Aires, 7 March 1895), as reproduced by Monner Sans in Julián del Casal y el modernismo hispanoamericano, p. 248.

3 "Revisión de Julián del Casal," Primer Congreso Nacional de Historia: Trabajos presentados, vol. II (1943), p. 253.

4 “Julián del Casal y Rubén Darío," Revista Bimestre Cubana, vol. L (September-October 1942), p. 193.

5 "El general Lachambre ...," in Monner Sans, p. 249.

6 Loc. cit. and Letras (Madrid: Editorial Mundo Latino, 1921), p. 180.

7 See "Salones. habaneros: Gran baile de trajes" ( $D, 15$ February 1890), in Ed. del Cent., vol. II, p. 55.

8 Ed. del Cent., vol. II, p. 95. On the following day, Casal published "Japonería," a short prose composition which he dedicated "A M. C." The text of this article leaves no doubt that he was addressing himself to María Cay (see Ed. del Cent., vol. II, p. 97). 
9 This version of the poem appeared in La Nación of Buenos Aires on 7 March 1895. A revised version was published the following year in Prosas profanas, where it was preceded by "Para una cubana," another sonnet that had been inspired by María Cay.

10 “El general Lachambre ...," in Monner Sans, p. 249.

11 "Nieve," in Revista Cubana, vol. XVI (August 1892), pp. 145-146. The entire review is reproduced in Appendix B. See, also, Rosa M. Cabrera's analysis of "Kakemono" in Antología comentada del modernismo, ed. Francisco E. Porrata and Jorge A. Santana (Sacramento: California State University, 1974), pp. 151-154.

\section{N43: VARIANTS}

l. HE
* 2 cual
5 belleza
7 mariposas,
9 níveo,
11 luna
28 japonesa $[s i c]$
31 tiñe
39 hechas $[s i c]$
50 nifones
58 noche,
59 arrebatarle
60 En
jarrones $[s i c]$
64 humanas
66 penas
75 las

$N$

por hermosura mariposas níveo luna, japonesa. tiene hechos

noche disputarle

iEn

hermosas males sus
GLIC

nipones

jarrones,

\section{N43: Note to Variants}

2: It is possible that, when this line was changed from "que te dio el cielo, cual nativo dote," to "que te dio el cielo, por nativo dote," the comma after cielo was left in by mistake. It is also possible that this comma was purposely retained in the $N$ version to emphasize the contrast between natural beauty and the more highly valued beauties of art. Since I feel that the latter possibility is consistent with Casal's way of thinking, I make no change in the punctuation of this line.

\section{N44: NOSTALGIAS}

The original version of "Nostalgias" came out on the title page of $L a$ Habana Elegante on 12 April 1891 and was dedicated "A Francisco Hermida." It will be recalled that, like Casal, Hermida had been commis- 
sioned by Manuel Serafín Pichardo in 1886 to write a chapter of the communal novel Solos for El Fígaro (see Ed. del Cent., vol. III, p. 126). Hermida continued his association with Pichardo for a good number of years after that. His fortune with Casal, however, was less favorable. Thus, when the Nieve version of "Nostalgias" appeared, it carried no dedication to him.

In a letter dated 19 March 1891 and addressed to Esteban Borrero, Casal, who was still recuperating from an illness (see my discussion of N36), spoke of artistic activities that he was planning for the future. First on his agenda was the completion of Nieve and a book of short stories. Once these were finished, he would devote himself to painting for a while. When sufficiently rested, he would write some literary impressions and two novels that were already turning into an obsession with him. According to Casal, the first novel would have the following characteristics:

Una será la historia de un joven inmensamente rico, cansado de todo, dotado de clara inteligencia y de buen corazón, es decir, un tipo no muy vulgar ni excepcional. Tiene aficiones artísticas y bastante cultura. Ha probado todos los placeres y queda huérfano a los veinticinco. Después de recoger su fortuna, sale de su país a recorrer el mundo. La excursión durará quince o veinte años. Al cabo de algún tiempo de permanencia en un país, donde pretenderá establecerse, tendrá que emigrar a otro, porque encontrará defectos que le serán insoportables. Así irá de país en país llegando al fin a adquirir la convicción de que unas veces por deficiencias del medio y otras por suficiencias, el mundo civilizado es inhabitable, porque en todas partes los hombres son iguales y concebirá la idea de suicidarse, pero al realizar su pensamiento pensará con Hamlet "ser o no ser", etc. y así terminará la novela, dejando al lector la solución.

Para hacerla bastaránme unos cuantos meses de lectura incesante de libros de viaje. Tres o cuatro de distintos autores sobre cada nación. El protagonista no hará más que asombrarse primero de un país, por regla general, vivir algún tiempo en él y anotar luego, sin decir si es bueno o malo, lo que le desagrade y le obligue a marchar.

El asunto se presta para grandes cuadros y como no se hablará más que de los mejores o los que pasan por tales, se podrá desarrollar en unas quinientas páginas. ${ }^{1}$

Casal, whose health grew steadily worse during the next few months, did not have enough time to execute this ambitious plan. It should be recognized, however, that although he failed to produce a five hundred page novel, he did manage to give literary form to his basic idea: on 12 April 
1891, less than a month after outlining his idea to Esteban Borrero, he published "Nostalgias" in La Habana Elegante. Even a superficial comparison of the poem and the quoted portion of the letter will reveal how similar the two are in essence. Among the similarities between the proposed novel and the finished poem, two deserve special attention.

First, the main function of plot in both works seems to have been to give Casal a plausible excuse for painting exotic cuadros. This should come as no surprise. On the one hand, the literary cuadro was a fundamental part of Casal's aesthetic heritage: among nineteenth-century novelists of all persuasions (Neoclassics, Romantics, Realists, Naturalists, and Modernists included), the ability to depict cuadros was as important as the ability to devise plots and to portray characters-indeed, some critics might argue that, in practice, it was even more important. On the other hand, Casal had a natural interest in the graphic arts, and to a certain extent because of this, he readily accepted the influence of Parnassian poets who were in vogue at the time.

The second similarity between the novel and the poem is that both are predicated on the belief that, while dreams of finding a better world may brighten our existence for a time, they will not improve our lot in the long run, for there is no place on earth capable of giving lasting satisfaction. A search of this kind - be it a real one, as in the novel, or an imaginary one, as in the poem - will lead only to disillusionment and, ultimately, spiritual exhaustion. $^{2}$

\section{N44: Notes to Introductory Statement}

1 Quoted from Duplessis, "Julián del Casal," p. 67; reproduced with variants in Ed. del Cent., vol. III, p. 68.

2 For a more detailed analysis of the poem, see Rita Geada-Prulletti, "Nostalgias," in Antología comentada del modernismo, ed. Francisco E. Porrata and Jorge A. Santana (Sacramento: California State University, 1974), pp. 157-161.

N44: VARIANTS

\begin{tabular}{|c|c|c|}
\hline $\begin{array}{l}\text { l. } H E \\
1 \text { Suspiro }\end{array}$ & $N$ & $\begin{array}{l}\text { GLIC } \\
\text { (ף) Suspiro }\end{array}$ \\
\hline 21 vivir & existir & \\
\hline 28 pueblos y & pueblos, & \\
\hline $\begin{array}{l}33 \text { Argel, } \\
38 \text { africana, }\end{array}$ & $\begin{array}{l}\text { Argel } \\
\text { africana }\end{array}$ & $H E$ \\
\hline
\end{tabular}

N44: Notes to Variants

1: Although the norm in the present edition is to indent the first line of every 
stanza, in this poem all such lines except 1,19 , and 91 are left-justified for aesthetic reasons.

21: This is a felicitous change because it conveys the idea of a passive, vegetative existence (see 1. 55) more effectively than does the verb vivir.

33: The comma of the $H E$ version is restored in order to give clear emphasis to the rhythmic and conceptual unit which begins in 1. 31 .

\section{N45: LA REINA DE LA SOMBRA}

"La reina de la sombra" was first published in the 10 May 1891 issue of La Habana Elegante. The dedication read "A Rubén Darío. / (Guatemala)." It is likely that Casal dedicated the poem this way in order to express his thanks to Darío for having reproduced some of his poems in El Correo de la Tarde (see Table 4) and especially for having sent him a copy of the Guatemalan edition of Azul ... in March 1891 (see N36). When preparing "La reina de la sombra" for inclusion in Nieve, Casal used only the first half of the original dedication because he knew that Darío was no longer residing in Guatemala. As fate would have it, a mere three months after Nieve came out, Darío, who had been commissioned an official representative to the Columbus Day celebrations in Spain, stopped off in Havana and met Casal personally. After Darío returned to Havana in December 1892, Casal published two important works that synthesized his impressions of his Nicaraguan colleague: the prose leyenda "Rubén Darío" ( $H E$, 15 January 1893), which was addressed to Enrique Gómez Carrillo in Paris, and the poem entitled "Páginas de vida" (HE, 22 January 1893), which was later incorporated into Rimas (R21).

"La reina de la sombra" should be included in any study of escapism in Casal. Appearing 56 times in Hojas, Nieve, and Rimas, the word sombra is the third most frequent noun in these collections. ${ }^{1}$ In many of the contexts, it is associated with evil, death, and the unknown; therefore, it inspires fear and revulsion in the poet and plunges him into a sea of sadness. In this poem, however, the stress does not fall on the negative aspects of sombra, but on its positive features. Darkness is shown to harbor a regal being who possesses distinctly maternal qualities; hence it is associated with safety, compassion, sweetness, and tranquillity. In this sense, it provides an environment where, as in childhood, the fancy can move freely, dreams can come alive, and illusion can bring true joy by replacing the noxious realities that make daytime existence so difficult to bear (see $\mathrm{Hp} 0) .^{2}$

\section{N45: Notes to Introductory Statement}

1 Only alma and ojo are more frequent than sombra. Their frequency is 134 and 58 , respectively. 
2 For another viewpoint, see Edward J. Mullen, "La reina de la sombra," in Antología comentada del modernismo, ed. Francisco E. Porrata and Jorge A. Santana (Sacramento: California State University, 1974), pp. 164-165.

\section{N45: VARIANTS}

l. $H E$

13 nichos, hiedra,

16 abalánzanse

27 desierta,

33 conservan

44 amantes,

63 dormidos,

68 iCuántos goces

* 69 ( ( Esa

72 florecen
N

nichos

hiedra

abalanzarse $[$ sic $]$

HE

desierta

conservan,

amantes

dormidos

¡Cuántas dichas

Esa

HE

GLIC

sollozan

\section{N45: Note to Variants}

69: The stanza break, though evident in $H E$, was impossible to discern in $N$ because 1) stanzas were not all of the same length, 2) the initial line of stanzas was not indented, and 3) this verse was printed at the top of a page.

\section{N46: PAISAJE DE VERANO}

"Paisaje de verano" made its first appearance on 21 June 1891 in La Habana Elegante. The poem was set in italics on the first page of the journal. Although a sonnet, it was printed without the stanza breaks that usually characterize poems of its class. More in keeping with the custom of the time, however, was the fact that the initial letter of each verse was capitalized.

On 24 June 1891, El País reproduced "Paisaje de verano" for its readers and acknowledged that its source was La Habana Elegante. Two format changes were made in this version of the poem: first, $11.1,5,9$, and 12 were indented; second, the initial letter of these verses (even verse 12!) was capitalized, while all others were printed in lower case. In addition to modifying the format, someone on El Pais also felt that a lexical improvement could be made in 1.5 (see record of variants).

This was not the last time that the poem would suffer at the hands of Casal's contemporaries. Although the Nieve version proves that Casal was quite content with what he had written the year before, the poem was criticized by Enrique José Varona (see Appendix B) and was the butt of a cruel parody by Ciriaco Sos Gautreau: 
Paisaje de otoño.

Calor y chinches. Bóveda brumosa

Donde algún trueno tableando brama,

Y como ovejas en inmunda lama,

Níveas espumas sobre mar luctuosa.

Todo glauco color toma, en la hojosa

Selva, el grisáceo tinte que derrama

La negra obscuridad, donde la llama

Del relámpago cruza presurosa.

Como no hay viento el árbol está quedo

Nuncio de algún ciclón, calma profunda;

Las aves pasan en fugaces corros.

iYo espero aquí la tempestad sin miedo!

¿Que el aire enfurecido me confunda

Y caiga el agua en crotolantes chorros! ${ }^{1}$

\section{N46: Note to Introductory Statement}

1 Julián del Casal o un falsario de la rima (Havana: Imprenta y Papelería "La Prensa," 1893), p. 6; Ed. del Cent., "Poesías," p. 370.

\section{N46: VARIANTS}

l. $H E$

2 trueno

5 ondas

6 relámpago,

8 [1]anza

12 [e]l

centellea
$P$

trueno,

olas

relámpago

( $\mathbf{I I )} \mathrm{El}[$ sic $]$

centellea,
$N$

$H E$

$H E$

$H E$

[t]raza

$H E$

$H E$

GLIC

(ף)el

\section{N47: FLORES DE ETER}

This poem, dedicated "A la memoria de Luis II de Baviera," was first published in the 5 July 1891 issue of La Habana Elegante. It appeared a second time on 6 November 1891, when the editors of El Pueblo reproduced it for their readers. In both versions, a centered rule was used to separate stanzas. The centered rule was suppressed from the Nieve version, and a few changes were made in wording and punctuation.

Ludwig II of Bavaria, scion of one of Europe's oldest ruling families, 
the Wittelsbachs, was born on 25 August 1845 at the castle of Nymphenburg not far from Munich. Together with his younger brother Otto, he was educated according to the stern precepts of his father, King Maximilian II. The isolation in which Ludwig was kept, the unappealing subjects he was obliged to study, the arid imagination of his tutors, and the strict routine he was forced to keep all had a marked effect on the development of the Prince's character. His lack of interest in the program that was set before him was evidenced in his tendency to abstract himself into a world of daydreams in which his imagination could wander freely without the restraint that the real world sought to impose on it. As time went on, this propensity to withdraw into an exclusive realm of private satisfactions became the dominant feature of his personality.

The event of most far-reaching consequence in Ludwig's life was his encounter with the works of Richard Wagner. Ludwig ascended the throne of Bavaria on 10 March 1864; the following month, he invited Wagner to Munich and offered to subsidize his work as a composer. The King's offer, which came at a very critical moment for Wagner, was accepted with alacrity. This was the beginning of a lifelong friendship-a friendship characterized on the King's part by intense admiration, and, on the part of his protégé, by gratitude and sincere affection. Unfortunately, however, the financial burden imposed on the people of Bavaria as a result of the King's support of Wagner, plus the fear that Ludwig might fall under Wagner's influence in matters of state, ultimately led to a demand for the composer's expulsion. This took place in 1865. In spite of this, the friendship between Ludwig and Wagner was not adversely affected. Indeed, it is known that the King, incognito, would often visit the composer in the latter's retreat near Lucerne.

Despite the fact that he disliked crowds and official ceremonies, Ludwig fulfilled most of the obligations of his kingly office during the early part of his reign. As the years passed, however, he became increasingly neglectful of his duties and widened the gulf between himself and his subjects. For example, in order to avoid confronting the mass of theatergoers at public performances, he would attend only the rehearsals of plays and operas; and where Wagner was concerned, he would insist on completely private performances, so that, in the darkness and solitude of the empty theater, he could pretend for a while that the world of illusion which unfolded before him was the true reality. When Bismarck's successful political maneuvers forced him to accept the supremacy of Prussia, his pride suffered a wound so deep that he resolved to absent himself as much as possible from the political and social life of his kingdom. After 1882, his search for seclusion became a real mania. Some of his time was spent in the old Wittelsbach castles of Berg and Hohenschwangau. Other periods were spent in new castles which, from 1869 on, he commissioned to be built in the most solitary and inaccessible spots in his kingdom: Neuschwanstein, Linderhof, and Herrenchiemsee (see Plate 40). ${ }^{1}$

If Ludwig's eccentric behavior offended the sensibilities of his subjects, 
his utter lack of fiscal responsibility posed a distinct threat to their economic well-being. It was finally resolved that Bavaria could be saved from disaster only if its king were deposed. On 10 June 1886, four psychiatrists - doctors who had not even troubled to examine him declared that, by reason of insanity, Ludwig was incapable of ruling. Prince Luitpold, his uncle, was made regent and the deposed monarch was confined in the castle of Berg on Lake Starnberg. Three days later, on 13 June 1886 , Ludwig was found dead in the shallow waters at the edge of the lake. A few meters away was the body of Dr. Bernhard von Gudden, one of the psychiatrists involved in the deposition. To this day, no one has ascertained the circumstances under which the two men met their death.

Ludwig II is one of those rare figures in history who became a legend in his own lifetime. He was just eighteen years of age when he ascended the throne of Bavaria, but even then he cut a very striking figure: the delicate beauty of his features, the uniqueness of his demeanor, and the dreamy wistfulness in his eyes (see Plate 39) created around him a romantic aura which strongly attracted almost everyone who came into his presence. In the words of Judith Gautier: "Son juvénile visage cause une surprise délicieuse: nous ne le prévoyions pas ainsi. Féminin et volontaire, candide et dominateur; sous les cheveux, très noirs, qui gardent, dressés sur le front, comme une ondulation de flamme, le teint est d'une pâleur chaude, presque bistrée, et un singulier accent d'énergie contraste avec la douceur des traits si délicatement modelés. Mais on est tout de suite fasciné par le resplendissement extraordinaire de ces yeux, glauques comme la mer, rayonnant de longs cils noirs, de ces yeux profonds, extasiés ... 'Rien ne peut donner l'idée de la magie de ce regard!' disait le Maître."”

The King's life seems to have been a constant effort to escape from the world of reality into an ideal world where beauty reigned supreme. One of his favorite retreats was a grotto whose entrance was half hidden among rocks in the garden of Linderhof Castle. This was a reproduction of the Grotta Azzurra of Capri, complete with stalactites, stalagmites, and lagoon. The famous blue light was produced artificially by electrical equipment that was carefully concealed from view. On the waters of the grotto, there was a replica of the enchanted boat of Lohengrin, while, in the background, there was a great painting that represented Tannhäuser at the feet of Venus (see Plate 41$){ }^{3}$

Julián del Casal was spiritually akin to Ludwig of Bavaria in many ways. Like the King, he yearned to escape the ugliness, vulgarity, stupidity, and belligerence that filled the world in which he lived. Symbolic of his general attitude was the pseudonym he used when writing his "Crónica semanal" for El Pais: Alceste, the misanthrope. Like the King, he could not tolerate crowds: "Yo odio los sitios públicos a la hora en que las muchedumbres se internan en ellos. No puedo contemplar, sin sentirme enfermo, muchos grupos de seres reunidos. Las iglesias, en los días festivos; los teatros, en las noches de estreno; y los salones, a la hora de la recepción, me entriste- 
PLATE 39

Ludwig II of Bavaria

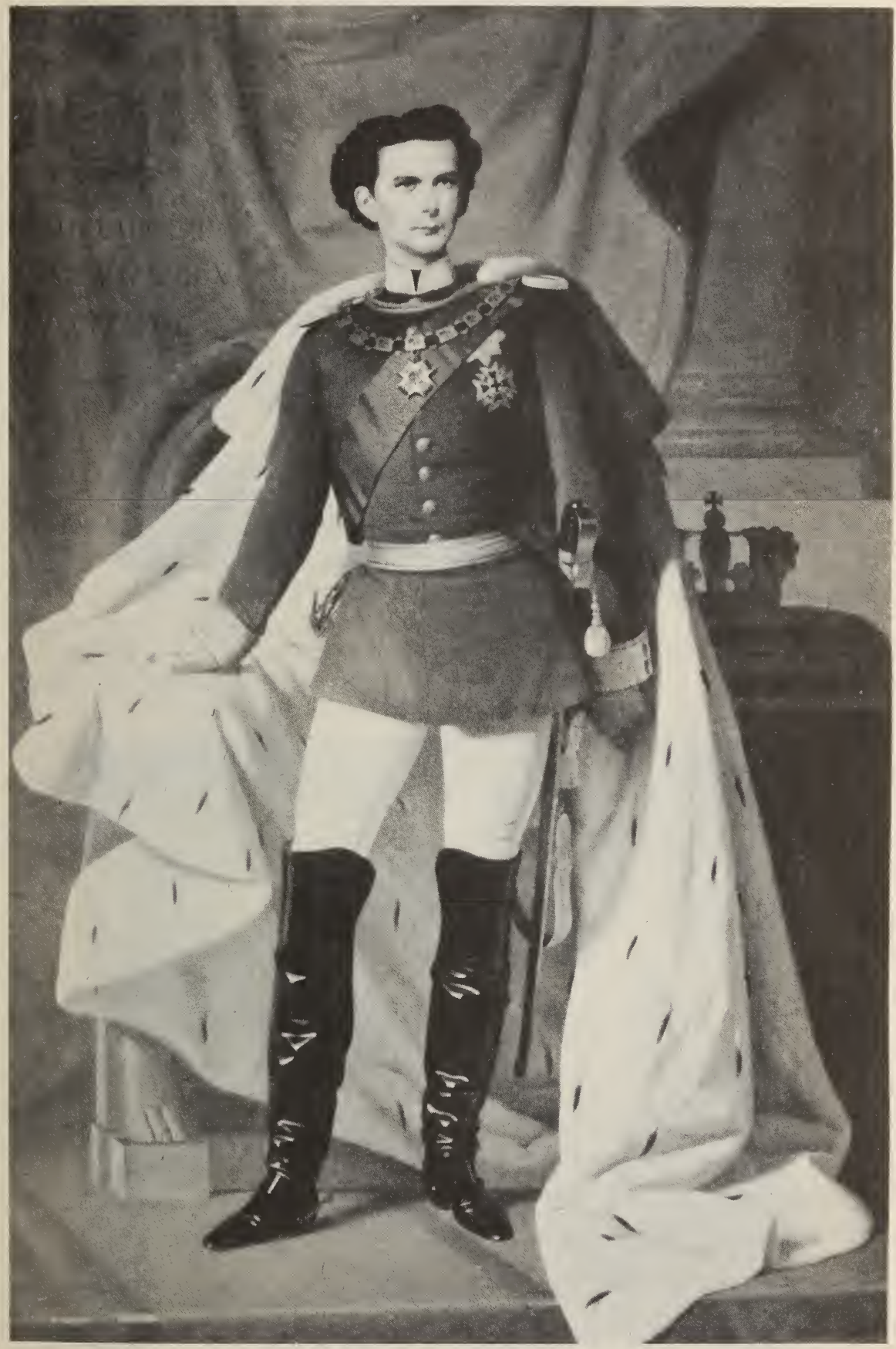

Photo Bayer. Verwaltung der Staatl. Schlösser, Gärten und Seen. 
PLATE 40

Neuschwanstein Castle

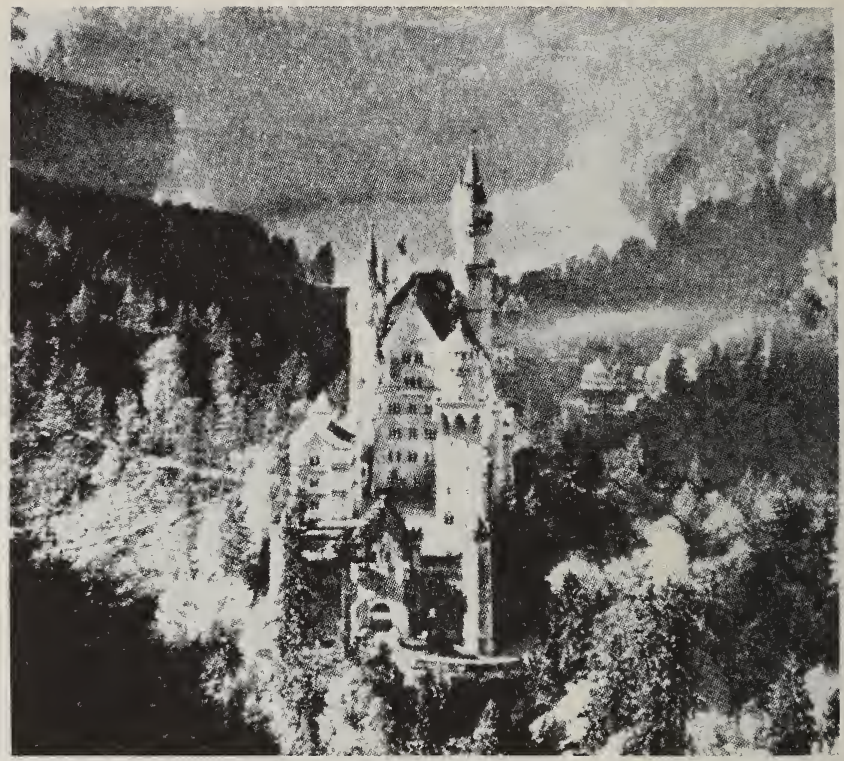

Photo Bayer. Verwaltung der Staatl. Schlösser, Gärten und Seen.

PLATE 41

Linderhof Castle: Replica of the Grotta Azzurra

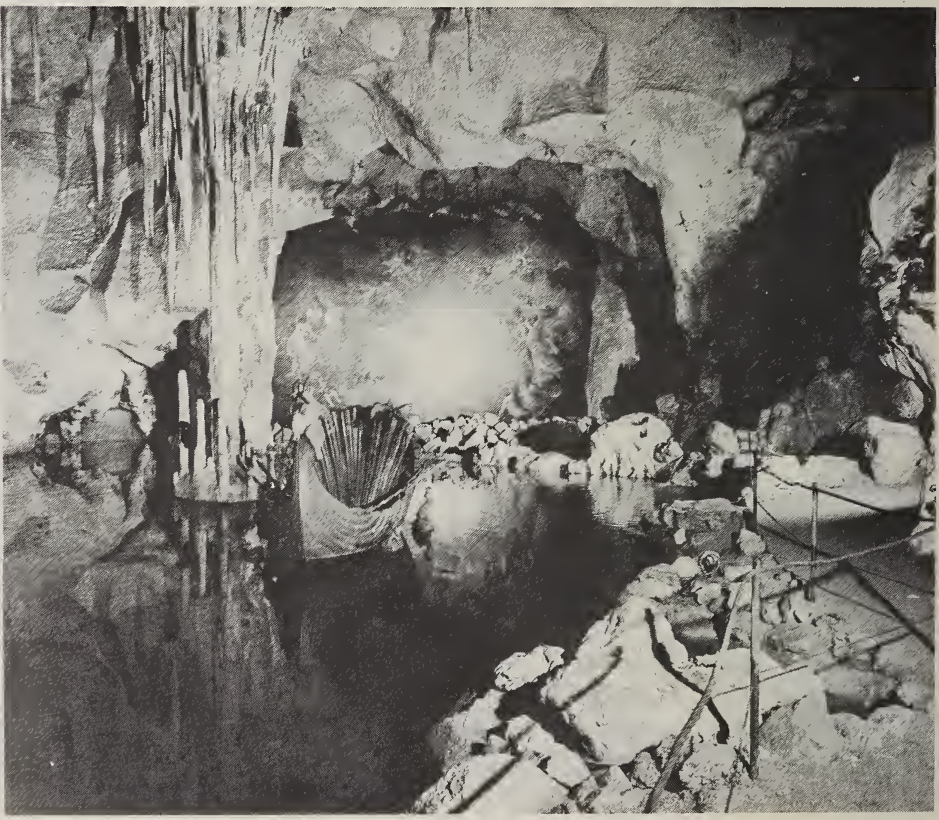

Photo Associated Press. 
cen, me desequilibran y me causan profundo malestar."4 Like the Roi Vierge of Bavaria, Casal found no woman of flesh and blood who could live up to the ideal standards which he imposed, yet his world of illusion housed a misty goddess of delight who constantly tantalized his passionate imagination. Like the King, Casal had an unbounded admiration for Wagner: "Ricardo Wagner es para mí una especie de dios. Temo hablar de él, porque mi admiración me arrastra hasta el laberinto de la extravagancia. Nunca he podido leer el Lohengrin o el Creprisculo de los Dioses sin sentir una conmoción profunda en todo mi ser. Tiene el don de arrebatarme a tales alturas que sufro intensamente al descender de ellas."5 Finally, like Bavaria's Roi Artiste ("aquel rey que pagó con su vida el goce infinito de haber palpado su ensueño"6), Casal surrounded himself with exotic objects that allowed him to create a private grotto of dreams in which he could nurture visions of unadulterated beauty and eternal contentment.

\section{N47: Notes to Introductory Statement}

1 In the 17 October 1886 issue of $H E$, Casal published an article entitled "Los siete castillos del rey de Baviera," which dealt mainly with Herrenchiemsee Castle. According to the Ed. del Cent. (vol. I, p. 13), that issue of $H E$ cannot be found in public or private Cuban libraries.

2 Judith Gautier, Le Collier des jours: Le troisième rang du collier (Paris: Librairie Félix Juven, 1909), pp. 196-197.

3 A description of this grotto may be found in Jacques Bainville, Louis II de Bavière (Paris: Librairie Nationale, 1911), pp. 169-170.

4 Ed. del Cent., vol. III, p. 56; see, also, my discussion of Hp0.

5 Ed. del Cent., vol. II, p. 93.

6 Ed. del Cent., vol. III, p. 56.

N47: VARIANTS

l. $H E$

5 con

12 soñadores,

23 Fantasía

24 arte.

30 deliquios

32 encantos. [sic]

41 [i]nsectos verdes

entre

48 brumas azules,

67 herencia,

68 impura,

75 aurora $[s i c]$

76 nieve.

$\begin{array}{ll}P b & N \\ \text { como [sic] } & H E \\ \text { soñadores; } & H E\end{array}$

Arte.

deliqios $[s i c] \quad H E$

encantos, $[s i c]$ encantos!

[v]erdes luciér-

nagas en

nieblas azules

$H E$

$H E$

nieve!

GLIC

Fantasía,

herencia;

impura;

aurora, 


\section{N48: MI ENSUEÑO}

"Mi ensueño" was originally published by El Pais on 16 November 1890. The poem bore the subtitle "Soneto"; below this, in parentheses, were the words "Por Julián del Casal."

On 7 December 1890, La Habana Elegante printed the poem together with "Blanco y negro" (N40), "Vespertino" (N42), "A un amigo" (see N24), and "Flores" (N41). All of these compositions were subsumed under the heading "Poesías diversas," and the author's name was given at the end of the series. The subtitle that had been used in El Pais was retained in this version of "Mi ensueño."

On 23 December 1890, the poem was reproduced by El Pueblo. In this printing, the subtitle was again retained. Further along on the page, the editors presented "Flores," the last of the "Poesías diversas." They printed the author's name after each one of the poems.

El Hogar published "Mi ensueño" on 14 February 1892. The original subtitle was suppressed from this printing, but the poet's name was given at the end. Internal evidence suggests that this version was based on the one that had appeared two years earlier in El Pais (see ll. 11 and 13).

Variants in the Nieve version were relatively few: Casal introduced some changes in wording and punctuation, and, as was his practice throughout Nieve, he suppressed the word "Soneto" as a subtitle.

On 11 November 1892, El País reprinted "Mi ensueño" for its readers. Since this version postdates Nieve, I do not list the variants that are found in it. However, in order to give an idea of Nieve's fortunes in the six months after its publication, I quote the statement with which El Pais introduced the poem: "Por complacer a Un suscriptor, le diremos que la edición del libro de poesías Nieve, de Julián del Casal, casi ha sido agotada, pues apenas si quedan algunos ejemplares (no pasan de diez) en la Galería Literaria." La Galería Literaria was a bookstore located at 55 Calle del Obispo and was owned by the heirs of José del Pozo. In 1889, shortly after returning from Europe, Casal installed himself in a room over the shop. That room, which the poet dubbed "mi celda," is described by Federico Villoch in "Viejas postales descoloridas: La celda de Casal" (Diario de la Marina, 30 March 1941). ${ }^{1}$ In another article, "Las tardes de la Galería Literaria" (Carteles, 25 March 1945), Villoch discusses at length the nature and consequences of the tertulias that were held at the bookshop every day between 2:00 and 5:00 P.M. ${ }^{2}$ Because of Casal's close relationship with its owners, La Galería Literaria came to be the principal distribution point for Nieve. Since Cuban stocks became depleted soon after Nieve appeared on the market, Casal's Mexican admirers undertook to reprint the book in 1893 (see my introduction to Np0).

\section{N48: Notes to Introductory Statement}

1 See Mario Cabrera Saqui, Poesías completas, p. 19.

2 See Ed. del Cent., "Poesías," pp. 302-307. 
N48: VARIANTS

l. $P$

1 roja

2 púrpura el negror del

4 ventana.

* 6 vivo

* 10 pico,

11 cabida,

13 [y],

14 vida.
$H E$

ventana $[s i c] \quad P$

cabida

[y]

vida $[$ sic $] \quad P$
$\mathrm{Pb} \quad \mathrm{Hg} \quad \mathrm{N}$

ardiente

rojo el nebuloso

GLIC

ardiente

pico $P$

P

\section{N48: Notes to Variants}

6: It is interesting to note that, in re-working the first two stanzas, Casal ended up using ardiente twice. Whether this repetition was intentional is open to question.

10: The comma of the $P$ version is restored after pico in order clearly to delimit the modifier of "mi ensueño." It is felt, however, that there is no need to restore the comma after "cabida" (l. 11), since the end-of-verse blank and the stanza break are strong enough to signal the syntactic function of 1.11 and, hence, to establish the proper rhythm for a smooth reading.

\section{N49: CANCION}

This poem first appeared in the 27 December 1891 issue of El Fígaro. It bore as its dedication the words: "Para la niña Aurelia Aróstegui y Mendoza." The date "(Diciembre, 1891)" was printed with the author's name at the end of the poem.

On 29 December 1891, El País informed its readers of El Fígaro's appearance and reprinted "Canción." This version preserved the dedication, date, and author's name just as they had appeared in El Fígaro. Introducing the poem was the following statement: "Del texto [of $F$ ] sacamos los versos que Casal dedica á la bella niña de nuestro querido amigo el Dr. Aróstegui ..." (italics mine).

"Canción" appeared for the third time when ElPueblo inserted it into its 5 January 1892 issue. The date of composition, which had been present in each of the previous versions, was omitted from this printing. The editors introduced the poem as follows: "Del último número del semanario ilustrado El Fígaro, correspondiente al 27 de Diciembre último, copiamos los siguientes magníficos versos dedicados á la bella niña de nuestro querido amigo el Dr. D. Gonzalo Aróstegui ..." (italics mine). The similarity between the El Pueblo statement and the one which appeared in ElPaís makes one wonder whether this version of the poem was indeed taken from El Figaro or whether it was copied from El País. Unfortunately, neither the quality 
of the text (see the record of variants) nor the fact that the date was suppressed provides us with sufficient evidence to identify the true source of this version.

Casal modified "Canción" prior to publishing his definitive version in Nieve. However, the number and character of his revisions suggest that he was basically content with what he had written originally.

As indicated above, the inspiration for "Canción" came from the infant daughter of Gonzalo Aróstegui del Castillo. Dr. Aróstegui (b. Camagüey, 27 June 1859) received his degree in medicine in Havana and, at the age of twenty-three, left Cuba to do specialized work abroad, first in Madrid, then in Paris. In the years following his return to Cuba, he made a distinguished name for himself as a physician and in other capacities as well. He founded the Junta Superior de Sanidad and was an active member of such organizations as the Consejo Escolar de la Habana, the Sociedad Económica de Amigos del País, the Sociedad de Estudios Clínicos, and the Academia de Ciencias Médicas, Físicas y Naturales. In addition, he served as editor of professional journals such as La Revista de Ciencias Médicas, El Progreso Médico, and La Revista de Medicina y Cirugía de la Habana; he wrote biographies of important figures in the medical world; he translated works by Wagner; he was an editor of El Camagüey, $L a L u z$, and El Pueblo; and he was a frequent contributor to other periodicals, among them El Triunfo, El País, and Enrique José Varona's Revista Cubana. Dr. Aróstegui had many opportunities to meet and exchange views with Casal, since he faithfully attended the daily gatherings at La Galería Literaria ${ }^{1}$ and participated in the social events of Havana's "beau monde" which Casal covered as a reporter. ${ }^{2}$

\section{N49: Notes to Introductory Statement}

1 See Ed. del Cent., "Poesías," pp. 303-305.

2 See Ed.del Cent., vol. III, pp. 42, 43, 53.

\section{N49: VARIANTS}

\begin{tabular}{|c|c|c|c|c|}
\hline l. $F$ & $P$ & $\mathrm{~Pb}$ & $N$ & GLIC \\
\hline 2 humanos & humauos [sic] & $F$ & & \\
\hline 5 huellas, & & & huellas & \\
\hline 7 rayos & & & discos & \\
\hline $\begin{array}{l}8 \text { las tinieblas } \\
\text { cendales. }\end{array}$ & & & $\begin{array}{l}\text { la tiniebla } \\
\text { cendales [sic] }\end{array}$ & $F$ \\
\hline 12 irisan & & irrisan $[s i c]$ & $F$ & \\
\hline 13 Si te adormeces & & & Y si te duermes & $(\mathbb{(})+N$ \\
\hline $\begin{array}{l}14 \text { [t] cuerpo finge, } \\
16 \text { [b]ajo los velos }\end{array}$ & & & $\begin{array}{l}\text { [f]inje tu cuerpo, } \\
{[\mathrm{e}] \mathrm{ntre} \text { los pliegues }}\end{array}$ & finge $+N$ \\
\hline 17 Angelicales & & Angélicos $[s i c]$ & $F$ & (ף) $+F$ \\
\hline 18 humanos & humanos. [sic] & humanos, & $F$ & \\
\hline
\end{tabular}


"Al carbón," whose title is a clear reflection of Casal's interest in the graphic arts, was first published in the 26 July 1891 issue of La Habana Elegante. It was printed in italics on the first page of the journal. Using the $H E$ version as its source, El Pueblo reproduced the sonnet on 4 August 1891. The only thing that marred this printing was a typographical error in 1.14.

The record of variants shows that the changes which Casal introduced into the Nieve version of "Al carbón" were very limited in number and could not possibly correct the principal flaw in the composition: lack of unity. This weakness stems from the fact that each stanza has a different subject - nenúfar, león, caverna, leona - and is poorly integrated with the others. As a result, one gets the impression that there are four distinct sketches, rather than one picture with interrelated foci of interest.

N50: VARIANTS

$\begin{array}{rlll}l . H E & P b & N & G L I C \\ 2 \text { plomiza } & & \text { negruzca } & \\ 12 \text { hirsuta, } & & \text { hirsuta } & H E \\ 14 \text { al entrar } & & \text { de yerba } & \\ \text { brizna. } & \text { brizna }[\text { sic }] & H E & \end{array}$

N50: Note to Variants

12: The presence of a prepositional phrase at the beginning of 1.13 makes it desirable to insert a comma after "con la piel hirsuta." Restoration of the original comma at the end of 1.12 clearly identifies "con la piel hirsuta" as the complete modifier of "una leona," and thus obviates the possibility of an initial misreading.

\section{N51: EN UN ALBUM}

This poem was originally published in the 15 March 1891 issue of $L a$ Habana Elegante. In this version, the title was "En el álbum de la Srta. Mercedes Marty y Carrillo." When preparing the poem for Nieve, Casal changed the title to "En un álbum."

The poet's friendship with Mercedes Marty may be traced to November 1890, when her sister married Enrique Hernández Miyares. ${ }^{1}$ Like so many of his contemporaries in the late nineteenth century, Casal wrote verses in albums which were kept with pride by members of the fair sex. In this poem, he gave a brief definition of what an album is, and, in so doing, he used examples of the language of luxury which became commonplace during the initial phase of the Modernist Movement: alabastro, perla, rubi, 
amatista. When reading N51 critically, however, we are reminded of another statement that Casal made about albums like the one which belonged to Mercedes Marty: "Un álbum - decía Barbey d'Aurevilly, el artista literario más grande de todos los siglos - me produce siempre el efecto de un banco de ostras: la perla se puede encontrar, pero suele ser una casualidad."'2

\section{N51: Notes to Introductory Statement}

1 See Casal's report on the wedding in his "Crónica semanal" $(P, 30$ November 1890), Ed. del Cent., vol. III, pp. 41-43.

2 From the "Crónica semanal" ( $P, 14$ December 1890), Ed.del Cent., vol. III, p. 54 .

\section{N51: VARIANTS}

l. $H E$

$N$

GLIC

1 (ף) - ¿Qué

¿Qué

(ा) $+N$

\section{N52: CANAS}

The original periodical version of "Canas" was the one published by $L a$ Habana Literaria on 15 December 1891. The poetic statement was made in five quintetos endecasilabos. The first four stanzas had an $A B A B A$ rhyme scheme, and the first and last verses of each stanza were equivalent. Stanza $\mathrm{V}$, however, had an $A B A A B$ rhyme scheme and was a straight quinteto endecasilabo without ritornello (see record of variants).

Before publishing the poem in Nieve, Casal made a most important textual change: he scrapped stanza $\mathrm{V}$ of the original version and replaced it with one that more closely resembled stanzas I-IV. In the new version, he made the rhyme scheme of stanza $\mathrm{V}$ conform with the $A B A B A$ pattern of the preceding stanzas; he duplicated the ritornello arrangement that he had used elsewhere in the poem; and, by changing from Parnassiantype imagery to imagery of a more Symbolist cast, he brought the contents of stanza $\mathrm{V}$ into tonal harmony with the rest of the poem.

It should be noted that Casal used the ritornello device elsewhere in his poetry. The work whose form most closely resembles that of "Canas" is "Recuerdo de la infancia" (R12), but the principle of the refrain is also found in "Rondeles" (R9), "Vieja historia" (R 14), and "Dolorosa" (R26). The proximity of R9, R12, and R14 with regard to date of initial publication - 30 August 1892, 4 September 1892, and 15 September 1892, respectively - suggests that Casal was not using the ritornello merely by chance during this period, as may have been the case earlier with a poem such as "La perla" (H48), but was actively experimenting with it as an 
instrument of poetic expression. According to Monner Sans, five authors in particular may have inspired him to do so: Baudelaire, Poe, Leconte de Lisle, Rollinat, and Banville. ${ }^{1}$ Table 2 and Index III of the present edition lend credibility to Monner's contention, for they show that Casal's familiarity with the works and theories of these writers went back to before his publication of Hojas.

\section{N52: Note to Introductory Statement}

1 Julián del Casal y el modernismo hispanoamericano, pp. 56, 73, 77-81.

\section{N52: VARIANTS}

\section{l. $H L$}

2 desoladas

3 nacer

* 4 amadas,

$5 \mathrm{i}[\mathrm{o}] \mathrm{h}$

$10 \mathrm{i}[\mathrm{o}] \mathrm{h}$

14 ilusiones

$15 \mathrm{i}[\mathrm{o}] \mathrm{h}$

20 i[o]h

21 (I)Mi rostro al contemplaros palidece,

$22[y]$ si la sangre en gotas carmesíes

23 [t]iñe vuestra blancura, me parece

24 [q]ue en vuestras sienes lívidas se mece

25 [c] asco de plata ornado de rubíes.
$N$

desoladas, brotar

ilusiones,

Emblema sois del sufrimiento humano

[y] brillando del joven en la frente

[o] en las hondas arrugas del anciano,

[m]i alma os venera, porque eternamente

[e]mblema sois del sufrimiento

humano. oh

oh

GLIC

oh

oh

(ף) $+N$

\section{N52: Note to Variants}

4: With the exception of 1.14 in the $H L$ version, the fourth verse in stanzas I- IV of $H L$ and $N$ ended with a comma, rather than with an exclamation point (to balance the exclamation at the beginning of the first verse) plus a comma. The fifth verse in these stanzas began and ended with an exclamation point. Thus, each of the stanzas had three exclamation points instead of four. It is felt that the presence of exclamation points in any intermediate position (i.e., at the end of the fourth verse and/or at the beginning of the fifth) would make the flow of sound and meaning less smooth than desirable. Therefore, Casal's system of punctuation is altered in $11.5,10,15$, and 20. 


\section{N53: MEDALLON}

This poem was first published in the 29 February 1892 issue of $L a$ Habana Literaria. Its title was "Alicia Sierra y Peñarredonda" and its subtitle was "(Para su álbum.)." A short time after publishing this version of the poem, Casal revised it for Nieve. He changed the title to "Medallón" -a designation much more in keeping with the Parnassian spirit of his book than the original title had been; he used the $H L$ title as a subtitle; he suppressed the $H L$ subtitle; and he introduced a few lexical and punctuation changes into the text.

\section{N53: VARIANTS}

\section{l. $H L$}

1 oro,

9 brazaletes

13 arrastre

16 camafeo,

20 abierta

23 [i]rísanse

25 ojos

* 26 rubís

27 caléndulas
$N$

oro

brazaletes, mezca

camafeo

$H L$

fresca

[i]rísance [sic]

$H_{\perp}$

GLIC

ojos,

caléndulas,

\section{N53: Note to Variants}

26: The presence of a plural adjective, ardientes, strongly suggests that rubis is not a typographical error. Needless to say, use of rubis is a most unorthodox -and unpoetic - way of keeping within the metrical limits which Casal imposed on himself. Nevertheless, Casal seems to have been satisfied with this form of the word, for he did not change it in Nieve. It is interesting to observe that ardientes rubis is duplicated in the 1893 Mexican edition of Nieve. In later editions of Casal's works (Geada, Cabrera Saqui, Monner Sans, and the Ed. del Cent.) the words ardiente rubi are substituted for the original expression. This device keeps the verse within the required metrical limits and does not ask the reader to accept a departure from normal Spanish morphology. In spite of this, the new wording is less than satisfactory: immediately after being offered a completely normal simile ("Verdes, como las ondas, son sus ojos"), the reader is given an image in which one term is singular and the other is plural ("como ardiente rubí sus labios, rojos"). This liberty is less difficult to accept than the ardientes rubis of $H L$ and $N$. However, ardientes rubis seems to have been the form that Casal preferred. Consequently it is retained in the present edition. 


\section{N54: HORRIDUM SOMNIUM}

This composition first appeared under the title "Horridus [sic] somnium" in the 15 September 1891 issue of La Habana Literaria. When Casal re-worked it for Nieve, he altered some of the wording and punctuation in the body of the poem, corrected the error in the title, and inserted a dedication to Raimundo Cabrera.

Raimundo Cabrera y Bosch (b. Havana, 9 March 1852; d. Havana, 21 May 1923), a person of great energy and diverse talents, was truly a self-made man. Although he lost his father at the age of eleven, his own diligence and encouragement from his mother made it possible for him to continue his education. After finishing secondary school, he joined the Cuban separatist movement, was arrested for subversive activities, and was imprisoned on the Isle of Pines. Upon being released, he went to Spain to study law. Once in possession of the degree, he returned to Cuba and set up practice as a barrister. In spite of his youthful experience with the Spanish authorities, he began to work actively to end Cuba's colonial status. As the years passed, his commitment to Cuba became more and more intense. Indeed, it can be said without exaggeration that, whether as a lawyer, judge, professor, academician, ${ }^{1}$ or writer, Cabrera's deepest concern was to insure the welfare of his homeland. His first important publication was Cuba y sus jueces (1887). This book, which was designed to set the record straight about what Cuba and the Cuban people were really like, went through ten editions, including an English translation that was published in Philadelphia under the title Cuba and the Cubans (1896). During Casal's lifetime, Cabrera produced two other major works: Mis buenos tiempos (1891), memoirs of his days as a student, and Cartas a Govín (1892-1893), a collection of letters which, during a visit to the United States, he wrote to Antonio Govín y Torres. His complete bibliography, however, also includes essays, novels, short stories, musical comedies, poetry, journalistic articles, and translations. ${ }^{2}$

Although Cabrera thought well of Casal, the two were not close friends;

Plate 42

\section{Raimundo Cabrera}

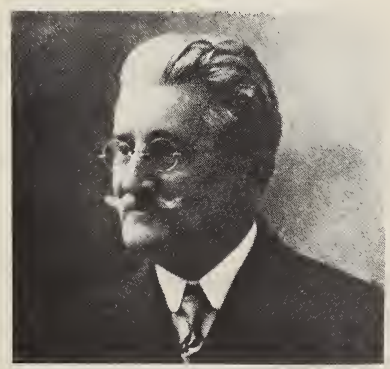

From William Belmont Parker, Cubans of To-day. Courtesy of The Hispanic Society of America, New York. 
as a matter of fact, they seldom had an opportunity to meet and exchange views. Therefore, it is hard to imagine why Casal dedicated an example of Decadent poetry like "Horridum somnium" to Cabrera, a man who was so deeply involved in the realities of his day. Of course, it may be that Casal had no ulterior motive and used the dedication merely as a public sign of admiration for Cabrera. On the other hand, he may have had some practical purpose in mind-conceivably, an aim like the one to which Cabrera refers in "Anécdota" (HE, 29 October 1893): "La última vez que lo vi me animaba para que organizásemos un salón público de lectura."3

\section{N54: Notes to Introductory Statement}

1 He was a charter member of the Academia Cubana de la Historia, which was founded by decree of President José Miguel Gómez on 20 August 1910.

2 See Max Henríquez Ureña, Panorama histórico de la literatura cubana, vol. II, p. 97, n. 30 .

3 Ed. del Cent., "Poesías," p. 291.

\section{N54: VARIANTS}
l. $H L$
4 sumido
17 alma,
37 nimbo
53 foso,
55 virgen,
57 blancos
$63 \mathrm{Y}$
aire

65 violacéa, [sic]

* 75 De [sic]

81 garras punzantes

82 roia mis huesos.

83 mendigos,

90 siniestros......

95 [y],

102 entre el hosco silencio
$N$

asumido [sic]

alma

manto

foso

virgen

negros

$\mathrm{Y}$,

aire,

violácea,

[१] De

pico acerado

roíame el sexo.

mendigos

siniestros.

[y]

en el frío silencio,
GLIC

$H L$

$H L$

$H L$

(ף) $+N$

(ף) $+\mathrm{De}$

\section{N54: Note to Variants}

75: Judging from the fact that, throughout this poem, the start of a stanza tends to coincide with the start of a sentence, one expects this line to be the beginning of a stanza. In the $H L$ version, however, a new stanza does not begin at this point. In view of this, the $H L$ format is recorded as a typographical error. 


\section{Rimas}

Casal began planning Rimas even before he had finished Nieve. This point is brought out in a letter that he wrote on 17 February 1892 to Gustave Moreau: “A present, je suis en finissant de faire d'autre recueil de rimes qui j’aurais l'honneur de vous envoyer. Aussitot imprimées, je songe à ecrire un roman et d'une troisieme volume de vers qui je ressens deja dans la tete et dans le cœur" (C6/70-79). The fact that Casal meant what he said is confirmed by the appearance of "A la Belleza" (R1) on 15 April 1892-in other words, just before Nieve went on sale in Havana.

This was a very trying period for Casal. His malady, which had still not been accurately diagnosed, grew steadily worse; his financial difficulties increased as his illness progressed; and these troubles, plus a variety of disappointments in his dealings with other people, lowered his psychological resistance considerably. Even the room in which he lived and worked was fundamentally inimical to his health. This is implicit in comments made both by Casal and by his friends. Ramón Meza, for example, provides the following description of the poet's quarters in the building that housed El País: "La habitación era enorme; fue vasto comedor de palacete señorial, mansión antigua de familia nobiliaria, a la que se ascendía por amplia escalera de piedra defendida por una baranda gruesa de caoba torneada. Semejaba vasta celda de prior o refectorio de fraile, con una puerta de entrada de bajo dintel y pesadas hojas de cedro tallado, donde rechinaba, al abrirse, el gozne. El techo, de puntal muy alto, de vigas de ácana y caoba y tablas de cedro, oscurecido por el tiempo; las puertas, pocas y cerradas, envolvían en tinieblas la amplia pieza; la vista del que entraba tenía que acostumbrarse a la tiniebla para distinguir algo de lo que había adentro. . . . Allí trabajaba entonces, allí escribía mucho, y preparaba Bustos y Rimas."1

As we have seen, Casal's search for happiness was rendered ineffectual not only by external realities which frustrated his desires, but also by great physical suffering and spiritual anguish. Inevitably under such circumstances, the temptation to commit suicide became very strong. Yet he did not succumb to this temptation. His failure to do so can be explained by 
several factors which perpetually influenced his behavior; among them were his profound fear of death, his paralyzing indecisiveness, his immense capacity to invent new dreams, and, not least of all, his association with a small group of friends who did their utmost to assist him and give him comfort in times of need. One of the most admirable of these friends was Domingo Malpica Labarca.

Domingo Malpica Labarca (1836-1894) was born on his father's coffee plantation in Matanzas. After receiving his initial training at the Colegio La Luz in Matanzas, he left Cuba and took up residence in Madrid, a city in which he could enjoy the finer things of life to a degree commensurate with the demands of his intellect, sensibility, and socio-economic position. Malpica married Fernanda Huidobro, and two children were born of their union: Leopoldo and Conchita. The former died at the age of twenty, and the latter, grief-stricken at the passing of her brother, died shortly thereafter. ${ }^{2}$ The Malpicas returned to Havana in 1882.

Although Don Domingo was mainly a collector of books and art works, he also made some modest contributions to contemporary letters. In 1874, he published a study entitled Del arte moderno (Madrid: Imprenta y Litografía de N. González), and in 1890, he brought out the novel En el cafetal (Havana: Tipografía "Los Niños Huérfanos"). The latter work, which contained a prologue by Aniceto Valdivia, was reviewed by Casal in the 7 September 1890 issue of La Habana Elegante. ${ }^{3}$ Much more important than Malpica's publications, however, was his enthusiastic support of promising young artists. This point is corroborated by an unimpeachable source: "según testimonio de su sobrina, la señora Conchita Valdivia de Santo Tomás, [Don Domingo] fue Mecenas generoso que se dedicó a proteger artistas y escritores y que celebró en su casa veladas semanales en que se reunía la gente de letras a recitar, hacer música y dar lectura a los textos que los jóvenes pensaban publicar."4

Casal, who was introduced to Malpica by Aniceto Valdivia, ${ }^{5}$ was especially favored by this munificent patron of the arts. The extent of Malpica's generosity is shown by the fact that he invited Casal to move into his home when the poet became ill on 24 December 1892. Casal accepted this offer with great enthusiasm and, a few days later, transferred his belongings to Don Domingo's residence on Virtudes Street. ${ }^{6}$ Despite this change of environment, however, Casal's health continued to deteriorate. Finally, when Dr. Francisco Zayas ${ }^{7}$ told him, in September 1893, that his illness was caused by a pulmonary tumor, he could no longer deceive himself about the fate that lay in store for him. This may have been the reason why he decided to depart from past practice and put out a volume consisting of prose and poetry.

Casal's awareness that he was in a race against time is evident in a remark which he made in a letter to Rubén Darío on 7 October 1893: "Te escribo estos renglones para demostrarte que, aun al borde de la tumba, a 
donde pronto me iré a dormir, te quiero y te admiro cada día más. Yo he sabido de ti por Gómez Carrillo, que me anunció tu llegada a París y tu marcha a Buenos Aires. Dentro de poco, quizás antes de que me muera, podré leer el libro que debes estar imprimiendo a estas horas. La Habana Elegante me está editando uno, pero que no tiene ningún valor. Yo te lo mandaré, o te lo mandarán." ${ }^{8}$ In the days after he wrote this letter, Casal made frequent trips from his rooftop apartment at Malpica's home to the offices of La Habana Elegante in order to supervise the printing of his new book. This caused a great deal of strain on him, and Dr. Zayas, fearing that so much exertion might have dire consequences, advised him to limit physical activity to an absolute minimum. In particular, he recommended that Casal find a way to avoid climbing so many flights of stairs each day. When Don Domingo learned of the doctor's recommendation, he made it possible for Casal to move into a room on the ground floor of his house. In recognition of courtesies such as this, which his benefactor constantly extended to him during this period of tribulation, Casal wrote the following dedication for Bustos y rimas:

Al Sr. D. Domingo Malpica Labarca, en testimonio de afecto, de gratitud y de consideración, dedica estas páginas

$$
\text { J. del C. }
$$

On Saturday, 21 October 1893, Casal went to the offices of La Habana Elegante and dispatched two small jobs: he did a review of Mi libro de Cuba, a volume of poems composed by the Puerto Rican writer Lola Rodríguez de Tió, ${ }^{9}$ and he corrected the latest galley proofs of his own Bustos y rimas, namely, the chapter on Aurelia Castillo de González. ${ }^{10}$ This means that, at the time of his death, he had gone only as far as p. 60, and that 203 pages of text remained to be typeset and/or proofread.

After the funeral, Enrique Hernández Miyares personally took charge of Bustos y rimas. Indeed, were it not for him, the book would probably never have come out. Yet one of the things that he did would undoubtedly have been censured by Casal: distressed by the sudden loss of his friend, Hernández Miyares inserted an unsigned eulogy, entitled "Al público," at the beginning of the volume (see Appendix A). ${ }^{11}$ Though wellintentioned, this was an unfortunate addition because, in general, Casal did not look favorably on prose introductions. He had a special aversion to them, however, when they were written by someone other than the author and when they were appended to books of poetry. This is confirmed by his words and by his practice. For example, when referring to Luis G. Urbina's Versos (1890), he said: "Ahora te hablaré del libro. Ante todo, debo decirte que lleva un prólogo de Justo Sierra, muy bien escrito, pero que, como todo prólogo, me disgusta, especialmente en un 
libro de versos." 12 Of course, what best corroborates the sincerity of this remark is the fact that neither Hojas nor Nieve contains a prose introduction written by Casal or by anyone else.

Without the manuscript of Bustos y rimas, it is impossible to determine how many changes came about as a direct result of Hernández Miyares' intervention. But even if the manuscript were available, there would be no way of predicting what modifications Casal might have made if he had been present when the remainder of the book was being printed. Even when speculation is limited to Rimas, several intriguing questions arise in this regard. Would Casal have suppressed the epigraph - stanza XV of Baudelaire's "Bénédiction" 13 - as he had done with the Soulary quotation when he put the final touches on the Nieve version of "Mi museo ideal" (see Np2)? Would he have written an original poem - possibly entitled "Introducción" - for insertion at the beginning of Rimas, as he had done for Hojas and Nieve? Would he have made additional adjustments in poem sequence during the printing of Rimas ${ }^{14}$ Would he have decided to organize Rimas into sections resembling those of Nieve? This is not an idle question, because fourteen of the Rimas poems had originally been published under headings not too different from those under which the poems of Nieve had been subsumed prior to their publication in book form. The headings of the Rimas poems were "Poesías diversas" (R5, R10, R11), 15 "Tres sonetos" (R13, R15, R17), "Sonetos" (R22, R27, R29, R31), and most interesting of all, "Escorias" (R33, R35, R39, R40). Would he have made last-minute changes in the title and/or subtitle of individual poems, as he had done, for example, with "Lazos de amor" (H12) and "Al Juez Supremo" (N32)? Would he have noticed that, in spite of having consistently omitted dedications from the Rimas version of his poems, he had failed to do so in the case of "Sensaciones" (R25)? Finally, would he have introduced eleventh-hour changes into the text and would he have caught some of the typographical errors which appear in the book as we have it? Although the answers to these questions will never be found, one thing seems fairly certain: if Casal had lived, he would probably have left the cover design of the book untouched. That design shows the seated figure of Poetry and contains the provocative inscription "ARS RELIGIO NOSTRA."

The inscription Ars religio nostra is of particular significance because it opens the way to an examination of three basic questions which all Casal scholars have asked at one time or another: What were Casal's feelings towards Catholicism? What was the nature of Casal's devotion to Art? And what were Casal's major achievements as an artist?

It is well known that Casal came from a family with a deep religious involvement. His maternal granduncle rose to the rank of Cardinal in the 
Catholic Church; ${ }^{16}$ his mother built a solid reputation for Christian piety among her Havana contemporaries $;{ }^{17}$ and his father, desperately seeking relief from sorrows that grew more intense with the passing of time, transformed his home into a somber shrine for prayer and penance. ${ }^{18}$ While the poet's childhood experience at home made him familiar with basic Catholic precepts, values, and practices, his six-year course of study at the Jesuit-directed Real Colegio de Belén (29 September 1873 to 6 June 1879) added new dimensions to his knowledge of Catholicism and left within him patterns of thought and feeling which, in essence, would be highly resistant to change during the remainder of his life.

In view of his religious training and the omnipresence of Catholicism in nineteenth-century Havana society, it is reasonable to assume that Casal would turn to the Church in certain instances, especially when he was gravely ill. But can this be taken as proof of Domingo Malpica Labarca's contention that Julián del Casal was "un perfecto creyente"? ${ }^{19}$ Marshall E. Nunn is one critic who has strong reservations about this claim. According to Nunn, Malpica's very insistence that Casal was a good Catholic "leads one to suspect that there was doubt of it in the minds of many others. Malpica's article is in the nature of a defense. If there had been no doubt as to the religious nature of Casal there would have been no necessity of a defense of this kind." 20

Those who prefer to see Casal as Malpica did would undoubtedly try to support their position by citing the words of contemporaries such as Gastón Mora, Enrique Fontanills, and Elga Adman. In the opinion of Mora - an opinion supposedly shared by all the poet's friends - Casal was a true disciple of Christ: “Amó el bien, amó la verdad, amó la pobreza, amó la justicia, amó la mansedumbre, detestó el mal. Fue manso y humilde de corazón. En este sentido el melancólico poeta fue un verdadero adepto del perfecto Jesús." ${ }^{21}$ Fontanills adds to Mora's credibility by quoting Casal on the importance of Thomas à Kempis' Imitation of Christ: “iAh! qué consolador y piadoso es ese libro .... Siempre que lo leo, aun en mis momentos de mayor angustia, siento que al calor de esas páginas se aligeran todas mis tristezas." ${ }^{22}$ And, reflecting on the poet's behavior shortly before his demise, Elga Adman indicates that, in his search for the ideal, Casal was beginning to lean in the direction of mysticism: "Ultimamente notábamos en él tendencias al misticismo y si no hubiese muerto quizás habríase acogido a ese último refugio de las grandes almas que en vano han buscado el ideal en lo mundano y perecedero." ${ }^{23}$

By way of contrast, those who question the strictness of Casal's adherence to Catholicism would probably insist that the passages just quoted must be taken with reserve, since all are extracts from a collection of eulogies published in La Habana Elegante a few days after the poet's death. In order to present the matter in proper perspective, the doubters would also remind us that some of Casal's friends considered him an indiferente ${ }^{24}$ 
and that one of them actually chided Casal in public for not believing in God. ${ }^{25}$

Logic tells us that, at this distance, it is impossible to judge the accuracy of appraisals made by any of Casal's contemporaries. It seems wiser, therefore, to search for evidence in what the author himself said and in what he can be shown to have done. For example, in a reference to the icy wind of skepticism that was chilling the moral atmosphere of his time, Casal emphasized that the ardor had been taken out of beliefs that were part of Cuba's fundamental cultural inheritance: "El cierzo del escepticismo que sopla en la atmósfera moral, se ha introducido en nuestro espíritu, helándonos las creencias que habíamos heredado de nuestros antecesores y que, como aves ateridas porel frío, han muerto acurrucadas en los rincones de nuestro corazón. Tal vez vuelva algún día la primavera y el sol se levante en el horizonte espiritual, pero ahora reina el invierno y la noche ha desplegado su tienda negra sobre nuestras cabezas." ${ }^{26}$ By using nosotros in this passage, Casal indicated that he, too, had been influenced by the currents of doubt that pervaded the moral climate of his age. In spite of this, the mark that Catholicism had impressed upon him in his youth did not disappear.

Reflections of Casal's religious background manifest themselves in various ways everywhere in his poetry. Two major poems, "La muerte de Moisés" (N4) and "El camino de Damasco" (N6), have biblical stories as their source of inspiration. Several compositions are set in places that have obvious religious connotations: a cemetery (V1), a convent (H3), Mount Moriah (N4), an anchorite's retreat (R27), etc. And other works - even those which are not religious in subject - contain images based on JudeoChristian motifs: in "La perla," for example, Cuba is described as a "divino presente / de las manos del Eterno" (H48/3-4) and in "Prometeo," Prometheus in his torment is compared to "Cristo en el Calvario"(N 10/2).

Of much greater importance, however, are the numerous contexts which indicate that, in the depths of his being, Casal preserved many of the essential features of the Catholic value system. He believed, for instance, that man is a weak and solitary being who is constantly preyed upon by evil. He was convinced, therefore, that suffering is man's lot on earth and that death alone can put an end to human misery. Nevertheless, he felt that man could defend himself while on earth and assure his ultimate salvation. The key to success in this regard lay in virtuous behavior: the individual, he contended, must use purity as a shield against corruption; he must be indifferent to the things of this world which threaten to divert him from his goal; he must follow the example of exceptional men and women; and he must exhibit sympathy for those who, like himself, experience the anguish of earthly existence.

As his works make plain, Casal's sympathy for others was virtually boundless. It extended to orphans, bereaved parents, and persons aggrieved by the loss of a lover, a spouse, or an illusion; to beggars, sinners, 
vagabonds, criminals, and pariahs; to victims of infidelity and injustice; and to idealists of every kind, who stoically undergo physical and spiritual torment in defense of their dreams. Within the latter category are the viejo ermitano (N52) and the humilde sacerdote (R 19). Casal's obvious sympathy for these figures is important because it raises the entire question of his attitude towards the clergy.

Judging from what he says in "La sotana" (R10), Casal reacted to the clergy with fear in his childhood, with indifference or boredom in his youth, and, afterward, with envy. To a great extent, the feeling of envy which he experienced in his later years derived from his growing appreciation of the symbolism behind the somber color of religious garb. As he saw it, "la sombra de la sotana" indicated that, by killing mundane passions and taking refuge behind a screen of otherworldly calm, clerics could banish conflict from their soul and dedicate their life to matters of eternal consequence. In his poetry, Casal sometimes gives the impression that he would willingly retreat into a cloister (see H2, V 13, R39). On other occasions, however, he demonstrates a strong aversion to monastic life and a marked preference for hermit-like seclusion (see H3, R8, R14, R27). Oddly enough, the clearest indication of what he finds objectionable in monasticism does not appear in a comment on religion, but in a remark concerning the drawbacks of working for a political newspaper. This statement and the context in which it is found show that he objected to monasticism primarily because it forces the individual to give up the freedom to be himself, and obliges him to subordinate his wishes to those of an external authority. ${ }^{28}$

Casal's reluctance to be completely submissive in the face of authority had several causes. Among them were 1) the Hispanic value system, which, though extolling the virtues of obedience, taught males to be individualistic and refractory from childhood; 2) the ideal of heroic individualism that permeated Western morality in the second half of the nineteenth century; 3 ) the behavior of Casal's father, which provoked in the poet feelings of hostility and insubordination; ${ }^{29} 4$ ) the strict discipline that was imposed on Casal by his Jesuit masters at the Real Colegio de Belén; ${ }^{30}$ and 5) the general climate of insurgency that existed in Cuba during the last years of Spanish rule. ${ }^{31}$ The presence of so many stimuli to disobedience leads one to ask about Casal's feelings towards the Divinity.

To begin with, there is abundant evidence to show that Casal sincerely believed in the existence of God. In his works, he speaks of God, the Father -Dios, el gran Creador, el Juez Supremo, el Señor - as a very real being. He indicates that God resides in heaven, he points out some of His major personality traits, and, in one place, he even describes His appearance. ${ }^{32}$ Furthermore, both Casal and his fictional characters make repeated attempts to establish contact with God through prayer. The contexts in which this occurs are especially significant because they reveal the true nature of the poet's relationship with God. Prayer does not generally 
appear in Casal's works as a medium for directly extolling God's greatness, for offering thanks, or for confessing sins, but, rather, as a vehicle for making requests. ${ }^{33}$ Needless to say, requests are normally directed only to those who are willing and able to grant them. In essence, therefore, supplication is a sign that the individual recognizes God's power.

A crucial element in the relationship, however, is the manner in which God responds to man's pleas. This, in fact, is the basic determinant of how the Lord will be treated. If He is attentive to the supplications, He will be treated in the same way as the beloved in "Quimeras":

\section{Si escuchas ioh adorada soñadora! mis amorosas súplicas, siempre serás la reina de mi alma y mi alma la fiel esclava tuya.}

In other words, if God listens to the individual's requests - if He is willing to use His power as a demonstration of His love - He will be glorified and obeyed. If, on the contrary, He turns a deaf ear to these entreaties, He will lose the person's fidelity and, instead of férvidas oraciones, ardientes súplicas, fervorosos ruegos, férvidas plegarias, and amorosas súplicas, He will hear only the most frightening blasphemies.

The contexts in which Dios, plegaria, and related words appear make it plain that Casal did not long for worldly goods and glory, but, rather, for an end to sadness. His dejection stemmed mainly from the loss of four things which he prized above all else in life: the company of understanding souls, hope for a brighter future, enthusiasm, and inner peace. In place of these blessings, which had been his in childhood, he found loneliness, disillusionment, world-weariness, and spiritual torment. Since, as he saw it, God alone was responsible for his privations, he drew further and further away from God as the years passed. "Flores" (N41), which was first published on 16 November 1890, showed how great a change had actually taken place within Casal:

Mi corazón fue un vaso de alabastro donde creció, fragante y solitaria, bajo el fulgor purísimo de un astro una azucena blanca: la plegaria.

Marchita ya esa flor de suave aroma, cual virgen consumida por la anemia, hoy en mi corazón su tallo asoma una adelfa purpúrea: la blasfemia.

On asking what Casal might have had to gain by substituting blasphemy 
for prayer, we discover an intriguing concatenation in his poetry. In the original version of "Paisaje espiritual," which appeared on 5 April 1891 that is, five months after "Flores" came out - Casal stated that consolation for his grief could be given only by "la boca del cañón de una pistola." ${ }^{4}$ Exactly one month later (7 June 1891), in "La muerte de Moisés," he used the prophet Moses as a medium through which to present a detailed list of his own basic grievances and a solution to his problems. Casal's complaints are rather easy to detect in Moses' words:

¿Por qué en la soledad hoy me abandonas tras de haberte mi vida consagrado y de la tierra en las opuestas zonas tu gloria formidable proclamado? ¿Por qué ya a consolarme nunca vienes y me abrevas de angustias infinitas? ¿Por qué nos colmas de divinos bienes y luego en un instante nos los quitas? ¿Por qué no fue mi obra comprendida? ¿Por qué no pude realizar los sueños de internarme en la tierra prometida? ¿Por qué me hiciste grande entre pequeños?

(N4/104-1 15)

What is especially interesting in Casal's version of the biblical story is that, when Moses sees that prayer will not induce the Lord to end his suffering, he raises his voice defiantly against his Master:

así yo, que en el mundo he cimentado el poder deslumbrante de tu nombre, lo abatiré, de mi valor armado, ante la vista atónita del hombre.

(N4/136-139)

Moses' direct provocation is a radical way of forcing God to put an immediate end to his torment, for, as the prophet knows, death will be the inevitable punishment for his blasphemy. In essence, therefore, it may be said that Moses utilizes blasphemy as a roundabout way of committing suicide. In "Al Juez Supremo," which came out only six weeks after "La muerte de Moisés," Casal insinuated that he, too, would raise his voice in blasphemy if God refused to heed one of his most persistent prayers:

Si algún día mi férvida plegaria ioh Dios mío! en blasfemia convertida vuela a herir tus oídos paternales, 
es que no siente mi alma solitaria, en medio de la estepa de la vida, el calor de las almas fraternales.

(N32/9-14)

The conclusion seems obvious. Since he found it impossible to exist without the things he prized so dearly - among them, "el calor de las almas fraternales" - Casal began to welcome the idea of death. Death did not come by natural means, however, and perhaps because of ingrained religious teachings or because what he really wanted was a sign that God was not utterly indifferent to him, Casal could not take his own life. Under the circumstances, Moses' strategem for provoking God into action looked like a foolproof way to break the deadlock. Unfortunately, instead of unleashing His wrath upon Casal, the Lord continued to be frigidly impassive. This humiliating response - the failure to give any response at all-apparently moved the poet to reduce his emotional involvement with God to a minimum.

It was at this point that Casal turned to Art as the most sublime of the religions. ${ }^{35}$ Indicative of his conversion was the change that took place in his attitude towards Beauty: in his youth, he considered Beauty as a revelation of divine omnipotence and as a vehicle by which man can express his gratitude to God; ${ }^{36}$ later, however, he stopped looking upon Beauty as a link between man and God, and began to treat it as a deity in its own right. One of the clearest signs of the wholehearted commitment to Beauty which characterized the latter period of Casal's life may be seen in "A la Belleza," the fervent hymn with which he opened Rimas. From the outset-"iOh divina Belleza!"-the reader is aware of the similarity between this poem and songs of praise that are addressed to the Deity in conventional religions. This similarity derives from the fact that Casal used the language and imagery of Catholicism as media for expressing his feelings towards the new divinity, Beauty. ${ }^{37}$

As far as Casal was concerned, the main attraction of Art was that it promised to make up for what Catholicism had failed to give him. As we know, Casal was lonely all his life, and a good part of his work was inspired by the pain that issued from his loneliness. Despite the anguish that solitude caused him, however, he was most reluctant to find permanent companionship. From childhood on, he had suffered as a consequence of forming close sentimental attachments to women. Marriage, therefore, might expose him to the horror of a new and unbearable loss. Such a loss might come about as a result of the death of his spouse or her infidelity; but, as the words of "Rondeles" indicate, it might also be occasioned by the poet's own tendency to become disillusioned after establishing an intimate personal relationship: 
Y sólo ansío olvidarte, nunca oírte y nunca verte, porque me causa la muerte con la tristeza de amarte el dolor de comprenderte.

(R9/30-34)

Instead of marrying, of course, he might spare himself the agony of loneliness by joining a religious order; yet this solution had serious drawbacks, too. As pointed out earlier, if Casal were to enter a monastery, he would be obliged to subordinate himself to outside authority and thus sacrifice his individuality. Needless to say, this was something he could never bring himself to do. Under these circumstances, Art had two distinct advantages for Casal: on the one hand, it allowed him to worship a female figure - la Belleza - who would never abandon, betray, or bore him; on the other, it made it possible for him to join a loose, but inspired brotherhood of coreligionaries-los artistas-which permitted him to enjoy the warmth of kindred spirits without limiting any of his personal freedom.

Besides enabling him to join a fraternity which counted among its members dedicated artists such as Manuel Gutiérrez Nájera, Rubén Darío, Francisco de Icaza, Enrique Gómez Carrillo, Bonifacio Byrne, José Arburu, and the talented Borrero family, the religion of Art had yet another feature which pleased Casal. Although Beauty was the supreme divinity, there existed a pantheon of lesser deities, as well-men who had immortalized themselves in the service of Beauty and who, much like the saints of Catholicism, could also become objects of veneration. Outstanding among these was Gustave Moreau, the "adoré, vénéré, idolâtré, divin maître," whose "vie exemplaire" served as a source of inspiration for the "très fanatique et très humble adorateur," Julián del Casal.

Another virtue of Art was that, like Catholicism, it drew the attention of the faithful away from this transitory vale of tears and led them to concentrate on an ideal meta-reality. Art differed from Catholicism, however, in that it offered immediate access into its promised land. In the sublime world of Art, the ugly sights, the shocking sounds, the repellent odors, and the terrifying deeds that were integral parts of daily living could be purged of their repulsiveness or omitted altogether; man could resist the temptation of material rewards and conquer immortality by heroically defending the purity of his dreams; and the human spirit, rising above the limitations of matter, could travel with utmost freedom through time as well as space.

Belonging to a heroic elite that faithfully served a beneficent divinity, finding inspiration in the immortal works of exalted masters, and abandoning the horrors of reality for the wondrous realm of Art not only helped Casal to forget his sadness for a while, but infused him with 
spiritual vigor and gave him a considerable measure of inner peace. As the poet said in Bustos, once the dreams of youth have gone, men of worth must be guided by some noble passion. That passion might be artistic, scientific, religious, or patriotic; but, whatever its nature, it alone can give purpose and significance to life: "Es una especie de posesión sagrada, contra la cual no hay más exorcismo posible que la muerte. Mientras el alma pueda alimentar una de esas nobles pasiones, la vida se le hará soportable, aunque la abrume tanto, por otra parte, como a Sísifo abrumaba el peso de su roca inmortal, porque tendrá siempre un objeto hacia el cual puede volver las miradas y ofrecerle en holocausto su corazón." ${ }^{8} 8$ In short, the sacred passion which Casal describes would inflame the soul with enthusiasm and, even in a frigid age of skepticism and indifference like his own, would put an end to such laments as "iYo también en el alma tengo frío!" (H10/36). Once possessed of this sacred passion, the individual would not only have the power to bear the discomforts of poverty and prolonged solitude, but, if forced to enter the arena of public combat, he would stand fearlessly against his opponents and, resisting every temptation offered by the masses, would have the courage to give up life itself in defense of his faith. ${ }^{39}$ Such resoluteness was possible because the individual could see that it was not inevitable to be split by antagonistic forces. If Beauty were his passion, he would discover that works of art were exempt from pernicious dualities. For example, the forms that Beauty had created did not have evil hidden in their depths, but were all of a piece. Therefore, no one could accuse Beauty of doing what the Lord had done:

Dios puso el mal bajo las formas bellas de tu cuerpo gentil que al mundo asombra, como puso detrás de las estrellas la región tenebrosa de la sombra.

$$
(\mathrm{H} 38 / 13-16)^{40}
$$

Furthermore, works of art were immune to the normal processes of change that affected living organisms. They did not attract one day and repel the next; they offered no unpleasant surprises; they stood defiant in the face of Time. Needless to say, this knowledge made it possible for the believer to eliminate anxiety and restore his soul to peace.

Casal derived great comfort from these thoughts. Nevertheless, as his health worsened during the spring and summer of 1893 , he found it more and more difficult to ignore two ideas which Catholicism had planted in his mind: first, that while the principles of Art might be of value during his brief sojourn in this world, they would not insure the salvation of his soul in the world beyond; and second, that the supreme ruler of both worlds was not Beauty, but God. Ultimately, these considerations led him to admit the shortcomings of his artistic ideal and to beg the Lord for 
mercy. ${ }^{41}$ In addition, on more than one occasion during the critical weeks prior to his demise, they induced him to take the sacraments and profess fidelity to Christian precept. ${ }^{42}$ Thus, in the end, Julián del Casal, who had strayed from the fold and transferred his allegiance to Beauty, reaffirmed the supremacy of God and died within the Catholic Church.

Max Henríquez Ureña observes that, in literature, Julián del Casal was a timid revolutionary. ${ }^{43}$ Nevertheless, Casal's poetry underwent considerable change during the seven years he spent as a professional writer-and this occurred primarily because of his willingness to explore any path that might lead to Beauty. For example, though formed in the Romantic tradition, he gave Parnassianism and Decadentism a sympathetic hearing, and, within a brief span of time, was writing with remarkable competence in both these veins. Parnassianism, which made its first appearance in Hojas al viento and, in the opinion of Verlaine, became the dominant aesthetic force in Nieve, ${ }^{44}$ also manifested itself prominently in Rimas. Indicative of its presence here are works like "Crepuscular" (R2), "Marina" (R4), "Sourimono" (R7), and "Medioeval" (R18), in which verbal painting is quite clearly the author's principal goal, and compositions like "Sensaciones" (R25), in which there appear, among the nonParnassian elements, such decidedly Parnassian images as:

Tu pupila, cual vívida esmeralda, guarda el fulgor de cosas celestiales, y descienden los rizos a raudales sobre el mármol bruñido de tu espalda.

$(\mathrm{R} 25 / 1-4)$

The presence of Parnassianism notwithstanding, works like "Post umbra" (H46) and "La canción de la morfina" (H47) reveal that Decadentism had also been an influence on Casal during the Hojas period of his career. This current attained considerably greater vigor in Nieve and, as shown by such major compositions as "Blanco y negro" (N40), "Nostalgias" (N44), "La reina de la sombra" (N45), "Flores de éter" (N47), "Canas" (N52), and "Horridum somnium" (N54), gave signs of becoming a strong rival of Parnassianism in Casal. ${ }^{45}$ As a matter of fact, in contrast to Verlaine, Casal's Cuban critics did not emphasize the Parnassianism of Nieve, but called attention, instead, to the Decadent features of the book. ${ }^{46}$ When Rimas came out, it became clear that those critics had made a very accurate appraisal of the direction in which Casal had been heading.

In good measure, both the Parnassian and the Decadent features of Casal's work owed their existence to his Romantic admiration for intrepid idealism. Idealism, he felt, had been responsible for history's most resplendent moments. Consequently, the heroes of idealism deserved to be 
commemorated with vivid words and glowing images. Casal's heroes were many: some, like Prometheus (N10), Moses (N4), and Saul of Tarsus (N6), had long ago attained mythological stature; some, like Pedro II of Brazil (H45), Ludwig II of Bavaria (N47), and Gustave Moreau (N 18), had risen above the mass in modern times. These individuals, together with such courageous types as the Bohemian wanderer (R6), the inspired soldier (R15), the poet (R29), and the dedicated man of God (R39), knew that life severely castigates the idealist. Nevertheless, they pursued their dreams with unabating obstinacy (R5).

There is abundant evidence to show that, despite his inclination towards self-abasement, Casal saw himself, also, as a heroic type: a dreamer searching valiantly for a trace of Beauty in a world of ugliness. This self-image made it possible for him to enter the noble circle of idealists who, in his eyes, gave purpose and meaning to existence. Membership in this elite order, however, obliged him to make a wide range of sacrifices, for, as everyone knows, intrepid idealism implies a rejection of life as it is commonly lived. It is not surprising, therefore, to find Casal repudiating the values, pursuits, and types of association - including those of an amorous nature (R9, R11, R28) - which society considered as normal and proper.

Having willingly abandoned the sunlit world of the majority, Casal interested himself in a host of things which society relegated to its kingdom of darkness. In his poetry, therefore, we encounter a region of the mysterious and the macabre. It is a place inhabited by such intriguing types as the prince who is brought to a peak of frustration by his crippling infirmity (R16), the necrophiliac king who embraces dead illusions (R17), the courtesan who suffers from emotional anemia (R24), the murderess who finds herself a prey to the sanguinary vulture of remorse (R26), the hermit who seeks consolation in the caresses of a snake (R27), and the child of sin who is thrown without mercy into the stream of life (R40).

Besides infusing more and more of his poems with "un'atmosfera malata e decadente, propria di influenze verlainiane," as Giuseppe Bellini describes it, ${ }^{47}$ Casal did other things that were characteristic of Decadentism. For example, he stressed the mysterious vagueness of certain phenomena; ${ }^{48}$ he tried to create images which would symbolically represent the intangibles of his spirit; he increased the musicality of his compositions; and he experimented with a number of meters and rhyme schemes that he had not essayed before.

In spite of these experiments, Casal was never a daring innovator where form was concerned. This is revealed, in part, by the kinds of meters that he used during his career (see Table 6). In the Hojas period (1881-1890), ${ }^{49}$ he tried his hand at writing tetrasyllables, heptasyllables, octosyllables, hendecasyllables, and alexandrines-generally in unimetric sequences but sometimes, as in the case of the tetrasyllables and heptasyllables, in polymetric combinations. During the Nieve period (1890-1892), 
he abandoned the straight octosyllable and the alexandrine, and added the enneasyllable, the decasyllable, and the dodecasyllable. It should be noted, however, that he introduced the latter forms rather late and utilized them in only eight poems. Furthermore, instead of increasing his experiments with polymetry, he reduced the number of polymetric compositions from nine to two. ${ }^{50}$ What Casal did not curb was his tendency to use the eleven-syllable line; on the contrary, he increased the proportion of hendecasyllabic poems from $54 \%$ to $84 \%$ of the total. Consequently, the Nieve period, which was one of fairly intense poetic activity for Casal, was surprisingly limited in metrical diversity. During the Rimas period (1892-1893), though still showing a marked preference for the hendecasyllable ( $62 \%$ of the total), he employed a wider range of meters than before. He returned on occasion to the octosyllable, the alexandrine, and the hendecasyllabic-heptasyllabic combination, all of which he had dropped completely in the Nieve period; he again attempted the decasyllable and the enneasyllable; and he explored the possibilities of the dodecasyllable.

Of the thirty poems composed between 13 February 1881 and 25 December 1887, twelve were octosyllabic or had octosyllabic sections. ${ }^{51}$ Only five more octosyllabic poems came out in the Hojas period, and this was in the brief span between 20 April 1890 and 5 May 1890, when Hojas al viento came off the press..$^{52}$ Thus, there was a period of over two years (January 1888 to mid-April 1890) during which no octosyllables were published. When we add to these data the fact that seven of the octosyllabic compositions written during the Hojas period were acknowledged imitations of works by foreign authors ( H7, H9, H15, H19, H23, H34, and $\mathrm{H} 40$ ), it becomes fairly obvious that, despite the importance of the octosyllable in Hispanic literature, Casal was not very partial to this meter for the expression of original ideas. Casal's lack of enthusiasm for the octosyllable revealed itself most clearly, however, in the Nieve period, for, of the fifty-six poems he wrote during this time, not one was octosyllabic. ${ }^{53}$ In spite of this reluctance to use the eight-syllable line, Casal did experiment with it in four poems of the Rimas period: "Juana Borrero" (V11), "Rondeles" (R9), "Vieja historia" (R 14), and "Dolorosa" (R26). Two facts suggest that this return to the octosyllable may not have been accidental, but may have actually represented a conscious effort to infuse new life into the meter: to begin with, three of the four poems (V 11, R9, and R14) came out within a very short time of each other (between 15 July and 15 September 1892); second, "Rondeles," "Vieja historia," and "Dolorosa" were cast from molds belonging to a single variety of Decadent inspiration. Promising though these experiments were, they were unable to counteract the poet's basic disinclination to use octosyllables, and, after February 1893, he abandoned the meter altogether.

Casal first employed the alexandrine in "iUna lágrima!" (V1) and "El poeta y la sirena" (V2) ${ }^{54}$ his earliest published works. For reasons that are 
still unknown, he did not use this meter again until his Rimas period, when he chose it for "Profanación" (R17) and "Laus noctis" (R30). Although all four compositions are regular alexandrines with a caesura after the seventh syllable, those of the later period exhibit far greater technical competence than do those of the earlier one. For example, consonant rhyme, which had been used only in the even lines of V 1 and V2, was used throughout R17 and R30; palabras esdrújulas, which had never appeared at the end of the first hemistich in V1 and V2, began to show up in that position in R17 (once) and R30 (six times); and punctuation at the caesura, which had been a sign of Casal's tendency to pad his lines in the early period, interrupted the movement of his verses much less often in R17 and R30.$^{55}$ As a result, the alexandrine, which had been clumsily executed in $\mathrm{V} 1$ and $\mathrm{V} 2$ - like the steps of an adolescent mechanically practicing a new dance pattern - acquired much more grace in the later poems.

Although not especially fond of combining hendecasyllables with heptasyllables, Casal did write a few poems of this kind. His earliest effort, "Tras la ventana" (H6), was published on 17 January 1886 and, being a silva, presented relatively few technical problems. Soon afterward, however, Casal began to write hendecasyllabic-heptasyllabic poems that required adherence to predetermined metrical and rhyme patterns. On 27 June 1886, he published "Del libro negro" (H4), which was organized into stanzas of four lines in an 11-11-11-7 sequence, with assonance. Some three weeks later, he used the meters for a 40-line insert in "El adiós del polaco" (H17). The form in this instance, however, was much more complex than in the previous poem, for it alternated 7-and 11-syllable lines in quatrains having an $\mathrm{aBaB}$ rhyme scheme. During the rest of 1886 and for most of 1887, Casal made no experiments requiring the combination of hendecasyllables and heptasyllables. Then, between 27 October 1887 and 1 January 1888 , he brought out three compositions in which the meters were again juxtaposed: "Las mujeres" (V6), "Dicen que eres un ángel ..." (V7), and "Quimeras" (H20). The first two, occasional pieces of minor significance, were metrically arranged in the same way as "Del libro negro" (i.e., 11-11-11-7), but they had consonant rhyme (ABAb in V6, $\mathrm{ABCb}$ in V7) instead of assonance. The last poem, "Quimeras," was a major work and, like "Del libro negro," revealed Casal's skill at using assonance in hendecasyllabic-heptasyllabic poems. In spite of having achieved good results with "Quimeras," Casal did not make a single attempt to combine the meters during the remainder of the Hojas period or during the Nieve period. Then, quite surprisingly, on 15 April 1892, he published "A la Belleza" (R1). This composition, which was destined to be the lead poem in Rimas, was a composite of features that had appeared in the earlier works: like $\mathrm{H} 4$ and $\mathrm{H} 20$, it had assonance; like H17, it alternated the meters; ${ }^{56}$ and like most of the previous poems, it showed a preference for organizing thoughts into four-line stanzas and for accenting the sixth syllable in the hendecasyllabic lines. ${ }^{57}$ Without doubt, this brief return to polymetry was highly successful. Nevertheless, it was 
anomalous, for, as shown in Table 6 , Casal's tendency after 1888 was to concentrate on the writing of unimetric compositions.

Casal began experimenting with the decasyllable in 1891 and used two forms of the meter during that year: he attempted the decasilabo dactílico, with assonantal rhyme, in "La reina de la sombra" (N45) and "Horridum somnium" (N54); and he tried his hand at the decasilabo compuesto, with consonant rhyme, in "Flores de éter" (N47) ${ }^{58}$ and "Canción" (N49). During the Rimas period, Casal wrote only two poems in decasyllables: "La sotana" (R10) and "Neurosis" (R24). Both of these were decasílabos compuestos and, like the earlier compositions of this type, followed a rigid consonantal rhyme pattern. "Neurosis," written in sextinas with a consistent AAB́CCB́ rhyme scheme, ${ }^{59}$ was technically the most sophisticated of all the poems and showed that Casal could attain a fairly high level of competence with the decasyllabic form. ${ }^{60}$ In spite of this, the decasyllable could not compete with other meters for the poet's favor and, after February 1893, was not used again.

The eneasilabo polirritmico, which had been employed by such prominent Spanish Americans as Andrés Bello, José María Heredia, and José Eusebio Caro, as well as by important French writers of the nineteenth century, was also attempted by the Modernists. Whether this was principally an imitative gesture by individuals wishing to introduce greater variety into the techniques of poetic expression, or whether it was a sign that they sincerely appreciated the meter's suitability for lyric reflection, the eneasilabo polirrítmico ultimately gained considerable prestige among Modernists throughout the Hispanic world ${ }^{61}$ One of the most inspired examples of its use was Rubén Darío's "Canción de otoño en primavera," which, though appearing long after the initial phase of Modernism had ended, proved how powerful the form could be as a literary instrument. Casal's experiments with the meter began in the Nieve period and produced a hybrid composition, "Hortensia del Monte" (V9). This poem was published in El Fígaro on 31 January 1892, but was not included in Nieve. It consisted of twenty-four enneasyllabic lines, plus a seven line envío composed of octosyllables and tetrasyllables. "Tardes de lluvia" (R38), Casal's second - and last - enneasyllabic poem came out some nineteen months later, at the end of the Rimas period. This composition resembled "Hortensia del Monte" in that it placed great emphasis on description. Nevertheless, it differed from its predecessor in four basic respects: it was not a metrical hybrid, but consisted entirely of enneasyllables; it was longer by thirteen lines; it had consonant rhyme instead of assonance; and it was imbued with an intensity of feeling that was sure to elicit a strong emotional response from its reader. The excellence of this poem, both with regard to form and content, is of considerable importance to students of Casal's artistic development, because it shows that, at this point in his career, the poet was able to express himself effectively even in meters which he had not used with frequency before.

The twelve-syllable line first appeared in the "Tipos españoles" series 
which Casal published on 15 February 1892 (see my discussion of Np3). The specific variety of dodecasyllable chosen for these poems was the dodecasilabo de seguidilla. This form, which consists of a heptasyllabic and a pentasyllabic segment in each line, was particularly well suited for the description of una maja and un torero, because, as Tomás Navarro indicates, "Al ritmo de la seguidilla, que según Cervantes, hacía cosquillas, se asocia la impresión del movimiento vivo y airoso de su música y baile .... En la canción popular suena a veces con majeza y arrogancia." ${ }^{22}$ In light of this statement, Casal's use of the dodecasilabo de seguidilla to describe a humble, mendicant friar - rather than one of those lusty, down-to-earth types so often depicted by Hispanic artists - is somewhat surprising. Nevertheless, the description is successful; and this is so because Casal found a way to hold the exhilarating rhythm of the form in check and make it advance with unaccustomed gravity. This experiment was followed by seven others in the Rimas period (V10, R7, R12, R21, R2, R32, R34) and, together, these efforts helped expand the functional possibilities of the dodecasilabo de seguidilla, a metrical form whose tonal range had been, by tradition, rather limited.

Perhaps the first impression one receives when reading the poetry of Casal is that it is very highly structured. For instance, even though it was written during an age in which liberty was a cherished ideal everywhere in the western world, his poetry offers no examples of free verse, and this is so because it was predicated on the conviction that the uniqueness of the artist lay in his ability to express his thoughts vigorously, gracefully, and accurately within the compass of pre-determined boundaries. ${ }^{63}$ Casal's insistence on working within prescribed limits manifests itself not only in his unswerving fidelity to meter, but also in his persistent allegiance to rhyme. A study of his work shows that rhyme is present in every poem in the corpus. Consonant rhyme is found in $69 \%$ of the lines in Hojas al viento, $78 \%$ of the lines in Nieve, and $87 \%$ of the lines in Rimas; ${ }^{64}$ and every poem that does not have consonant rhyme has assonance. Indeed, excepting the odd-numbered verses in poems with assonance, one finds unrhymed lines only in $\mathrm{H} 6, \mathrm{~N} 18, \mathrm{~V} 1, \mathrm{~V} 2$, and V7.

Interesting also in regard to Casal's emphasis on form is the fact that the vast majority of rhyming groups in poems with consonance are composed of palabras llanas, while only a minute number are made up of agudas or esdrujulas. The specific number of words in these categories is shown in the following chart:

$\begin{array}{lrrr} & \text { Hojas } & \text { Nieve } & \text { Rimas } \\ \text { Llanas } & 1024 & 1255 & 988 \\ \text { Agudas } & 70 & 32 & 78 \\ \text { Esdrújulas } & 0 & \frac{2}{1289} & \frac{6}{1072}\end{array}$

The fact that $97.6 \%$ of the total number of rhyming words in Hojas, Nieve, 
and Rimas are palabras llanas, while only $2.4 \%$ are agudas or esdrújulas, would seem to contradict the laws of probability. Let us investigate this point by examining the esdrújulas.

At first glance, it would appear that $2.5 \%$ of the words in Hojas, Nieve, and Rimas (i.e., 654 items in a universe of 25,947 running text-words) are esdrújulas. Closer inspection of these forms discloses, however, that they are not all treated as esdrújulas. Not only is océano (H47/35) pronounced oceano, but all esdrújulas ending in -eo, -ea, and -oe regularly function as llanas. ${ }^{65}$ Consequently, the real number of esdrújulas is 566 -i.e., $2.18 \%$ of the total.

In a study of modern written Spanish, Tomás Navarro found that esdrújulas accounted for $1.90 \%$ of his sample.$^{66}$ It might be said, therefore, that the percentage of esdrújulas in Casal's three books corresponds to a norm in modern usage. The correspondence seems to break down, however, when the esdrujulas occur in rhyming position, for while the words in Casal's books and in Navarro's sample represent every syntactical category, Casal's rhyming words belong to the three groups which yield virtually all of the esdrújulas in Spanish - the nouns, adjectives, and verbs:

\begin{tabular}{|c|c|c|c|c|c|}
\hline Function of rhyming words & Hojas & Nieve & Rimas & & Totals \\
\hline Nouns & 621 & 776 & 732 & $=$ & 2129 \\
\hline Adjectives & 309 & 307 & 191 & $=$ & 807 \\
\hline Verbs & 153 & 194 & 140 & $=$ & 487 \\
\hline Other & 11 & 12 & 9 & $=$ & 32 \\
\hline & $\overline{1094}$ & $\overline{1289}$ & $\overline{1072}$ & $=$ & $\overline{3455}$ \\
\hline
\end{tabular}

In other words, simple probability would suggest that, in 3455 lines, there should be many more esdrújulas in rhyming position than the 8 which are actually found.

In point of fact, however, the laws of probability cannot be applied in this instance, for there exists in Spanish a convention which discourages poets from using esdrujulas for consonant rhyme. ${ }^{67}$ Therefore, when we read a work such as José Asunción Silva's "Un poema" and run across 3 pairs of rhyming esdrújulas in 20 lines, we may fairly assume that the author was consciously going against convention. Likewise, when we find piélago rhyming with archipiélago in "Nostalgias" (N44/76,77), alcohólicos rhyming with melancólicos in "Páginas de vida" (R21/9,11), and, in particular, two instances of esdrújula rhyme in "Tardes de lluvia" - álamos with tálamos (R38/5,7) and creprisculos with músculos (R38/41,43) - we may justifiably suspect that conscious experimentation was taking place.

These experiments were very modest, indeed. Nevertheless, there is reason to believe that they were part of a larger mosaic that Casal was putting together during the last years of his life. From the summer of 1891 onward, he began experimenting in his sonnets with rhyme patterns other than the CDE, CDE arrangement which he had preferred until that 
time: he resurrected the CDC, DCD combination, which he had dropped after publishing "El anhelo de una rosa" (H24) back in June of 1886; he made one attempt at the unusual CDC, DEE configuration in "Flor de cieno" (N33); and, starting with "Venus Anadyomena" (N14), he worked up a series of sixteen sonnets whose tercets had a CCD, EED rhyme scheme. The most startling experiment with rhyme did not take place in the sonnets, however, but in "En el campo" (R36). This 33-line hendecasyllabic composition, dating from August 1893, was written in tercetos monorrimos-one of the least common rhyme configurations in Spanish.

In addition to these experiments with sound patterns in consonant rhyme, Casal did other things which reflected a growing interest in the acoustical aspects of composition. For example, after having practically abandoned the use of palabras agudas in consonant rhyme for ten years, ${ }^{68}$ he began to acquire a new appreciation of its possibilities in the spring of 1891. The results can be seen in "Nostalgias" (N44), whose coplas de pie quebrado follow an aabccb pattern which gives dynamic movement to the poet's thoughts and feelings. Despite his success with "Nostalgias," Casal did not use agudas in regular sequence throughout a poem again until the late summer of 1892, when he wrote "Vieja historia" (R14). These sporadic efforts were followed in early 1893 by three consecutive essays at aguda rhyme: "Neurosis" (R24), "Dolorosa" (R26), and "Laus noctis" (R30). The first and last of these poems represent really significant achievements, for, unlike "Dolorosa," which was written in octosyllables and used agudas in only 8 of its 17 stanzas, they were composed in versos de arte mayor and used agudas in a consistent pattern throughout.

Casal's interest in exploring the advantages of repeating sound patterns led him to go beyond the repetition of word endings and to experiment with the repetition of more extensive units. Illustrative of his endeavors in this direction are "Rondeles" (R9), "Recuerdo de la infancia" (R12), and "Vieja historia" (R14). These poems, which came out between 30 August and 15 September 1892, are all based on the periodic repetition of whole lines. In "Recuerdo de la infancia," the repetition takes place within every stanza, while in the other compositions, it occurs within each part. The high point in Casal's efforts to expand the scope of repetition was reached on 19 February 1893 with the publication of "Dolorosa" (R26): in this poem, an entire stanza was repeated word for word three times.

Repetition is actually one of the most common features of Casal's art. One finds, for example, that there is structural and conceptual repetition, as well as acoustical repetition, even in the earliest poems: three consecutive stanzas in "iUna lágrima!" (V1) begin with a possessive adjective + noun, and conclude with a verbal complement which indicates that an important quality has been lost (ll. 5-16); three consecutive stanzas in "Huérfano" (V3) follow the pattern: noun + adjective clause + ven $a+$ complement (ll. 41-52); and three consecutive stanzas in "Amor en el claustro" (H3) begin with cuando (ll. 61-72) and lead to a common conclu- 
sion (ll. 73-76). Curiously enough, the tendency to organize thought in repetitive sequences became even more pronounced at the end of Casal's career. For instance, the first part of "Las alamedas" (R19) consists of an affirmation ("Adoro las sombrías alamedas") plus six clauses beginning with the word donde (ll. 2, 5, 9, 13, 17, 21), and the second part is composed of six stanzas beginning with the word alli (ll. $25,29,33,37,41,45) \cdot{ }^{69}$ Like the first part of "Las alamedas," the sonnet "Aegri somnia" (R23) is made up of an initial assertion ("Yo sueño en un país de eterna bruma") and a series of qualifiers beginning with donde (ll. 2, 5, 9, 12). And "Laus noctis" (R30) has at its core six consecutive stanzas which lead off with an indirect object (ll. 13, 17, 21, 25, 29, 33).

Structural equivalents were not only concatenated between stanzas, but also within stanzas. One passage which illustrates the procedure is found in "La muerte de Moisés" (N4): here, in the space of twelve lines, the Hebrew prophet asks God six questions all of which are arranged in such a way that the words por qué appear at the beginning of the verse (ll. 104-115). In "La cólera del infante" (R 16), a series of 7 infinitives, 6 of which occupy initial position in the line, are linked together in a stanza of twenty verses (ll. 22-41). And in "Cuerpo y alma" (R41), 6 descriptions of cuerpo and 5 descriptions of alma, each presented in the form of a simple analogy, are concatenated so that the reader may appreciate the intensity of Casal's longing to end the conflict that torments him.

The technique of expressing thoughts and feelings through the concatenation of structurally equivalent segments is found not only in Casal's poetry, but also in his prose. One sentence from his article "Rubén Darío" shows just how far Casal was willing to go in the use of this technique. As the reader will note, the introductory portion of this sentence is composed of 12 sub-sections each beginning with fuerza que:

Pero si, por el contrario, están dotados de la fuerza misteriosa que infunde el amor a las ideas abstractas, fuerza que se nutre con la propia sangre, fuerza que respira en medio del bloqueo, fuerza que se acrecienta al sentir el primer ataque, fuerza que atrofia en el hombre los apetitos brutales, fuerza que aúna estrechamente la inteligencia a la voluntad, fuerza que pone un puñal en las manos de un santo, fuerza que asciende los mártires a la hoguera, fuerza que es el honor, a la par que la locura, de las naturalezas extraordinarias, fuerza que amarga el corazón, sin despojarlo de sus más excelsas cualidades, fuerza que hoy parece concentrada en las razas esclavas, fuerza que conocen los anacoretas, los pensadores, los artistas y hasta los grandes criminales; entonces aquellos espíritus acaban por imponer sus ideas, sus gustos y sus producciones, a despecho de encarnizados enemigos que, como manada de perros ahuyentados por el lobo que acosaban, huyen medrosos a la soledad. ${ }^{70}$ 
Of the conceptual patterns which manifest themselves in Casal's poetry, the one he cultivated most assiduously was antithesis, ${ }^{71}$ while, of the rhetorical forms, simile stands out as a constant favorite. Indeed, the latter actually became more important to him at the end of his career than it had been at the beginning. Several things corroborate this point. First of all, even though Rimas was 363 lines shorter than Hojas and 420 lines shorter than Nieve, it contained approximately one and a half times as many similes as either of these collections. In addition, Rimas had more individual poems with a high concentration of similes than did the earlier books. Topping the list was "Cuerpo y alma," whose 82 lines contained a total of 16 such images. Finally, Rimas had a greater number of complex similes than the other books. As a matter of fact, four whole compositions were conceived of as extended similes - "A un héroe" (R15), "Profanación" (R17), "Preocupación" (R22), and "A un poeta" (R29) - and this was more than the total of such poems in Hojas and Nieve combined.

When seen in conjunction with his disinclination to cultivate a large variety of meters and rhyme schemes, these examples suggest that Casal's literary inventiveness tended to be more in tensive than extensive in nature. In other words, they give the impression that, except where momentary enthusiasm led him to experiment with some novel form, he preferred to do a lot of variations on a relatively small number of basic patterns. Such a procedure, however, was not typical of Casal alone; rather, it was characteristic of the age in which he lived. That age, despite its desire to do away with many of the restraints that inhibited its freedom, was extremely reluctant to give up its dependence on highly structured forms. In this sense, Casal and his contemporaries were not unlike the protagonist of "Neurosis" (R24): none could find complete satisfaction even in the most exotic beverage, unless it were contained within a highly polished vessel, exquisitely designed and richly ornamented.

\section{Rp0: Notes to Introductory Statement}

1 “Julián del Casal," in Ed. del Cent., "Poesías," pp. 234-235.

2 For detailed information about Don Domingo's family, see León Malpica Hidalgo, Bosquejo del árbol genealógico de la familia Malpica, 2nd ed. (Valencia: Tip. Minerva, 1945).

3 See Ed.del Cent., vol. I, pp. 220-222.

4 Ed. del Cent., vol. III, p. 143.

5 Loc. cit.

6 Brief descriptions of this room are found in Aniceto Valdivia, "Julián del Casal" ( $L, 23$ October 1893), and in Ramón Meza, op. cit. The passages in question may be found in the Ed. del Cent., "Poesías," pp. 297 and 261, respectively.

7 The third article in Bustos is devoted to Dr. Zayas.

8 Quoted by Darío in a letter to Enrique Hernández Miyares. This letter, 
which was originally published in $H E$ on $17 \mathrm{June} 1894$, may be found in the $E d$. del Cent., vol. I, pp. 31-35.

9 This review, which appeared without a by-line in the 22 October 1893 issue of $H E$, is reproduced in the $E d$. del Cent., vol. III, p. 243.

10 See A. Miranda, "Anécdota" (HE, 29 October 1893), in Ed. del Cent., "Poesías," p. 294.

11 In "La obra póstuma de Casal: Bustos y rimas," Wen Gálvez indicates that this prologue was written by Hernández Miyares. Gálvez' article, which originally appeared in the 8 February 1894 issue of $F$, is reproduced in Appendix B of the present edition.

12 "Carta abierta" to Carlos Noreña ( $F, 14$ September 1890), in Ed. del Cent., vol. I, p. 167.

13 From the section entitled "Spleen et idéal" in Les Fleurs du mal.

14 Differences between the order in which the poems were published in journals and the sequence in which they were presented in Rimas will be found in Index II.

15 In Nieve, some of the poems which were ultimately given the section title "La gruta del ensueño" appeared originally under the rubric "Poesías diversas" (see my discussion of Np5).

16 See my discussion of $\mathrm{H} 25$.

17 See my discussion of N26. Also, Manuel de la Cruz, Cromitos cubanos (Havana: "La Lucha," 1892), p. 301; reproduced in Ed. del Cent., "Poesías," p. 317.

18 See my discussion of $\mathrm{H} 8$.

19 Domingo Malpica Labarca, "Nota biográfica," $H E, 29$ October 1893, p. 16 (italics are mine); the entire article is reproduced in Appendix A.

20 Nunn, "The Life and Works of Julián del Casal," p. 79.

21 Quoted by Vitier in "Julián del Casal en su centenario," p. 29.

22 Fontanills, "Episodio," $H E$, 29 October 1893; reproduced in Ed. del Cent., "Poesías," p. 294.

23 Adman, "Pobre Julián," HE, 29 October 1893; quoted by Nunn, op. cit., p. 78.

24 Among those who held this position was Francisco de Coronado; see Nunn, op. cit., p. 76.

25 See Eugenio Sánchez de Fuentes, “A Julián del Casal, después de haber leído su poesía 'Nihilismo'”; reproduced in my discussion of R3.

26 Casal, "José Fornaris," in Bustos, pp. 111-112; reproduced in Ed. del Cent., vol. I, p. 278. This statement gives a new facet of symbolic meaning to remarks such as "iYo también en el alma tengo frío!" (H10/36) and to the choice of Nieve as a title for the second collection of poems.

27 Despite the fact that "Salomé" and "La aparición" deal with events that are recorded in the New Testament, Casal did not use the biblical account as his direct source of inspiration. For information on the origin of these poems, see my discussions of N8 and N9.

28 Casal, "Esteban Borrero Echeverría," in Bustos, p. 66; reproduced in Ed. del Cent., vol. I, p. 261. 
29 See my discussion of $\mathrm{H} 8$.

30 See "Internato" in Appendix A for a description of one serious breach of discipline by Casal.

31 In this regard, it is appropriate to recall the poet's verbal thrust against General Sabas Marín in La Sociedad de la Habana (see my discussions of $\mathrm{H} 25$ and H44).

\section{See N 18/44-63.}

33 Consult vol. III of the present edition for exact locations of oración, plegaria, ruego, súplica, and related words. It is interesting to note that hosanna, which appears in $\mathrm{H} 20 / 36$, is a song of praise directed to God not by men, but by "los blondos serafines."

34 See N28, Variants, 1. 14.

35 See "Recuerdos de Madrid. Un poeta mejicano: Francisco de Icaza" ( $H E$, 3 February 1889), where Casal voices the hope that there will be a return of "los días serenos, los días inolvidables de la antigüedad, en que la Belleza era un culto, el Amor un sacerdocio y el Arte la más sublime de las religiones" (Ed. del Cent., vol. I, p. 200).

36 See "Manuel Reina," in Ed. del Cent., vol. I, p. 183. The article was originally published in December 1885, when Casal was twenty-two years of age.

37 A similar transfer took place in the literature of courtly love, where the troubadour used the language and imagery of religion to express his amorous feelings towards his beloved. See C. S. Lewis, The Allegory of Love (New York: Oxford University Press, 1958), pp. 20-22.

38 "Enrique José Varona," in Bustos, pp. 26-27; reproduced in Ed. del Cent., vol. I, p. 250

39 The image of the gladiator or the gladiator-martyr was a fairly common one among the Modernists. Although it does not appear with very great frequency in the works of Casal, it is significant nevertheless. In some compositions, it is the principal image (e.g., N3); in others, it is one of several less extensive motifs (e.g., H2/41-48); while elsewhere, it occurs as a subtle reference in passing (e.g., N28/1-2). Of all the examples of this image in Casal's collected works, probably the most interesting is the one that appears in the first section of "Rubén Dario: Azul y A. de Gilbert" (HL, 15 November 1891), for there the parallel between the artist and the martyr of early Christianity is drawn with extraordinary clarity.

40 Images of God as a wrongdoer appear elsewhere in the corpus. Two examples from Rimas are: “¿Por qué has hecho ioh Dios mío! mi alma tan triste?" (R21/60) and "tal es ioh Dios! el alma que tú has hecho / vivir en la inmundicia de mi carne ..." (R41/68-69); italics are mine.

41 For example, see "Oración” (R33), which came out on 13 August 1893 in $H E$.

42 In "Nota biográfica," Domingo Malpica Labarca says that, from the time of his first severe attack onward, Casal "ratificó su propósito de vivir y morir en el seno de la Iglesia Católica. 'Yo soy cristiano - decía - he procurado siempre cumplir los preceptos de la Doctrina Cristiana", (see Appendix A). On 7 October 1893, Casal informed Darío that "Desde julio a la fecha he recibido dos veces los Santos Sacramentos." 
43 Breve historia del modernismo, 2nd ed., p. 133.

44 See above, pp. 143-144.

45 Although Parnassianism manifested itself slightly before Decadentism in Casal's poetry, it must be remembered that the two currents co-existed during the author's years of greatest productivity. Therefore, it is not surprising to find that four of the "Decadent" compositions in Nieve (N40, N44, N45, and N47) antedated all of the sonnets in "Mi museo ideal" with the sole exception of "Salomé" (N8).

46 See above, pp. 145-146.

47 La letteratura ispano-americana dall'età precolombiana ai nostri giorni (Milan: Sansoni-Accademia, 1970), p. 227.

48 It is interesting to observe how the word vago increased in frequency from book to book. In Hojas, it appeared once (H37/16); in Nieve, it occurred three times (N4/67, N47/43, N47/48); but in Rimas, it came up in nine separate contexts (R1/10, R10/2, R12/33, R19/5, R25/13, R31/13, R32/55, R37/1, R38/43).

49 For convenient reference in the present discussion, I have divided Casal's poetic career into three periods. Each of these is tagged with the name of the book which closed the period. When the terms "Hojas period," "Nieve period," and "Rimas period" are used, my comments refer both to the collected works and to the Varia selections that were written during the designated period. However, when the word "period" is not used after the name of a book, my comments refer only to the collected works.

50 In the sense that it is a metrical hybrid, V9 belongs in the same category as V2, H 17, and the original version of N5. Casal's lack of fondness for juxtaposing metrically different sequences in the same poem is shown by his exclusion of V2 from Hojas and V9 from Nieve, by his suppression of the 50-line octosyllabic portion of N5 (see my discussion of this point in N5 and Np 1), and by the absence of such juxtapositions in poems of the Rimas period.

51 "El adiós del polaco" (H17) was a hybrid which had two octosyllabic sections: ll. 1-8 and ll. 49-56.

52 Since "La nube" (H7), "Todavía" (H26), and "La canción del torero" (H40) were not published before they appeared in Hojas, there is no way of estimating when they were written. The only thing that can be stated with certainty is that "La canción del torero" could not have been composed before the fall of 1889 (see my discussion of $\mathrm{H} 40$ ).

53 Although "La agonía de Petronio" (N5) had 50 octosyllabic lines in its first published version, these lines were suppressed when the poem was revised for publication in Nieve.

$54 \mathrm{~V} 2 \mathrm{had}$ alexandrines in 11. 49-68. The rest of the poem (i.e., ll. 1-48 and 69-76) was written in hendecasyllables.

55 The frequency of punctuation at the end of the first hemistich is as follows: 17 out of 44 lines in V 1, 5 out of 20 lines in V2, 1 out of 14 lines in R 17, and 4 out of 44 lines in R30.

$56 \mathrm{H} 17$ had a 7-11-7-11 combination, while R 1 had an 11-7-11-7 combination.

57 Despite the fact that most of Casal's hendecasyllables are cadenced in 
this manner, every poem has lines which depart from the pattern. This is not unusual, however, for, as Tomás Navarro indicates, "Son escasos relativamente en las manifestaciones ordinarias del endecasílabo los versos que sólo constan de los acentos indicados" (Métrica española,p. 176). See also, Dorothy Clotelle Clarke, "A Chronological Sketch of Castilian Versification Together with a List of Its Metric Terms," in University of California Publications in Modern Philology, vol. XXXIV (1948-1952), pp. 310-311.

58 There is a curious metrical flaw in this poem: 1. 3 is a decasilabo dactílico instead of a decasílabo compuesto.

59 The sextina with AABCCB rhyme scheme first appeared in "La agonía de Petronio" (N5), which was published on 17 May 1891. On 30 August of the same year, Casal adopted a variant of this pattern - CCD, EED - in the sonnet "Venus Anadyomena" (N 14). The CCD, EED rhyme scheme, which was destined to become the dominant one in the sonnets of Rimas, appeared again in the sestets of "Tipos españoles" (N19, N20, N21) on 15 February 1892, and, strangely enough, on 29 February, the AABCCB pattern showed up in "Medallón” (N53). These data suggest that Casal's use of the CCD, EED pattern in the sonnets may have been more closely related to his experiments with the sextina than has thus far been imagined.

60 Its excellence notwithstanding, the poem does have some weaknesses. For example, in 1. 36, the word ansía must be pronounced ansia if the meter is to be preserved. According to the norms of pre-Modernist poetry, 11. 5, 17, and 32 would also be considered defective, because esdrújulas obliterate the caesura, rather than highlighting it as they should. Emiliano Díez Echarri indicates, however, that Modernist poets tended consciously to suppress the caesura ("Métrica modernista: Innovaciones y renovaciones," Revista de Literatura, vol. XI, nos. 21-22 [January-June 1957], p. 105). From the Modernist point of view, therefore, ll. 5,17 , and 32 would be perfectly acceptable.

61 Tomás Navarro, Métrica española, pp. 420-421.

62 Ibid., p. 417.

63 During the early stages of Modernism, Spanish American poets tended not to make a violent break with traditional precepts on matters of form; nevertheless, they often felt a need to give the movement of their ideas a new flexibility. Casal was very much like his contemporaries in this respect. That is, even though he paid careful attention to factors such as line length and the conceptual integrity of stanzas, he made some effort to create freer flowing rhythms within the formal structures that he had chosen. For example, from time to time he would use esdrujulas to obliterate, rather than to highlight, caesuras (see above, note 60); he would use enjambment not only between lines (e.g., N44/17-18), but, on occasion, even between stanzas (e.g., N9/4-5); and he would displace the conceptual and rhythmic centers of gravity of certain passages by beginning a new sentence near the end of the line, rather than at the beginning (see, for ex., N3, N18, N40, N42. $\mathrm{N} 43$, and R41). In spite of this, there is no doubt that the major characteristic of his art was obedience to form.

64 The precise figures for consonant rhyme are: 1094 out of 1593 lines in Hojas, 1289 out of 1650 lines in Nieve, and 1072 out of 1230 lines in Rimas. 
65 In Julián del Casal y el modernismo hispanoamericano, Monner Sans affirms that "El lenguaje a trechos modernista de Nieve . . se prolonga a Rimas. Con la singularidad de que de un libro a otro aumenta la adjetivación esdrújula: róseo, gríseo, áureo, purpúreo, livido, níveo, lánguido, marmóreo, férreo, nítido, fúlgido, lumínico, fosfórico, cálido, ígneo, gélido, árido, áspero, hórrido, etc.” (p. 83). An examination of the words listed by Monner Sans does not corroborate his assertion. To begin with, Casal invariably diphthongized the strong vowels at the end of adjectives of the -eo variety; this, of course, changed them into palabras llanas. Hence, they cannot be considered as part of Casal's “adjetivación esdrújula." Furthermore, only one of the eleven other adjectives cited by Monner Sans as becoming more frequent towards the end of Casal's career actually occurred more often in Rimas than it had in Nieve; that word was áspero. The frequency of one word (nítido) remained constant, and that of all the rest declined-in four cases (livido, fosfórico, gélido, and hórrido) to zero:

$\begin{array}{lccc}\text { Adjective } & H & N & R \\ \text { lívido } & 1 & 2 & 0 \\ \text { lánguido } & 3 & 4 & 3 \\ \text { nítido } & 1 & 2 & 2 \\ \text { fúlgido } & 5 & 7 & 2 \\ \text { lumínico } & 1 & 2 & 1 \\ \text { fosfórico } & 0 & 1 & 0\end{array}$

$\begin{array}{lccc}\text { Adjective } & H & N & R \\ \text { cálido } & 0 & 4 & 1 \\ \text { gélido } & 1 & 2 & 0 \\ \text { árido } & 1 & 2 & 1 \\ \text { áspero } & 1 & 3 & 4 \\ \text { hórrido } & 2 & 2 & 0\end{array}$

66 Estudios de fonología (New York: Las Americas, 1966), p. 57.

67 Esdrújulas in assonance are quite acceptable, however, and they occur fairly often in Hispanic poetry. Casal himself used them in this type of rhyme: see, for example, relámpagos (H2/24), pájaros (H2/36), súplicas (H20/2), púrpura (H20/16), lágrimas (H28/8), nácares (N45/24), ejército (R41/18), and céfiros (R41/34). He also used esdrújulas in terminal position in non-rhyming lines: for example, cadavérico (H2/29), diabólicos (N54/33), lágrimas (N54/97), víctimas (R41/29), cándida (R41/61), melancólico (V9/17), melancólicos (V12/3), and espíritu (V13/111).

68 Between April 1881 and March 1891, Casal occasionally used agudas as well as llanas in poems with consonant rhyme. At no time during this period, however, did he use agudas in a consistent pattern throughout an entire poem.

69 The only variation in this pattern occurs in 1. 25, where Van alli, rather than Alli alone, begins the statement.

70 HL (15 November 1891), pp. 97-98; reproduced in Ed. del Cent., vol. I, p. 170 .

71 The most competent study of this feature of Casal's style is Ivan A. Schulman's "Las estructuras polares en la obra de José Martí y Julián del Casal” (Revista Iberoamericana, vol. XXIX, no. 56 [July-December 1963], pp. 251-282). In discussing Casal's use of antithesis, Schulman says that "La base de las construcciones antitéticas de Casal es un núcleo de tropos materialistas, símbolos constantes de su poética: pantano, miasma, cieno, abismo, lodazal, fango; a estos tropos el poeta contrapone un símbolo de filiación idealista para completar la estructura" (p. 260). See, also, Schulman's article entitled "Casal's Cuban Counterpoint of Art and Reality," in Latin American Research Review, vol. XI, no. 2 (1976), pp. 113-128. 
Casal's poems are listed chronologically in this Table. Six pieces of information are provided about each work: the code number by which the poem is designated in this edition, the date of its earliest version, the number of lines in its final version, the number of syllables in each line, the number of lines per stanza, and the rhyme scheme used.

Some special signs will be found in the Table. Their meaning is given below (and examples from the Table are cited in parentheses):

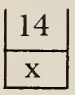

\begin{tabular}{|c|c|c|}
11 & 12 & 14 \\
\hline $\mathrm{x}$ & & $\mathrm{x}$ \\
$\mathrm{x}$ & & \\
\hline
\end{tabular}

4

$8^{6}$

$4^{5}$

$4^{2}$

S

4-4-5

4-4-(5)

$+\ldots$

$+$

á-o

V́
Shows the number of syllables per line throughout the poem (V 1: 13 Feb 81).

Line lengths vary in different parts of the poem (V2: 5 Mar 81).

An Arabic number under the heading "Regular" indicates the number of lines per stanza throughout the poem (V1: 13 Feb 81).

The presence of more than one number under the heading "Regular" means that the poem is organized into sections and that a different type of stanza is used in each section. Superscripts show how many stanzas of each kind there are in the poem (V2: 5 Mar 81).

The poem is a sonnet (H24: 13 Jun 86).

This stanzaic pattern is repeated throughout the poem (R 14: 15 Sep 92).

Any inconsistency in the pattern is shown by a number in parentheses (R9: 30 Aug 92).

Stanzas vary in length, but they do not follow a consistent pattern throughout the poem (H5: 3 Jan 86).

The poem is composed of a single tirada (H14: $25 \mathrm{Jul} \mathrm{86).}$

Assonant rhyme appears in part of the poem (H3: 5 Aug 83) or throughout the work (H2: 30 Mar 90).

Assonance, but with a different aguda rhyme scheme in each stanza (V3: 27 Mar 81). 
AB́CB́

Capital letters under the heading "Consonance" show the rhyme pattern in lines of more than 8 syllables. Accent marks signify that agudas appear consistently throughout the poem in the position indicated (V1: 13 Feb 81).

ab́ab́

Lower-case letters show the rhyme scheme in lines of 8 syllables or less (V4: 30 May 85).

$\mathrm{ABABCDCD} .$. The rhyme scheme progresses through the stanza in the form indicated (N3: 19 Apr 91).

$\mathrm{a}+\mathrm{b}$ or $\mathrm{A}+\mathrm{B} \quad$ Two rhyming elements appear in varying combinations in each stanza (H21: 25 Dec 87; R34: 20 Aug 93).

$\mathrm{A}+\mathrm{B}+\mathrm{C} \ldots$ Several rhyming elements appear in varying combinations in each stanza (N40: 2 Nov 90).

(R) A line is occasionally left unrhymed (H6: 17 Jan 86).

CDC, DCD Since the quatrains in all of Casal's sonnets follow an ABBA pattern, only the rhyme scheme of the tercets is described in this Table (H24: 13 Jun 86).

\begin{tabular}{|c|c|c|c|c|c|c|c|c|c|c|}
\hline \multirow[t]{3}{*}{ Period } & \multirow{3}{*}{$\begin{array}{l}\text { Total } \\
\text { no. of } \\
\text { poems }\end{array}$} & \multicolumn{9}{|c|}{ Syllables per line } \\
\hline & & \multicolumn{6}{|c|}{ Unimetric } & \multicolumn{3}{|c|}{ Polymetric } \\
\hline & & 8 & 9 & 10 & 11 & 12 & 14 & $8 / 4$ & $11 / 7$ & Other \\
\hline Hojas & 56 & 16 & 0 & 0 & 30 & 0 & 1 & 1 & 6 & $2^{(1)}$ \\
\hline Niev & 56 & 0 & 0 & 4 & 47 & 3 & 0 & 1 & 0 & $1^{(2)}$ \\
\hline Rimas & 45 & 4 & 1 & 2 & 28 & 7 & 2 & 0 & 1 & 0 \\
\hline Totals & 157 & 20 & 1 & 6 & 105 & 10 & 3 & 2 & 7 & 3 \\
\hline
\end{tabular}

(1)V2: hendecasyllables in 11. 1-48, alexandrines in 11. 49-68, hendecasyllables in 11. 69-76. H17: octosyllables in ll. 1-8, hendecasyllables + heptasyllables in 1l. 9-48, octosyllables in 1l. 49-56.

(2) V9: enneasyllables in 11. 1-24, octosyllables + tetrasyllables in ll. 25-31. 


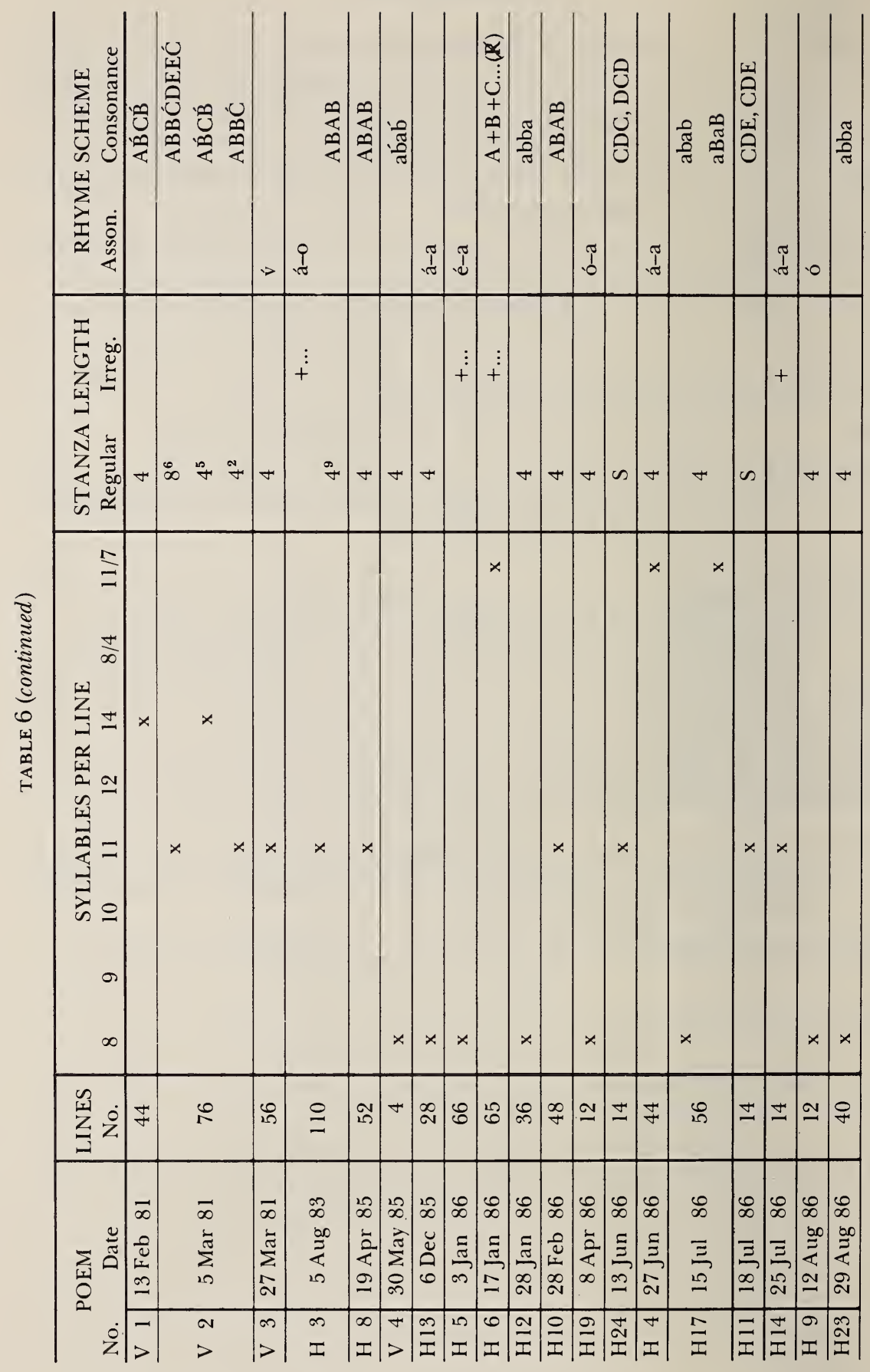




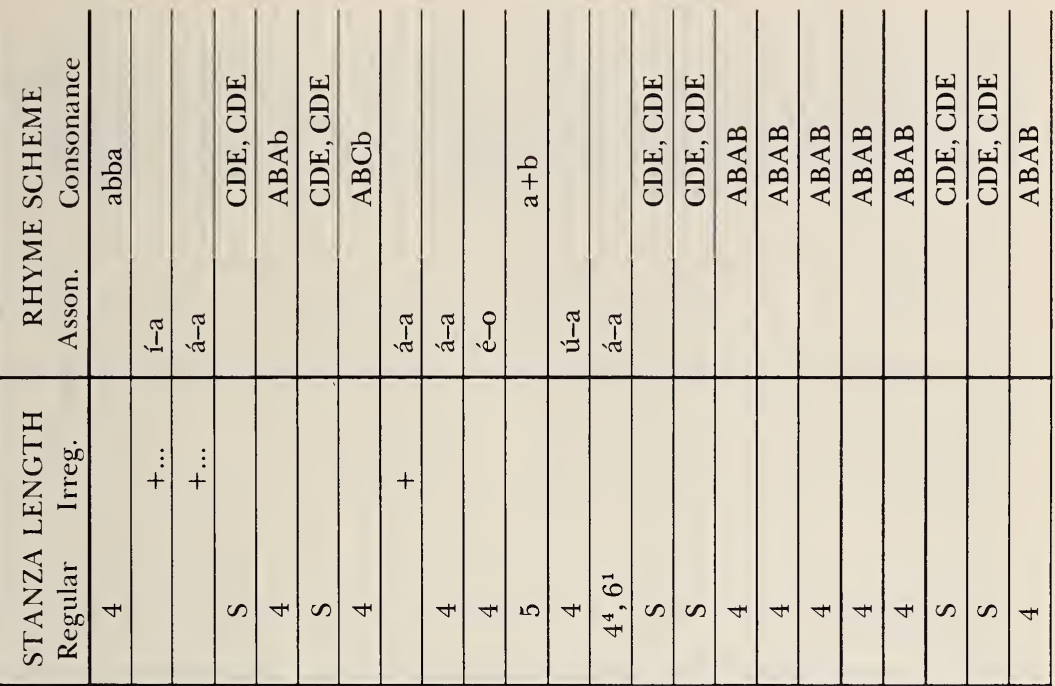

$\equiv$

$\star$

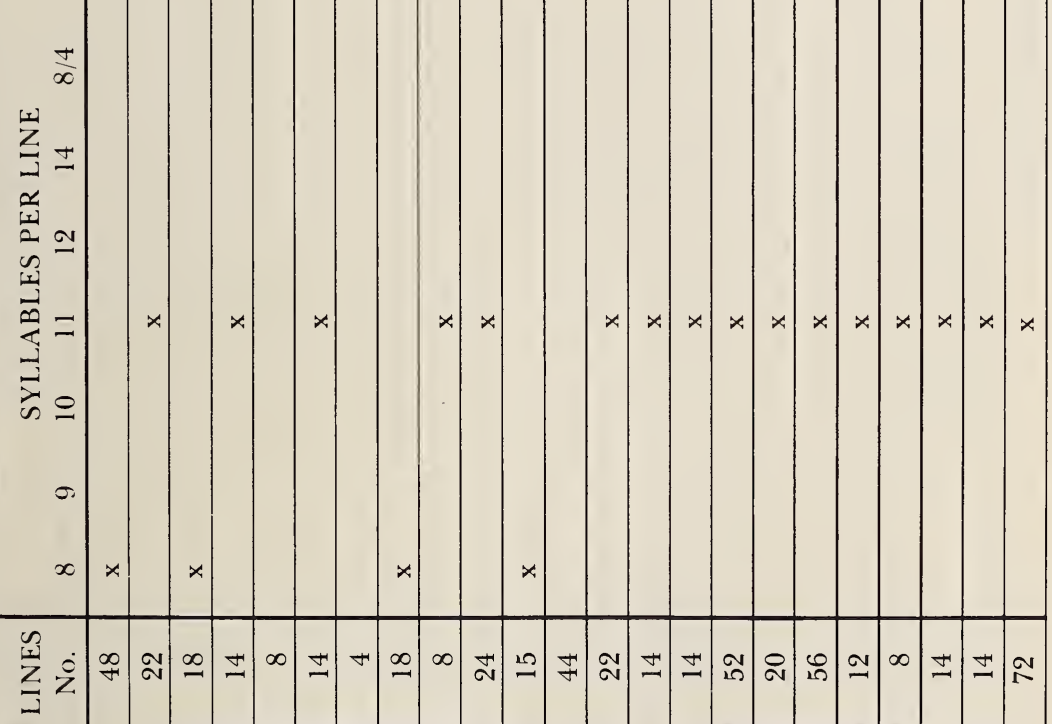

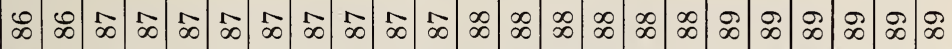

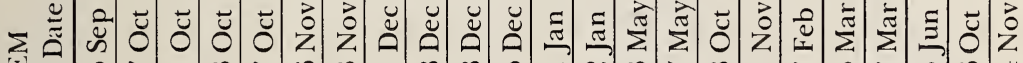

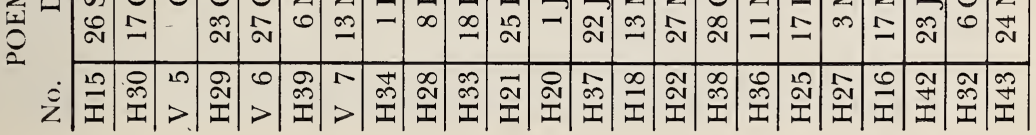




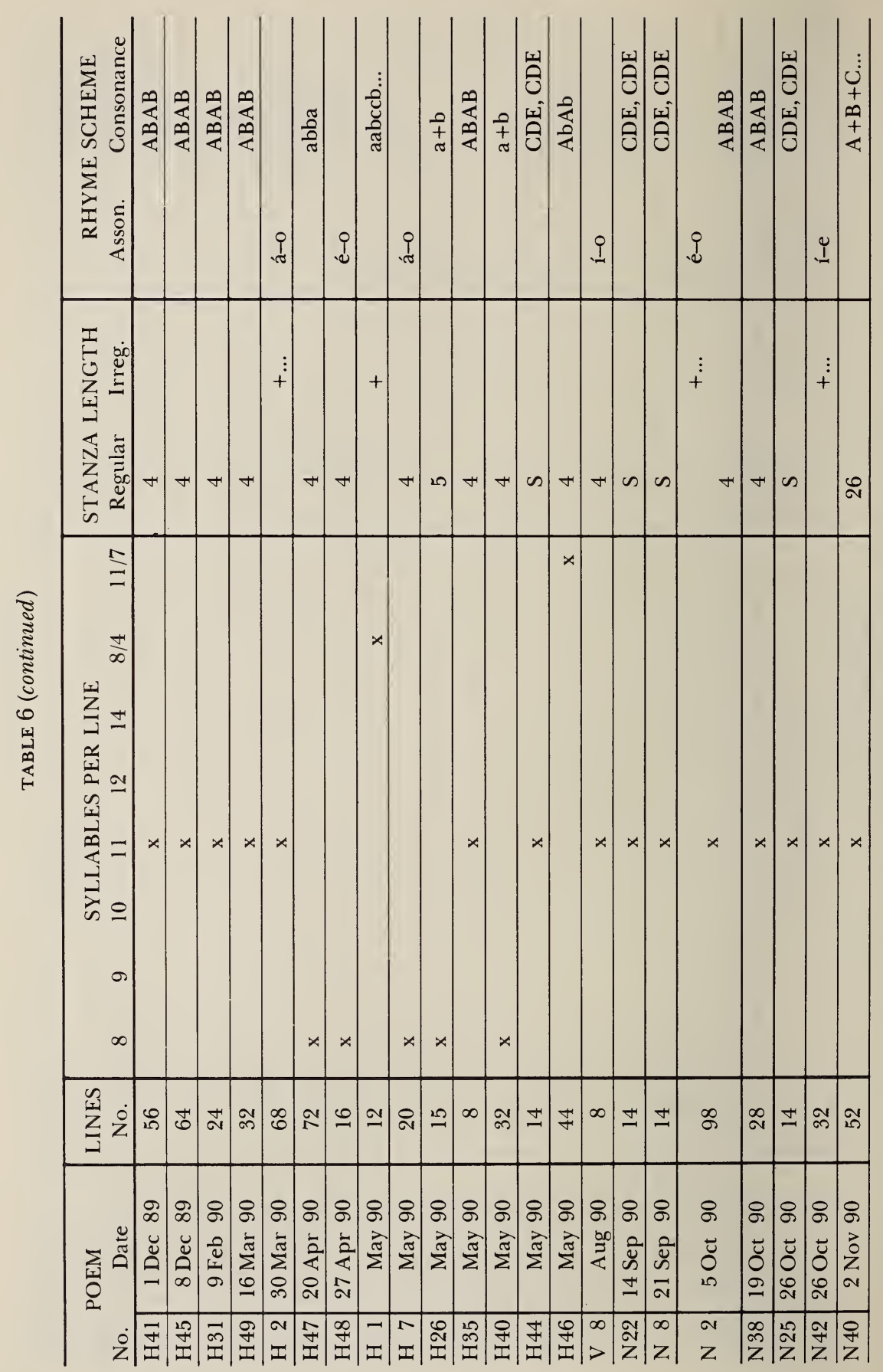




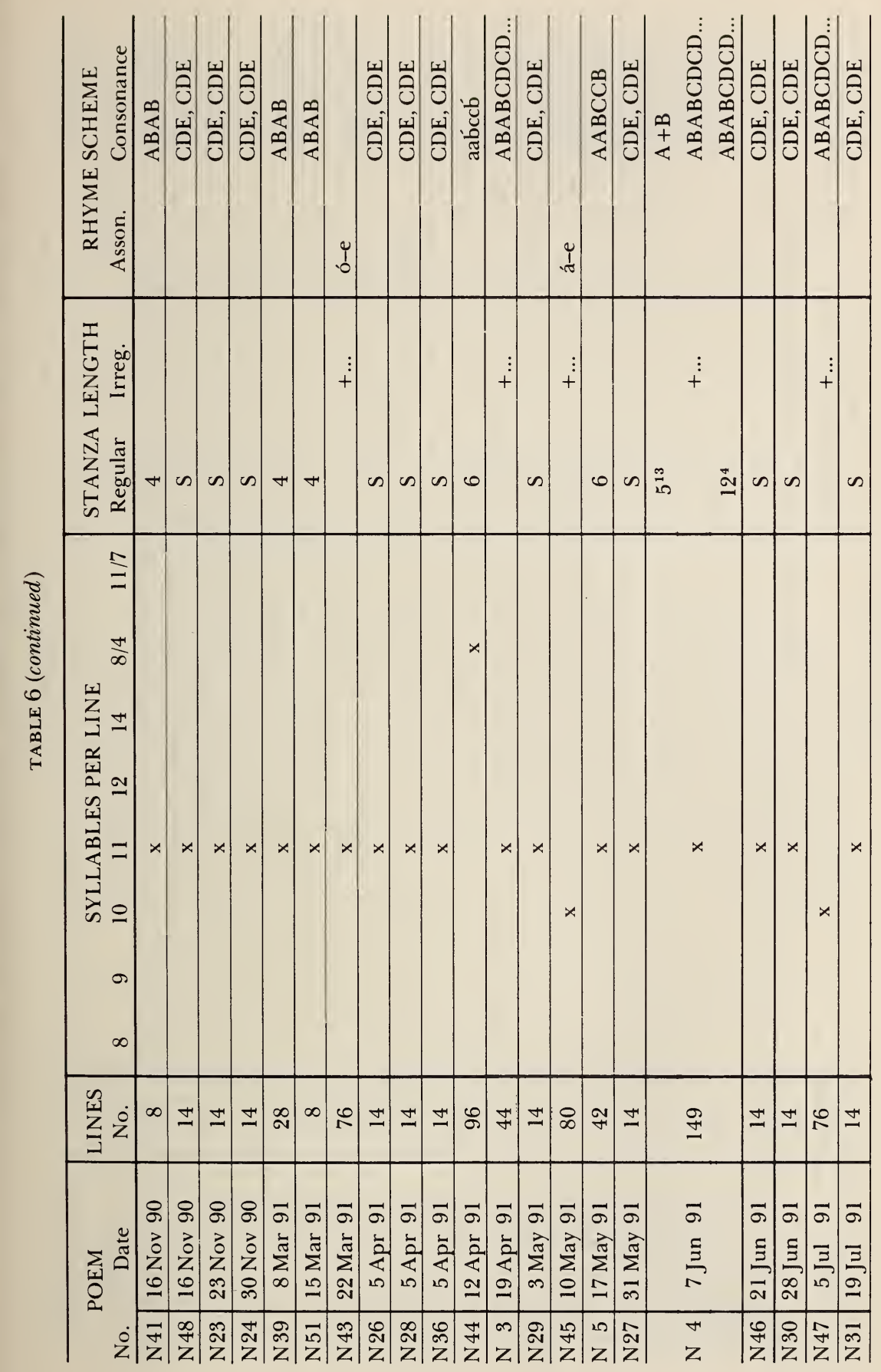




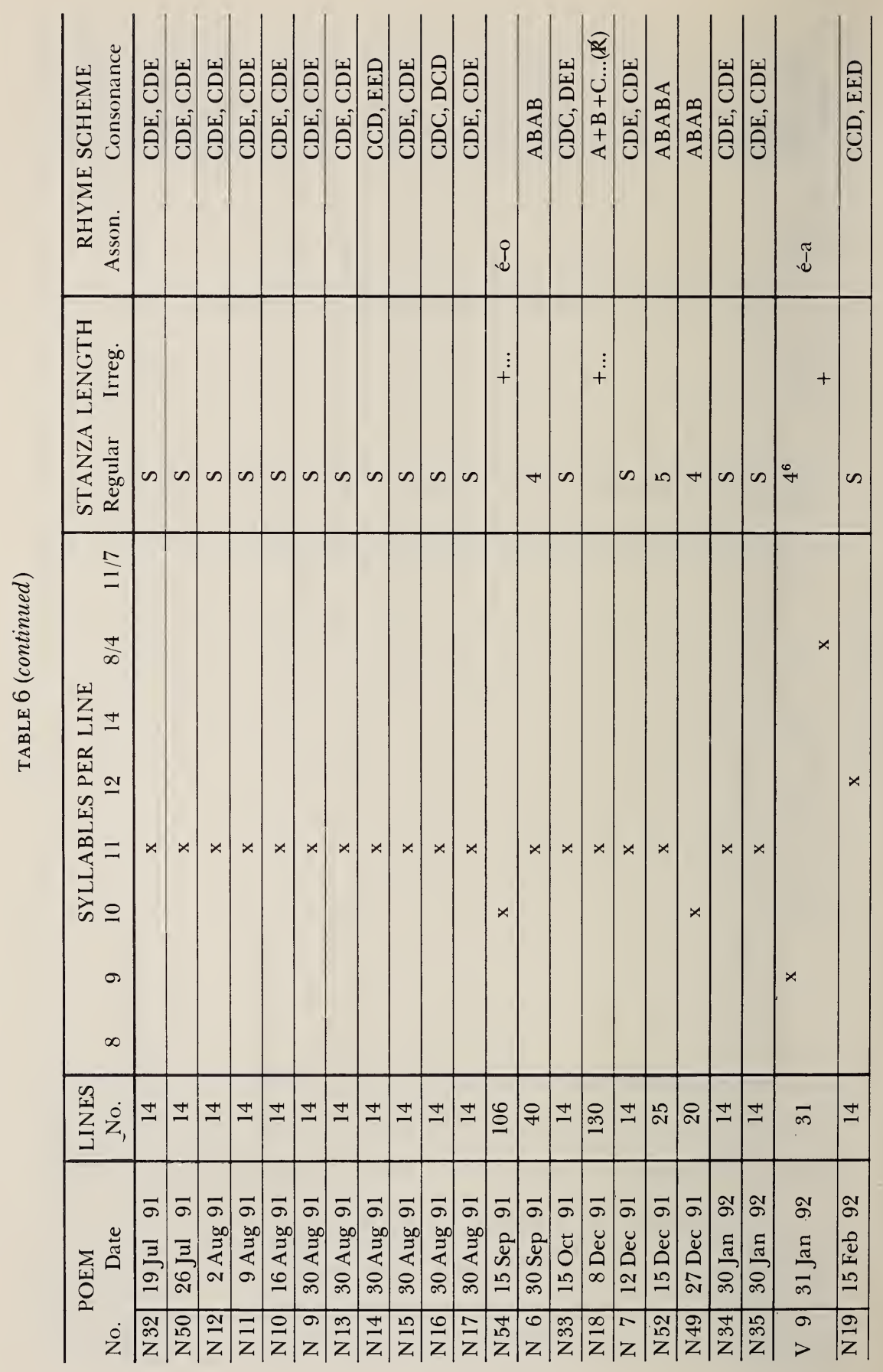




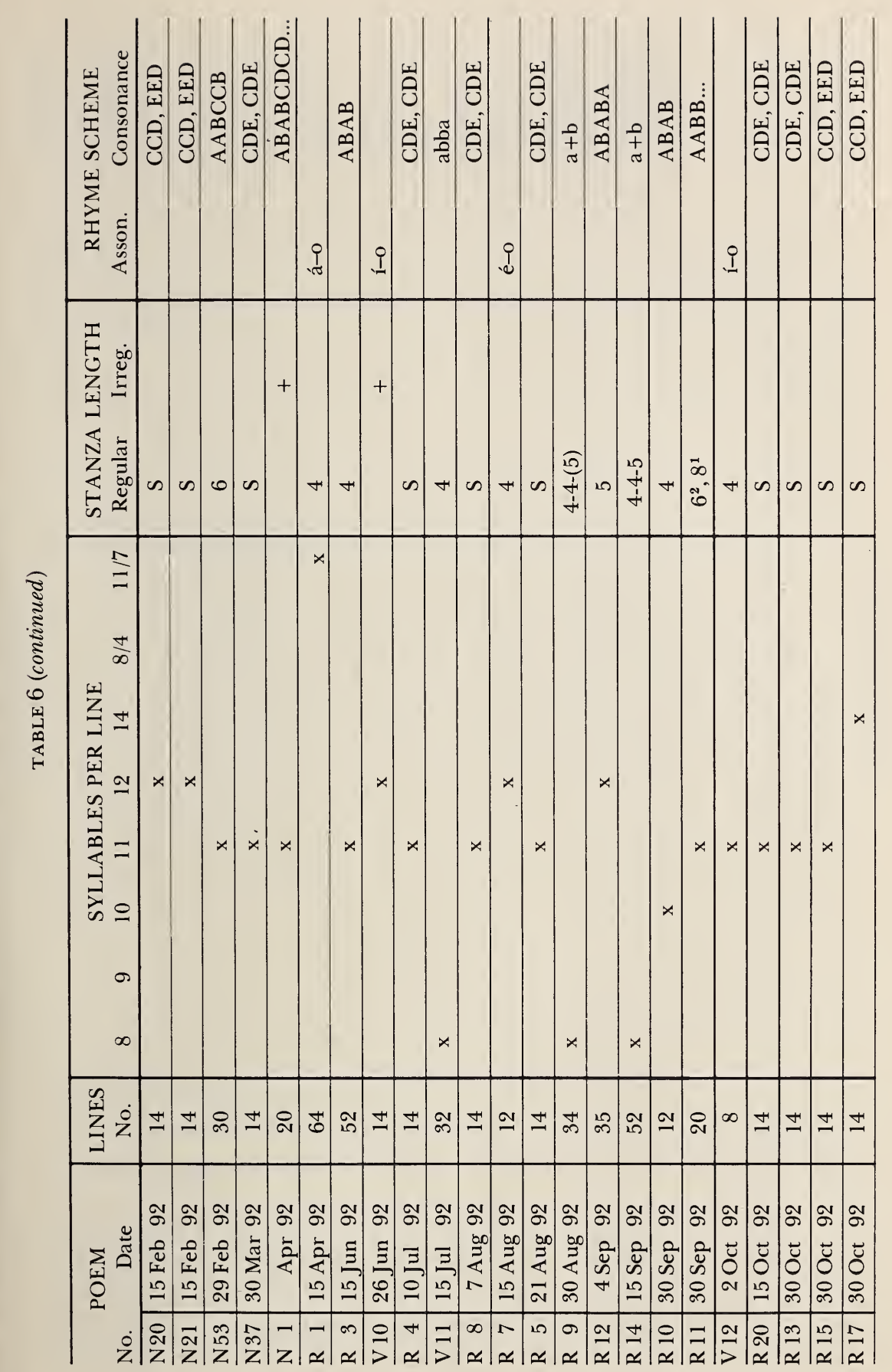




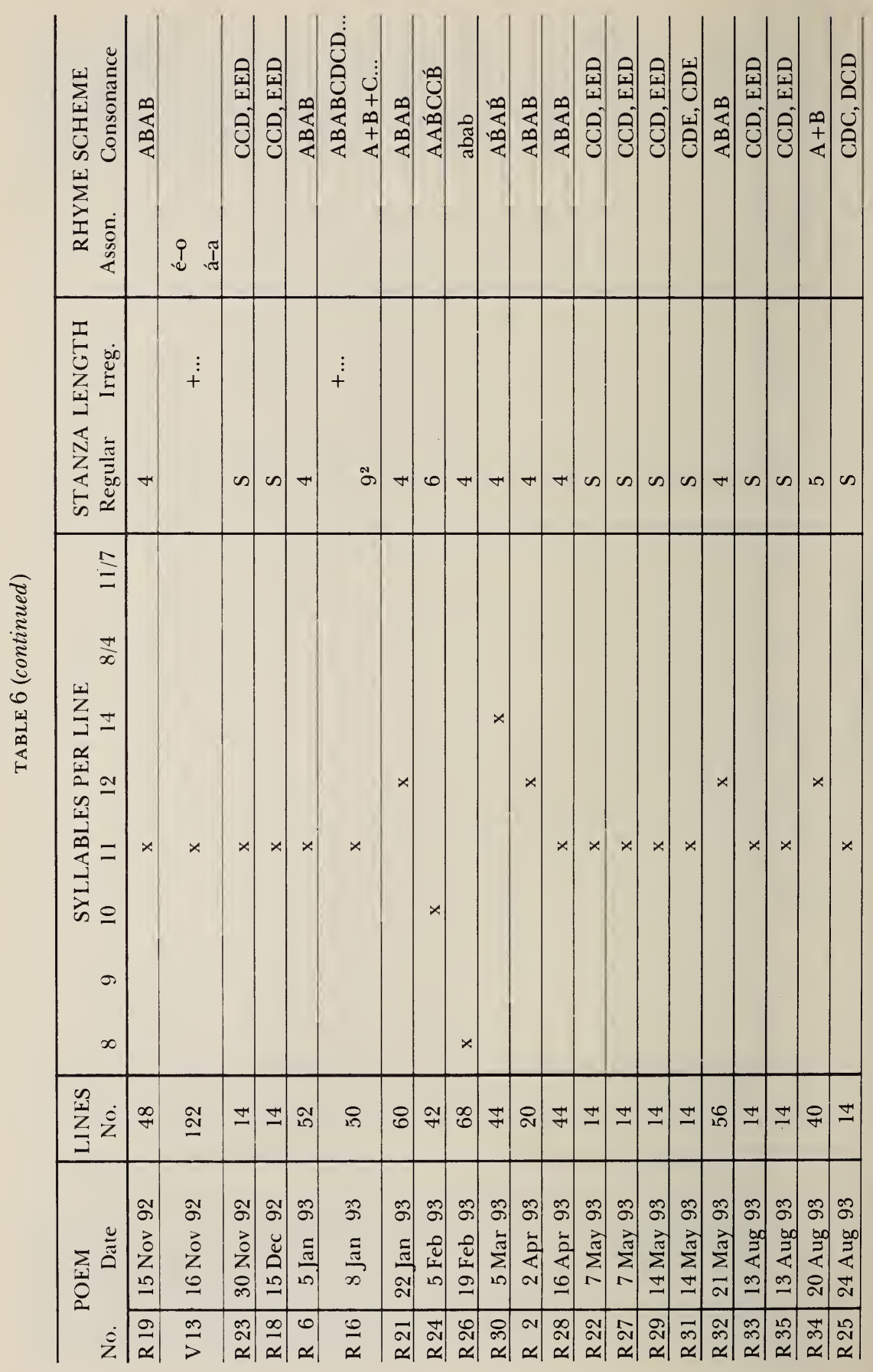




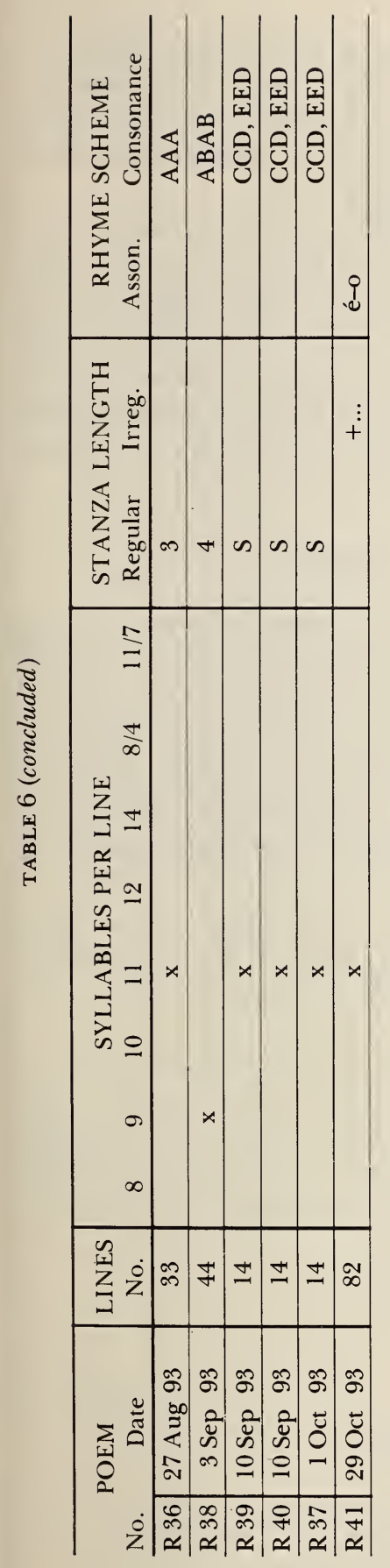




\section{R1: A LA BELLEZA}

This lengthy composition was first published in the 15 April 1892 issue of La Habana Literaria. Although the first verse in each stanza was not indented, stanzas were clearly delimited by the insertion of a blank space after every fourth line. This highlighted the fact that Casal had organized the poem into syntactical units of four lines each.

The poem was next printed in Rimas. ${ }^{1}$ In this version, the blank space between stanzas, though not suppressed, was reduced to the point where those unfamiliar with the format of the $H L$ version might easily overlook it. This is precisely what happened in versions that were published after Casal's death. Since I feel that the format of the original was purposefully designed to emphasize structure, I restore the $H L$ format in this edition. My only departure from the original is that I indent the first line of the poem. ${ }^{2}$

\section{R1: Notes to Introductory Statement}

1 The bibliography of the Ed. del Cent. (vol. III, p. 217) is incorrect in stating that this composition appeared in Nieve. Without indicating the year in question, the bibliography also indicates that "A la Belleza" came out on 21 January in $E l$ Pais. Cuban sources made it clear that the poem was not published on that date in 1892. They could not inform me, however, whether it was published on 21 January 1893. Whatever the case, the record of variants suggests that if such a printing exists, it cannot be very different from either of the versions $(H L$ or $R$ ) which I have examined.

2 For an analysis of this poem, see Louis Howard Quackenbush, "A la belleza," in Antología comentada del modernismo, ed. Francisco E. Porrata and Jorge A. Santana (Sacramento: California State University, 1974), pp. 167-170.

R1: VARIANTS

l. $H L$

* 2 santuario,

9 hablas,

13 encuentre,

15 enfermo sombra

$25 \operatorname{tas}$ [sic]

$34 \mathrm{mï}$ [sic]

* 38 mancillado,

40 lirio

$*$

46 temblando,

50 cristianos,
$R$

santuario

hablas

encuentre

enfermo,

sombra,

tus

mí

mancillado

lirios

temblando

cristianos
GLIC

$H L$ 
l. $H L$

54 antros,

57 arte regiones,

58 entreví

64 encontrado, [sic]
$R$

antros

Arte

regiones

encontré

encontrado.

\section{R1: Notes to Variants}

2: The comma of the $H L$ version has been restored in order to stress the vocative value of the utterance "Visión casta / de incógnito santuario ...."

38: Lines 38-39 are relative clauses whose antecedent is las almas (1. 37). Both clauses are introduced by que, which functions as a relative pronoun in the objective case in 1.38 , and which, in 1.39 , is the understood subject of surgen. Because of their relationship with las almas, these clauses are essential parts of the same thought unit. In addition, they function as the initial term of the simile which is completed in 1 . 40. Since the punctuation of the $R$ version makes these relationships clear on first reading, it is considered to be an improvement over the system used in $H L$.

40: In reality, 1l. 37-56 are components of a compound sentence whose constituents are "Yo te busqué" plus a series of complementary statements that answer the question "¿Dónde?" In view of this fact, it would seem logical to use a semicolon rather than a period at the end of each segment of the sentence (i.e., at the end of ll. 40, 44, 48, and 52). However, since no alternative punctuation is present in the $H L$ or $R$ versions, Casal's preference in this case seems clear and it is respected in the present edition.

\section{R2: CREPUSCULAR}

This oft-quoted work first appeared with the title "Vespertino" in the 2 April 1893 issue of La Habana Elegante. It should not be confused with the "Vespertino" of Nieve, which was first published by El País on 26 October 1890 (see N42). When preparing the poem for Rimas, Casal changed the title and made one lexical substitution in the text.

\section{R2: VARIANTS}

l. $H E$

$R$

GLIC

* 5 negras

húmedas

\section{R2: Note to Variants}

5: At first glance, this lexical change might seem to create a defective verse: that is, a line of thirteen syllables instead of twelve. However, on closer inspection of 
the grammatical and metrical structure of the poem, it becomes evident that Casal was not in error but was availing himself of a legitimate option in Spanish prosody. Each verse of "Crepuscular" was conceived in segments of 7 and 5 syllables. Because humedas is the last word before the expected pause in 1.5 , it can be treated in the same manner as any palabra esdrijula which occurs at the end of a verse or a hemistich. The reduction of humedas from three syllables to two automatically creates a verse of the proper length.

\section{R3: NIHILISMO}

Although Geada states that "Nihilismo" was published before 1888 (Selección de poesias, p. lviii), all other sources indicate that the poem first appeared in the 15 June 1892 issue of La Habana Literaria. Since Geada does not document his assertion, its accuracy cannot be verified. One thing may be said without question, however: from the moment that it came out in La Habana Literaria, "Nihilismo" managed to evoke intense reactions. On 16 June 1892, for example, Eugenio Sánchez de Fuentes ${ }^{1}$ wrote a poem showing his distress at Casal's pessimism. This response to "Nihilismo" appeared in the 30 June 1892 issue of La Habana Literaria:

\section{A JULIAN DEL CASAL, DESPUES DE HABER LEIDO SU POESIA “NIHILISMO”.}

\section{IMPROVISACION.}

iEres joven, muy joven, tus cabellos No cubre aún la nieve de los años, Ni las arrugas hondas y crüeles "Entreabierta te aguarda ya la tumba" Te gritan como a míl...... Pero no puedo Callar cuando tus versos aplaudidos Leo, y me asusta el desencanto horrible, La amarga hiel y escepticismo helado, Que a Byron y al autor del Intermezzo No cesa de pedir, Casal, tu musa.

-No, caro amigo; rasga ya las nieblas, Que en tu inspirada frente se amontonan;

iDeja latir tu corazón de fuego,

Sin que lo muerda el áspid de la duda, Que infelice te hará, y odiar la vida, 
iY blasfemar al fin!...... Fija tus ojos

En el límpido azul del firmamento,

Donde el nombre de Dios graban brillantes

Miriadas de estrellas en las noches

De este bendito Edén, de nuestra Cuba.

-Es la duda la puerta maldecida

Del dolor, de la hiel, de los martirios

Que sufren nuestras almas, más crüeles,

Mil y mil veces más, que los que un día

Soportaron innúmeros cristianos

De tigres y leones en las garras,

Allá en los circos de la antigua Roma,

De Cristo por la Fe..... iLa duda impía

Traer no puede entre sus negras alas

La clara luz de inspiración sublime!......

-Es amor, regalada y pura fuente,

Para aquel a quien Dios hizo poeta;

Mas no podrás beber la dulce linfa,

Si de una bella en el ardiente seno

No depositas de tu fe el tesoro......

iPorque amar es creer!...... ¿Y condenarte

Pretendes iay! al bárbaro tormento

De no creer en Dios, ni en las mujeres,

Ofendiendo, Julián, en tu locura

A la bendita sombra de tu Madre?......

-iAh, no es posible! Un vértigo espantoso

Hoy nubla tu razón; tu pluma ardiente,

Empapada en la hiel del infortunio,

Sin bañarse en los plácidos fulgores

De la divina fe, trazó los versos,

Cuyo fondo tristísimo una lágrima,

Arranca a tu leal y anciano amigo.

\section{E. SANCHEZ DE FUENTES.}

Habana 16 de Junio de 1892.

The same issue of La Habana Literaria carried a second response to Casal: it was composed on 19 June 1892 by Aurelia Castillo de González and represented a point of view noticeably different from that of Sánchez de Fuentes: 
Si indiferente, cual herida fiera, $L a$ voz oyes que vibra en tus oídos; Con alma henchida de emoción sincera Todos aquí escuchamos tus gemidos.

Huésped terrible que en tu pecho habita, Hace en tu corazón inmensa llaga;

Todas las flores para ti marchita, Y hasta el anhelo de vivir te apaga.

Y porque muere el sol y surge el rayo, Porque al panal deslízase el veneno, Porque hace presa el huracán en Mayo, $\mathrm{Y}$ dan fulgores de la luna en cieno;

Porque pétalos blancos de claveles Vuelan al agua del estanque impura, $Y$ la risa que finge cascabeles Concluye en alaridos de locura;

El te lanza extraviado en el delirio, $Y$, del buitre infernal de Prometeo Emulo vencedor, en tu martirio

$\mathrm{Ni}$ aun te deja las ansias del deseo.

Y a nadie extrañe su poder satánico Hasta en los campos de la guerra heroicos, Cuando se anuncia furibundo el pánico, Suelen palidecer los más estoicos.

Y el pánico en tu pecho alienta y manda. Infame, con dos lentes te circuye.

Convexa para el mal, siempre lo agranda;

Cóncava para el bien, lo disminuye.

¡Rompe esas lentes con viril coraje,

Y mira a ambos extremos con fijeza!

Y ni la dicha el corazón relaje,

$\mathrm{Ni}$ abatan los pesares tu entereza. 
De aquel maldito en el terrible asedio, Poeta y generoso, yaces triste.

Flor de un instante el bien, te causa tedio Porque absoluto en tu redor no existe.

iOh, no me taches de insensible y dura! iYo sé que el mal te aprisionó en sus lazos! iSé que se agita en ondas de amargura Tu pobre corazón hecho pedazos!

Alcanzo lo infinito de tus duelos. Nadie cual yo respeta tus dolores. iTú debiste nacer bajo otros cielos Alumbrados de eternos resplandores!

iPero nunca en la angustia que te ciega, Y reprimiendo apenas tus enojos, Digas que el luto de las sombras niega Quien siempre con la luz bañó sus ojos!

Que es fácil el valor en la fortuna; Que nace de la dicha la esperanza; Que alguien tuvo guirnaldas en su cuna Y alborozado por la vida avanza.

Tal que sonrisas muestra siempre iguales Y en cuya historia de venturas fías, ¿Quizás época tuvo en que tus males Quisiera para hacer sus alegrías!

¿Quizás la que paloma te parece, Acosada se vio cual las panteras! ¿Quizás la que al combate te enardece Luchó cual luchan las heridas fieras!

¿Por ella? ¿Por la vida? ¿Por un nombre? Siempre tales miserias tuvo en nada. Luchaba por los otros. Porque el hombre Su vida a los demás tiene obligada.

Mas si niegas la tuya, si tus manos Apartas con horror de estas cadenas, Siempre te oiremos con amor de hermanos. iSon tan bellos los himnos de tus penas! 
Y, aunque hoy delire de dolor transida,

Es pura el alma que anegada en lloro,

Dijo a la que murió por darle vida:

"Como quiera que estés siempre te adoro."

\section{AURELIA CASTILLO DE GONZALEZ}

Guanabacoa, 19 Junio 1892.

The following year, Ciriaco Sos Gautreau, Casal's most belligerent critic, published Julián del Casal o un falsario de la rima. In that pamphlet, Sos inserted a note concerning Da. Aurelia's reaction to "Nihilismo." The note read as follows: "La Sra. Da. Aurelia Castillo de González calificó de bellísima esta poesía en La Habana Literaria, pero como un escritor que firma Elindo manifestara, también por letras de molde, su inconformidad con semejante calificativo aplicado a una composición detestable, y señalara los defectos de que está plagada, rectificó su juicio Da. Aurelia, confesando en una carta dirigida a su contradictor, que en efecto la poesía Nihilismo no tiene nada de excelente."2 Because Ciriaco Sos did not reproduce the alleged letter in his pamphlet, it is impossible to determine the exact nature of $\mathrm{Da}$. Aurelia's second thoughts on "Nihilismo"-if indeed she had any. There is no doubt concerning Sos's opinion of the poem, however, for in his tirade against Casal, he included the following parody of the original composition:

\section{NIHILUM.}

Aunque vigor mi corazón pregone, esta inquietud que sin cesar me asedia, como tortura mórbida se impone con tétricos insomnios de tragedia.

La tumba, siempre al infortunio abierta, con ansiedad famélica me llama, y por la ruta donde voy, desierta, siento el clamor del huracán que brama.

Llévese el viento, en loco torbellino, el áspero rugir de mis querellas: ni un árbol que dé sombra en el camino, ni luz bajo el dosel de las estrellas!

Cuánto delirio palpitó en mi vida es un puñal agudo que me hiere: 
belleza que al deleite me convida, o se envilece en la saburra, o muere!

¿Por qué soñar delicia bienhechora, cuando si miro hacia el lejano monte, en vez de hallar el nimbo de la aurora, encuentro el tinte gris del horizonte?

Sueños! Sueños de amor! Sueños que un día me hablaron de una eterna venturanza . . . . . !

iAquí está la vorágine sombría y el sudario que envuelve mi esperanza!

Rosa del corazón, no abras tu broche en este ambiente de ponzoñas lleno! iAllá bajo del cielo, todo es noche! Aquí sobre la tierra todo es cieno!

Desconocida voz en la conciencia me repite con grito enfurecido: "para tu hondo dolor-iindiferencia!para tu enfermo corazón-iolvido!”-

Devórame si quieres con tus garras, horrible decepción que así me acosas: ven a mi alcoba y llévate las arras de tantas liviandades engañosas!

Nada! Nada! La niebla en el vacío, la obscura soledad con sus horrores, sin pájaros el bosque, seco el río, marchitas del jardín todas las flores!

Oh! la que fue mi adoración! Tenía como del mar la desbordada onda, rizos de espuma e intención bravía, ojos de tigre y cabellera blonda!

Aun recuerdo su pompa nauseabunda en lo que anima el exterior, lo humano; pero en el alma, podredumbre inmunda, los miasmas deletéreos del pantano!

Rango, promesas, ideales, todo cuanto quise con santa preferencia; gardenias que se hundieron en el lodo, sólo un instante disfruté su esencia.

Espíritu rebelde a lo divino, ya que no existe ese cariño eterno, a tu poder diabólico me inclino, sepúltame en los antros del Infierno! 
Y el espíritu dijo:-iPare el tango!

¿Qué aluvión de pinturas, camarada!

iNi usté ha visto gardenias en el fango, ni ha padecido decepción, ni....nada!

\section{JUAN DE LAS PEÑAS. ${ }^{3}$}

\section{R3: Notes to Introductory Statement}

1 Eugenio Sánchez de Fuentes (b. Barcelona, 15 November 1826; d. 1894) was elected to the honorary position of Académico Correspondiente by the Real Academia de la Lengua because of his contributions to XIX century Spanish letters. Since he frequently published material in local journals, the Cuban public was quite familiar with his work. On 15 May 1892, the following notice appeared in La Habana Literaria: "El ilustrado escritor y venerable anciano Sr. D. Eugenio Sánchez de Fuentes, ha coleccionado algunas de sus más bellas producciones, en un tomo que con el título de 'Risa y llanto' pondrá a la venta dentro de breves días" (p. 216). In August 1892, in preparation for the Columbus Day celebrations, Sánchez de Fuentes published a loa entitled iCuatro siglos después! This was performed in October at the "El Progreso" society of Sancti Spiritu, Cuba (see $H L, 30$ October 1892, pp. 192-193).

2 Julián del Casal o un falsario de la rima (Havana: Imprenta y Papelería "La Prensa," 1893), p. 8; Ed. del Cent., "Poesías," p. 373.

3 Sos, pp. 7-8; Ed. del Cent., "Poesías," pp. 374-375.

\section{R3: VARIANTS}
l. $H L$
2 la sombra
11 late,
14 fneron [sic]
23 asco
28 vivieron
39 [y]a
$40[\mathrm{y}] \mathrm{a}$
46 alcanzar
49 siento,
50 pobreza,

las sombras

late

fueron

tedio

vivisteis

[y]o

[y]o

ansiosa

siento

pobreza

\section{R4: MARINA}

This sonnet was first published in El Fígaro on 10 July 1892. The following dedication was printed below the title: "Para Juana Borrero. / pintora y poetisa." The date "(Julio 1892)" was given at the end of the 
poem. As the record of variants shows, "Marina" was published in Rimas with almost no changes in the text. Indeed, the biggest difference between the Rimas version and the original lies in the fact that Casal omitted the entire dedication when he prepared the poem for its 1893 printing.

\section{R4: Note to Introductory Statement}

1 For information on Juana Borrero, see my discussion of R34.

\section{R4: VARIANTS}

l. $F$

3 [y]rguese

5 mujer,
$R$

[í]rguese

mujer
GLIC

F

\section{R5: OBSTINACION}

This sonnet was originally published in Ecos de las Damas on 21 August 1892. Among other compositions which appeared on the same page was a poem by Eugenio Sánchez de Fuentes, who had criticized "Nihilismo" in La Habana Literaria two months earlier (see R3). One may assume that the majority of ladies who read the 21 August issue of Ecos de las Damas derived greater pleasure from the Sánchez poem than from "Obstinación," for while Casal was directing himself to a select minority, Sánchez was catering to the vulgar tastes of the average reader. This point will become clear if we compare the style and message of "Obstinación" with those of Sánchez' poem, the last stanza of which reads as follows:

No lo extraño; en Grecia y Cuba nunca una fea nació, y fue y será la Belleza siempre madre del Amor.

During his short career as a poet, Casal occasionally wrote poems of inferior quality, but seldom-if ever-did he descend to the level of Sánchez de Fuentes in this composition.

"Obstinación" came out a second time on 30 September 1892. On this date, it was printed in La Habana Literaria together with "La sotana" (R 10) and "Nocturno" (R11). The three poems were subsumed under the collective title "Poesías diversas." Among the changes which Casal made in this version was the correction of the metrical error in 1.9 of the original: by substituting sonador for señor, he brought the syllable count up to the required number.

On 7 October 1892, the editors of El País listed the contents of the 30 
September issue of La Habana Literaria and, as a sample item, reproduced "Obstinación" for their readers. The Rimas version, which came out a year later, differed only slightly from its predecessors.

R5: VARIANTS

\begin{tabular}{|c|c|c|c|c|}
\hline l. ED & $H L$ & $P$ & $R$ & GLIC \\
\hline 2 venas $[s i c]$ & venas; & & & \\
\hline 4 inmunda, & inmunda; & & & \\
\hline 7 tus & & & $E D$ & \\
\hline 8 hunda, & hunda; & hunda. [sic] & $H L$ & \\
\hline $\begin{array}{l}9 \text { es, } \\
\text { señor! }\end{array}$ & $\begin{array}{l}\text { es } \\
\text { soñador! }\end{array}$ & & & \\
\hline 10 carrera, & & & & carrera; \\
\hline 11 [p]ero & [p]ero, & & & \\
\hline $\begin{array}{r}\text { la voz con que } \\
\text { la nombra }\end{array}$ & $\begin{array}{r}\text { esa ley que tu alma } \\
\text { asombra, }\end{array}$ & & & \\
\hline quimera & quimera, & & & \\
\hline
\end{tabular}

\section{R6: BOHEMIOS}

Esperanza Figueroa ("Bibliografía de Julián del Casal," p. 38) and the Ed. del Cent. (vol. III, p. 220) indicate that "Bohemios" was first published on 5 January 1893 in La Habana Elegante. Unfortunately, Cuban library sources which I consulted did not have that issue of the journal in their holdings. For this reason, the version given in my edition is based exclusively on the one found in Rimas.

"Bohemios" is of interest primarily because it exposes an important area of the poet's system of values. Among the people whom Casal admired most were those who steadfastly sought to realize a dream, no matter what it might cost them in physical discomfort or in mental anguish. Casal's admiration was based on the fact that, unlike himself, the bohemian wanderers described in this poem were not only able to withstand all the attacks that a hostile environment could launch against them, but were also unhampered by the kind of innate irresoluteness which makes fidelity to an ideal fundamentally impossible. To be all of one piece is what Casal desired most as the years went by; to be ever more fragmented by indecision is the tragic fate that life held in store for him.

\section{R7: SOURIMONO}

This short composition was originally published in the 15 August 1892 issue of La Habana Literaria. The title - written according to the rules of 
French, rather than Spanish, orthography - was followed by a dedication which read: "(Para un abanico de la señora de Valdivia)." The lady referred to here was probably Concepción Huidobro, the wife of Aniceto Valdivia and the mother of Serafina Valdivia y Huidobro. ${ }^{1}$ When Casal prepared "Sourimono" for Rimas, he suppressed the $H L$ dedication, corrected two typographical errors that had marred the original, and made three lexical changes whose apparent function was to elevate the tone of the affected lines to the level maintained elsewhere in the poem.

The most extensive statement about Casal's reaction to the wave of orientalism that reached Cuba towards the end of the nineteenth century is to be found in Ramón Meza's article "Julián del Casal." Recalling his visits to the poet's room behind the editorial of fices of La Habana Elegante, Meza says:

Fue la época de su admiración hacia todo lo que procedía del país del marfil, del sándalo y del crisantemo. Quiso rodearse, penetrarse, saturarse de las sensaciones reales voluptuosas de aquella exótica y lejana civilización. Leía y escribía en un diván con cojines donde resaltaban como en biombos y ménsulas y jarrones, el oro, la laca, el bermellón. En un ángulo, ante un ídolo búdico ardían pajuelas impregnadas de serrín de sándalo. Transformó aquel rinconcillo en la morada modesta, pero auténtica, de un japonés. En los cuadros, de fondo azul, y mar más azul aún, volaban en bandadas interminables, grandes grupos de aves blancas, de pico rojo, de largas patas, al través de pagodas, de ciénagas orilladas de bambúes, de juncos conduciendo sobre nubes parejas jóvenes de carillas de marfil.

Se abanicaba leyendo en el diván, perdida la noción del tiempo y olvidado de la necesidad de alimentación. Amaba las flores; habíase formado un jardín ideal en que entraban como ornamento preferente el crisantemo, la ixora, amarylis, myosotis, el ilang, los clorilopsis... Preocupábanle asuntos como éste: si la Princesa Nourjihan, en el imperio del Gran Mogol, fue la que descubrió el perfume sacado de la esencia de las rosas y le adoptó por favorito.

Guy de Maupassant y Pierre Loti abrieron ante su fantasía, como en bella aurora, las puertas del Oriente, poniendo ante sus ojos admirados el esplendor deslumbrante de los templos budistas cargados de soles de oro, radiantes de pedrería incrustada en ébano, nácar, marfil y plata; los jardines de arbolillos enanos, de lagos con kioskos octogonales de armadura de bambú, y palacios defendidos por laberintos de flores.

Teófilo Gautier le seducía. No poco esfuerzo costó disuadirle de sus propósitos de salir por las calles de la Habana en piyama lujosa, recamada de oro, como aquél por las de París, 
en traje raro. Creo que más fuerza tuvieron para lograrlo, las sugestiones irónicas y regocijadas de jóvenes de inalterable buen humor, entrevistas a tiempo por el poeta, que nuestros consejos desinteresados y discretos.

$\mathrm{Su}$ inspiración estaba entonces allá, en aquel lejano y fantástico país de leyendas nuevas y raras, de grandes trágicos, ágiles atletas y de mujeres que recogían su abundante cabellera negra con grandes clavos de oro. ${ }^{2}$

Casal's interest in oriental objects and motifs was not a unique phenomenon; the fact is that the last twenty-five years of the nineteenth century was a period when, for the first time in history, East and West came into close political and economic contact. As a result, a considerable number of Eastern motifs entered the mainstream of Occidental culture. This can be documented by a study of contemporary periodicals in all nations of the West. Indeed, even a colonial outpost like Cuba felt the impact of $f i n d e$ siglo orientalism. In Havana, for example, there were shops where one could easily purchase items such as the dorado pebetero oriental which Casal mentioned in the initial paragraph of "Manuel Reina" (HE, 20 December 1885) $;{ }^{3}$ the jarrones chinescos, ornados de figuras y animales fantásticos to which he referred in Chapter XIII of La Sociedad de la Habana (HE, 24 June $1888) ;{ }^{4}$ the buicaro japonés which he described at length in "Japonería" $(D$, 2 April 1890); ${ }^{5}$ the tapices orientales and porcelanas japonesas to which he alluded in one of his "Crónicas semanales" $\left(P, 2\right.$ November 1890); ${ }^{6}$ and the colorful biombo japonés which he saw among the wedding gifts received by Enrique Hernández Miyares and Francisca Marty $(P, 30$ November 1890). ${ }^{7}$ Local sources also indicate that operettas like El Gran Mogol were as popular in Cuba as elsewhere in the West ${ }^{8}$ that spectaculars such as the Circo Oriental were immediate sellouts in Havana, ${ }^{9}$ and that interest in the Orient was extensive enough for bookstores to have ordered several copies of Louis Gonse's L'Art japonais (Paris: Quantin, 1883) ${ }^{10}$ and an even larger number of Pierre Loti's Madame Chrysanthème. ${ }^{11}$ In addition, contemporary documents show that officials of Oriental countries were present in Cuba and entertained with a fair degree of regularity. Therefore, it is not surprising to find Casal, in his capacity as society columnist for $L a$ Discusion, attending a gathering at the home of Tam-Kin Cho, Consul General of China. The following is part of the report which Casal published on 21 April 1890: "Luego llegué a reconocer, en medio de esa masa compacta, luminosa y ondeante, a los señores agregados Tso-Sim, vestido de amarillo anaranjado y azul celeste; a Tam-Chan, de gris perla y verde Nilo; y a Sing-Sang, de azul Prusia y amarillo de ámbar, quien ha alcanzado el título de maestro y cuya faz tiene el color amarillento de los libros sagrados que tiene incesantemente abiertos ante sus ojos. ... Durante el intermedio, las parejas se refugiaban, ora en el cuarto de Tam-Kin Cho, donde admiraban los primores del arte chino; ora en el de Sing-Sang, 
donde el sándalo chisporroteaba en los pebeteros; ora en el de Tso-Sim, donde se oía música celeste; ora en el comedor, donde había todo lo que el estómago más exigente y más refinado podía apetecer." ${ }^{2}$ Among the guests of Tam-Kin Cho was the lovely María Cay, who, the following year, would cause a sensation in her exquisite Japanese costume and would inspire Casal to write the famous "Kakemono" (see my discussion of N43).

The art objects, stage shows, books, and personages that have just been mentioned were not creations of Casal's imagination. Quite the opposite: they were part of everyone's life at the end of the nineteenth century. ${ }^{13}$ If oriental elements were found in the real world, it should not seem extraordinary to find them, together with elements from other cultures, in Casal's work too. A representative mixture of such items may be seen in "Neurosis" (R24), where Casal recreates a fin de siglo boudoir that is rather typical because of the cosmopolitan nature of its furnishings, and also in "Nostalgias" (N44), where the poet, seeking escape from the oppressive world in which he lives, speaks of the Orient as only one of several ideal regions that have captured his imagination.

Occasionally, a chance visit would bring oriental motifs into special prominence. For example, when Rubén Darío stopped in Havana in the summer of 1892, he was invited with Casal to the home of Raoul Cay, where there was an impressive collection of Chinese and Japanese art objects: "Primero las distinciones enviadas al Sr. Cay por el gobierno del gran imperio: los parasoles, los trajes de seda bordados de dragones de oro, los ricos abanicos, las lacas, los kakemonos y surimonos en las paredes, los pequeños netskes del Japón, las armas, los variados marfiles. Julián del Casal ... gozaba con toda aquella instalación de preciosidades orientales: se envolvía en los mantos de seda, se hacía con las raras telas turbantes inverosímiles ...." ${ }^{14}$ Less than two weeks after Darío's departure for Spain, Casal published "Sourimono" in the fortnightly journal $\mathrm{La}$ Habana Literaria. Although no information is available concerning the genesis of the poem, it is quite possible that Casal composed it while Darío was still in Havana. Indeed, he may even have been inspired to write the poem by an experience that he had while he and Darío were at the home of their friend Raoul. After all, as Darío pointed out in his article, there were surimono on the walls of the Cay residence.

The term surimono literally means "printed thing." As commonly used, however, it signifies a wood-block print. In The Prints of Japan, Frank A. Turk indicates that "Surimono represent the acme of the printer's and engraver's art." 15 They are done on the finest quality paper, utilize the full range of the printer's colors, and sometimes include such refinements as metal powders and mother-of-pearl. Surimono are generally used to convey personal greetings on festive occasions such as New Year's Day. Sizes vary greatly, but probably the most popular of all is the kakuban, which is about $18 \mathrm{~cm}$. $x 21 \mathrm{~cm}$. Most of the designs are of the still life variety. This allows the artist "to render textures to a degree which, had such prints not 
been known, one might have thought impossible for the technique of wood-engraving." 16 In spite of this preference for still life, a fair number of surimono represent figures and landscapes (see Plate 43). Although Casal created a surimono of the latter variety, it is impossible to determine whether his source of inspiration was a print that showed a single landscape, whether it was a composite of two or three scenes, or whether it was a set of prints each containing a separate scene. Whatever the case, "Sourimono" has defects for which Casal alone was responsible: Japanese prints generally show cranes, not flamingos (1. 2), and subir is a verb that cannot logically be used to describe the movement of a sol poniente (11. 5-6).

\section{R7: Notes to Introductory Statement}

1 A photograph of the Valdivia family may be found in the Ed. del Cent., vol. II. Casal had published a poem about little Serafina in the 26 June 1892 issue of $E l$ Fígaro, but did not see fit to include it in Rimas (see V10).

2 Ed.del Cent., "Poesías," pp. 225-226.

3 Ed.del Cent., vol. I, p. 179.

4 Ed.del Cent., vol. I, p. 152.

5 Ed.del Cent., vol. II, p. 97.

6 Ed.del Cent., vol. III, p. 21.

7 Ed. del Cent., vol. III, p. 42.

8 Ed. del Cent., vol. II, pp. 106-108.

9 Ed. del Cent., vol. II, pp. 121-122.

10 Casal's review of this work by Gonse (b. Paris, 1846; d. Paris, 1921) appeared in La Discusión on 17 June 1890; it is reproduced in Ed. del Cent., vol. II, pp. 157-159.

11 Casal found one copy in the boudoir that he described in his "Crónica semanal" of 23 November 1890 (originally published in ElPais; reproduced in Ed. del Cent., vol. III, p. 39). Madame Chrysanthème, a novel in which the plot was a pretext for presenting a series of exotic cuadros of Japan, was published in 1887 by Louis-Marie-Julien Viaud (b. Rochefort, 16 January 1850; d. Hendaye, 10 June 1923). Viaud, who is more commonly known by his pseudonym, Pierre Loti, joined the navy at the age of seventeen and served for many years in the Far East. The nickname Loti was given him by his comrades because of his shyness: the lot is a small Indian flower which symbolizes timidity, as the violet does in our culture.

12 Ed.del Cent., vol. II, pp. 110-111.

13 See Casal's descriptions of a painter's study and a lady's apartment in Ed. del Cent., vol. I, pp. 152 and 163-164, respectively.

14 From "El general Lachambre: Recuerdo de la Habana" (La Nación of Buenos Aires, 7 March 1895), as reproduced by Monner Sans, pp. 248-249.

15 The Prints of Japan (Worcester and London: Arco, 1966), p. 232.

16 Ibid., p. 236. 
PLATE 43

Two Surimono of the Kind that Inspired Casal

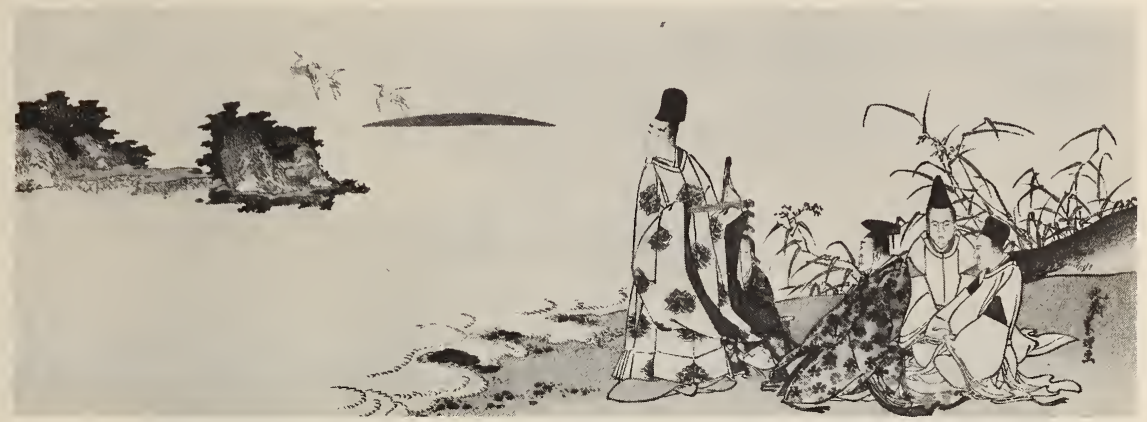

Katsushika Hokusai, Surimono. Courtesy of The Museum of Fine Arts, Boston.

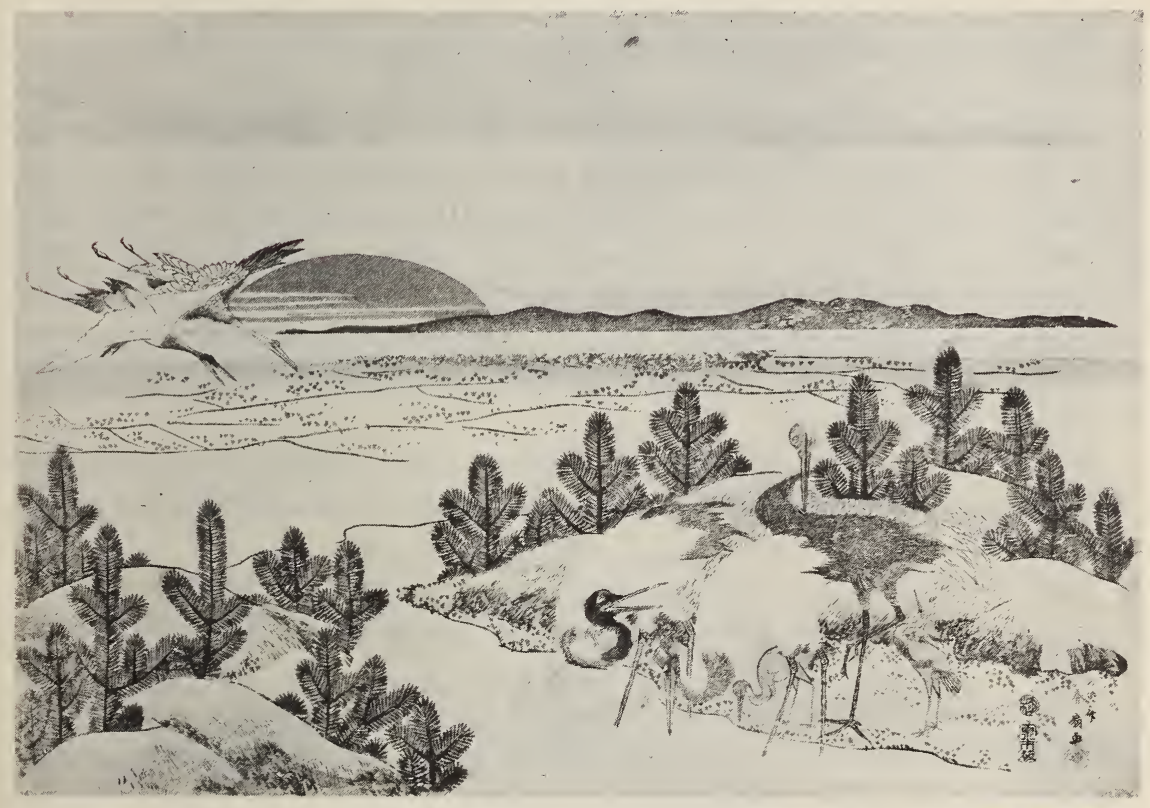

Katsukawa Shunsen, Ukiyoe. Courtesy of The Tokyo National Museum. 


\section{R7: VARIANTS}

l. $H L$

* 3 [p]oplando [sic]

* 6 cubre.[sic]

7 levanta

8 muerto.

12 buques
$R$

[p]oblando

sube

desprende

yerto.

esquifes

\section{R7: Note to Variants}

3, 6: A fortnight after "Sourimono" came out in $H L$, the editors informed their readers that poplando and cubre were errata which should be corrected to poblando and sube ("Notas y Noticias," HL, 30 August 1892, p. 95).

\section{R8: COQUETERIA}

This sonnet was first published in the 7 August 1892 issue of El Figaro. The date "(Agosto, 1892)" was printed beside the author's name at the end of the poem. On 9 August 1892, "Coquetería" was reproduced by $E l$ Pais. Immediately before the poem, there appeared a summary of the contents of El Figaro. In one of the paragraphs of that summary, the editors made reference to Rubén Darío. Their comment proves that Darío visited Havana in the summer of 1892 on his way to the quadricentennial celebrations in Spain: "La nota artística raya a gran altura: un retrato magnífico, debido a Torriente del inspirado Rubén Darío, que nos ha visitado últimamente...."1

As shown by the record of variants, the definitive version of "Coquetería" which Casal published in Rimas was virtually the same as the original version.

\section{R8: Note to Introductory Statement}

1 For further information on Darío's visits to Cuba in 1892, see my discussion of R21. The artist mentioned in the ElPaís note was Ricardo de la Torriente y Torriente (1867-1934). Torriente, who had studied for several years in French and Spanish schools, returned to Cuba after receiving the bachelor of arts degree. He worked for a while on the staff of the Matanzas journal El Album and then moved to Havana, where he gained renown as caricaturist for El Figaro. Examples of his work may be found in vols. I and III of the Ed. del Cent.: of principal interest are the pictures of Carlos Norena, Ezequiel García, Ricardo del Monte, Esteban Borrero Echeverría, and José Fornaris which are reproduced in vol. I. After General Valeriano Weyler's Reconcentration Decree was put into effect (1896), Torriente emigrated to New York. There, he worked as a cartoonist on such 
prominent newspapers as The Journal, The Herald, and The World. In 1900 when peace returned to Cuba, Torriente ended his exile. Besides devoting himself to journalism (he established his own paper, La Política Cómica, in 1906), he taught classes in art at the Escuela Nacional de Pintura y Escultura. Although he was competent in oils, his best works were portraits done in pencil. As a cartoonist, he was most widely known as the creator of Liborio, a humorous figure purporting to voice the opinion of Cuba's average man on important issues of the day.

R8: VARIANTS

l. F P

$R$

GLIC

12 mano,

mano

\section{R9: RONDELES}

"Rondeles" first came to public attention when it was printed in the 30 August 1892 issue of La Habana Literaria. The poem was organized into three sections. These had the following characteristics in common: each section was headed by a Roman numeral, was formed of two cuartetas and a quintilla, and was composed of verbal elements some of which were repeated in each stanza of the section. With respect to the last-mentioned feature, the common elements of Parts I and III were placed in the last two verses of each stanza, while those of Part II were distributed according to a less rigid pattern (see the italicized lines in the version which follows):

De mi vida misteriosa

Tétrica y desencantada,

Oirás contar una cosa

Que te deje el alma helada.

Tu faz de color de rosa

Se ha de quedar inmutada,

$\mathrm{Al}$ oir la extraña cosa

Que te deje el alma helada.

Mas sé para mí piadosa

Si de mi vida ignorada,

Cuando yo duerma en la fosa,

Oyes contar una cosa

Que te deje el alma helada. 
Quizás sepas algún día

El secreto de mis males,

De mi honda melancolía

Y de mis tedios mortales.

Las lágrimas á raudales

Marchitarán tu alegría,

Si á saber llegas un día

El secreto de mis males.

(21a) Deja que mi alma sombría

(21b) Por las rutas terrenales

(21c) Vaya hoy sin rumbo ni guía...

(21d) iQuizás sepas algún día

(21e) El secreto de mis males!

III

Quisiera de mí alejarte, Porque me causa la muerte,

Con la tristeza de amarte

El dolor de comprenderte.

Mientras pueda contemplarte

Me ha de deparar la suerte,

Con la tristeza de amarte

El dolor de comprenderte.

Y sólo ansío olvidarte,

Nunca oirte y nunca verte,

Porque me causa la muerte,

Con la tristeza de amarte,

El dolor de comprenderte.

The Rimas version of "Rondeles" differs in two respects from its predecessor. On the one hand, it incorporates a few minor changes in punctuation and wording. On the other, it is shorter than the $H L$ original by one whole stanza (ll. 21a-21e). It is impossible to determine with certainty whether Casal wanted the stanza to be suppressed or whether someone involved in the preparation of Rimas left it out by mistake. The latter possibility is supported by the fact that Casal used a 4-4-5 stanza pattern without variation in "Vieja historia" (R14), but this alone is not sufficient evidence on which to build a case for unintentional omission. 
Whatever the cause of the omission, its value is debatable. On the positive side, suppression of the quintilla meant the elimination of a stanza that was syntactically and rhythmically different from all the others in the poem. That is, while every other stanza presented an unbroken flow of thought, this one divided the thought into two distinct sentences (ll. 21a-21c, 21d-21e). On the negative side, omission of the quintilla destroyed the overall structural congruity of the parts, which typified the original version. Instead of having three parts each subdivided into a 4-4-5 pattern of verses, the poem acquired a new structure: 4-4-5, 4-4, 4-4-5. One of the results was that, in Rimas, the title "Rondeles" tended to expose the poem's structural irregularities ${ }^{1}$ rather than to obscure them as it had in the $H L$ version.

\section{R9: Note to Introductory Statement}

1 One of these - the irregular pattern of word repetition - has already been mentioned. Another is the inexplicable departure of $11.18-21$ and 30-34 from the rhyme pattern of the other cuartetas and quintillas in the poem.

\section{R9: VARIANTS}

\section{l. $H L$}

1 misteriosa

6 [s]e ha de quedar inmutada,

9 piadosa

* 21

23 muerte,

32 muerte,

33 amarte,
$R$

misteriosa,

[s]e quedará demacrada, piadosa,

muerte

muerte

amarte

\section{R9: Note to Variants}

21: In the $H L$ version, there was a five-line stanza following 1. 21. The text of this stanza is reproduced in my introduction to the poem.

\section{R10: LA SOTANA}

This poem was first published in the 30 September 1892 issue of $L a$ Habana Literaria. On this occasion, it was printed under the heading "Poesías diversas" together with "Obstinación" (R5) and "Nocturno" (R11). Casal made no changes in "La sotana" when he included it in Rimas. 


\section{R11: NOCTURNO}

This poem was first published in the 30 September 1892 issue of $\mathrm{La}$ Habana Literaria. It was printed with "La sotana" (R10) and "Obstinación" (R5) under the heading "Poesías diversas." In this version, the last stanza was set off from the two preceding ones by a cluster of asterisks. In Rimas, the asterisks were suppressed and minor changes were made in punctuation and wording.

\section{R11: VARIANTS}

$\begin{aligned} \text { l. } & H L \\ 4 & \text { misteriosas } \\ 7 & \text { estela, } \\ 18 & \text { suave } \\ 19 & \text { su }\end{aligned}$

$R$

GLIC

misteriosas,

estela

suave,

el

\section{R12: RECUERDO DE LA INFANCIA}

"Recuerdo de la infancia" was first published in the 4 September 1892 issue of El Fígaro. The date "(Septiembre, 92)" was printed after the text. This composition is especially interesting because of its formal similarity to "Canas" (N52), which appeared in the winter of 1891. Although both poems are composed of five-line stanzas and utilize the same kind of ritornello device, "Recuerdo de la infancia" is conceptually and structurally more complex than "Canas." In certain instances, the tendency towards greater complexity improves the quality of a poet's work. In the case of "Recuerdo de la infancia" it did not. For example, in stanzas II, IV, $\mathrm{V}$, and VII, it led Casal to change perspective more often than he should have and, in the process, caused him to use participial constructions in a strained and graceless manner. As the record of variants shows, none of the most serious defects in the poem were corrected when it was revised for publication in Rimas.

\section{R12: VARIANTS}

\section{l. $F$}

3 cariño

4 profecía

* 7 hombro,

11 melancolía-

18 hallará

21 goce,
$R$

cariño, profecía, hombro melancolía encontrará goce
GLIC

F 
l. $F$

22 encontrarán remedio,

26 amargo

28 verdugo,

29 impotencia. [sic]

30 amargo

* jugo.

32 pensamientos
$R$

GLIC

habrá para

remedio

F

estéril

verdugo

impotencia

estéril

jugo-[sic]

jugo.-

\section{R12: Notes to Variants}

7: Given the context in which it is found, this is one of the clumsiest verses in Casal's poetry. The $F$ version is restored in the present edition in order to show the parenthetical nature of "extendiendo mi cuello sobre mi hombro"; it will be observed, however, that no change in punctuation can improve the strained imagery or the lame structure of the sentence.

22: The comma of the $F$ version is restored in order to prepare the reader for the change in perspective which takes place in the following verse. In this sense, l. 22 is akin to l. 32 .

26: This lexical change may have been motivated by a desire to avoid repeating amargo, which had already been used in 1. 24.

30: The dash after jugo is a valuable sign because it indicates that discourse has come to an end. From this point of view, the $R$ version is an improvement over the original.

\section{R13: O ALTITUDO!}

This sonnet first appeared in the 30 October 1892 issue of La Habana Literaria. It was printed together with "A un héroe" (R15) and "Profanación" (R17) under the caption "Tres sonetos." In this version, the title was a hybrid of Spanish and Latin as far as punctuation and spelling were concerned: "iOh Altitudo!" (italics mine).

The Rimas version of the poem differed from the original in a few details. The title was completely Latinized, two lexical changes were introduced into the body of the work, and the punctuation was altered in three places. Furthermore, the poem was separated from those which had been its companions in the $H L$ printing.

\section{R13: VARIANTS}

l. $H L$

1 idealismo

5 mal,
$R$

idealismo, mal; 
6 dolorosas

en flor mortales

7 propones,

11 llama propones juzga

\section{R13: Note to Variants}

1: The lack of punctuation at the end of 1.1 in the $H L$ version leads the reader to see this stanza as a composite of parallel images which occupy ll. 1-2 and ll. 3-4, respectively. Both images express a downward movement from el azul de tu idealismo to cieno-abismo. If translated into prose and then diagrammed, the essential thought of the stanza might be summarized in the following way:

$$
\text { Joven, }\left\{\begin{array}{c}
\text { viste - bajar-tus ilusiones }-\begin{array}{c}
\text { desde el azul } \\
\text { de tu idealismo }
\end{array}-\text { al cieno } \\
\text { сомо } \\
\text { seve-caer-alos alciones - } \begin{array}{c}
{[\text { desde el azul }} \\
\text { de tu idealismo }]
\end{array}-\text { al abismo. }
\end{array}\right.
$$

By inserting a comma at the end of 1.1 in the $R$ version, Casal caused a change to take place in the relationship between desde el azul de tu idealismo and tus ilusiones. This seemingly minor change altered the entire image. The result is that el azul de tu idealismo no longer indicates the starting point of ilusiones' downward movement. Rather, by being forced into close association with joven, it comes to signify the vantage point from which joven observes the downfall of his illusions. The basic idea of the new image might be diagrammed in the following manner:

$$
\text { Joven, desde el azul } \begin{gathered}
\text { de tuidealismo, } \\
\text { seve-caer-a los alciones - al abismo. }
\end{gathered}
$$

The re-association of components, which is necessitated by the change in punctuation, creates an image that is in keeping with Casal's growing tendency to remove himself from the vicissitudes of life and to stand aloof as a disillusioned observer. For this reason, the punctuation of the $R$ version is retained in this edition.

\section{R14: VIEJA HISTORIA}

This poem was first brought before the public by La Habana Literaria on 15 September 1892. It was divided into four parts and was printed in a 
two-column format in which the first two parts (ll. 1-13, 14-26) were set on the left side of the page and the last two (1l. 27-39, 40-52) were set on the right. Centered asterisks were placed between the parts, and the initial letter in each line of the poem was capitalized.

El Hogar reproduced "Vieja historia" on 6 November 1892. In this version, although the two-column format of the original was retained, two minor changes were made in the presentation: the year of composition (1892) was added at the bottom left and, with the exception of the first verse in each stanza, the initial letter in every line - including 1. 25 - was printed in lower case. When the structure of $11.22-26$ is appraised in the light of the latter change, it becomes clear that the suspension points at the end of 1. 24 do not represent the conclusion of a sentence (as Cabrera Saqui, for example, would have us believe), but function instead as a dramatic porque which introduces the reason why the dreamer could not be consoled.

The version of "Vieja historia" which came out in Rimas differed from the El Hogar version in several respects. First, the date of composition was suppressed; this was in keeping with Casal's practice in all three of his published books. Second, the asterisks that had appeared between 11. 26-27 in the periodical versions were suppressed in this printing; thus, "Vieja historia" came to the readers of Rimas as a three-part, rather than as a four-part poem. Since it is impossible to determine whether this change was made on the initiative of Casal or of someone else involved in the publication of the book, the Rimas structure is reproduced in the present edition. Third, the publishers of Rimas started every line of poetry with a capital letter. Consequently, whether Casal would wish it or not, his intent concerning the function of the suspension points in 1. 24 was obscured. My own feeling is that El Hogar correctly interpreted Casal's intent. For this reason, I do not capitalize tenía in 1. 25.

\section{R14: VARIANTS}

l. $H L$

16 [c]omo

* 36 hollando

37 [s]iguió,

48 ( $) \mathrm{Y}$,

\begin{tabular}{ll}
$H g$ & $R$ \\
& {$[$ c]omo el } \\
\multirow{2}{*}{ siguió } & hallando $[$ sic $]$ \\
& $H L$ \\
& $\mathrm{Y}$
\end{tabular}

GLIC

$H L$

( $)+R$

\section{R14: Note to Variants}

36: My impression is that the $R$ version was the result of an error on the part of the typographer. My disinclination to believe that Casal deliberately changed the original verb is based on the following considerations: 1) In this context, hallando fails to express the intense suffering of the subject on his journey through life. 2) The original verb, hollando, is much more in keeping with the 
tone of 1l. 35-39 and the poem as a whole. 3) Variants of the hollar image are found elsewhere in Casal's poetry; among them are:

H 369 cuando del mundo en el sendero, hollaba

70 blandas alfombras de fragantes flores,

H17 19 hollando las hermosas

20 flores que esparce pródigo el verano?

H41 11 aunque obstruyan tu paso los abrojos

12 dejándote la planta ensangrentada.

R30 $41 \quad \ldots$ aunque nos hieran las plantas los abrojos

\section{R15: A UN HEROE}

This composition was first published in the 30 October 1892 issue of $\mathrm{La}$ Habana Literaria. It was printed together with "O Altitudo!" (R13) and "Profanación" (R17) under the rubric "Tres sonetos." According to Geada, the idea for the poem originated when "uno de los bravos de la guerra del 68, emigrado en el extranjero, vino a Cuba con objeto de sondear las voluntades de sus compatriotas, y fracasado en su empeño, hubo de retornar abatido y triste" (Selección de poesías, p. lxxviii). Supplementing Geada’s statement, Duplessis (“Julián del Casal,” p. 60) indicates that the person in question was General Maceo.

Antonio Maceo y Grajales was born in Santiago de Cuba on 14 June 1845. His parents, Marcos Maceo and Mariana Grajales, were members of a minority class of the agricultural bourgeoisie which was formed by a small number of free negroes and mulattoes. After attending a racially segregated primary school, Maceo went to work on his family's land. When the Guerra de los Diez Años broke out, he joined the insurgent forces of Captain Juan Bautista Rondón (25 October 1868). His rise was meteoric: he was promoted to the rank of captain on 11 December 1868, became a major on 16 January 1869 , and was made a lieutenant colonel on 26 January 1869 . As a result of his military successes, he became a living legend to his followers and earned the respect of his Spanish opponents. However, when he was promoted to full colonel on 22 March 1872, some of the white officers in the revolutionary forces expressed alarm about what might happen if high positions of responsibility were given to members of "la clase de color." In spite of racist opposition of this sort, Maceo's military competence was rewarded again in June 1873, when he was made a brigadier general, and in January 1878, when he was promoted to the rank of major general. Shortly thereafter, the revolution came to an end and Maceo left Cuba. 
In his introduction to Antonio Maceo: Documentos para su vida (Havana: Archivo Nacional, 1945), Julián Martínez Castells indicates that Spanish colonial authorities allowed Maceo to make brief visits to Cuba in 1890 and 1893. Speaking at a banquet in his honor at the Hotel Venus in Santiago during the first of these visits, Maceo declared that Cuba should make every effort to free itself from Spanish rule as quickly as possible. The response from his compatriots was less than enthusiastic, however, and he left the island in sadness. Despite this lack of local support, he continued to work zealously for Cuba's liberation, and, in 1895, returned with the Ejército Libertador to renew military action on Cuban soil. In a skirmish in San Pedro on 7 December 1896, he gave his life for the cause he had so long and faithfully espoused.

It is indeed possible, as Duplessis asserts, that "A un héroe" was inspired by Maceo, for this outstanding patriot was the subject of a letter that Casal sent to Esteban Borrero Echeverría on 1 August 1890:

Sólo he encontrado en estos días una persona que me ha sido simpática. ¿Quién se figura que sea? Maceo, que es un hombre bello, de complexión robusta, inteligencia clarísima y voluntad de hierro.

No sé si esa simpatía que siento por nuestro General es efecto de la neurosis que padezco y que me hace admirar los seres de condiciones y cualidades opuestas a las mías; pero lo que le aseguro es que pocos hombres me han hecho tan grata impresión como él. Ya se ha marchado y no sé si volverá. Después de todo me alegro, porque las personas aparecen mejor a nuestros ojos vistas de lejos. ${ }^{1}$

If "A un héroe" was in fact inspired by the experiences of Antonio Maceo, whom Casal met in 1890, certain questions remain to be answered. For example, if Casal wrote the poem soon after meeting the General, why did he delay publishing it for two years? On the other hand, if he wrote the poem shortly before publishing it in 1892, what motivated him at that time to compose a work based on the fortunes of Maceo? Unless future investigators can answer these questions satisfactorily, the history of opinion on this poem will have to be re-examined. Specifically, it would become necessary to determine whether Geada's obvious source, Enrique Hernández Miyares, really had Antonio Maceo in mind when he spoke of "uno de los bravos de la pasada guerra," 2 or whether later researchers like Duplessis made a false assumption-an assumption that was taken as fact by scholars who came after him.

\section{R15: Notes to Introductory Statement}

1 Ed. del Cent., vol. III, p. 82. 
2 Enrique Hernández Miyares, "Julián del Casal, patriota," in Obras completas (Havana, 1916), vol. II, p. 37.

\section{R15: VARIANTS}
l. $H L$
$R$
GLIC
$5(\Phi)[y]$
[y],
(I) $+R$
12 decoro,
decoro

\section{R16: LA COLERA DEL INFANTE}

"La cólera del Infante" was first published on 8 January 1893 in $L a$ Habana Elegante. In a commentary on Casal, which he published in $\mathrm{El}$ Fígaro on 30 October 1910, Rubén Darío identified the protagonist of the poem as Casal himself. ${ }^{1}$ Darío was probably right in seeing the Infante as an idealized projection of the author who, with the passage of time, suffered ever greater physical and emotional agonies as a result of his life-sapping illness. It is of particular interest to consider the Infante's inability to rise from his chair (ll. 42-45) in light of a statement which Casal made about his own malady in the spring of 1892: "No pude ir el domingo pasado porque estaba atacado, y aún lo estoy, de crueles dolores-no sé si reumáticos o nerviosos, porque no he querido ver ningún médico, temiendo que ensayen en mí los alcaloides de que habla Guy de Maupassant-, que me asesinan el ánimo y me clavan en mi desvencijado sillón. Creo que tengo el lado izquierdo del cuerpo, desde el hombro hasta la rodilla, en peligro de muerte. Esta mañana sufrí un gran susto porque no lo podía mover. Además tengo frecuentes vahidos y pérdida total de la vista. En fin, todos los signos de una gran anemia que me amenaza devorar."

Still concerned with the fine points of his art despite the rapid deterioration of his physical and psychological condition, Casal altered the wording of two verses and modified some of the punctuation before publishing the definitive version of this poem. In every instance, the changes which Casal introduced into Rimas represented an improvement over the original.

\section{R16: Notes to Introductory Statement}

1 Ed. del Cent., vol. III, p. 131.

2 Ed. del Cent., vol. III, p. 90; italics are mine.

\section{R16: VARIANTS}

l. $H E$

11 arboleda

$22-\mathrm{Ah}$ !
$R$

alameda

$-i \mathrm{Ah}$ !

GLIC

(ף) $+R$ 
l. $H E$

30 [p]erseguir,

* lebreles,

38 [y],

41 venas-[sic]

$42 \mathrm{y}$,

43 [c]ual botón mústio sobre el frágil tallo

45 vasallo

47 avispas,
$R$

[p]erseguir

[y]

y

[c]omo se alza un botón sobre

su tallo,

vasallo,

avispas lebreles

venas.-
GLIC

\section{R16: Note to Variants}

30: This stanza is composed of a long series of coordinate clauses which, by their rapid succession, help communicate the speaker's ardent longing for freedom. The very punctuation which Casal used at the end of each clause commas rather than semicolons - emphasized the speaker's anxiety by accelerating the rhythm of the entire stanza. For this reason, omission in Rimas of the comma after perseguir is considered to have been an improvement over the original. However, in order to keep the thought unit unbroken in 11. 30-32 and, hence, to maintain the rhythm of the stanza, it is felt that the comma after lebreles should also be suppressed.

\section{R17: PROFANACION}

This poem first appeared in the 30 October 1892 issue of La Habana Literaria. It was printed together with "O Altitudo!" (R13) and "A un héroe" (R15) under the rubric "Tres sonetos." As shown by the record of variants, only minor changes were introduced into the Rimas version of the poem.

\section{R 17: VARIANTS}

l. $H L$

5 tremulento

8 momento.

9 ( $($ ) Tal hora,
$R$

tremulento, momento;

$[\mathrm{t}] \mathrm{al}$
GLIC

$H L$

$($ I) $+R$

hora

\section{R17: Note to Variants}

9: In the $H L$ and $R$ versions, the comma at the end of 1.9 gives the impression that siente in 1.10 is dependent on que rather than on si. In order to avoid the chance of an initial misreading, the comma is omitted in this edition. 


\section{R18: MEDIOEVAL}

This sonnet was first published in the 15 December 1892 issue of $L a$ Habana Literaria. On 22 January 1893, El Hogar reproduced the poem without change. When revising "Medioeval" for publication in Rimas, Casal made slight modifications in the wording and punctuation of the original text.

R18: VARIANTS
l. $H L$
3 senderos
4 balsámico
9 bocinas,
12 romper

$H g$

$R$

senderos, aromático bocinas hendir

\section{R19: LAS ALAMEDAS}

This poem was originally published in the 15 November 1892 issue of La Habana Literaria. Only minor changes distinguish the Rimas version from the original. However, the one lexical change (1. 38: orejas $>$ miradas) was indeed a felicitous one.

R19: VARIANTS
l. $H L$
6 alma,
26 mústia
38 orejas
46 rastros,

$R$

alma

mustia,

miradas

rastros

GLIC

\section{R20: DIA DE FIESTA}

"Día de fiesta" was originally published on 15 October 1892 in El Pais. The date "(Octubre 1892.)" appeared with the author's name at the end of the poem. One year later, the sonnet was reproduced in Rimas without textual change.

In “Ausencia y presencia de Julián del Casal," Dulce María Loynaz makes the following statement about the poem: "Como una nota interesante y poco conocida, diré que doña Carmen [del Casal de Peláez, the poet's sister] recuerda y me ha contado en todos sus detalles familiares, que el soneto 'Día de Fiesta' fue un desahogo de la amargura que en su amado hermano producía el espectáculo de la ciudad puesta de gala por 
PLATE 44

Eulalia de Borbón

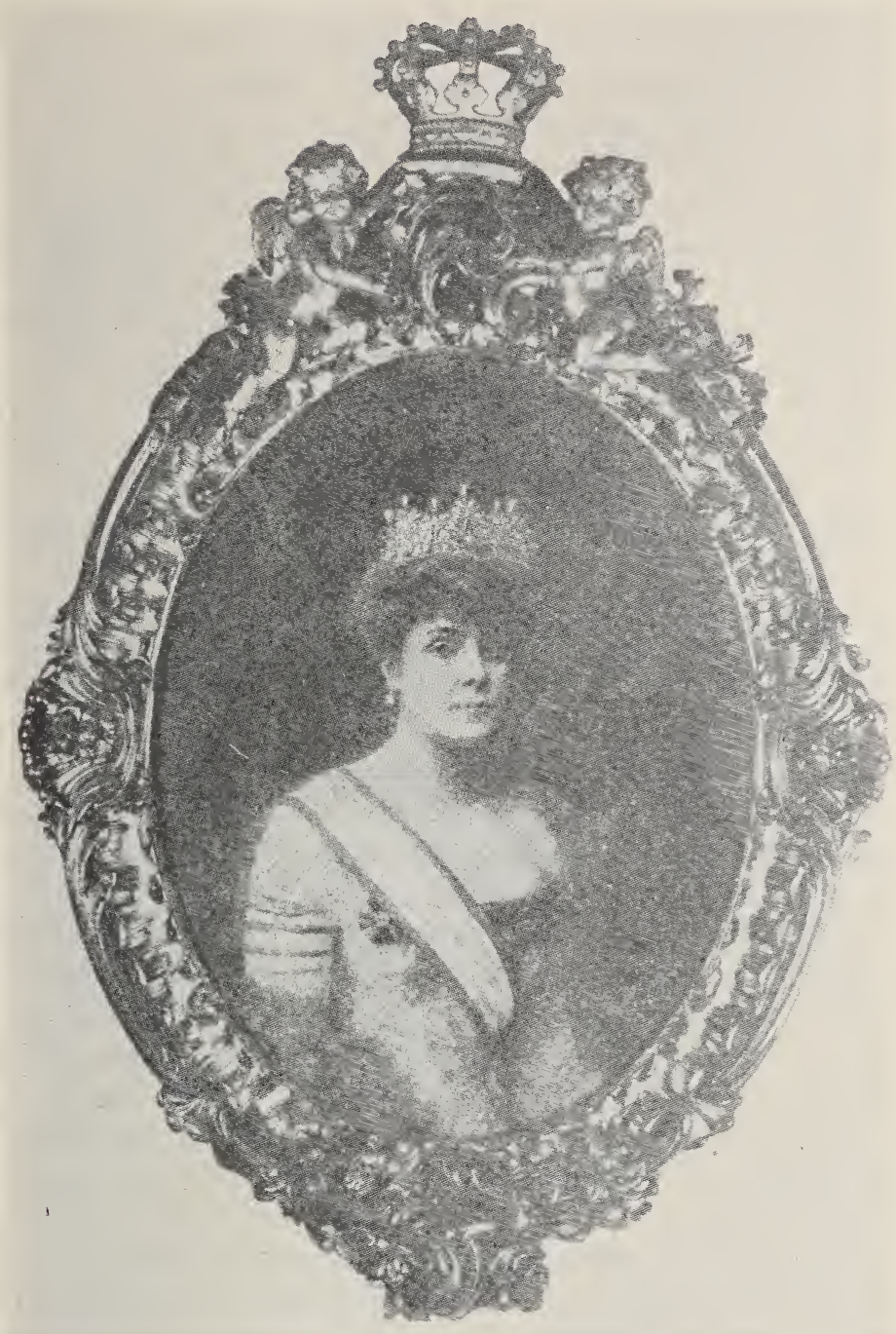

la visita de la Infanta Eulalia."1 Although this statement sounds especially convincing because of its source, it is contradicted by certain information concerning Princess Eulalia.

Eulalia de Borbón was born to Isabel II and Francisco de Asís on 12 February 1864. The political upheaval of 1868 obliged the Royal Family to leave Spain and take up residence in France. Eulalia was sent back to Spain to complete her education after her brother Alfonso was proclaimed king in 1874. She married Antoine d'Orléans on 6 March 1886. The couple had two children: Alfonso, born on 12 November 1886, and 
Luis Fernando, born on 5 November 1888. Because of her charming personality, Doña Eulalia was selected to represent the Court of Spain at important international functions, among them Queen Victoria's Jubilee (London, 1887) and the World's Columbian Exposition (Chicago, 1893). From the Infanta's memoirs, it is evident that Casal's sister was mistaken about the events that inspired "Día de fiesta," for Princess Eulalia clearly states that she arrived in Havana on the morning of 8 May 1893-that is, seven months after the $E l$ Pais version of the poem had appeared. ${ }^{2}$ Thus, while the sonnet's date of original publication (15 October 1892) suggests that Columbus Day celebrations in Havana had inspired Casal, the diary of Princess Eulalia leads us to conclude that her name should not be associated with the genesis of this particular composition.

\section{R20: Notes to Introductory Statement}

1 Anales de la Academia Nacional de Artes y Letras, vol. XXXVIII (1954-1958), p. 124 .

2 Information on the trip to Cuba is to be found in Memorias de doña Eulalia de Borbón, Infanta de España (Barcelona: Editorial Juventud, 1958), pp. 89-94.

\section{R21: PAGINAS DE VIDA}

"Páginas de vida" was inspired by Rubén Darío’s visits to Havana in July and December of 1892 (see below) and was first published in the 22 January 1893 issue of La Habana Elegante. The Rimas version of the poem differed slightly from the original in wording and punctuation.

Rubén Darío began to keep abreast of contemporary trends in Cuban literature on a regular basis some time before 1887, when he gained access to La Habana Elegante. ${ }^{1}$ In turn, the first reference to Darío in Cuban periodicals was made on 31 July 1887. Writing in La Habana Elegante, Enrique Hernández Miyares gave his opinion of Dario's poetic art as exemplified by Abrojos. This commentary was based on an article which Pedro Balmaceda Toro had published in La Epoca of Santiago de Chile on 20 March 1887. As can be seen from the following quotation, Hernández Miyares' impression of Abrojos - an impression apparently derived from poems reproduced in Balmaceda Toro's review, rather than from a first-hand examination of the complete text - was not altogether favorable: "En cuanto a las otras citas no he de reproducirlas; el abuso y mal uso de los diptongos es la invasión churrigueresca en el grandioso templo levantado a las musas por los inmortales poetas del Sud, que nos han dejado por herencia un nombre entre irradiaciones gloriosas, y sigue siendo el golpe de cincel antiartístico que descompone las estatuillas de terra-cotta que hoy presentan en los museos de papel, -periódicos- los llorosos acompañantes al lugar de descanso de la poesía; diosa que muere 
llorada por Macaulay y a despecho de los versos del protestante Gustavo Adolfo." 2

In the years immediately following this reference to Abrojos, La Habana Elegante gave its readers additional opportunities to familiarize themselves with Darío's art. For example, on 11 December 1887, it published "Caso cierto," 3 and on 13 October 1889, it printed an early version of "Claro de luna."4 By April of 1891, Darío was well-known enough in Cuba for La Habana Elegante to announce that copies of Azul . . . had been received by Julián del Casal, Raoul Cay, and Enrique Hernández Miyares, ${ }^{5}$ and that the journal would reproduce the most novel works from that volume in subsequent issues (see N36). As one of the recipients of Azul ..., Casal showed his gratitude for Darío's thoughtfulness by dedicating "La reina de la sombra" to him. This poem was published by $L a$ Habana Elegante on 10 May 1891 (see N45). A few months later, Casal wrote his first full-length article on the Nicaraguan author. This commentary, which he entitled "Rubén Darío," was printed on 15 November 1891 by La Habana Elegante's successor, La Habana Literaria. Between 30 September 1891 and 30 May 1892, ten compositions by Darío were published in the pages of La Habana Literaria alone. ${ }^{6}$ This background gives ample reason for the warm reception that was accorded to Darío when he paid his first visit to Cuba.

Darío, who was travelling to Spain on the "S. S. Veracruz," arrived in Cuba on or about 28 July 1892 . Evidence that this was the time of his first visit is found in Havana periodicals, although Darío himself does not mention it anywhere in his collected writings. On 28 July, El Fígaro published "Los Centauros: Bajo-relieve," which was dedicated to Raoul Cay; ${ }^{7}$ on 29 July, El País brought out "Como palomas"; and on $30 \mathrm{July,} L a$ Habana Literaria not only printed "Un Sermón" but, in a separate announcement, also made it known that Darío would leave for Spain a few days later. On 9 August, El Pais indicated that Darío was no longer in Havana; however, it called attention to a portrait of the young writer which had been done by Ricardo de la Torriente and which had appeared in the 7 August issue of El Figaro (see R8). Finally, it should be noted that, on 14 August, La Caricatura published the original version of "La negra Dominga," a poem that Darío had composed in Havana a few days before.

An announcement in the 5 December 1892 issue of El Pais clearly shows that Darío made a second stop in Havana when he returned from the quadricentennial celebrations in Spain: "A bordo del 'Alfonso XIII', llegado ayer a nuestro puerto, han regresado de la Península, de paso para las repúblicas de Nicaragua y Colombia, respectivamente, los señores D. Rubén Darío, afamado poeta muy conocido en Cuba; D. Fulgencio Mayorgas y el notable publicista y arqueólogo D. Emilio Restrepo. Dichos caballeros llevaron la representación de sus países a la Península con motivo del centenario de Colón." ${ }^{8}$ Julio Saavedra Molina confirms that Darío landed in Havana on 4 December; ${ }^{9}$ it would appear, however, that 
the poet's visit on this occasion was limited to the time needed by the "Alfonso XIII" to take on passengers, fuel, and supplies.

To summarize, then, it appears that Darío stopped in Havana for a few days at the end of July and the beginning of August 1892, and for one day - possibly only a few hours - in December of the same year. Although the length of Darío's stay on each of these occasions has not been determined with exactitude, the nature of his activities in Havana in 1892 is fairly well known. Since a summary of his movements is provided by Esperanza Figueroa, ${ }^{10}$ and since Darío's own descriptions of specific activities are easily accessible, ${ }^{11}$ it is not necessary to go into details here. What is important to bring out is that these visits gave Casal a much better opportunity to acquaint himself with Darío's values, ideals, and genius than he could have had merely by reading the Nicaraguan's works. What Casal thought of Darío as a poet and as a man, after meeting him in 1892 , may be seen in his carta-ensayo to Enrique Gómez Carrillo ${ }^{12}$ and in his poem "Páginas de vida."

\section{R21: Notes to Introductory Statement}

1 Esperanza Figueroa, "Julián del Casal y Rubén Darío," Revista Bimestre Cubana, vol. L (September-October 1942), p. 198.

2 Ibid., p. 199.

3 Later entitled "Caso" and incorporated into El canto errante.

4 Darío did not include this work in any of his books of poetry.

5 The book in question was the 1890 edition, published in Guatemala. One of the poems included in it was "Caupolicán," which Darío dedicated to Hernández Miyares. The poem had first appeared on 11 November 1888 in $L a$ Epoca of Santiago de Chile under the title "El Toqui." At the time of its first printing, however, it did not have a dedication.

6 For a list of the works that Darío published in La Habana Literaria, see N36.

7 This poem had first come out in March 1892 in the Revista de Costa Rica; it would later be included in Prosas profanas under the title "Palimpsesto."

8 Quoted by Monner Sans, p. 34; italics are mine. It should be noted that, in an article entitled "El general Lachambre: Recuerdo de la Habana" (La Nación, 7 March 1895), Darío indicated that he had stopped in Havana in November of 1892. The passage quoted from El Pais of 5 December 1892 makes it plain that Darío erred concerning the exact time of his return to Cuba.

9 Rubén Darío, Poesías completas, ed. Alfonso Méndez Plancarte (Madrid, 1954), p. 1325.

10 Op. cit., pp. 192-194.

11 See, for example, "Manuel S. Pichardo," Darío's prologue to Pichardo's Credos y visiones (although Pichardo's book was never published, Darío's critique was included in Letras); "Films habaneros: El poeta Julián del Casal" (El Figaro, 21 October 1910); "El general Lachambre: Recuerdo de la Habana" (Buenos Aires, La Nación, 7 March 1895); "Julián del Casal” (a letter written to Enrique Hernán- 
dez Miyares and published in La Habana Elegante on 17 June 1894). Ramón Catalá told Marshall E. Nunn that he was the one who introduced Casal to Darío. The following is Nunn's summary of Catalás report: "The literary men of Havana gave a dinner in honor of their distinguished guest, and according to Catalá, it was Julián who had charge of all the details. .. When Rubén arrived at the banquet hall he called to the head waiter - 'Soy yo el primer poeta de América. ¿Qué clase de bebida va a servirme?' Catalá also told me that Casal was a very heavy drinker, but could not be compared in this respect with Darío, who drank unceasingly" ("The Life and Works of Julián del Casal," p. 57).

$12 H E$, 15 January 1893; Ed. del Cent., vol. I, pp. 223-246.

\section{R21: VARIANTS}

l. $H E$

* 5 nave,

* tumbo,

21 Mas, hombre

26 i Fervorosa

27 puerto,

28 [y]o

* 29 cambio, que afligido escuchas

48 miedo!-

51 cima

55 cruel

59 pregunta [sic]

60 - ¿ंPor
$R$

Mas

hombre, iSalvadora puerto!

Yo

cambio que, doliente $[s i c]$ cambio, que doliente escuchas, miedo! cima, fiel pregunto, ¿Por
GLIC

nave tumbo

(ף) $+R$

puerto.

\section{R21: Notes to Variants}

5: It is clear that the original commas around tumbo tras tumbo had a rhythmic rather than a syntactic function. It is the opinion of this editor, however, that those commas put such heavy stress on 1.5 that they adversely affect the total image presented in $11.5-8$. Therefore, they are omitted from the present edition.

29: The presence of a comma after que cannot be justified on syntactic or rhythmic grounds. The only way it can be accounted for is by assuming that the compositor erred when he incorporated the change from afigido to doliente into the $R$ version.

\section{R22: PREOCUPACION}

This composition first appeared on 7 May 1893 in La Habana Elegante. It was printed after "Voe soli" (R27) under the heading "Sonetos." On 9 
May 1893, El País, acknowledging its source, reproduced both sonnets in their original order. Two months later, on 16 July 1893, El Hogar reprinted "Preocupación" (without "Voe soli") for its readers. The editors cited the date of composition as "1893"; this information had not been appended to the earlier versions. As far as wording and punctuation were concerned, however, El Hogar made an exact duplicate of the $H E$ and $P$ versions. The version which appeared in Rimas differed slightly from its predecessors. The most provocative variant is found in 1.3 , where rastrojos was printed in place of the original word, abrojos. This change is discussed at some length in my note to the variants.

\section{R22: VARIANTS}

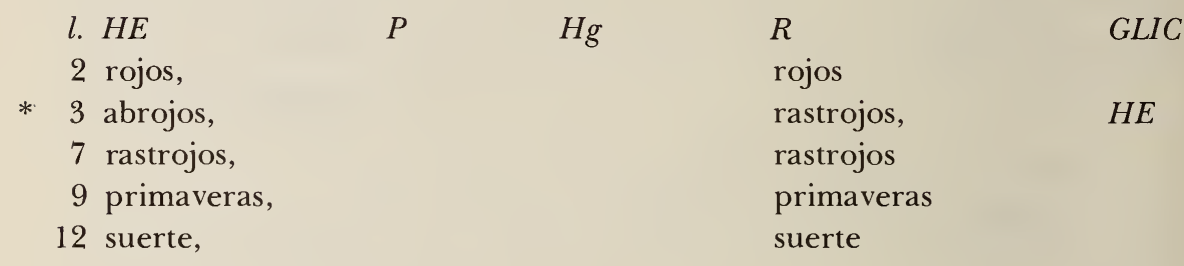

\section{R22: Note to Variants}

3: Who substituted rastrojos for abrojos in Rimas? One line of reasoning would lead to the conclusion that Casal was personally responsible for this change. The following points could be adduced to support this opinion: Casal revised "Preocupación" for Rimas some five months after first publishing it in $H E$, and, coming back to the poem after this length of time, he may simply have lost sight of the reasons why he had used abrojos in the original version. A study of the variants in his poetry reveals that such lapses did occur on other occasions when he revised his work. In spite of this, it is difficult to believe that Casal was in fact responsible for the change from abrojos to rastrojos. The argument against this possibility would emphasize three things: 1) Rastrojos suggests that the labrador sowed his field the year before; however, this contrasts with the spirit of the tercets, which imply that the yo-sembrador de quimeras is a waiting the first harvest of his youthful dreams. Casal's original choice, abrojos, does not create such a conceptual disharmony because it implies that the labrador was preparing and cultivating his field for the first time. 2) Rastrojos appears in terminal position in 1.7 of all versions of the poem. It seems unlikely that, at this stage in his development as a poet, Casal would reject a perfectly adequate word, abrojos, and would repeat rastrojos in rhyming position in so short a composition as a sonnet. 3) The close-interval repetition of a word in rhyming position occurs by mistake elsewhere in Rimas: see R38/11, for example, where laureles was erroneously used in place of claveles in one edition. It is clear that the question of abrojos $>$ rastrojos is not an easy one to answer. My own 
inclination is to believe that the change to rastrojos was made by the compositor of Rimas and not by Casal. Therefore, I restore the $H E$ wording in the present edition.

\section{R23: AEGRI SOMNIA}

This sonnet was first published in the 30 November 1892 issue of $L a$ Habana Literaria. On 25 December, the editors of El Hogar reproduced the poem. They indicated that it was composed in "(1892)" but they did not acknowledge the source of their version. With one minor exception, the Rimas text was exactly the same as the $H L$ original.

\section{R23: VARIANTS}

$\begin{array}{llll}\text { l. } H L & H g & R & \text { GLIC } \\ 12 \text { asombra, } & \text { asombra. }[s i c] & \text { asombra } & \end{array}$

\section{R24: NEUROSIS}

This poem was first published in the 5 February 1893 issue of $L a$ Habana Elegante. It was printed in italics on the title page of the journal and, though accompanied by the name of its author, lacked any indication of when it had been composed. ${ }^{1}$ Basically content with his original text, Casal made only one lexical change when preparing the poem for Rimas. ${ }^{2}$

\section{R24: Notes to Introductory Statement}

1 Geada (Selección de poesias, p. lix) affirms that "Neurosis" was written around 1887. He offers no documentation for his statement and, to my knowledge, no one has yet found evidence to support his assertion.

2 For an analysis of the poem, see Robert Jay Glickman, "Neurosis," In Antología comentada del modernismo, ed. Francisco E. Porrata and Jorge A. Santana (Sacramento: California State University, 1974), pp. 172-175.

\section{R24: VARIANTS}
l. $H E$
8 chisporrotea
40 le
42 sangre roja

$R$ chisporretea [sic]

la $[s i c]$

roja sangre
GLIC

$H E$

$H E$ 


\section{R25: SENSACIONES}

This sonnet was first published on 24 August 1893 by El País. Aside from a lexical change in 1.4 , the Rimas version was the same as the original. Both versions were dedicated to Gonzalo Aróstegui y González de Mendoza. Born on 13 December 1891, Gonzalo was only twenty months old when "Sensaciones" first appeared in print. Son of Dr. Gonzalo Aróstegui del Castillo, one of Casal's contertulianos at La Galería Literaria, and brother of Aurelia Aróstegui for whom the poet wrote "Canción" (N49), Gonzalo ultimately gained renown in Cuba not only as the scion of a distinguished family, but also as a physician and surgeon of great talent. He began his medical studies in Havana, took advanced training at the Mayo Clinic, and trained under the famous French surgeon Victor Pauchet in Paris. After his return to Cuba, he became Chief Surgeon at the Hospital Freyre de Andrade and was elected to membership in such outstanding professional organizations as the Academia de Ciencias Médicas, Físicas y Naturales, the Academia de Estudios Clínicos, and the Academia de Cirugía.

\section{R25: VARIANTS}

l. $P$

4 [p]or
$R$

[s]obre

GLIC

\section{R26: DOLOROSA}

"Dolorosa" was first published in the 19 February 1893 issue of $L a$ Habana Elegante. When the author reviewed the poem for Rimas, he decided to keep the original wording intact but made several changes in punctuation. These refinements altered the rhythmic pattern of the composition.

R26: VARIANTS

l. $H E$

* 9 lamparilla,

14 [y],

18 ladrar

20 avanzar;

21 [y]

50 gimen

65 sanguinario,
R

lamparilla

[y]

ladrar, avanzar.

$\mathrm{Y}$

gimen,

sanguinario
GLIC

(ף) $+R$ 
9: It is suspected that the comma after lamparilla was suppressed in $R$ in order to decrease emphasis on 1. 10. As a result of eliminating the comma, the rhythm of 11. 9-10 is accelerated and greater stress is made to fall on the direct object found in ll. 11-12. On the basis of this assumption, the $R$ version is followed in the present edition.

\section{R27: VOE SOLI}

This sonnet was first published by La Habana Elegante on 7 May 1893. It was printed with "Preocupación" (R22) under the heading "Sonetos." Both poems were reproduced under the same heading and in the same order - "Voe soli" followed by "Preocupación" - in El País on 9 May 1893. The editors of El Pais acknowledged their source as La Habana Elegante, and, as shown by the record of variants, their version was an exact copy of the original. Casal introduced no major changes into the poem when he published it in Rimas.

R27: VARIANTS

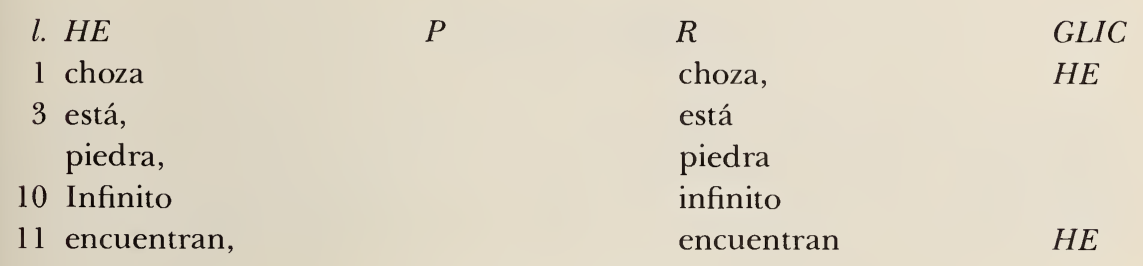

\section{R28: ESQUIVEZ}

This poem was first published in the 16 April 1893 issue of La Habana Elegante. It was printed in italics on the title page of the journal. Several modifications in wording and punctuation were made before the poem was brought out in Rimas.

R28: VARIANTS

l. $H E$

10 encierra,

11 [m] as

14 lucho.

15 iQuizás

17 (ๆ)Brinda
$R$

encierra

[y]

lucho:

[q]uizás

Lleva
GLIC

$i+R$

(ब) $+R$ 
l. $H E$

19 i[e]n

20 noche!

25 ( $($ )Nimbada

26 cielos:

27 [y]o

28 hielos.

31 tenebrosa

35 las flores
$R$

[e]n

noche.

Nimbada

(ף) iNimbada

cielos!

Yo

hielos!

silenciosa

un lirio
GLIC

iYo

\section{R29: A UN POETA}

This sonnet was first published by La Habana Elegante in its 14 May 1893 issue. It was printed to the left of "Ruego" (R31), and both compositions were subsumed under the heading "Sonetos." On 16 May 1893, the editors of El Pais reprinted the poems under the same rubric and in the same order (i.e., R29 followed by R31). Casal made only one change in the text before publishing the work in Rimas. In none of the printings does one find evidence concerning the identity of the poet to whom Casal was addressing himself.

R29: VARIANTS

$\begin{array}{rlll}\text { l. } H E & P & R & \text { GLIC } \\ 9 \text { corona } & \text { corona, } & H E & \\ 14 \text { humanos } & & \text { terrenos }\end{array}$

\section{R30: LAUS NOCTIS}

When this poem was originally published in the 5 March 1893 issue of La Habana Elegante it was entitled "Nocturno." The editors of the journal printed it in italics on the first page, a position of honor given to a considerable number of Casal's poetic compositions. Before publishing the work in Rimas, Casal changed the title and introduced a few minor variants into the text.

R30: VARIANTS
l. $H E$
3 [1]levan
9 tierra,
34 tropel
40 consolación. [sic]
41 abrojos,

$R$

[t]raen

tierra

tropel,

abrojos
GLIC

consolación! 


\section{R31: RUEGO}

"Ruego" was first brought before the public by La Habana Elegante on 14 May 1893. It was printed together with "A un poeta" (R29) under the heading "Sonetos." Both poems were reproduced by El Pais on 16 May 1893. The original heading was retained and, although printed here in vertical order rather than in the horizontal order of La Habana Elegante, the poems were sequenced as they had been before (i.e., R29 followed by R31). El País was so faithful to the $H E$ version in fact, that it copied the typographical error in 1.14 of its source. Although the 1.14 misprint was corrected in Rimas, a much more serious mistake was made in 1.10 . This error has been perpetuated over the years by editors of Casal's poetry. Fortunately, the availability of the $H E$ and $P$ versions exposes the problem and allows us to rectify the error.

\section{R31: VARIANTS}

$\begin{array}{llll}\text { l. } H E & P & R & \text { GLIC } \\ 9 \text { calma, } & & \text { calma } & \\ 10[y], \text { al rendirme } & & \text { [y], rendirme [sic] } & H E \\ 14 \text { irradación [sic] } & & \text { irradiación } & \end{array}$

\section{R32: PARA UNA MUERTA ...}

This poem was first published in the 21 May 1893 issue of La Habana Elegante. It was printed on the title page of the journal. When Casal prepared this composition for publication in Rimas, he made lexical modifications in four verses and changed some of the punctuation. Perhaps the most interesting variant is the one found in 1.19 .

\section{R32: VARIANTS}

\section{l. $H E$}

9 madreselvas

18 en el aire

* 19 blanca luna

$21 \mathrm{Oh}$ ! la

24 cuello!.....

30 entables!.....

31 No

35 i[p]ara

38 carnales [sic]

42 [c]ual

44 los seres

47 el tuyo

49 montañas
$R$

madreselvas,

a mi lado

la luna

cuello.

entables!

[p]ara

carnales.

[c]omo

las almas

montañas,
GLIC

(ף) iOh! ila cuello!

¡No

HE

¿el tuyo 


\section{R32: Note to Variants}

19: Each verse in this poem was originally composed of a heptasyllabic segment plus a pentasyllabic segment. In the $H E$ version, metrical consistency demanded that melancólica, the last word before the caesura in 1. 19, be given a value of four rather than five syllables. By replacing blanca with la in Rimas, however, Casal obliterated the required caesura; this, of course, made 1.19 metrically different from every other verse in the poem. Since Casal did not alter 1. 11, which also has an esdrújula immediately before the caesura, his reason for modifying 1.19 is particularly difficult to understand.

\section{R33: ORACION}

This sonnet was first published in the 13 August 1893 issue of $L a$ Habana Elegante. It was printed together with "Las horas" (R35) on the first page of the journal, and both poems were subsumed under the rubric "Escorias." They were printed side by side, with R33 on the left and R35 on the right. On 15 August 1893, the editors of El Pais reproduced "Oración" for their readers. They indicated that their source was $L a$ Habana Elegante. The compilers of the Ed. del Cent. (vol. III, p. 221) state that the poem was also reprinted in the 20 August 1893 issue of La Unión Constitucional. Since this version could not be procured from Cuba, there is no record of its characteristics in the list of variants which follows.

\section{R33: VARIANTS}

$\begin{array}{llll}\text { l. } H E & P & R & \text { GLIC } \\ 1 \text { iAh, } & (\text { () }+H E & \mathrm{Ah},[\text { sic }] & P \\ 9 \text { Oh, Señor! } & \text { (ף) iOh, Señor! } & & \text { (ף) iOh Señor! } \\ \quad \mathrm{Si} & & \text { si } & \end{array}$

\section{R34: VIRGEN TRISTE}

This composition was first published in the 20 August 1893 issue of $L a$ Habana Elegante. As the record of variants shows, the Rimas version of the poem was almost an exact copy of the original. Although the poem bore no dedication in either printing, we are told by Carlos Pío Uhrbach that it was written for Juana Borrero (see below).

Juana Borrero Pierra (b. Havana, 18 May 1877; d. Key West, 9 March $1896)^{1}$ belonged to an unusually talented family. Her paternal grandfather, Esteban de Jesús Borrero, wrote poems of remarkable spontaneity and sensitivity, and passed this gift on to his children: Manuel, Elena, and Esteban. ${ }^{2}$ Juana's mother, Consuelo Pierra y Agüero, was related to two 
outstanding Cuban writers, Gertrudis Gómez de Avellaneda (her cousin) and Martina Pierra de Poo (her sister), and was herself an extremely cultured woman who had a special interest in mythology and astronomy.

An intense love of beauty filled the hearts of Don Esteban and Dona Consuelo. In view of this, it is not surprising to find similar feelings manifesting themselves in Juana at an early age. She did her first drawing under the inspiration of Romeo and Juliet, which Don Esteban put into her hands when she was only five years old. As shown in Plate 45, the sketch presents Romeo in the guise of a carnation, and Juliet in the form of a rose. Besides giving evidence of her precociousness as an artist, this drawing is a precious record of the little girl's emotional sensitivity. At the age of seven, Juana wrote her first poem, "Sol poniente":

Por la tarde, en los sitios misteriosos cuando cesa la alondra de cantar y Véspero se oculta tembloroso

en el seno del mar; cuando agoniza el sol reverberante y extiende por el cielo su arrebol, sobre mi frente pensativa siento

bajar la inspiración! $!^{3}$

In succeeding years, she read widely but had a distinct preference for the melancholic muse of Heine and the sentimental style of Bécquer. At the same time, she cultivated her talent for drawing and painting. She studied first in Puentes Grandes under Dolores Desverine. Then, at the age of nine, she took more formal instruction from Professors Mendoza and Herrera at the Academia de Pintura y Escultura de San Alejandro. A short time later, she became a pupil of Armando García Menocal. ${ }^{4}$

Julián del Casal met Esteban Borrero early in 1890. Shortly thereafter, Casal was invited to Puentes Grandes and became acquainted with Don Esteban's family. Dulce María Borrero describes that occasion in the following way:

Vino el bardo a nuestra casa traído de la mano por el mismo padre que cuidaba de nuestros corazones con un celo angustiado y expectante. ... Nuestro padre nos fue presentando a él uno a uno, con aquel contenido acento de orgullo con que presentó sus hijas al Rey-Bueno la madre dichosa en la balada de "Los siete Caballeros".

Nos miró a todos por la primera vez, menos a Juana, que ya la conocía por la miniatura sonora de sus versos primeros, que el padre le había dado a conocer....

Aquel día, hasta la madre de Juana, que no bajaba nunca durante el día a la sala de recibo, . . . bajó a conocer al bien- 


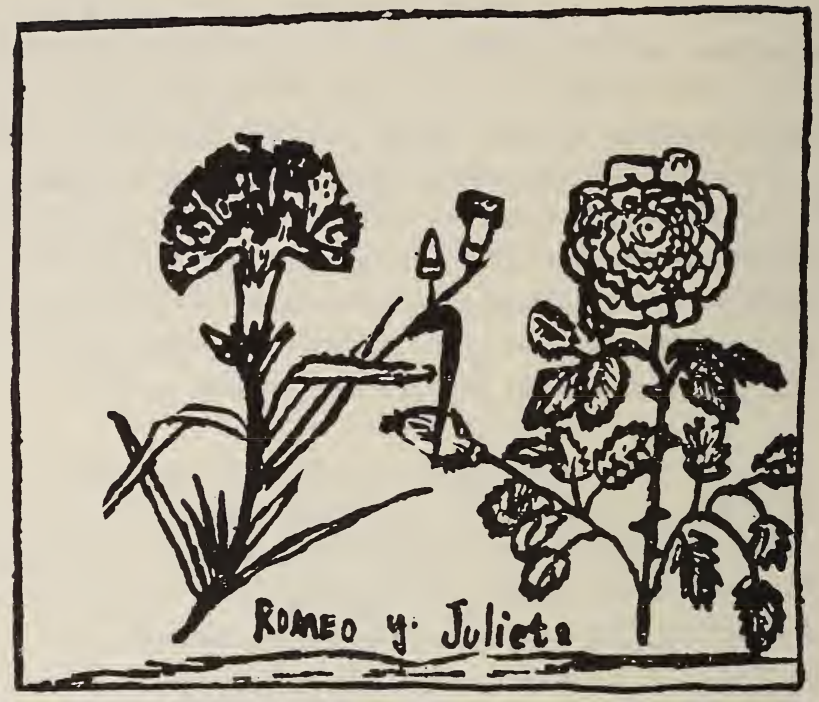

venido, y su rostro . . . tuvo una sonrisa más tierna y también más duradera, que le dejó para muchos días alumbrada la faz ... ${ }^{5}$

Casal, too, was deeply affected by his visit to Borrero's home. Not only did he see aspects of Don Esteban's multifaceted personality that could not reveal themselves fully elsewhere, but he also received an unexpected gift which, though intangible, was of inestimable value to him: he was fussed over by a family of warm, dynamic, talented individuals each of whom wished to be his friend. For a man who carried a heavy burden of doubt about his own worth, this was no small boon.

In the months that followed, Casal made other visits to Don Esteban's home. When returning from one of his trips to Puentes Grandes, he was inspired to write a poem describing Juana Borrero, whom he had come to admire more than any of Don Esteban's other children (see V11). This composition was published first in La Habana Literaria on 15 July 1892, then in El Hogar on 28 August 1892, and finally in Bustos in 1893.

On 26 January 1891, Don Esteban read Casal some poems that Juana had written. Casal was so impressed by these compositions that he decided to write an article about them and, in this way, formally introduce them to the public. ${ }^{6}$ The poem that he liked best of all was "Vespertino":

Hacia el ocaso fúlgido titila el temblador lucero vespertino, y a lo lejos, se escucha del camino el eco vago de lejana esquila. 
Como escuadrón de caprichosa fila nubecillas de tono purpurino se desvellonan en celaje fino, etérea gasa, que disuelta oscila.

El rayo débil que las nubes dora, lentamente se extingue, agonizante, sus fulgores lanzando postrimeros;

y la noche se apresta vencedora a desceñir sobre el cenit triunfante su soberbia diadema de luceros. ${ }^{7}$

Since Borrero did not give him a copy of "Vespertino" or the other poems, Casal abandoned the idea of writing his article about Juana. Then, without the knowledge of either Juana or her father, a copy of the sonnet was sent to La Habana Elegante and was published by the editors of that journal on 17 May $1891 .^{8}$ Immediately thereafter, F. Paula Coronado, using the pseudonym César de Madrid, printed a harsh criticism of the poem in the satirical journal Gil Blas. This very much annoyed both Borrero and Casal. Don Esteban felt that the unauthorized publication of "Vespertino" was an invasion of privacy and that the severity of the criticism was potentially harmful to the development of Juana's artistic personality: "Mis versos para mí han sido siempre cosa íntima; sólo a mis amigos los he mostrado y este sentimiento de reserva me subía de punto al pensar en la publicación de los primeros versos de un hijo mío; de una niña casi, pues no cuenta más que 13 años de edad; y no hubiera querido dar a nadie el derecho de lastimar su personalidad artística - para mí deficiente y todo-,

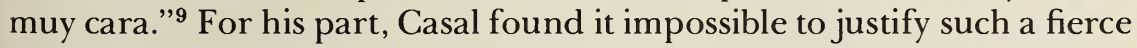
attack on the poem, because his appraisal of it was diametrically opposed to that of the critic: "No creo que haya habido aquí, en ninguna época, un solo poeta que haya escrito un soneto tan perfecto a esa edad, ni creo que entre los que hoy escriben versos, no siendo Varona, exista quien la pueda igualar. El soneto de un extremo a otro está saturado de verdadera poesía. Allí se respira una ráfaga de melancolía infinita y majestuosa que perfuma el espíritu de inefable bienestar. Da la sensación que daría un ramo de rosas blancas aspirado en una onda de éter. Tiene el colorido de un crepúsculo de otoño, la armonía silenciosa de un ejército de nubes fugitivas y a través de los versos una luz semejante a la que vierten las estrellas sobre las ramas de los árboles. Me ha hecho la misma impresión que algunos paisajes de Sanz. Además tiene para mí el mérito de no estar escrito con más objeto que el de producir una sensación de belleza en el ánimo del lector." 10

Casal's admiration for Juana continued to grow with the passing of time. As a sign of his esteem, he dedicated the first version of "Marina" to her on 10 July 1892 (see R4); on 15 July, he published his essay "Juana 
Borrero" (see my discussion of V11); and a little over a month later, he brought out "Virgen triste," a poem which, as shown by Carlos Pío Uhrbach in the following anecdote, was inspired by Juana: "En las noches melancólicas de luna; cuando la naturaleza parecía narcotizada por la lumbre fría de los astros, recitábame [Juana] las inmortales rimas que le consagró el pobre Casal y cuando llegaba al último verso 'Porque en ti veo la honda tristeza - de los seres que deben morir temprano' - su cabeza hacía signos afirmativos y su voz desfallecía, desvaneciendo sus timbres flébiles, como se apagan las notas musicales en las penumbras de los templos.". 11 In number of years, Juana was so very young; nevertheless, according to Casal, she had the intellect of a person more than twice her age: "Hay pocos seres que, con doble número de años, tengan percepciones tan claras de las cosas y puedan emitir juicios tan acertados sobre ellas. Sin haber visto nada, dijérase que lo ha visto todo." ${ }^{12}$

Although Casal's feelings for Juana seem not to have gone beyond the limits of fraternal affection and a sincere admiration for her talent, Juana saw in Casal the embodiment of that ideal love which she visualized in her dreams. In the words of José Antonio Portuondo, "Eduardo Spranger le hubiera puesto las manos sabias sobre los bucles y le hubiera dicho que tras de sus pupilas ansiosas aún no había amor, sino ese delicado y complejo sentimiento que se llama el erotismo adolescente, es decir, el impulso apasionado de dación a lo que se admira, a las grandes ideas o a una figura que se nos aparece grande y noble." ${ }^{13}$ It is conceivable that, under normal circumstances, Juana would have quickly outgrown her adolescent crush on Casal. The poet's tragic death, however, caused her to see him in an even more romantic light than she had when he was alive. Thus, in her imagination, he became the man whose memory would fill her heart with unsatisfied longings and immeasurable grief until the end of time.

In spite of her good intentions, Juana soon learned that life's implacable forces ultimately subvert all monuments-even those erected by strong-willed adolescents. At the end of 1894, Carlos Pío and Federico Uhrbach published Gemelas, a book of verse dedicated to the memory of Casal. The Uhrbachs sent Juana an autographed copy of the book and, when she read it, she discovered that "Exótica," one of the sonnets that Carlos Pío had written, was dedicated to her. That night, much to her surprise, she dreamed of the young poet. By the following night, she was already asking Casal to forgive her for being inconstant and was confessing to her diary that she had fallen in love with Carlos: “iOh Dios mío así es el hombre que yo he soñado! . . . OOh mi pobre durmiento... perdóname! iLo amo!"14

The year 1895 was filled with excitement for Juana. On 10 March, she met Carlos Pío for the first time; this meeting took her love out of the realm of fantasy and laid the foundation for a passion that would last until her death. Later that year, she saw the publication of Grupo de familia: 
Poesias de los Borrero (Havana: Imprenta la Moderna, 1895). This book, which had a flattering prologue by Aurelia Castillo de González, not only contained works by Esteban de Jesús Borrero, Manuel Borrero Echeverría, and Esteban Borrero Echeverría, but also included nine poems by Juana: "Madrigal a Jacinta," iTodavía!," "Mis quimeras," "Crepuscular," "¿Qué somos?," "Las hijas de Ran," “Apolo," "Himno de vida," and "El ideal." Shortly thereafter, Juana put out a book of poetry all her own. Entitled Rimas and published by the Establecimiento Tipográfico "La Constancia," this volume contained 19 poems - the nine that had appeared in Grupo de familia, plus ten additional ones - and had an exergo by Aniceto Valdivia. Finally, during 1895, Juana gained increasing recognition for her achievements in the graphic arts. ${ }^{15}$ However, as Julián del Casal had predicted in "Virgen triste," the young artist was destined to be an early victim in her struggle with life. Because of the deteriorating political situation in Cuba, the Borrero family emigrated to Key West, Florida, in January 1896. Two months later, Juana contracted typhus and, on 9 March, just one day before the first anniversary of her meeting with Carlos, she died of complications arising from the disease.

\section{R34: Notes to Introductory Statement}

1 Critics differ on the question of Juana's birthdate. I have accepted the date given by Juan J. Remos in his Historia de la literatura cubana (Havana: Cárdenas y Cía., 1945), vol. III, p. 93. This date has been cited by other scholars, among them, Max Henríquez Ureña, Panorama histórico de la literatura cubana (Puerto Rico: Ediciones Mirador, 1963), vol. II, p. 251, and Cintio Vitier, "Las cartas de amor de Juana Borrero," in Juana Borrero, Epistolario (Havana: Academia de Ciencias de Cuba, 1966), vol. I, p. 29.

2 For further information on Esteban Borrero Echeverría, see my discussion of N36.

3 Juana Borrero, Poesias (Havana: Academia de Ciencias de Cuba, 1966), p. 111.

4 Angel I. Augier, "Juana Borrero, la adolescente atormentada," in Cuadernos de Historia Habanera, no. 15 (1938), p. 38.

5 Dulce María Borrero, "Evocación de Juana Borrero," Revista Cubana, vol. XX (July-December 1945), pp. 32-33. Another version of Casal's introduction to the Borrero family appears in Esteban Borrero Echeverría's "El lirio de Salomé" (El Figaro, 22 October 1899), which is reproduced in Ed. del Cent., vol. I, pp. 37-39.

6 See Casal's letters of 27 January and 25 May 1891, in Ed. del Cent., vol. III, pp. 82-83 and 87 , respectively.

7 Juana Borrero, Poesías, p. 117.

8 In his letter of 27 May 1891 to Casal, Borrero tells how "Vespertino" came to be published without his consent; see Ed. del Cent., vol. III, pp. 88-89.

9 Ed. del Cent., vol. III, p. 88.

10 Ibid., pp. 87-88. 
11 Juana Borrero, Poesias, p. 172. This anecdote is part of a eulogy written on 12 March 1896 and published three days later in El Figaro.

12 Bustos y rimas, p. 82; Ed. del Cent., vol. I, p. 267.

13 Augier, "Juana Borrero...," p. 42.

14 Juana Borrero, Epistolario, vol. I, p. 40.

15 Some of her works are reproduced in her Poesias and her Epistolario, as well as in vol. III of the Ed. del Cent.

R34: VARIANTS

l. $H E$

23 descuellas

24 dalias,

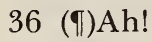

* 38 [y]
$R$

descuellas, dalias

$\mathrm{Ah}$ !
GLIC

(ף)iAh!

\section{R34: Note to Variants}

38: Casal took a liberty which goes beyond the limits of good taste. By adding to 11. 36-37 a statement which begins with $y$ and which ostensibly depends on the por of porque, Casal disorients the reader.

\section{R35: LAS HORAS}

This sonnet was first published on 13 August 1893 in La Habana Elegante. It appeared beside "Oración" (R33) on the title page of the journal and, with its companion, was subsumed under the heading "Escorias." Both sonnets were laid out in clear blocks of four stanzas, but no lines were indented.

According to the Ed. del Cent.'(vol. III, p. 221), "Las horas" was reprinted in La Unión Constitucional on 17 August 1893. Since it was impossible for me to procure this version, references to it are absent from the record of variants.

On 18 August 1893, just three days after reproducing "Oración" from the $H E$ version, $E l$ Pais reprinted "Las horas." In this instance, however, the editors did not indicate that their source was La Habana Elegante. Furthermore, instead of indenting the first verse of every stanza and leaving a blank space between stanzas, as they had done with "Oración," they indented only 11.1 and 9, and left no blank spaces anywhere in the poem.

In Rimas, the poem was laid out as it had been in the $H E$ printing. Only two punctuation changes differentiated this version from the original. 
R35: VARIANTS

\begin{tabular}{|c|c|c|c|}
\hline l. $H E$ & $P$ & $R$ & $G L I C$ \\
\hline 1 Qué & $($ I) $+H E$ & $H E$ & (I)iQué \\
\hline 2 cieno & & cieno, & \\
\hline 5 [c]ruzan & & & $(\mathbb{I})+H E$ \\
\hline 9 Yo & (ף) Yo & $H E$ & $P$ \\
\hline $\begin{array}{l}12 \text { [d]e } \\
\text { desconfío, }\end{array}$ & & desconfío & $\begin{array}{l}(\mathbb{\Phi})+H E \\
H E\end{array}$ \\
\hline
\end{tabular}

\section{R36 EN EL CAMPO}

"En el campo" was first published in the 27 August 1893 issue of $L a$ Habana Elegante. It was printed in italics on the first page of the journal. The Rimas version of the poem was identical to the original, except for one change in word order (see below).

No works of Casal were published between 21 May and 13 August 1893. The reason for this gap in publication is that Casal's health had deteriorated to the point where he found it difficult to carry out his customary activities. In June, he left Havana and went to the home of his sister in Yaguajay. There in the interior, he hoped to recuperate his strength and elevate his spirits. Unfortunately, his short holiday ${ }^{1}$ improved neither his physical condition nor his state of mind. This is evident from his 7 October comment to Darío that "desde julio a la fecha he recibido dos veces los Santos Sacramentos" (see R37) and from the negative assessment of country living which he incorporated into "En el campo."

When reading the monorhymed tercets of "En el campo," one should not imagine that Casal was merely imitating the Decadent preference for artificial, as opposed to natural, environments. In point of fact, Casal's distaste for country living and for the countryside itself went back some time. Take, for example, the following statement which the poet made to Esteban Borrero Echeverría in his letter dated 10 February 1890: "Hace unos días que llegué del campo y no había querido escribirle porque traje de allí muy malas impresiones. Se necesita ser muy feliz, tener el espíritu muy lleno de satisfacciones para no sentir el hastío más insoportable a la vista de un cielo siempre azul, encima de un campo siempre verde. La unión eterna de estos dos colores produce la impresión más antiestética que se puede sentir. Nada le digo de la monotonía de nuestros paisajes, incluso las montañas. Lo único bello que presencié fue una puesta de sol, pero ésas se ven en la Habana todas las tardes." ${ }^{2}$

\section{R36: Notes to Introductory Statement}

1 The exact duration of Casal's stay has yet to be determined. However, 
after an interview with the poet's sister, Marshall E. Nunn stated that Casal was away from Havana for "algunas semanas" ("Vida y obras de Julián del Casal," América, vol. IV [October 1939], p. 50).

2 Ed. del Cent., vol. III, p. 81. For an analysis of the poem, see Fausto Avendaño, "En el campo," in Antología comentada del modernismo, ed. Francisco E. Porrata and Jorge A. Santana (Sacramento: California State University, 1974), pp. 176-179.

R36: VARIANTS

l. $H E$ $R$

3 [y] prefiero

[p]refiero yo

GLIC

\section{R37: ENRIQUE GOMEZ CARRILLO}

This sonnet was first published in the 1 October 1893 issue of $L a$ Habana Elegante. A footnote indicated that the poem had been "Escrito para el Pórtico de un nuevo libro de E. G. C." The subtitle in this version was "(Viendo su retrato)." A row of dots following 1.8 divided the poem into two distinct parts: in the cuartetos, Casal presented a verbal portrait of Gómez Carillo, while in the tercetos, he summarized his feelings of spiritual affinity with the Guatemalan author whom Death would prevent him from meeting. Casal's awareness of the gravity of his illness at this time is revealed in his letter of 7 October 1893 to Gómez Carrillo's friend and mentor, Rubén Darío. ${ }^{1}$ The letter reads as follows: "Mi inolvidable Rubén: si ha caído en tus manos, por casualidad, algún periódico cubano de estos últimos tiempos, te habrás enterado de que me encuentro muy enfermo; tan enfermo, que desde julio a la fecha he recibido dos veces los Santos Sacramentos. Ahora estoy mejor, pero sin esperanzas de curación, porque ningún médico conoce mi enfermedad. Todos aseguran (me han visto los mejores de aquí, donde los hay muy buenos) que es un mal obscuro y misterioso, desconocido por ellos. Te escribo estas líneas para demostrarte que aun al borde de la tumba, adonde pronto me iré a dormir, te quiero y te admiro cada día más. Yo he sabido de ti por Gómez Carrillo, que me anunció tu llegada a París y tu marcha a Buenos Aires. Dentro de poco, quizás antes de que me muera, podré leer el libro que debes estar imprimiendo en estas horas. La Habana Elegante me está editando uno [Bustos y rimas], pero no tiene ningún valor. Yo te lo mandaré, o te lo mandarán."2

When preparing R37 for publication in Rimas, Casal suppressed the original footnote, lengthened the subtitle to "(Viendo su retrato por Cazals)," ${ }^{3}$ and introduced two lexical variants into the text. He preserved the divided format of the $H E$ printing, however. 


\section{R37: Notes to Introductory Statement}

1 It will be recalled that Gómez Carrillo had collaborated with Darío on El Correo de la Tarde (Guatemala, 1890-91).

2 HE, 17 June 1894; Ed. del Cent., vol. I, p. 33.

3 The artist referred to here was Frédéric-Auguste Cazals (b. Paris, 31 July 1865; d. Paris, 2 March 1941).

\section{R37: VARIANTS}
l. $H E$
8 pedrería....
10 pesar
13 ternura

$R$

pedrería.

dolor

pureza

\section{R38: TARDES DE LLUVIA}

This poem was first published in the 3 September 1893 issue of $L a$ Habana Elegante. The last four stanzas, in which Casal expressed his reactions to the multifaceted scene he had just described, reveal the degree to which his already somber view of reality had been darkened by the severity of his illness and the consciousness of his tragic destiny. Despite the progressive deterioration of his health in the days following his composition of the poem, however, Casal made several minor changes in it for the definitive Rimas version.

\section{R38: VARIANTS}

\section{l. $H E$}

* 11 laureles, [sic]

13 fulgor

15 capullo peonía

25 campana

$41 \mathrm{Y}$ crepúsculos
$R$

claveles, flulgor [sic] botón peonía, campana, $\mathrm{Y}$, crepúsculos,
GLIC

$H E$

( $)+R$

\section{R38: Note to Variants}

11: The sense of this stanza strongly suggests that the repetition of laureles in 1.11 of the $H E$ version was a typographical error. Thus, the word claveles in the $R$ version is considered to be a correction and not a deliberate lexical change. 


\section{R39: UN SANTO}

This sonnet first came to public attention in the 10 September 1893 issue of La Habana Elegante. It was printed to the left of "El hijo espurio" (R40) and, with its companion, was subsumed under the heading "Escorias." No lines were indented. On 13 September 1893, El País reproduced the poems in the same sequence, but in vertical format (i.e., R39 above R40 in the same column). Except for the fact that El Pais indented the first line of each stanza, this version was an exact replica of the original. The Rimas version differed from its predecessors only in the spelling of the name of the artist mentioned in 1.11.

R39: VARIANTS

l. $H E$ $P$ $R$ GLIC

11 Rivera,

Ribera,

\section{R40: EL HIJO ESPURIO}

This poem was originally published in the 10 September 1893 issue of La Habana Elegante. It was printed to the right of "Un santo" (R39), and both sonnets were subsumed under the heading "Escorias." No lines were indented in this version. On 13 September 1893, El Pais reproduced both poems in the same sequence but in vertical format (i.e., R40 beneath R39). The first line of each stanza was indented in this printing. Casal made one lexical change in the text of "El hijo espurio" before submitting it for publication in Rimas.

R40: VARIANTS
l. $H E$
$P$
$R$
GLIC
* 3 [que,
9 de un
12 largas,
del
largas que

R40: Note to Variants

3: Because the comma after que gives a false sign of syntactic relationship and, in the process, also disturbs the rhythm of the line, it is omitted from the present edition. 


\section{R41: CUERPO Y ALMA}

Julián del Casal died on 21 October 1893. Eight days later, on 29 October, La Habana Elegante published the first periodical version of "Cuerpo y alma." The poem was printed in italics. The black border around the page and the cross before the author's name were a final tribute to the young man who had died so suddenly at the height of his literary career. A footnote informed the readers of La Habana Elegante that "Cuerpo y alma" was the last poem that Casal had written for his forthcoming book, Bustos y rimas. A photograph of this version of the poem is exhibited in Plate 46.

Except for one lexical variant, the Rimas version and the $H E$ original are identical. This variant, however, raises a problem whose solution is more difficult than any other one in Rimas. The alternatives are discussed below.

\section{R41: VARIANTS}

l. $H E$

$R$

GLIC

* 82 crezca

viva

$H E$

\section{R41: Note to Variants}

82: The $H E$ version appeared eight days after Casal's death, and at a time when $R$ was still in press. In the periodical version, the verb crezca was used in 1. 82. When $R$ came out, however, crezca was gone and viva appeared in its place. If we compare both versions of the poem, we find that 1l. 81-82 contain five words in common and that these words occur in the same order:

$$
\begin{aligned}
& 81 \text { quela alondra no viva junto al tigre, } \\
& 82 \text { que la rosa no }\left\{\begin{array}{l}
\text { crezca } \\
\text { viva }
\end{array}\right\} \text { junto al cerdo. }
\end{aligned}
$$

On first impression, it would seem that the presence of viva in 1.82 of $R$ was the result of a typographical error which was caused by the occurrence of viva in a similar cluster of words just above it. Since this is the only variant in the poem, the explanation appears to be quite plausible. However, if we examine 11. 69-70, we discover that the author did use a form of vivir in two consecutive verses:

69 vivir en la inmundicia de mi carne,

70 comovive una flor presa en el cieno. 


\section{Cuerpo y alma}

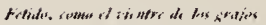

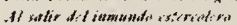

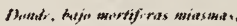

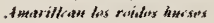

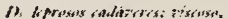

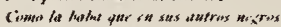

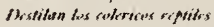

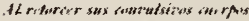

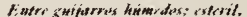

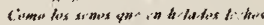

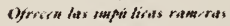

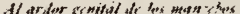

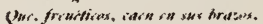

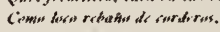

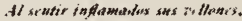

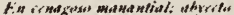

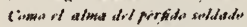

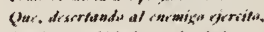

liverirt acribille le per las halas

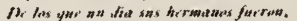

sin temer quen le rend les hrridas,

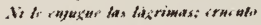

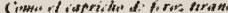

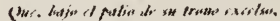

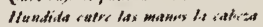

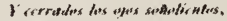

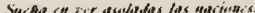

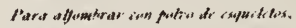

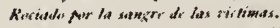

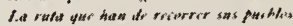

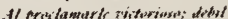

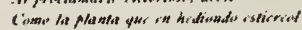

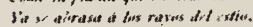

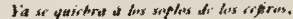

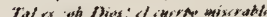

(jur arrastere dit tivir for las semderies.

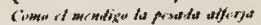

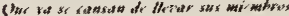

II

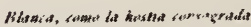

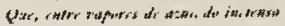

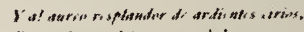

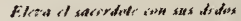

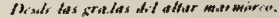

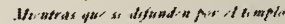

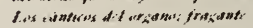

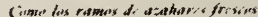

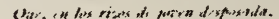

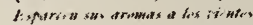

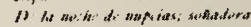

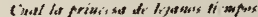

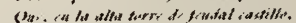

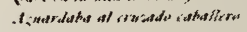

I quich juratid stater derma; idsto

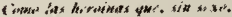

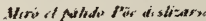

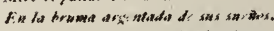

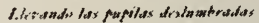

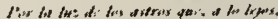

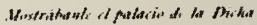

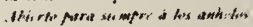

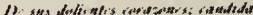

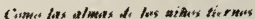

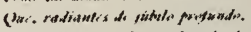

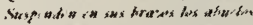

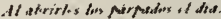

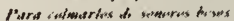

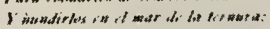

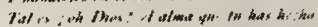

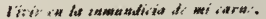

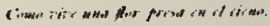

$$
\text { (1) }
$$

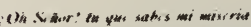

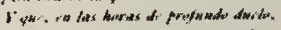

V.

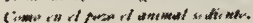

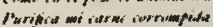

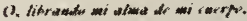

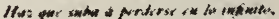

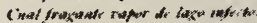

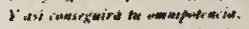

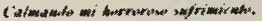

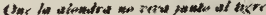

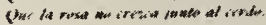


Like ll. 81-82, these verses are the closing lines of a stanza. What is more, 1.70 contains the same basic image as 1.82 of the $R$ version. The corresponding elements in 11.70 and 82 are flor-rosa, vive-viva, and cieno-cerdo. This threefold parallelism in $R$ (a parallelism of vocabulary, imagery, and position within the stanza) suggests that the change from crezca to viva may indeed have been deliberate. In order to accept this hypothesis, two key questions would have to be answered: Who could have made the change, and when could he have done so? Obviously, the answers would have to take into consideration the fact that the $H E$ version came out eight days after Casal's death, and at a time when $R$ was already in press. Two possibilities are: 1) that, after Casal died, someone on the editorial staff of La Habana Elegante changed one version of the poem or the other for reasons best known to himself; or 2) that La Habana Elegante had two copies of the poem in its possession. The first explanation is difficult to accept because viva is the only variant in $R$; even the punctuation of the two versions is identical! In order to accept the second explanation, it would be necessary to assume that the editors. of La Habana Elegante had received one copy of the poem some time before 21 October, but delayed publishing it in the journal; and that, in the meanwhile, Casal had inserted a corrected copy into the $R$ portfolio. This is clearly within the realm of possibility. Nevertheless, such a hypothesis is not entirely convincing. First, if the editors of La Habana Elegante had received the manuscript of "Cuerpo y alma" early in the month, it seems strange that they would fail to publish the poem in their issues of 8,15 , or 22 October which, incidentally, contained no poetic contribution by Casal. Second, if the editors of La Habana Elegante had a corrected version available when setting the type for Rimas, it seems odd that, eight days after Casal's death, they would turn to an earlier, unrevised version of the poem. And third, it is particularly hard to believe that Casal, whose tendency was to modify the punctuation of his poems much more frequently than the wording, would go through 82 verses of "Cuerpo y alma" without altering the punctuation, but would change a single word at the very end of the composition-especially when that word was already part of an extremely repetitive context. On the contrary, it seems more reasonable to believe that Casal had submitted "Cuerpo y alma" to his editors a few days before he died; that they used that manu script for both the periodical and the book versions; and that, in a moment of distraction at the end of his job, the compositor of Rimas misread the last line and substituted viva for crezca. My preference for this hypothesis leads me to restore crezca in the present edition. 


\section{Varia}

Casal published 144 compositions in Hojas, Nieve, and Rimas; and over the years, 13 additional works have come to light. There is reason to believe, however, that this group of 157 poems does not represent the author's total production. First of all, it is so hard to imagine that "iUna lágrima!," Casal's earliest known work, was his initial attempt at versifying, that we feel obliged to postulate the existence of still earlier compositions. Second, the discovery of a few poems in the albums of friends leads us to suspect that Casal wrote similar pieces in albums of other acquaintances, who, for one reason or another, never made them public. Lastly, comments in Casal's correspondence imply that, even at the height of his career, he had more in his portfolio than he saw fit to publish (see C8/17-26 and C10/37-39). Hopefully, further research in Cuba will reveal the whereabouts of some of the lost poems. Until this happens, however, we must content ourselves with an examination of the thirteen items which now constitute the Varia section of the corpus. These poems range in date from 1881 to 1892 and may be discussed under four general headings.

Early works (V1, V2, V3)

“iUna lágrima!" (V1), "El poeta y la sirena” (V2), and "Huérfano" (V3) are Casal's earliest known compositions. Although these works are put together skilfully enough to suggest that a certain amount of poetry had preceded them, they are obviously the creation of an inexperienced versifier. Indeed, lack of experience helps explain why the poems are so clearly imitative in nature and why, as noted by José María Monner Sans, they have "resobados motivos de inspiración, común tono gemidor, inocultables deficiencias de léxico, pobretona y rutinaria versificación."1

Imitative and imperfect though they may be, these early compositions are interesting nevertheless, for they reveal the presence of concepts and techniques that would be repeated in much of Casal's later work. Perhaps the most obvious feature of the poems is the author's preoccupation with the loss of a loved one and with the loneliness, sadness, and internal 
coldness which result from that loss. Closely related to the experience of loss is the tendency to see the world as a place that is fraught with danger. Paradoxically, one of the worst perils that the individual faces in the very world that has robbed him of love, security, and joy is the promise of immediate sensual gratification. This danger is especially serious because the deep feeling of privation which he experiences whets the appetite of his senses and thereby increases his vulnerability. Seeing reality in this way, he prizes purity and attempts to protect himself from evil. Safety, he assumes, can be guaranteed in two basic ways: first, by remaining doggedly faithful to the loved one who is lost (or to an ideal which functions as a substitute for that person) and, second, by rejecting life's temptations in favor of complex fantasies describing gratifications that can be had in some distant place or time.

What Casal was, and how he felt and thought did not manifest themselves only as concepts in his poetry, but also as techniques. The following examples from his early works may be cited to illustrate this point. Suspicious by nature, Casal approached people, places, and things as warily in his poetry as in his life, and tended to examine them in detail before initiating any action. Viewing existence as a struggle between good and evil, he constantly presented a confrontation of opposites: before-now, there-here, heaven-earth, light-dark, man-woman, joy-sadness, dreamreality. Sensuous in the extreme, he was inclined to dwell on the shape, color, and texture of the things that came to his attention. Rebellious, yet childishly afraid of doing wrong, he looked for models who would give direction to his creative urge and who, by their example, would justify his cautious attempts to break with convention. And fearful of experiencing even greater solitude than he already knew, he honored friends and acquaintances by dedicating poems to them.

\section{Album pieces $(V 4, V 5, V 7, V 8, V 10, V 12)$}

Dating from 30 May 1885 to 2 October 1892, the poems in this category were written either for the private albums of female acquaintances or for album-type columns that appeared on a regular basis in the local press. All of the works are short (4-18 lines). However, since Casal did not disdain brevity - H16, H28, H35, N41, and N51, for instance, are all only eight lines long - it is assumed that length was not the main factor determining the exclusion of the album pieces from his books. A more likely reason is quality, for, once they are analyzed, most of the poems seem to be aesthetically weaker than contemporaneous compositions which were selected for publication in Hojas, Nieve, and Rimas.

The fact that these six poems were excluded from Hojas, Nieve, and Rimas does not mean that they are any less revealing than collected works which were conceived during the same period. For example, "Dos fechas" (V5) is an excellent illustration of Casal's tendency to see reality in terms of antitheses. "Serafina Valdivia y Huidobro" (V 10) shows his willingness to 
experiment with a metrical pattern in a variety of circumstances once he had overcome his natural reluctance to depart from routine, ${ }^{2}$ and also exemplifies his inclination to use simile with increasing frequency during the last years of his life. "Aves mis versos son ..." (V8) reflects the degree of suffering that he experienced in his passage through the world, and suggests the extent of his need to be accepted by people whom he admired. "Pensaba darte consejos..." (V4) and "Dicen que eres un ángel ..." (V7) indicate how easily the words of others affected his behavior. Finally, "Corina Rowland y del Monte" (V12) reveals how sensitive he was to feminine charms and how much emotional energy he consumed in trying to express his admiration for women.

\section{Poetic portraits (V9, V11)}

Although extremely inhibited where women were concerned and ever wary about becoming sentimentally involved with any one lady, Casal did write a number of verse portraits of female contemporaries. Well-known examples of this type of poetry are "Versos azules" (H49), "Camafeo" (N39), and "Medallón" (N53), whose subjects were Ina Lasson, María Cay, and Alicia Sierra y Peñarredonda, respectively.

Similar to the verbal portraits just mentioned are Casal's descriptions of Hortensia del Monte and Juana Borrero. In the case of "Hortensia del Monte" (V9), the trite imagery and syntactical repetitiveness of the poem would have given Casal ample reason for omitting it from Nieve. Another factor leading him to exclude it, however, might have been his uneasiness about its metrical structure ( 24 enneasyllabic lines, followed by an envio combining octosyllables and tetrasyllables), for, as shown in my general discussion of metrics, ${ }^{4}$ Casal never did have a fondness for enneasyllables; furthermore, he was reluctant to mix meters within a poem, and was especially disinclined to do so if, as in this instance, the mixture was not strongly supported by convention.

"Juana Borrero" (V 11) had a slightly different literary fate from "Hortensia del Monte," for, after being published in Havana periodicals, it was included in one of Casal's collections: Bustos. Since Bustos came out together with Rimas, however, one wonders why Casal did not simply lift the work out of the prose section of the book ${ }^{5}$ and incorporate it into the poetry section. One thing that may have kept him from doing this is the fact that Juana was already the subject of an important composition in Rimas, "Virgen triste" (R34). This point acquires added significance when the quality of the two poems about Juana is considered. With respect to content, R34 is much more interesting than V11, for it deals primarily with Juana's spiritual traits rather than with her physical characteristics. In addition, it is more sophisticated than V11 from the standpoint of form: while "Juana Borrero" is structured on an ordinary redondilla framework, "Virgen triste" is composed of dodecasílabos de seguidilla which 
are grouped in five-line stanzas that have a flexible rhyme scheme. In view of this, it seems that Casal did well to keep V11 in its original place, where it would not be exposed to comparison with R34.

\section{Topical items (V6, V13)}

An examination of the corpus shows that Casal did not publish many poems of a topical nature; nevertheless, the pieces he did bring out make it plain that he was not as disinterested in the subjects and events of his day as he is reputed to have been. See, for example, "Las mujeres" (V6), which appeared in El Fígaro on 27 October 1887. During the latter half of the nineteenth century, even in colonial Cuba, rapid change was shaking urban society to its very foundations. Quite naturally, public morality was one of the areas affected by the forces of "progress" that filled the world; and, in the male-dominated nations of the West, the behavior of women the most idealized, yet "unstable" element in society - became a cause of more than usual concern. Undoubtedly, "Las mujeres" is of little import from the aesthetic point of view. However, it does confirm the existence in Casal of a social consciousness based on strong principles of morality. Indeed, the same underlying rectitude which prompted him to compose this poem led him to undertake the writing of La Sociedad de la Habana and, at later stages of his career, to criticize local tastes, values, and customs in articles written for La Discusión and El País.

In the collected works, the most significant poems having their inspiration in particular historical events are "A los estudiantes" (H44) and "Adiós al Brasil del Emperador don Pedro II" (H45). In the Varia, there is also a major poem of this type: "Colón en la Rábida" (V13). Recited by a student of the Real Colegio de Belén at one of the Colegio's public functions in the fall of 1892 , this romance endecasilabo - one of the longest pieces Casal is known to have written ${ }^{6}$ - was later published in a volume entitled Corona poética que a la eterna memoria del gran Cristóbal Colón of recen en el IV centenario del descubrimiento de América los alumnos del Real Colegio de Belén. The version that appeared in this book was shorter and more polished than the manuscript version which preceded it. Nevertheless, Casal saw fit to exclude it from Rimas. Why he did so is unknown, although it is possible that factors such as the approach to the subject and the quality of the imagery influenced his decision. Whatever the case, after lying in obscurity since being published in 1892, the revised version of "Colón en la Rábida" is now available for examination by students of Casal.

\section{Vp0: Notes to Introductory Statement}

1 Julián del Casal y el modernismo hispanoamericano (Mexico: El Colegio de México, 1952), p. 41.

2 Casal began to use the dodecasilabo de seguidilla with the "Tipos españoles" 
trilogy (N 19, N20, N21), which he published in February of 1892. In the following months, he used this meter for seven more poems, each one quite different from the others (V10, R7, R12, R21, R2, R32, R34).

3 The impression that Casal used simile more frequently in the last years of his life than in earlier periods is confirmed by the following data from his collected works:

$\begin{array}{lllr} & H & N & R \\ \text { como } & 65 & 66 & 102 \\ \text { cual } & 16 & 19 & 30\end{array}$

4 See above, pp. 298-302.

5 If one sentence before the poem and one sentence after it had been suppressed, the excision could have been made without adversely affecting the article.

6 Five poems in the corpus exceed 100 lines in their final version: "La muerte de Moisés" (N4), 149 ll.; "Sueño de gloria" (N 18), 130 ll.; "Colón en la Rábida” (V13), 122 ll.; "Amor en el claustro" (H3), 110 1l.; and "Horridum somnium" (N54), 106 ll. We are reminded by “Colón en la Rábida," however, that some of these pieces were even longer in earlier versions.

\section{V1: iUNA LAGRIMA!}

This is Casal's first known work. It appeared on 13 February 1881 in the "Sección Poética" column of El Ensayo, a weekly journal that had begun publishing in Havana on Sunday, 6 February 1881. In this version, the title was printed in boldface caps and was surrounded by double exclamation points; all lines were left-justified; the initial letter in every verse was capitalized; 11.30 and 31 were set in a smaller typeface than the other lines in the poem, because they were too long to fit into the horizontal space available; and the initials "J. C." were printed below the text and to the right of the date, "Enero $1881 . "$

This composition, which was published when the poet was only seventeen years old, is important for several reasons. First of all, it suggests that although more than a decade had passed since his mother's death, the memory of that tragic event still caused Casal profound anguish. Confirmation of this impression is given by "Huérfano" (V3), which came out only six weeks after "iUna lágrima!" and was dedicated to Clara Krick, a long-time friend of Casal's mother. Second, the poem clearly reflects Casal's literary preferences during his teens: "Los alejandrinos de iUna lágrima!," says Monner Sans, "denuncian al lector de Zorrilla ...." It is obvious, for example, that the double exclamation points around the title in the $E$ version are taken directly from the Romantic tradition. Third, the work shows how poetically immature Casal was at this stage in his career: 
once the reader passes beyond the title, he discovers an insubstantial text, inflated by emphatic repetitions. Contributing to the sonorous emptiness of the composition are Casal's frequent duplication of structural patterns in contiguous hemistichs (see 1l. 2, 4, 6, 8, 11, 14, 31, 37, and 38); his excessive use of vacuous qualifiers, either alone or in clusters; and his windy interjections that fill out stanzas but add no substance to the poem. Needless to say, the overall feeling of emptiness is increased by Casal's depiction of the grieving daughter, whose melodramatic gestures and exaggerated manifestations of sorrow (11. 21-24, 33-36) are so obviously derived from nineteenth-century Romantic convention. Finally, 11. 1-16, which introduce the protagonist, show that Casal's penchant for doing verbal bustos was not a late addition to his style, but went back to his earliest years as a writer. ${ }^{2}$

\section{V1: Notes to Introductory Statement}

1 Julián del Casal y el modernismo hispanoamericano, p. 41. For a list of authors whom Casal mentioned in works published before May 1890, see Table 2 in the present edition.

2 For further information on this subject, see my discussions of $\mathrm{Hp} 0$ and H3.

\section{V1: VARIANTS}

l. $E$

* 29 Cuán [sic]

* 31 Qué [sic] que [sic] mente. [sic]

* 32 Que [sic]

* 37 rezos; [sic]

* 40 i[p]aréce [sic]

* 41 vírgen
GLIC

(đ) iCuán

iQué

qué

mente!

iQué

rezos,

iparece

virgen,

\section{V1: Notes to Variants}

29, 31, 32: Although the introductory exclamation point appears in lines 7, 19, 30,40 , and 44 of the $E$ version, it is missing from 1l. 29 and 32; and both the introductory and the terminal exclamation points are absent from 1. 31 . It is felt that omission of these punctuation marks, as well as of the accent on qué in 11. 31 and 32, was not the work of Casal, but rather of the compositor, who had a problem with the entire stanza because of the length of 11.30 and 31 (see my introductory statement, above). In view of this, I am inclined to treat the omissions as errata, and to add the normal punctuation marks and diacritics to the lines in question. Unfortunately, the addition of punctuation marks 
cannot improve 11. 29-30, where, because of the sequencing chosen by Casal, de hinojos prosternada seems to refer to madre instead of to the logical referent, niña.

37: The sense of the sentence suggests that a comma, and not a semicolon, was supposed to go after rezos.

40: Since the initial letter in every line of the $E$ version was capitalized, there is no way of knowing whether a new sentence was to begin in 1.40 , or whether that verse was supposed to conclude the thought expressed in 11. 37-39. Because of evidence found in $11.6-7,18-19$, and $43-44$, I tend to favor the latter possibility.

41: In order to emphasize the role that cubierto su semblante plays in the sentence, a comma is added after virgen in the present edition.

\section{V2: EL POETA Y LA SIRENA}

This composition was originally published in the "Sección Poética" column of El Ensayo on 5 March 1881. It was dedicated "A mi buen amigo Carlos Noreña" and was signed "J. C." The first verse in every stanza was indented and the initial letter of each line was capitalized. Because of its length, 1.53 was set in smaller characters than those used elsewhere in the poem. Centered rules were printed between the title and the dedication, between the dedication and the text, and between all stanzas except XI and XII-the latter being separated, instead, by two rows of dots whose function was to underscore the end of the siren's speech and emphatically introduce the echo's moralizing commentary.

Even a quick survey of the composition will show that it is the work of an inexperienced poet. The following are among its most glaring defects: assonance is used in place of consonant rhyme in 11.12 and 16 (zafir-cenit); words and phrases are frequently repeated, even in rhyming position (see, for ex., esencia virginal in 11. 20 and 56; amor-esencia del amor in 11. 32, 60 , and 68; and dolor in 1l. 52 and 66); vacuous filler material is inserted into the text in order to bring the syllable or verse count up to the desired number; and ill-contrived images like that of 1.45 ("Tendida entre la espuma cristalina") vie for attention with clichés such as those of 1.3 ("va tendiendo la noche su ancho velo") or 1. 33 ("Su breve pie de nacarado esmalte"). Fortunately, as the years passed, Casal learned to reduce the frequency with which defects of this kind appeared in his poetry.

Certain other features of "El poeta y la sirena" were favored by Casal, and, hence, were destined to appear fairly often in his later works. Among those that stand out most prominently are the depiction of idealized and/or exotic beings; the tendency to externalize the struggle between the spirit and the flesh; the inclination to use lengthy introductory descriptions; and the preference for writing "mono-dialogues," rather than true dialogues. 


\section{V2: VARIANTS}

l. $E$

* 12 zafír, [sic]

13 [c] omo

17 occeano [sic]

* 35

* 36 azul [sic]

37 [1]leva

* 69 dijo,

* 72 verdad.

* 73 espuma
GLIC

zafir.

Como

oceano

azul.

Lleva

dijo

verdad.-

espuma,

\section{V2: Notes to Variants}

12, 36: Since all thoughts in the poem are expressed in sentence units of four verses, this editor feels that 11.12 and 36 were incorrectly punctuated when they were transcribed by El Ensayo.

35: Cabrera Saqui omitted this line, and his error was repeated by the compilers of the Ed. del Cent.

69: No justification can be found for placing a comma between a verb and its subject in a case where synaloepha is obligatory. Therefore, the comma that appears between dijo and $u n$ in the $E$ version has been removed.

72: If a terminal dash is used in 1.68 to mark the end of discourse, then a dash should be used in 1.72 for the same purpose. Indeed, it is even more necessary in 1.72 , because no other sign is present to show that the words which follow are not spoken by the eco, but are enunciated by the narrator.

73: A comma is inserted at the end of 1.73 in order to make it immediately evident that the adjectives in 1.74 modify la maga and are in no way related to la espuma.

\section{V3: HUERFANO}

"Huérfano" was published in the "Sección Poética" column of El Ensayo on 27 March 1881. It bore the dedication "A la Sra. Dona Clara Krick, / a la buena amiga de mi desgraciada madre" and it was signed "J. C." All verses were left-justified and the initial letter in every line was capitalized.

The poem is obviously the work of a novice. It is of special interest to students of Casal, however, because it contains a number of thematic and technical features which were destined to manifest themselves quite often in the poet's later work. Among the themes that may be cited as typical of Casal are the death of a loved one; unswerving fidelity, even after death; sympathy for those who wander in solitude through a world devoid of joy; and withdrawal into an idealized sanctuary where one can take refuge 
from the evils of earthly reality. Technical features that may be considered as characteristic of Casal are the use of antithesis; the creation of images that communicate a feeling of spiritual coldness; and the expression of thoughts in series of two-line segments.

\section{V3: VARIANTS}

l. $E$

23 inscripciones. [sic]

53 peregrino;
GLIC inscripciones peregrino,

\section{V4: [PENSABA DARTE CONSEJOS ...]}

Casal wrote these verses in the album of María Morales de los Ríos on 30 May 1885. Scholars did not know of the poem's existence until 1945, when Mario Cabrera Saqui published it in the Poesias completas of Julián del Casal. The present version differs from Cabrera Saqui's transcription of the original in only one respect: a dash has been inserted at the end of 1.2 in order to show the parenthetical nature of the exclamation "iverdad fue!"

\section{V5: DOS FECHAS}

Casal wrote this poem in the album of María Chacón in October 1887. The work remained unpublished until 26 May 1897, on which date it was printed in Havana's Diario de la Familia. The DF version, entitled "El álbum de María Chacón," was reproduced in 1945 by Mario Cabrera Saqui in the Poesias completas of Julián del Casal. The present version is an exact copy of the Cabrera Saqui transcription.

\section{V6: LAS MUJERES}

"Las mujeres" was published in the 27 October 1887 issue of El Fígaro. Centered rules were placed beneath the title and between stanzas; the first verse in each stanza was indented; the first word in every line was capitalized; and "(Octubre)," the month of publication, was printed together with the author's name at the end of the poem.

\section{V7: [DICEN QUE ERES UN ANGEL ...]}

This brief composition was published in the 13 November 1887 issue of La Habana Elegante together with a four-line poem by Enrique Hernández 
Miyares. Both works were printed under the rubric "En el álbum de la Srta. María Suárez y Pérez." Below this heading was the joint dedication "A María." The first letter in each line of V7 was capitalized, and the author's name, right-justified, was printed below the poem. The question that Casal asked in ll. 3-4 of "Dicen que eres un ángel ..." was answered in the following way by Hernández Miyares:

Poeta: dile en notas de tu lira, Idioma de los ángeles, que abajo, En este valle hondo, oscuro y triste, El roce de sus alas es un bálsamo!

\section{V8: [AVES MIS VERSOS SON ...]}

Casal wrote this eight-line composition in the album of Rosario Armenteros de Herrera. Although he did not give the poem a title or dedication, he signed it and placed the date "Agosto 1890" on the line below his name. ${ }^{1}$ The signature was right-justified, the date and all text-lines were left-justified, and the initial letter in every verse was capitalized. See vol. III of the Ed. del Cent. for a photographic reproduction of the manuscript version.

Less than a month after Casal's death, Doña Rosario permitted El Hogar to publish the poem. The $\mathrm{Hg}$ version, which came out on 19 November 1893, differed from the original in several respects: a title, "En el álbum de la señora Rosario Armenteros de Herrera," a dedication, "A Charito," and a capitalized subtitle, "(Inéditos)," were placed before the text; centered rules were inserted beneath the title and between 11.4 and 5; a cross $(\dagger)$ was placed before the author's name; the date of composition was removed; 11.1 and 5 were indented; upper- and lower-case letters were used at the beginning of lines, as required by context; five punctuation changes were made; and three lexical variants were introduced into the text.

On 22 November 1893, the editors of El Pais reproduced the $\mathrm{Hg}$ version without substantive change. Since both periodical versions appeared after Casal's death, however, they are not represented in the record of variants, below.

\section{V8: Note to Introductory Statement}

1 In 1890, Casal's duties as a society columnist and current events reporter caused him to see Doña Rosario fairly often and to mention her name in reports on the activities of Havana socialites. References to her may be found, for example, in "Armando Menocal: Nuevos retratos" (D, 3 March 1890), Ed. del Cent., vol. II, p. 63; "Salones habaneros: Una recepción" (D, 7 July 1890), Ed. del Cent., vol. II, p. 176; and "Crónica semanal” ( $P, 21$ December 1890), Ed.del Cent., vol. III, p. 59. 


\section{V8: VARIANTS}

l. $M S$

* 7 los

GLIC

las

\section{V8: Note to Variants}

7: The word los in 1.7 of the manuscript version refers to versos in the first line of the poem. In the $H g$ and $P$ printings, los was replaced by las. This substitution is justified by the fact that, once the author speaks of versos as aves, he should be consistent in his imagery: that is, he should make the direct object of acoges agree in gender and number with aves (1. 1), todas (1. 5), and prestas (1. 7). Since it is felt that Casal would have made this change if the matter had been brought to his attention, las is used in the present edition. The appropriateness of this adjustment in the text should be judged against the background of Casal's behavior in similar situations. For example, in $\mathrm{H} 35$, a poem composed at about the same time as V 8 and very much like it in form and concept, Casal opened by establishing the image versos = mariposas $(1.1)$ and then used the feminine referent alguna de ellas (1. 6) to conclude the discourse.

\section{V9: HORTENSIA DEL MONTE}

This work was first published on 31 January 1892 in the "Album femenino" column of El Fígaro. A picture of Miss del Monte (see Plate 47) was placed between the column-heading and the poem-title. A footnote indicated that the photograph had been taken by "los Sres. Codina y Barbarrosa, O'Reilly." As far as the poem is concerned, the $F$ version had the following characteristics: the title, set in caps, was followed by a centered rule; the initial verse in each stanza was indented; the first letter of every line was capitalized; the words hortensias and Envio were italicized; and the date "(Enero, 1892.)" was printed at the end of the poem together with the author's name.

On 2 February 1892, the editors of El País reproduced the $F$ version of the poem with minor modifications in the format of the title, signature, and date. The photograph of Miss del Monte was not included in this printing.

Hortensia del Monte was one of the daughters of Ricardo del Monte, the gentleman to whom Casal had dedicated Hojas al viento. Since Hortensia actively participated in Havana social life in the 1890's, her name frequently appeared in society columns of local periodicals. A typical reference may be found in the 30 November 1890 issue of ElPais, where, in his weekly report on social events, Casal indicates that Hortensia was present with her parents and her sister Herminia at the wedding of Enrique Hernández Miyares and Francisca Marty (see Ed. del Cent., vol. III, p. 42). 
PLATE 47

Hortensia del Monte

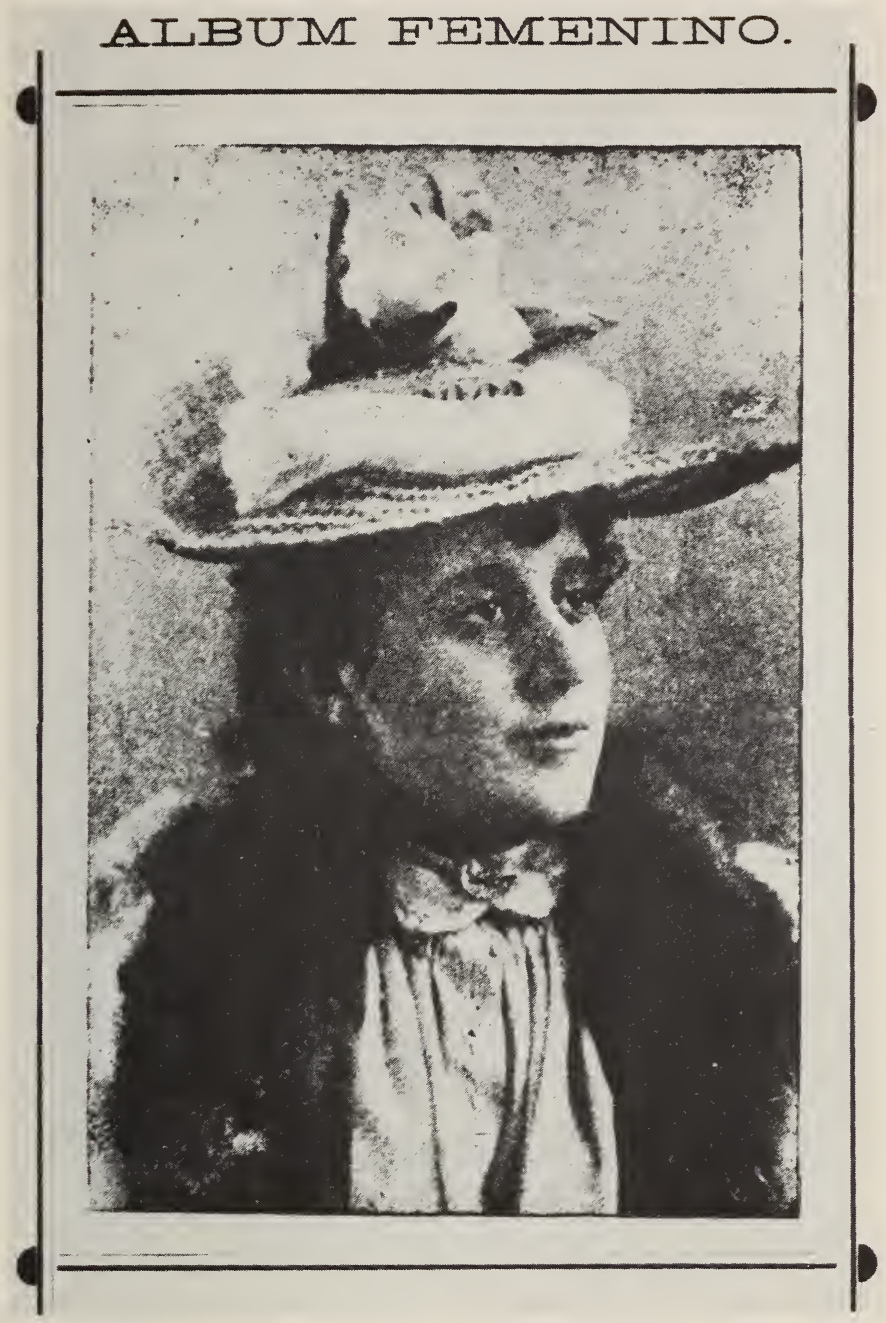

Casal's poem is of special interest because of its form. The work consists of two parts. The main section is composed of twenty-four eneasilabos polirritmicos which are grouped into six stanzas with assonantal rhyme $(e ́-a)$ in the even lines. The concluding section is a seven-line envio which combines octosyllables and tetrasyllables and which continues the $\dot{e}-a$ rhyme in the tetrasyllabic verses. The variable stress, the use of assonance in two consecutive verses (1l. 28-29), ${ }^{1}$ and the juxtaposition of nine-, eight-, and four-syllable lines make this poem quite different from traditional, as well as contemporary, enneasyllabic compositions in Spanish. This point can be verified by comparing it, for example, with Darío's "El clavicordio de la abuela," which appeared, with a dedication to Casal, on 
PLATE 48

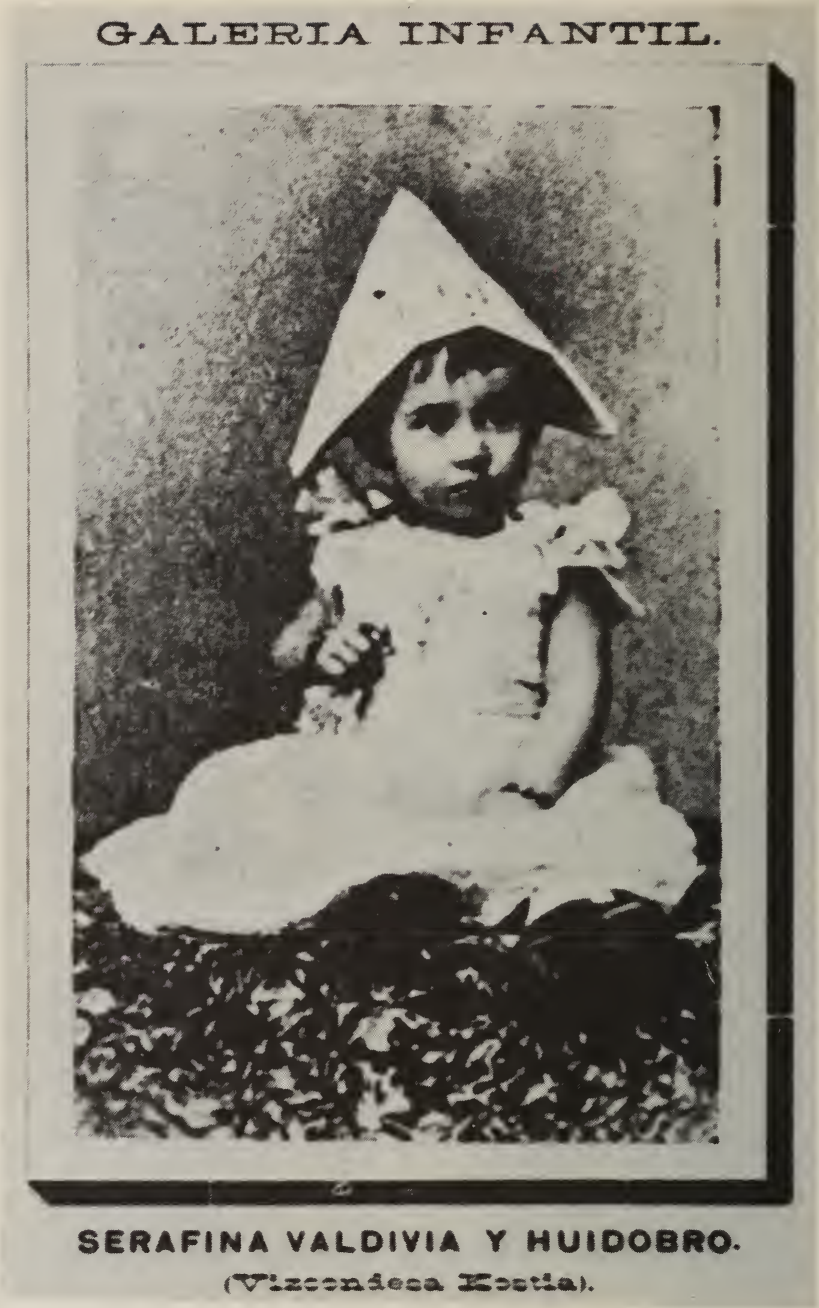

24 December 1891 in Costa Rica's Diario del Comercio and on 15 March 1892 in Cuba's La Habana Literaria. ${ }^{2}$

\section{V9: Notes to Introductory Statement}

1 The departure from the norm in line length and rhyme at this point makes us wonder whether a verse was unintentionally omitted by the typographer in the $F$ printing.

2 See Monner Sans, Julián del Casal y el modernismo hispanoamericano, pp. 33-34, 69-70. 


\section{V10: SERAFINA VALDIVIA Y HUIDOBRO}

This short work was published in the "Galería infantil" column of $E l$ Fígaro on 26 June 1892. The photograph shown in Plate 48 was printed beneath the column-heading and served to introduce the poem. ${ }^{1}$ The title, in caps, was followed by a subtitle indicating that the child who inspired the composition was the daughter of Aniceto Valdivia (see H42). A centered rule separated the subtitle from the text; the first line of the poem was indented; the initial letter of all verses was capitalized; and the author's name, right-justified and set in caps, was printed at the end. As he so frequently did in compositions dealing with contemporary personalities, Casal told more about himself in this poem than about the apparent subject of his work: thus, through the unpleasant images of mosca, murciélago, and sierpe, he revealed the degree of his depression during this trying period of his life and showed how distant he felt he was from the childhood state of innocence that little Serafina represented.

\section{V10: Note to Introductory Statement}

1 A photo of the Valdivia family may be found in vol. II of the Ed. del Cent. This group picture was taken a few years after the snapshot of Serafina that accompanied V 10.

\section{10: VARIANTS}

l. $F$

* 5 riscosa

8 alrredor $[s i c]$
GLIC

alredor

\section{V10: Note to Variants}

5: The image "sierpe purpúrea de piel riscosa" is so strange that we cannot help wondering whether Casal actually used the adjective riscosa to evoke a sensation of roughness or whether the compositor wrote the word, by mistake, in place of viscosa, a qualifier that is frequently associated with reptiles. Since there is no way of finding the answer to this puzzle, riscosa is retained in the present edition.

\section{V11: [JUANA BORRERO]}

This well-known composition was originally published in the 15 July 1892 issue of La Habana Literaria as part of Casal's article "Juana Bo- 


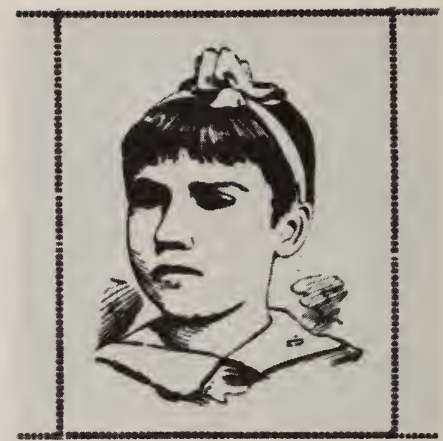

rrero." A picture of Juana (see Plate 49) was presented on the first page of the article, and the poem, without a title, was printed in single-column format on the following page. The first line of every stanza was indented and the initial letter of every verse was capitalized.

The poem was reproduced on 28 August 1892 in the "Galería infantil" column of El Hogar. In this version, the picture of Juana that had appeared in La Habana Literaria was placed beneath the column-heading; the title "Juana Borrero" was printed in caps under the picture; the text was arranged in a two-column format; the date "(1892)" was placed after 1. 16; and the author's name was located after 1. 32 .

In 1893, when selecting material for his third book, Casal decided to include the article on Juana that he had published in La Habana Literaria the year before. Since V11 was part of that article, it was printed in the Bustos section of the book, rather than among the Rimas. Like the $H L$ original, the $B$ version of the poem had no title. Unlike the original, however, its stanzas were printed in block format: that is, with no lines indented. In the present edition, the $H L$ format is restored and "Juana Borrero" - the title by which the poem is generally designated, but which was not used in versions prepared under Casal's personal supervision - is added in brackets. A short bio-bibliography of Juana, plus a commentary on her relationship with Casal, may be found in my discussion of R34.

V11: VARIANTS

l. $H L$

$\mathrm{Hg}$

29 (ा) Doce

(I) iDoce

$B$

GLIC

Doce

$\mathrm{Hg}$

\section{V12: CORINA ROWLAND Y DEL MONTE}

This eight-line composition was published in the "Album femenino" 
PLATE 50

Corina Rowland y del Monte

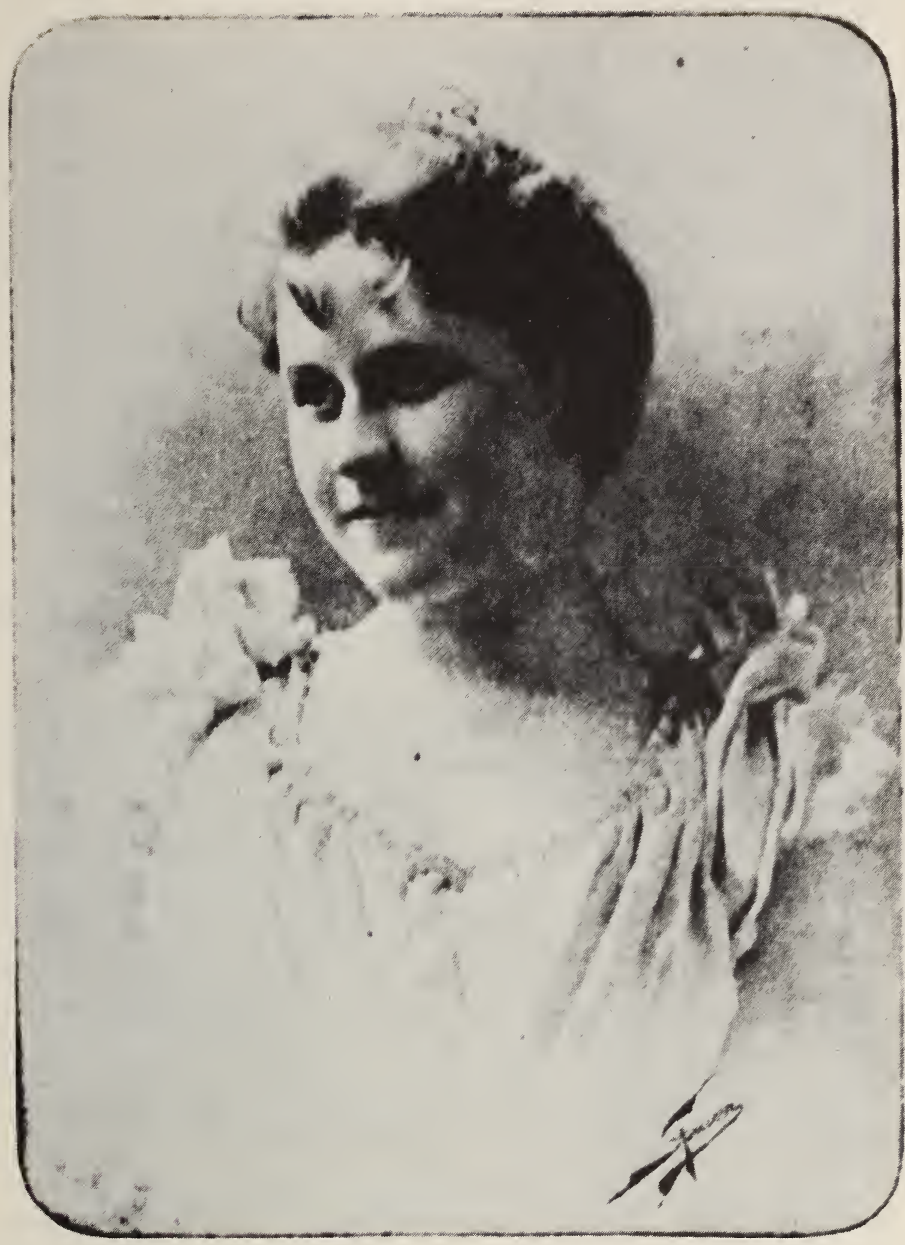

column of El Fígaro on 2 October 1892. A photograph of Corina Rowland y del Monte (see Plate 50) was placed beneath the column-heading; the poem-title was printed in caps below Miss Rowland's picture; 11.1 and 5 were indented; the initial letter of every verse was capitalized; "(Septiembre, 92)" and the author's name were printed at the end of the poem.

\section{V13: COLON EN LA RABIDA}

As 1892 drew near, elaborate preparations were made throughout the Hispanic world to commemorate the discovery of America. The Spanish 
government chose important personalities to serve as official representatives at major celebrations in Europe and the Western Hemisphere (see my discussion of R20); cultural societies of every kind - among them the Real Academia Española - planned special quadricentennial activities (see Plate 51); periodicals held literary contests dealing with the discovery and conquest of the New World (see Plate 52); and educational institutions invited staff, students, and alumni to participate in a variety of ceremonial observances. Like so many other schools throughout the Hemisphere, the Real Colegio de Belén prepared a series of commemorative functions. Among them was a velada poética at which specially selected students would recite pertinent works in several European languages. As an alumnus of the Colegio, Julián del Casal was asked to contribute a poem that might be included in the program. His offering was "Colón en la Rábida." Once accepted, the composition was assigned to Rafael Angulo y Mendiola, a first-year interno from Havana, who recited it, as planned, on the evening of 16 November 1892. Shortly thereafter, the work was published in the Corona poética que a la eterna memoria del gran Cristóbal Colón ofrecen en el IV centenario del descubrimiento de América los alumnos del Real Colegio de Belén. ${ }^{1}$

By a quirk of fate, the $C p$ version of "Colón en la Rábida" fell into oblivion, while an earlier and less perfect manuscript version was published several times, ${ }^{2}$ as though it were the only version extant. The history of this strange substitution of texts came about in the following way. Some years after Casal's death, a six-page manuscript version in the poet's handwriting was given to Aniceto Valdivia by Carmen del Casal as a donation to the Biblioteca Cubana of the Real Colegio de Belén. In January 1932, a transcription of this version was published in the school's journal, Belén, together with a short article about the poem. As part of his commentary, the author of the $\operatorname{article}^{3}$ gave a brief description of the $M S$ version and specified his reasons for publishing it:

Si comparamos las dos composiciones, la original y la impresa en la "Corona Poética", vemos que no están en todo conformes, habiéndose publicado la segunda algo más abreviada y retocada; concuerdan, sí en el fondo, pero difieren en el número de versos, y en ciertos adornos y variantes de expresión. Consta el autógrafo de 145 versos endecasílabos ${ }^{4}-$ 23 más que en la impresa - distribuidos en dos partes, y escritos en 6 hojas de papel de cuaderno de 22 por $17 \mathrm{cms}$., las tres primeras con tinta morada y las otras tres a lápiz, con varias tachaduras y correcciones, todo de puño y letra de Casal.

La transcribimos aquí copiada de su original, no porque la juzguemos en conjunto superior en méritos a la ya publicada, sino por tratarse de un autógrafo de Casal, escrito expresamente para el Colegio, cuando le quedaba un año escaso 
de vida . . y y porque así podrá apreciarse mejor su valer, cotejando la primera inspiración del poeta con el trabajo cincelador del artista. ${ }^{5}$

Unfortunately, none of the scholars who subsequently prepared editions of Casal's poetry - even those who did their work in Cuba - ever troubled to locate the $C p$ text and compare it with the $M S$ transcription, as was suggested in the Belén article. Instead, they used the $M S$ transcription as their exclusive source and allowed the revised version of the poem to remain in obscurity.

A comparison of the two texts shows that Casal made extensive revisions in the poem before publishing it in the Corona poética. His most important modification consisted of a reduction of 20 lines $^{6}$ in the opening segment of Part I:

\section{MS ("Belén" transcription)}

1 La luna como rostro de alabastro

(la) Dormido en un cojín de raso negro

(1b) Ostenta el disco de bruñida plata

2 Encima del negror del firmamento,

3 Tachonado de estrellas. Cual bandada

(3a) De blancos cisnes que en sesgado vuelo

(3b) Buscan las ondas de apacible lago,

(3c) Vuelan las nubes hacia el mar. El viento

(3d) Vaga entre las frondosas arboledas

(3e) Y, perturbando el sepulcral silencio

(3f) De la noche serena, mezcla al paso

4 El olor de los verdes datileros

(4a) Al aroma que brota de las flores

5 Del naranjo, el granado y el almendro.

6 Cual gigante fantasma silencioso

(6a) Que, por un manto de crespón envuelto,

(6b) Detuviera su planta fatigada

(6c) A la margen de límpido arroyuelo,

(6d) Para aplacar la sed abrasadora

(6e) Que le sofoca el interior del pecho,

(6f) Y antes de humedecer los rojos labios

(6g) Del claro arroyo en los raudales frescos,

(6h) Inmóvil se quedara largo instante,

(6i) [

(6j) Así, cerca de un río caudaloso,

(6k) De la luna a los fúlgidos destellos,

7 Yergue altivo su mole gigantesca

8 De la Rábida el santo monasterio,

9 Tras cuyos firmes muros de granito

10 Hallaron siempre celestial consuelo

11 Para ligeras culpas, los donceles,

12 Para nefandos crímenes los reos.

\section{Corona poética}

1 Era una noche mansa y apacible

2 Y la luna en el alto firmamento

3 Dejaba resbalar sus blancos rayos

4 Entre bosques de dátiles y almendros,

5 Granados, limoneros y naranjos,

6 Que hermosura y frescor prestan a un tiempo

$7 \mathrm{Al}$ que se yergue cual gigante altivo

8 De la Rábida el santo Monasterio;

9 Tras cuyos firmes muros de granito

10 Hallaron siempre celestial consuelo

11 Para ligeras culpas, los donceles,

12 Para nefandos crímenes, los reos. 
This modification was a felicitous one because it did away with a distracting series of stereotyped images and brought Columbus, the subject of the poem, quickly into the foreground. After seeing how Casal modified the opening section of the work, one finds it regrettable that he did not revise the remainder of the composition in an equally radical way. Had he done so, there is little doubt that "Colón en la Rábida" would have gained considerably in dramatic power and artistic value.

\section{V13: Notes to Introductory Statement}

1 Havana: Imp. y Papelería "La Universal," de Ruiz y Hermano, 1892. "Colón en la Rábida" appears on pp. 21-25 of this extremely rare book, one copy of which is housed in the Cuban Collection of the Harvard College Library. The volume consists of the following items: an unsigned "Prólogo"; an unsigned "Discurso preliminar" addressed to Don Alejandro Rodríguez Arias, Captain General of Cuba; a "Corona poética" divided into three parts - I. "Colón en Europa" (4 poems in Spanish, 1 in English); II. "Colón en el mar" (1 poem in Basque, 2 in Spanish, 1 in Gallego, 1 in Italian, 1 in French); III. "Colón en América" (3 poems in Spanish, 1 in Latin, 1 in Catalan, 1 in German, 1 in Greek)an "Epílogo," and thirteen epigraphs in Latin; a description of the gold and silver "Corona artística" offered by the students as a symbol of their esteem for Columbus; and alphabetical lists of the 214 alumnos internos and 94 alumnos externos attending the Real Colegio de Belén in 1892.

2 See Poesías completas (1945), Ed. del Cent. (1963), and Julián del Casal: Viday obra poética (1970). Although the compilers of these editions do not so indicate, they have made slight changes in the text of the Belén transcription.

3 The author identifies himself only as "E.H., S.J."

4 In view of the fact that "Colón en la Rábida" is a romance, it is difficult to determine why it should have consisted of an odd number of verses. Two explanations of this strange datum come to mind: either Casal failed to include a line when he copied the $M S$ version from an earlier draft, or else the autograph version was incorrectly transcribed in 1932 . Whatever the case, the $e$-o rhyme scheme of Part I reveals that there is a gap after line $6 \mathrm{~h}$ (see below, where major revisions in the opening section are presented).

5 "Una composición inédita de Julián del Casal," Belén, no. 31 (January 1932), p. 133.

6 As indicated in note 4 , one line (6i) seems to have been omitted from the MS by mistake.

V13: VARIANTS

l. MS ("Belén" transcription)

$C p$

GLIC $* 1-6$

7 [y]ergue altivo su mole gigantesca

[a]l que se yergue cual

$C p+$ gigante altivo 
PLATE 51

$H E, 10$ May 1891

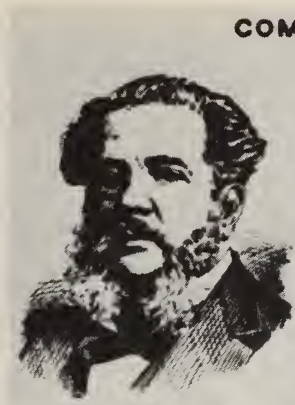

COMISION LITERARIA.

La Keal Academia Fspañola, en su deseo de contribuir con ia mayor bri. llantes y lucimiento á las solemnidades del cuarto centenario del descubrimien. to de Imérica, ha abierto un certámen litcrario cuyo programa ya han dado á conorer numerosos periódicos de esta ciudarl y se propone publicar, por su cuenta, una Antología hispano-americana, en dos tomos en $4 "$, con un tercero por apéndice, que encerrará la biblio. grafia de toda la América española.

Realizará su cometido la respetable Academia con la cooperación de las correspondientes constituidas en las primeras repú. bliras americanas ó la de las Comisiones especiales, las cuales tienen el encargo de elegir las otras poéticas de cada una de esas naciones, que han de ser comprendidas en la Antología, encargo igualmente recibido por el Ciobernador General, senor Polavieja, para formar una Comisión Cubana destinarla á elegir la de composiciones de poetas antillanos.

En la sala de Sesiones de la Real sociedad ficonómica se constituyó, dias pasados, dicha Comisión en la forma si. guiente:

Presidente: el Sr. D. Nicolás Azcárate.

$$
\text { licales: }
$$

Sr. J). Rafael Montoro.

Fixcmo. Sr. D). Luciano P'érez de Acevedo.

Sr. D. Kafael Fernández de Castro.

sr. D. José de Armas y Césuedes.

Sr. 1). José E. Triay.

Sr. 1). Saturnino Martínez.

Sr. D. José $\mathrm{M}^{*}$ Césperles y Orellana.

Sr. 1). Kicardo del Monte.

Secrelario: - St. D, Manuel Serafin Pichardo.

l. MS ("Belén" transcription) CP

GLIC

8 monasterio,

Monasterio;

12 crímenes

16 [e]rizados los húmedos crímenes,

cabellos,

17 [y] undirse [sic]

cabeza. [sic]

19 tranquilo

[s]in aliño y sin orden los

cabellos

[y] hundida

cabeza,

dormido

[s]entado está Colón. Ante

demanda,

navegante,

en torno de su cuerpo,

fría,

(I) ¿ Quién sois?

(ף) - ¿Quién sois? -

voz - Pobres [sic]

voz. - Pobres

viajeros, 
PLATE 52

$H L, 15$ July 1892 , p. 1

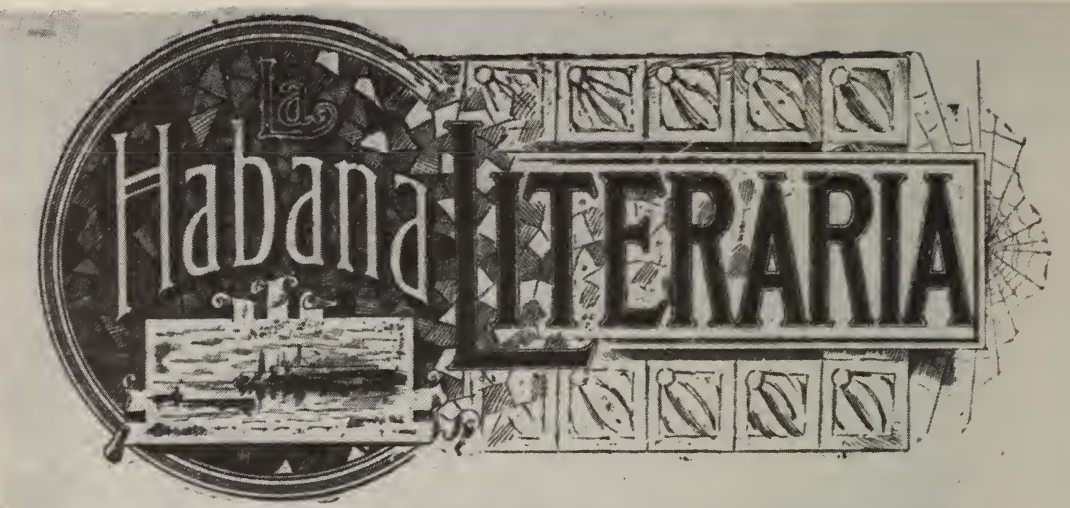

REVISTA QUINCENAI ILUSTEADA.

170 11

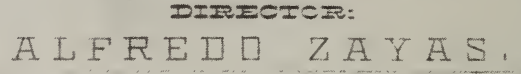

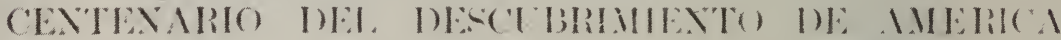

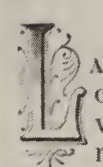

a Habaxa Larbikaria, deseandu conmemorar ei acontecimiento tal vez más grandioso de la historia, ze realizalo por el génio del arrojalo nauta genoves, intenta la celeliracioin de: un certímen, que, habría de revestir no pequeña inportancia, y te presentar noleseasos estímulos, si las fueraas y recursos de que nuestro períslico dispone igualaran á nuestras aspiratones. Pero sin otra proteceión que el favor del público, y el auxilio de cultísimos colaboradores, llegamos hasta demole podemos en tolo lo que levante el nombro del país, y propenda á comyui-tarle estimación en el munflo civilizato.

Con motivo, pués, del enarto ('entenario del descubrimiento de América celebra esta Revista un certimen literario en las siguientes condiciones.

1? Los trabajos que se envich al eertámen podrán ser en verso ó en prosa, pero estos últimos no octuparán más de 40 cuartillas de pajel español común.

2\% Tratarin de cualquier tema quese relacione con el descuhrimiento y conquista de las Américas, 6 con las personas que intervinieron en los mismos; serán inéditos; y en ellos no se alterarí esencialmente la verdad historica.

30. Se remitirán antes del día 1 ? de Uctubre al Director de La Habaxa Ia-
Tkksmi (cuba núm. 1:3,) precerlides de un lema, y acompañalos de un wolore rerralo quite contenga el nombre del atutor. y wastente el nisimo lema.

4". Fintrarín on certímen los trabajow que lox jurarlos arlmitan. Ios rechazarlos se ruemarín junto con los solores contentirns de lus nombres de sus antores.

5? En al número de LA II Amaxi La-

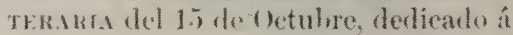
- oleminizar el centenario, se publicarín las actas de los juratos, y los trabajos que olbtengan premios y areesits.

6". Para Los trabajos en prosa habra un fremin monsistente en una pluma de sro, com raho de nácar y oro, en sll wtuele correspondiente $y$ un diploma, $y$ un aceesit comstante en otro diphoma. Para las composiciones poétieas habrá irentios premio y acessit.

7. El juralo fuara los trabajom en por - at lo fornan los sres. 1). Jone silverio Jorrín D. Ratael Montero, y D. Jose Varela Zequeira; y para lats composicionepoéticas los rese. D. Ricardo del llonte 1). Finrique Jose Varona, y D. I.eppolito Cancio que dispensan a li IIAmaxi la-

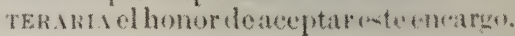

Habaua Julio 15 de de Is:

Nuta logamos a nuestros colmug la 16 : ducción do lis precerdentes linfas. 
l. MS ("Belén" transcription) C p

39 demandaros

40 lecho.

42 reflejos,

45 Es de día. Caldeado

46 [d]el sol abrasador

48 [p]one un

49 vetusto

50 líquida esmeralda

51 [q]ue alentejuela el sol

57 En el patio florido del convento

58 las ramas

59 senderos,

61 Hierve

63 despliega, subiendo por los aires

67 [e]rguidas aromas

71 hacia el espacio,

74 su verde cortina de hojas anchas,

78 donde sangra

79 [p]álido Cristo que los ojos vuelve

80 [d] la agonía en las postreras

81 [a]l claro firmamento.

Duro

87 tersa

89 [f]ray Juan Pérez

91 sonrisa,

93 [y]a apoya

94 [y]a acaricia

95 como un lebrel

96 [j]uega con estampas.

98 estancia,

101 abatido,

104 horas

solitaria,

106 [e]n que ahogando la voz de sus plegarias,

* 106a [b]rotaba la blasfemia de sus labios, demandaros,

destellos

(ף) Amaneció. Envuelto

[d]el apacible sol

[p]renden manto

devoto

trasparencia vaga,

transparencia $+C p$

[r] egado por la luz

(ף) Del convento en el patio florecido

el ramaje

senderos

Bulle

despliega

lecho. -

$C p+$,

ascendiendo por el aire,

[n]acidas

aromas,

por el aire,

la cortina de hojas

ensanchadas,

que clavada

[d] evota imagen de Jesús presenta,

[a]l ferviente cristiano, que en sus

[1]a mira con fervor.

El duro

limpia

[m]udo Marchena

sonrisa

[a]poya

[y] acaricia

como lebrel

[m]udo

les miraba.

abatido. [sic]

estancia

días

solitaria

[t]erribles noches de mortales ansias.
$M S$

$M S$

$C p+$ presenta 
l. MS ("Belén" transcription) 106b [c]omo brotan los fétidos miasmas

106c [d] el fondo cenagoso del pantano

106d [a]l caer una piedra entre las aguas.

110 [y] con el soplo

111 [r] eanima en el espíritu

112 esperanza... del genio

115 conducía

120 palmas,

122 fondo

$\left.\right|^{C p}$

[y] al grato influjo

[v]uelve a lucir ante el turbado espíritu

esperanza..........

MS conducía, palmas

seno

\section{V13: Notes to Variants}

1-6: See above for a full description of the original version of these lines and the author's subsequent revisions.

106a-106d: The fact that the poem was to be read at a Jesuit function may have been the reason why Casal suppressed this allusion to blasphemy from the final version. 


\title{
Appendixes
}

\section{APPENDIX A \\ Some Bio-Bibliographical Articles on Casal}

\author{
CASAL $* 1$ \\ (Notas de mi cartera.)
}

Que Casal no pertenece a esta época mercantilista hasta dejarla de sobra, es cosa en la cual no cabe un adarme de duda.

Si existiera la metempsícosis, aseguraría que Casal encarnó en el espíritu de algún romántico de mediados del siglo.

No hay más que verlo caminar por esas calles de Dios, para comprenderlo en seguida.

Con la mirada fija en el espacio, como buscando el ideal acariciado, abstraído por completo de las miserias de la tierra, camina a pasos desiguales y con andar de autómata.

Cuántas ocasiones lo he encontrado así y he tenido que llamarlo repetidas veces, para que rompiera con sus meditaciones y se fijara en mí.

- ¿Qué es de tu vida? ¿En qué pensabas ahora? - le he preguntado.

- Pues, en nada.

$\mathrm{Y}$ hemos emprendido una de esas conversaciones que empiezan sin motivo y concluyen lo mismo, no obstante su prolongación.

Y, hablando así, como al descuido, pasando de un asunto a otro, como sin darnos cuenta de ello, me ha interrumpido para exclamar con doloroso acento:

- iPobre Alfredo de Musset!

Esta es una de las cosas de Casal.

El las hace sin fijarse, respondiendo a necesidad imperiosa de su espíritu; es un desahogo que da a su corazón.

Y paso a referir algunos rasgos suyos, originalísimos.

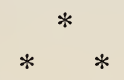

Venía una noche de visitar a una estimada familia, y lo encontré a su paso.

- ¿Dónde has estado?

*El Fígaro (26 November 1885), pp. 2-3; Ed. del Cent., vol. III, pp. 246-248.

1 Este Casal es un joven, amigo mío, muy poeta y muy romántico. 
- En casa de N...

- ¿Y con quién has hablado más tiempo durante la noche?

- Con T..., que estaba angelical.

- ¿Y de qué te hablaba?

Aquí Casal me miró con asombro, y repuso:

- ¿Pues de qué querías que me hablase? - De música, de pájaros y de flores. Esa debe ser la conversación de los ángeles.

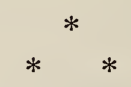

Otro día estábamos en el Louvre y llegó a nuestra mesa una niña, de poco más de 4 años, vendiéndonos billetes.

Casal la miró con lástima y cuando la niña se marchaba ya, la llamó a su lado y la preguntó:

- ¿Qué se dice por el paraíso?

Y como nosotros lo miráramos, prosiguió:

- Sí; tu cuerpo está aquí, pero tu espíritu, vaga por el paraíso.

Y lo decía con convicción profunda.

$$
* *
$$

Pasamos juntos unos días en el campo, y era de ver a Casal.

Allí estaba en su elemento.

Aquella soledad era para él la cosa más deliciosa.

Vivir apartado del ruido mercantil de la ciudad, tiene para él encantos indecibles.

Por las noches hablábamos de literatura; con qué fogosidad hablaba del romanticismo francés.

El, tan reservado y frío, daba rienda suelta a su entusiasmo, en medio de aquella paz y soledad gratísimas.

En medio de nuestros paseos a caballo, quería echar pie a tierra para darme un abrazo de agradecimiento, por haberle llevado a aquel edén.

$\mathrm{Y}$, cuando a los pocos días de nuestro regreso, le hablaba de otro viaje idéntico, me contestó:

- No quiero ir, porque no quiero volver. ¿Quieres que vea el cielo, que es aquél, y luego vuelva al infierno, que es éste?

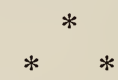

Enrique Hernández le contó una noche los tristísimos detalles que acompañaron a la violenta muerte del infortunado Simón Baralt.

Y Casal lo oyó con un interés bien fácil de comprender.

Al día siguiente lo encontré y al preguntarle qué tal le había ido después que nos separamos, me dijo: "La muerte de Baralt no se ha apartado de mi mente.

"iPobre Baralt!" 
Y después me habló de las mil ideas que cruzarían por aquel cerebro extraviado, de sus ensueños de ventura, de sus despertares tristísimos a las impurezas de la realidad, que dijo el ilustre orador; todas las causas, en fin, que motivaron la muerte del desgraciado joven.

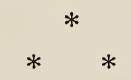

En literatura tiene una adoración a la que rinde culto ardentísimo: Alfredo de Musset.

La triste vida del gran lírico francés, sus versos armoniosos e inspirados, su romanticismo, todo, hace que Casal adore en el cantor de Lucía.

García Gutiérrez es otro de sus favoritos.

Los versos inmortales de "El Trovador" están siempre en sus labios.

Yo le he oído recitar, sin cansarme, actos enteros; y digo sin cansarme, para hacer notar otra cualidad de Casal: recita admirablemente.

Se le oye, por lo tanto, con gusto, aunque sea largo lo que recite.

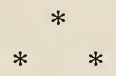

Nunca habla de política.

Para su naturaleza, poética como pocas, la política es cortesana impúdica que vende en público sus favores; y a él, que le parece corto el tiempo que dedica, y se lo dedica todo a la poesía, le parecería indigno, y con razón, distraer su atención de la casta musa, para fijarla en la política.

$\mathrm{El}$ adora el arte por el arte; ya esté en las obras de un neo o en las de un republicano.

Quiere, como el que más, a su país.

No sé si grita: "iViva el danzón!"”

Lo que sí puedo asegurar es que no lo baila.

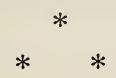

Casal, joven como es, ha leído más, mucho más, que algunos viejos que pasan por ilustrados.

Y ha leído con provecho.

No como muchos que andan por ahí, que se han metido, con pasta y todo, multitud de libros en la cabeza y luego no han sacado en limpio más que tener una olla en el cerebro.

Casal ha leído, entendiendo lo que leía, formando juicios, por lo general, acertados.

Cuando se equivoca, es por rendir un culto demasiado exagerado a sus aficiones románticas.

\footnotetext{
2 Esto lo digo por el Arabe de nuevo cuño.
} 
De la vida de Casal nada más puedo decir, porque quiero que quede para otros, con más merecimientos que yo, la tarea de juzgar sus versos, que revelan un poeta.

Sólo he querido hacer mención de él, para que el público, que no es más que un niño, con todas las impertinencias de éstos, se acostumbre a oír su nombre y entre en deseos de apreciar sus méritos.

Hoy, que tantos mamarrachos pasan por autores dramáticos (?), conviene ir presentando a jóvenes como el de que me ocupo, de verdadero talento y sólida instrucción.

Y la patria, quizás, me lo tenga en cuenta.

Francisco Chacón

\section{INTERNATO*}

A Julián del Casal.

Una mañana nebulosa y desapacible del mes de junio de 1879 , varios jóvenes internos del Colegio de Belén, regresaban de la Madama, después de primera y deliciosa noche de placeres mundanos, refocilándose con los variados incidentes de algunas horas de incomparable regocijo, nunca olvidadas, que recuerdan la época feliz de las ilusiones y de las esperanzas.......

Aquel grupo, alegre y bullicioso, de estudiantes del último curso de la segunda enseñanza, había hecho su debut, quizás prematuro, en la vida de las tentaciones irresistibles.

Acababan los neófitos de iniciarse en los misterios del arte; y de rendir culto a Venus, la Diosa inmortal de la juventud.

El mayor de aquellos escolares sólo contaba veinte años de edad. Todos pertenecían a la misma peña o corrillo, como se llamaba entonces en el colegio a la reunión de íntimos amigos; en la cual no se admitía a ningún otro alumno, por más que todos fuésemos compañeros. Era la costumbre establecida y todos los internos la observaban, con rigor inflexible. - Al desgraciado que la quebrantaba se le dirigían calificativos muy severos, por los menos cultos, o era castigado con el silencio absoluto por parte de los que poseían una educación exquisita.

Por de contado que esos corrillos se distinguían, casi siempre, por los jóvenes que los formaban.

Rara vez pudo notarse confusión de clases o de condiciones.

Ya se sabía. - El grupo tal dedicaba las horas de recreo a la moda, los carruajes y caballos.

Eran los ricos. - En el otro, de libres pensadores, sólo se oía hablar de

*La Habana Elegante (21 December 1890). 
ciencias, literatura, mundanismo y, sobre todo, de política. Ese grupo tenía su periódico manuscrito que redactábamos, clandestinamente, Julián del Casal y yo, sufriendo numerosos secuestros, y penas tan aflictivas sus redactores como la pérdida del postre en las comidas, o el refresco, sambumbia, por la noche. A este grupo se le llamaba el de los inteligentes e ilustrados, y en él figurábamos Casal y el que suscribe. (Yo sin poseer las cualidades referidas.) Más allá se veía el de los peloteros (a la vizcaína), el de los guajiros o hacendados, fumadores de tabacos; el de los religiosos intransigentes; el de los fuertes o gimnastas; el de los revoltosos y bailadores del danzón "Las campanillitas", único que se conocía en la época a que me refiero, $y$, últimamente el grupo de los sportsmen de cierta índole, aunque entonces no se usaba mucho de ese término, pero que tenía su significado en español, que equivalía a tanto como guagüero, que no eran pocos a pesar de sus tiernos años de existencia....

Como se ve, los alumnos internos de Belén se dividían, según sus gustos y aficiones. A veces el Rector dictaba bandos - más trascendentales que el del General Marín - prohibiendo los grupos.... Se apelaba a ciertos recursos coloniales, y los bandos no se cumplían.

Los jóvenes que regresaban de la Chorrera constituían el corrillo de los inteligentes e ilustrados.

Todos tenían marcado en el brazo derecho el sello distintivo del grupo: un triángulo masónico, formado por tres puntos, hechos en la piel, con la punta de un lápiz azul. Era una prueba dolorosa, cuya señal conservan algunos; Casal entre ellos.

El día de la noche consabida era de salida oficial para los internos; que estaban obligados a pernoctar en el Colegio. A los que no cumplían el precepto reglamentario, se les castigaba con rigor excesivo.

Pero nada les importaban a los trasnochadores debutantes las penas determinadas en el reglamento, porque eran filósofos (así se les llamaba a los alumnos del 5: año), estaban examinados, y concluían para ellos los honores del internato de 2a enseñanza. No temían a ningún castigo, porque ya en realidad, no eran alumnos del Colegio. - Sólo faltaban cuatro o cinco días para la salida definitiva de los que habían terminado sus estudios.

¡Ventajas de la impunidad que los filósofos aprovecharon de manera increíble!

Lejos de pernoctar en el Colegio, se reunieron, con ruidosa algazara, y allá se fueron ellos a donde había placeres; pertrechado, cada uno, con el dinero que pudo conseguirse durante el día, por medio de combinaciones honrosas e inéditas.

Juventud, alegría y dinero. Con tales elementos la primera noche de libertad de los nuevos calaveras fue tanto más encantadora e inolvidable, cuanto que habían violentado la disciplina del colegio. Y es cosa indiscu- 
tible, los deseos que se satisfacen con más deleite, son aquellos que originan grandes dificultades.

Cuando los jóvenes, cuasi Bachilleres, llegaron a la Habana en aquella triste mañana de junio, pálidos y ojerosos, por turbulenta noche de insomnio, acordaron la forma de entrar en el colegio. Se discutió poco, porque los rendía el sueño; y a ellos lo que les interesaba era dormir. Con la indiferencia artificial que producen los desvelos del que trasnocha, por placer, se dirigieron al colegio. Uno tras otro, traspasaron los umbrales de la puerta principal.

La entrada de esos alumnos pródigos escandalizó a los P. P. Jesuitas, y llevó los gérmenes de la indisciplina, a las huestes escolares.

Llevados a presencia del prefecto, ahí fue la gorda. Hubo amenazas y resistencias; acusaciones y defensas; insinuaciones y sonrisas......venciendo, al fin, la impunidad, después de amonestaciones y consejos paternales.

Nuestra suerte fue venturosa; y Casal quiso solemnizarla, conquistando para el mundo a uno de los Padres. Le habló de las riquezas, de las comodidades del lujo, de los encantos de la vida social, de esto y de lo otro, de aquello y de lo de más allá. Todo fue inútil. El Padre lo apostrofó duramente; exclamando Casal:

\section{iAd majorem Dei gloriam!}

Casal, antes que poeta y escritor, fue misionero infortunado de los que gustan de la vida, por los goces que ésta proporciona.

Diciembre 1890

Arturo Mora y Varona

\section{DEUDA*}

Yo también traigo mi ofrenda. No será más que una hoja sin olor y marchita, cogida en huerto agostado, una pálida siempreviva, símbolo de recuerdo imborrable; pero ellas no podían faltar en la guirnalda fúnebre consagrada por la amistad y el cariño a la memoria de Casal, del dulce y melancólico poeta, del joven de alma grande y destino triste con quien he vivido en los últimos años en tan estrecha comunión de ideas y de sentimientos, que la muerte no ha podido desatarla sin romper fibras que llegan a lo más hondo del pecho.

No me propongo hacer una biografía; para ello carezco de los datos que

* La Habana Elegante (29 October 1893), pp. 5-7. 
habrían de serme necesarios si intentase fijar la relación forzosa de los hechos por mí desconocidos y de los antecedentes personales, con las manifestaciones que conozco de la vida interna de Casal, con su manera de sentir, y con la índole de sus obras. Tampoco quiero hacer de éstas un examen crítico: sería intempestivo, y más que eso, sería doloroso hasta la crueldad. El cirujano más endurecido en el oficio, no hunde su escalpelo en las vísceras del hermano; llora y cubre de flores el cadáver. Esto quiero y debo, y nada más.

Durante tres años de intimidad, sólo interrumpida por breves intervalos de ausencia o de enfermedad, yo he tenido ocasión de penetrar hasta el fondo en el abismo de un espíritu, como era el de mi joven y querido amigo, complicado y original, triste y tenebroso por las sombras que en él dejaron los accidentes de la vida, y por las dolorosas enseñanzas de la funesta escuela a que en mal hora acudió cuando despertó su instinto literario; pero luminoso y puro por sus cualidades ingénitas, por la claridad interna que irradia de una inteligencia egregia, de un corazón lleno de nobleza, generosidad y ternura; y ahora que me siento pesaroso y arrepentido de haber sido con Casal muy reservado y parco en las demostraciones que merecían las suyas, siempre tan deferentes y cariñosas, yo quiero pagarle a su memoria la deuda de amor y de estimación que en vida hubiera agradecido aquel pecho tan ávido de afección y de simpatía.

En efecto, un exterior frío, taciturno, al parecer indiferente y desdeñoso, encubrían en Casal una sensibilidad enfermiza, ternuras y delicadezas femeninas, capacidad para las afecciones más hondas y duraderas; del mismo modo que su vida solitaria, su alejamiento de las fiestas mundanas, su precoz desencanto y sus demostraciones de hastío y de pesimismo, encubrían un alma templada para el combate, con grandes alientos y alas vigorosas que habrían podido elevarlo a las cumbres a que aspiraba su ambición, viva y ardorosa, aunque escondida en su seno como águila herida.

De estas contradicciones y anomalías, yo puedo desentrañar tres causas. La primera tuvo su origen en los azares y accidentes que desde muy temprano entristecieron su espíritu y malograron sus esperanzas. Hay una dolorosa historia de una niñez sin caricias, de una orfandad prematura, de un hogar solitario, sin calor ni alegría; de una catástrofe que convierte en estudiante pobre al que había nacido heredero de una inmensa fortuna; pero de estas influencias sólo tengo vagas noticias y no puedo apreciar el grado en que hayan marchitado la flor de juventud y entenebrecido la imaginación del poeta.

De la segunda causa puedo hablar con más seguridad. Consistía en esa fatalidad que condena a algunos a vivir en antagonismo con su época, o 
con la sociedad en que han nacido y hasta con el mundo externo que los rodea: fatalidad que acarrea necesariamente luchas y protestas, y que en los temperamentos poéticos, provocando inmensos dolores y esfuerzos apasionados, ha robustecido sus potencias y dado origen a obras inmortales como las de Edgar Poe, Shelley y Lord Byron.

Así vivió el pobre Casal, en perpetua contradicción con su tierra, Cuba, con la sociedad que lo rodeaba, con el medio ambiente moral, científico y literario predominante en nuestra época, y hasta con su idioma nativo que hubiera trocado gustosamente por el de Baudelaire y de Huysmans: aun más, en contradicción también consigo mismo, puesto que había en su mente una fuerza y sutileza de análisis que pugnaba con sus calurosas afecciones y su desenfrenada imaginación. En efecto, el azul intenso de nuestro cielo, y el rojo sol, y los contornos definidos del paisaje y la espléndida verdura de nuestros campos, le eran menos gratos, menos poéticos, que las nieblas, las brumas, la tibia lumbre, los largos crepúsculos, la nieve y el cielo gris de los climas setentrionales. Temperamento melancólico y desafecto a los goces y las convenciones sociales, debía de encontrar deleite, como los misántropos y los ascetas, en la contemplación y el estudio de la naturaleza. Pues sucedía todo lo contrario: huía del campo; y le oí decir muchas veces que la naturaleza sólo le causaba horror y espanto. Y luego al disgusto de vivir bajo un cielo tropical y un sol tan ardiente, se agregaban otros más dolorosos de orden moral, y que también provenían de la misma indicada causa: el pesar de no ver aquí empleo adecuado ni campo para sus actividades intelectuales y sus fuerzas poéticas. Estas se habían nutrido y educado con elementos extraños, con ideas, sentimientos, genialidades, convencionalismos de otro pueblo y de otro mundo. De una sociedad sensual y utilitaria ¿̇podría esperar eco, aplausos y simpatía? Era inevitable la discordancia. Por un lado la agitación industrial, la sed del lucro; el Arte, la Poesía y el Genio pisoteados por el mercantilismo: por otro las delicadas aspiraciones, los ensueños etéreos, los ideales deliquios de un espíritu ebrio con la quinta esencia del decadentismo francés, y los refinamientos de la neurosis.

¿Qué podía esperarse de tantas discrepancias, obrando a la vez y continuamente? Ya hemos visto su desastrosa influencia en la vida anómala del poeta, en su espíritu quebrantado, y en los tonos tristísimos de sus cantos.

Aún no he dicho la última y más poderosa de las causas que influyeron en el espíritu de Casal y en los caracteres distintivos de su obra poética. Poco he de detenerme en esto, porque la ocasión y el impulso de piadosa afección que me hace escribir, me obligan a no decir todo lo que el asunto sugiere, sino sólo lo estrictamente necesario para explicar ciertas anomalías. No habla el crítico; no voy á juzgar las poesías contenidas en las dos colecciones que publicó Casal, Hojas al viento y Nieve, tan merecida y calurosamente encomiadas por jueces competentes y aun por renom- 
brados poetas de España, de la América latina y de Francia; pero debo con el celo del fiel amigo que prevé los cargos a que pudieran dar motivo ciertos extravíos y algunas deficiencias incuestionables, anticiparme a esos reparos, previniendo a los que quieran exagerar esas faltas, con la advertencia que voy a hacer: en los dos citados tomitos, como en el titulado Bustos y Rimas que se está imprimiendo, la versificación hábil y melodiosa, la frase animada y correcta, el riquísimo colorido, la abundancia y el brillo de las imágenes, la fuerza y originalidad de algunos cuadros, y la intuición y el encanto genuinamente poéticos que en todas las páginas resplandecen, eso es de Casal, todo suyo, como producto espontáneo de una individualidad poderosa, que de no haberse malogrado cuando no había hecho más que ensayar sus alas hubiera subido a la cima en que veneramos a Heredia, la Avellaneda y Milanés; mientras que las exageraciones, las rarezas, lo que el juicio condena y el buen gusto rechaza, todo eso es extraño, prestado y postizo, falsa pedrería que anda ahora corriendo el mundo bajo la prestigiosa marca de fábrica de los decadentes y simbolistas franceses y belgas.

Casal tuvo su iniciación poética en la buena escuela de Gautier, Leconte de Lisle y los parnasianos, adoradores de la forma perfecta y la pureza del estilo. Luego lo sedujeron los períodos musicales, el lenguaje pictórico, la gracia amanerada pero a veces exquisita de Flaubert y los hermanos Goncourt y ya de aquí era fácil el descenso al cenáculo simbolista, abierto el camino por la funestísima fascinación que en él como en los jóvenes del temperamento desequilibrado de Casal debían ejercer el diabólico Baudelaire y el sombrío y trágico pero poderoso estilo de Barbey d'Aurevilly.

La inteligencia ociosa, por falta de objetos y de estímulos, el alma sumida en el hastío de su tristeza congénita y de su discordancia con el medio en que vive, gime y se revuelve atormentada por el ansia de nuevas impresiones. Faltando la acción y los cuidados y deberes de la vida práctica, las facultades internas y afectivas se irritan, y si no pueden esparcirse en las ciencias siempre nuevas, siempre sin límites, tienen que consagrarse al arte, al misticismo, a la poesía, a lo que sirva para dar pábulo a la fiebre interna y ofrecer sensaciones más variadas e intensas. Esto tiene que ser así por ley de correlación de las energías del espíritu; pero en nuestros días son más temibles las consecuencias de la acción convertida en pasión o en contemplación, porque el refinamiento social, el vuelo de las ciencias, el dominio de la naturaleza mediante las nuevas prodigiosas fuerzas de que la civilización dispone han hecho más hondo el problema humano que cuando los filósofos griegos lo escudriñaban bajo la columnata de Sunium y en las alamedas del jardín de Academo. Knowledge is sorrow. Al ensancharse los horizontes se va alejando lo invisible, que los antiguos creían tocar casi con la mano. La hiperestenia de los órganos condenados a pensar con tenacidad o sentir con fuerza trae la neurosis y su secuela, pero ¿cómo evitarlo?

La dilatación de los espacios cósmicos y de las facultades humanas por 
los progresos científicos, ha traído la dilatación de los espíritus por medio de los nuevos recursos y métodos de investigación y de análisis. Este acrecentamiento de las fuerzas mentales, en época en que se han derrumbado los fundamentos de toda clase de autoridad, deja a muchos espíritus sin saludable ejercicio, sin objetos o ideales proporcionados al furor de las ansias, a la impaciencia de las ambiciones exacerbadas, al cúmulo complicado de las crecientes excitaciones, y el resultado es conocido: en el campo de la voluntad, el anarquismo; en el campo intelectual, el desequilibrio de las más brillantes facultades, la locura de Maupassant, los neuróticos delirios de Huysmans, el neo-misticismo de convención, sin base en la fe sincera ni concordancia con las conquistas de la ciencia, ni aun con las creencias corrientes del vulgo; la rebusca de lo falso y artificioso con tal que aparezca inaudito y nuevo.

Casi sin querer he indicado las circunstancias sociales y psicológicas que han preparado la invasión y determinado los caracteres de esa falange de los simbolistas y decadentes, y vuelvo al punto de arranque de mi digresión para repetir que esa escuela es la responsable de todo lo que disuena en los versos de Casal y de las sombras que manchan la nitidez marmórea en algunas de sus más puras creaciones. Avido de sorpresas y novedades, dejóse alucinar por esos taumaturgos del misterio, seducido por la absoluta consagración que ellos predican al culto del Ideal, del Arte y de la Belleza, en medio de los arrebatos, demasiado aparatosos para sentidos, con que significan un misticismo dislocado y tardío. Casal practicaba y sentía de veras lo que los decadentes pregonan: entusiasmo artístico, amor desinteresado a lo bello, la aspiración al infinito; por eso creyó en sus oráculos y se aficionó de sus maestros y hierofantes, el erudito y brillante Huysmans, Esteban Mallarmé, P. Verlaine, Kahn, Rimbaud, VieléGriffin, Moréas. Y así acabó por adoptar a veces la manera y los dogmas de una escuela cuya doctrina estética falsa, o por lo menos incompleta, reniega de los principios, como si no fueran leyes naturales deducidas de la constitución del cerebro sano y la inteligencia en perfecto equilibrio, pretendiendo desligar la literatura y el arte de sus enlaces con el orden social, con la ética y la razón, para practicar a su sabor la teoría de el arte por el arte, dedicándolo a acelerar la circulación de la sangre, precipitar y variar las impresiones, y estremecer las fibras nerviosas a todo trance, ya con cascadas de sonidos y contrastes de colores, ya con los ensueños delirantes del opio, pues sólo a estos efectos sensuales encamina el decadentismo sus ritmos complicados y su fraseología empalagosa o hermética, pictórica o simbólica.

Sin embargo, la clarísima inteligencia del joven poeta tenía al cabo que alejarlo de una secta que sólo lo había atraído por el misterio y el idealismo; y al mismo fin concurrían las advertencias de consejeros de más edad, empeñados en hacerle ver que esas delicadezas artísticas inventadas para deleite de los neuróticos, pasado el incentivo de la novedad, serán en definitiva rechazadas dondequiera que no estén en mayoría los enfermos; 
que pese al prestigio intelectual de París, y a la potencia impulsiva de la lengua francesca, el horizonte de los boulevares no abarca todo el mundo; y que hay en las naciones cultas de uno y otro hemisferio millones de inteligencias que viven robustas y saludables, sin dárseles un bledo del modernismo, y dispuestas a reírse de los bizantinos del Sena, aunque tengan secuaces y encomiadores entre una minúscula parte de una población bastante buen humorada y alegre, a la que un día hacen enloquecer el penacho de Boulanger con su caballo blanco, otro día las bordaduras de oro en el paño azul de los marinos rusos.

Sí, Casal aspiraba a lo más alto, y a lo más alto hubiera llegado. Mientras cultivaba sus fuerzas poéticas que crecían de día en día, muchas obras suyas en prosa, publicadas en los dos últimos años, notas biográficas, narraciones y monografías literarias, aparecen trazadas con tan cultas formas, con estilo tan vigoroso y tan profunda penetración psicológica, que le aseguraban lugar conspicuo entre nuestros primeros escritores, cualquiera que fuese el que lograse entre los poetas. Que también lo tendría al lado de los eminentes cantores cubanos, no lo dudarán los que hemos visto sus aptitudes, su temperamento, la viveza y la intensidad de sus impresiones, la fuerza de imaginación con que pintaba sus sueños poéticos, la vibración con que resonaban sus dolores y sus deseos, en acentos del más puro lirismo.

Esto creíamos y esperábamos. Una oleada de sangre ahogó presente y porvenir, promesas y realidades, la triste y cansada vida del poeta y la gloria soñada y entrevista. Se acostó sin acabar su tarea. Murió cuando no había hecho más que ensayar sus fuerzas, como Chatterton, el niño sublime, como el prodigioso Keats, como el profundo Tonellé, como el delicado Maurice de Guérin, Hércules de la poesía moderna, vencedores casi desde la infancia.

Blanqueaba el alba en el horizonte cuando la nube negra cubrió el sol que iba a despuntar.

El pobre joven, no nos deja más que las flores de su primavera. Es verdad que hay cosechas enteras de otoño que no valen lo que esas primicias. Por eso vivirá su nombre ungido en la dulce tristeza de las esperanzas incumplidas, de los destinos malogrados, de la juventud tronchada en flor, porque así lo quieren los dioses.

Al concluir estas líneas que trazo desordenada y rápidamente, pienso que acaso no he cumplido bien mi propósito. ¿ Me habrán hecho traición el árido estilo, el tono rudo y dogmático? Es probable; pero si no he pagado con moneda de buena ley, mi deuda es sagrada y deuda de honor, y yo sé que si fue torpe la pluma, mi corazón sabrá pagarla completa. 
En esas horas de solemne silencio y recogimiento, cuando la fantasía, despertada como por una música sin sonidos, cree escuchar extrañas melodías a la vez que percibe imágenes que se desvanecen y acentos de una deliciosa tristeza, evocando facciones y voces de los ausentes que hemos amado, entonces un latido del corazón, una lágrima dolorosa pagarán mi deuda a la memoria del querido poeta, de mirada noble y sonrisa triste que me llamaba maestro cuando diariamente estrechaba mis manos con ternura filial.

Ricardo del Monte

\section{NOTA BIOGRAFICA*}

No es mi ánimo juzgar a Julián del Casal como poeta, como literato. En mi concepto era un poeta y un literato. $\mathrm{Y}$ en la simple enunciación de este doble concepto está hecha su apología. Residían en él la inspiración y el gusto estético; los dos elementos culminantes que constituyen al poeta. Pero sobre estas cualidades, que suelen obcecar y deslumbrar a los por ellas favorecidos, sobresalían la mesura, el juicio reposado, el don de observación, el estudio paciente y ordenado, los títulos que revisten al poeta de la doble aureola del genio que crea y de quien medita y da base y firme asiento a sus creaciones.

Alguna vez, declarándole previamente mi incompetencia, me permití, en la intimidad de nuestro trato, reconvenirle por el tono fúnebre y la tendencia nihilista que imprimía a sus versos; temía no incurriese en un fatigoso amaneramiento; Casal sonreía; sonreía siempre; en su cerebro podría Satanás haber hallado morada por breve tiempo: dentro de su alma habitaba pura la angélica "Imitación de Cristo". Su dulzura inagotable vencía toda objeción. La santidad de su buen trato, que no le abandonaba nunca, era una muralla que le separaba y le aislaba de los conceptos que la melancolía y el celibato le dictasen o los preceptos de una escuela decadente le impusiesen.

La juventud es alegre -le decía-; esparce vida, luz; regenera lo que el tiempo mutila o quebranta; vibra bulliciosa en un mundo de ilusiones y de locas esperanzas; pero no se abate y reniega de la creación; no deja caer sobre un rostro placentero el peso arrugado de los años; la ruina, la desolación, el desengaño prematuro de una existencia hueca y vacía, envuelta en vida en el sudario de la muerte.

Casal se entristecía. Cual el ave prisionera hubiera deseado tender sus alas por los espacios de un férvido y lozano idealismo; su gran talento llegaba a todas partes; penetraba en todos los confines; pero se consultaba a sí propio; medía el estado interior de su ser y la voz secreta del mal que le devoraba le negaba vida, porvenir, esperanzas. El hielo del desengaño se

*La Habana Elegante (29 October 1893), p. 16. 
implantaba allí donde debía reinar la confiada excedencia en sus propios medios y recursos.

Uno de sus últimos sonetos, "El hijo espurio", retrata con grandiosidad poemática el estado de su alma. Quienquiera lo haya leído se habrá hallado a sí propio envuelto en los horizontes infinitos de una desesperación sin alivio ni consuelo.

No hay dolor comparable al dolor mío; Porque teniendo el alma de amor llena, La convicción profunda me envenena De que está el mundo para mí vacío.

Nunca con menos palabras se ha retratado un alma de un modo tan espacioso y colosal. Sería preciso repetir todo el soneto; pero estará en la memoria de todos. Basta a mi propósito indicar su estrofa más gráfica y saliente.

Julián del Casal era un perfecto creyente.

En la noche de la agonía, como la tituló el sapientísimo Doctor Zayas, delirante a veces, estremeciéndose violento otras entre los asaltos de la asfixia y el desvanecimiento del sudor copiosísimo que le agotaba, en momentos lúcidos expresó su anhelo de confesión y su dolor intenso por las faltas que hubiese podido cometer; y repetidas veces en aquella noche angustiosa y en otras ocasiones, ya restablecido, ratificó su propósito de vivir y morir en el seno de la Iglesia Católica. "Yo soy cristiano-decía-; he procurado siempre cumplir los preceptos de la Doctrina Cristiana".

Lo repetimos. Si Casal no hubiese estado inspirado en la frecuente lectura de "La Imitación de Cristo", según asevera Valdivia, que le ha visto leyéndola, por su genio apacible, por la bondad de sus sentimientos, por el deseo perenne de complacer y ser útil a propios y extraños, hubiese adivinado ese libro y se le hubiese creído un fiel observante de la pureza inmaculada de sus máximas y consejos.

En aquella misma noche de la agonía, larga, todo un firmamento de acerbos dolores, solía el poeta, exasperado por el sufrimiento, tener visiones; se creía muerto y andando por el Mundo de ultratumba; descubría senderos, torrentes, montañas; mas volvía a su acuerdo, y mirándonos y reconociéndonos exclamaba: “¿Ven ustedes? Ya resucito. He estado muerto y me hallaba muy bien en el otro mundo. Siento volver a esta vida miserable y desgraciada”.

Estas palabras que podrían estimarse reflejo y expresión de un estado transitorio y anormal del ánimo enfermo, eran con frecuencia repetidas en otra forma en los períodos preparatorios de nuevos accesos: "Yo no temo a la muerte -decía-; no seré tan temerario que sostenga la deseo; la naturaleza se revela contra ella; pero si viene, que vendrá muy pronto, no me cojerá de sorpresa; estoy a ella preparado".

En efecto; nunca en la dilatada postración del mal, en medio de rudos y 
crueles ataques de una asfixia devorante y ensañada, nunca aquel joven plácido y sereno, dulce y afectuoso, perdió el dominio de sí propio, ni se turbó o mostró decaimiento ni desánimo. Tenía un espíritu grande: discutía sereno sobre las probabilidades de su curación posible, y solamente concibió la esperanza, la cuasi certeza de hallarla cuando supo que una linda señorita de esta ciudad había tenido un padecimiento análogo al suyo y había logrado dominarlo en absoluto.

Entonces volvió a ser poeta: pensó en la publicación de un nuevo libro; se creyó salvado; el mal fue para él un incidente indigno de exclusiva atención.

Y en este período de optimismo le halló la muerte. Después de haber sufrido en cuatro meses un siglo de dolores le arrebató en un solo instante, sin tiempo de preverla ni sentirla; en el momento que entre amigos dilataba su espíritu por entre planes de porvenir y gloria.

Termino. No ha sido otro mi propósito que el de complacer a mi distinguido amigo, el Director de LA HABANA ELEGANTE. Era éste gran amigo del muerto Julián del Casal. Creo le será grato ver consignado por un testigo presencial que el poeta Julián del Casal, dulcísimo, suave, un candidato a la santidad, sin cólera en los choques del mundo, sin despecho en los rigores del sufrimiento, un verdadero imitador de Cristo, era, cual lo fue Cristo, un alma estoica, impávido ante la muerte, capaz de heroísmo, siguiendo la línea recta del deber.

Así le amaron todos. Nunca enfermo alguno, alto o bajo, ha sido mejor atendido. Tenía una habitación por él elegida en la azotea de esta casa. Allí reina un fresco perpetuo, graduado a voluntad por el juego de ventanas. Decorada a estilo de una cámara de buque, la soledad y el retiro correspondían en ella a sus gustos literarios. En la noche de la agonía, su primer terrible ataque, los criados de la casa, sin otro mandato que el de su propio impulso, pasaron horas enteras de rodillas sosteniéndole y ayudándole. Confortó su ánimo en aquella noche de prueba su gran amigo y maestro D. Ricardo del Monte; su presencia era para él un remedio; el del contagio de la salud, que transmite un espíritu sano, docto y eminentemente humanitario.

¿Quién no rinde culto y admiración al talento y bondad sin límites del Doctor Zayas? ¿Quién no conoce y pondera los méritos de los Doctores Desvernine y Vicente Benito Valdés? Le auxiliaron con su ciencia; una ciencia que retrocedía arma al brazo ante una afección interna por desgracia incurable. Fueron hermanos del alma; porque se negaron a percibir sus honorarios, el pan cuotidiano indispensable en este viaje terreno. ¿Cómo omitir al Doctor González Curquejo que puso a disposición del enfermo cuantos medicamentos le fueron precisos? ¿Y por qué callar las excelencias de esas Siervas de María, penetradas del espíritu de caridad, centinelas perpetuos de día y de noche a la cabecera de un enfermo?

En esta obra de amor, que incesante rodeó al doliente, puso el sello y remate D. Antonio San Miguel. Declaró suyos los gastos de entierro. Y el entierro ha sido de primera clase; último testimonio de afecto al finado. 
Descanse en paz Julián del Casal. Le sobrevive el amor que ha inspirado. i Cuán cierto es: ama y serás amado!

Octubre 24 de 1893

Domingo Malpica

\section{JULIAN DEL CASAL*}

Cuba ha perdido un poeta. La muerte ha destrozado una de las más delicadas organizaciones artísticas que ha producido la patria de Heredia y Plácido. Casal muere en la flor de sus años. Su alma nostálgica ha dicho de súbito adiós al mundo quimérico en que se cernía. Su huella por la tierra serán algunos versos exquisitos, y el recuerdo que deja profundamente sellado en cuantos lo conocimos y lo amamos.

Nosotros no olvidaremos ciertamente al joven pálido, tan desentendido de cuanto lo rodeaba, cuya sonrisa plácida y dolorosa parecía proponernos el enigma de una existencia, que se ocultaba de propósito, con el pudor de las almas selectas al sentirse violentamente ajadas por la vulgaridad de las cosas y de los hombres.

Los médicos dirán de qué dolencia ha fallecido. Para nosotros ha muerto de nostalgia del ideal. Vivía aquí, pero no estaba con nosotros. Sus lecturas le habían infundido un espíritu exótico, que debía encontrarse extrañamente prisionero en esta sociedad esclava dèl peso y la medida. Murió creyendo en el arte refinado, en la belleza recóndita, en una existencia de placeres sutiles de la mente, en el misticismo artístico. iDichoso siquiera en esto: que no llegó a tocar lo ilusorio de estas fantasías, ni a saber a ciencia cierta que la vida de artista con que soñaba ni es menos miserable, ni menos tediosa al cabo que la nuestra cotidiana! Vivir con un solo órgano, aunque sea la imaginación alada y coronada de astros, es condenarse por modo irremisible al desequilibrio y al dolor. Refinar la sensibilidad es exponernos más desnudos a las punzadas venenosas de lo externo. Y es bien pequeño desquite, y bien pobre consuelo, sentirnos más aptos para la queja desgarradora o la imprecación fulminante.

Casal vivió inconforme y reservado; pero sonriendo a la idea de que, en otros países más próximos al oriente maravilloso, se vivía de otra suerte, desde luego más elevada, más digna de la excelencia y de las facultades de nuestro espíritu escrutador y creador. Así realizó su rápido viaje hacia la sombra, mirando siempre adelante y siempre a lo lejos. Reciba el adiós supremo de los que seguimos con ojos entristecidos la estela vacilante de su alma bella que se apaga.

Octubre 22

[Enrique José Varona]

*Revista Cubana, vol. XVIII (October 1893), pp. 340-341; reproduced, with minor changes, from La Habana Elegante (29 October 1893), p. 8. 


\section{AL PUBLICO*}

El autor del presente libro, después de haberlo compaginado, de haber dirigido la impresión y salvado las erratas de los primeros pliegos, un día, cuando en la ficticia convalescencia de terrible mal, poblaba de nuevo su cerebro de más bellas ilusiones, de más irrealizables anhelos y quimeras, rindió su cuerpo a las caricias de la Muerte, que con tan consoladora tenacidad lo perseguía, ensombreciendo su rima primorosa.

Si los que mueren jóvenes son amados de los dioses, Julián del Casal, que ha muerto mozo y cercado de esperanzas que reverdecían en su alma triste, como el musgo que festona una encina carcomida; Julián del Casal, que era el poeta aclamado por los exquisitos; Julián del Casal, que a despecho de su modestia inmaculada alcanzó renombre y aplausos fervientes más allá del horizonte donde empieza la cultura refinada y acaban los apasionamientos lugareños; Julián del Casal que murió en una sobremesa íntima, sonriendo, casi feliz, porque lo colmaban de alegría las ilusiones que alejaban de su vista la tumba entreabierta y sus locos proyectos de soñador y artista; Casal - decíamos - no era sólo el amado de los dioses, sino el llamado por ellos a compartir la gloria imperecedera de la fama, ceñida la cabeza de laureles, exenta el alma de ruindades humanas, colmado su corazón de las más castas idealidades; de los más bellos ensueños su fantasía y del asco más profundo todo su ser, por lo que no fuera la Belleza y el Arte, que juntos sollozan al pie de su tumba.

$\mathrm{Al}$ comienzo de este libro se leen con tristeza, con lágrimas, sus proyectos literarios. En la tenacidad inquebrantable de su carácter indómito, que no cejó un solo instante, porque en medio de la lucha supo contrarrestar su apariencia de abatido con los triunfos secretos de su espíritu genial; en su carácter confiábamos sus amigos, sus admiradores, para que el poeta que tan sólo recogió, con las primicias del aplauso, las dulces satisfacciones de las primeras victorias, lograra al cabo la apoteosis del genio, entre la aclamación de los vítores y el reconocimiento innegable de sus conquistas.

Pero comoquiera que sea, sus trofeos bastan para embalsamar su memoria. Allí está su primer libro -Hojas al viento-; ahí está Nieve, y aquí se halla Bustos y rimas. Después quedan religiosamente ordenados, guardados con amor santo, sus otros trabajos sin compaginar: estudios, críticas, cuentos, poemas en prosa; un tesoro que ha de aumentar su gloria, cuando los legatarios de su cariño los reúnan y publiquen.

Queda otra cosa además. El dolor inmenso de haberlo perdido en mitad del camino de la vida; "asesinado por la Muerte" - según la frase de los Goncourt-; queda el recuerdo imborrable de sus claros ojos relampagueantes, que infundían cariño y lástima, tristeza y espanto; queda su culto en muchos corazones que lo amaban apasionadamente, porque su alma era gemela de todos los que sufrían; y queda imperecedera la

*Bustos y rimas (Havana: Imprenta La Moderna, 1893), pp. i-iv. 
memoria del poeta exquisito que cincelaba rimas tan tristes como su alma, tan bellas como sus quimeras.

Ni prólogo, ni advertencia; sólo un aviso de su muerte al que leyere, son estas líneas escritas por un admirador de Julián del Casal, un hermano, un compañero, que no osa poner su firma al pie, temeroso de profanar su memoria con vana ostentación.

El sabe quién las ha escrito y ha llorado escribiéndolas; y eso le basta.

[Enrique Hernández Miyares] 


\title{
APPENDIX B
}

\section{Some Early Criticism of Casal's Poetry}

\author{
JULIAN DEL CASAL*
}

\section{(Hojas al viento)}

Don Julián del Casal - con algunos más, aunque pocos - se ha consagrado a mantener latente la tradición poética cubana que, sin ellos, hubiera podido darse por extinguida. Casal la mantiene a su modo y por su cuenta. No hay que buscar su genealogía en Heredia, Plácido, Luaces y la Avellaneda. Con ser característica de sus versos la nota sentimental, nada tiene de común ni siquiera con el dulce Milanés y el melancólico Zenea. Estos poetas ilustres, aún viviendo entre las dificultades y violencias del antiguo régimen y aún siendo víctimas de la preponderancia absoluta de los intereses materiales, nunca perdieron la fe en su noble empresa que era algo más que un entretenimiento sin trascendencia, que era una revelación anticipada de futuras transformaciones.

En Casal, si juzgamos por sus Hojas al viento, no vibra la cuerda sonora de la esperanza. Es un caso exótico, una manifestación extraña, entre nosotros, de esa enfermedad que hace estragos por el mundo con el nombre de decadentismo o modernismo decadente.

A la verdad, yo siento que el Sr. Casal haya tomado esa senda, porque el tal decadentismo es tanto un fenómeno social como un fenómeno literario. Su mismo nombre indica que se trata de una escuela sin ideales definidos y, por lo tanto, propia de espíritus gastados y de una sociedad envejecida. Pruébalo, también, la preferencia con que mira - principalmente en su variedad parnasiana - el trabajo exquisito de la forma que viene a sustituir la falta de savia ideológica y la ausencia de un propósito fecundo. En este sentido, los parnasianos son los chinos de la literatura, porque como los chinos ejercitan su decrepitud artística en labores tan minuciosas como inútiles.

Además, es preciso tener en cuenta que Cuba no es Europa y que los caracteres de la vida criolla difieren, esencialmente, de esos síntomas de disolución moral que pululan como gusanos en las sociedades europeas. Las altas clases del viejo mundo están debilitadas por exceso de placeres, no por exceso de dolores. El hombre es allí víctima de sus goces. La civilización le brinda todos sus refinamientos, la carne todos sus incentivos y el arte todos sus encantos. Y sucede que los hartazgos matan el deseo y anulan los estímulos y que ciertos solaces que, para nosotros son casi imposibles, constituyen para los parisienses, por ejemplo, una repetición insoportable de emociones conocidas.

*Puntos de vista (Havana: A. Alvarez, 1892), pp. 170-175. 
Entonces se apela a lo exótico, a lo inusitado, a lo extravagante, a la exhibición de tribus salvajes en el Jardín de Plantas, a las novelerías que despiertan las visitas del Shah, de Buffalo Bill, de zulúes, malayos y lapones. Agotados los tesoros del Arte, hartos los amateurs de las formas clásicas, sencillas y graciosas, de los desbordamientos románticos y hasta de la crudeza naturalista, o reaccionan por necesidad o por moda hacia el neo-espiritualismo que refleja Paul Bourget, o buscan lo que está lejos con Pierre Loti que inspira sus argumentos en pueblos semi-salvajes y con Richepin que se cree un turanio extraviado en medio de la civilización occidental.

Y los que no van por ahí caen a la postre en la sedación o laxitud que produce el hastío en los que gozan con demasiada intensidad. Estos sólo piden reposo, indiferencia y, a veces, morfina. Su ideal es la abstracción inconsciente que, a manera de nirvana, les deje quietos y aislados, sin comercio ni relaciones con la monótona realidad que les circunda.

A hora bien: nosotros casi ni hemos caminado por esa vía. En materia de placeres andamos bastante retrasados. Hay una gran indiferencia para todo; pero estos fenómenos son obra de nuestros dolores colectivos. Los temperamentos no se gastan aquí por el abuso sino por la inacción, y el tedio no viene de haber gozado sino de haber sufrido mucho. Los moldes históricos de nuestra vida están dispuestos de un modo adecuado para que la actividad mental sea casi nula y para que la obra de materialización no se interrumpa. Sin embargo, siempre surge un elemento ilustrado que trabaja, con verdadera abnegación, en medio de tantas dificultades.

Como Casal figura en ese grupo, yo espero que su decadentismo será cosa pasajera, y me hace esperarlo la circunstancia de que hallándose, como se halla, en los albores de la vida, aún no ha tenido tiempo de llegar a la plenitud de su conciencia artística. Comprendo que lucha con un medio rebelde y obstruccionista; convengo, así mismo, en que el desaliento suele apoderarse de los que llevando algo en la cabeza se miran muy pequeños al compararse con los que llevan algo en el bolsillo; admito que ciertos dolores íntimos hacen envejecer prematuramente al que los sufre; mas no por eso el hombre debe hacer un sepulcro de sí mismo.

Hay en Hojas al viento poesías muy sentidas y, sobre todo, muy bellas. Sobresale el Sr. Casal en la parte descriptiva y posee el secreto de la forma que sabe presentar lindamente cincelada. Véanse el soneto Mis amores, La estatua de carne, Idilio realista, Acuarela y Desde mi ventana. En esas y otras poesías versifica gallardamente y derrama con profusión primores de estilo y pensamiento; pero en casi todas pone la mancha negra de su tristeza. Esto imprime a sus producciones cierta melancólica monotonía que es un dato preciso para conocer la tendencia constante del poeta. Leyendo su libro experimentamos un efecto parecido al que nos produciría un salón lleno de marfiles, sedas, estatuas y dorados; pero a obscuras. El bello sol de la alegría no penetra nunca en esa estancia lujosa y severa que el dolor, con inesperado sibaritismo, ha sabido prepararse.

Pero como, hasta ahora, Casal no es más que una promesa, repito que 
hay que confiar en alguna metamorfosis posible. Entonces quizás se enamore de un ideal robusto, dejando a un lado ese decadentismo malsano, que tiene su lugar en otros climas, para tomar el oxígeno de los campos de su tierra y no como los enfermos en los globos que fabrican las farmacias.

Nicolás Heredia

HOJAS AL VIENTO*

(Me espera el cajista)

A mí no me toca hablar de tu primer libro de poesías en mi periódico, Casal, porque ya verás cómo digo lo que siento, y cómo lo que siento me va a traer hablillas y censuras, dichas a mis espaldas las más, y algunas cara a cara; porque los hay de los que no tienen reparo en ser críticos apasionados porque sí, porque tú vales más que ellos, o porque tal vez no los saludaste cierta vez con afecto mentido, o con hipócrita sonrisa.

Desde aquel día que te apareciste - como una bomba - enseñándome las pruebas del primer pliego de tu primer tomito, hasta hoy que me lo entregas pequeño, recortado, blanco desde la cubierta y con sus noventa páginas, he pensado y sigo pensando, que cuanto a valer literario, las "Hojas al Viento" que has echado a volar, son los mejores versos escritos en Cuba desde hace mucho tiempo. Tus "Hojas al Viento" son hojas -iay! como diría Espronceda - desprendidas de tu corazón sano de poeta hondísimo, que siente y canta, como canoro pájaro en dorada jaula, ya dulcemente, porque lo embriaga el aroma primaveral, ya con melancolía, porque siente las nostalgias de las frondas rumorosas.

Todas esas poesías que has escogido entre las tuyas, como si posible fuera escoger monedas de oro de un mismo valor; todos tus versos encerrados en el tomo que me dedicas firmándote "El Autor", con una rúbrica, los he visto, primero esbozarse en tu imaginación cuando en el diálogo te quedabas distraído sin contestar; luego, con lápiz, en el borrador, tachados y tallados; con tinta luego en el original que se da a la imprenta, e impresos al fin, y celebrados y reproducidos. Todavía los he visto de otra manera, recitados por labios de hermosas vírgenes; y aun los he visto encarnarse o materializarse en líneas y contornos, en mis horas amargas o dulces, a medida que iba yo murmurando tus estrofas.

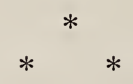

*Obras completas (Havana: Academia Nacional de Artes y Letras, 1916), vol. II, pp. 9-13. 
¿Cuál de tus poesías me agrada más? Esta pregunta que tantas veces me he hecho, tiene una respuesta siempre. Si me domina la tristeza, recito "Invernal":

¡Oh hermosa primavera! ¿ por qué escondes tu encanto virginal a mis sentidos? ¿dónde estás que te llamo y no respondes, no respondes jamás a mis gemidos?

Yo también en los campos de mi vida siento el invierno lóbrego y sombrío; imi alma es una floresta destruida! iyo también en el alma tengo frío!

La alegre juventud, aquella diosa que a mis pasos sus flores arrojaba, huyó de mí, icuando era más hermosa! icuando yo más que nunca la adoraba!

Yo dije al verla huir: ¿ por qué te alejas ioh juventud! cuando te quiero tanto? y ella no oyó mis penetrantes quejas, ni su mano enjugó mi acerbo llanto.

Sólo en mi mente oscura y tenebrosa su indeleble recuerdo me ha quedado, como queda en el valle alguna rosa después de haber el huracán pasado.

Cuando por el contrario me besa amorosamente la esperanza, o alguna aurora sonrosada advierto dibujarse en los cristales de mis ilusiones, entonces recito aquel "Mensaje", que comienza:

Versos que arranco del laúd sonoro...

o el soneto de "Mis amores":

Amo el bronce, el cristal, la porcelana, o aquellas entusiastas estrofas de la poesía “Quimeras”:

Si escuchas ioh adorada soñadora! mis amorosas súplicas...

Oh... ninguna otra, porque en mi poeta favorito domina la nota 
melancólica, como cuando le canta - vicioso decadentista - a la morfina; o "A Berta", de quien fue esclavo apasionado; o como cuando en "Post Umbra", rasgando el porvenir, ve a la que un tiempo fue su amada, aprovechar su muerte, abandonar su alcoba y salir:

...con su belleza de española a buscar otro amante.

El poeta de "Post Umbra" no se indigna contra la infame... la perdona; porque él:

resignado a su falsía, soportará el martirio:

¿quién pretende que dure más de un día el aroma de un lirio?

Al lector: O me dejas transcribir el tomito "Hojas al Viento", de Casal, o me perdonas que haya hablado así, tan ligeramente de un libro que yo considero un tesoro, porque cada poesía que encierra es una joya.

Julián del Casal es mi amigo del alma y ha sido el alma de este semanario mucho tiempo. i Imposible que yo le señale, como algunos críticos al uso, asonancias y alguna que otra ligera incorrección! Julián del Casal es mi hermano en ideas, aunque yo figuro en la izquierda del partido exótico, de que él es "leader". Así es que disimulo sus exageraciones y admiro sus quimeras.

El es un poeta sin tacha y sin miedo, como se decía de los caballeros de la Edad Media. Ha impreso su libro y “ya está”; como él dice. Le abruma que le hablen de él, y de seguir regalándoselo a todo el mundo, como sigue, ipobre editor!

Con todo, "si el libro gusta y la edición se vende", ya veremos pompa en la alcobita de Julián, donde hay mayólica en los estantes, libros hasta en los percheros, y se ve la efigie del Santo Padre al lado de Sarah Bernhardt. 


\section{HOJAS AL VIENTO*}

Primeras poesías. Por Julián del Casal. Habana, 1890.

Like the lark at break of day arising

From sullen earth, sings hymns at heaven's gate.

Shakespeare. Sonnet 29.

Hay razón, sin duda, para exigir cierto valor absoluto en las obras de arte. Este es el punto de vista del espectador, que solamente busca la emoción o la sensación, que para muchos hace las veces de tal. Para éste no es, no puede ser el punto de vista del crítico, que necesita conocer, indagar o suponer las relaciones entre el autor y su medio, para alcanzar las relaciones entre el autor y su obra. Sólo así podría llegar a penetrarse la verdadera significación - como obra literaria - de esta colección de bellas poesías, producto singular de un talento muy, real y de un medio completamente artificial.

Entendemos aquí por medio el conjunto de las influencias externas - reales e ideales - que obran sobre el espíritu del artista, lo impresionan y lo inducen a producir. Hay en quienes las influencias reales ejercen incontestable predominio; hay quienes son tan sensibles a las ideales, que éstas constituyen en buena parte su mundo verdadero; con una fantasía igualmente poderosa el uno siente agigantarse dentro de sí sus sensaciones, sus percepciones, y bajo esta obsesión reproduce con relieve, color y vida los objetos que ha tocado y visto; el otro se siente como abstraído de la realidad, ve en su interior crecer e invadirlo todo las imágenes y las ideas, y estos signos se sustituyen para él de tal modo a los objetos, que los considera y los trata como tales, los ama o los aborrece, y son al cabo la materia de su inspiración.

En las épocas de gran cultura, en que la variedad prodigiosa, el refinamiento y la sutileza de las ideas forman una especie de atmósfera mental para los espíritus elevados, es más fácil que abunden los talentos imaginativos de esta segunda clase, los cuales no son de ningún modo inferiores a los de la primera; ni aun desde el punto de vista del poder artístico; aun cuando puedan no ser tan gustados por la generalidad del público. Y esto basta quizás para rectificar la teoría errónea de Macauley, quien enseñaba que las épocas y las sociedades en cierto modo primitivas eran las adecuadas para la gran poesía.

Hay un fenómeno conexo con el que acabamos de señalar que nos aproxima al punto a que nos dirigimos. Existen temperamentos psicológicos para quienes los signos verbales - las palabras - adquieren importancia decisiva, les dan casi las sensaciones de la realidad; en éstos el influjo de sus lecturas es preponderante; llega a equilibrar cuando no a

*Revista Cubana, vol. XI (May 1890), pp. 473-477; first published in the 1 June 1890 issue of La Habana Elegante. The earlier version of this review is reproduced in Ed. del Cent., vol. I, pp. 26-29. 
vencer la influencia de las circunstancias externas. Claro está que en cierto sentido bien puede llamarse esto un medio artificial. La realidad pasa por dos refracciones antes de llegar de este modo al cerebro. Y no por eso deja de ser muy real la impresión producida. Más de una vez se ha observado que en todas las épocas literarias es fácil encontrar autores que parecen rezagos de otras generaciones ya pasadas. Es que viven en medio de ellas por sus lecturas.

Ahora bien, nada de extraño tiene que un joven de temperamento artístico exquisito, que se encuentra aislado y como perdido en medio de una sociedad que no realiza sino imperfectamente su concepción de la vida o sus aspiraciones poéticas, si no ha llegado a una concepción plena de la vida, se refugie más o menos conscientemente en el mundo ideal que le forjan sus libros favoritos, derive de él sus emociones más refinadas, y se las devuelva tamizadas por sus versos. Con este procedimiento suelen producirse obras muy endebles; no es el mérito menor de Julián del Casal haber producido con él obras vigorosas, con vida que nada tiene de facticia; flores de invernadero, que muestran a veces la frescura de las flores de los prados.

Nuestra sociedad - adviértase que no decimos nuestro país - está condenada, por causas muy fáciles de determinar, a la imitación; que es la atmósfera donde se asfixia más fácilmente la originalidad. Es decir, a ser reflejo pálido de otras más ricas, más cultas y sobre todo, porque esto es aquí lo esencial, infinitamente más numerosas. Son por todo ello entre nosotros plantas del todo exóticas el mundanismo, la literatura decadente y otras preciosidades y melindres sociales, que pululan en los salones selectos y semi-selectos de París. Esto no es decir que no tengamos personas muy cultas, muy elegantes y hasta muy refinadas. Hablamos del tono general de nuestra sociedad. En este ambiente, los jóvenes con tendencias al neurosismo, que leen libros franceses o sus malas imitaciones madrileñas, no encuentran el alimento que necesita su imaginación, sino exagerando las proporciones de las cosas, y desfigurándolas del modo más cómico. Esto en la vida real suele tener sus inconvenientes, pero puramente personales, y quizás tenga sus compensaciones; pero cuando esos jóvenes son escritores nos dan una literatura tan excesivamente convencional, a veces tan falsa, que, sin pensarlo ni quererlo sus autores, degenera por una pendiente insensible en caricatura escrita. Muy poderoso talento se necesita para poner el sello de sentimientos propios en composiciones escritas en condiciones tan desventajosas. Y nos complace reconocer que el ingenio del señor Casal ha salido victorioso de esta dura prueba, a que quizás sin notarlo se ha sometido.

Desde luego convenimos en que entre nosotros, lo mismo que en todas partes, se pueden marchitar temprano las ilusiones que florecen como en suelo propio en el alma de los adolescentes, y no es difícil tocar desde la primera hora la dura realidad que se disimula bajo las blandas apariencias de la belleza y de los afectos puros; los aspectos risibles o trágicos de la vida humana, el desconcierto y la horrible inmoralidad de la naturaleza 
pueden herir una imaginación juvenil, y dejar en ella un sedimento de amargura que vaya aumentando y consolidándose con los años, lo mismo aquí que en Berlín o Moscow; por eso el señor Casal puede ser y es probable que sea sinceramente pesimista; y su pesimismo puede muy bien haber tomado esa forma harto frecuente de amor a lo pasado-es decir a los cuadros que nuestra imaginación nos pinta como correspondientes a una época que no conocemos sino por referencias remotas-, amor que ha inspirado tantas obras bellas en todos los dominios del arte. Pero aquí empieza lo insólito del caso del señor Casal, y lo que nos autoriza a llamar artificial el medio puramente subjetivo en que se alimenta su inspiración. En su espíritu flotan visiones que nada tienen que ver con nuestra vida pasada: trovadores vagabundos y castellanas melancólicas; jaurías y monteros; góndolas azules y pajes efebos; conventos en ruinas y monjes sombríos; y llega hasta a contemplar pastorcillas rubias bajo el sol tropical o a la sombra de los plátanos rumorosos. Todo ello está demostrando el influjo decisivo de las reminiscencias de lo leído. Esto no es decir que el poeta no ame todos esos símbolos de edades muertas, sino que ese amor le ha venido por el canal de sus lecturas; puesto que ellos nada han podido dejar en nuestras costumbres, en nuestras tradiciones, no perteneciendo a nuestra historia.

Hay otra forma más sutil en que se manifiesta esa misma influencia: la elección de ciertos motivos poéticos, como se ve en La canción de la Morfina; la transformación que sufren hasta las personas, las cuales toman sus caracteres de costumbres bastante ajenas a las nuestras, según puede verosímilmente sospecharse de la especie de hetaira que ha inspirado las estrofas de Post umbra; y hasta la manera general del poeta, en que son visibles los modelos literarios de su preferencia.

Ahora, de cualquier modo que se haya enamorado de estas antiguallas el joven escritor; y sean cuales fueren las fuentes de sus gustos exóticos, es lo cierto que canta sus amores id eales con tal frescura de inspiración y tanta intensidad de sentimiento, que no puede el lector menos de sentirse cautivado; casi tanto como cuando canta con emoción profunda sus amores reales, malogrados o indignos. La forma de sus versos, por otra parte, es elegantísima; y su fantasía, vivaz y espontánea, encuentra fácilmente el molde para vaciar sus imágenes, que se destacan claras y completas. Con tan feliz instrumento a su disposición, con espíritu tan sensible, con temperamento tan artístico, Julián del Casal tendría delante una brillante carrera de poeta; si no viviese en Cuba. Porque aquí se puede ser poeta, pero no vivir como poeta. Leamos pues con amor y tratemos de saborear estas exquisitas poesías, primeros cantos de la alondra "que se levanta con el día para entonar sus trinos a las puertas del empíreo"; y ojalá nos sea dado escuchar los posteriores, si otras realidades, más duras y punzantes que las ya conocidas por el poeta, no apagan su voz melodiosa en sollozos de rabia impotente o en el sombrío silencio de la desesperación inerte.

E[nrique] J[osé] V[arona] 


\section{HOJAS AL VIENTO*}

\section{Poesías de Julián del Casal \\ (Habana, 1890.)}

Dijérase, al recorrer las páginas de este libro, que en una copa bohemia se desborda la mirra ofrecida por un descreído al dios adolescente de la fe. Paradoja extravagante, pero real. Imposible, ante los fríos dogmatismos del raciocinio; verosímil, en el mundo de la pasión y del sentimiento. Fenómeno que pugna con la lógica escrita, pero que se deriva fácil y comprensible de esta otra lógica en que bullen la circunvalación cerebral bajo la irritabilidad del dolor, el nervio bajo la excitación del deseo, el músculo idealizado que salta en el pecho bajo los estímulos de la emoción. Fenómeno que escapa a los silogismos de gabinete, pero que resulta verdadero en la vida real como increíble corolario impuesto por el delirio de una felicidad que nunca llega, por el malestar de un descontento incurable, por la neurosis de la aspiración jamás calmada, por la embriaguez, en fin, de una ventura entrevista, en pos de la cual se vuela dudando de ella.

Julián del Casal es, pues, un creyente que duda de todo; un escéptico que si canta su ventura es porque cree en la felicidad que le falta y que persigue; un romántico dedicado a desnudar ideales; un soñador que vive despierto relatando en hermosas rimas lo que puede soñarse; un condenado al suplicio de Tántalo complacido en modelar Venus tentadoras para luego arrojar a la cloaca los despojos esqueléticos de sus creaciones. Tal el temperamento de este poeta: su libro lo denuncia en todas sus páginas como a la hoguera encerrada el humo que escapa por las grietas del muro. Allí está, con su modo ilógico, inconsecuente consigo mismo, distinto hoy de ayer, y mañana de hoy, y siempre el mismo. Allí está, deleitando si deja discurrir la fantasía como serena corriente; amargando si clava en el encanto el harpón de la duda.

Por allí vuela, sin rumbo fijo, con alas vigorosas desplegadas por el vacío de la nostalgia, con plegarias entrecortadas por maldiciones, denunciando que hay en su genial poético algo indeciso e increado, algo que lucha por tomar forma definitiva, algo que palpita en crisálida, algo naciente, algo, finalmente, que promete doradas esperanzas al espléndido cielo de la lírica cubana. Después de todo, ese genial no es nuevo: itantos comoél....!

Enérgico en sus pensamientos, franco en sus arranques, atrevido en sus conclusiones, vehemente en la expresión de las ideas, por completo dueño de la forma externa, fácil en la rima y con un matiz de originalidad en los giros poéticos que encanta, se lanza Julián del Casal por el piélago de todos los infortunios y de todos los naufragios. Es el suyo, un llanto simpático aunque infecundo como el de Becker; son sus blasfemias ten-

*El Fígaro (29 June 1890), pp. 3-4. 
tadoras, comprensibles para todos los que sufren, aunque estériles, como las de Heine. Tiene también horas de amor, y noches de Weimar como Goethe: amores humeantes y vaporosos que pierden en el libro el tributo que pagan a la vulgaridad, gracias al ingenio del cantor. Pudieran aceptarse esas tendencias líricas si como en Poetefi Sandor quedase obscurecida la nota quejumbrosa y romántica ante los dardos satíricos o la carcajada cínica, porque así agitándose el poeta en la esfera real de los humanismos puede comprenderse que pasee a la luz de la luna soñando con idealismos de gloria al par que se rebuja cuidadosamente en el embozo por si acaso tropieza con algún acreedor ... O pudiera aceptarse esa tonalidad de ingenio, si como Stagnelius, el gran sueco, que así pensaba y así sentía en sus versos, tuviera que caldear los apáticos instintos de un pueblo ártico, o encender sobre nevadas cumbres, para remover una literatura linfática, las brillantes luminarias del numen. Mas no es éste el caso. Julián del Casal es un creyente disfrazado de pagano y canta allá, en la hermosa Cuba, en la cuna gentil de una literatura exuberante y copiosa que tuvo feliz navidad en las melodías sonantes y dulcísimas de aquellos primeros cantores que espaciaron la fantasía

\section{a orillas del Yarayabo \\ del agua oyendo el rumor...}

Julián del Casal ríe demasiado poco en sus versos y no le toca con ellos deshacer hielos escandinavos. En su modo literario hay, pues, pecado, y la crítica le hará responsable si su ingenio se derrocha estérilmente sin contornos peculiares y sin cauce.

En todas las páginas del libro "Hojas al Viento," centellea la fantasía del poeta. Incierta, movediza, incontinente, a veces; deslumbrante, atractiva, conmovedora, otras. Casi siempre nueva y casi siempre original, lo que constituye inapreciable cualidad que consagrará en el porvenir la fama del cantor. Hay allí rastros de luz como huellas de bólidos despeñados en el cielo de sus sueños. Hay sonoridades métricas tan espontáneas y lozanas que recuerdan el germinar copioso de un campo de amapolas. Hay formas poéticas en las que parece que se besa la memoria de Virgilio y Meléndez Valdés. Y rimas tan suaves como el discurrir de linfas cristalinas entre guijas doradas. Todo eso hay: todo, menos conjunto preciso; menos humanidad que se reconcentra para sondar los dramas de la vida; menos tendencias a martillar en mármoles y bronces. Todo allí escrito en la arena, lanzado al viento, impreso en la niebla, grabado en la espuma. . . . Dice que no cree:

\section{LA URNA.}

"Veo, con mirada fría, Que está la urna sagrada Como mi alma: vacía." 


\section{LA CANCION DE LA MORFINA.}

"Amantes de la quimera Yo calmaré vuestro mal;

Soy la dicha artificial, Que es la dicha verdadera."

Y sin embargo, le dice a su pensamiento en Introducción:

"Que al volver las primaveras, Harán en ti las quimeras Nuevo nido..."

y en Autobiografía exclama:

"Guardo siempre en el fondo de mi alma Cual hostia blanca en cáliz cincelado, La purísima fe de mis mayores ..."

y en Ausencia:

"iTriste es la vida no amando! ¡Bello es vivir si se ama!"

y en El Puente:

“- Yo te haré un puente si subir deseas. - ¿Cuál es tu nombre? dije - La Plegaria."

y en el Adiós del Polaco:

\section{"iSiempre al patriótico acento El amor enmudeció!"}

probando elocuentemente que con tal descreimiento es imposible socavar los cimientos del templo de la fe. Dice que no ama:

\section{LA ULTIMA NOCHE.}

"Y una voz dijo en tono lamentable:

- Yo soy un corazón que nunca he amado..."

y esa negación en abierta oposición con los delicados efluvios que emanan de sus afectos subjetivos, cae a poco derribada por los arranques de una lira apasionada y vehemente, sumisa a los halagos de la ilusión y cautiva a 
los pies de su dama. Muy presto aquel que creyó no haber amado nunca, dice en Tras la ventana:

"Desde mi estancia lóbrega y desierta

Pensaba en mi adorada

Para esos goces muerta;

La que sacó mi alma de la nada

Infundiéndole vida

Con la brillante luz de su mirada ..."

y en otras poesías de su libro:

"Estreché convulsivo su garganta, Y en aquel triste abrazo y mudo beso La dejé toda el alma."

"Es porque siempre los celos Asedian a quien bien ama."

"iSiempre te llevo en la mente! iSiempre te llevo en el alma!"

"Mi alma es como esa palmera:

De noche ensueños de rosa A ella vienen y de día Huyen como las palomas."

"Siempre serás la reina de mi alma Y mi alma la fiel esclava tuya."

"Ya que no podré nunca libertarme De esta pasión que causa mi locura ..."

"Cuando en mi corazón que tuyo ha sido, Se muevan los gusanos..."

Colígese, pues, que esto constituye un verdadero tibi dabo de amor. Quien así no ama es vena abierta en el manantial de piadosos sentimientos y eterno enamorado que muere de amor

"De un ave oyendo el armonioso trino..."

De los versos de Julián del Casal puede decirse lo que de sus obras dijo Goethe: todas mi obras son fragmentos de una confesión general. En "Hojas al Viento" el poeta diafaniza al hombre. Sus ternuras, sus aspiraciones, sus 
ensueños, todo surge en la rima y no hay secreto de aquel corazón que no se trence con ansia comunicativa en las cuerdas de esa lira. El amor, el eterno femenino, palpita en todos los lugares del libro como medio ambiente que nutre el vigor de las estrofas, como atmósfera que envuelve las armonías y cadencias. De esta suerte, el mundo exterior queda para el poeta anulado por completo. El geniecillo de observación externa, huelga; la lente analítica, está opaca; el histrión de la comedia humana, dormita; la música trágica, yace ebria con las libaciones que le ofrece Venus. De las grandes jornadas del arte moderno no se ve en el libro ni una huella. Las grandes revoluciones de los gustos en privanza, los grandes efectos del modernismo, las irresistibles tendencias plasmadoras del arte coetáneo; inútil buscarlos allí. Parecen versos hechos en el aislamiento, bajo la campana neumática de un temperamento reconcentrado. Y en esa Cuba cuyo renacimiento se opera al presente con pasmosa actividad, el arte lírico modificándose también y sacudiendo la tutela del gusto viejo, está menesteroso de saludables renovaciones que cambien los dejos florentinos del verso por la energía fustigadora del concepto y por la humanización de los ideales. Será porque tiene que ser: nada en el haz de lo creado está inmóvil. Julián del Casal, apto sin ningún género de duda, seguirá esos senderos. El movimiento de su época lo arrastra y su gallarda lira acabará por recoger los ecos flotantes de su torno.

Por lo demás, hay en el libro trabajos de innegable mérito. La "Canción de la Morfina", el "Adiós del Polaco" y "Amor en el Claustro" tienen realce y se apoderan del ánimo. Algunos sonetos y el "Idilio realista" cautivan la atención. Y sobre muchos trabajos de empeño, sobresale el "Adiós al Brasil del Emperador D. Pedro II", poesía conocidísima y recibida con plácemes por los amigos de las letras.

El libro de Julián del Casal se necesita en nuestras bibliotecas, significa una faz de nuestro desenvolvimiento literario y un remanso en las ricas márgenes de la lírica hispano-americana.

(Ponce, Puerto Rico.)

M[anuel] Zeno Gandía

\section{NIEVE*}

Cuando veo un joven como Casal, de talento y perdido en las letras, no sé qué cosa desagradable se me pasea por el cuerpo. A veces se me figura que soy yo y no él el extraviado, y que esa exageración de sus versos es de un rico sabor literario. Pero otras veces, entrando en razón, compadezco al pobre joven que anda tan descaminado.

Son pocos los que, al ocuparse en Casal, no saquen a relucir la influencia francesa. ¿Y por qué no la de Grecia, agrego yo? ¿Acaso la literatura

*El Fígaro (12 June 1892), p. 6. 
griega no es parte del decadentismo hoy en boga? Niego en redondo que éste constituya un género literario. Ya en otra ocasión algo he dicho sobre esta materia. Insisto, porque lo creo de mi deber, y lamento que Casal se pierda de esa manera tan lastimosa, embriagado por los aplausos de amigos cariñosos.

Su tomo de poesías Nieve, me ha dejado un frío intenso en el alma. Me parece que es obra de un amigo de la rima y no de un poeta.

Hay en el libro un despego a la vida que raya en delirio. ¿Por qué? La vida no es tan mala.

Véase lo que dice el poeta en un soneto dedicado a un crítico:

"Mas sin que sienta de vivir antojos

Y sin que nada mi ambición despierte,

Tranquilo iré a dormir con los pequeños,

Si veo fulgurar ante mis ojos,

Hasta el instante mismo de la muerte,

Las visiones doradas de mis sueños."

De modo que, pensando rectamente, el poeta vive sólo por sus visiones. Ellas le consuelan y le dan ánimos para vivir.

A un amigo a quien le envía su retrato, le dice que sólo encontrará en sus facciones

"La indiferencia del que nada ansía."

Por más vueltas que le doy, no me explico ese pesimismo. Si acaso fuera ficción de poeta, acaso sería disculpable, pero odiar la vida a la edad que él tiene, es cosa que pone espanto en el ánimo.

Yo, que estoy habituado a reírme de muchas cosas que el vulgo tiene por sacrosantas y de varios críticos que se las dan de profundos, confieso que encuentro algo en las poesías de Casal que me corta la risa. Al ocuparme en sus estrofas, no encuentro el buen humor que casi siempre me acompaña cuando escribo, sino al contrario, cierta dolorosa impresión, una especie de decaimiento que me hace ser más perezoso de lo que suelo. Paréceme que sus poesías son la labor de un extraviado que se ha propuesto combinar palabras para no decir nada.

Cuidado que yo habré leído versos malos, y por ahí andan algunos que no me dejarán mentir, pero sin embargo, aun siendo tan malos, hay en ellos alguna idea que el poeta (llamémosle así) ha querido rimar. Pero en Casal no se descubre esa idea ni ninguna otra, son sus versos harmoniosas combinaciones de vocablos que nada dicen. Sus admiradores han dado en llamar envidiosos a los que no nos gusta su poesía, y no comprendo por qué han de despertar envidia las poesías de Casal. Aunque bien pensado, esto tiene su explicación. Sucede en muchas ocasiones que las personas a 
medio ilustrar dan en la manía de celebrar aquello que no entienden, por el temor de caer en ridículo. Yo sé de personas que se hacían lenguas hablando de los sermones de un cura de aldea, sermones que ni él mismo llegó nunca a entender. Y esto es lo que sucede a ciertos admiradores de Casal.

No hay más que pasar la vista por el índice de Nieve, para comprender cuáles son los asuntos que seducen al poeta: "Flores de éter," "Nostalgias," "Mi sueño," "Canas," "La Reina de las Sombras," "Horridum Somnium," "Flor de cieno," etc.

Véase ahora cómo expresa el poeta su desilusión:

“Así mi ensueño, pájaro canoro

De níveas plumas y rosado pico,

$\mathrm{Al}$ querer en el mundo hallar cabida

Encontró de lo real los muros de oro

Y deshecho, cual frágil abanico,

Cayó entre el fango inmundo de la vida."

Sabe Dios - si es que hay Dios - cómo pensaba Casal que era la vida, cuando su ensueño, tropezando con los muros de aquélla, se quebró como un abanico frágil, pero comoquiera que fuese, debió poner algo de su parte, porque si en la juventud no encuentra más goce que sus visiones, aunque la frase no sea de las más suaves, se confiesa un visionista, como aquí se dice, que odia a las mujeres y al mundo.

$\mathrm{Y}$ es que cada cual toma el mundo a su manera. A unos les da por creerse muy dichosos porque van todas las noches al teatro, y a otros por creerse que están muy hastiados en todas partes, cuando en realidad se divierten tanto como el que más.

Pero no basta que se digan las cosas para que sean creídas, y si Casal confiesa que morirá tranquilo, si ve fulgurar ante sus ojos las visiones doradas de sus sueños, y ésas las ve constantemente, ¿̇a qué ese despego a la vida? Al contrario, si eso es lo que más le satisface, viva en buen hora, que lo que es por ver visiones no quedará. i Digo! iy en Cuba!

Si el poeta continúa por la senda que parece haberse trazado, me tendrá siempre opuesto en diámetro, porque una cosa es la amistad y otra cosa es la poesía.

Creo innecesario disculparme con él, porque se trata de un joven discreto y sabe el sentido ${ }^{1}$ en que se dicen estas cosas. A buen seguro que no creerá, como otros, que mueve la envidia mi pluma. Yo no hago versos. Pero así pienso, y así lo digo con más sinceridad acaso de la que ponen en sus elogios sus íntimos.

1 Como en tal sentido, y dejando independencia a sus redactores, EL Fígaro admite la publicación de este trabajo. $-N$. de $D$. 
Admito que se escriba en verso, sobre todo, en verso bueno -porque de otra manera se echa todo a perder-, pero que se diga algo. $\mathrm{Y}$ en el decadentismo no sucede eso; que el verso esté bien hecho, aunque no diga nada, y ya está satisfecho el poeta. Y no es eso icaramba! Si así fuera, ¿dónde iríamos a parar? Los genios, los verdaderos genios que en el mundo han sido, por lo mismo que eran tales, se salieron de los moldes antiguos y hasta crearon metros para cantar lo que bullía en sus cerebros privilegiados, pero cantaron cosas tan bellas, que en gracia a ello, se les permitía que abandonaran los moldes. Ahora tenemos el decadentismo que no es otra cosa más que la exageración o descomposición del idealismo. Que el verso sea sonoro, que brille, que cautive por su melodía crotolante y su onomatopeya tableteante, y basta.

Lo más doloroso es que el poeta ha tomado ya su resolución y cada vez acentúa más su tendencia, y el mejor día concluye sus estrofas en una casa de orates, que no en balde se puede jugar con la razón. Repito que es una lástima que joven de talento como Casal, ya que es aficionado a la poesía y que conoce tan bien el arte de la rima, pierda su tiempo en esos extravíos, envolviendo en su caída iQuién sabe a cuántos!......

Algunos disculpan su escuela, admitiéndola como género literario, y se fundan en que todos los géneros bien cultivados son buenos, pero olvidan que no se trata de un género sino de una moda que, moda al fin, tiene que pasar. Durará más o menos tiempo, y cuando se opere la reacción, que ya se está operando en Francia, caerá en el mayor de los descréditos, como producto gastado, como un gongorismo insufrible. Ya es rechazado por el público que no se deja alucinar por los oropeles de que está revestido.

No sé qué profundo desengaño habrá sufrido el alma del poeta, porque no me inclino a creer que cultive ese género gotoso porque viene de París y por seguir las corrientes de la moda. Yo, que conozco algo íntimamente a Casal, entiendo que su alma estaba preparada - por acontecimientos ajenos al arte - para dejarse influir por el decadentismo, que, sin traerle consuelos ni esperanzas, encajaba bien en su manera de ser y en su pesimismo prematuro.

Pero todavía es tiempo. Aún Casal es joven y puede inclinar sus aptitudes hacia el verdadero arte, y entonces, cultivándolo, ocupará uno de los primeros puestos, y su nombre figurará entre nuestros poetas mejores, para gloria de este país que harto lo necesita.

Y si para entonces vivo y no he perdido el hábito de escribir para el público, realizaré una de mis aspiraciones más hermosas: la de proclamar bien alto el triunfo de un paisano y la victoria de uno de mis amigos más consecuentes.

Wen Gálvez

(Junio, 92) 
La poesía cubana ha tenido siempre un carácter filosófico determinado. Heredia, Plácido, la Avellaneda, Milanés, hasta Tejera, se han inspirado teniendo por base, indistintamente, la creencia en lo Supremo, en algo que se espera, el progreso siempre creciente, infinito, y la fe y la esperanza, como brújula y timón. El único de nuestros poetas con tendencias panteístas, y que difiere por tanto de los demás, es Francisco Sellén. En los versos de Enrique José Varona se nota cierto sabor positivista, pero no constituyen escuela, como sus trabajos en prosa. No ha habido en nuestro Parnaso ni descreídos como Heine, ni desesperados materialistas como Leopardi. La inspiración del cubano, de suyo apasionada y romántica, ha visto en lo desconocido otro mundo, un tránsito que perfecciona el espíritu.

Sobra a veces en nuestra poesía el sabor místico, producto natural del medio ambiente de respeto público a las creencias religiosas que predominan en la mayoría del pueblo, que no ha presentado contraste con otros cultos, y donde, hasta hace poco, no había más tribuna que el púlpito católico y los bancos de los tribunales.

Así es que nos ha llamado profundamente la atención el espíritu de los versos que contiene el tomo Nieve, que acaba de dar a la estampa en la Habana un poeta de la novísima generación, Julián del Casal.

Julián del Casal quiere formar fila entre los modernistas de la literatura, los decadentistas, que pululan en París, donde otro cubano de mucho talento y numen poético, Augusto de Armas, ha dado a la publicidad composiciones de ese género, en un volumen que intitula Rimes Byzantines. Adeptos del decadentismo son Pelladan, Verlaine, Moréas, Mallarmé y otros. Los decadentistas creen que su escuela responde a una necesidad real del espíritu humano, a una transformación de la sociedad. Consideran que es la forma última que el arte debe revestir, en la actual época decrépita y corrompida.

Suponen a la presente edad en decadencia, y la poesía por tanto debe ser decadente, y se dedican a pintar - como dice el mismo Armas en defensa de su escuela - "las angustias, las desesperaciones, los ensueños eróticos y criminales, las blasfemias, las alternativas de duda y fe, las postraciones casi criminales y los asaltos orgullosos de esos corazones viejos desde que nacen, hastiados antes de haber vivido, en fin, asqueados de todo, comenzando por ellos mismos."

Julián del Casal, el joven poeta habanero, aparenta ser un decadentista. Oigase este soneto que dedica a un amigo a quien envía su retrato:

No busques tras el mármol de mi frente Del Ideal la esplendorosa llama,

*La Habana Literaria, vol. II, no. 12 (30 June 1892), pp. 269-271. 
Que hacia el templo marmóreo de la Fama

Encaminó mi paso adolescente;

Ni tras el rojo labio sonriente

La paz del corazón de quien te ama, Que entre el verdor de la florida rama Ocúltase la pérfida serpiente.

Despójate de vanas ilusiones, Clava en mi rostro tu mirada fría, Como su pico el pájaro en el fruto,

Y sólo encontrarás en mis facciones

La indiferencia del que nada ansía O la fatiga corporal del bruto.

El estado decadente del espíritu de Casal, parece que se revela en este Paisaje Espiritual:

Perdió mi corazón el entusiasmo Al penetrar en la mundana liza, Cual la chispa al caer en la ceniza Pierde el ardor en fugitivo espasmo.

Sumergido en estúpido marasmo Mi pensamiento atónito agoniza $\mathrm{O}$, al revivir, mis fuerzas paraliza Mostrándome en la acción un vil sarcasmo.

$\mathrm{Y}$ aunque no endulcen mi infernal tormento Ni la Pasión, ni el Arte, ni la Ciencia, Soporto los ultrajes de la suerte,

Porque en mi alma desolada siento El hastío glacial de la existencia Y el horror infinito de la muerte.

Y como el poeta carece de toda esperanza, se consuela con esta invocación: En un Hospital:

Tabernáculo abierto de dolores

Que ansía echar el mundo de su seno,

Como la nube al estruendoso trueno

Que la puebla de lóbregos rumores; 
Plácenme tus sombríos corredores

Con su ambiente impregnado del veneno

Que dilatan en su ámbito sereno

Los males de tus tristes moradores.

Hoy que el dolor mi juventud agosta Y que mi enfermo espíritu intranquilo Ve su sueño trocarse en hojarasca,

Pienso que tú serás la triste costa Donde podré encontrar seguro asilo En la hora fatal de la borrasca.

Ahora bien: ¿a qué obedece el decadentismo de que hace alarde el novísimo poeta cubano Julián del Casal? Sus dolores morales, en sus pocos años, no le pueden haber conducido al descreimiento de Heine, ni tampoco la naturaleza le ha producido en lo físico aquellos tormentosos dolores que inspiraban a Leopardi. Suponen algunos pesimistas que el medio cubano, actualmente, está en completa desmoralización, que allí no hay ideales, que las conciencias, por el malestar político, están en completo desorden, que se carece de fe, que las virtudes cívicas están prostituidas, en una palabra, que aquel país está en período decadente; consecuencia muy natural que podía derivarse del dejo decadente que inspira al poeta Casal, hijo legítimo de la presente generación. Hay que tener en cuenta dos circunstancias: primera, que el decadentismo literario desarrollado en París, no tiene como medio ambiente el París brillante y progresista, donde se exhiben los prosélitos de aquella escuela, sino que han ido a inspirarse en Bizancio, especie de patria ideal, y que por tanto, es puramente simbólica e imaginaria. En Francia, más tal vez que en ninguna otra nación europea, hay extraordinario vigor intelectual; las gentes son ricas, felices; se cultiva con ardor la ciencia, se paga tributo al arte. Ahora bien, ninguno de los que cultivan la escuela decadentista son esos tipos corrompidos, que desprecia la sociedad. Su poesía es vistosa, llena de colores, y las imágenes brillantes, y el verso lleno de sonoridad.

La otra circunstancia, es que Casal dista mucho de ser descreído. El amor, los sentimientos más nobles y generosos, se anidan en su alma. Sólo en ellos podría inspirarse para producir este admirable soneto, lleno de pasión y de fuego, que dice: A mi Madre:

No fuiste una mujer, sino una santa Que murió de dar vida a un desdichado; Pues salí de tu seno delicado Como sale una espina de una planta. 
Hoy que tu dulce imagen se levanta

Del fondo de mi lóbrego pasado,

El llanto está a mis ojos asomado,

Los sollozos comprimen mi garganta,

$\mathrm{Y}$ aunque yazgas trocada en polvo yerto

Sin ofrecerme bienhechor arrimo,

Como quiera que estés siempre te adoro

Porque me dice el corazón que has muerto

Por no oírme gemir, como ahora gimo,

Por no verme llorar, como ahora lloro.

Y aun suponiendo que el poeta viviera en la atmósfera más corrompida, aunque estuviera revuelto en el cieno más inmundo, la conciencia de Casal es la de un ser creyente y bueno, capaz de salvarse de todas las impurezas de la vida. Oigase su otro soneto Flor de Cieno:

Yo soy como una choza solitaria Que el viento huracanado desmorona Y en cuyas piedras húmedas entona Hosco buho su endecha funeraria.

Por fuera sólo es urna cineraria Sin inscripción, ni fecha, ni corona, Mas dentro, donde el cieno se amontona, Abre sus hojas fresca pasionaria.

Huyen los hombres al oír el canto Del buho que en la atmósfera se pierde $\mathrm{Y}$, sin que sepan reprimir su espanto,

No ven que, como planta siempre verde, Entre el negro raudal de mi amargura Guarda mi corazón su esencia pura.

Deducimos en consecuencia que la escuela decadentista es simplemente una originalidad, por más que pregonen sus adeptos que es la única poesía posible en esta época de duda, de indiferencia y de sociedad. Por otra parte, no es el medio ambiente el que produce a los decadentistas, porque si Casal obedeciera al estado supuesto de decadencia del pueblo cubano, no podríamos atribuir esa circunstancia a Pelladan, Mallarmé y sus adeptos franceses. Y no es decadente el medio cubano, tampoco. Hay descomposición natural en un país que ha luchado hasta ahora en vano, para moverse en esfera independiente. Falta, para constituirse en 
definitiva, que sus elementos, como presupone Sanguily, se conglomeren. Esto en cuanto al orden político, que en cuanto al social, ha dado un paso trascendental destruyendo la esclavitud. En cuanto al orden intelectual, Cuba no decae, y al presente han surgido, como constelación sorprendente, en filosofía Enrique José Varona; en oratoria Montoro; en literatura, por corrección de estilo, galanura y método de exponer, Manuel Sanguily, y en la interpretación del arte musical - en sus más brillantes armonías - cuando aún sobrevive White, se levanta Díaz Albertini. Y al estro poderoso de la Avellaneda, y a las cadencias dulcísimas y delicadas de Luisa Pérez, surge esplendente Nieves Xenes.

Y el mismo Julián del Casal, el que aparenta pertenecer a la escuela decadentista, el incrédulo, el falto de fe, es a nuestro modesto juicio, la prueba más evidente de que Cuba progresa, que no decae su literatura, honra de España y de la América española. Julián del Casal es, entre nuestros poetas, una originalidad. Tal vez su natural triste y sombrío, al buscar la forma de expresión, escogió lo más moderno, la escuela decadentista, por falsa que ésta sea. Su estro poderoso necesitó base para mayores emociones, ecos intensos, desesperados, desgarradores. Su poesía es potente y seductora, cincela, pinta, esculpe, talla. Sus acentos dolorosos son de una mezcla extraña, quiere reír y solloza; muchas veces transforma y a veces crea.

Leed sus Nostalgias, donde trata el poeta de revelar su esceptismo, con su lira fresquísima, llena de color y de fantasía, con sonoridad de ritmo peculiar y con encantos de dulces melodías.

Julián del Casal revela la fuerza de concepción del intelecto poético del pueblo cubano. No son sus versos signos de decadentismo, sino himnos que demuestran que el pueblo cubano va adelante, que su porvenir es grande. Si para gloria de su patria, Julián del Casal vive largo tiempo y sigue produciendo, de seguro que habrá de curarse de sus rarezas e hipocondrías, y ya se inspire en el acento consolador y fortificante de un Víctor Hugo - cuyos cantos hieren las fibras más sensibles del corazón humano - o ya vaya a buscar a los decadentistas de la Bizancio imaginaria e ideal, ha de ser siempre un poeta original, un poeta de grandes facultades.

Enrique Trujillo

\section{NIEVE*}

Por Julián del Casal. Habana, 1892.

El tiempo en que la aparición de un volumen de versos era en Cuba un acontecimiento literario ha mucho que pasó. La última edición de las poesías del dulce Mendive rodó por las librerías casi inadvertida. José

*Revista Cubana, vol. XVI (August 1892), pp. 142-146. 
Joaquín Palma, portentoso forjador de versos de oro, nos envió un lindo tomo que apenas se ha leído. Las últimas obras del culto Sellén no han salido mejor libradas. Por eso resulta aún más digno de nota el éxito incontestable de la nueva colección del poeta de las Hojas al viento. El aplauso ha sido general, y ha resonado a lo lejos, fuera de la Isla. Ha habido reservas, ¿cómo no? pero ha prevalecido la aprobación, que en muchos casos ha frisado con el entusiasmo.

Casal ha cautivado, porque tiene dotes de verdadero poeta: notable imaginación pictórica, sensibilidad profunda que sabe hacerse contagiosa, carácter original que se revela espontáneamente en sus asuntos y en su dicción. Es de los que ponen sello a lo que escribe. Quiere decir que es escritor.

Por lo mismo, al dar ahora cuenta de su bello libro, nos sentimos irresistiblemente inclinados a tomar la parte del advocatus diaboli. Aunque Casal se muestra muy desdeñoso de la crítica, su talento es demasiado real, para que no aprecie el valor de ciertos reparos. Un poeta de verdad es algo muy exquisito; y para los que saben estimarlo, resulta siempre lástima grande que se malogren o deslustren las facultades en que estriba su verdadero valor poético. ¿Qué no darían los españoles por tener a Góngora sin el gongorismo!

Pero ya el autor del Polifemo pertenece a la historia, y el autor de Horridum Somnium, no. Todavía Casal puede hojear menos a Verlaine, Aicard, Moréas y demás poetas menores de las escuelas decadente y simbolista, y consultar más su corazón y su oído. Todavía puede evitar el terrible escollo hacia el cual parece desviarse, el amaneramiento. Hay, desde luego, en poesía, como en las demás artes, procedimientos técnicos, susceptibles, por tanto, de cambio y progreso. Pero en realidad un metro más, caso de que llegue a inventarse, no vale lo que un grito patético, que nos sacuda, como el soneto $A$ mi Madre. El valor poético de una palabra no se aprecia por su extrañeza; el tabletear, el crepitante, los brillos astrales, las uñas marfileñas chocan, y no logran añadir ni fuerza, ni claridad, ni elegancia a la expresión. En el fondo los elementos de que dispone el poeta se reducen a imágenes y emociones. Con sus palabras nos ha de hacer que veamos o nos conmovamos. Y al cabo lo que nos haga ver ha de encerrar algo significativo que toque el corazón.

Ahora bien, enumerar no es pintar. Cuando Verlaine empieza una de sus "Aguas Fuertes": La nuit. La pluie; el efecto es el de las acotaciones de una pieza de teatro. En ello no hay nada de pictórico. Lo mismo pasa cuando Casal comienza un poema: Noche de primavera. O cuando principia: Noche de soledad. O bien: Polvo y moscas. A la inversa tampoco se logra formar imagen aglomerando palabras de una misma especie. Por ejemplo:

"nubes coloreadas

De nácar, de granate, de topacio

Y amatista" (Sueño de gloria). 
"Aureo globo, esmaltado de esmeraldas,

Perlas, zafiros y ópalos” (Ibid.).

"el sol espolvoreada de rubíes

Esmeraldas, topacios, amatistas

Y zafiros" (Vespertino).

- No hay tiempo material para pasar mentalmente de un matiz a otro. Se oyen palabras; no se ve nada.

Por otra parte ciertas figuras de porte hierático que pueden decir algo en un cuadro, por una especie de procedimiento iconográfico, como el nimbo en las antiguas telas religiosas, en poesía no tienen más valor que el instrumento, el que dependa del efecto que logren producir, y si se repiten, cansan al lector y le causan un efecto que tiene algo de cómico. Por una vez, parece bien que Salomé muestre alzado en la diestra

"Un loto blanco de pistilos de oro."

Pero si a poco se tropieza con Elena,

"Irguiendo un lirio en la rosada mano,"

y a la otra página con blancas nereidas que llevan entre las manos elevadas

"Níveas conchas de perlas nacaradas, Igneas ramas de fúlgidos corales,"

a pesar de que son muy bellos los versos, la imagen llega a parecer monótona. ¿Conoce el poeta más eficaz disolvente de la emoción artística que la monotonía? Para ver siempre lo mismo, no es necesario asomarnos al belvedere de las Musas.

Si en nuestras manos estuviera, no repetiría Casal descripciones como la de su cadáver en Horridum Somnium. No creerá el poeta que sean estos remilgos de humanista a la antigua. En los clásicos aprendimos a llamar las cosas por su nombre. El padre Homero se permite descripciones tan poco limpias, como el menos escrupuloso realista. Algunos pormenores de la infancia de Aquiles (Ilíad., lib. IX, vs. 482) caen algo más abajo de lo familiar. En época de mucho mayor refinamiento, en uno de los más exquisitos paisajes trazados por la amable y risueña fantasía de Teócrito alterna con el chirrido estridente de la cigarra, el croar de la rana (1). Pero hay un límite que no debe salvar ningún artista, y que ha marcado con

1 Vamos a permitirnos decir algo de las metamorfosis de esta rana de Teócrito; porque ilustran la manera que han tenido los modernos de interpretar a los antiguos. En la versión latina que acompaña la traducción francesa de Firmin Didot el ololygoon del poeta siracusano se ha convertido, siguiendo la autoridad de 
singular penetración el psicólogo Bain, cuando ha dicho que la verdadera antítesis de lo bello no es lo feo, sino lo nauseabundo.

Todavía vamos a extremar las exigencias. Culpe Casal a su talento. Los asuntos antiguos, cuando no pertenecen a un pasado muy remoto o se pierden en la penumbra de la leyenda, es decir, cuando no se prestan ampliamente a lo convencional o si se quiere a lo simbólico, pueden fácilmente degenerar en simples pastiches. La muerte de Moisés nos parece muy bella; pero La agonía de Petronio se nos antoja un ánfora etrusca moldeada en una tienda de bric-a-brac en París. Un poeta que puede aspirar a tanto como Casal, no debe exponerse a ser vencido por un prosista. Hay dos cortos pasajes de Tácito, que forman el cuadro de la muerte del cónsul Petronio, y hacen innecesario tocar de nuevo el asunto.

No sabemos si los kakemonos japoneses llegarán a aclimatarse en el arte occidental. Pero nos agradaría ver empleadas las facultades exquisitas de Casal en asuntos más altos, que en pintar en jarrones, biombos, platos, estuches o abanicos, una gentil criolla con los atavíos postizos de una emperatriz de los nipones en un bal masqué. El poeta, hastiado de nuestra vida prosaica de factoría americana, se escapa a las regiones soñadas de ese oriente remoto forjado en la fantasía de invernadero de Judith Gautier. Busca el arte a lo lejos, para vivir por el arte. ¿ Por qué habrá dicho Proudhon: l'art pour l'art aboutit à des chinoiseries?

Un poeta, de los pocos, de los buenos, un poeta digno de ser amado por Casal, Keats, ha declarado que se había propuesto never to write for the sake of writing. No escribir para casar colores, ni cincelar frases, que resulten vacías. Las frases que quedan cinceladas, sin esfuerzo, son las que reflejan, en su orbe breve de gota límpida, los dolores o las quimeras de la humanidad.

De éstas hay en los Marfiles Viejos.

$\mathrm{E}[$ nrique] J[osé] V[arona]

\section{LA OBRA POSTUMA DE CASAL*}

Bustos y rimas

Han tenido los admiradores del poeta Casal - que son muchos - la feliz idea de elevar un modesto mausoleo en el cementerio al joven desaparecido. La envidia que tiende a socavarlo todo, ha escogido la opor-

Cicerón, en acredula, nombre de un ave desconocida. En la traducción en verso francés de Didot es nada menos que un ruiseñor, la dulce Filomela; y el Obispo Montes de Oca, Ipandro Arcaico entre los Arcades, la transforma en calandria, que chilla entre las espinas. Sólo en la traducción inglesa de Mr. Calverley hemos visto reaparecer la viscosa rana, tree- $[f]$ rog, que oyó Teócrito con Eucrito y Amintas en casa de Frasidamo. Disimúlenos Casal la digresión.

* El Fígaro (8 February 1894), p. 54. 
tunidad para mofarse de la idea, si no en público, porque la envidia es cobarde y trata de ocultarse, al menos en los corrillos, sin pensar que, con todos sus defectos, Julián del Casal era un joven de mérito indiscutible, según ha sancionado la crítica sana de este país, por boca de sus apóstoles del Monte, Montoro y Sanguily, trinidad admirable. Cierto que no todos entonan himnos de alabanza al joven poeta porque no habían llegado a la plenitud de su desarrollo sus aptitudes, ni era el género que cultivó el más propio para cautivar a los pensadores de la época. Y en esto precisamente estribaba quizá el mayor mérito de Casal: en conquistar aplausos en un terreno mal acondicionado para cosecharlos. Si en vez de cultivar esa poesía exótica en todos los países - aun en el mismo París, de donde proviene - su musa se hubiera complacido en cincelar versos más en consonancia con el gusto moderno, el triunfo hubiese sido más completo y más decisivo tal vez. A su edad, muy pocos han alcanzado lo que alcanzó Casal, no ya entre nosotros que supimos comprender su alma candorosa y lamentar su extravío, sino en lejanos países donde contaba con entusiastas admiradores, que han llorado su muerte con lágrimas salidas del fondo del alma. Y esto es mucho. Es necesario darse cuenta del medio en que vivimos para comprender el esfuerzo que se necesita hacer, no digamos para que nuestro nombre pase el mar, sino hasta para que se extienda por la propia isla. Y sin embargo, los periódicos americanos, en su mayoría, dieron publicidad a las poesías de Casal, y en algunos países, como en Nicaragua, su nombre era tan conocido como es aquí el de Rubén Darío. Sólo en España era poco conocido. Salvador Rueda y Emilio Bobadilla, por las relaciones constantes que mantienen con esta tierra, tan olvidada siempre en la Metrópoli, conocían al poeta. Es probable que Clarín no sepa quién fue Casal, el mismo Clarín que tal vez hable de un mediano poeta ruso, polaco o chino. Mas no debe esto extrañarnos, porque España necesitó que muriera Bécquer para saber que era poeta y necesitó que viniera impresa en alemán una obra de un español residente en España, para saber que contaba con un escritor hondo.

Es cierto que Casal no alcanzó popularidad, ni podía alcanzarla tampoco. Era entre nosotros el que menos podía adquirirla, no tanto por sus hábitos de anacoreta como por la índole y la forma de sus versos. Es seguro que el día de difuntos - día de recibo en nuestra Necrópolis - la multitud ante el busto de Casal pregunte quién era el joven y se sorprenda al leer en la inscripción, que era un poeta; pero así y todo, la posteridad, las generaciones sucesivas sin odios y sin rencores, aplaudirán la idea y comprenderán el mérito de Casal. Aún no es tiempo. Todavía sobre la tumba recién abierta del autor de Nieve, vuelan los cuervos envidiosos, queriendo sacarle los ojos.

Casal era de los más laboriosos de nuestros escritores jóvenes. Tal vez en esta virtud del trabajo, sólo Valdivia le iguala, entre los supervivientes, y como dice con verdad Enrique Hernández Miyares en el sencillo y cariñoso prólogo de Bustos y Rimas, se leen con tristeza, con lágrimas, sus 
proyectos literarios (los de Casal). Porque Casal, que al revés de Emilio Zola, amaba el arte por el arte, desoía ex profeso las indicaciones de la crítica y seguía impasible su ruta, tratando de imponerse y triunfar, al fin, por medio de su labor constante. Ars religio nostra, era su lema. Entre los libros que deja esbozados se enumeran Lajoven América (estudios críticos), Las Desolaciones (poesías), Seres enigmáticos (estudios psicológicos), Puah (novela), Los amados de los dioses (estudios críticos), Mis dioses y mis semi-dioses (estudios críticos).

Este catálogo, uniéndole Bustos y Rimas, Nieve y Hojas al viento, es una prueba fehaciente de su amor al trabajo, que en él era tan grande como su amor al arte, que era extraordinario. Sabía que su arte, era para pocos, para los que han dado en la flor de llamarse exquisitos, y escribía para ellos libros y más libros, a la manera de peones camineros que rompen las piedras sin reparar en el polvo que levantan. Por eso es de admirar más el esfuerzo de Casal; el pez nada bien a favor de la corriente, mientras que le es difícil nadar en contra de ella, y Casal nadaba casi siempre en contra. Por eso muchos que no supieron comprenderlo, le atacaban; por eso otros que le comprendíamos, lamentábamos que pretendiera salirse del curso ordinario. Si Casal no se desvía, hubiera sido el poeta indiscutible de la actual generación cubana, porque pocos como él supieron sorprender los secretos de la rima, pocos como él supieron combinar vocablos y adjetivar. Y cosa rara; él que sabía tan bien hacer versos, tenía una idea falsa de la poesía, y aquí está la clave de sus composiciones.

"Los poetas son, por regla general, seres quiméricos, descontentos y antojadizos." "Sólo creerían encontrarse bien, si se encontraran, como gime uno de ellos, en el sitio en que no están. Si estuvieran en el cielo, tendrían la nostalgia de la tierra, como estando en la tierra tienen la nostalgia del cielo. Bajo el fuego del Ecuador suspiran por los hielos del Norte. Prefieren ser amados por una Teodora que por la virgen más hermosa de su valle natal. Calígula les parece más interesante que cualquier Cleveland."

Yo me permito creer, en contra de las ideas de Casal, que en nuestros tiempos el poeta no debe de tener nada de quimérico, sino que, al revés, debe ser un hombre como otro cualquiera, un hombre culto, sobre todo, porque esos vates repentistas que surgen del pueblo, de cuando en cuando, ni son poetas verdaderos, ni escriben nada que dure. Lo que sucede es que a medida que vamos instruyéndonos nos enteramos de lo mucho bueno que han dicho los grandes poetas; y los que van saliendo quieren ser completamente originales. ¿Qué van a cantar? Ya no pueden ser más pesimistas que Espronceda y Byron, más eróticos que Bécquer, más desilusionados que Bartrina, etc., y hay que buscar la quimera, que por fortuna no es campo tan vasto como parece. Los arabescos, los dibujos, los caprichos tienen la piedra y el vidrio y no necesitan de la poesía para nada. Eso es tan pueril como si quisiéramos hacer estatuas con papel. Que es una novedad, convenido; pero eso no dura, porque no es 
real, porque no es verdad, ni siquiera se acerca a lo cierto, y como todo lo que se aleja de ella, ha de caer pronto en el descrédito, lo mismo que, merced a los descubrimientos científicos, van cayendo las bien urdidas leyendas religiosas.

Febrero, 94

Wen Gálvez 


\section{Bibliography}

Adman, Elga. "Pobre Julián" (La Habana Elegante, 29 October 1893), in Marshall E. Nunn, "Life and Works of Julián del Casal." Doctoral dissertation, University of Illinois, 1939. P. 78.

Armas y Cárdenas, José de. "Julián del Casal" (Las Avispas, 23 October 1893; El Hogar, 29 October 1893), in his Estudios y retratos. Madrid:

Librería General de Victoriano Suárez, 1911. Pp. 307-311.

Augier, Angel I. "Juana Borrero, la adolescente atormentada," Cuadernos de Historia Habanera, no. 15 (1938), pp. 29-61.

. "6 notas sobre Julián del Casal," Universidad de la Habana, vol. XXVII, no. 164 (November-December 1963), pp. 161-170.

Avendaño, Fausto. "En el campo," in Antología comentada del modernismo. Ed. Francisco E. Porrata and Jorge A.Santana. Sacramento: California State University, 1974. Pp. 176-179.

Bainville, Jacques. Louis II de Bavière. Paris: Librairie Nationale, 1911.

Barrès, Maurice. Le Jardin de Bérénice. Paris: Librairie Académique Didier, 1891.

- Le Jardin de Bérénice. Paris: Librairie Plon, 1921.

Baudelaire, Charles. Les Fleurs du mal. Ed. Antoine Adam. Paris: Éditions Garnier Frères, 1961.

Bellini, Giuseppe. La letteratura ispano-americana dall'età precolombiana ai nostri giorni. Milan: Sansoni-Accademia, 1970.

Berger, Margaret Robinson. "The Influence of Baudelaire on the Poetry of Julián del Casal," The Romanic Review, vol. XXXVII, no. 2 (April 1946), pp. 177-187.

Blanco-Fombona, Rufino. El modernismo y los poetas modernistas. Madrid: Editorial Mundo Latino, 1929.

Borbón, Eulalia de. Memorias de doña Eulalia de Borbón, Infanta de España. Barcelona: Editorial Juventud, 1958.

Borrero, Dulce María. “Evocación de Juana Borrero," Revista Cubana, vol. XX (July-December 1945), pp. 5-63.

Borrero, Juana. Epistolario. Ed. Cintio Vitier and Fina García Marruz. 2 vols. Havana: Academia de Ciencias de Cuba, 1966.

- Poesías. Ed. Fina García Marruz. Havana: Academia de Ciencias de Cuba, 1966.

Borrero Echeverría, Esteban. "El lirio de Salomé," El Fígaro, 22 October 1899 , p. 391.

Bouilhet, Louis. Oeuvres de Louis Bouilhet: Festons et astragales; Melaenis; Dernières Chansons. Paris: Alphonse Lemerre, n. d.

Cabello de Carbonera, Mercedes. "Cromitos cubanos," El Perú Artístico, 15 March 1894, p. 212.

Cabrera, Raimundo. “Anécdota” (La Habana Elegante, 29 October 1893), 
in Julián del Casal, Edición del Centenario. Havana: Consejo Nacional de Cultura, 1963. "Poesías," p. 291.

- "La isla de Capri," La Habana Literaria, 15 October 1891, pp. 54-57.

Cabrera, Rosa M. Julián del Casal. Vida y obra poética. New York: Las Americas Publishing Co., 1970.

. "Kakemono," in Antología comentada del modernismo. Ed. Francisco

E. Porrata and Jorge A. Santana. Sacramento: California State University, 1974. Pp. 151-154.

Carilla, Emilio. El romanticismo en la América hispánica. Madrid: Editorial Gredos, 1958.

Casal, Julián del. Bustos y rimas. Havana: Imprenta La Moderna, 1893.

- Edición del Centenario. 4 vols. Havana: Consejo Nacional de Cultura, 1963.

-. Hojas al viento. Havana: Imprenta El Retiro, 1890.

—. Nieve. Havana: Imprenta La Moderna, 1892.

—. Nieve. Mexico: Edición de "El Intransigente," 1893.

—. Poesías completas. Ed. Mario Cabrera Saqui. Havana: Ministerio de Educación, 1945.

—. Selección de poesías. Ed. Juan J. Geada y Fernández. Havana: Cultural, 1931.

- Selected Prose of Julián del Casal. Ed. Marshall E. Nunn. University, Alabama: University of Alabama Press, 1949.

-. Sus mejores poemas. Madrid: Biblioteca Andrés Bello, n. d.

Castellanos García, Gerardo. Panorama histórico: Ensayo de cronología cubana desde 1492 hasta 1933. Havana: Ucar, García y Cía., 1934.

Castillo de González, Aurelia. “A 'La maja' de Casal,” La Habana Literaria, 29 February 1892, p. 76.

_- "Al autor de la bellísima poesía 'Nihilismo," La Habana Literaria, 30 June 1892, p. 285.

Cay, Raoul. “A Casal” (La Habana Elegante, 29 October 1893), in Julián del Casal, Edición del Centenario. Havana: Consejo Nacional de Cultura, 1963. "Poesías," p. 293.

Chacón, Francisco. “Casal,” El Fígaro, 26 November 1885, pp. 2-3.

Chacón y Calvo, José María. "En torno a un epistolario de Julián del Casal," Boletín de la Academia Cubana de la Lengua, vol. VII, nos. 3-4 (July-December 1958), pp. 346-373.

Clarke, Dorothy Clotelle. "A Chronological Sketch of Castilian Versification Together with a List of Its Metric Terms," in University of California Publications in Modern Philology, vol. XXXIV (1948-1952), pp. 278-381.

Coppée, François. Oeuvres complètes de François Coppée. Vol. II. Paris: L. Hébert, 1892.

Cotarelo y Mori, Emilio. Diccionario biográfico y bibliográfico de calígrafos españoles. 2 vols. Madrid: Impr. de la "Revista de Archivos, Bibliotecas y Museos," 1916. 
Cruz, Manuel de la. "Julián del Casal," in his Cromitos cubanos. Havana: "La Lucha," 1892. Pp. 301-321.

—_. "Julián del Casal" (La Habana Elegante, 29 October 1893), in his Literatura cubana. Madrid: Saturnino Calleja, 1924. Pp. 425-428.

Cuba. Antonio Maceo: Documentos para su vida. Prefacio del Dr. Julián Martínez Castells. Havana: Archivo Nacional, 1945.

Cuba en la mano: Enciclopedia popular ilustrado. Havana: Ucar, García y Cía., 1940.

Darío, Rubén. "El general Lachambre: Recuerdo de la Habana" ( $L a$ Nación, 7 March 1895), in José María Monner Sans, Julián del Casal y el modernismo hispanoamericano. Mexico: El Colegio de México, 1952. Pp. 248-250.

. "Films habaneros: El poeta Julián del Casal" (La Nación, 1 January 1911), in José María Monner Sans, Julián del Casal y el modernismo hispanoamericano. Mexico: El Colegio de México, 1952. Pp. 254-257. __. "Julián del Casal," La Habana Elegante, 17 June 1894, p. 4.

- Letras. Madrid: Editorial Mundo Latino, 1921.

. Poesías completas. Ed. Alfonso Méndez Plancarte. Madrid: Aguilar, 1954.

, del Monte, Ricardo. "El efectismo lírico," La Revista de Cuba, vol. III (1878), pp. 133-172.

—_. "Mi deuda," La Habana Elegante, 29 October 1893, pp. 5-7.

Díez Echarri, Emiliano. "Métrica modernista: Innovaciones y renovaciones," Revista de Literatura, vol. XI, nos. 21-22 (January-June 1957), pp. 102-120.

Duplessis, Gustavo. "Julián del Casal," Revista Bimestre Cubana, vol. LIV, no. 1 (July-August 1944), pp. 31-75; no. 2 (September-October 1944), pp. 140-170; no. 3 (November-December 1944), pp. 241-286. Durán-Cerda, Julio. "Elena," in Antología comentada del modernismo. Ed. Francisco E. Porrata and Jorge A. Santana. Sacramento: California State University, 1974. Pp. 138-145.

Faurie, Marie-Josèphe. Le Modernisme hispano-américain et ses sources françaises. Paris: Centre de recherches de l'Institut d'études hispaniques, 1966.

Fernández de Castro, José Antonio. "Fragmentos de una correspondencia de Julián del Casal,” Social, vol. VIII, no. 3 (March 1923), p. 13.

_. "Glosa a unas líneas de Casal," Social, vol. VIII, no. 3 (March 1923), p. 14.

Figueroa, Esperanza. "Bibliografía cronológica de la obra de Julián del Casal," Revista Iberoamericana, vol. XXXV, no. 68 (May-August 1969), pp. 385-399.

. "Bibliografía de Julián del Casal," Boletín de Bibliografía Cubana, vol. II, nos. 3-4 (July-December 1942), pp. 33-38.

- "Comentario biográfico y rectificaciones," in Esperanza Figueroa et al., Julián del Casal: Estudios críticos sobre su obra. Miami: Ediciones Universal, 1974. Pp. 9-31. 
. "Julián del Casal y el modernismo," Revista Iberoamericana, vol. XXXI, no. 59 (January-June 1965), pp. 47-69.

. "Julián del Casal y Rubén Darío," Revista Bimestre Cubana, vol. L, no. 2 (September-October 1942), pp. 191-208.

- "Luz y Sombra en la poesía casaliana," in Esperanza Figueroa et al., Julián del Casal: Estudios críticos sobre su obra. Miami: Ediciones Universal, 1974. Pp. 33-46.

—. "Revisión de Julián del Casal," in Primer Congreso Nacional de Historia: Trabajos presentados (Havana, 1943), vol. II, pp. 251-255.

Fontanella, Lee. "Parnassian Precept and a New Way of Seeing Casal's Museo ideal," Comparative Literature Studies, vol. VII, no. 4 (December 1970), pp. 450-479.

Fontanills, Enrique. "Episodio" (La Habana Elegante, 29 October 1893), in Julián del Casal, Edición del Centenario. Havana: Consejo Nacional de Cultura, 1963. "Poesías,” pp. 293-294.

Gálvez, Wen[ceslao]. "La obra póstuma de Casal: Bustos y rimas,” El Fígaro, 8 February 1894, p. 54.

. "Nieve," El Fígaro, 12 June 1892, p. 6.

García Girón, Edmundo. "'La azul sonrisa’: Disquisición sobre la adjetivación modernista," Revista Iberoamericana, vol. XX, no. 39 (March 1955), pp. 95-116.

Gautier, Judith. Le Collier des jours: Le troisième rang du collier. Paris: Librairie Félix Juven, 1909.

Gautier, Théophile. Oeuvres de Théophile Gautier. 3 vols. Paris: Alphonse Lemerre, 1890.

-Poésies complètes de Théophile Gautier. Paris: Charpentier, 1862.

Geada de Prulletti, Rita. "Bibliografía de y sobre Julián del Casal (1863-1893)," Revista Iberoamericana, vol. XXXIII, no. 63 (JanuaryJune 1967), pp. 133-139.

. "El sentido de la evasión en la poesía de Julián del Casal," Revista

Iberoamericana, vol. XXXII, no. 61 (January-June 1966), pp. 101-108.

—_. "Nostalgias," in Antología comentada del modernismo. Ed. Frạncisco E. Porrata and Jorge A. Santana. Sacramento: California State University, 1974. Pp. 157-161.

Gicovate, Bernardo. "Tradición y novedad en un poema de Julián del Casal,” Nueva Revista de Filología Hispánica, vol. XIV, nos. 1-2 (1960), pp. 119-125.

Glickman, Robert Jay. "Julián del Casal: Letters to Gustave Moreau," Revista Hispánica Moderna, año XXXVII, nos. 1-2 (1972-1973), pp. 101-135.

. "Neurosis," in Antología comentada del modernismo. Ed. Francisco E. Porrata and Jorge A. Santana. Sacramento: California State University, 1974. Pp. 172-175.

. "Vespertino," in Antología comentada del modernismo. Ed. Francisco E. Porrata and Jorge A. Santana. Sacramento: California State University, 1974. Pp. 147-149. 
González Prada, Manuel. "Victor Hugo," in his Pájinas libres. Paris: Tipografía de Paul Dupont, 1894. Pp. 165-175.

Guanabacoa, César de [Ciriaco Sos Gautreau]. Julián del Casal o un falsario de la rima. Havana: Imprenta y Papelería "La Prensa," 1893.

Gutiérrez Nájera, Manuel. "Cartas del jueves," La Habana Literaria, 15 February 1892, p. 62.

—_. "Julián del Casal," Revista Azul, 17 February 1895, p. 246.

H[ ], E[ ]. "Una composición inédita de Julián del Casal," Belén, no. 31 (January 1932), pp. 133-135.

Heine, Heinrich. Buch der Lieder. Ed. G. A. E. Bogeng. Hamburg-Berlin: Hoffmann und Campe, 1923.

Henestrosa, Andrés. "La nota cultural," El Nacional (Mexico), 13 May 1964, p. 3.

Henríquez Ureña, Camila. "Julián del Casal, poeta de la muerte," Universidad de la Habana, vol. XXVII, no. 164 (November-December 1963), pp. 145-160.

Henríquez Ureña, Max. Breve historia del modernismo. 2nd ed. MexicoBuenos Aires: Fondo de Cultura Económica, 1962.

- Panorama histórico de la literatura cubana. 2 vols. Puerto Rico: Ediciones Mirador, 1963.

. "Poetas cubanos de expresión francesa," Revista Iberoamericana, vol. III, nos. 5-6 (February-May 1941), pp. 301-344.

Hérédia, José Maria de. "Chanson de Torero," Le Figaro (Paris), Literary Supplement, 21 September 1889, p. 1.

."La Fête de Paris-Murcie," La Vie Moderne (Paris), 20 December 1879, p. 588.

L Les Trophées. Paris: Alphonse Lemerre, n. d.

"Redondillas," Monde Poétique (Paris), 10 June 1884, pp. 11-12.

Heredia, Nicolás. "Julián del Casal (Hojas al viento)," in his Puntos de vista. Havana: A. Alvarez, 1892. Pp. 170-175.

Hernández Miyares, Enrique. "Al público," in Julián del Casal, Bustos y rimas. Havana: Imprenta La Moderna, 1893. Pp. i-iv.

. "Aniversario de Casal," in his Obras completas. Havana: Academia

Nacional de Artes y Letras, 1916. Vol. II, pp. 127-128.

.. "A un poeta," La Habana Literaria, 30 May 1892, p. 238.

. "Hojas al viento," in his Obras completas. Havana: Academia Nacional de Artes y Letras, 1916. Vol. II, pp. 9-13.

—. "Julián del Casal," in Julián del Casal, Edición del Centenario. Havana: Consejo Nacional de Cultura, 1963. "Poesías," pp. 311-315. —. "Julián del Casal, patriota," in his Obras completas. Havana: Academia Nacional de Artes y Letras, 1916. Vol. II, pp. 35-40.

Hernández Miyares, Julio E. "Julián del Casal: sus ideas y teorías sobre el arte y la literatura," in Esperanza Figueroa et al., Julián del Casal: Estudios críticos sobre su obra. Miami: Ediciones Universal, 1974. Pp. 47-80. 
Herrera Frangutti, Alfonso. Martí en México: Recuerdos de una época. Mexico: Imprenta A. Mijares y Hno., 1969.

Hill, Edna Earle. "The Influence of French Romanticism, Parnassianism, and Symbolism upon the Poetry of Julián del Casal, Precursor of the Modernista Movement in South America." Master's thesis, University of Alabama, 1948.

Holten, Ragnar von. L'Art fantastique de Gustave Moreau. Paris: JeanJacques Pauvert, 1960.

Hugo, Victor. Oeuvres poétiques complètes. Montreal: Éditions Bernard Valiquettes, 1944.

Huysmans, Joris-Karl. À rebours. Paris: G. Crès et Cie., 1922.

Ibrovac, Miodrag. José-Maria de Heredia: sa vie-son oeuvre. Paris: Les Presses Françaises, 1923.

Jiménez, Luis A. "Elementos decadentes en la prosa casaliana," in Esperanza Figueroa et al., Julián del Casal: Estudios críticos sobre su obra. Miami: Ediciones Universal, 1974. Pp. 81-119.

Lazo, Raimundo. "Julián del Casal y su poesía a los cien años," Universidad de la Habana, vol. XXVII, no. 164 (November-December 1963), pp. 135-143.

- La literatura cubana: Esquema histórico desde sus orígenes hasta 1964. Mexico: Universidad Nacional Autónoma de México, 1965.

Leavitt, Sturgis E., et al. Revistas hispanoamericanas. Indice bibliográfico: 1843-1935. Santiago de Chile: Fondo Histórico y Bibliográfico José Toribio Medina, 1960.

Leopardi, Giacomo. I canti. Ed. Luigi Russo. Firenze: G. C. Sansoni, 1967. _. Zibaldone di pensieri. 2 vols. Verona: Arnaldo Mondadori, 1967.

Leslie, John Kenneth. "Casal's Salomé: The Mystery of the Missing Prophet," Modern Language Notes, vol. LXII, no. 6 (June 1947), pp. 402-404.

Lewis, C[live] S[taples]. The Allegory of Love. New York: Oxford University Press, 1958.

Loynaz, Dulce María. “Ausencia y presencia de Julián del Casal," Anales de la Academia Nacional de Artes y Letras, vol. XXXVIII (1954-1958), pp. 111-125.

Malpica Hidalgo, León. Bosquejo del árbol genealógico de la familia Malpica. 2nd ed. Valencia: Tip. Minerva, 1945.

Malpica Labarca, Domingo. "Nota biográfica," La Habana Elegante, 29 October 1893, p. 16.

Márquez Sterling, Manuel. "Julián del Casal," Revista Azul, 24 March 1895 , pp. 328-330.

Meza, Ramón. "Julián del Casal" (Revista de la Facultad de Letras y Ciencias, September 1910), in Julián del Casal, Edición del Centenario. Havana: Consejo Nacional de Cultura, 1963. "Poesías," pp. 221-264.

Miranda, A. "Anécdota" (La Habana Elegante, 29 October 1893), in Julián del Casal, Edición del Centenario. Havana: Consejo Nacional de Cultura, 1963. "Poesías," pp. 294-295. 
Mocega, Esther P. "Tres momentos poéticos en Julián del Casal," Cuadernos Hispanoamericanos, vol. LXXIX, no. 236 (August 1969), pp. 473-483.

Monner Sans, José María. Julián del Casal y el modernismo hispanoamericano. Mexico: El Colegio de México, 1952.

Mora y Varona, Arturo. "Internato," La Habana Elegante, 21 December 1890.

Mullen, Edward J. "La reina de la sombra," in Antología comentada del modernismo. Ed. Francisco E. Porrata and Jorge A. Santana. Sacramento: California State University, 1974. Pp. 164-165.

Musée Gustave Moreau. Catalogue sommaire des peintures, dessins, cartons et aquarelles exposés dans les galeries du Musée Gustave Moreau. Introduction by Henri Rupp. Paris, 1926.

Navarro Tomás, Tomás. Estudios de fonología española. New York: Las Americas Publishing Co., 1966.

- Métrica española: Reseña histórica y descriptiva. Syracuse, New York: Syracuse University Press, 1956.

Nunn, Marshall E. “Julián del Casal, First Modernista Poet," Hispania, vol. XXIII, no. 1 (February 1940), pp. 73-80.

. "Life and Works of Julián del Casal." Doctoral dissertation, University of Illinois, 1939.

. "Vida y obras de Julián del Casal," América, vol. IV, no. 1 (October 1939), pp. 49-55.

Olivera, Otto. “El Correo de la Tarde (1890-1891) de Rubén Darío," Revista Iberoamericana, vol. XXXIII, no. 64 (July-December 1967), pp. 259-280.

Ortal, Yolanda. "La muerte en Julián del Casal," Papeles de Son Armadans, vol. LIII, no. 159 (April 1969), pp. 317-324.

Parker, William Belmont. Cubans of To-day. New York: G. P. Putnam's Sons, 1919.

Phillips, Allen W. "Una nota sobre el primer modernismo: Julián del Casal y algunos poetas mexicanos," in his Cinco estudios sobre literatura mexicana moderna. Mexico: SepSetentas, 1974. Pp. 21-37.

Poncet, Carmen P. "Dualidad de Casal," Revista Bimestre Cubana, vol. LIII (May-June 1944), pp. 193-212.

Porrata, Francisco E. "Salomé," in Antología comentada del modernismo. Ed. Francisco E. Porrata and Jorge A. Santana. Sacramento: California State University, 1974. Pp. 134-137.

Portuondo, José Antonio. "Angustia y evasión de Julián del Casal" (Cuadernos de Historia Habanera, 1937), in Julián del Casal, Edición del Centenario. Havana: Consejo Nacional de Culturä, 1963. Vol. I, pp. 42-68.

Quackenbush, Louis Howard. "A la belleza," in Antología comentada del modernismo. Ed. Francisco E. Porrata and Jorge A. Santana. Sacramento: California State University, 1974. Pp. 167-170. 
Real Colegio de Belén. Corona poética que a la eterna memoria del gran Cristóbal Colón ofrecen en el IV centenario del descubrimiento de América los alumnos del Real Colegio de Belén. Havana: Imp. y Papelería "La Universal," de Ruiz y Hermano, 1892.

Remos y Rubio, Juan J. Historia de la literatura cubana. 3 vols. Havana: Cárdenas y Cía., 1945.

Rosell y Malpica, Eduardo. Diario del teniente coronel Eduardo Rosell y Malpica. Havana: Imprenta "El Siglo XX," 1949.

Sáenz, Gerardo. Luis G. Urbina, vida y obra. Mexico: Ediciones de Andrea, 1961.

Sánchez de Fuentes, Eugenio. “A Julián del Casal después de haber leído su poesía 'Nihilismo,'” La Habana Literaria, 30 June 1892, p. 267.

Schulman, Ivan A. "Introducción" in José Martí, Versos libres. Barcelona: Editorial Labor, 1970. Pp. 11-48.

—_. "Las estructuras polares en la obra de José Martí y Julián del Casal," Revista Iberoamericana, vol. XXIX, no. 56 (July-December 1963), pp. 251-282.

- "Casal's Cuban Counterpoint of Art and Reality," Latin American Research Review, vol. XI, no. 2 (1976), pp. 113-128.

Sierra, Justo. "Prólogo," Obras de Manuel Gutiérrez Nájera: Poesía. Mexico: Oficina Impresadora del Timbre, 1896. Pp. iii-xvii.

Soulary, Joséphin. Oeuvres complètes. Paris: Alphonse Lemerre, 1883.

Stecchetti, Lorenzo [Olindo Guerrini]. Le rime di Lorenzo Stecchetti. Bologna: Zanichelli Editore, 1962.

Torres Ríoseco, Arturo. "A Rebours and Two Sonnets of Julián del Casal," Hispanic Review, vol. XXIII, no. 4 (October 1955), pp. 295-297.

Trujillo, Enrique. "Nieve," La Habana Literaria, 30 June'-1892, pp. 269-271.

Turk, Frank A. The Prints of Japan. Worcester and London: Arco, 1966.

Urbina, Luis G. "Nieve, por Julián del Casal," in Julián del Casal, Nieve. Mexico: Edición de "El Intransigente," 1893. Pp. i-xii.

Valdivia, Aniceto. "Julián del Casal" (La Lucha, 23 October 1893), in Julián del Casal, Edición del Centenario. Havana: Consejo Nacional de Cultura, 1963. "Poesías," pp. 295-300.

Varona, Enrique José. "Hojas al viento," in Revista Cubana, vol. XI (May $1890)$, pp. 473-477.

__. "Julián del Casal" (La Habana Elegante, 29 October 1893), rpt. with minor changes in Revista Cubana, vol. XVIII (October 1893), pp. 340-341.

. "Nieve," Revista Cubana, vol. XVI (August 1892), pp. 142-146.

Villoch, Federico. "Las tardes de la Galería Literaria" (Carteles, 25 March 1945), in Julián del Casal, Edición del Centenario. Havana: Consejo Nacional de Cultura, 1963. "Poesías," pp. 302-307.

. "Viejas postales descoloridas: La celda de Casal" (Diario de la Marina, 30 March 1941), partially reproduced in Julián del Casal, 
Poesías completas. Ed. Mario Cabrera Saqui. Havana: Ministerio de Educación, 1945. Pp. 19-20.

Vitier, Cintio. "Casal como antítesis de Martí," in his Lo cubano en la poesía. Havana: Instituto del Libro, 1970. Pp. 283-314.

. "Julián del Casal en su centenario," in his Estudios críticos. Havana: Biblioteca Nacional José Martí, 1964. Pp. 9-37.

. "Las cartas de amor de Juana Borrero," in Juana Borrero, Epistolario. Havana: Academia de Ciencias de Cuba, 1966. Vol. I, pp. 7-31.

Williams, Mary Wilhelmine. Dom Pedro the Magnanimous, Second Emperor of Brazil. New York: Octagon Books, 1966.

Zaldívar, Gladys. "Significación de la nostalgia de otro mundo en la poesía de Julián del Casal," in Esperanza Figueroa et al., Julián del Casal: Estudios críticos sobre su obra. Miami: Ediciones Universal, 1974. Pp. 121-133.

. "Dos temas de la búsqueda metafísica en Huysmans y Casal," in Esperanza Figueroa et al., Julián del Casal: Estudios críticos sobre su obra. Miami: Ediciones Universal, 1974. Pp. 135-144.

Zeno Gandía, Manuel. “Hojas al viento,” El Fígaro, 29 June 1890, pp. 3-4. 


\section{List of Names and Subjects}

Académie des Beaux-Arts, 179.

Acosta, Miguel, 167.

Adman, Elga, 289.

Aganoor, Vittoria, 168.

"Alagôas," 112.

Alcântara, Pedro de. See Pedro II.

Alfonso XII, 351.

“Alfonso XIII," 354.

Alié, Thérèse, 254.

Alighieri, Dante, 74, 208.

Alvarez de la Campa, Alonso, 107.

Angulo y Mendiola, Rafael, 392.

Antici, Adelaide degli, 231.

Arburu, José, 295.

Arciniegas, Germán, 49.

Arciniegas, Ismael Enrique, 176.

Armenteros de Herrera, Rosario, 153, 385.

Arolas, Juan, 8.

Aróstegui del Castillo, Gonzalo, 277, 278, 358.

A róstegui y González de Mendoza, Gonzalo, 358.

Aróstegui y Mendoza, Aurelia, 138, 277, 358.

Aurora (La), 78.

Autonomismo, 12, 13.

Balmaceda Toro, Pedro, 352.

Bandera Veracruzana (La), 148.

Banville, Théodore de, 176, 252, 281.

Barbey D'Aurevilly, Jules, 9, 71, 280.

Barrès, Maurice, 170, 174.

Bartrina, Joaquín María, 8.

Bárzaga, Rafael, 101.

Baudelaire, Charles, 4, 9, 24, 117-119, 174, 181, 187, 281, 288.

Bécquer, Gustavo Adolfo, 8, 353, 363.

Bello, Andrés, 49, 301.

Bermúdez, Anacleto, 107.

Bismarck, Otto von, 87, 271.

Blas, Rui, 14.

Borrero, Esteban de Jesús, 245, 362, 367.

Borrero Echeverría, Esteban, 108, 126, 138,
$162,164,244,245-247,266,267,338$,

$347,362,363,364,365,367,369$.

Borrero Echeverría, Manuel, 247, 362, 367.

Borrero Pierra, Ana María, 246.

Borrero Pierra, Consuelo, 246.

Borrero Pierra, Dolores, 246.

Borrero Pierra, Dulce María, 139, 246, 363.

Borrero Pierra, Elena, 246, 362.

Borrero Pierra, Esteban, 246.

Borrero Pierra, Juana, 101, 138, 139, 164, $246,247,330,331,362-367,378,389$, 390.

Borrero Pierra, Manuel, 246.

Borrero Pierra, Mercedes, 246.

Bouilhet, Louis, 89-90.

Bourget, Paul, 9.

Brisas del Capiro (Las), 109.

Burne-Jones, Edward, 254.

Bustillos, José María, 139, 151, 154.

Byrne, Bonifacio, 295.

Byron (George Gordon), 168.

Cabello de Carbonera, Mercedes, 67.

Cabrera, Raimundo, 138, 251, 283-284.

Carducci, Giuseppe, 168.

Caricatura (La), 353.

Caridad del Cerro (La), 105, 162.

Caro, José Eusebio, 301.

Caro, Miguel Antonio, 49.

Carpaccio, Vittore, 178.

Casal, Andrés del, 235.

Casal, Carmen del, 37, 139, 236, 350, 369, 392.

Casal, Julián del. Life. Baptismal certificate, 40; education, 27, 39, 40, 289, 291; sexual initiation, 85; trip to Spain, 7, 11-12, 71, $73,84,103,168,219$; employment, 11 , $12,13,71,73,125-126,152,185-186$, $218,261,262,385$; pseudonyms, 9,10 , 122, 126, 223, 255, 273; residences, 39, $125,152,245,247,248,276,283,286$, 287,306 ; state of health, $100,125,128$, 185-186, 230, 244-245, 248, 266, 
286-287, 348, 369-370, 371; correspondence, $111,127,138-139,143,169,177$, 180-181, 186-187, 189-190, 370. Personality: world-view, 121, 267, 290, 376-377; self-image, $25,63,121,127-128,227$, 232, 298; specific traits, $12,39,73,99$, $133,135,147-148,185,229,236,247$, 273, 275, 290-291, 298, 332, 344, 347, 378. Attitudes towards: his environment, 3-4, 11, 72, 127, 245, 369; Cuban values, 108, 126, 163-164, 379; women, 94, 95, 136, 252, 275, 294-295, 378, 379. Casal and: art, 4-6, 27-28, 46, 127, 132-133, $178,180-181,208,266,288,294-296$; literature, 7-9, 16-22; religion, 76, 80, 135, 288-294, 296-297, 308, 398; love, 28-29, 46, 62-63, 75, 185; patriotism, 58-59, 108, 121 ; escapism, 3, 5, 7, 14, 25, 230, 268, 273, 291, 383-384; Mexico, 7, 72, 148-149, 154-155, 175; death, 25, 28 , 63, 108, 236-237, 376-377, 383; suicide, 227, 266, 286, 293-294. Works. Preparation of: Hojas al viento, 24; Nieve, 126-131, 158-159, 184, 210, 215, 226-228, 250, 283, 307; Rimas, 127, 283, 288, 307. Publication of: $H, 10-12,14,23 ; N, 11$, 128-129, 151-152, 154-155, 184, 220, $231 ; R, 11,221,287,370$. Sale of: $H, 14$, $48 ; N, 151,276,283$. Courtesy copies of: $H, 14,149 ; N, 99,128,143-144,151,154$. Critical reception of: $H, 14,164$, 167-168, 219; $N$, 129, 131-132, 143-145, 147, 164, 220, 297. Literary art: general survey, $7,14,70,80,99,129,131$, 146-147, 153, 184, 222, 260, 297-306, 309-32 1, 378, 381-382, 384; antithesis, $33-34,94,161,229,259,306,311,377$, 384 ; verbal portraits, $5,39,124,132-133$, 222, 267, 297, 378, 381; album pieces, $136,255,279-280,376-378,384-385$, 390.

Casal y Ugareda, Julián del, 36-40, 121, 235, 237, 289.

Castañón, Gonzalo, 107.

Castillo, Carlos R. del, 235, 236.

Castillo de González, Aurelia, 138, 166, 167-168, 169, 176, 182, 224, 287, 325, $328,367$.

Castrillo de Polavieja, Concepción, 117.

Catalá, Ramón, $111,355$.

Cay, María, 85, 105, 138, 256, 257, 261-262, $264,265,335,378$.

Cay, Raoul, 104, 105-106, 138, 243, 248, 259, 261, 335, 353.

Cazals, Frédéric-Auguste, 370, 371.

Cervantes Saavedra, Miguel de, 302.

Cervecería Inglesa (La), 72.

Céspedes, Benjamín de, 14.

Céspedes, José María de, 27, 101.
Chacón, Francisco, 14.

Chacón, María, 384.

Chacón y Calvo, José María, 69.

Chassériau, Théodore, 178.

"Château Margaux," 71.

Cherbuliez, Victor, 101.

Círculo Habanero (El), 13, 101, 162, 218.

Colegio La Luz, 286.

Collazo, Guillermo, 5 .

Columbus Day celebrations, 244, 330, 338, 352, 353, 391-392, 394, 395, 396.

Coppée, François, 9, 41-42, 51, 168, 251.

Coronado, Francisco de, 307.

Correo del Golfo (El), 148.

Correo de la Tarde (El), 149, 156, 268.

Costa Rica Ilustrada, 149, 156.

Cruz, Manuel de la, 67-69, 70, 85 .

D’Annunzio, Gabriele, 168.

Dante. See Alighieri.

Darío, Rubén, 3, 16, 17, 106, 138, 139, 149, $152,153,157,170,176,237,243-244$, $248,261,262,264,268,287,295,301$, $306,335,338,348,352-354,369,370$, $371,387$.

Daudet, Alphonse, 9, 154.

Decadentism, 11, 14, 102, 128, 145, 146, 147, 284, 297, 298, 299, 309, 369.

Degas, Edgar, 180.

Dehmel, Richard, 174.

Delacroix, Eugène, 178.

Delauney, Élie, 179.

Destello (El), 109.

Desverine, Dolores, 363.

Diario del Comercio (El), 156.

Díaz, Fernando, 111.

Díaz Albertini, Rafael, 146.

Díaz Mirón, Salvador, 7, 149.

Dos Hermanas, Marquesa de, 124.

Du Barry (Jeanne Becu, Comtesse), 46.

Du-Bouchet, América, 139.

Echegaray, José, 101.

Ercilla y Zúñiga, Alonso de, 8.

Espronceda, José de, 8.

Eulalia de Borbón, 351-352.

Eyssette, Daniel. See Urbina, Luis G.

Fábregas, Virginia, 88.

Farchetti, Ugo, 17.

Fernández Bremón, José, 8.

Fígaro (El), 67, 78, 101, 110, 162.

Figueroa, Miguel, 100.

Flaubert, Gustave, 9, 90.

Flores, Eugenio Antonio, 8.

Fonseca, Manoel Deodoro da, 109, 112.

Fontanills, Enrique, 137, 138, 192, 206, 220, 289.

Fornaris, José, 12, 101, 166, 338. 
Gaceta del Gobierno (La), 148.

Gaceta de la Habana (La), 123.

Gaceta Oficial (La), 148.

Galería Literaria (La), 67, 105, 110, 151 , $162,276,278,358$.

Gálvez, Wenceslao, 68, 145, 146, 221.

García, Ezequiel, 338.

García Menocal, Armando, 5, 143, 184, $233,363$.

Gautier, Judith, 139, 169, 264, 273.

Gautier, Théophile, 9, 34-35, 36, 60-61, 78, $91,176,180,333$.

Ghil, René, 102.

Goethe, Johann Wolfgang von, 123.

Gómez, José Miguel, 284.

Gómez Carrillo, Enrique, 139, 268, 287, 295, 354, 370, 371

Gómez de Avellaneda, Gertrudis, 363 .

Gonse, Louis, 334, 336.

González, Eladio, 107.

González del Hoyo, Francisco, 167.

Govantes y Govantes, Vivino, 137, 138, 165-166.

Govín y Torres, Antonio, 13, 283.

Gozzoli, Benozzo, 178.

Grajales, Mariana, 346.

Gran Logia de Colón (La), 36.

Granados, Cristina, 70.

Gras y Elías, Francisco, 8.

Grotta Azzurra (La), 251, 273, 274

Guanabacoa, César de. See Sos Gautreau, Ciriaco.

Gudden, Bernhard von, 273.

Guerra de los Diez Años, 346.

Guerrini, Olindo. See Stecchetti.

Gutiérrez González, Gregorio, 49.

Gutiérrez Nájera, Manuel, 7, 8, 16, 137, 138, 139, 149, 175-177, 209, 295.

Habana Elegante (La), 13, 67, 68, 162, 218 , $219,243$.

Habana Literaria (La), 148, 162, 220, 223, 243.

Hebbel, Friedrich, 174.

Heine, Heinrich, 86-87, 146, 363.

Held, Oscar, 87, 262.

Heraldo de Costa Rica (El), 156.

Hérédia, José Maria de, 97-99, 128, 131, $143,184$.

Heredia, Nicolás, 14.

Heredia y Heredia, José María, 301.

Hermida, Francisco, 138, 265-266.

Hernández Miyares, Enrique, 9, 14, 43, 58, $68,71,84,107,108,137,138,144,145$, $175,217-221,223,243,279,287,288$, $306,307,334,347,352,353,354,384$, 385,386 .

Horizonte (El), 78 .

Hugo, Victor, 9, 10, 49-50, 65, 78, 168.
Huidobro de Malpica, Fernanda, 286.

Huidobro de Valdivia, Concepción, 333.

Humbert, Jacques-Charles-Ferdinand, 253 , 254.

Huysmans, Joris-Karl, 5, 128, 139, 143, 180 , 181, 187, 206, 207.

Icaza, Francisco A. de, 7, 72-73, 138, 139, 148, 170, 171, 174, 175, 295.

Ilustración Española $(\mathrm{La}), 72$.

Ingres, Jean-Auguste-Dominique, 178.

Isabel II, 351.

Jardín de las Delicias (El), 4.

Job, Duque. See Gutiérrez Nájera, Manuel.

Joran Sisters, 122, 123.

Kakemono, 261, 263, 264, 335.

Kempis, Thomas à, 289.

Kostia, Conde. See Valdivia, Aniceto.

Krick, Clara, 236, 380, 383.

Laborde, Angel, 107.

Lachambre, General, 261.

La Fontaine, Jean de, 179.

Lagomaggiore, Francisco, 67.

Lamartine, Alphonse de, 168.

Lambert, Juliette, 9.

Lasson, Ina, 122-124, 378.

Lastra, Antonio de la, 72, 235.

Lastra, José de la, 235.

Lastra, Luis de la, 72, 289.

Lastra y Owens, María del Carmen de la, 37, 40, 75, 235-236, 237, 289.

Lastra y Owens, Matilde de la, 235.

Leconte de Lisle, Charles-Marie, 244, 281.

Lemaître, Jules, 17, 162.

León, Matilde, 76.

Leopardi, Giacomo, 146, 227, 231-232.

Liborio, 339.

Liliencron, Detlev von, 174.

Linderhof Castle, 251, 271, 273, 274.

Llona, Numa Pompilio, 176.

Loti, Pierre (pseud. of Louis-Marie-Julien Viaud), 333, 334, 336.

Louis XV, 46.

Louvre (El), 71.

Luaces, Antonio L., 167.

Lucha (La), 101, 103.

Ludwig II, 124, 251, 270-273, 298.

Luz de la Infancia (La), 109.

Maceo y Grajales, Antonio, 346-347.

Madrid, César de. See Paula Coronado, F.

Mallarmé, Stéphane, 17.

Malpica Labarca, Domingo, 101, 248, 286, $287,289,306$.

Mantegna, Andrea, 178.

Marcos Medina, José de, 107. 
Maria Leopoldina, 111.

Marín y González, Sabas, 7 1, 76, 108, 109, 308.

Márquez Sterling, Manuel, 149, 168.

Marroquín, José Manuel, 49.

Martí, José, 69, 108, 169.

Martínez Ibor, Myrta, 88.

Marty y Carrillo, Francisca, 219, 334, 386.

Marty y Carrillo, Mercedes, 279, 380.

Matamoros, Mercedes, 168.

Maupassant, Guy de, 9, 333, 348.

Maximilian II, 271.

Mayorgas, Fulgencio, 353.

Meléndez Valdés, Juan, 8.

Mendès, Catulle, 9, 218, 243.

Menocal, Armando. See García Menocal, Armando.

México Intelectual, 148.

Meza, Ramón, 67, 68, 102, 103, 107, 168, 283, 285.

Michelena, Arturo, 49.

Misa, Ignacio, 143.

Mitjans, Aurelio, 67.

Modernism, 41, 77, 121, 152, 170, 242, 260, 267, 301, 308, 310, 311.

Molière (Jean-Baptiste Poquelin), 9, 126, 252.

Monitor Republicano (El), 156.

Monte, Domingo del, 12.

Monte, Herminia del, 386.

Monte, Hortensia del, 378, 386, 387.

Monte, Ricardo del, 12-13, 101, 125, 126, $137,338,386$.

Montesquiou-Fézansac, Robert de, 139.

Montoro, Rafael, 101, 146.

Mora, Gastón, 289.

Mora y Varona, Arturo, 85.

Morales de los Ríos, María, 384.

Moreau, Gustave, 11, 29, 98, 99, 118, 128, $133,139,143,144,152,178-181$, $184-187,188,189,190,191,192,193$, 206, 207, 208, 209, 211, 214, 215, 233, 236, 251, 252, 283, 295, 298.

Mundo Literario Ilustrado (El), 148.

Musée Gustave Moreau, 143, 153.

Nación (La), 67 .

Nacional (El), 148.

Naturalism, 267.

Negri, Ada, 168.

Neoclassicism, 267.

Neuschwanstein Castle, $271,274$.

Nietzsche, Friedrich Wilhelm, 174.

Noreña, Carlos, 148, 154, 175, 338, 382.

Núñez de Arce, Gaspar, 8.

Obligado, Rafael, 176.

Olaguíbel, Francisco M., 154.

Oliva, Ernestina, 83, 84.

Orientalism, 89, 261, 262, 264, 333-336.
Orléans, Antoine d', 351.

Othón, Manuel J., 7.

Owens, Elena, 235.

Pailleron, Edouard, 252.

País (El), 13, 152, 248.

Palou, J., 124.

Papel Periódico Ilustrado (El), 49.

Pardo Bazán, Emilia, 8, 139.

Parnassianism, 39, 97, 129, 144, 145, 146 , 153, 175, 267, 280, 282, 297, 309.

Partido Liberal (El), 12, 13, 100.

Partido Liberal (El), 148, 149, 156.

Patria (La), 148.

Pauchet, Victor, 358.

Paula Coronado, F., 365.

Pedro I, 111.

Pedro II, 29, 109, 111-113, 139, 244, 298.

Peñas, Juan de las. See Sos Gautreau, Ciriaco.

Pérez Bonalde, Antonio, 86.

Pérez de la Riva, Demetrio, 262.

Perugino (Pietro Vannucci), 28, 133.

Peza, Juan de Dios, 7.

Philibert, Jean, 102.

Photographie des Beaux-Arts, 133, 181, 211, 212.

Pi y Margall, Francisco, 8.

Pichardo, Manuel Serafín, 78, 101, 109-111, 112, 154, 266.

Picón Febres, Gonzalo, 176.

Picot, François, 178.

Pierra de Poo, Martina, 363.

Pierra y Agüero, Consuelo, 246, 247, 362, 363.

Poe, Edgar Allan, 123, 281.

Política Cómica (La), 339.

Pompadour (Antoinette Poisson, Marquise de), 46 .

Price, Edouard Cornelius, 46, 47, 137, 138, 139, 185, 209, 210, 251, 252.

Proudhon, Pierre Joseph, 264.

Puga y Acal, Manuel, 7.

Queiroz, Eça de, 69.

Quesada, Vicente G., 176.

Quesada y Aróstegui, Gonzalo de, 169.

Radical (El), 78.

Ramiro, Mariano, 78, 109, 110.

Read, Henry Charles, 17.

Real Academia Española, 392.

Real Colegio de Belén, 39, 40, 85, 283, 289, 291, 379, 392, 394.

Realism, 267.

Reina, Manuel, 8.

Rembrandt van Rijn, 28, 133.

Renan, Ary, 180.

Renoir, Auguste, 254.

Restrepo, Emilio, 353. 
Revista Azul (La), 88.

Revista Cubana (La), 67, 162.

Revista de Méjico (La), 148.

Ribot, Théodule, 162.

Riva Palacio, Vicente, 7, 171.

Rodríguez Arias, Alejandro, 394.

Rodríguez de Tió, Lola, 287.

Rodríguez y Pérez, Pascual, 107.

Rollinat, Maurice, 101, 103, 281.

Romanticism, 130, 178, 267, 297, 380, 381.

Rondón, Juan Bautista, 346.

Rosell, Eduardo, 137, 138, 184, 187.

Rouault, Georges, 179.

Roux, Antony, 179.

Rowland y del Monte, Corina, 390-391.

Rueda, Salvador, 8, 171.

Ruiz Aguilera, Ventura, 8.

Saavedra, Héctor de, 68.

Saint Paul, Albert de, 102.

Salamanca y Negrete, Manuel, 76.

Salazar y Quintana, F., 8.

Samary, Léontine-Pauline-Jeanne, 252-254, 255.

Sánchez de Fuentes, Eugenio, 324-325, $330,331$.

Sanguily, Manuel, 146.

San Miguel, Antonio, 101.

Sanz, Eulogio Florentino, 86.

Selgas y Carrasco, José, 8.

Sellén, Antonio, 49.

Sellén, Francisco, 86.

Sierra, Justo, 8, 288.

Sierra y Peñarredonda, Alicia, 282, 378.

Siglo XIX (El), 151, 152.

Silva, José Asunción, 49, 170, 303.

Sincero, Juan. See Cruz, Manuel de la.

Sociedad de la Habana (La), 53, 71, 73, 218, 308, 334, 379.

Solos, 15, 70, 101, 110, 266.

Sos Gautreau, Ciriaco, 105, 107, 147, 151, $164,222-223,269,328$.

Soulary, Joséphin, 181-183, 288.

Souza, Robert de, 102.

Stecchetti, Lorenzo (pseud. of Olindo Guerrini), 77.

Suárez y Pérez, María, 385.

Surimono, 264, 332, 335-337.

Symbolism, 102, 130, 144, 146, 280.

Tacón, Gran Teatro de, 122, 124.

Thereza Christina, 112.
Torre, Carlos Augusto de la, 107.

Torriente, Ricardo de la, 338-339, 353.

Triunfo (El), 13.

Trujillo, Enrique, 145-146.

Trunco (El), 13.

Turgenev, Ivan, 174.

Ugareda, Casimira, 235.

Uhrbach, Carlos Pío, 362, 366.

Uhrbach, Federico, 366.

Unión Constitucional (La), 362.

Universal (El), 156.

Urbina, Luis G., 7, 16, 139, 149-151, 152, 154, 287.

Uriarte, Ramón, 176.

Valdés Domínguez, Fermín, 107.

Valdivia, Aniceto, 50, 100-103, 139, 286, 333, 367, 389, 392.

Valdivia de Santo Tomás, Conchita, 286.

Valdivia y Huidobro, Serafina, 333, 336, 389.

Valera, Juan, 243.

Varona, Enrique José, 14, 101, 138, 146-147, 161-164, 165, 220, 245, 260, $264,269,278,365$.

Varvara, Mario, 102.

Vecchietta, Lorenzo, 197, 208.

Veintimilla, María de, 176.

$\operatorname{Verdad}(\mathrm{La}), 36$.

Verdugo, Carlos, 107.

Vergil, 116.

Verlaine, Paul, 17, 108, 128, 139, 143-144, 145, 146, 153, 297.

Villaverde, Cirilo, 139.

Villegas, Esteban Manuel de, 8.

Voz de Cuba (La), 107.

Wagner, Richard, 271, 275, 278.

Weyler, Valeriano, 338.

Whitman, Walt, 244.

Wittelsbach, Otto von, 271.

Xenes, Nieves, 146, 168.

Zayas, Alfredo, 175, 220, 243.

Zayas, Francisco, 286, 287.

Zeno Gandía, Manuel, 14.

Zola, Émile, 9.

Zorrilla, José, 8, 380 .

Zorrilla de San Martín, Juan, 176. 


\section{Indexes to Publication Data}

\section{INDEX I}

\section{Alphabetical Listing of Titles and Variant Titles}

\section{A. ALPHABETICAL LIST OF TITLES}

$>$ indicates variant titles.

* indicates variant subtitles.

+ indicates variant dedications.

\begin{tabular}{|c|c|}
\hline No. & Title \\
\hline H38 & $>$ A Berta \\
\hline H 5 & Acuarela \\
\hline $\mathrm{H} 45$ & $\begin{array}{l}\text { Adiós al Brasil del Emperador } \\
\text { don Pedro } 11\end{array}$ \\
\hline R 23 & Aegri somnia \\
\hline R 1 & A la Belleza \\
\hline N31 & A la Castidad \\
\hline N29 & A la Primavera \\
\hline N50 & Al carbón \\
\hline $\mathrm{N} 32+$ & $>$ Al Juez Supremo \\
\hline N24 & *> Al mismo \\
\hline $\mathrm{H} 44$ & A los estudiantes \\
\hline N26 & A mi madre \\
\hline $\mathrm{H} 3+$ & Amor en el claustro \\
\hline N38 & $>$ Ante el retrato de Juana Samary \\
\hline $\mathrm{H} 23$ & $>$ A Olimpia \\
\hline N23 & * A un amigo \\
\hline N30 & A un crítico \\
\hline N35 & A un dictador \\
\hline $\mathrm{R} 15$ & A un héroe \\
\hline R29 & A un poeta \\
\hline $\mathrm{H} 13$ & $>$ Ausencia \\
\hline H 2 & Autobiografía \\
\hline V 8 & [Aves mis versos son ...] \\
\hline N $3+$ & Bajo-relieve \\
\hline $\mathrm{N} 40$ & Blanco y negro \\
\hline$N p 1$ & Bocetos antiguos \\
\hline R 6 & Bohemios \\
\hline N39 & $>$ Camafeo \\
\hline N52 & Canas \\
\hline N49 & Canción \\
\hline V 13 & Colón en la Rábida \\
\hline $\mathrm{H} 16$ & Confidencia \\
\hline R 8 & Coquetería \\
\hline V 12 & Corina Rowland y del Monte \\
\hline R 2 & $>$ Crepuscular \\
\hline$N p 3$ & $>$ Cromos españoles \\
\hline $\mathrm{H} 42+$ & - Croquis perdido \\
\hline R 41 & Cuerpo y alma \\
\hline H 4 & Del libro negro \\
\hline $\mathrm{H} 29$ & Desolación \\
\hline $\mathrm{R} 20$ & Día de fiesta \\
\hline V 7 & [Dicen que eres un ángel...] \\
\hline R 26 & Dolorosa \\
\hline V 5 & Dos fechas \\
\hline $\mathrm{H} 17$ & El adiós del polaco \\
\hline $\mathrm{H} 15$ & * El anhelo del monarca \\
\hline
\end{tabular}

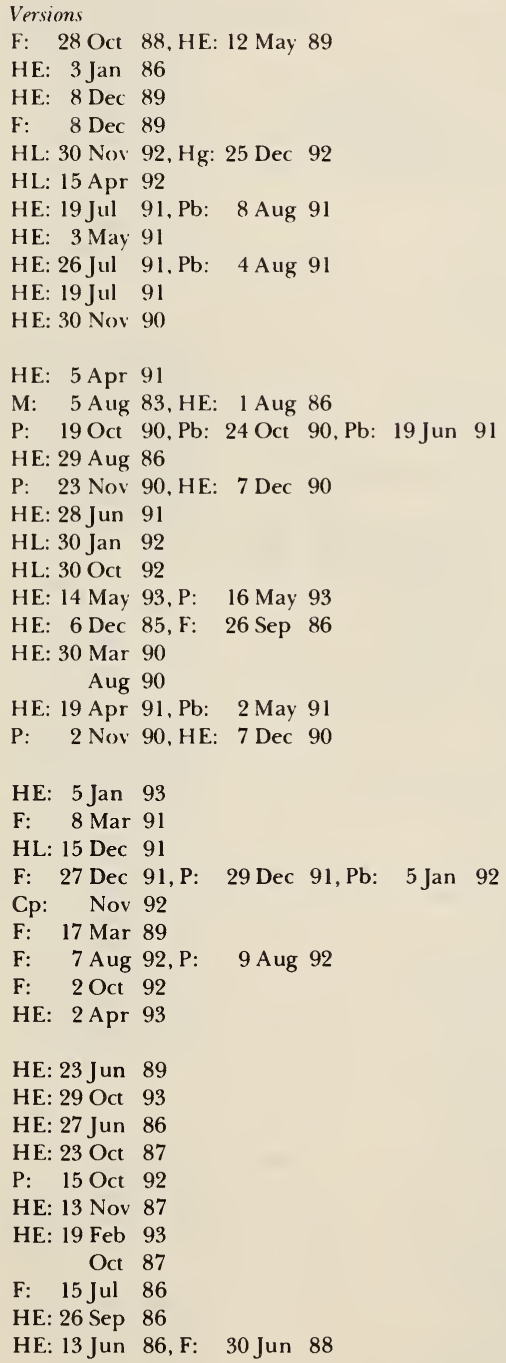




\begin{tabular}{|c|c|}
\hline $\mathrm{H} 22$ & El Arte \\
\hline N $6+$ & El camino de Damasco \\
\hline H $9 *$ & $*>\mathrm{El}$ eco \\
\hline $\mathrm{N} 12+*$ & * Elena \\
\hline $\mathrm{R} 40$ & El hijo espurio \\
\hline V 2 & El poeta y la sirena \\
\hline H 14 & El puente \\
\hline $\mathrm{H} 30$ & El sueño en el desierto \\
\hline R 36 & En el campo \\
\hline H32 & $>$ En el mar \\
\hline $\mathrm{H} 27 *$ & * Engañada \\
\hline R $37 *$ & * Enrique Gómez Carrillo \\
\hline N51 & $>$ En un álbum \\
\hline N37 & En un hospital \\
\hline R 28 & Esquivez \\
\hline H33 & Estatua de carne \\
\hline H37 & $>$ Fatuidad póstuma \\
\hline N33 & Flor de cieno \\
\hline N41 & Flores \\
\hline N47 & Flores de éter \\
\hline $\mathrm{N} 11+$ & Galatea \\
\hline N 13 & Hércules ante la Hidra \\
\hline N 17 & Hércules y las Estinfálides \\
\hline N54+ & Horridum somnium \\
\hline V 9 & Hortensia del Monte \\
\hline V 3 & Huérfano \\
\hline H43 & Idilio realista \\
\hline H41 & In memoriam \\
\hline N34 & Inquietud \\
\hline H 1 & Introducción \\
\hline N 1 & Introducción \\
\hline $\mathrm{H} 10 *$ & $*>$ Invernal \\
\hline V 11 & [Juana Borrero] \\
\hline N 16 & Júpiter y Europa \\
\hline $\mathrm{N} 43+$ & $>$ Kakemono \\
\hline N 5 & La agonía de Petronio \\
\hline N 9 & La aparición \\
\hline $\mathrm{H} 47$ & La canción de la morfina \\
\hline $\mathrm{H} 40$ & La canción del torero \\
\hline R 16 & La cólera del Infante \\
\hline$N p 5$ & La gruta del ensueño \\
\hline $\mathrm{H} 18$ & La mayor tristeza \\
\hline N 4 & La muerte de Moisés \\
\hline H 7 & La nube \\
\hline H34 & La pena \\
\hline H48 & La perla \\
\hline $\mathrm{N} 45+$ & La reina de la sombra \\
\hline R 19 & Las alamedas \\
\hline R 35 & Las horas \\
\hline V 6 & Las mujeres \\
\hline N 2 & Las oceánidas \\
\hline R 10 & La sotana \\
\hline H19* & * Las palomas \\
\hline H36 & La última noche \\
\hline $\mathrm{H} 21$ & La urna \\
\hline R 30 & $>$ Laus noctis \\
\hline H 12 & $>$ Lazos de amor \\
\hline H35 & Madrigal \\
\hline$N p 4$ & Marfiles viejos \\
\hline R $4+$ & Marina \\
\hline N53* & *> Medallón \\
\hline R 18 & Medioeval \\
\hline H31* & * Mensaje \\
\hline N48* & * Mi ensueño \\
\hline$N p 2$ & Mimuseo ideal \\
\hline N27 & Mi padre \\
\hline H11* & * Mis amores \\
\hline R 24 & Neurosis \\
\hline
\end{tabular}

HE: 27 May 88

HL: 30 Sep 91

F: 12 Aug 86

HE: 2 Aug 91, P: 4 Aug 91, Pb: 11 Aug 91, HE: 30 Aug 91

HE: 10 Sep 93, P: 13 Sep 93

E: 5 Mar 81

HE: 25 Jul 86

HE: 17 Oct $86, \mathrm{~F}: \quad 4$ Nov 88

HE: 27 Aug 93

F: 6 Oct 89

HE: 3 Mar 89

HE: 1 Oct 93

HE: 15 Mar 91

HL: 30 Mar 92

HE: 16 Apr 93

HE: 18 Dec 87

HE: 22 Jan 88

HL: 15 Oct 91

P: 16 Nov 90, HE: 7 Dec 90, Pb: 23 Dec 90

HE: 5 Jul 91, Pb: 6 Nov 91

HE: 9 Aug 91, HE: 30 Aug 91

HE: 30 Aug 91

HE: 30 Aug 91

HL: 15 Sep 91

F: 31 Jan 92, P: 2 Feb 92

E: 27 Mar 81

HE: 24 Nov 89

F: 1 Dec 89

HL: $30 \mathrm{Jan}$ 92, P: 3 Feb 92, Hg: 21 Feb 92

HE: 28 Feb 86

HL: 15 Jul 92, Hg: 28 Aug 92

HE: 30 Aug 91

HE: 22 Mar 91

HE: 17 May 91

HE: 30 Aug 91

HE: 20 Apr 90

HE: 8 Jan 93

HE: 13 May 88

HE: 7 Jun 91

F: 1 Dec 87

HE: 27 Apr 90

HE: 10 May 91

HL: 15 Nov 92

HE: 13 Aug 93, UC: 17 Aug 93, P: 18 Aug 93

F: 27 Oct 87

HE: 5 Oct 90

HL: 30 Sep 92

F: $\quad 8 \mathrm{Apr} 86$

HE: 11 Nov 88

HE: 25 Dec 87

HE: 5 Mar 93

F: 28 Jan 86

F: $10 \mathrm{Jul} 92$

HL: 29 Feb 92

HL: 15 Dec 92, Hg: 22 Jan 93

HE: 9 Feb $90, \mathrm{~Pb}: 15$ Feb 90

P: 16 Nov 90, HE: 7 Dec 90, Pb: 23 Dec 90, Hg: 14 Feb 92

HE: 31 May 91, P: 2 Jun 91

HE: 18 Jul 86

HE: 5 Feb 93 


\begin{tabular}{|c|c|c|c|c|c|c|c|}
\hline R 3 & Nihilismo & HL: 15 Jun & 92 & & & & \\
\hline H 8 & Nocturno & HE: $19 \mathrm{Apr}$ & 85 , Ve: & $20 \mathrm{Jan}$ & 86 & & \\
\hline $\mathrm{H} 25$ & Nocturno & HE: 17 Feb & 89 & & & & \\
\hline R 11 & Nocturno & HL: 30 Sep & 92 & & & & \\
\hline $\mathrm{N} 44+$ & Nostalgias & HE: $12 \mathrm{Apr}$ & 91 & & & & \\
\hline R 13 & O Altitudo! & HL: 30 Oct & 92 & & & & \\
\hline R 5 & Obstinación & ED: 21 Aug & 92, HL: & 30 Sep & 92, P: & $7 \mathrm{Oct}$ & 92 \\
\hline $\mathrm{H} 28 *$ & $*>$ Ofrenda & F: $\quad 8 \mathrm{Dec}$ & 87 & & & & \\
\hline R 33 & Oración & HE: 13 Aug & $93, \mathrm{P}:$ & 15 Aug & 93, UC: & : 20 Aug & 93 \\
\hline R 21 & Páginas de vida & HE: 22 Jan & 93 & & & & \\
\hline N46 & Paisaje de verano & HE: 21 Jun & 91, P: & 24 Jun & 91 & & \\
\hline N28 & > Paisaje espiritual & HE: $5 \mathrm{Apr}$ & 91 & & & & \\
\hline R 32 & Para una muerta & HE: 21 May & 93 & & & & \\
\hline N25 * & * Pax a nimae & HE: 26 Oct & 90 & & & & \\
\hline V 4 & [Pensaba darte consejos....] & 30 May & 85 & & & & \\
\hline H46 & Post umbra & & & & & & \\
\hline R 22 & Preocupación & HE: 7 May & 93, P: & 9 May & 93, Hg: & $16 \mathrm{Jul}$ & 93 \\
\hline R 17 & Profanación & HL: 30 Oct & 92 & & & & \\
\hline N $10 *$ & * Prometeo & HE: 16 Aug & $91, \mathrm{HE}:$ & 30 Aug & 91 & & \\
\hline $\mathrm{H} 20 *$ & *> Quimeras & HE: 1 Jan & 88 & & & & \\
\hline R 12 & Recuerdo de la infancia & F: $\quad 4 \mathrm{Sep}$ & 92 & & & & \\
\hline R 9 & Rondeles & HL: 30 Aug & 92 & & & & \\
\hline R 31 & Ruego & HE: 14 May & 93, P: & 16 May & 93 & & \\
\hline N $8+*$ & * Salomé & HE: 21 Sep & $90, \mathrm{P}:$ & 23 Sep & 90, HE: & $30 \mathrm{Aug}$ & 91 \\
\hline R 25 & Sensaciones & P: 24 Aug & 93 & & & & \\
\hline V 10 & Serafina Valdivia y Huidobro & F: 26 Jun & 92 & & & & \\
\hline R $7+$ & Sourimono & HL: 15 Aug & 92 & & & & \\
\hline N 18 & Sueño de gloria & MS: 8 Dec & 91, HL: & $30 \mathrm{Dec}$ & 91 & & \\
\hline R 38 & Tardes de lluvia & HE: 3 Sep & 93 & & & & \\
\hline $\mathrm{H} 26$ & Todavía & & & & & & \\
\hline H 6 & $>$ Tras la ventana & HE: 17 Jan & 86 & & & & \\
\hline N 36 & Tras una enfermedad & HE: 5 Apr & 91 & & & & \\
\hline $\mathrm{N} 22 *$ & * Tristissima nox & HE: 14 Sep & 90, P: & 16 Sep & 90 & & \\
\hline V 1 & ¡Una lágrima! & E: $\quad 13 \mathrm{Feb}$ & 81 & & & & \\
\hline N 19 & Una maja & HL: 15 Feb & 92, P: & $17 \mathrm{Feb}$ & 92 & & \\
\hline N 15 & Una peri & HE: 30 Aug & 91 & & & & \\
\hline N21 & Un fraile & HL: 15 Feb & 92, P: & $17 \mathrm{Feb}$ & 92 & & \\
\hline R 39 & Un santo & HE: 10 Sep & 93, P: & 13 Sep & 93 & & \\
\hline N20 & Un torero & HL: 15 Feb & 92, P: & $17 \mathrm{Feb}$ & 92 & & \\
\hline $\mathrm{N} 14$ & Venus Anadyomena & HE: 30 Aug & 91 & & & & \\
\hline H49 & * Versos azules & HE: $16 \mathrm{Mar}$ & 90, L: & $21 \mathrm{Mar}$ & 90 & & \\
\hline H39 & $>$ Vespertino & HE: $6 \mathrm{Nov}$ & 87 & & & & \\
\hline $\mathrm{N} 42+$ & Vespertino & P: $\quad 26 \mathrm{Oct}$ & 90, Pb: & $7 \mathrm{Nov}$ & 90, HE: & $7 \mathrm{Dec}$ & 90 \\
\hline N $7 *$ & *> Vestíbulo & MS: $12 \mathrm{Dec}$ & 91, F: & 15 Jan & 92, P: & $21 \mathrm{Jan}$ & 92 \\
\hline R 14 & Vieja historia & HL: 15 Sep & 92, Hg: & 6 Nov & 92 & & \\
\hline R 34 & Virgen triste & HE: 20 Aug & 93 & & & & \\
\hline R 27 & Voe soli & HE: 7 May & 93, P: & 9 May & 93 & & \\
\hline
\end{tabular}

\section{B. ALPHABETICAL LIST OF VARIANT TITLES}

$\begin{array}{ll}\text { No. } & \text { Variant Titles } \\ \text { H38 } & \text { Abismos } \\ \text { H38 } & \text { A Coralia } \\ \text { N53 } & \text { Alicia Sierra y Peñarredonda } \\ \text { H39 } & \text { Al llegar la noche } \\ \text { N38 } & \text { Ante el retrato de una } \\ & \text { desconocida } \\ \text { H23 } & \text { A una mexicana } \\ \text { N24 } & \text { A un amigo } \\ \text { H13 } & \text { Desde lejos } \\ \text { H24 } & \text { El deseo de una rosa } \\ \text { H32 } & \text { El viajero } \\ \text { N51 } & \text { En el álbum de la Srta. Mercedes } \\ & \text { Marty y Carrillo } \\ \text { H20 } & \text { Ensueño } \\ \text { N } 7 & \text { Gustavo Moreau }\end{array}$

$\begin{aligned} & \text { Definitive Title } \\ & >\text { A Berta } \\ & >\text { A Berta } \\ & >\text { Medallón } \\ & >\text { Vespertino } \\ & >\text { Ante el retrato de } \\ & \text { Juana Samary } \\ & >\text { A Olimpia } \\ & >\text { Al mismo } \\ & >\text { Ausencia } \\ & >\text { El anhelo de una rosa } \\ & >\text { En el mar } \\ & >\text { En un álbum } \\ & >\text { Quimeras } \\ & >\text { Vestíbulo }\end{aligned}$


H 9 Intima

H10 Invierno

H12 Lazos de muerte

H 6 Luz y sombra

H24 Monólogo de una rosa marchita

R 30 Nocturno

H28 Ofrenda a Mariano Ramiro

N43 Pastel japonés

N32 Revelación

N28 Sonrisas negras

N39 Srita. María Cay

Np3 Tipos españoles

H37 Vanidad póstuma

R 2 Vespertino
$>$ El eco

$>$ Invernal

$>$ Lazos de amor

$>$ Tras la ventana

$>\mathrm{El}$ anhelo de una rosa

$>$ Laus noctis

$>$ Ofrenda

$>$ Kakemono

$>$ Al Juez Supremo

$>$ Paisaje espiritual

$>$ Camafeo

$>$ Cromos españoles

$>$ Fatuidad póstuma

$>$ Crepuscular 


\title{
Chronological Listing of Poems.
}

\author{
POEMS IN ORDER OF APPEARANCE
}

1. HOJAS AL VIENTO.

$>$ indicates variant titles.

* indicates variant subtitles.

+ indicates variant dedications.

No. Title

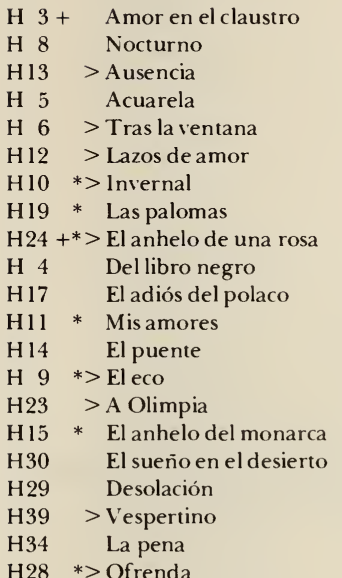

H33 Estatua de carne

H21 La urna

H20 *> Quimeras

H37 > Fatuidad póstuma

H18 La mavor tristeza

$\mathrm{H} 22 \quad$ El Arte

H38>A Berta

H36 La última noche

H25 Nocturno

$\mathrm{H} 27 *$ Engañada

H16 Confidencia

$\mathrm{H} 42+$ Croquis perdido

H32 > Enel mar

H43 Idilio realista

$\mathrm{H} 4 \mathrm{I}$ In memoriam

H45 Adiós al Brasil del Emperador don Pedro 11

H31 * Mensaje

H49* Versos azules

H 2 Autobiografía

$\mathrm{H} 47$ Lacanción de la morfina

$\mathrm{H} 48$ La perla
Order of Appearance

M: 5 Aug 83, HE: 1 Aug 86

HE: 19 Apr 85 , Ve: 20 Jan 86

HE: 6 Dec 85, F: 26 Sep 86

HE: 3 Jan 86

HE: 17 Jan 86

F: 28 Jan 86

HE: 28 Feb 86

F: $\quad 8$ Apr 86

HE: 13 Jun $86, F$ : 30 Jun 88

HE: 27 Jun 86

F: 15 Jul 86

HE: 18 Jul 86

HE: $25 \mathrm{Jul} 86$

F: 12 Aug 86

HE: 29 Aug 86

HE: 26 Sep 86

HE: 17 Oct $86, F$ : 4 Nov 88

HE: $23 \mathrm{OCt} 87$

HE: $6 \mathrm{Nov} 87$

F: 1 Dec 87

F: $8 \mathrm{Dec} 87$

HE: $18 \mathrm{Dec} 87$

HE: 25 Dec 87

HE: 1 Jan 88

HE: 22 Jan 88

HE: 13 Mav 88

HE: 27 May 88

F: 28 Oct 88, HE: 12 Mav 89

HE: 11 Nov 88

HE: 17 Feb 89

HE: $3 \mathrm{Mar} 89$

F: 17 Mar 89

HE: 23 Jun 89

F: $\quad 6 \mathrm{OCt} 89$

HE: $24 \mathrm{Nov} 89$

F: 1 Dec 89

HF: 8 Dec 89

F: 8 Dec 89

HE: 9 Feb $90, \mathrm{~Pb}: 15$ Feb 90

HE: 16 Mar 90, L: 21 Mar 90

HE: 30 Mar 90

HE: $20 \mathrm{Apr} 90$

HE: 27 Apr 90

First published in "Hojas al viento":

$\mathrm{H} 1$ Introducción

H 7 La nube

H26 Todaría

H35 Madrigal

H40 La canción del torero

H44 A los estudiantes

H46 Post umbra 


\begin{tabular}{|c|c|}
\hline No. & Title \\
\hline N22 & * Tristissima nox \\
\hline $\mathrm{N} 8+$ & * Salomé \\
\hline N 2 & Las oceánidas \\
\hline N 38 & $>$ Ante el retrato de Juana Samary \\
\hline N25 & * Pax animae \\
\hline $\mathrm{N} 42+$ & Vespertino \\
\hline N40 & Blanco y negro \\
\hline N41 & Flores \\
\hline $\mathrm{N} 48$ & * Mi ensueño \\
\hline $\mathrm{N} 23$ & * A un a migo \\
\hline N 24 & $*>\mathrm{Al}$ mismo \\
\hline N39 & $>$ Camafeo \\
\hline N51 & $>$ En un álbum \\
\hline $\mathrm{N} 43+$ & > Kakemono \\
\hline N26 & A mi madre \\
\hline N 28 & $>$ Paisaje espiritual \\
\hline N36 & Tras una enfermedad \\
\hline $\mathrm{N} 44+$ & Nostalgias \\
\hline N $3+$ & - Bajo-relieve \\
\hline N29 & A la Primavera \\
\hline $\mathrm{N} 45+$ & La reina de la sombra \\
\hline N 5 & La agonía de Petronio \\
\hline $\mathrm{N} 27$ & Mi padre \\
\hline N 4 & La muerte de Moisés \\
\hline N46 & Paisaje de verano \\
\hline N30 & A un crítico \\
\hline $\mathrm{N} 47$ & Flores de éter \\
\hline N31 & A la Castidad \\
\hline $\mathrm{N} 32+$ & $>\mathrm{Al}$ Juez Supremo \\
\hline N50 & Al carbón \\
\hline $\mathrm{N} 12+$ & * Elena \\
\hline $\mathrm{N} 11+$ & Galatea \\
\hline N 10 & * Prometeo \\
\hline N 9 & La aparición \\
\hline N 13 & Hércules ante la Hidra \\
\hline $\mathrm{N} 14$ & Venus Anadyomena \\
\hline N 15 & Una peri \\
\hline N 16 & Júpiter y Europa \\
\hline N 17 & Hércules y las Estinfálides \\
\hline N54+ & Horridum somnium \\
\hline N $6+$ & El camino de Damasco \\
\hline N33 & Flor de cieno \\
\hline N 18 & Sueño de gloria \\
\hline N 7 & $*>$ Vestíbulo \\
\hline N52 & Canas \\
\hline N49 & Canción \\
\hline N34 & Inquietud \\
\hline N35 & A un dictador \\
\hline N 19 & Una maja \\
\hline $\mathrm{N} 20$ & Un torero \\
\hline N21 & Un fraile \\
\hline N53 & *> Medallón \\
\hline N37 & En un hospital \\
\hline
\end{tabular}

First published in "Nieve":

N 1 Introducción
Order of Appearance

HE: 14 Sep 90, P: 16 Sep 90

HE: 21 Sep 90, P: 23 Sep 90, HE: 30 Aug 91

HE: 5 Oct 90

P: 19 Oct $90, \mathrm{~Pb}: 24$ Oct $90, \mathrm{~Pb}: 19$ Jun 91

HE: 26 Oct 90

P: 26 Oct $90, \mathrm{~Pb}: 7$ Nov $90, \mathrm{HE}: 7 \mathrm{Dec} 90$

P: 2 Nov 90. HE: 7 Dec 90

P: 16 Nov 90, HE: 7 Dec 90, Pb: 23 Dec 90

P: 16 Nov 90, HE: 7 Dec 90, Pb: 23 Dec 90, Hg: 14 Feb 92

P: 23 Nov $90, \mathrm{HE}: 7 \mathrm{Dec} 90$

HE: 30 Nov 90

F: 8 Mar 91

HE: 15 Mar 91

HE: 22 Mar 91

HE: 5 Apr 91

HE: 5 Apr 91

HE: 5 Apr 91

HE: 12 Apr 91

HE: 19 Apr 91, Pb: 2 May 91

HE: 3 May 91

HE: 10 May 91

HE: 17 May 91

HE: 31 May 91, P: 2 Jun 91

HE: 7 Jun 91

HE: 21 Jun 91, P: 24 Jun 91

HE: 28 Jun 91

HE: 5 Jul 91, Pb: 6 Nov 91

HE: 19 Jul 91, Pb: 8 Aug 91

HE: 19 Jul 91

HE: 26 Jul 91, Pb: 4 Aug 91

HE: 2 Aug 91, P: 4 Aug 91, Pb: 11 Aug 91, HE: 30 Aug 91

HE: 9 Aug 91, HE: 30 Aug 91

HE: 16 Aug 91, HE: 30 Aug 91

HE: 30 Aug 91

HE: 30 Aug 91

HE: 30 Aug 91

HE: 30 Aug 91

HE: 30 Aug 91

HE: 30 Aug 91

HL: 15 Sep 91

HL: 30 Sep 91

HL: 15 Oct 91

MS: 8 Dec 91, HL: 30 Dec 91

MS: 12 Dec 91, F: 15 Jan 92, P: 21 Jan 92

HL: 15 Dec 91

F: 27 Dec 91, P: 29 Dec 91, Pb: 5 Jan 92

HL: 30 Jan 92, P: 3 Feb 92, Hg: 21 Feb 92

HL: 30 Jan 92

HL: 15 Feb 92, P: 17 Feb 92

HL: 15 Feb 92, P: 17 Feb 92

HL: 15 Feb 92, P: 17 Feb 92

HL: 29 Feb 92

HL: 30 Mar 92

\section{RIMAS.}

$\begin{array}{ll}\text { No. } & \text { Title } \\ \text { R } 1 & \text { A la Belleza } \\ \text { R } 3 & \text { Nihilismo } \\ \text { R } 4+ & \text { Marina } \\ \text { R } 8 & \text { Coquetería } \\ \text { R } 7+ & \text { Sourimono }\end{array}$

Order of Appearance

HL: 15 Apr 92

HL: 15 Jun 92

F: 10 Jul 92

F: 7 Aug 92, P: 9 Aug 92

HL: 15 Aug 92 


$\begin{array}{ll}\text { R 5 } & \text { Obstinación } \\ \text { R 9 } & \text { Rondeles } \\ \text { R 12 } & \text { Recuerdo de la infancia } \\ \text { R 14 } & \text { Vieja historia } \\ \text { R 10 } & \text { La sotana } \\ \text { R 11 } & \text { Nocturno } \\ \text { R 20 } & \text { Día de fiesta } \\ \text { R 13 } & \text { O Altitudo! } \\ \text { R 15 } & \text { A un héroe } \\ \text { R 17 } & \text { Profanación } \\ \text { R 19 } & \text { Las alamedas } \\ \text { R23 } & \text { Aegri somnia } \\ \text { R 18 } & \text { Medioeval } \\ \text { R 6 } & \text { Bohemios } \\ \text { R 16 } & \text { La cólera del Infante } \\ \text { R21 } & \text { Páginas de vida } \\ \text { R 24 } & \text { Neurosis } \\ \text { R 26 } & \text { Dolorosa } \\ \text { R30 } & \text { > Laus noctis } \\ \text { R 2 } & \text { > Crepuscular } \\ \text { R 28 } & \text { Esquivez } \\ \text { R 22 } & \text { Preocupación } \\ \text { R27 } & \text { Voe soli } \\ \text { R 29 } & \text { A un poeta } \\ \text { R 31 } & \text { Ruego } \\ \text { R 32 } & \text { Para una muerta } \\ \text { R33 } & \text { Oración } \\ \text { R35 } & \text { Las horas } \\ \text { R 34 } & \text { Virgen triste } \\ \text { R 25 } & \text { Sensaciones } \\ \text { R36 } & \text { En el campo } \\ \text { R 38 } & \text { Tardes de lluvia } \\ \text { R39 } & \text { Un santo } \\ \text { R 40 } & \text { El hijo espurio } \\ \text { R 37 } & \text { * Enrique Gómez Carrillo } \\ \text { R 41 } & \text { Cuerpo y alma } \\ & \\ \end{array}$

ED: 21 Aug 92, HL: 30 Sep 92, P: 7 Oct 92 HL: 30 Aug 92

F: 4 Sep 92

HL: 15 Sep 92, Hg: 6 Nov 92

HL: 30 Sep 92

HL: 30 Sep 92

P: 15 Oct 92

HL: 30 Oct 92

HL: 30 Oct 92

HL: 30 Oct 92

HL: 15 Nov 92

HL: 30 Nov 92, Hg: 25 Dec 92

HL: 15 Dec 92, Hg: 22 Jan 93

HE: 5 Jan 93

HE: 8 Jan 93

HE: 22 Jan 93

HE: 5 Feb 93

HE: 19 Feb 93

HE: 5 Mar 93

HE: 2 Apr 93

HE: 16 Apr 93

HE: 7 May 93, P: 9 May 93, Hg: 16 Jul 93

HE: 7 May 93, P: 9 May 93

HE: 14 May 93, P: 16 May 93

HE: 14 May 93, P: 16 May 93

HE: 21 May 93

HE: 13 Aug 93, P: 15 Aug 93, UC: 20 Aug 93 HE: 13 Aug 93, UC: 17 Aug 93, P: 18 Aug 93 HE: 20 Aug 93

P: 24 Aug 93

HE: 27 Aug 93

HE: 3 Sep 93

HE: 10 Sep 93, P: 13 Sep 93

HE: 10 Sep 93, P: 13 Sep 93

HE: 1 Oct 93

HE: 29 Oct 93

\section{VARIA}

Order of Appearance

E: $13 \mathrm{Feb} 81$

E: 5 Mar 81

E: 27 Mar 81

30 May 85

Oct 87

F: 27 Oct 87

HE: 13 Nov 87

Aug 90

F: 31 Jan 92, P: 2 Feb 92

F: 26 Jun 92

HL: 15 Jul 92, $\mathrm{Hg}$ : 28 Aug 92

F: 2 Oct 92

Cp: Nov 92 


\section{INDEX III}

\section{Poems in Book Order}

\section{HOJAS AL VIENTO.}

$>$ indicates variant titles.

* indicates variant subtitles.

+ indicates variant dedications.

\begin{tabular}{|c|c|}
\hline No. & Title \\
\hline $\mathrm{HpO}$ & Hojas al viento \\
\hline $\mathrm{H} 1$ & Introducción \\
\hline H 2 & Autobiografía \\
\hline H $3+$ & Amor en el claustro \\
\hline H 4 & Del libro negro \\
\hline H 5 & Acuarela \\
\hline H 6 & $>$ Tras la ventana \\
\hline H 7 & La nube \\
\hline H 8 & Nocturno \\
\hline H 9 & *> El eco \\
\hline $\mathrm{H} 10$ & *>. Invernal \\
\hline H11 & * Mis a mores \\
\hline $\mathrm{H} 12$ & $>$ Lazos de amor \\
\hline $\mathrm{H} 13$ & $>$ Ausencia \\
\hline $\mathrm{H} 14$ & El puente \\
\hline $\mathrm{H} 15$ & * El anhelo del monarca \\
\hline H 16 & Confidencia \\
\hline $\mathrm{H} 17$ & El adiós del polaco \\
\hline $\mathrm{H} 18$ & La mayor tristeza \\
\hline H19 & * Las palomas \\
\hline $\mathrm{H} 20$ & *> Quimeras \\
\hline $\mathrm{H} 21$ & La urna \\
\hline $\mathrm{H} 22$ & El Arte \\
\hline $\mathrm{H} 23$ & $>$ A Olimpia \\
\hline $\mathrm{H} 24+$ & * $>\mathrm{El}$ anhelo de una rosa \\
\hline $\mathrm{H} 25$ & Nocturno \\
\hline $\mathrm{H} 26$ & Todavía \\
\hline $\mathrm{H} 27$ & * Engañada \\
\hline $\mathrm{H} 28$ & $*>$ Ofrenda \\
\hline $\mathrm{H} 29$ & Desolación \\
\hline H30 & El sueño en el desierto \\
\hline H31 & * Mensaje \\
\hline H32 & $>$ En el mar \\
\hline H33 & Estatua de carne \\
\hline $\mathrm{H} 34$ & La pena \\
\hline H35 & Madrigal \\
\hline H36 & La última noche \\
\hline H37 & $>$ Fatuidad póstuma \\
\hline H38 & $>$ A Berta \\
\hline H39 & $>$ Vespertino \\
\hline $\mathrm{H} 40$ & La canción del torero \\
\hline $\mathrm{H} 41$ & In memoriam \\
\hline $\mathrm{H} 42+$ & Croquis perdido \\
\hline $\mathrm{H} 43$ & Idilio realista \\
\hline $\mathrm{H} 44$ & A los estudiantes \\
\hline $\mathrm{H} 45$ & $\begin{array}{l}\text { Adiós al Brasil del Emperador } \\
\text { don Pedro II }\end{array}$ \\
\hline $\mathrm{H} 46$ & Post umbra \\
\hline $\mathrm{H} 47$ & La canción de la morfina \\
\hline $\mathrm{H} 48$ & La perla \\
\hline $\mathrm{H} 49$ & * Versos azules \\
\hline
\end{tabular}

Versions

HE: $30 \mathrm{Mar} 90$

M: 5 Aug 83 , HE: 1 Aug 86

HE: 27 Jun 86

HE: 3 Jan 86

HE: 17 Jan 86

HF: 19 Apr 85, Ve: 20 Jan 86

F: 12 Aug 86

HE: 28 Feb 86

HE: 18 Jul 86

F: 28 Jan 86

HE: 6 Dec 85, F: 26 Sep 86

HE: 25 Jul 86

HE: 26 Sep 86

F: 17 Mar 89

F: 15 Jul 86

HE: 13 May 88

F: 8 Apr 86

HE: 1 Jan 88

HE: 25 Dec 87

HE: 27 May 88

HE: 29 Aug 86

HE: 13 Jun $86, F$ : 30 Jun 88

HE: 17 Feb 89

HE: 3 Mar 89

F: 8 Dec 87

HE: 23 Oct 87

HE: 17 Oct $86, F$ : 4 Nov 88

$\mathrm{HE}: 9 \mathrm{Feb} 90, \mathrm{~Pb}: 15 \mathrm{Feb} 90$

F: 6 Oct 89

HE: 18 Dec 87

F: 1 Dec 87

HE: 11 Nov 88

HE: 22 Jan 88

F: 28 Oct 88 , HE: 12 May 89

HE: 6 Nov 87

F: 1 Dec 89

HE: 23 Jun 89

HE: 24 Nov 89

HE: 8 Dec 89

F: 8 Dec 89

HE: 20 Apr 90

HE: 27 Apr 90

HE: 16 Mar 90, L: 21 Mar 90

2. NIEVE. 


\begin{tabular}{|c|c|}
\hline \multirow{2}{*}{$\begin{array}{lll}N & 1 \\
N & 1\end{array}$} & Introducción \\
\hline & Bocetos antiguos \\
\hline N 2 & Las oceánidas \\
\hline N $3+$ & Bajo-relieve \\
\hline N 4 & La muerte de Moisés \\
\hline N 5 & La agonía de Petronio \\
\hline N $6+$ & El camino de Damasco \\
\hline$N p 2$ & Mi museo ideal \\
\hline N 7 & $*>$ Vestíbulo \\
\hline N $8+*$ & * Salomé \\
\hline N 9 & La aparición \\
\hline $\mathrm{N} 10$ & * Prometeo \\
\hline $\mathrm{N} 11+$ & Galatea \\
\hline $\mathrm{N} 12+*$ & * Elena \\
\hline $\mathrm{N} 13$ & Hércules ante la Hidra \\
\hline $\mathrm{N} 14$ & Venus Anadyomena \\
\hline N 15 & Una peri \\
\hline N 16 & Júpiter y Europa \\
\hline N 17 & Hércules y las Estinfálides \\
\hline N 18 & Sueño de gloria \\
\hline$N p 3$ & $>$ Cromos españoles \\
\hline N 19 & Una maja \\
\hline N20 & Un torero \\
\hline N21 & Un fraile \\
\hline $\mathrm{Np} 4$ & Marfiles viejos \\
\hline N22 & * Tristissima nox \\
\hline N23 & * A un amigo \\
\hline N24 & $*>\mathrm{Al}$ mismo \\
\hline $\mathrm{N} 25$ & * Pax animae \\
\hline $\mathrm{N} 26$ & A mi madre \\
\hline N27 & Mi padre \\
\hline N 28 & $>$ Paisaje espiritual \\
\hline N29 & A la Primavera \\
\hline N30 & A un crítico \\
\hline N31 & A la Castidad \\
\hline $\mathrm{N} 32+$ & $>$ Al Juez Supremo \\
\hline N33 & Flor de cieno \\
\hline N34 & Inquietud \\
\hline N 35 & A un dictador \\
\hline N36 & Tras una enfermedad \\
\hline N 37 & En un hospital \\
\hline Np5 & La gruta del ensueño \\
\hline N38 & $>$ Ante el retrato de Juana Samary \\
\hline N39 & $>$ Camafeo \\
\hline $\mathrm{N} 40$ & Blanco y negro \\
\hline N41 & Flores \\
\hline $\mathrm{N} 42+$ & Vespertino \\
\hline $\mathrm{N} 43+$ & $>$ Kakemono \\
\hline $\mathrm{N} 44+$ & Nostalgias \\
\hline $\mathrm{N} 45+$ & La reina de la sombra \\
\hline $\mathrm{N} 46$ & Paisaje de verano \\
\hline N47 & Flores de éter \\
\hline N48 & * Mi ensueño \\
\hline N49 & Canción \\
\hline N50 & Al carbón \\
\hline N51 & $>$ En un álbum \\
\hline N52 & Canas \\
\hline N53 & *> Medallón \\
\hline
\end{tabular}

$\mathrm{N} 54+$ Horridum somnium
HE: 5 Oct 90

HE: 19 Apr 91, Pb: 2 May 91

HE: 7 Jun 91

HE: 17 May 91

HL: $30 \mathrm{Sep} 91$

MS: 12 Dec 91, F: 15 Jan 92, P: 21 Jan 92 HE: 21 Sep 90, P: 23 Sep 90, HE: 30 Aug 91 HE: 30 Aug 91

HE: 16 Aug 91, HE: 30 Aug 91

HE: 9 Aug 91, HE: 30 Aug 91

HE: 2 Aug 91,P: 4 Aug 91, Pb: 11 Aug 9l, HE: 30 Aug 91 HE: 30 Aug 91

HE: 30 Aug 91

HE: 30 Aug 91

HE: 30 Aug 91

HE: 30 Aug 91

MS: 8 Dec 91, HL: 30 Dec 91

HL: 15 Feb 92, P: 17 Feb 92

HL: 15 Feb 92, P: 17 Feb 92

HL: 15 Feb 92, P: 17 Feb 92

HE: 14 Sep 90, P: 16 Sep 90

P: 23 Nov $90, \mathrm{HE}: 7$ Dec 90

HE: 30 Nov 90

HE: 26 Oct 90

HE: 5 Apr 91

HE: 31 May 91, P: 2 Jun 91

HE: 5 Apr 91

HE: 3 May 91

HE: 28 Jun 91

HE: 19 Jul 91, Pb: 8 Aug 91

HE: 19 Jul 91

HL: 15 Oct 91

HL: 30 Jan 92, P: 3 Feb 92, Hg: 21 Feb 92

HL: 30 Jan 92

HE: 5 Apr 91

HL: 30 Mar 92

P: 19 Oct $90, \mathrm{~Pb}: 24$ Oct $90, \mathrm{~Pb}: 19$ Jun 91

F: 8 Mar 91

P: 2 Nov 90, HE: 7 Dec 90

P: 16 Nov 90, HE: 7 Dec 90, Pb: 23 Dec 90

P: 26 Oct $90, \mathrm{~Pb}: 7$ Nov $90, \mathrm{HE}: 7$ Dec 90

HE: 22 Mar 91

HE: 12 Apr 91

HE: 10 May 91

HE: 21 Jun 91, P: 24 Jun 91

$\mathrm{HE}: 5 \mathrm{Jul} 91, \mathrm{~Pb}: 6$ Nov 91

P: 16 Nov 90, HE: 7 Dec 90, Pb: 23 Dec 90, Hg: 14 Feb 92 F: $27 \mathrm{Dec}$ 91, P: $29 \mathrm{Dec} 91, \mathrm{~Pb}: 5$ Jan 92

HE: 26 Jul 91, Pb: 4 Aug 91

HE: 15 Mar 91

HL: 15 Dec 91

HL: 29 Feb 92

HL: 15 Sep 91

\section{RIMAS.}

Versions

HL: 15 Apr 92

HE: 2 Apr 93

HL: 15 Jun 92 


\begin{tabular}{|c|c|}
\hline R $4+$ & Marina \\
\hline R 5 & Obstinación \\
\hline R 6 & Bohemios \\
\hline R $7+$ & Sourimono \\
\hline R 8 & Coquetería \\
\hline R 9 & Rondeles \\
\hline R 10 & La sotana \\
\hline R 11 & Nocturno \\
\hline R 12 & Recuerdo de la infancia \\
\hline R 13 & O Altitudo! \\
\hline R 14 & Vieja historia \\
\hline R 15 & A un héroe \\
\hline R 16 & La cólera del infante \\
\hline R 17 & Profanación \\
\hline R 18 & Medioeval \\
\hline R 19 & Las alamedas \\
\hline R 20 & Día de fiesta \\
\hline R 21 & Páginas de vida \\
\hline $\mathrm{R} 22$ & Preocupación \\
\hline R 23 & Aegri somnia \\
\hline R 24 & Neurosis \\
\hline R 25 & Sensaciones \\
\hline $\mathrm{R} 26$ & Dolorosa \\
\hline $\mathrm{R} 27$ & Voe soli \\
\hline R 28 & Esquivez \\
\hline R 29 & A un poeta \\
\hline R 30 & $>$ Laus noctis \\
\hline R 31 & Ruego \\
\hline R 32 & Para una muerta \\
\hline R 33 & Oración \\
\hline R 34 & Virgen triste \\
\hline R 35 & Las horas \\
\hline R 36 & En el campo \\
\hline R 37 & * Enrique Gómez Carrillo \\
\hline R 38 & Tardes de lluvia \\
\hline R 39 & Un santo \\
\hline $\mathrm{R} 40$ & El hijo espurio \\
\hline R 41 & Cuerpo y alma \\
\hline
\end{tabular}

R41 Cuerpo y alma
F: 10 Jul 92

ED: 21 Aug 92, HL: 30 Sep 92, P: 7 Oct 92

HE: 5 Jan 93

HL: 15 Aug 92

F: 7 Aug 92, P: 9 Aug 92

HL: 30 Aug 92

HL: 30 Sep 92

HL: 30 Sep 92

F: 4 Sep 92

HL: 30 Oct 92

HL: 15 Sep 92, Hg: 6 Nov 92

HL: 30 Oct 92

HE: 8 Jan 93

HL: 30 Oct 92

HL: 15 Dec 92, Hg: 22 Jan 93

HL: 15 Nov 92

P: 15 Oct 92

HE: 22 Jan 93

HE: 7 May 93, P: 9 May 93, Hg: 16 Jul 93

HL: 30 Nov 92, Hg: 25 Dec 92

HE: 5 Feb 93

P: 24 Aug 93

HE: 19 Feb 93

HE: 7 May 93, P: 9 May 93

HE: 16 Apr 93

HE: 14 May 93, P: 16 May 93

HE: 5 Mar 93

HE: 14 May 93, P: 16 May 93

HE: 21 May 93

HE: 13 Aug 93, P: 15 Aug 93, UC: 20 Aug 93 HE: 20 Aug 93

HE: 13 Aug 93, UC: 17 Aug 93, P: 18 Aug 93

HE: 27 Aug 93

HE: 1 Oct 93

HE: 3 Sep 93

HE: 10 Sep 93, P: 13 Sep 93

HE: 10 Sep 93, P: 13 Sep 93

HE: 29 Oct 93

\section{VARIA.}

\section{Order of Appearance}

E: 13 Feb 81
E: 5 Mar 81
E: 27 Mar 81
30 May 85
Oct 87
F: 27 Oct 87
HE: 13 Nov 87
$\quad$ Aug 90
F: $\quad 31$ Jan $92, \mathrm{P}: \quad$ 2 Feb 92
F: 26 Jun 92
HL: 15 Jul $92, \mathrm{Hg}: 28$ Aug 92
F: $\quad$ 2 Oct 92
Cp: $\quad$ Nov 92




$$
1124
$$





\section{PLEASE DO NOT REMOVE CARDS OR SLIPS FROM THIS POCKET}

\section{UNIVERSITY OF TORONTO LIBRARY}

$P Q$

7389

C266AI7

1976

v.2
Casal, Julián del

The poetry of Julián del Casal 
